
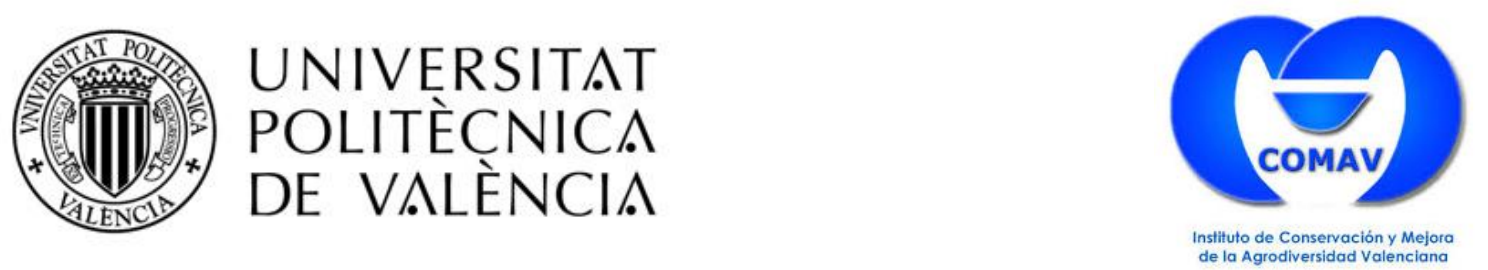

Tesis Doctoral

\title{
APROVECHAMIENTO DE HERRAMIENTAS GENÉTICAS Y GENÓMICAS PARA DESARROLLO DE NUEVAS POBLACIONES PARA LA MEJORA DEL MELÓN POR RESISTENCIA A PATÓGENOS Y CALIDAD
}

Gabriel Elías Castro Alcocer

Directores: Dra. Cristina Esteras Gómez

Dra. María Belén Picò Sirvent

Valencia, julio del 2019 



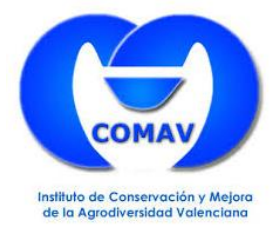

Dra. Cristina Esteras Gómez, Profesora Contratada de la Universitat Politècnica de València y miembro del Instituto de Conservación y Mejora de la Agrodiversidad Valenciana,

Dra. María Belén Picò Sirvent, Catedrática de la Universitat Politècnica de València y miembro del Instituto de Conservación y Mejora de la Agrodiversidad Valenciana,

CONSIDERAN: que la memoria titulada "Aprovechamiento de herramientas genéticas y genómicas para desarrollo de nuevas poblaciones para la mejora del melón por resistencia a patógenos y calidad" que presenta Don Gabriel Elías Castro Alcocer, para aspirar al grado de Doctor de la Universitat Politècnica de València, y que ha sido realizada bajo su dirección en el Instituto de Conservación y Mejora de la Agrodiversidad Valenciana de la Universitat Politècnica de València , reúne las condiciones adecuadas para constituir su tesis doctoral, por lo que AUTORIZAN al interesado para su presentación.

Valencia, Septiembre de 2019

Fdo.: Dra. Cristina Esteras Gómez
Fdo.: Dra. María Belén Picò Sirvent 



\section{AGRADECIMIENTOS}

Todo objetivo empieza con un sueño, y cuando ese sueño se llena de ilusiones se convierte en una meta, y una meta apoyada por acciones y personas maravillosas se vuelve una realidad.

Las primeras líneas de mis agradecimientos quiero dedicar a dos personas que han constituido los pilares fundamentales en el desarrollo de esta Tesis: las Dras. María Belén Picò Sirvent y Cristina Esteras Gómez, vuestra guía y sabiduría a lo largo de todo el proceso fueron trascendentales para alcanzar todos los objetivos planteados a lo largo de mi doctorado. Dra. Belén, gracias por haberme brindado la oportunidad de venir al COMAV y pertenecer a su grupo de investigación, un grupo maravilloso, no imagino un mejor grupo en este mundo, y poder vivir esta experiencia única. Dra. Cristina, tengo un sentimiento de agradecimiento infinito hacia Ud. por su comprensión y apoyo en todo momento, esta tesis no hubiera sido posible sin su tenacidad y dedicación incondicional. A las dos, GRACIAS TOTALES por todo lo que han sembrado en mi, y gracias a la vida por haber permitido que nuestros caminos se crucen.

Detrás de todo esto, están mis padres, Luis y Lida, entiendo lo difícil que tuvo que haber sido ver a su único hijo marcharse a los 17 años a estudiar lejos de casa y años después despedirlo en un aeropuerto para cruzar un océano por cumplir un sueño. Gracias por su comprensión en momentos difíciles y su apoyo incondidional, gracias por no haber tenido el egoísmo de atarme a ustedes a pesar de ser su único hijo, ustedes también son parte de esta Tesis. Han envejecido y me he perdido gran parte de sus vidas lejos de casa, no podré recuperar el tiempo que no pudimos compartir, pero prometo ahora que regrese a casa hacer del tiempo que nos queda inolvidable.

Todavía recuerdo cuando subí por primera vez aquel avión, rumbo a un lugar desconocido, empaqué mis ganas de vivir, un par de abrazos, una foto y mil recuerdos; desde que subí a ese avión sentí que ya no era de Ecuador porque me marchaba ni de allá, mi destino, porque no sabía a donde iba. Y en la confusión del tiempo, uno trata de encontrar una familia, amigos y comenzar a construir una vida, de volver a nacer. Y allí, tuve el placer de conocer el primer día a Gorka, a quien las palabras no alcanzarían para expresar todo lo que ha significado en mi vida, su aopoyo en el laboratorio, su guía y sus consejos no solo contribuyeron a formarme como profesional sino también como persona. Estoy seguro que la vida te depara cosas grandes, por el gran trabajador y la magnífica persona que eres. 
Y con el paso de los años me fui dando cuenta que hay gente y sitios que hacen que el tiempo pase volando, Elena, Leandro, Ana María, Miguel, Juan, Alejandro y Cristina, ustedes sencillamente son personas que saben no solamente alegrar la vida sino también el alma. Un agradecimiento especial a Cristina, mi compañera favorita de despacho, eres maravillosa, las conversaciones y anécdotas compartidas quedarán grabadas siempre en mí. Eres la compañera perfecta de despacho y la amiga ideal de vida. Del mismo modo quisiera extender mis agradecimientos a Eva, quien supo brindarme su ayuda en momentos oportunos. Extrañaré mucho nuestras comidas y cervezas,

Y cuando las emociones se calman, llega la realidad, llena de buenos momentos pero también de dificultades, y gracias a quienes fueron Mi Familia durante estos años, ayudándome siempre a sobrellevar los días difíciles, hiceron que tenga un pedacito de casa a miles de kilómetros, gracias a todos los chicos de Ecuador (incluido Anisa, Carla, Oriana, Patrizia y Albita, que son ecuatorianas de corazón) con quienes compartí todos estos años aquí en valencia, la historia la continuamos allá.

Muchas mudanzas y muchas nuevas amistades a lo largo de todo este tiempo; sin embargo, ha sido un placer enorme compartir vivencias y piso con Nika, Ivan, Klaudia y Alicia, hay veces que hubiera deseado que este doctorado no termine para seguir compartiendo con ustedes.

Y por último, quiero agradecer infinitamente a María José, no te hubiera conocido sino hubiera sido por este Doctorado, gracias por haberme regalado las mejores experiencias de mi vida a mis 30 años. Y aunque siempre te lo he dicho, quiero plasmarlo en esta Tesis, tienes una nobleza infinitva y una magia para alegrar la vida.

Me voy con una reflexión producto de todos estos años, la única herramienta que necesitamos para cumplir nuestros sueños es La Vida. 




\section{ÍNDICE}

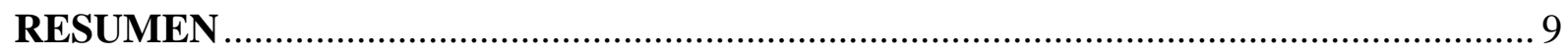

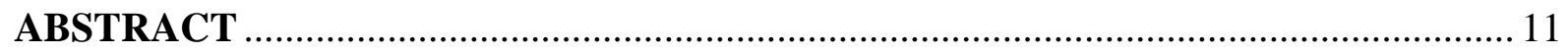

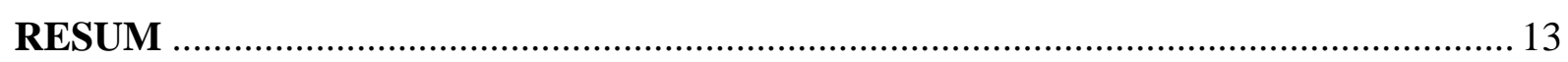

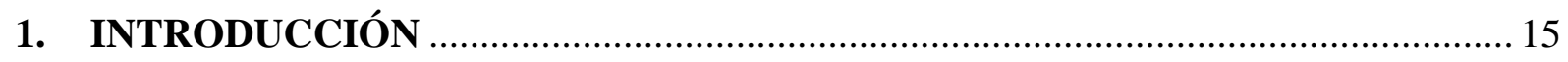

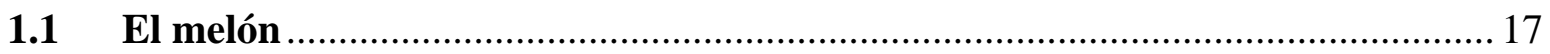

1.1.1 Origen y domesticación del melón ……………………………………..... 17

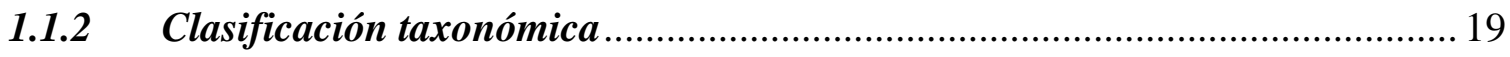

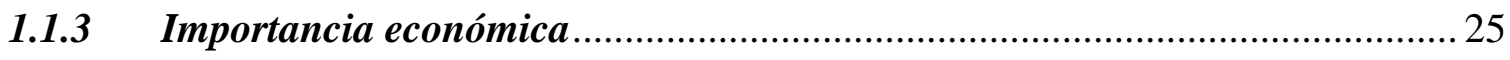

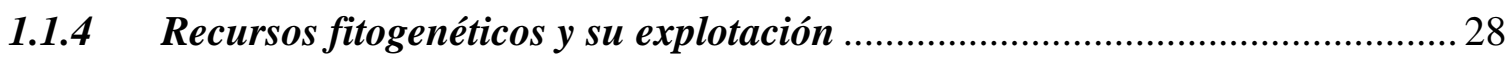

1.1.5 Herramientas genómicas disponibles en melón ..............................................2 29

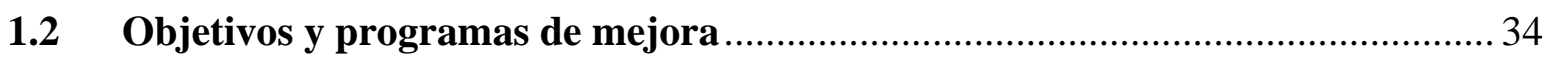

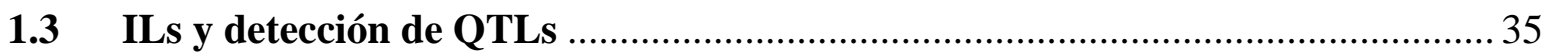

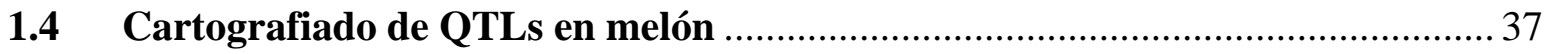

1.4.1 QTLs relacionados con la calidad del fruto ...................................................... 38

1.4.2 QTLs relacionados con la maduración del fruto ............................................. 41

1.4.3 QTLs relacionados con resistencia a enfermedades ....................................... 45

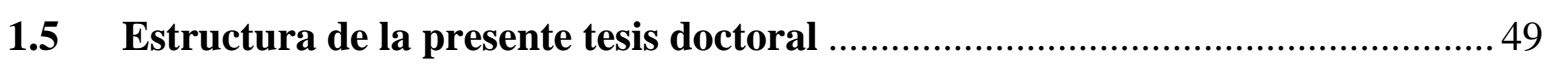

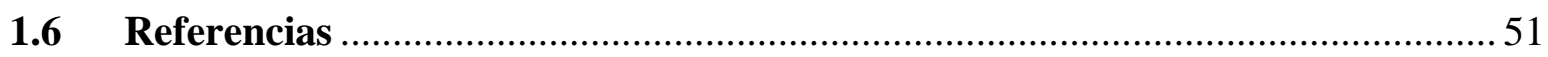

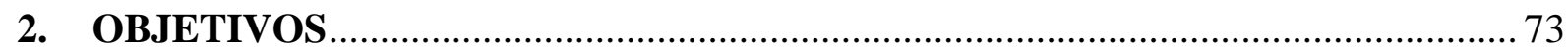

3. APROVECHAMIENTO DE LA VARIABILIDAD INTRAESPECÍFICA DEL MELÓN PARA LA MEJORA DE LA CALIDAD ………………………………….... 77

3.1 Detección de QTLs durante el proceso de desarrollo de la colección de líneas de

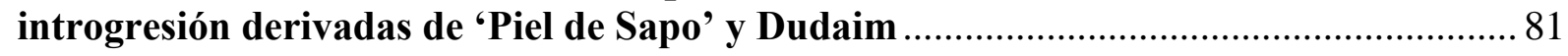

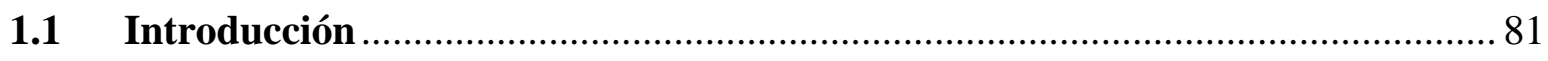

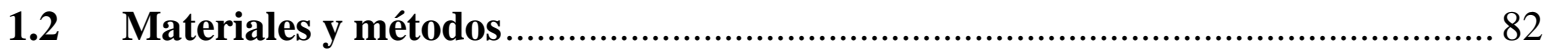

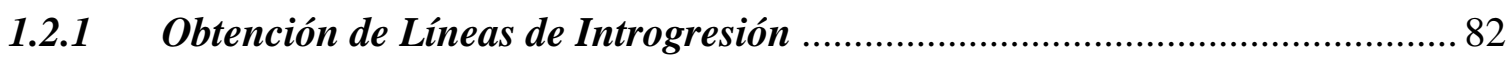

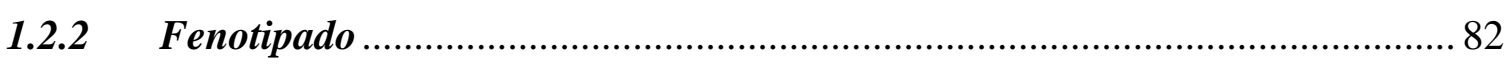

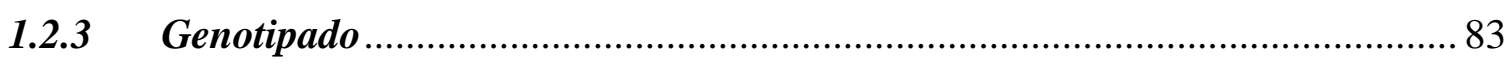

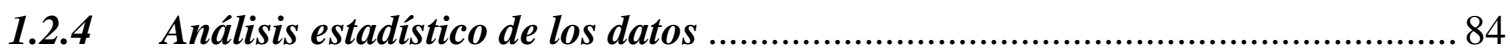

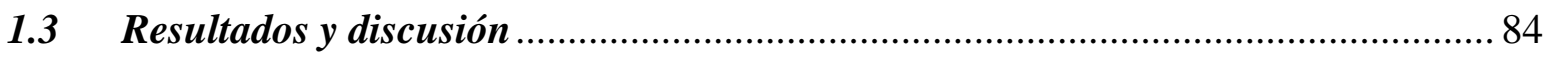

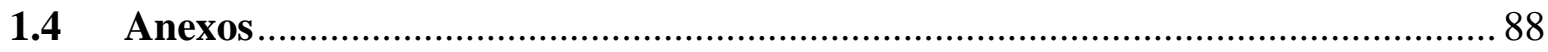

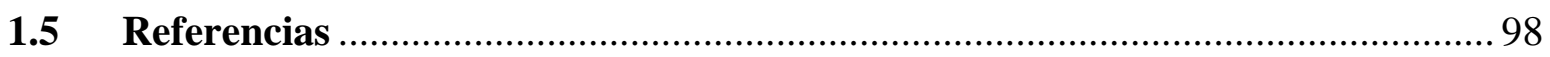

3.2 New melon introgression lines in a 'Piel de Sapo' genetic background with desirable agronomical traits from Dudaim melons.......................................................... 107

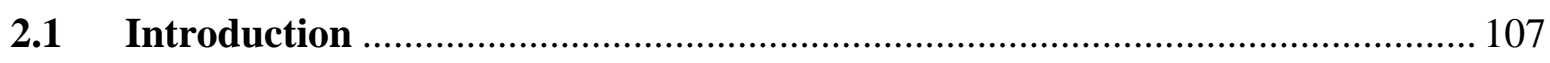

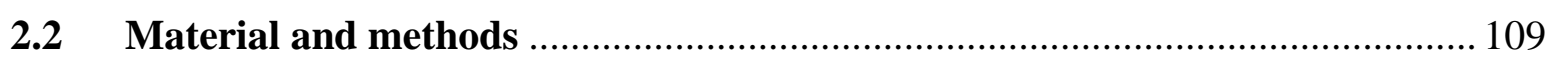




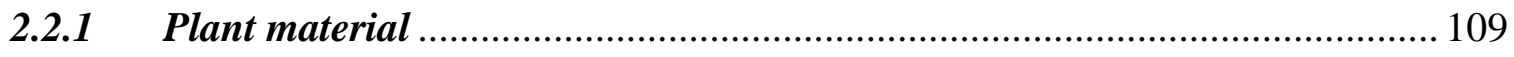

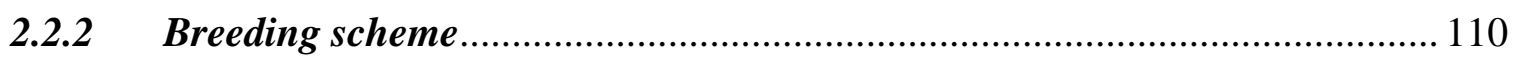

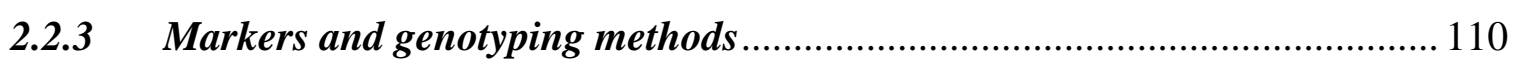

2.2.4 Agronomic evaluation and traits measured ................................................... 111

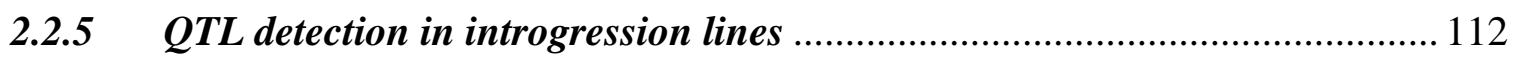

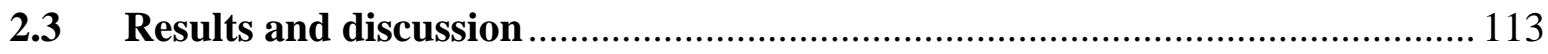

2.3.1 Development of the several IL generations ..................................................... 113

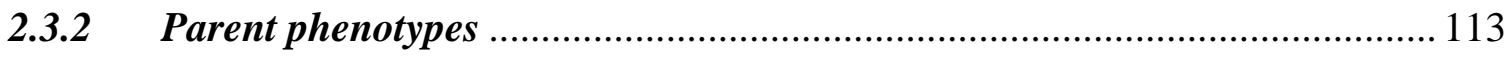

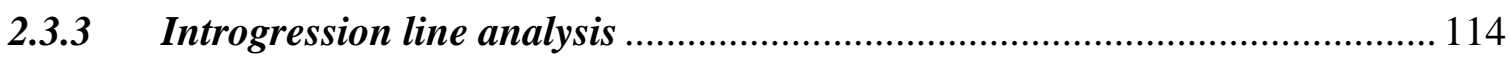

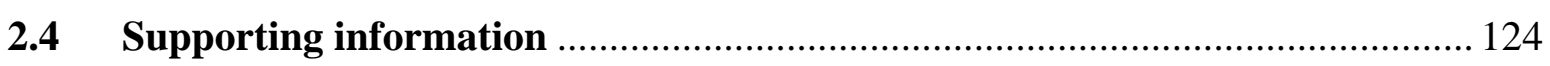

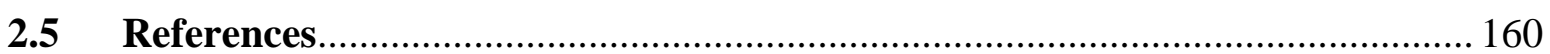

3.3 Aumentando la diversificación de las variedades de melón 'Piel de Sapo', aprovechando la variación de variedades asiáticas tipo Dudaim .................................. 171

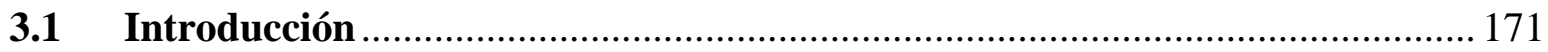

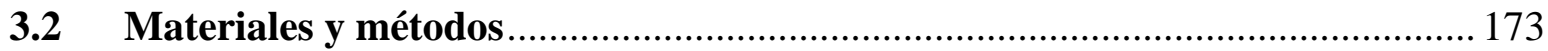

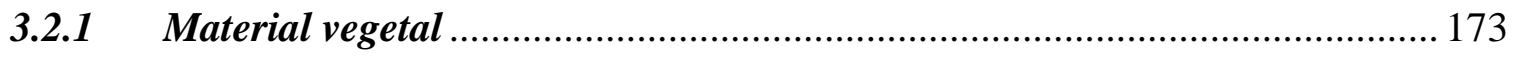

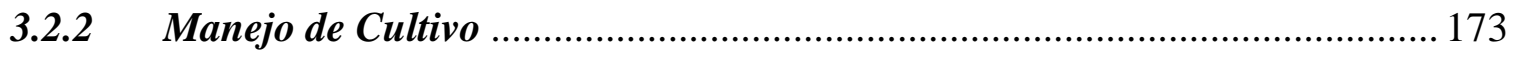

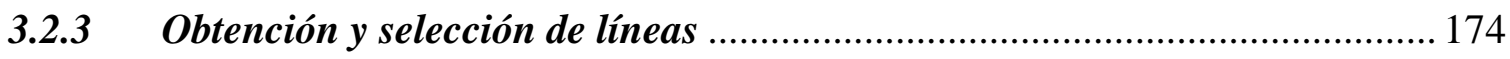

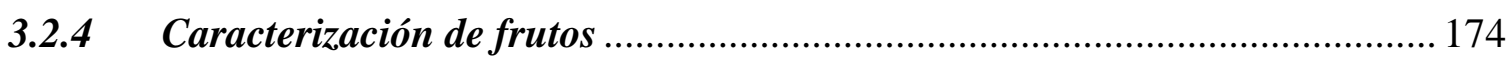

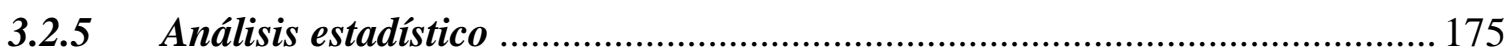

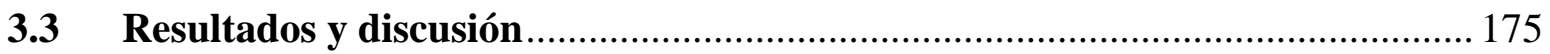

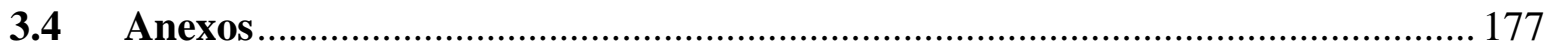

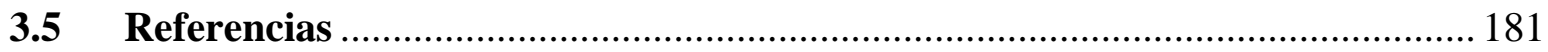

3.4 A 'Mini PS': A new small rounded 'Piel de Sapo' breeding line derived from

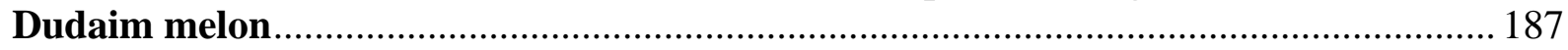

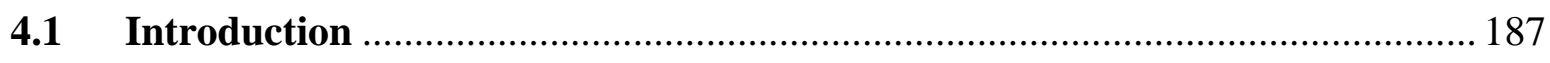

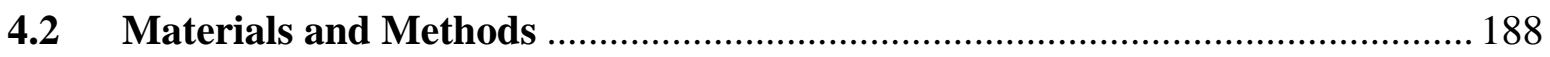

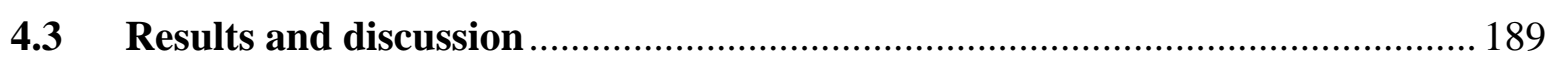

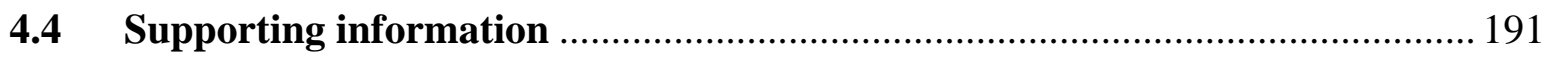

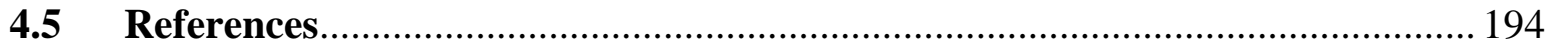

4. APROVECHAMIENTO DE LA VARIABILIDAD INTRAESPECÍFICA DEL MELÓN PARA LA RESISTENCIA A HONGOS DEL SUELO ................................... 197

4.1 Evaluación de la colección de líneas de introgresión de 'Piel de Sapo' derivada de Dudaim por su respuesta al hongo Macrophomina pasheolina. .................................... 201

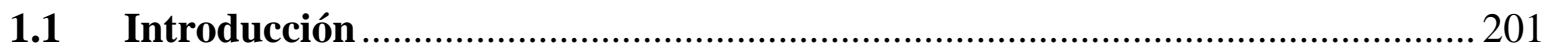

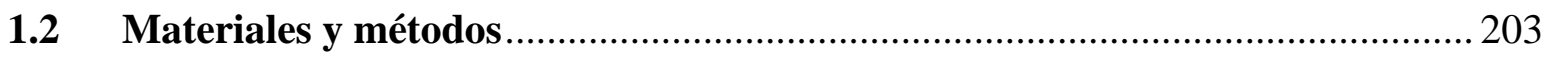

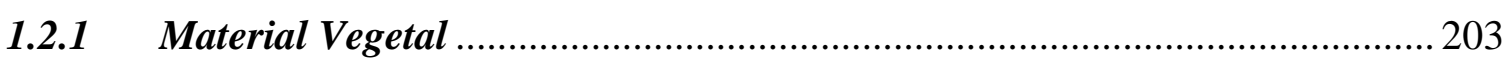

1.2.2 Inóculo de Macrophomina phaseolina ......................................................... 203

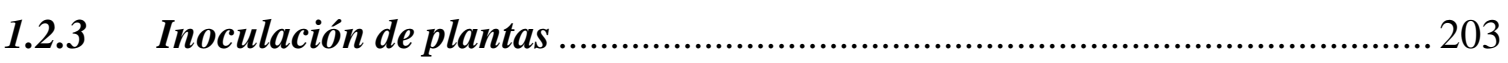




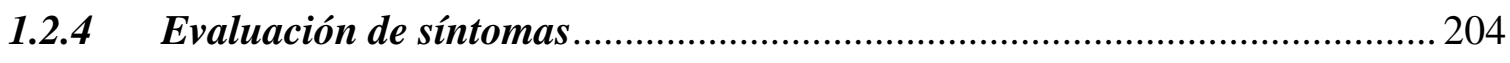

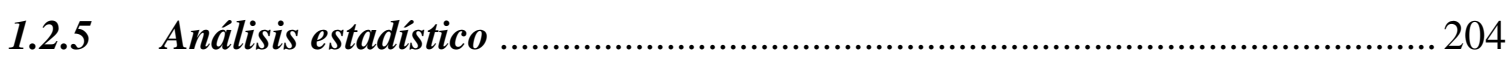

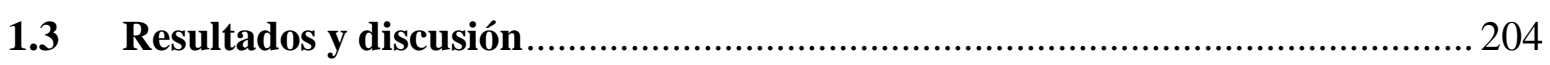

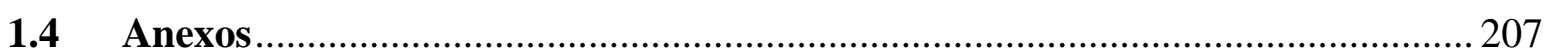

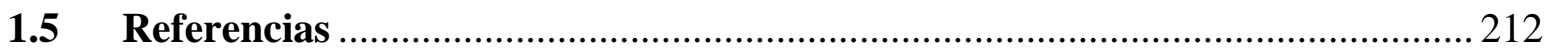

4.2 Effect of temperature on charcoal rot on stem of melons. ..................................... 219

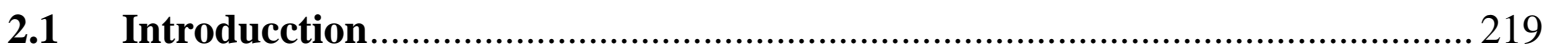

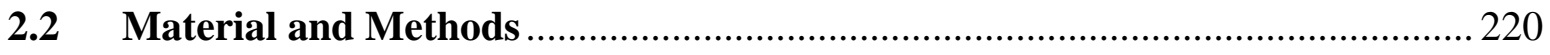

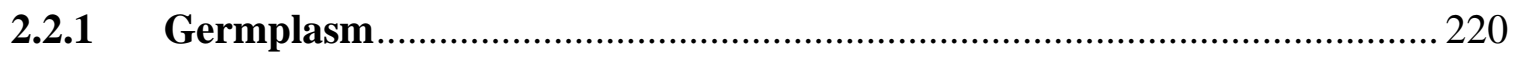

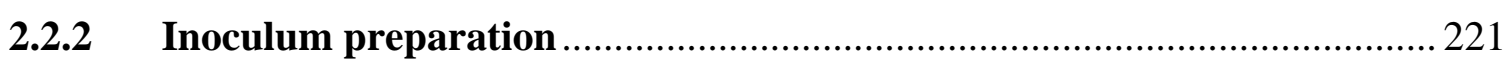

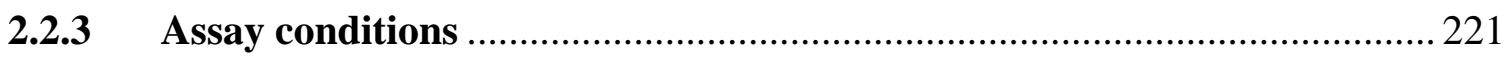

2.2.4 Plant inoculation and disease assessment.............................................. 221

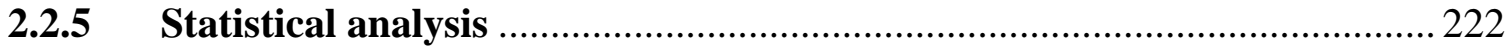

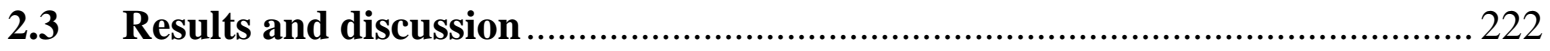

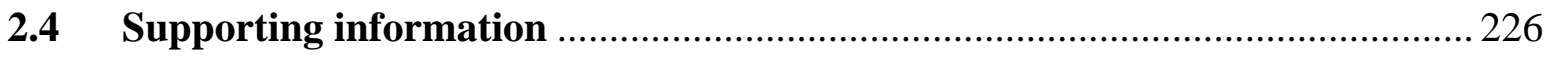

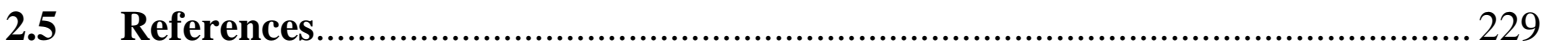

4.3 Resistance in melon to Monosporascus cannonballus and M. eutypoides; fungal pathogens associated with Monosporascus root rot and vine decline ........................... 237

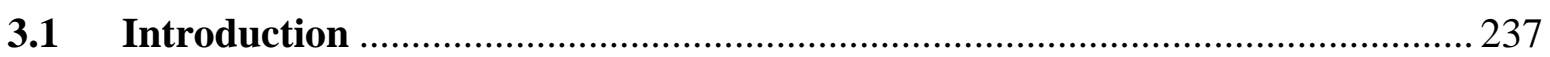

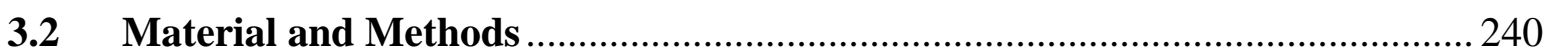

3.2.1 Isolates of Monosporascus cannonballus and eutypoides .............................2240

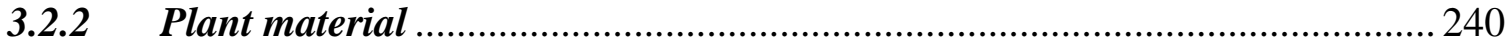

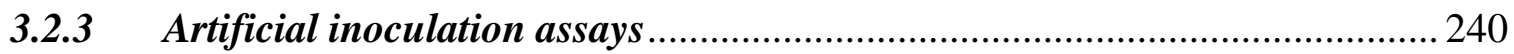

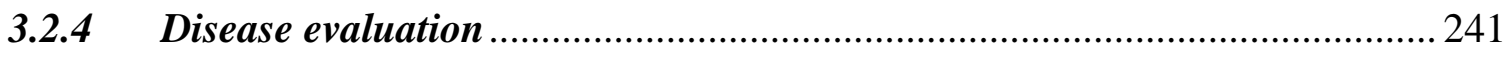

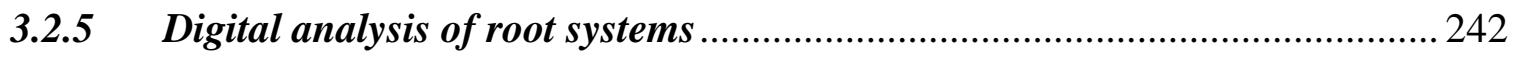

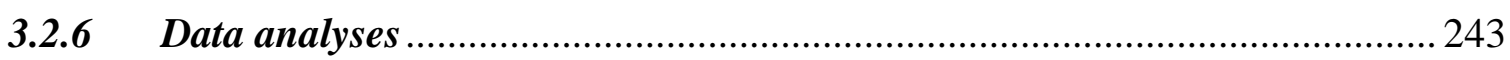

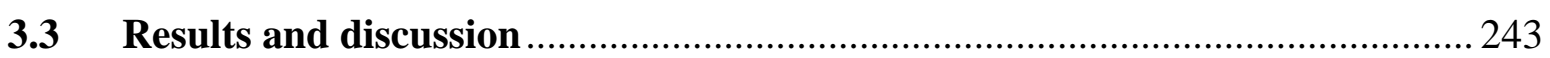

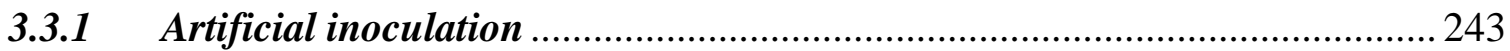

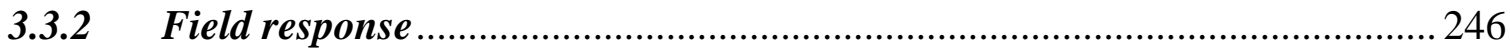

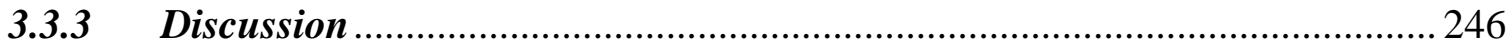

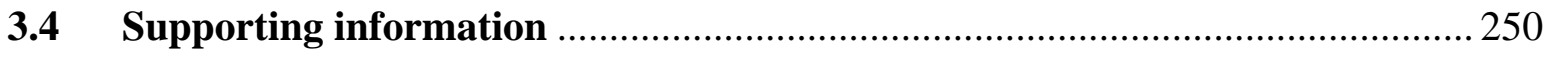

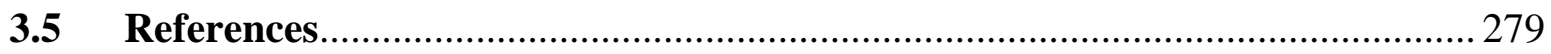

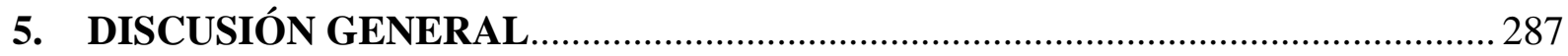

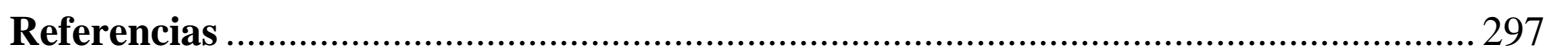

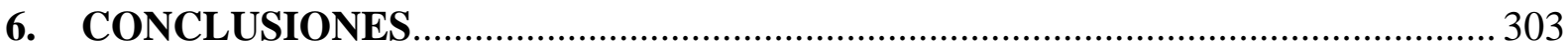





\section{RESUMEN}

En la actualidad, el melón (Cucumis melo L.) es un cultivo con gran impacto económico mundial que se cultiva en más de 100 países. Su adaptación a diversas regiones en todo el mundo ha dado como resultado el gran polimorfismo actualmente observado en la especie. Esta variabilidad genética es un recurso imprescindible en los programas de mejora, pues constituye un reservorio valioso de nuevos alelos. La utilización de herramientas moleculares permite la optimización de los programas de mejora convencionales, consiguiendo el desarrollo de nuevas variedades más rápidamente y adaptándose así a las exigencias del productor y las preferencias del consumidor. El desarrollo de líneas de introgresión (ILs) mediante la ayuda de técnicas moleculares que facilitan el proceso de selección, constituye una estrategia óptima para la introducción de características favorables procedentes de tipos silvestres en cultivares comerciales. En la presente Tesis Doctoral se describe el desarrollo de una colección de ILs usando la entrada Queen's Pocket melon (del grupo Dudaim) de Irak, como parental exótico donante y el cultivar español 'Piel de Sapo' (del grupo Ibericus) como parental recurrente. Durante el proceso de generación de las ILs no sólo se tuvo en cuenta el genotipado (mediante diversas técnicas como HRM, la plataforma Agena Bioscience y GBS) para optimizar la recuperación del fondo genético recurrente, el número de introgresiones y la cobertura del genoma del parental donante, sino también el fenotipo mostrado por las diferentes familias. La selección final, formada por 16 ILs, presenta un promedio de 1,4 introgresiones por IL y representa el 62,6\% del genoma del parental donante.

La caracterización fenotípica de esta colección de ILs permitió la identificación de 32 QTLs (Quantitative Trait Loci) estables en los dos ambientes evaluados. De éstos, 22 QTLs corresponden a caracteres morfológicos como peso, forma, reticulado, ancho de pulpa y cavidad; 9 QTLs están relacionados con características asociadas a maduración climatérica como la presencia de la capa de abscisión, aroma y firmeza de la pulpa; y uno se refiere al contenido de sólidos solubles. Muchos de los QTLs identificados en este trabajo no han sido descritos anteriormente, lo cual constituye un valioso recurso tanto de alelos nuevos potencialmente interesantes en mejora como para el estudio de las regiones genómicas y genes implicados en el control de ciertos caracteres de interés agronómico. Por otra parte, otros QTLs confirmaron regiones previamente descritas por otros autores. En esta Tesis se describen líneas potencialmente interesantes en cuanto a presencia de aroma, tamaño reducido del fruto y/o formas más redondeadas, características buscadas en el mercado de tipos 'Piel de Sapo' o que pueden ser interesantes para ampliar su comercialización en otras regiones donde están más acostumbrados a perfiles más aromáticos o con otra morfología. 
La caracterización de ese conjunto de ILs también se llevó a cabo para la resistencia a un hongo patógeno del suelo, Macrophomina phaseolina. A pesar de la moderada resistencia descrita en trabajos anteriores para el parental Dudaim, ninguna línea resultó resistente. El estudio que se presenta en esta Tesis acerca de la influencia de la temperatura en la patogenicidad de este hongo ha demostrado que la resistencia del parental es superada con temperaturas altas y por tanto, no es estable. En este cribado, tan sólo una entrada silvestre africana resultó resistente a temperaturas altas.

De igual manera se realizó un ensayo de tolerancia a los hongos del suelo Monosporascus cannonballus y $M$. eutypoides, principales responsables del colapso del melón, que causa también muchas pérdidas económicas. Los resultados permitieron concluir que $M$. cannonballus presenta mayor patogenocidad que M. eutypoides y que la temperatura también afecta de forma importante a la severidad de los síntomas, apoyando estudios previos. Las dos entradas africanas y de la India que presentaron mayor tolerancia a Monosporascus spp. pueden ser de interés en futuros programas de mejora. 


\section{ABSTRACT}

Nowadays, the melon (Cucumis melo L.) is a crop with great economic impact worldwide that is grown in more than 100 countries. Its adaptation to diverse regions around the world has turned out in the high polymorphism this species shows. This genetic variability is an indispensable resource for breeding programs, since it is a valuable reservoir of new alleles. The use of molecular tools allows the optimization of conventional breeding programs, achieving the development of new varieties more quickly and adapting to the demands of the producer and to consumer preferences. The development of Introgression Lines (ILs) employing molecular techniques to assist in the selection process, constitutes an optimal strategy for the introduction of favourable traits from wild types in commercial cultivars. In this $\mathrm{PhD}$ thesis the development of an ILs collection is described, using the Queen's Pocket melon accession (Dudaim group) of Irak as the exotic donor parental and the Spanish cultivar 'Piel de Sapo' (Ibericus group) as the recurrent parental. During the ILs generation process, not only genotyping was taken into consideration (several techniques such as HRM, the Agena Bioscience platform and GBS were used) to optimize the recovery of the recurrent genetic background, the number of introgressions and the coverage of the donor genome, but also the phenotype shown by the different families. A set of 16 ILs was finally selected, bearing an average of 1.4 introgressions per IL and representing $62.6 \%$ of the donor genome.

The phenotypic characterization of this IL collection allowed the identification of 32 stable QTLs (Quantitative Trait Loci) in the two environments evaluated. Out of these, 22 QTLs correspond to morphological traits such as weight, shape, netting, flesh width and cavity; 9 QTLs are related to traits associated with the climacteric ripening such as the presence of the abscission layer, aroma and flesh firmness; and one related to the soluble solids content. Many QTLs identified in this work have not been described previously. This implies new alleles of potential interest not only in breeding but also in the study of new genomic regions and genes controlling agronomical and quality traits. On the other hand, other QTLs confirmed regions previously described by other authors. In this work, interesting lines are described in terms of the presence of aroma, reduction of fruit size and / or more rounded shapes, characteristics requested by 'Piel de Sapo' consumers or that may be interesting to extend its reach in other regions, where they are more accustomed to more aromatic profiles or with other morphology. The phenotyping of this set of ILs was also carried out for searching for resistance to a pathogenic soil fungus, Macrophomina Phaseolina. Despite the moderate resistance described for the Dudaim parental in a previous work, no line was resistant. The study presented herein about the influence of temperature on the pathogenicity of this fungus, has shown that the 
resistance of the donor parenal is overcome with the temperature increase and therefore, is not stable. In this screening, only one African wild accession was resistant to high temperatures. In addition, an assay searching for tolerance to the fungi of the soil, Monosporascus cannonballus and M. eutypoides, the main responsible for melon collapse, was carried out. The results allowed us to conclude that $M$. cannonballus presents higher pathogenicity than $M$. eutypoides. Additionally, temperature also affected the symptoms severity, which is coherent with previous studies. Two African and one Indian accessions were the ones displaying higher tolerance to Monosporascus spp. They may be of great interest in future melon breeding programs. 


\section{RESUM}

A l'actualitat, el meló (Cucumis melo L.) és un conreu amb gran impacte econòmic que es cultiva en més de 100 països. La seua adaptació a diverses regions per tor el món ha donat com a resultat el gran polimorfisme que actualment observem en l'espècie. Esta variabilitat genètica és un recurs imprescindible en els programes de millora, ja que constitueix un reservori valuós de nous al·lels. La utilització de ferramentes moleculars permet l'optimització dels programes de millora convencionals, aconseguint el desenvolupament de noves varietats més ràpidament i adaptant-se així a les exigències del productor i les preferències del consumidor. El desenvolupament de línies d'introgressió (ILs) mitjançant l'ajuda de tècniques moleculars que faciliten el procés de selecció, constitueix una estratègia òptima per a la introducció de característiques favorables vinents de tipus silvestres en cultivars comercials. En la present Tesi Doctoral es descriu el desenvolupament d'una col·lecció d'ILs usant l'entrada Queen's Pocket melon (grup Dudaim) d'Iraq, com a parental exòtic donant i el cultivar espanyol 'Piel de Sapo' (grup Ibericus) com a parental recurrent. Durant el procés de generació de les ILs no solament es tingué en compte el genotipatge (mitjançant diverses tècniques com HRM, la plataforma Agena Bioscience i GBS) per a optimitzar la recuperació del fons genètic recurrent, el nombre d'introgressions i la cobertura del genoma del parental donant, sinó també el fenotip mostrat per les diferents famílies. La selecció final, formada per 16 ILs, presenta una mitjana de 1,4 introgressions per IL i representa el 62,6\% del genoma del parental donant.

La caracterització fenotípica d'aquesta col·lecció d'ILs permeté la identificació de 32 QTLs (Quantitative Trait Loci) estables en els dos ambients avaluats. D’aquests, 22 QTLs corresponen a caràcters morfològics com pes, forma, reticulat, amplària de polpa i cavitat; 9 QTLs estan relacionats amb característiques associades a maduració climatèrica com la presència de la capa d'abscissió, aroma i fermesa de la polpa; i un es refereix al contingut de sòlids solubles. Molts dels QTLs identificats en este treball no han sigut descrits anteriorment, cosa que constitueix un valuós recurs tant d’al·lels nous potencialment interessants en millora com per a l'estudi de les regions genòmiques i gens implicats en el control de certs caràcters d'interés agronòmic. Per una altra banda, altres QTLs confirmaren regions prèviament descrites per altres autors. En esta Tesi es descriuen ILs potencialment interessants respecte a la presència d'aroma, mesura reduïda del fruit, i/o formes més arrodonides, característiques buscades en el mercat de tipus 'Piel de Sapo' o que poden ser interessants per a apliar la seua comercialització en altres regions on estan més acostumats a melons més aromàtics o amb altra morfologia.

La caracterització d'aquesta col·lecció d'ILs també es va dur a terme per a la resistència a un fong patogen del sòl, Macrophomina phaseolina. Malgrat la moderada resistència descrita en 
treballs anteriors per al parental Dudaim, cap línia resultà resistent. L'estudi que es presenta en aquesta Tesi sobre la influència de la temperatura en la patogenicitat d'aquest fong ha demostrat que la resistència del parental es superada amb temperatures altes i per tant, no és estable. En aquest estudi, tan sols una entrada silvestre africana resultà resistent a temperatures altes.

També es va realitzar un assaig de tolerància als fongs del sòl Monosporascus cannonballus i M. eutypoides, principals responsables del col·lapse del meló, que causa també moltes pèrdues econòmiques. Els resultats permeteren concloure que M. cannonballus presenta major patogenicitat que $M$. eutypoides i que la temperatura també afecta de forma important a la severitat dels símptomes, recolzant estudis previs. Les dues entrades africanes i la hindú que presentaren major tolerància a Monosporascus spp. poden ser d'interés en futurs programes de millora. 
1. INTRODUCCIÓN 



\section{INTRODUCCIÓN}

\subsection{El melón}

El melón (Cucumis melo L.) es una especie diploide $(2 \mathrm{n}=2 \mathrm{x}=24)$, perteneciente a la familia Cucurbitaceae. Las cucurbitáceas constituyen una amplia familia, la cual comprende casi 200 géneros y alrededor de 800 especies (Kocyan, Zhang, Schaefer, \& Renner, 2007). El origen de las cucubitáceas se sitúa en Asia (Schaefer, Heibl, \& Renner, 2009). Sin embargo, se han encontrado fósiles de semillas de curcubitáceas en Europa de hace 65 millones de años (Collinson, Boulter, \& Holmes, 1993). Las cucurbitáceas se han expandido alrededor del mundo, mucho más allá de sus centros de origen. Esta expansión se ha dado fundamentalmente a través del comercio, lo que marca la importancia de la interacción con los humanos a lo largo de la historia (McCreight, 2017). Las cucurbitáceas se cultivan principalmente en zonas tropicales y subtropicales (Zhang, Simmons, Kocyan, \& Renner, 2006). Entre las especies cultivadas que destacan por su importancia económica tenemos: la sandía [Citrullus lanatus (Thunb.) Matsum. \& Nakai], el melón (Cucumis melo L.), el pepino (Cucumis sativus L.) y las calabazas y calabacines (Cucurbita spp.) (Bai, Zhang, \& Fei, 2017; McCreight, 2017).

\subsubsection{Origen y domesticación del melón}

El melón pertenece al género Cucumis, que comprende aproximadamente 66 especies (Sebastian, Schaefer, Telford, \& Renner, 2010), entre las que destaca también el pepino ( $C$. sativus). Se considera que la especie $C$. melo surgió hace aproximadamente 3 millones de años (Endl et al., 2018; Sebastian et al., 2010). Durante mucho tiempo se tuvo dudas sobre su lugar de domesticación (Thakur, Sharma, \& Thakur, 2019). A pesar de que se establece Asia de forma inequívoca como el centro de origen de la familia Cucurbitaceae, el melón pudo no haber surgido en este continente. Se plantea que pudo originarse a partir de alguno de los grupos de cucurbitáceas ancestrales que se dispersaron en África. Esto se ha visto en otros géneros, por ejemplo, las calabazas del peregrino, género Lagenaria, son de origen africano, pero se dispersaron hasta América Central donde se domesticaron (Kistler et al., 2014).

La controversia sobre el origen de C. melo estuvo marcada en gran medida por la distribución de sus formas silvestres (Gómez-Guillamon \& Álvarez, 2016). Por tal motivo, durante mucho tiempo se pensó que el ancestro silvestre del melón era originario de África, y que este cultivo fue posteriormente domesticado en Oriente Medio y la India (Robinson \& Decker-Walters, 1997). En el pasado, el género Cucumis tenía una clasificación infragenérica basada en dos subgéneros, Cucumis (x=7) y Melo (x=12) (Jeffrey, 1980). En esta línea, Kirkbride (1993) planteaba que el subgénero Cucumis era de origen asiático y el subgénero Melo, de origen 


\section{INTRODUCCIÓN}

africano. La existencia de $C$. melo silvestres en África y Asia hace pensar que pudieron existir varios eventos de domesticación independientes, fueran o no simultáneos (Kerje \& Grum, 2000; Pitrat, 2008; Pitrat, 2013). Los resultados de Endl et al. (2018) respaldan esta afirmación. Aunque en este trabajo se identificaron tres linajes de melón silvestre con claras diferencias genéticas, una de origen asiático, otra australiano y otra africano. Los tipos cultivados o modernos estudiados derivan de dos linajes, el asiático (ssp. melo f. agrestis), siguiendo nomenclatura de Endl et al. (2018) y el africano (ssp. meloides), apoyando la hipótesis de al menos dos eventos de domesticación, uno en Asia y otro en África. Además, estos autores sitúan a $C$. trigonus, procedente de la India, como un pariente silvestre cercano a $C$. melo al mismo nivel que la australiana C. picrocarpus (Sebastian et al., 2010), por lo que la región de la India cobra especial relevancia. Sin embargo, a pesar de haber podido establecer los posibles lugares geográficos donde se domesticó esta especie, ha sido difícil determinar con exactitud el momento exacto de su domesticación. El registro arqueológico sugiere que la domesticación en África comenzó hace al menos 5.000-6.000 años, quizás antes que en Asia (Endl et al., 2018). Estas dataciones son complicadas, no sólo por la dificultad de encontrar registros arqueológicos bien conservados, sino también por la confusión existente en la antigüedad entre diferentes tipos y nomenclaturas (como el caso de melones no dulces más o menos alargados confundidos frecuentemente con pepino), que hacen difícil establecer un consenso en lo relacionado a las primeras épocas de su consumo y/o cultivo.

Al día de hoy, se tiene conocimiento que en la zona actual del sur del Mediterráneo y noroeste de África se cultivaban, hace más de 2.000 años, melones no dulces de forma alargada, conocidos como qishu'im y consumidos principalmente en cocidos. También, aunque menos comunes, se han descrito melones con forma redonda, denominados melopepo, consumidos principalmente frescos en estado maduro (Janick, Paris, \& Parrish, 2007). Este último podría representar una transición importante en el desarrollo de melones dulces (Burger et al., 2002).

Se considera que el melopepo pudo haber sido similar a los melones Adana listados por Pitrat, Hanelt, \& Hammer (2000).

También hay registros de cultivo de melones en China desde hace 3.000 años (Walters, 1989). Lo más probable es que estos melones hayan sido de tipo Conomon (una de las variedades reconocidas en la actualidad y englobadas en el grupo de melones exóticos del lejano oriente) (Pitrat et al., 2000). Los melones verdaderamente dulces, habitualmente con formas redondeadas, parecen haberse descrito en la primera mitad del siglo XIV en el suroeste de Asia (Pitrat, 2003). Posteriormente, se expandieron a través de las rutas comerciales de Europa del este, los Balcanes e Italia, llegando a Europa antes del final del siglo XV (Goldman, 2002; Szabó et al., 2005), donde tuvieron muy buena aceptación. Por el contrario, los melones de 
frutos largos y no dulces disminuyeron su popularidad (Burger et al., 2010). Esta aseveración ha sido respaldada recientemente por Sabato et al. (2019), quienes determinaron que semillas de la edad de bronce encontradas en la isla de Cerdeña, punto importante de rutas comerciales en la antigüedad, pertenecían a un tipo de melón cultivado emparentado con las variedades actuales de Chate, Flexuosus y Ameri (melones no dulces o con bajo nivel de azúcar). Se cree que los tipos Ameri, procedentes de Oriente Próximo y Asia Central, son los ancestros de las variedades dulces modernas, entre los que destacan los melones de tipo Inodorus e Ibericus, como los 'Piel de Sapo', y Cantalupensis, como los 'Charentais'. Posteriormente, durante el período colonial, los melones llegaron a América, donde tuvieron muy buena aceptación, especialmente las variedades dulces (Ríos, 2015).

\subsubsection{Clasificación taxonómica}

Los intentos de clasificar los cultivares de melón se remontan a la primera mitad del siglo XIX (Pitrat et al., 2000). A pesar de los esfuerzos, ni la morfología o fisiología, ni el uso de técnicas moleculares ha permitido llegar a un consenso entre las distintas agrupaciones propuestas, debido al gran polimorfismo observable dentro de la especie (Lebeda et al., 2007). Siempre se ha planteado que una clasificación debe reflejar no sólo las relaciones genéticas, sino también la relación entre los rasgos observados, teniendo en cuenta la importancia de los mismos para científicos, productores, comerciantes y consumidores (Paris, 1989).

El género Cucumis fue descrito por primera vez por Linnaeus en el siglo XVIII en su trabajo Species plantarum (1753) (Kirkbride, 1993). En el siglo XIX, Naudin (1859) realiza la primera clasificación de 13 especies del género Cucumis en dos grupos. Más adelante, Cogniaux (1881) realizó una descripción diferente a Naudin, clasificando 26 especies dentro del género Cucumis, en 10 grupos informales. Surgieron otras clasificaciones, sin embargo el fundamento de las mismas no varió mucho de las anteriores, por lo que se considera que la circunscripción de Cucumis se mantuvo prácticamente estable desde Linnaeus (1753). Fue Jeffrey (1980), quien transformó la base de la clasificación, pasando de un sistema basado solamente en rasgos morfológicos a un sistema emplazado en aspectos fitoquímicos, anatómicos y cromosómicos. De esta manera, consideró que el género Cucumis L. podía dividirse en dos subgéneros, como se ha comentado anteriormente, basados en el número cromosómico, el subgénero Cucumis $(\mathrm{x}=7)$ y el subgénero Melo $(\mathrm{x}=12)$, y este último en cuatro grupos: Metuliferus, Anguria, Melo e Hirsutus. De este modo, por primera vez los melones fueron clasificados en una categoría única. Asimismo, se establecieron dos subespecies dentro de C. melo de acuerdo a la pilosidad del ovario, ssp. agrestis y ssp. melo (Jeffrey, 1990; Kirkbride, 1993). Munger \& Robinson (1991) propusieron dividir la especie en una variedad que incluía todos los tipos silvestres 


\section{INTRODUCCIÓN}

(Agrestis) y seis variedades de tipos cultivados (Cantalupensis, Inodorus, Conomon, Dudaim, Flexuosus y Momordica). Aunque por su simplicidad esta clasificación ha sido una de las más empleadas, con el desarrollo de las técnicas moleculares este criterio resultó muy básico, debido a que resultados de secuenciación de ADN y de genotipado indicaban que algunas variedades designadas taxonómicamente como grupos separados se encontraban filogenéticamente en el mismo grupo (Esteras et al., 2013; Leida et al., 2015; Ghebretinsae, Thulin, \& Barber, 2007; Gonzalo et al., 2019; Renner, Schaefer, \& Kocyan, 2007). Por estos motivos, diversas clasificaciones han ido surgiendo como la de Pitrat et al. (2000), o posteriormente la de Pitrat (2008), en la que se proponían 8 grupos botánicos para la ssp. melo (Tibish, Chate, Flexuosus, Cantalupensis, Reticulatus, Ameri, Inodorus y Dudaim) y 5 para la ssp. agrestis (Conomon, Makuwa, Chinensis, Momordica y Acidulus). Ésta ha sido la clasificación más empleada en los últimos años hasta que recientemente, Pitrat (2017) ha propuesto una nueva basada en 19 grandes grupos. A continuación se detallan las principales características de éstos, incidiendo en los grupos a los que pertenecen los genotipos empleados en el presente trabajo, principalmente tipos 'Piel de Sapo' (PS) y Dudaim (DUD).

\subsubsection{Grupo Agrestis}

No se cultivan, se encuentran silvestres en África, Asia y Australia. Las plantas suelen ser monoicas. Desarrollan frutos pequeños $(20-50 \mathrm{~g})$, de forma redondeada y superficie lisa, generalmente de color verde claro, a veces con manchas o rayas oscuras, sin azúcar ni aroma, y tienen una larga vida postcosecha, aunque pueden encontrarse variedades dehiscentes o no dehiscentes.

\subsubsection{Grupo Kachri}

Son tipos intermedios entre los silvestres (grupo Agrestis) y otros tipos cultivados localmente. Están presentes en algunas zonas de la India. Las plantas son monoicas. Es un grupo heterogéneo, generalmente con frutos pequeños aunque más grandes que los Agrestis (100-200 g), de forma redonda o elíptica, sin costillas. Tienen un color uniforme, que puede ser verde claro, amarillo o crema, con manchas o franjas de color verde oscuro o naranja, sin aroma ni azúcar, y tienen una vida postcosecha larga. Los hay dehiscentes y no dehiscentes.

\subsubsection{Grupo Chito}

Son tipos que se consideran asilvestrados y que se encuentran distribuidos en la zona de América Central y el Caribe. Las plantas de este grupo son monoicas. Los frutos son pequeños (50-100 g), de forma redonda u ovoide, y tienen un color verde claro uniforme, con la superficie 
lisa, sin costillas, ni reticulado. No presentan aroma ni azúcar, y tienen una larga vida postcosecha. Presentan pedúnculo dehiscente.

\subsubsection{Grupo Tibish}

Son melones cultivados endémicos de Sudán, donde son consumidos en estado inmaduro. Son andromonoicas. Sus frutos son pequeños, de forma elíptica o piriforme, sin tractos venosos ni costillas, con corteza suave y de color verde claro con manchas verde oscuras (o lo opuesto). No presentan aroma ni azúcar, y tienen una larga vida postcosecha. Son frutos no dehiscentes.

\subsubsection{Grupo Acidulus}

Se cultiva principalmente en la India y Sri Lanka. Son plantas monoicas de frutos pequeños, de forma ovalada o elíptica, sin costillas ni arrugas. Normalmente presentan un color de corteza que va de amarillo a naranja, con rayas. No presentan aroma ni azúcar, y tienen una larga vida postcosecha. No dehiscente. Es un grupo interesante por presentar entradas con diversas resistencias a enfermedades (virus, oidio, mildiu, Aphis gossypii).

\subsubsection{Grupo Momordica}

Este grupo se cultiva principalmente en la India y el Sudeste Asiático. Son plantas monoicas. Desarrolla frutos medianos, con una forma heterogénea que va de alargada a ovalada, y con una corteza suave y lisa de un color uniforme o con moteado o rayado. La pulpa es de textura harinosa con bajo contenido en azúcares y $\sin$ aroma. Son de maduración temprana y climatérica, con pedúnculo dehiscente, y tienen una vida postcosecha muy corta, pues se rompen o rajan en la madurez. Hay descritas muchas resistencias a enfermedades en entradas de este grupo.

\subsubsection{Grupo Conomon}

Se cultivan en el Lejano Oriente (China, Japón) y se consumen en estado inmaduro crudos o en encurtidos. Las plantas son andromonoicas. Sus frutos presentan forma ovalada o alargada, generalmente son de color verde claro o blanco y con la superficie lisa. No presentan aroma ni azúcar, y tienen una vida postcosecha larga.

\subsubsection{Grupo Makuwa}

También se cultivan en el Lejano Oriente. Mayoritariamente son tipos andromonoicos, aunque existen unas pocas entradas hermafroditas. Tienen frutos medianos, de forma redondeada, sin arrugas ni reticulado. Tienen un contenido medio en azúcar y una vida postcosecha corta, con maduración temprana y dehiscencia. Se han encontrado muchas resistencias a enfermedades en este grupo (virus, Fusarium wilt race 1.2, A. gossypii). De acuerdo a la coloración de la corteza 


\section{INTRODUCCIÓN}

y a la presencia/ausencia de venas así como de la forma de las semillas se consideran varios subgrupos (Katsumata \& Yasui, 1964): 'Ogon', 'Nashi-uri', 'Yuki', 'Kanro', 'Ginmakuwa' y 'Seikan'.

\subsubsection{Grupo Chinensis}

Como los melones Conomon y Makuwa, también es cultivado en el Lejano Oriente. Son plantas andromonoicas, con frutos piriformes de tamaño medio, sin reticulado, de color verde claro con manchas verde oscuras. La pulpa tiene bajo contenido de azúcar y aroma. Presentan una maduración tardía, son no dehiscentes y presentan una larga vida postcosecha. Se han descrito varias resistencias a enfermedades en este grupo (virus, A. gossypii).

\subsubsection{Grupo Flexuosus}

Se cultivan en una extensa área que abarca la región mediterránea hasta la India. Son plantas monoicas que desarrollan frutos de forma alargada que pueden alcanzar hasta $2 \mathrm{~m}$, y que se consumen en estado inmaduro como el pepino. Suelen ser de color uniforme, verde claro u oscuro que se vuelve color crema en la madurez. Su pulpa es de textura harinosa, sin azúcar y sin aroma. Su vida postcosecha es muy corta. Dependiendo de si la superficie del fruto es lisa, arrugada o acostillada se distinguen tres subgrupos: 'Adjour', 'Tara' y 'Arya'.

\subsubsection{Grupo Chate}

Como el grupo Flexuosus, los tipos Chate se cultivan para consumo en inmaduro. Son plantas monoicas que desarrollan frutos de tamaño medio con formas redondas a ovaladas y con una superficie vellosa, generalmente con tractos venosos o acostillamiento. Son frutos de color crema, de pulpa blanda y textura harinosa en la madurez, con muy bajo contenido en azúcar y sin aroma. Presentan maduración temprana, pedúnculo dehiscente y una vida postcosecha corta.

\subsubsection{Grupo Chandalak}

Este grupo se cultiva desde Asia Central hasta la India. Son plantas andromonoicas. Sus frutos, de tamaño medio, presentan forma redonda o achatada, sin costillas o ligeramente acanalados, con reticulado variable y con frecuencia presencia de vetas verdes. La corteza es de color uniforme, verde, anaranjada o blanca, en ocasiones con motas. La pulpa es de textura fibrosa, con un contenido medio de azúcar y bajo aroma. Son dehiscentes, de maduración temprana y corta vida postcosecha. En función del reticulado y los tractos venosos se definen varios subgrupos: 'Zami', 'Tachmi', 'Garma' y 'Bucharici'. 


\subsubsection{Grupo Indicus}

Se cultivan en la India Central. Son plantas andromonoicas. Sus frutos son considerados de muy buena calidad. Son medianos, de forma elíptica, con tractos venosos de color verde oscuro, sin costillas, ni arrugas. La corteza puede presentar diversas coloraciones: gris, naranja, marrón, crema. La pulpa tiene un alto contenido en azúcares y presenta una consistencia firme y jugosa. Son dehiscentes y tienen una vida postcosecha media.

\subsubsection{Grupo Ameri}

Se cultivan en Asia, desde Turquía a China Occidental. Son plantas andromonoicas, con frutos de forma ovalada o cilíndrica, de peso medio a alto, y sin costillas ni arrugas. La pulpa es de textura lisa, jugosa y a veces crujiente, con un alto contenido de azúcar. Su vida postcosecha es media-larga. De acuerdo con el color de la corteza y la presencia/ausencia de tractos venosos, se pueden clasificar en estos subgrupos: 'Ananas', 'Maculati', 'Bargi’ y 'Mashhadi'.

\subsubsection{Grupo Cassaba}

Se cultiva principalmente en Asia Occidental y Central. Son plantas andromonoicas, con frutos piriformes de tamaño medio-alto, que suelen presentar arrugas y corteza gruesa, pero no costillas ni reticulado. La pulpa presenta un alto contenido en azúcares. Son de maduración tardía, no dehiscentes y tienen una larga vida postcosecha. De acuerdo con el color de la corteza se clasifican en estos subgrupos: 'Kirkagac', 'Hassanbey’ y 'Kuscular'.

\subsubsection{Grupo Cantalupensis}

Este grupo se desarrolló en Europa, probablemente derivado de melones turcos, y tiene gran importancia económica, no sólo en Europa sino también en EE.UU. Son plantas típicamente andromonoicas, con frutos de tamaño medio redondos o achatados. Poseen escaso reticulado, no presentan arrugas y su color externo varía de blanco a verde, mientras que el color de la pulpa suele ser naranja. La pulpa, de textura lisa y jugosa, presenta alto contenido en azúcares y fuerte aroma. Tiene maduración climatérica, con dehiscencia y una vida postcosecha cortamedia. Presenta una diversidad notable, con seis subgrupos: 'Prescott', 'Saccharinus', ‘Charentais', ‘Ogen', ‘American Western' y ‘American Eastern'.

\subsubsection{Grupo Inodorus}

Son melones poco aromáticos y de larga vida, que se cultivan principalmente en América o en Japón, aunque derivan de tipos europeos. Son plantas andromonoicas, con frutos de tamaño medio y forma redonda, sin arrugas ni costillas, y pueden presentar o no reticulado. Son frutos no dehiscentes, de corteza gruesa y pulpa muy dulce. Se identifican dos subgrupos: 'Honeydew' y 'Earl's'. 


\section{INTRODUCCIÓN}

\subsubsection{Grupo Ibericus}

Este grupo se cultiva principalmente en España, pero también es popular en toda la región mediterránea, América del Norte y del Sur. Sus plantas suelen ser andromonoicas. Desarrollan frutos de forma elíptica, a veces redonda, más o menos arrugados, sin costillas y generalmente $\sin$ reticulado. Su peso varía de medio a alto. El exocarpo es de piel gruesa y la pulpa es jugosa, muy dulce y poco aromática. Son frutos de maduración tardía y no climatéricos. De acuerdo principalmente con el color externo y alguna otra característica morfológica, Pitrat (2017) define cinco subgrupos: 'Piel de Sapo', 'Amarillo', 'Tendral', 'Rochet' y 'Branco'.

La variedad de tipo 'Piel de Sapo' ha sido utilizada en la presente Tesis por su destacada importancia económica en España. La zona tradicional de cultivo de esta variedad es CastillaLa Mancha (Ribas et al., 2011), aunque pueden encontrarse variedades locales en muchas regiones españolas, como por ejemplo en la Comunidad Valenciana, Aragón, Extremadura, Andalucía, Cataluña, Murcia y la Comunidad de Madrid (Lázaro et al., 2017). Al ser el principal tipo comercial, en la actualidad se cultiva en todas las zonas productoras de nuestro país. Los frutos de los cultivares de tipo 'Piel de Sapo' presentan en general forma ovalada. Su corteza es de color verde con manchas oscuras, y puede ser lisa o de rugosidad variable. La pulpa es blanca, crujiente, jugosa y con un alto contenido en azúcar.

\subsubsection{Grupo Dudaim}

Los melones de este grupo no se consumen, sino que se usan de forma ornamental por su original apariencia y fragancia (Pitrat, 2017).

No se tiene registros de descripciones de melones del grupo Dudaim en la Europa Mediterránea antigua (500 D.C). Un estudio realizado por Paris, Amar \& Lev (2012) establece que la primera mención de melones Dudaim se registra en el siglo IX en la zona que actualmente corresponde a Irán e Irak. Posteriormente, en el siglo X se mencionan en Túnez (Sabbah, 1992), Egipto (Leclerc, 1883) y en los alrededores de Córdoba, España (Pellat, 1961). Se conoce que a finales del siglo XII el cultivo de Dudaim se encontraba extendido en el oeste de España como una planta ornamental y a finales del siglo XV su presencia era muy común en Turquía (Paris et al., 2012). Estos registros históricos plantean que, aparentemente, los melones Dudaim se difundieron hacia el oeste, desde Irán e Irak, hasta el Mediterráneo. Esta expansión se debió en gran medida a las rutas de comercio marítimas establecidas durante el Imperio Islámico (Harvey, 1975). Actualmente, se cultivan melones Dudaim desde Turquía a Afganistán y hacia el norte hasta Turkmenistán (Pitrat, 2017).

Las plantas de Dudaim son andromonoicas. Los frutos son climatéricos, maduran aproximadamente un mes después de la polinización. Cuando son inmaduros son parecidos a 
diminutas sandías, con franjas verde oscuro y manchas que se alternan con franjas verde claro (Paris et al. 2012). En la madurez cambian de color a amarillo con franjas naranja/ocre (Pitrat, 2017). Son relativamente pequeños, de unos $6 \mathrm{~cm}$ de diámetro, esféricos, rayados, lisos y aterciopelados, sin reticulado, lóbulos, surcos, o arrugas (Figura 1.1) (Paris et al., 2012). La pulpa es blanquecina, flácida e insípida. Aunque la pulpa no es muy dulce, un rasgo notable es el fuerte aroma que desprende la corteza, que es mucho más fina que la de los melones comerciales (Figura 1.1). El aroma de la corteza generalmente es descrito como una mezcla de cantalupo, piña y un toque de jazmín (Aubert \& Pitrat 2006). Aubert \& Pitrat (2006), en un estudio de los componentes volátiles de la corteza y pulpa de melons de tipo Dudaim, vieron que la distribución de los mismos difería ligeramente, siendo más elevado el nivel de volátiles en la corteza. En base a este estudio formularon la hipótesis de que el eugenol, principal volátil presente en la corteza (15.3\%), ésteres de tioéter y distintos tipos de lactonas, eran los compuestos responsables del aroma único de este tipo de melón. En un trabajo más reciente, Esteras et al. (2018), indicaron que el aroma de la pulpa de Dudaim es similar a los melones de makuwa, pero con niveles más altos de algunos monoterpenoides y sobretodo de $\gamma$ dodecalactona, así como también de eugenol, lo que confirma estos resultados previos.

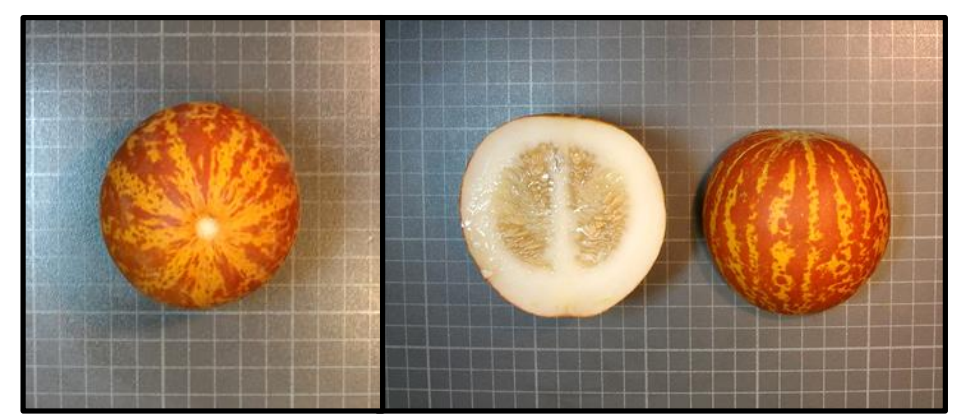

Figura 1.1. Melones grupo Dudaim.

\subsubsection{Importancia económica}

El melón es un cultivo con importancia a escala mundial, por lo que su producción tiene un gran impacto a nivel económico. Generalmente se consume como fruta. Su dulzor, sabor, textura y, en algunos casos, aroma lo hacen un producto de gran demanda en el mercado (Lester, 2008). Los tipos no dulces en estado inmaduro también son consumidos en ensaladas, encurtidos, etc. Por otra parte, este fruto también es rico en nutrientes como ácido ascórbico, carotenos, ácido fólico y potasio, así como en una serie de otros compuestos bioactivos beneficiosos para la salud (Lester \& Hodges, 2008). En China, las frutas y las raíces de esta especie se toman como emético, las hojas y las semillas se usan para tratar el hematoma y los tallos para reducir la hipertensión (Nuñez-Palenius, Huber, Klee, \& Cantliffe, 2007). 


\section{INTRODUCCIÓN}

En el año 2017, la producción mundial de melón superó los 31 millones de toneladas. Actualmente, a escala global China es el principal productor, con 17 millones de toneladas, seguido de Turquía e Irán. España ocupa la octava posición (Figura 1.2A).
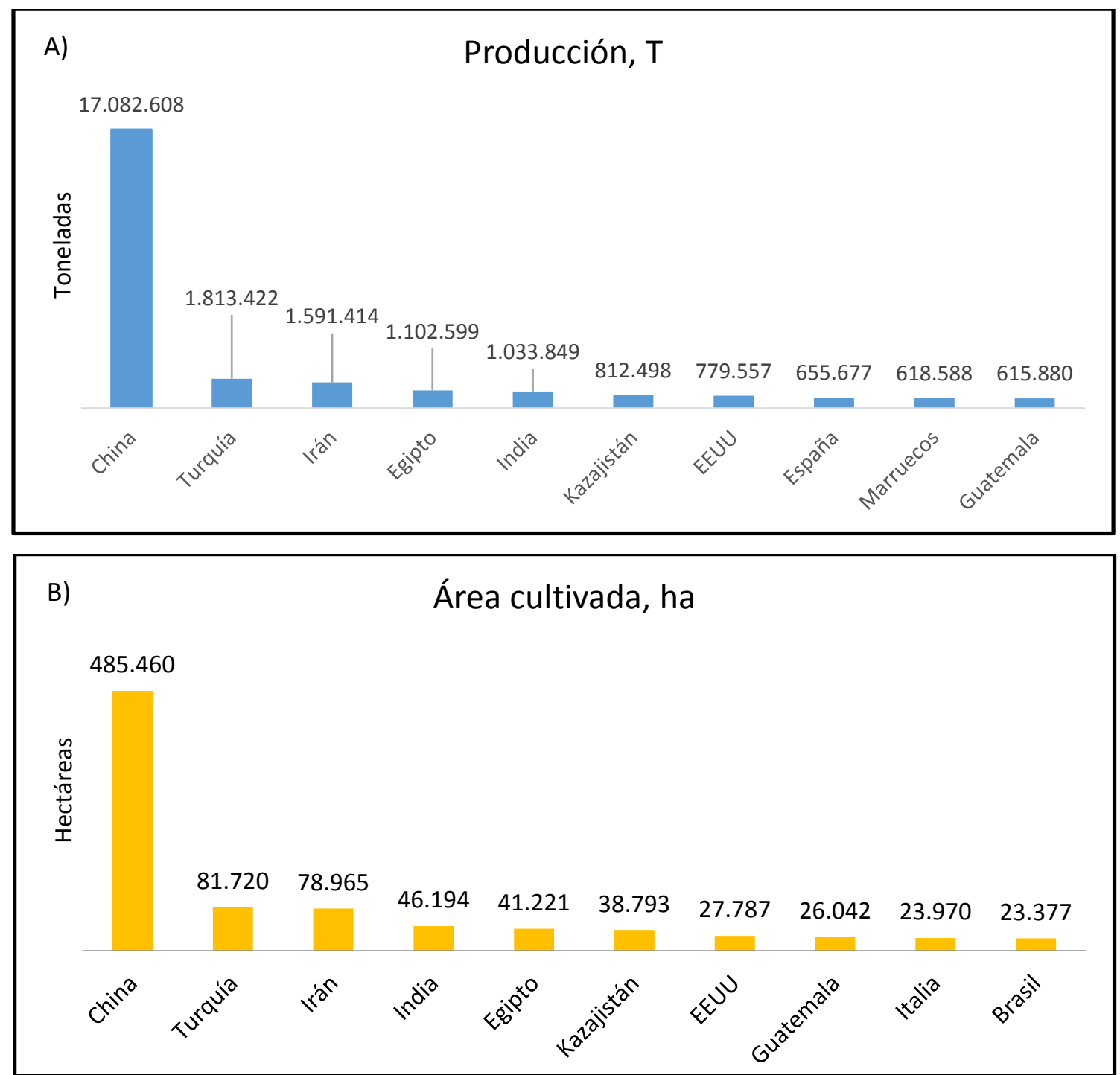

Figura 1.2. Listado de los 10 países (A) con mayor producción de melón expresada en toneladas (Tn) y (B) con mayor área cultivada expresada en hectáreas (ha) (datos del año 2017). Fuente: FAOSTAT http://faostat3.fao.org

Por continentes, Asia es el principal productor, con el $75,70 \%$ de la producción mundial, seguido por América (11,20\%), África (6,40\%), Europa $(5,90 \%)$ y Oceanía $(0,80 \%)$ (Figura $1.3)$. 


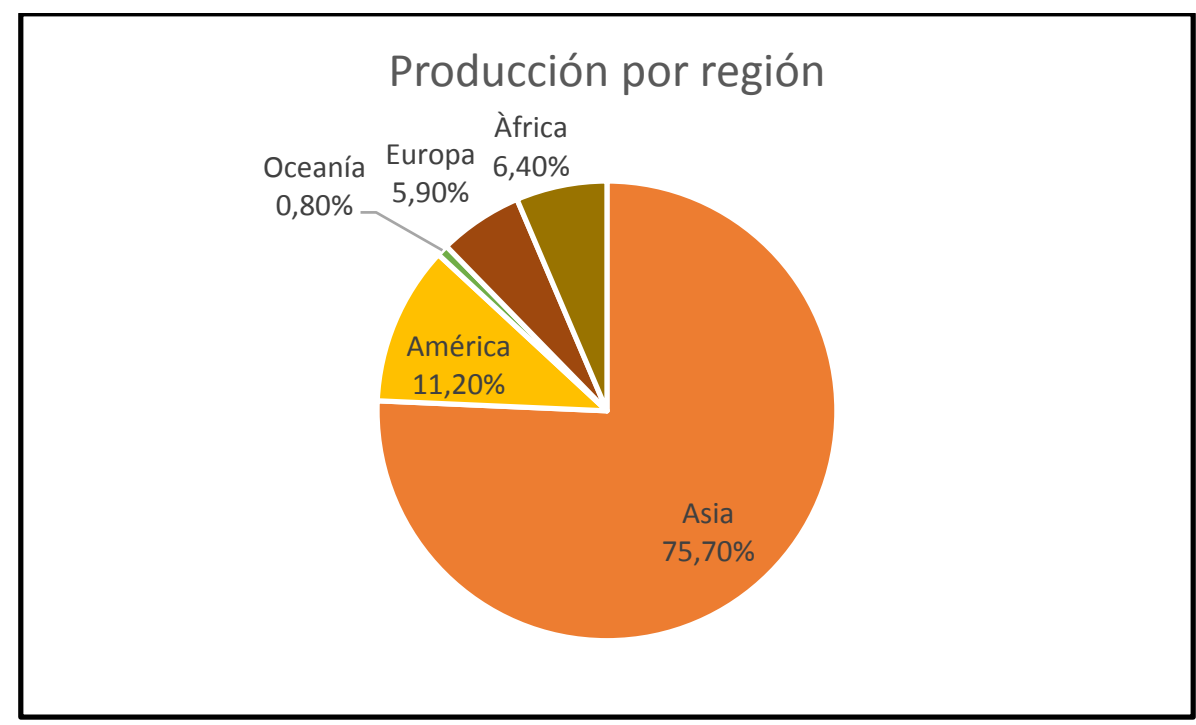

Figura 1.3. Distribución del porcentaje de producción por continentes (datos del año 2017). Fuente: FAOSTAT http://faostat3.fao.org

La producción de España en 2017 fue de 655.677 toneladas (Figura 1.2A) obtenidas en 20.473 hectáreas cultivadas. A pesar de que China es el mayor productor global, casi toda su producción la destina para consumo interno. En cambio, España destina la mayor parte de su producción para la exportación, de hecho, en 2016 lideró la lista de países con la mayor tasa de exportación de melón a nivel mundial (Figura 1.4). En este año, España destinó un 68,24\% de la producción total a la exportación. A pesar de que España no se encuentra entre los 10 principales países productores en términos de área cultivada de melón (Figura 1.2B), el rendimiento de su producción por superficie es notable, lo que evidencia el gran impacto económico que tiene este cultivo en nuestro país.

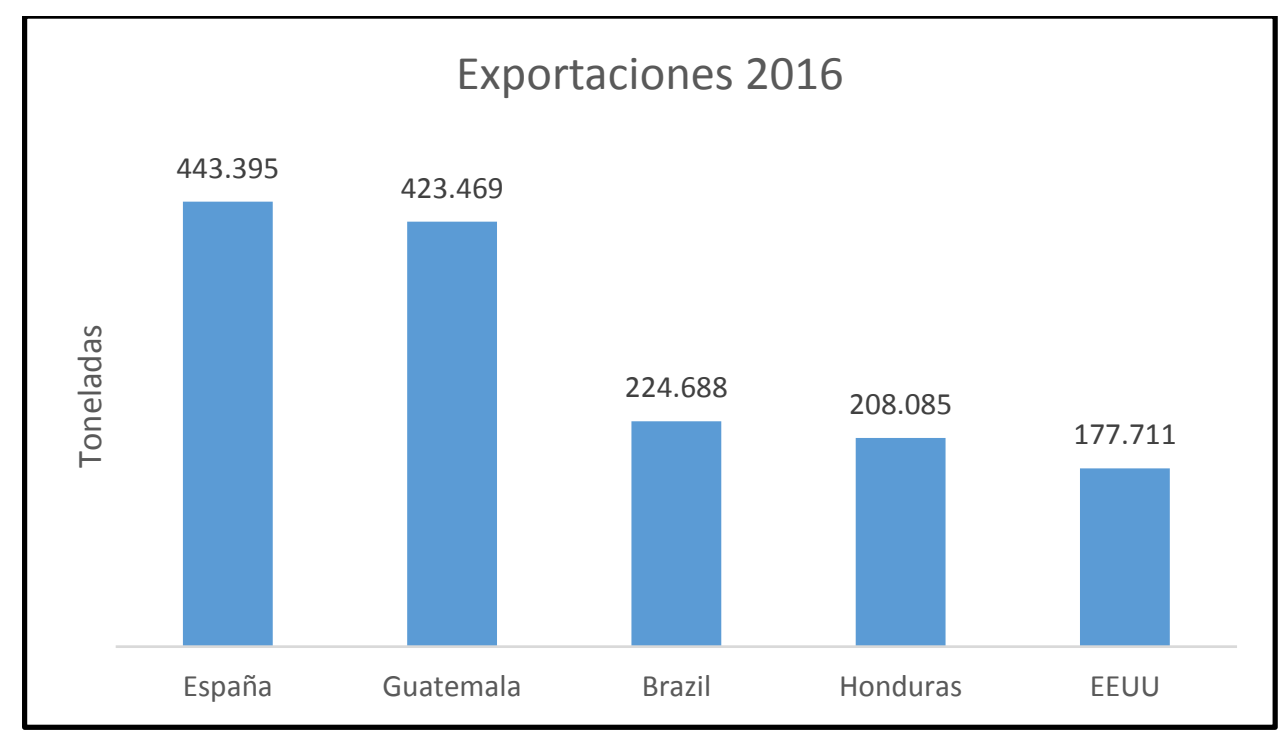

Figura 1.4. Listado de los 5 países con mayor exportación de melón registrada en el año 2016. Fuente: FAOSTAT http://faostat3.fao.org 


\section{INTRODUCCIÓN}

\subsubsection{Recursos fitogenéticos y su explotación}

La difusión de los ancestros del melón actual a diversas regiones del planeta, así como las hibridaciones espontáneas, son la principal causa de la gran diversidad que se observa en esta especie. Se conocen diversos centros primarios y secundarios de diversidad, como Turquía, Irán, Afganistán, India, Japón, China, Portugal y España, entre otros (Luan, Delannay \& Staub, 2008). Sin embargo, la tendencia de los últimos años en los mercados de ofrecer productos con características estandarizadas y variedades uniformes altamente productivas y adaptadas a cultivo intensivo, ha ido asociada a una pérdida importante de diversidad en este cultivo. Los recursos fitogenéticos son la base biológica de la seguridad alimentaria, incluyen materiales de variedades tradicionales, de cultivares modernos, así como también de variedades silvestres afines a los cultivos (FAOSTAT, 2019).

Las especies silvestres del género Cucumis, al que pertenece el melón, presentan considerables problemas de incompatibilidad sexual. De hecho, sólo en melón se han descrito hasta el momento cruzamientos intraespecíficos exitosos (Hogenboom, 1973; Kho, Den Nijs \& Franken, 1980). Por ello, la mejora de esta especie se ha orientado fundamentalmente al empleo de la variabilidad intraespecífica. Se han empleado accesiones de algunos de los grupos horticulturales descritos anteriormente, tanto para la mejora de la resistencia a enfermedades como para la mejora de la calidad. Por ejemplo, algunas entradas de interés pertenecientes a los grupos Kakri y Momordica de la India (IC 274014, IC 274031, IC 274046, IC 267378, PI 414723, PI 180280, PI 180283, PI 124112), Acidulus de la India (TGR-1551) y Chinensis del Lejano Oriente (PI 161375) (Dhaliwal, 2016; Dhillon, Singh, Pitrat, Monforte, McCreight, 2015; Dogimont, 2011) han demostrado ser un valioso reservorio de genes de utilidad frente a enfermedades víricas como el virus del amarilleo transmitido por pulgón (Cucurbit aphid borne yellow virus, CABYV), virus del mosaico del calabacín (Zucchini yellow mosaic virus, ZYMV), virus del cribado (Melon necrotic spot virus, MNSV), virus del enanismo amarillo de las cucurbitáceas (Cucurbit yellow stunting disorder virus, CYSDV), virus del mosaico del pepino (Cucumber mosaic virus, CMV), virus del mosaico de la sandía (Watermelon mosaic virus, WMV); fúngicas como el oidio (principalmente Podosphaera xanthii) o Fusarium oxysporum f. sp. melonis (Fom), y plagas de insectos como Aphis gossypii. De igual manera, en relación con la calidad, la gran variabilidad fenotípica de la especie ha permitido modificar rasgos como la morfología y el color del fruto, el tipo de maduración y el contenido de nutrientes (Eduardo et al., 2007; Monforte et al., 2004; Perpiñà, Esteras, Gibon, Monforte, \& Picò, 2016).

Las colecciones de germoplasma son fundamentales para la conservación y utilización de estos recursos genéticos (Fergany et al., 2011; Grumet, Garcia-Mas \& Katzir, 2017; Malik et al., 
2014; Renner \& Schaefer, 2016; Singh et al., 2015), siendo las colecciones de germoplasma asiático y africano las más interesantes hasta el momento (Thakur et al., 2019).

Los repositorios de germoplasma del USDA (United States Department of Agriculture)/NPGS (National Plant Germplasm System) (https://www.ars-grin.gov/npgs/), han estado durante años a disposición de investigadores de todo el mundo para la mejora del melón (McCreight, 2017). Adicionalmente, existen colecciones de interés en otros países (Grumet et al., 2017). En la Universitat Politècnica de València se encuentra el Instituto Universitario de Conservación y Mejora de la Agrodiversidad Valenciana (COMAV) que conserva su propia colección de melón y especies relacionadas (http://www.comav.upv.es). La existencia de múltiples colecciones, además de proporcionar una gran diversidad de germoplasma, también garantiza la seguridad contra posibles pérdidas.

El incremento de herramientas genómicas disponibles en esta especie está favoreciendo la caracterización y la conservación de estos recursos fitogenéticos. Los proyectos de secuenciación y las plataformas de genotipado masivo permiten el re-descubrimiento de variabilidad existente que se ha pasado por alto (Chomicki \& Renner, 2017; Sebastian et al., 2010).

\subsubsection{Herramientas genómicas disponibles en melón}

El uso de marcadores moleculares constituye la principal herramienta en el estudio genético del melón (O’Brien, 1990). Los primeros marcadores moleculares probados en esta especie fueron las isoenzimas (Becerra \& Paredes, 2000). Posteriormente, el desarrollo de marcadores basados en secuencias de ADN (Winter \& Kahl, 1995), como RFLP (Restriction Fragment Length Polymorphisms), permitió la construcción de los primeros mapas genéticos en melón (Oliver et al., 2001). Los SSRs (Simple Sequence Repeats) fueron los marcadores de referencia en genética vegetal desde finales de los 90 (Hamada, Petrino, \& Karkunaga, 1982) hasta la llegada de los marcadores SNPs (Single-Nucleotide Polymorphism). Los SNPs son marcadores bialélicos, codominantes, y se encuentran distribuidos aleatoriamente por el genoma de cualquier especie (Mammadov et al., 2012). En la actualidad, están disponibles amplias colecciones de marcadores de tipo SNP en melón, habiéndose validado muchos de ellos con diversas plataformas de genotipado (Blanca et al., 2011, 2012; Esteras et al., 2013; Gonzalo et al., 2019; Leida et al., 2015). Estos marcadores constituyen hoy en día un pilar fundamental en el estudio de la genética del melón.

El desarrollo de las nuevas tecnologías de secuenciación masiva (NGS), significó una "revolución" en el campo de la mejora de especies no modelo. Los proyectos de secuenciación de transcriptomas y genomas, así como de resecuenciación en busca de variantes entre diversos 


\section{INTRODUCCIÓN}

genotipos, pudieron abordarse en especies, como C. melo, para las que habrían sido inviables estas aproximaciones con la metolología clásica de secuenciación Sanger. La secuencia del genoma del melón se completó en 2012, empleando el sistema 454 de Roche en el marco del proyecto MELONOMICS (http://www.melonomics.net) (Garcia-Mas et al., 2012).

En la primera secuencia completa publicada del melón, versión v.3.5, el 90\% del ensamblaje estaba contenido en 78 scaffolds (González et al., 2010). Trabajos posteriores al proyecto MELONOMICS, como los realizados por Argyris et al. (2015), permitieron optimizar y actualizar el ensamblaje del genoma, obteniendo una versión mejorada, v.3.5.1. En esta versión, el 98,2\% del genoma estaba contenido en 141 scaffolds, el $90.5 \%$ de los mismos anclados al genoma. Posteriormente, Ruggieri et al. (2018) presentaron un ensamblaje mejorado (v.3.6.1) del genoma y una nueva versión de las anotaciones (v4.0). En esta nueva versión (v.3.6.1), 375,3 Mpb se encuentran en 147 scaffolds, respresentando una mejora del ensamblaje del $5,74 \%$ con respecto a la versión anterior (v.3.5.1).

El proyecto MELONOMICS, en el marco del cual se secuenció la primera versión del genoma del melón, significó un antes y un después en la investigación en este cultivo, ya que además posibilitó la generación de mapas genéticos anclados al genoma más saturados que los obtenidos hasta ese momento (Baudracco-Arnas \& Pitrat, 1996; Deleu et al., 2009; FernandezSilva et al., 2008; Gonzalo et al., 2005; Harel-Beja et al., 2010; Oliver et al., 2001; Périn et al., 2002a), siendo necesaria la realización de mapas consenso que unificaran la información hasta el momento generada con diversas poblaciones (Argyris et al., 2015; Díaz et al., 2011; 2015). Cabe destacar otras herramientas (Microarrays, Tilling, RNA-Seq) que se han desarrollado a partir de marcadores moleculares y han permitido profundizar en el estudio de la genómica funcional del melón. Trabajos basados en la utilización de microarrays de ADN (MascarellCreus et al., 2009) han aportado información valiosa a nivel transcriptómico de expresión de genes en tejidos y condiciones específicas. Técnicas derivadas de microarrays, como DArTseq, han permitido la identificación de SNPs en melón (Zaitoun et al., 2018). Otra técnica muy extendida es el desarrollo de plataformas Tilling (Targeting Induced Local Lesions in Genomes) y Ecotilling, métodos de genética reversa, para la caracterización de mutantes inducidos a partir de la mutagenización de semillas o polen, o de variación natural. En este sentido, trabajos en melón como los de Dahmani-Mardas et al. (2010), González et al. (2011) o Tadmor et al. (2007) han permitido un mejor estudio de la función de los genes y la generación de nueva variación. La gran ventaja que ofrece esta técnica respecto a otras es la capacidad de estudiar la variabilidad funcional de diferentes alelos de un mismo gen sin requerir la obtención de transgénicos. 
La técnica del RNA-seq está también aplicándose cada vez más en melón para estudiar el patrón de expresión de los genes en distintos tejidos o condiciones. Por ejemplo, en un estudio reciente Yano, Nonaka \& Ezura (2018) analizaron mediante RNA-seq la expresión génica de más de 20.000 genes en 30 tejidos diferentes de la accesión japonesa de melón "Harukei-3"; (https://gene.melonet-db.jp/ap/mvw). Esta herramienta permitirá grandes avances en el estudio de la genómica funcional del melón.

Entre las herramientas disponibles, una de las más empleadas en los programas de mejora genética del melón es la selección asistida por marcadores mediante el uso de distintas plataformas de genotipado.

\subsubsection{Métodos de genotipado de SNPs}

Un aspecto primordial que persiguen las herramientas genómicas consiste en permitir establecer la conexión entre el genotipo y el fenotipo, para esto resulta imprescindible la identificación de regiones genómicas asociadas a rasgos de interés. La detección de dichas regiones es posible gracias a la existencia de polimorfismos nucleotídicos. Por consiguiente, la disponibilidad de una buena secuencia genómica es de gran ayuda en la asociación de la variabilidad fenotípica a genes o regiones genómicas, parte primordial en los procesos de mejora para el desarrollo de nuevos cultivares (Rubio-Cabetas, Picò, Casas, \& Badenes, 2014).

Actualmente, el desarrollo vertiginoso de las plataformas de secuenciación masiva permite disponer de grandes cantidades de secuencias genómicas a bajo costo y en menor tiempo. La secuenciación masiva en $C$. melo ha proporcionado amplias colecciones de marcadores polimórficos entre accesiones de interés (Gonzalo et al., 2019). La selección asistida por marcadores constituye en sí una técnica de gran impacto en los procesos de mejora, ya que permite disminuir considerablemente el número de generaciones para conseguir los objetivos propuestos. La aplicación práctica de estos marcadores en programas de mejora pasa por el empleo de estrategias de genotipado de densidad baja, media o alta. A continuación se describen tres técnicas de uso muy extendido en programas de mejora y que han sido utilizadas en la presente Tesis Doctoral.

\subsection{Secuenciación "Genotyping by Sequencing" (GBS)}

Este método está basado en tecnología NGS (Next-Generation Sequencing). A diferencia de otros métodos que utilizan la técnica RAD-seq (Restriction Site Associated DNA Markers Sequencing), en la que el ADN genómico tras la digestión con endonucleasas de restricción es sometido a una segunda fragmentación aleatoria (López de Heredia, 2016), la técnica de GBS utiliza enzimas de restricción sensibles a metilación, evitando así regiones repetitivas del 


\section{INTRODUCCIÓN}

genoma y realizando una secuenciación más eficiente de fragmentos únicos o con menor número de copias en los genomas (Elshire et al., 2011). Una de las ventajas de la técnica GBS, por tanto, es su mayor simplicidad para reducir la complejidad del genoma empleando ciertas enzimas de restricción que, además de asegurar la suficiente cobertura de secuenciación de esos fragmentos, generen extremos cohesivos y no presenten un excesivo número de dianas de restricción, en el genoma en general y en secuencias transponibles y repetitivas en particular. Además, estas técnicas de genotipado asociadas a NGS incrementan la eficiencia empleando sistemas de multiplexing gracias al uso de secuencias o barcodes que identifican cada muestra de forma inequívoca. En el caso de la técnica GBS, estas combinaciones de barcodes son diseñadas de forma que se diferencian al menos en tres bases para asegurar una mínima tasa de error en la identificación de las lecturas de cada muestra. El protocolo básicamente consiste en la generación de una genoteca GBS, la posterior secuenciación de ésta mediante técnicas NGS Illumina y el posterior análisis bioinformático hasta la detección de los polimorfismos existentes entre las diferentes muestras. La construcción de la genoteca se realiza empleando un enzima de restricción que cumpla los requisitos mencionados anteriormente. Tras la digestión de los ADN genómicos, se ligan dos adaptadores a los extremos generados (uno de ellos incluye la secuencia barcode) y se conforma el pool con los fragmentos de todas las muestras ya identificados por su barcode. El empleo de cebadores complementarios a los adaptadores posibilita la amplificación posterior necesaria para el proceso de secuenciación (Elshire et al., 2011). Con los millones de lecturas obtenidas se realiza un proceso complejo de limpieza y filtrado para realizar la identificación de SNPs únicamente con las lecturas con un mínimo de calidad y cobertura (Elshire et al., 2011).

La cantidad de SNPs obtenida con GBS es tan grande que permite aplicar criterios muy restrictivos en el proceso de selección en programas de mejora (Rubio-Cabetas et al., 2014). De hecho, este método ha sido utilizado en los últimos años con el propósito de tener una caracterización más completa de líneas o variedades desarrolladas y de construir mapas saturados en muchas especies, incluyendo nuestra especie objetivo, el melón (Chang, Wang, \& Tung, 2017; Gur et al., 2017a; Nimmakayala et al., 2016; Pavan et al., 2017; Pereira et al., 2018).

\subsection{Plataforma de genotipado Agena Bioscience iPLEX}

Existen plataformas de genotipado de mediana o pequeña escala, utilizadas para validar un número limitado de marcadores polimórficos, previamente seleccionados, en determinadas muestras. Entre ellas destaca la tecnología Agena Bioscience iPLEX ® Gold MassARRAY (antiguamente denominada Sequenom iPLEX) (Gabriel et al., 2009), que resulta de 
modificaciones de la técnica descrita por Tang et al. (1999), basada en la extensión de cebador y espectrometría de masas. Esta técnica Agena Bioscience iPLEX consiste en la realización de una PCR multiplex de los fragmentos de ADN que contienen los SNPs de interés. Tras una PCR específica de locus tiene lugar una extensión de cebador específica de locus en el que el cebador se une justo antes del sitio polimórfico. En este paso se incorporará el nucleótido correspondiente a la variante del SNP. Esta incubación se lleva a cabo con dideoxinucleótidos terminadores de masa modificada, lo que permitirá su posterior identificación. En segundo lugar, mediante espectrometría de masas y empleando la tecnología MALDI-TOF (MatrixAssisted Laser Desorption/Ionization-Time Of Flight), se determina la masa de los cebadores extendidos y así se distinguen los diferentes alelos para los diferentes loci (Gabriel et al., 2009). La disponibilidad de software específico ayuda en el proceso semi-automático de conversión de estos datos a un genotipo concreto para cada muestra y locus.

Esta plataforma ha sido muy utilizada para genotipado asociado a diagnóstico en humanos, pero también en pequeños ensayos en muchas especies de interés agronómico como C. melo (Nunes et al., 2017; Perpiñà et al., 2016; Sáez et al., 2017).

\subsection{High Resolution Melting (HRM)}

A diferencia de la técnicas anteriores, la técnica HRM (High Resolution Melting) no permite el genotipado de varios loci de forma simultánea, pero en los casos en los que interesa pasar pocos SNPs en pocas muestras resulta muy útil, especialmente en ciertos momentos de los programas de mejora en los que se busca la selección de ciertos individuos con una introgresión concreta (Rubio-Cabetas et al., 2014).

La técnica HRM (Vossen, Aten, Roos, \& den Dunnen, 2009) se basa en la realización de una amplificación de una secuencia que contiene el sitio polimórfico y su posterior desnaturalización para obtener las curvas de disociación y calcular la temperatura de fusión (Tm). Esta Tm será diferente en función de la secuencia de cada alelo, de forma que permitirá determinar el genotipo de cada muestra. Para ello, se requiere del uso de una molécula intercalante emisora de fluorescencia (dye) y de un aparato Real Time-PCR muy sensible y preciso, que detecte la pérdida de fluorescencia a pequeños aumentos de temperatura durante la desnaturalización, para poder calcular con precisión estas curvas identificativas de cada variante.

Como en las técnicas anteriores, el genotipado de SNPs mediante HRM se ha utilizado con éxito en muchas especies (Chagné et al., 2008; de Koeyer et al., 2010; Perpiñà et al., 2016; Wu et al., 2009). 


\section{INTRODUCCIÓN}

\subsection{Objetivos y programas de mejora}

Desde la antigüedad, la mejora vegetal se ha realizado seleccionando genotipos con mejores propiedades agronómicas (Diamanti, Battino, \& Mezzetti, 2011). Sin embargo, el empleo de métodos clásicos de mejora es relativamente lento y se restringe a un conjunto reducido de rasgos (Bardin, Dogimont, Nicot, \& Pitrat, 1999). Por esta razón, el uso de las herramientas moleculares previamente descritas en melón está permitiendo el avance a pasos agigantados en los programas de mejora de este cultivo, facilitando el desarrollo de nuevas variedades de forma más eficiente, en menos generaciones y más dirigida, incluso evitando en algunos casos las barreras genéticas naturales.

En la década de los 80, con el inicio de la agricultura intensiva, el objetivo principal de los programas de mejora de hortalizas era el aumento de la productividad, incluso a expensas de pérdidas en atributos de calidad (Diamanti et al., 2011). La mejora de la productividad ha estado basada, aparte de en el incremento de la producción per se, en la mejora de la resistencia a plagas y enfermedades, sobre todo hongos del suelo y virus, causantes de enfermedades con gran impacto económico en estos cultivos y cuya importancia se incrementa en las condiciones actuales de cambio climático y agricultura sostenible con reducción de tratamientos.

Sin embargo, durante los últimos años, los objetivos de mejora se han centrado en optimizar los estándares de calidad de la fruta (Kumar, Volz, Alspach, \& Bus, 2010). La definición de calidad de la fruta en melón es compleja, ya que incluye factores como la forma, el color, la textura, el aroma, el dulzor, el contenido nutricional y la vida post-cosecha (Fernandez-Trujillo, Picò, Garcia-Mas, Alvarez, \& Monforte, 2011). Por ejemplo, entre las demandas actuales de los consumidores se encuentra la preocupación por el contenido nutricional y nutracéutico de las frutas, que en el melón está relacionado con el contenido de carotenos y vitaminas, así como también la percepción sensorial (Diamanti et al., 2011), asociada a rasgos como el aroma. Además, en algunas variedades, rasgos como el tamaño han adquirido cierta relevancia por la tendencia hacia un consumo más individual en algunas sociedades.

A esto se suma que la percepción de calidad en una especie tan polimórfica como el melón, depende en gran medida de la variedad. Por ejemplo, existen variedades en las que los frutos se consumen inmaduros en ensaladas o cocidos, como los melones no dulces del grupo Flexuosus, mientras que otros se consumen maduros, habitualmente de postre por su dulzor, como los melones de los grupos Cantalupensis, Inodorus e Ibericus. Sin embargo, incluso dentro de los melones dulces los parámetros de calidad varían de un cultivar a otro. Así, de melones como los cantalupos se espera que sean aromáticos, dulces, de forma redonda y color amarillo en la madurez. En cambio de los melones 'Piel de Sapo' se espera que sean de color verde, de forma oval, sin el aroma típico de un climatérico, con alto contenido de azúcares y una larga vida útil. 
Por lo tanto, los programas orientados hacia la mejora de la calidad de la fruta deben tener en cuenta las demandas del mercado para cada variedad (Fernandez-Trujillo et al., 2011).

La extrema variabilidad intraespecífica del melón ofrece la oportunidad de hacer frente a todas estas problemáticas en la mejora de hoy, posibilitando el diseño de nuevos cultivares. Sin embargo, el control poligénico al que se encuentran sometidos ciertos rasgos complica enormemente las labores de mejora. Aunque algunos carácteres están controlados por uno o pocos “genes mayores", otros, como el tamaño, el contenido de azúcares y la maduración, están bajo un control poligénico y con influencia ambiental (Monforte et al., 2004; Obando-Ulloa et al., 2008; Paris, Zalapa, McCreight, \& Staub, 2008; Zalapa, Staub, McCreight, Chung, \& Cuevas, 2007).

El análisis de QTLs (Quantitative Trait Loci) resulta de mucha utilidad en los programas de mejora, ya que permite localizar los distintos genes responsables de la variación de un determinado rasgo y explorar sus efectos e interacciones (Torres, Monforte, Millan, \& Šatović, 2012). Para garantizar el éxito de un análisis de QTLs, un factor crucial es el empleo de una población segregante adecuada. La selección de la población depende en gran medida de la finalidad hacia el cual está orientado el estudio. Así, si el objetivo es estudiar la variabilidad existente en un cruzamiento entre dos parentales, las más útiles son las derivadas de un cruce entre dos líneas puras ( $\mathrm{F}_{2}$, retrocruzamientos (BCs), dobles haploides (DHLs), líneas recombinantes consanguíneas (RILs), líneas de introgresión, ILs), en cambio las poblaciones de tipo MAGIC (Población multiparental de intercruzamientos avanzados) y NAM (Población anidada para mapeo por asociación) permiten estudiar la variabilidad entre una amplia gama de parentales. Una vez definido el objetivo del estudio, la selección de la población se define en base a las diferencias existentes entre ellas en relación al coste de generación, la potencia de detección de QTLs, y sobre todo la perspectiva futura (Torres et al, 2012).

Teniendo en cuenta todos estos aspectos, se puede decir que en el estudio de aprovechamiento de la variabilidad de especies exóticas con perspectivas futuras de transferencia de resultados a programas de mejora, la población óptima la constituyen las líneas de introgresión (ILs), ya que permiten una mejor validación de QTLs específicos procedentes de un tipo exótico concreto en un fondo genético seleccionado, que puede ser ya un fondo genético comercial.

\subsection{ILs y detección de QTLs}

Las líneas de introgresión son un recurso genético valioso para la identificación, caracterización y confirmación de la presencia de QTLs de importancia agronómica (Di Matteo et al., 2010; Eduardo et al., 2007; Falke, Miedaner \& Frisch, 2009; Finkers et al., 2007; Fu et al., 2010; Pereira, 2018; Périn et al., 2002b, c; Perpiñà et al., 2016). 


\section{INTRODUCCIÓN}

Una genoteca de líneas de introgresión es un conjunto de líneas en las que se ha introgresado, en cada una de ellas, un único segmento cromosómico de una especie relacionada o parental donante de interés, en un fondo genético común (Eshed \& Zamir, 1994). Idealmente, el conjunto de introgresiones representaría el genoma completo del parental donante. Para su obtención, se parte de un híbrido F1, obtenido del cruce inicial entre el parental recurrente y donante, y se realizan al menos tres ciclos de retrocruzamiento del híbrido F1 sobre el parental recurrente. A continuación, usando marcadores moleculares, se realiza una selección de las líneas que presentan la distribución más óptima del genoma del parental donante y, posteriormente, las líneas seleccionadas se someten a sucesivas autofecundaciones hasta obtener líneas homocigóticas para la introgresión y con un alto porcentaje del fondo genético del parental recurrente (Figura 1.5).

A diferencia de otras poblaciones donde la frecuencia de alelos de cada parental es similar, dificultando el análisis de QTLs sobre todo cuando uno de los parentales es silvestre, las ILs presentan una mayor frecuencia de alelos del cultivar de élite. Es decir, los fenotipos obtenidos son más similares a las variedades élites y es más probable detectar alelos que supongan diferencias respecto a carácteres de interés agronómico. Asimismo, estas líneas permiten también la realización de estudios de interacciones QTL-ambiente y QTL-QTL mediante cruzamientos (Torres et al., 2012). Sin embargo, se considera que la principal ventaja del uso de este tipo de poblaciones es la facilidad de transferencia de un rasgo de interés a una variedad de élite (Ali, Sanchez, Yu, Lorieux, \& Eizenga, 2010; Monforte, Friedman, Zamir, \& Tanksley, 2001; Pereira et al., 2018; Perpiñà et al., 2016).

Existen pocas colecciones de líneas de introgresión descritas en melón, por la ardua labor que conlleva su desarrollo. Entre ellas, es preciso destacar la desarrollada por Eduardo et al. (2007), empleando el cultivar 'Piel de Sapo' como parental recurrente y la accesión coreana 'Shongwan Charmi' como parental donante. Perpiñà et al. (2016) desarrollaron su colección de ILs utilizando el cultivar cantalupo francés tipo Charentais 'Védrantais', como parental recurrente y la accesión japonesa 'Ginsen Makuwa', como donante. Recientemente, Pereira (2018) decribió el desarrollo de dos colecciones recíprocas de ILs utilizando los dos parentales recurrentes de las poblaciones anteriores, 'Védrantais', como variedad climatérica, y 'Piel de Sapo', como variedad no climatérica. 


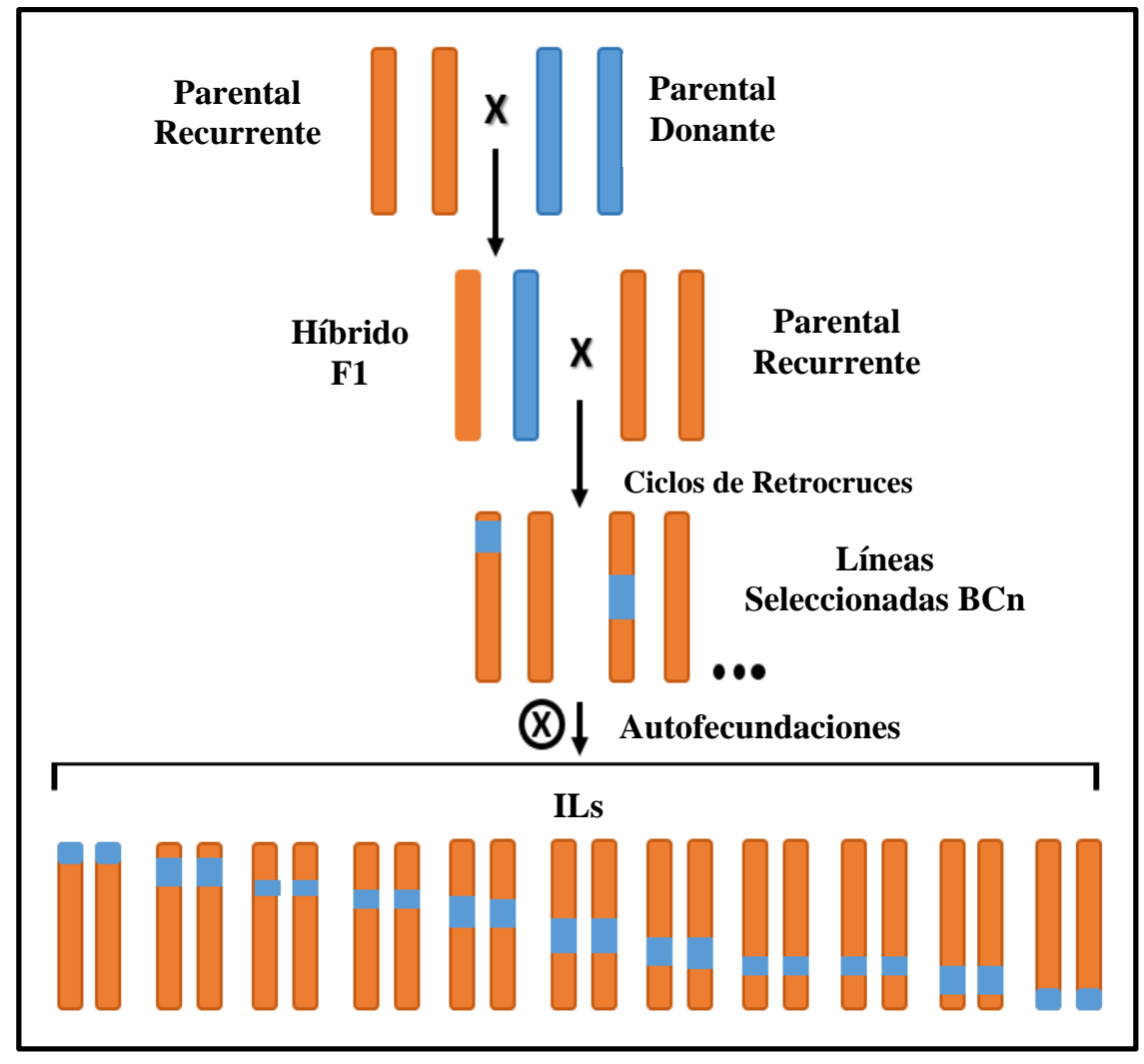

Figura 1.5. Representación gráfica del proceso de obtención de una colección de Líneas de Introgresión.

\subsection{Cartografiado de QTLs en melón}

Como se ha explicado anteriormente, el análisis de QTLs permite conocer la localización cromosómica de una región que afecta o controla un rasgo, así como también la magnitud y el efecto de la influencia de un QTL sobre el mismo, el modo de acción génica (dominante o aditiva) y la interacción entre diferentes QTLs o entre los mismos y el ambiente (Torres et al., 2012).

El punto de partida es siempre la obtención de una población segregante. El genotipado de calidad, con un número adecuado de marcadores moleculares distribuidos por todo el genoma, y la caracterización fenotípica también de calidad, no sólo en cuanto a reproducibilidad sino también en cuanto a la selección adecuada de los carácteres a evaluar en la población, es fundamental en la obtención de resultados fiables y de interés. Posteriormente, el empleo de métodos estadísticos apropiados permite detectar uno o varios QTLs para cada rasgo. Las poblaciones de líneas fijadas como las ILs o las RILs permiten este análisis en varios ambientes por lo que resultan especialmente adecuadas para este propósito. Debido al número limitado de individuos con los que se suele trabajar, la localización de estos QTLs identificados se presenta en intervalos de varios centimorgans (cM), que a nivel de posición física en los genomas suele corresponder a un millar de genes o más. 


\section{INTRODUCCIÓN}

Una vez identificados los distintos QTLs de interés, se debe proceder a validar sus efectos. Para esto, se pueden utilizar diferentes tipos de poblaciones, por ejemplo, líneas de introgresión, que permiten evaluar el efecto del QTL mediante la variación de los diferentes caracteres asociados al QTL respecto a un parental recurrente. (Grandillo \& Tanksley, 2005).

El mapeo de QTLs se ha utilizado ampliamente en diversas especies, por lo que existe ya mucha información disponible al respecto. Un ejemplo para cucurbitáceas es el mapa consenso de Díaz et al. $(2011,2015)$ en el que se localizan los QTLs de mayor interés hasta ese momento en $C$. melo.

El primer mapa de QTLs en melón (para carácteres como forma del ovario y del fruto) fue desarrollado por Périn et al. (2002a), empleando una población de RILs. A partir de ese trabajo, se han llevado a cabo numerosos estudios de mapeo para identificar QTLs relacionados con diversos rasgos del fruto en melón (Gonzalo \& Monforte, 2017). Asimismo, aunque el control genético de la resistencia a enfermedades es en ocasiones sencillo y se han identificado algunos genes concretos que proporcionan resistencia a virus y hongos (Dogimont, 2011), la tolerancia a algunas enfermedades presenta un control poligénico y también se han realizado análisis de QTLs para identificar las regiones genómicas, y los genes subyacentes, que controlan la variación observada para estos caracteres (Gonzalo \& Monforte, 2017). En este avance en la identificación de QTLs ha tenido gran relevancia la disponibilidad de mapas genéticos saturados de marcadores de calidad y en muchos casos anclados al genoma, lo que ha facilitado la identificación y clonaje de genes candidatos, contribuyendo de manera notable en los programas de mejora (Pereira, 2018; Perpiñà et al., 2016). Díaz et al. (2011, 2015) realizaron una recopilación de QTLs identificados en diferentes poblaciones, presentándolos en un mapa consenso e integrándolos con los previamente descritos en el mapa ICuGI (International Cucurbit Genomics Initiative, http://cucurbitgenomics.org/project). A continuación se presenta un resumen de los principales resultados descritos hasta el momento.

\subsubsection{QTLs relacionados con la calidad del fruto}

El aspecto del fruto de melón es el resultado de una combinación de características complejas que se perfilan durante las distintas etapas de desarrollo del fruto (Grumet \& Colle, 2017). Los carácteres involucrados en el aspecto final suelen agruparse en tres categorías: tamaño y forma, apariencia interna (morfología de la cavidad, contenido y color de la pulpa) y apariencia externa (color, reticulado, suturas, costillas, etc). 


\subsubsection{Tamaño y Forma}

Se ha analizado el control genético del peso y la forma del fruto en melón. Mientras que el peso presenta una fuerte influencia ambiental, la forma tiene un componente genético más importante y está correlacionada con la forma del ovario y los procesos que le ocurren a éste, antes y después de la fecundación (Grumet \& Colle, 2017; Périn et al., 2002b; Ramamurthy \& Waters, 2015; Wu et al., 2018).

Díaz et al. (2011) describieron un total de 102 QTLs para la longitud, el diámetro, la forma y el peso del fruto, obtenidos en varios trabajos utilizando diferentes poblaciones de mapeo. En investigaciones y revisiones posteriores, como las de Perpiñà et al. (2016), Díaz et al. (2017), Gonzalo \& Monforte (2017) y Pereira et al. (2018), este número se incrementa hasta 182 QTLs relacionados con la forma y tamaño del fruto de melón. De éstos, 139 QTLs estarían asociados con la forma del fruto y 43 con el peso. Los QTLs para la forma del fruto se han descrito mayoritariamente en los cromosomas 1, 2, 7, 8, 11 y 12 (Díaz et al., 2014, 2017; Eduardo et al., 2007; Harel-Beja et al., 2010; Monforte et al., 2004; Paris et al., 2008; Pereira et al., 2018; Périn et al., 2002b; Perpiñà et al., 2016; Ramamurthy \& Waters, 2015; Tomason, Nimmakayala, Levi, $\&$ Reddy, 2013). Con respecto al peso del fruto se encuentran concentrados mayoritariamente en los cromosomas 1, 2, 3, 6, 8 y 11 (Díaz et al. 2017; Eduardo et al. 2007; Harel-Beja et al. 2010; Monforte et al. 2004; Pereira et al. 2018; Perpiñà et al. 2016; Ramamurthy \& Waters 2015; Tomason et al. 2013; Zalapa et al. 2007). Estos resultados, evidencian que tanto el tamaño como la forma del fruto están bajo un complejo control poligénico (Fernandez-Trujillo et al., 2011). Estos estudios, junto con la búsqueda de genes homólogos involucrados en estas características en otras especies, han abierto la puerta a la identificación de genes candidatos asociados a la variación del tamaño y la forma del fruto en melón, así como a la descripción de diversos meta-QTLs de peso y forma (Monforte, Díaz, Caño-Delgado, \& van der Knaap, 2014). Estos genes corresponden principalmente con genes que codifican proteínas de la familia ovate, OFP (represor transcripcional) (Huang, van Houten, Gonzalez, Xiao, \& van der Knaap, 2013; Wu et al., 2015). Wu et al. (2018) presentaron evidencias sólidas de que la familia ovate tiene un papel crítico en la regulación de la forma de la fruta, al cambiar los patrones de división celular al inicio del desarrollo de los órganos en diferentes especies de plantas. En este sentido, en melón se postula CmOFP13 (MELO3C025206) como un gen candidato que explica el QTL de forma localizado en el cromosoma 8 (Wu et al., 2018). Por otra parte, un factor adicional que se cree determinante en la morfología del fruto es la expresión sexual floral. Es así como se han identificado QTLs para peso y forma en el cromosoma 2, probablemente efectos pleiotrópicos del gen andromonoecious (a) que, junto al gen $g$ (gynoecious) en el cromosoma 5 y $M$ (monoecious) en el 7, determina la expresión en melón (Gonzalo \& Monforte, 2017). 


\section{INTRODUCCIÓN}

\subsubsection{Apariencia interna}

Entre los carácteres que determinan la apariencia interna del fruto, el tamaño de la cavidad seminal es un rasgo importante de calidad. Los consumidores en general prefieren las cavidades pequeñas, rodeadas de una alta proporción de pulpa comestible, y las cavidades con semillas compactadas en el centro de la fruta (Fernandez-Trujillo et al., 2011). Périn et al. (2002a) mapearon en el cromosoma 2 el gen que controla el tamaño de la cavidad. Sin embargo, el control genético de la mayoría de las diferencias observadas en el tamaño de la cavidad no está dilucidado.

En lo relacionado al color de la pulpa, éste es un rasgo independiente de la liberación de etileno (Flores, Romojaro, Ben Amor, Pech, \& Latché, 2001a), y consiste en una combinación de pigmentos, clorofilas y carotenoides, que dan como resultado una diversidad de color blanco, verde y naranja, con distintas tonalidales o intensidades de color debido fundamentalmente al contenido en beta-carotenos (Burger et al., 2006; Cuevas, Staub, Simon, \& Zalapa, 2009; Gur, et al., 2017b; Rodrigo, et al., 2008; Watanabe, Saito, Hirota, Takahashi, \& Fujishita, 1991). El color de la pulpa está controlado principalmente por dos genes: gf (green flesh) (Hughes, 1948) y wf (white flesh) (Iman, Abo-Bakr \& Hanna, 1972) situados en los cromosomas 8 y 9 respectivamente, que actúan epistáticamente (Monforte et al., 2004). Existen QTLs menores que afectan el color de la pulpa. En una de estas regiones, en el cromosoma 6, también se ha mapeado un QTL involucrados en el nivel de carotenoides, consistente en tres estudios (Cuevas, Staub, Simon, Zalapa, \& McCreight, 2008; Harel-Beja et al., 2010; Monforte et al., 2004), apoyando la importancia de los carotenoides en la variabilidad del color de la pulpa.

\subsubsection{Apariencia externa}

La apariencia externa de la fruta está basada en una combinación de color de la corteza, textura de la superficie (lisa, arrugada, reticulada), y la presencia o ausencia de suturas o costillas longitudinales (Fernandez-Trujillo et al., 2011). El color de la corteza está definido por varias capas, una de color de fondo y otros colores secundarios, con un diseño diferente, moteado (manchas $<0.5 \mathrm{~cm}$ ), manchado (manchas $>0.5 \mathrm{~cm}$ ), rayado o veteado (Fernandez-Trujillo et al., 2011). El color de fondo está determinado por la acumulación de clorofilas, flavonoides y carotenoides (Tadmor et al., 2010). Durante el proceso de maduración, este color de la corteza puede cambiar. El color blanco de la fruta inmadura está regulado por el gen Wi (White color of immature fruit) localizado en el cromosoma 7 (Dogimont, 2011; Pereira, 2018). El color en la madurez resulta principalmente de la degradación de la clorofila y la acumulación de carotenos y otros pigmentos de tipo flavonoide (Guis et al., 1997; Tzuri et al., 2015). Este cambio de color, en general, depende de la síntesis de etileno, que a su vez influye en la 
INTRODUCCIÓN

degradación de la clorofila (Flores et al., 2001a; Flores, Martínez-Madrid, Sánchez-Hidalgo, \& Romojaro, 2001b). En este sentido, Monforte et al. (2004) y Eduardo et al. (2007) describieron cinco QTLs involucrados en la variación del color de la corteza del melón, sugiriendo que se trata de un rasgo de control poligénico. Uno de los cinco QTLs se co-localiza en el cromosoma 10 con un gen que codifica una proteína F-box con un dominio Kelch (MELO3C011980), del que Feder et al. (2015) demostraron que regula negativamente la acumulación de naringenina chalcona en la corteza, produciendo el cambio de blanco a amarillo y actuando probablemente mediante un mecanismo de degradación de proteínas sobre las enzimas 4-coumarato-CoA ligasa o chalcona sintasa.

En cuanto al dibujo del color secundario, Périn et al. (2002b) describieron el QTL $m t$-2, como responsable del moteado en el cromosma 2, y otro QTL, $s-2$, relacionado con las suturas en la corteza en el cromosoma 11. Danin-Poleg et al. (2002) a su vez, mapearon genes relacionados con el epicarpio liso en el cromosoma 3. Adicionalmente, se han descrito 10 QTLs responsables del rayado, suturas y reticulado en diversas poblaciones (Harel-Beja et al., 2010; Perpiñà et al., 2016; Wang et al., 2016).

\subsubsection{QTLs relacionados con la maduración del fruto}

La calidad no se relaciona únicamente con la apariencia de la fruta, sino también con factores, como la madurez del fruto (etileno, firmeza de la pulpa y corteza), aspectos organolépticos (contenido de azúcar, acidez, volátiles) y nutricionales (minerales, vitaminas, etc.) (Passam, Karapanos \& Alexopoulos, 2011). Se considera que los procesos de maduración, como la respiración climatérica, la producción de aromas, la formación de capa de abscisión, la duración de la vida útil y el cambio de color, se ven muy afectados por los mecanismos reguladores dependientes del etileno, mientras que la acumulación de azúcar, la acidez valorable, el metabolismo de los ácidos orgánicos, los sólidos solubles totales, el peso y el tamaño de la fruta, el número de semillas, el tamaño del mesocarpio y la acumulación de carotenoides en la pulpa se ven afectados por factores independientes del etileno (Guis et al., 1997; Ben-Amor et al., 1999; Pech, Bouzayen, \& Latché, 2008).

\subsubsection{Madurez de fruto}

Al término de un determinado período, cuando el fruto de melón ha alcanzado el tamaño adecuado y las semillas están completamente desarrolladas, se desencadena una serie de cambios bioquímicos que inducen modificaciones, sobre todo en las propiedades organolépticas. Estos cambios constituyen el proceso de maduración (Karlova et al., 2014; 


\section{INTRODUCCIÓN}

Pereira, 2018). Este proceso, que mejora la calidad del fruto, afecta a su vida útil, produciendo un rápido deterioro después de la cosecha (Yano \& Ezura, 2017).

En general, las variedades de melón se dividen en dos grandes grupos, climatéricas y no climatéricas, en función de la presencia o ausencia de un incremento en la producción de etileno autocatalítico durante la maduración (Burger et al., 2010). Sin embargo, existe una gran diversidad de tipos intermedios en cuanto a estos dos patrones clásicos de maduración (mayor o menor abladamiento, más o menos tardío, formación de capa de abscisión o no, grados en el cambio de coloración externa, etc) (Yano \& Ezura, 2017). En este sentido, se han identificado varios QTLs implicados en la producción de etileno y por consiguiente en el proceso de maduración (Moreno et al., 2008; Pereira, 2018; Périn et al., 2002 c; Vegas, Garcia-Mas, \& Monforte, 2013). A continuación, se comentan aquellos que se han podido estudiar con más profundidad y por tanto se ha podido identificar el gen responsable o candidatos altamente probables.

Moreno et al. (2008) realizaron un análisis de QTLs del comportamiento climatérico en una línea casi isogénica (NIL) derivada de un cruce entre dos melones no climatéricos, 'Piel de Sapo' (PS) y ‘PI 161375' (SC), identificando un QTL (ETHQB3.5), situado en el cromosoma 3, que inducía un comportamiento de maduración climatérico, con aumento de la respiración y los niveles de etileno, lo que indicaba que el fenotipo no climatérico es provocado por diferentes mecanismos en 'Piel de Sapo' y 'PI 161375'. Vegas et al. (2013) describieron un QTL adicional en el cromosoma 6 (ETHQV6.3), en la misma colección de NILs. Ambos QTLs han demostrado ser capaces de inducir independientemente la maduración climatérica, en el fondo genético PS, cuando el alelo SC está presente. Sin embargo, el efecto de ETHQB3.5 es más débil y con mayor influencia ambiental que el de ETHQV6.3. Expresados de forma conjunta dan lugar a un fenotipo mucho más climatérico que de forma aislada, lo que sugiere que al menos dos genes pueden estar alterados en el fenotipo no climatérico de PS (Ríos et al., 2017). Ríos et al. (2017) identificaron el gen MELO3C016540, que codifica un factor de transcripción de dominio NAC (CmNAC-NOR), como responsable del efecto del QTL ETHQV6.3 en la inducción del climaterio en el fondo genético PS. Asimismo, Pereira (2018) identificó candidatos para la región del cromosoma 3 (ETHQB3.5) que incluyen una kinasa, una proteína 14-3-3 y un citocromo P450 78A5. Empleando otra población derivada de PS (RILs derivadas de Vedrantais), Pereira también detectó un QTL mayor en el cromosoma 8 (ETHQV8.1) e identificó un gen candidato, una serina/treonina kinasa tipo CTR1. Todos estos trabajos ponen en relieve el carácter poligénico de la maduración climatérica y la amplia gradación en cuanto a fenotipos existente. 
La textura del melón es otro rasgo crítico para los consumidores. A pesar de que el ablandamiento es una característica apetecible a nivel de textura, constituye un rasgo subjetivo de acuerdo a la variedad (Tucker, 2014). Este rasgo está relacionado con atributos físicos, como la firmeza del fruto y la pulpa, y tiene una influencia también en la vida útil del fruto. Existe un número limitado de investigaciones en este sentido, probablemente debido a la complejidad de los carácteres (Harel-Berja et al., 2010; Moreno et al., 2008; Obando \& Fernández-Trujillo, 2008; Paris et al., 2008). A pesar de esto, se han podido identificar varios QTLs relacionados con la firmeza de la pulpa en los cromosomas 3 y 6, que colocalizan con QTLs de maduración climatérica, siendo el ablandamiento muy probablemente una consecuencia de los efectos pleiotrópicos de la maduración climatérica sobre la firmeza de la fruta (Harel-Beja et al., 2010; Moreno et al., 2008). Aunque los cambios en la textura durante la maduración son deseables para el consumidor en un nivel adecuado, también tienen consecuencias negativas, como un aumento en la susceptibilidad a patógenos (Pereira, 2018). Además, un ablandamiento excesivo, que generalmente aparece en las últimas etapas de la maduración, puede llevar a una textura indeseable y complica el transporte y almacenamiento de las frutas (Goulao \& Oliveira, 2008).

\subsubsection{QTLs relacionados con calidad nutricional y propiedades organolépticas}

\section{Contenido en azúcares}

Existe una variabilidad genética muy amplia para el contenido de azúcar en melón (Burger et al., 2010, Gur et al., 2017b). En los melones de tipo dulce, su calidad se determina principalmente por el contenido total de azúcar (Yamaguchi, Hughes, Yabumoto, \& Jennings, 1977), que está directamente relacionado con su nivel de sacarosa en el momento de la cosecha. Esta acumulación de sacarosa está controlada por un gen recesivo, presente en las variedades de melón dulce y ausente en los melones no dulces (Burger et al., 2002). A pesar de este conocimiento, no ha sido posible dilucidar con plena certeza el control molecular-genético de la acumulación de azúcar en toda la especie (Harel-Beja et al., 2010). Uno de los principales problemas asociados al estudio de este rasgo es la gran influencia del ambiente sobre el mismo y la ocurrencia de interacción genotipo-ambiente en la mayoría de los estudios (FernandezTrujillo et al., 2011).

La gran variabilidad en cuanto al contenido de azúcar en $C$. melo ha sido objeto de innumerables estudios. Setenta y seis QTLs se han localizado, distribuidos prácticamente en todos los cromosomas, siendo más frecuentes en los cromosomas 2, 3, 5 y 8 (Gonzalo \& Monforte, 2017), lo que sugiere que el contenido de azúcar está bajo control poligénico. Harel-Beja et al. (2010), Park, Hwang, \& Crosby (2009) y Perpiñà et al. (2016) describieron seis QTLs relacionados 


\section{INTRODUCCIÓN}

directamente con el contenido en sacarosa del fruto maduro. Uno de los de mayor interés es el descrito por Perpiñà et al. (2016), en una línea derivada del cruce entre el cultivar francés 'Vedrantais' x la línea japonesa 'Ginsen makuwa', un QTL para sólidos solubles totales (SSC), ssc.10, co-localizado con otro QTL involucrado en el contenido de sacarosa, suc.10.

\section{Acidez}

La acidez del fruto está determinada por la acumulación de ácidos orgánicos y con la actividad de los mecanismos de transporte de $\mathrm{H}+$ en las vacuolas de los tejidos de la fruta. Esta acumulación en melón es específica de cada variedad. Por ejemplo, algunas accesiones ácidas, como los tipos del grupo Flexuosus acumulan principalmente ácido málico, mientras que otras acumulan niveles más altos de citrato (Burger et al., 2003). Aunque se ha determinado que un solo gen en el cromosoma 8 controla este rasgo (Harel-Beja et al., 2010; Sherman et al., 2013) (MELO3C025264, un transportador de membrana descrito por Cohen et al., (2014)), se han identificado también QTLs que modulan esta acidez de la pulpa (Cohen et al., 2012).

\section{Aroma}

El aroma es un factor importante en la percepción del sabor por parte del consumidor. El sabor de la fruta se percibe a través del gusto y el olfato. El primero está relacionado con la presencia de azúcares, mientras que el aroma está determinado por una amplia gama de compuestos volátiles (Passam et al., 2011). A diferencia de la acumulación de azúcar, que se detiene al cosechar el fruto, la formación de moléculas aromáticas continúa activamente durante la poscosecha, siempre que los frutos de melón se cosechen maduros (Beaulieu \& Grimm, 2001). Por consiguiente, la producción de etileno tiene una correlación positiva con los compuestos volátiles (Burger et al., 2010). Diversos estudios han revelado más de 300 compuestos volátiles diferentes en varios cultivares y accesiones de melón (Aubert \& Bourger, 2004; Aubert \& Pitrat, 2006; Beaulieu \& Grimm, 2001; Beaulieu \& Lancaster, 2007; Buttery et al., 1982; Hayata et al., 2003; Jordán, Shaw, \& Goodner, 2001; Kemp, Stoltz, \& Knavel, 1972, 1973; Kourkoutas, Elmore, \& Mottram, 2006; Obando-Ulloa, Ruiz, Monforte, \& Fernández-Trujillo, 2010; Pang et al., 2012; Perry, Wang, \& Lin, 2009; Shalit et al., 2001; Verzera et al., 2011; Wyllie \& Leach, 1992; Yamaguchi et al., 1977). Estos compuestos aromáticos son fundamentalmente ésteres derivados de aminoácidos y ácidos grasos, aldehídos, alcoholes, mono- y sesquiterpenos, apocarotenoides, lactonas, furanos, derivados fenólicos, ácidos volátiles, sulfuros y tioles (Aubert \& Bourger, 2004; Beaulieu \& Grimm, 2001; Esteras et al., 2018; Portnoy et al., 2008; Schwab, Davidovich-Rikanati, \& Lewinsohn, 2008; Shalit et al., 2001;). Entre estos compuestos, los ésteres volátiles son cuantitativamente los más importantes y, por lo tanto, tienen un papel clave en la producción del aroma (Burger et al., 2010). Las variedades no 
aromáticas tienen niveles mucho más bajos de estos compuestos volátiles, principalmente de ésteres y alcoholes (Aubert \& Bourger, 2004; Burger et al., 2006). Cabe anotar que ObandoUlloa et al. (2010), describieron cuatro QTLs aromáticos no dependientes de etileno en los cromosomas 4, 8 y 11; dos para el ester 3-hidroxi-2,4,4-trimetil-pentil 2-metilpropanoato, uno para (Z,Z)-3,6-nonadienal, y un QTL para octanal. En general, existen pocos estudios sobre mapeo de QTLs implicados en la síntesis de componentes volátiles, no obstante se han identificado algunos genes implicados en la síntesis de precursores volátiles en el melón (Gonda et al. 2013; Portnoy et al. 2008; Tang et al. 2015).

En base a todo lo anteriormente descrito, se puede apreciar que la calidad de la fruta está determinada por complejos procesos moleculares, fisiológicos y bioquímicos que incluyen desde el metabolismo de carbohidratos, hasta la formación de compuestos volátiles. Un desequilibrio en alguno de estos procesos puede afectar negativamente la calidad a través de una alteración en la composición, textura, aroma o apariencia de la fruta. La importancia del conocimiento y la comprensión de los diferentes mecanismos y rutas relacionados con los carácteres de calidad radica en el objetivo de obtener nuevas variedades con características específicas sin la alteración de otros rasgos intrínsecos (Passam et al., 2011).

\subsubsection{QTLs relacionados con resistencia a enfermedades}

La calidad del melón depende principalmente de las características mencionadas en el apartado anterior, pero la base para que estas características puedan desarrollarse adecuadamente es que los frutos se recolecten de plantas sanas y libres de patógenos. El melón se ve afectado por numerosas plagas y enfermedades que producen pérdidas económicas significativas en la producción y calidad de este cultivo en todo el mundo, entre las cuales destacan las ocasionadas por virus y hongos. Las cucurbitáceas son susceptibles al menos a 59 virus de plantas (Lecoq $\&$ Desbiez, 2012). La mayoría de estos virus son transmitidos por vectores como pulgones o moscas blancas (Thakur et al., 2019). Se han realizado numerosos estudios relacionados con la tolerancia/resistencia a diferentes virosis. Como se indica en el apartado 1.1.4, se han encontrado algunas fuentes de resistencia en entradas de la ssp. agrestis, habiéndose estudiado el control genético de las mismas para su empleo en programas de mejora. En algunos casos como la resistencia a CMV procedente de PI 161375, se describe un control complejo dependentiente de la cepa, pudiendo ser monogénico para algunas cepas y oligogénico para otras (Guiu-Aragones et al., 2014). Estos mecanismos de resistencia poligénicos representan una dificultad en el desarrollo de cultivares resistentes, aunque incluso en estos mecanismos complejos se ha verificado que generalmente la resistencia depende mayoritariamente, al menos en cuanto a un grupo de razas del virus CMV, de un gen recesivo, e incluso ha sido posible la 


\section{INTRODUCCIÓN}

clonación de dicho gen $(\mathrm{cmvl})$ que actuaría probablemente como punto de control, impidimento el transporte del virus a través del floema (Giner et al., 2017). Sin embargo, en la mayoría de los casos los mecanismos de resistencia no son tan complejos y se basan en la existencia de un gen mayor, dominante o recesivo, que confiere resistencia por sí solo o complementada por otras regiones genómicas con un menor impacto en la resistencia. Por ejemplo, Pitrat \& Lecoq (1984) describieron un gen dominante, Zym, responsable de la resistencia a ZYMV en PI 414723, McCreight (2000) identificó un gen recesivo en PI 313970 responsable de la resistencia a CYSDV, y Nieto et al. (2006) clonaron el gen recesivo Cm-eIF4E responsable de la resistencia a MNSV. En cambio, Palomares-Rius et al. (2016), describieron dos regiones genómicas involucradas en la resistencia a CYSDV en la línea TGR 1551, una responsable de la multiplicación del virus y la otra asociada al desarrollo de los síntomas. Recientemente, Pérez de Castro et al. (2019), en una población de RILs proveniente del cruce entre TGR 1551 y el cultivar español 'Bola de Oro' (C. melo grupo Ibericus), han descrito un gen dominante responsable de la resistencia a WMV, cuya respuesta depende de otros dos genes menores. Para nuevas virosis de interés, como el Cucurbit chlorotic yellows virus (CCYV) o el Tomato leaf curl new delhi virus (ToLCNDV), se han realizado cribados de diversas fuentes de resistencia (Okuda et al., 2013; Sáez et al., 2017), e incluso se ha estudiado la genética de la resistencia, encontrándose un gen mayor dominante para el ToLCNDV en el cromosoma 11, derivada de la entrada India WM7, que junto con otros dos factores menores repartidos por el genoma actúa epistáticamente sobre el control del progreso de la enfermedad y la carga viral (Sáez et al., 2017).

Entre las enfermedades causadas por hongos las más estudiadas han sido el oidio y las fusariosis vasculares. El oidio de las curcubitáceas es la enfermedad micótica más grave que afecta a las cucurbitáceas a nivel global, y que puede afectar tanto en condiciones de campo como invernadero (McGrath \& Thomas, 1996; Nunes et al., 2017), reduciendo el crecimiento de la planta y por consiguiente el rendimiento y la calidad del melón (Lebeda, Kř́ístková, Sedláková, McCreight, \& Coffey, 2016). Esta enfermedad es causada por tres especies de hongos, Leveillula taurica (Lev.) Arnaud, considerada la de menor impacto ecnómico (Lebeda et al., 2016), Golovinomyces orontii (Castagne) Heluta (Braun \& Cook, 2012), con mayor incidencia en áreas templadas y condiciones frías de campo (Kř́stková et al., 2007), y Podosphaera xanthii (Castag.) U. Braun y N. Shish. (Shishkoff, 2000), común en áreas tropicales, subtropicales y en condiciones de invernadero (Nunes et al., 2017). G. orontii y P. xanthii pueden actuar tanto en forma individual o formar una interacción compleja entre ambos (Lebeda et al., 2016; McCreight, 2006; Nunes et al., 2017; Sales-Júnior et al., 2011). Se ha sugerido la existencia de 28 cepas de $P$. xanthii, algunas de las cuales podrían ser variantes de las principales cepas 1 y 
2, originalmente descritas (Jahn, Munger, \& McCreight, 2002). Sin embargo se han observado diferencias en el comportamiento y virulencia de una gran cantidad de aislados de ambas especies en dependencia de factores territoriales y climáticos (Lebeda \& Sedláková, 2006, 2010; Křístková, Lebeda, \& Sedláková, 2009, Sedláková, Lebeda, Gryczová, \& Křístková, 2014), por lo que se considera que solo un número limitado de cepas altamente patógenas tienen una incidencia en áreas grandes (McCreight, Coffey, Sedlaková, \& Lebeda, 2012). Por tal motivo, se ha planteado que la mejor estrategia para hacer frente a esta enfermedad es la identificación y estudio de la cepa prevalente en una región en particular y la implementación de programas de mejora específicos para dicha región (Lebeda et al., 2016; Nunes et al., 2017). A pesar de estas dificultades, a día de hoy, se han identificado más de 30 fuentes de resistencia en melón frente a 22 razas de $P$. xanthii (Alvarez, Gomez-Guillamon, Tores, Canovas., \& Floris, 2000; McCreight, 2006; McCreight et al., 2012; Nunes et al., 2017), en su mayoría pertenecientes al grupo Momordica (Dhillon et al., 2012), así como también al grupo Acidulus, de India y África (McCreight, 2003; Gómez-Guillamón, Lopez-Sese, Sarria, Yuste-Lisbona, 2006), al grupo Flexuosus (Liu, Chen, Su, Zhang, \& Zhu, 2010; Dhillon et al., 2012) o variedades tradicionales genéticamente cercanas a estos grupos (Nunes et al., 2017).

De igual manera, se han identificado QTLs y genes involucrados en la tolerancia a oidio en los cromosomas 2, 5, 7, 9 y 12 (Fazza et al., 2013; Fukino et al., 2008; Liu, 2010; Perchepied, Bardin, Dogimont, \& Pitrat, 2005; Périn et al., 2002a; Pitrat, 1991; Teixeira, Barreto, \& Camargo, 2008; Yuste-Lisbona et al., 2011). Aunque el efecto de los genes depende de las razas, se dispone de una gran batería de resistencia que utlizadas convenientemente y en un manejo sostenible combinado con tratamientos pueden resultar en un control satisfactoria de la enfermedad (Nunes et al., 2017)

La fusariosis del melón ha venido fundamentalmente asociada a Fusarium oxysporum f. sp. melonis (FOM), aunque estudios recientes reportan numerosas especies del complejo $F$. solani, que también podrían causar daños al cultivo, pero que todavía no se encuentran convenientemente estudiadas ni clasificadas (Gomez et al., 2014). La genética de la resistencia a FOM se ha estudiado con detalle. Se han descrito cuatro genes involucrados en la tolerancia a FOM: fom-1, fom-2, fom-3 y fom-4 (Oumouloud, Arnedo-Andrés, González-Torres, \& Álvarez 2010; Thakur et al., 2019). Los genes fom-1 y fom-2 se localizan en los cromosomas 9 y 11 (Périn et al., 2002a). Estos genes son dominantes y proporcionan una alta resistencia, que generalmente no se ve afectada por el estrés ambiental y el nivel de inóculo en el campo, o por condiciones de inoculación artificial (Burger et al., 2010). Se han identificado 9 QTLs relacionados con resistencia recesiva en la línea de reproducción francesa 'Isabelle', que confieren resistencia recesiva a la raza 1.2, una de las más agresivas y que supera la resistencia 


\section{INTRODUCCIÓN}

de los genes dominantes anteriormente descritos (Perchepied, Dogimont, \& Pitrat, 2005; Perchepied \& Pitrat, 2004).

En las condiciones de cultivo actual, en un escenario de subida general de las temperaturas y de desarrollo de una agricultura más sostenible con el medio, con menos insumos (agua, abonos y plaguicidas), están surgiendo otros patógenos que, aunque ya eran conocidos en melón, estaban restringidos a áreas muy calurosas y secas, y ahora se están difundiendo a otras zonas y están incrementando la gravedad de los síntomas. Éste es, por ejemplo, el caso de dos grupos de hongos, pertenecientes a los géneros Monosporascus spp., causante de la pudrición de raíz y tallo que conlleva al colapso del melon, y Macrophomina, con las especie M. phaseolina (Tassi) Goidanich, causante de la podredumbre carbonosa (Burger et al., 2010; Salari, Panjehkeh, Nasirpoo, \& Abkhoo, 2012).

\subsubsection{Monosporascus spp.}

Este género incluye hongos responsables de la enfermedad conocida como Monosporascus root rot and vine decline (MRRVD). Esta enfermedad se ha relacionado fundamentalmente con $M$. cannonballus (Pollack \& Uecker, 1974), aunque recientemente se ha detectado una especie cercana, M. eutypoides (Petrak), que también participa en la enfermedad en algunas zonas (Ben Salem et al., 2013). Los síntomas de MRRVD a menudo aparecen en el momento cercano a la recolección de los frutos, cuando la inversión en el cultivo ya está hecha. Este aspecto contribuye al gran impacto negativo que supone la enfermedad. Destacan la ocurrencia de un amarilleamiento de la planta, seguido de flacidez y decaimiento. Estos síntomas en parte aérea derivan de los daños en el sistema radicular, donde la infección por el hongo causa podredumbres y lesiones necróticas, en el sistema radicular principal y secundario, además de una pérdida significativa de raíces secundarias y terciarias (Martyn \& Miller, 1996; Cluck et al., 2009).

Uno de los principales inconvenientes en la mejora frente a Monosporascus spp., es que la influencia de los factores ambientales en la expresión de los síntomas asociados a MRRVD dificulta la identificación de resistencias. La comparación de las fuentes de resistencia evaluadas en diferentes condiciones también supone una dificultad. A pesar de estos inconvenientes, se ha descrito resistencia moderada a M. cannonballus en cultivares de melón como 'Doublon' y 'Deltex' (Crosby, 2000; Crosby, Wolff, \& Miller, 2000; Wolff, 1995; Wolff \& Miller, 1998), y en entradas pertenecientes a la ssp. agrestis (Iglesias, Picò, \& Nuez, 2000a,b; Crosby, 2001; Fita, Picò, Dias, \& Nuez, 2009; Roig et al., 2012). Estas resistencias todavía no se han empleado en cultivares comerciales. Con respeto a $M$. eutypoides todavía no se ha llevado a cabo ningún cribado de germoplasma para la identificación de resistencias. 


\subsubsection{Macrophomina phaseolina}

Macrophomina phaseolina es la causante de la enfermedad conocida como 'podredumbre carbonosa'. Se trata de un patógeno muy polífago que causa enfermedad en muchas especies y con alto índice de patogenicidad a nivel mundial (Cohen et al., 2016). Entre las cucurbitáceas afecta fundamentalmente a sandía y melón (Cohen, Elkabetz, \& Edelstein, 2016). Este hongo produce una podredumbre "seca" en distintos tejidos de la planta y el efecto sobre el cuello y la raíz puede causar la muerte de la planta (Wyllie, 1989).

Los estudios relacionados con la selección de fuentes de resistencia a M. phaseolina en melón son muy escasos. Ambrósio et al. (2015), identificaron mediante un cribado de germoplasma algunas accesiones con distintos niveles de resistencia. Entre ellas, se encontraban dos entradas pertenecientes al grupo Dudaim, una del grupo Conomon y dos entradas de tipo Agrestis silvestres. Aunque este estudio se realizó en condiciones de inoculación artificial y el comportamiento de estas entradas y su resistencia debe ser confirmada en condiciones de infestación natural en campo, ofrece una idea del posible comportamiento ante la infección.

En general, la utilidad de las fuentes de resistencia descritas para estos dos grupos de hongos está condicionado por su respuesta en campo, ya que la respuesta final depende de factores ambientales, como temperatura y luz, así como también el estado fisiológico de las plantas evaluadas (Burger et al., 2010).

\subsection{Estructura de la presente tesis doctoral}

La presente Tesis Doctoral constituye una recopilación de trabajos publicados y otros en vía de publicación en los que el doctorando ha participado. Estos trabajos han sido llevados a cabo en el grupo de Mejora Genética de Curcubitáceas del COMAV de la Universitat Politècnica de València (UPV), en algunos casos en colaboración con otros grupos, como el grupo de Genómica en Mejora Vegetal del IBMCP, liderado por Antonio Monforte, el grupo de Mejora de melón de la Universidade Federal Rural do Semi-árido de Brasil (UFERSA), liderado por Glauber Henrique de Sousa Nunes, y el grupo de Patología Vegetal de la UPV, liderado por Josep Armengol.

La Tesis está estructurada en dos grandes bloques. En ambos casos se pretende el aprovechamiento de la variabilidad intraespecífica del melón, para la mejora de calidad por un lado, y para la mejora para resistencia a hongos del suelo, por otro.

En el primer bloque, se aborda el desarrollo de líneas de introgresión a partir del cruce entre un cultivar de tipo 'Piel de Sapo' (PS) (ssp. melo, grupo Ibericus) y la entrada exótica 'Queen's pocket melon' (DUD) (PI 273438, ssp. melo, grupo Dudaim). En esta parte de mejora de la calidad se presentan cuatro capítulos. En el primero, se describe el procedimiento de obtención 


\section{INTRODUCCIÓN}

de las líneas de introgresion y el análisis de QTLs realizado en las distintas generaciones segregantes. En el segundo, se describen la obtención de la colección de 16 ILs y el análisis de QTLs asociados a su caracterización en tres ambientes y su genotipado con plataformas de densidad media y alta. Esto ha permitido la identificación de regiones genómicas implicadas en diversos carácteres de interés agronómico (maduración climatérica, tamaño, forma o color del fruto), localizándose posibles genes candidatos responsables de la variación observada en estos rasgos. Este capítulo constituye un paper que está actualmente en fase de revisión en la revista SCI Euphytica. En tercer lugar, se describen desde el punto de vista agronómico algunas de las ILs con características de mayor interés para la diversificación del mercado de los melones de tipo 'Piel de Sapo'. Se trata de un artículo de divulgación publicado en la revista Agrícola Vergel, para hacer llegar al sector el resultado de este programa de mejora en forma de líneas de utilidad para el desarrollo de nuevos cultivares. Por último, en el cuarto capítulo se describe el análisis en tres ambientes de una línea de mejora derivada de esta población, 'Mini PS', que produce frutos de tamaño adecuado para el consumo unipersonal y presenta forma redondeada, más adecuada para su comercialización. Este trabajo se ha enviado para su publicación a la revista SCI Horticultural Science, encontrándose en fase de revisión.

El segundo bloque, incluye tres capítulos relacionados con el cribado de germoplasma por resistencia a los hongos de suelo Monosporascus cannonballus, M. eutypoides y Macrophomina phaseolina en melón. Tras un cribado previo de la colección de germoplasma del grupo de Mejora de Cucurbitáceas del COMAV en colaboración con el grupo de la UFERSA (Ambrósio et al, 2015), se vio que la entrada DUD, empleada como parental donante exótico de la colección de ILs descrita en el bloque 1, era resistente a Macrophomina phaseolina. El interés de esta resistencia y la posibilidad de estudiar su control genético nos condujo a realizar un cribado de las ILs para la detección de QTLs involucrados en esta resistencia. Este trabajo conforma el capítulo 1 de este segundo bloque. La no consistencia de la respuesta resistente que se encontró en las ILs podría explicarse debido al efecto de factores ambientales sobre la expresión de la resistencia. Por ello, y de nuevo en colaboración con la UFERSA, se planteó un trabajo para estudiar el efecto de la temperatura sobre la resistencia a Macophomina phaseolina que constituye el capítulo 2, trabajo que se encuentra en fase de preparación para su envío a la revista SCI Plant Disease. Con la experiencia adquirida para trabajar con este tipo de patógenos, decidimos hacer un primer estudio de cribado, teniendo en cuenta la influencia de la temperatura sobre el MRRVD, causado no sólo por M. cannonballus sino también por M. eutypoides, lo que constituye el pimer cribado de materiales frente a esta especie. Los resultados se discuten en el capítulo 3, que supone un trabajo de investigación que se encuentra en fase de revisión en la revista SCI Annals of Applied Biology. 


\subsection{Referencias}

Ali, M. L., Sanchez, P. L., Yu, S. B., Lorieux, M., \& Eizenga, G. C. (2010). Chromosome segment substitution lines: a powerful tool for the introgression of valuable genes from Oryza wild species into cultivated rice (O. sativa). Rice, 3(4), 218.

Alvarez, J. M., Gomez-Guillamon, M. L., Tores, N. A., Canovas, I., \& Floris, E. (2000). Virulence differences between two spanish isolates of Sphaerotheca fuliginea race 2 on melon. Acta Horticulturae, 510, 67-69.

Ambrósio, M. M., Dantas, A. C., Martínez-Perez, E., Medeiros, A. C., Nunes, G. H., \& Picò, M. B. (2015). Screening a variable germplasm collection of Cucumis melo L. for seedling resistance to Macrophomina phaseolina. Euphytica, 206(2), 287-300.

Argyris, J. M., Ruiz-Herrera, A., Madriz-Masis, P., Sanseverino, W., Morata, J., Pujol, M., ... Garcia-Mas, J. (2015). Use of targeted SNP selection for an improved anchoring of the melon (Cucumis melo L.) scaffold genome assembly. BMC Genomics, 16(1), 4.

Aubert, C., \& Bourger, N. (2004). Investigation of volatiles in Charentais cantaloupe melons (Cucumis melo var. cantalupensis). Characterization of aroma constituents in some cultivars. Journal of agricultural and food chemistry, 52(14), 4522-4528.

Aubert, C., \& Pitrat, M. (2006). Volatile compounds in the skin and pulp of Queen Anne's pocket melon. Journal of Agricultural and Food Chemistry, 54(21), 8177-8182.

Bai, Y., Zhang, Z., Fei, Z. (2017). Databases and bioinformatics for cucurbit species. In: R. Grumet, N. Katzir, \& J. Garcia-Mas (Eds.), Genetics and genomics of Cucurbitaceae (Vol. 20, pp. 253-263). Cham, Switzerland: Springer Nature.

Bardin, M., Dogimont, C., Nicot, P., \& Pitrat, M. (1999). Genetic analysis of resistence of melon line PI 124112 to Sphaerotheca fuliginea and Erysiphe cichoracearum studied in recombinant inbred lines. Acta Horticulturae, 492, 163-168.

Baudracco-Arnas, S., \& Pitrat, M. (1996). A genetic map of melon (Cucumis melo L.) with RFLP, RAPD, isozyme, disease resistance and morphological markers. Theoretical and Applied Genetics, 93(1-2), 57-64.

Beaulieu, J. C., \& Grimm, C. C. (2001). Identification of volatile compounds in soybean at various developmental stages using solid phase microextraction. Journal of Agricultural and Food Chemistry, 49(17), 1345-1352.

Beaulieu, J. C., \& Lancaster, V. A. (2007). Correlating volatile compounds, sensory attributes, and quality parameters in stored fresh-cut cantaloupe. Journal of Agricultural and Food Chemistry, 55(23), 9503-9513.

Becerra, V., \& Paredes, M. (2000). Use of biochemical and molecular markers in genetic diversity studies. Agricultura Técnica, 60(3), 270-281. 


\section{INTRODUCCIÓN}

Ben Salem, I., Correia, K. C., Boughalleb, N., Michereff, S. J., León, M., Abad-Campos, P., ... Armengol, J. (2013). Monosporascus eutypoides, a cause of root rot and vine decline in Tunisia , and evidence that $M$. cannonballus and M. eutypoides are distinct species. Plant Disease, 97, 737-743.

Ben-Amor, M., Flores, B., Latché, A., Bouzayen, M., Pech, J. C., \& Fomojaro, F. (1999). Inhibition of ethylene biosynthesis by antisense ACC oxidase RNA prevents chilling injury in Charentais cantaloupe melons. Plant, Cell \& Environment, 22(12), 1579-1586.

Blanca, J., Cañizares, J., Ziarsolo, P., Esteras, C., Mir, G., Nuez, F., ... Picò, M. B. (2011). Melon transcriptome characterization: Simple sequence repeats and single nucleotide polymorphisms discovery for high throughput genotyping across the species. The Plant Genome Journal, 4(2), 118-131.

Blanca, J., Esteras, C., Ziarsolo, P., Pérez, D., Fernández-Pedrosa, V., Collado, C., ... Picò, B. (2012). Transcriptome sequencing for SNP discovery across Cucumis melo. BMC Genomics, 13(1), 280.

Braun, U., \& Cook, R. T. A. (2012). Taxonomic manual of the Erysiphales (Powdery Mildews). Utrecht, Netherlands: CBS-KNAW Fungal Biodiversity Centre.

Burger, Y., Paris, H. S., Cohen, R., Katzir, N., Yishay, R., \& Schaffer, A. A. (2010). Genetic diversity of Cucumis melo. In J. Janick (Ed.), Horticultural reviews (Vol. 36, pp. 165-198). New York, USA: Wiley-Blackwell.

Burger, Y., Sa'ar, U., Distelfeld, A., Katzir, N., Yeselson, Y., Shen, S., \& Schaffer, A. A. (2003). Development of sweet melon (Cucumis melo) genotypes combining high sucrose and organic acid content. Journal of the American Society for Horticultural Science, 128(4), $537-540$.

Burger, Y., Saar, U., Katzir, N., Paris, H. S., Yeselson, Y., Levin, I., \& Schaffer, A. A. (2002). A single recessive gene for sucrose accumulation in Cucumis melo fruit. Journal of the American Society for Horticultural Science, 127(6), 938-943.

Burger, Y., Sa'ar, U., Paris, H. S., Lewinsohn, E., Katzir, N., Tadmor, Y., \& Schaffer, A. A. (2006). Genetic variability for valuable fruit quality traits in Cucumis melo. Israel Journal of Plant Sciences, 54(3), 233-242.

Buttery, R. G., Seifert, R. M., Ling, L. C., Soderstrom, E. L., Ogawa, J. M., \& Turnbaugh, J. G. (1982). Additional aroma components of honeydew melon. Journal of Agricultural and Food Chemistry, 30(6), 1208-1211.

Chagné, D., Gasic, K., Crowhurst, R. N., Han, Y., Bassett, H. C., Bowatte, D. R., ... Korban, S. S. (2008). Development of a set of SNP markers present in expressed genes of the apple. Genomics, 92(5), 353-358. 
Chang, C. W., Wang, Y. H., Tung, C. W. (2017). Genome-wide single nucleotide polymorphism discovery and the construction of a high-density genetic map for melon (Cucumis melo L.) using genotyping-by-sequencing. Frontiers in plant science, 8, 125.

Chomicki, G., \& Renner, S. S. (2017). Watermelon origin solved with molecular phylogenetics including Linnaean material: Another example of museomics. New Phytologist, 205(2), 526-532.

Cluck, T. W., Biles, C. L., Duggan, M., Jackson, T., Carson, K., Armengol, J., ... Bruton, B. D. (2009). Association of dsRNA to down-regulation of perithecial synthesis in Monosporascus cannonballus. The Open Mycology Journal, 3(1), 9-19.

Cogniaux, A. (1881). Cucurbitacées. In: A. P. de Candolle, \& C. de Candolle (Eds.), Monographiae phanerogamarum (Vol. 3, pp. 340-954). Paris, France: Masson.

Cohen, R., Elkabetz, M., \& Edelstein, M. (2016). Variation in the responses of melon and watermelon to Macrophomina phaseolina. Crop Protection, 85, 46-51.

Cohen, S., Itkin, M., Yeselson, Y., Tzuri, G., Portnoy, V., Harel-Baja, R., ... Bar, E. (2014). The PH gene determines fruit acidity and contributes to the evolution of sweet melons. Nature communications, 5, 4026.

Cohen, S., Tzuri, G., Harel-Beja, R., Itkin, M., Portnoy, V., Sa'ar, U., ... Aharoni, A. (2012). Co-mapping studies of QTLs for fruit acidity and candidate genes of organic acid metabolism and proton transport in sweet melon (Cucumis melo L.). Theoretical and applied genetics, 125(2), 343-353.

Collinson, M. E., Boulter, M. C., \& Holmes, P. R. (1993). Magnoliophyta (Angiospermae). In: M. J. Benton (Ed.), The fossil record 2 (pp. 806-841). London, UK: Chapman \& Hall.

Crosby, K. M. (2000). Impact of Monosporascus cannonballus on root growth of diverse melon varieties and their F1 progeny in the field. Subtropical Plant Science, 52, 8-11.

Crosby, K., Wolff, D., \& Miller, M. (2000). Comparisons of root morphology in susceptible and tolerant melon cultivars before and after infection by Monosporascus cannonballus. HortScience, 35(4), 681-683.

Crosby, K.M. (2001). Screening Cucumis melo L. agrestis germplasm for resistance to Monosporascus cannonballus. Subtropical Plant Science, 53, 24-26.

Cuevas, H. E., Staub, J. E., Simon, P. W., \& Zalapa, J. E. (2009). A consensus linkage map identifies genomic regions controlling fruit maturity and beta-carotene-associated flesh color in melon (Cucumis melo L.). Theoretical and applied genetics, 119(4), 741-756.

Cuevas, H. E., Staub, J. E., Simon, P. W., Zalapa, J. E., \& McCreight, J. D. (2008). Mapping of genetic loci that regulate quantity of beta-carotene in fruit of US Western Shipping melon (Cucumis melo L.). Theoretical and applied genetics, 117(8), 1345-1359. 


\section{INTRODUCCIÓN}

Dahmani-Mardas F., Troadec Ch., Boualem A., Leveque S., Alsadon A. A., Aldoss A. A., ... Bendahman A. (2010). Engineering melon plants with improved fruit shelf life using the TILLING approach. PLoS ONE, 5, e15776.

Dhaliwal, M. S. (2016). Breeding vegetables for biotic stress resistence. In: K. L. Chadha, P. Kalia, \& S. K. Singh (Eds.), Horticulture for inclusive growth (pp. 478-489). New Delhi, India: Horticultural Society of India.

Danin-Poleg, Y., Tadmor, Y., Tzuri, G., Reis, N., Hirschberg, J., \& Katzir, N. (2002). Construction of a genetic map of melon with molecular markers and horticultural traits, and localization of genes associated with ZYMV resistance. Euphytica, 125(3), 373-384.

Deleu, W., Esteras, C., Roig, C., González-To, M., Fernández-Silva, I., González-Ibeas, D., ... Garcia-Mas, J. (2009). A set of EST-SNPs for map saturation and cultivar identification in melon. BMC Plant Biology, 9(1), 90.

Dhillon, N. P. S., Monforte, A. J., Pitrat, M., Pandey, S., Singh, P. K., Reitsma, K. R., ... McCreight, J. D. (2012). Melon landraces of India: contributions and importance. In: J. Janick (Ed.). Plant breeding reviews (Vol. 35, pp. 85-150). Oxford, UK: Wiley-Blackwell.

Dhillon, N. P. S., Singh, H., Pitrat, M., Monforte, A. J., McCreight, J. D. (2015). Snapmelon (Cucumis melo L. Momordica group), an indigenous cucurbit from India with immense value for melon breeding. In: R. Srinivasan, M. Mecozzi, \& J. D. H. Keatinge (Eds.), ISHS Symposium on Promoting the Future of Indigenous Vegetables Worldwide (pp. 99-108), Brisbane, Australia: ISHS Acta Horticulturae 1102.

Di Matteo, A., Sacco, A., Anacleria, M., Pezzotti, M., Delledonne, M., Ferrarini, A., ... Barone, A. (2010). The ascorbic acid content of tomato fruits is associated with the expression of genes involved in pectin degradation. BMC plant biology, 10(1), 163.

Diamanti, J., Battino, M., \& Mezzetti, B. (2011). Breeding for fruit nutritional and nutraceutical quality. In: M. A. Jenks \& P. J. Bebeli (Eds.), Breeding for Fruit Quality (pp. 61-79). Oxford, UK: Wiley-Blackwell.

Díaz, A., Fergany, M., Formisano, G., Ziarsolo, P., Blanca, J., Fei, Z., ... Monforte, A. J. (2011). A consensus linkage map for molecular markers and Quantitative Trait Loci associated with economically important traits in melon (Cucumis melo L.). BMC Plant Biology, 11(1), 111.

Díaz, A., Forment, J., Argyris, J. M., Fukino, N., Tzuri, G., Harel-Beja, R., ... Monforte, A. J. (2015). Anchoring the consensus ICuGI genetic map to the melon (Cucumis melo L.) genome. Molecular Breeding, 35(10), 188.

Díaz, A., Martín-Hernández, A. M., Dolcet-Sanjuan, R., Garcés-Claver, A., Álvarez, J. M., Garcia-Mas, J., ... Monforte, A. J. (2017). Quantitative trait loci analysis of melon 
(Cucumis melo L.) domestication-related traits. Theoretical and applied genetics, 130(9), 1837-1856.

Díaz, A., Zarouri, B., Fergany, M., Eduardo, I., Álvarez, J. M., Picò, B., \& Monforte, A. J. (2014). Mapping and introgression of QTL involved in fruit shape transgressive segregation into 'Piel de Sapo'melon (Cucucumis melo L.). PLoS One, 9(8), e104188.

Dogimont, C. (2011). 2011 Gene List for Melon. Cucurbit Genetics Cooperative Report 33-34, 104-133.

Eduardo, I., Arús, P., Monforte, A. J., Obando, J., Fernández-Trujillo, J. P., Martínez, J. A., ... van der Knaap, E. (2007). Estimating the genetic architecture of fruit quality traits in melon using a genomic library of near isogenic lines. Journal of the American Society for Horticultural Science, 132(1), 80-89.

Elshire, R. J., Glaubitz, J. C., Sun, Q., Pol, J. A., Kawamoto, K., Buckler E. S., \& Mitchell, S. E. (2011). A robust, simple genotyping-by-sequencing (GBS) approach for high diversity species. PLoS ONE, 6, e19379.

Endl, J., Achigan-Dako, E. G., Pandey, A. K., Monforte, A. J., Picò, B., \& Schaefer, H. (2018). Repeated domestication of melon (Cucumis melo) in Africa and Asia and a new close relative from India. American Journal of Botany, 105(10), 1662-1671.

Eshed, Y., \& Zamir, D. (1994). Introgressions from Lycopersicon pennellii can improve the soluble-solids yield of tomato hybrids. Theoretical and Applied Genetics, 88(6-7), 891897.

Esteras, C., Formisano, G., Roig, C., Díaz, A., Blanca, J., Garcia-Mas, J., ... Picò, B. (2013). SNP genotyping in melons: Genetic variation, population structure, and linkage disequilibrium. Theoretical and Applied Genetics, 126(5), 1285-1303.

Esteras, C., Rambla, J. L., Sánchez, G., López-Gresa, M. P., González-Mas, M. C., FernandézTrujillo, J. P., ... Picò, M. B. (2018). Fruit flesh volatile and carotenoid profile analysis within the Cucumis melo L. species reveals unexploited variability for future genetic breeding. Journal of the Science of Food and Agriculture, 98(10), 3915-3925.

Falke, K. C., Miedaner, T., \& Frisch, M. (2009). Selection strategies for the development of rye introgression libraries. Theoretical and applied genetics, 119(4), 595-603.

FAOSTAT. (2019). Food and Agriculture Organization Corporate Statistical Database. Retrieve from http://faostat3.fao.org/home/S [Access on 14 April 2019].

Fazza, A. C., Dallagnol, L. J., Fazza, A. C., Monteiro, C. C., de Lima, B. M., Wassano, D. T., \& Camargo, L. E. A. (2013). Mapping of resistance genes to races 1, 3 and 5 of Podosphaera xanthii in melon PI 414723. Crop Breeding and Applied Biotechnology (online), 13(4), 349-355. 


\section{INTRODUCCIÓN}

Feder, A., Burger, J., Gao, S., Lewinsohn, E., Katzir, N., Schaffer, A. A., ... Fei, Z. (2015). A Kelch domain-containing F-Box coding gene negatively regulates flavonoid accumulation in muskmelon. Plant physiology, 169(3), 1714-1726.

Fergany, M., Kaur, B., Monforte, A. J., Pitrat, M., Rys, C., Lecoq, H., ... Dhaliwal, S. S. (2011). Variation in melon (Cucumis melo) landraces adapted to the humid tropics of southern India. Genetic Resources and Crop Evolution, 58(2), 225-243.

Fernandez-Silva, I., Eduardo, I., Blanca, J., Esteras, C., Picò, B., Nuez, F., ... Monforte, A. J. (2008). Bin mapping of genomic and EST-derived SSRs in melon (Cucumis melo L.). Theoretical and Applied Genetics, 118(1), 139-150.

Fernandez-Trujillo, J. P., Picò, M. B., Garcia-Mas, J., Alvarez, J. M., \& Monforte, A. J. (2011). Breeding for fruit quality in melon. In: M. A. Jenks \& P. J. Bebeli (Eds.), Breeding for Fruit Quality (pp. 261-278). Oxford, UK: Wiley-Blackwell.

Finkers, R., van Heusden, A. W., Meijer-Dekens, F., van Kan, J. A., Maris, P., \& Lindhout, P. (2007). The construction of a Solanum habrochaites LYC4 introgression line population and the identification of QTLs for resistance to Botrytis cinerea. Theoretical and Applied Genetics, 114(6), 1071-1080.

Fita, A., Picò, B., Dias, R. C. S., \& Nuez, F. (2009). 'Piel de Sapo' breeding lines tolerant to melon vine decline. HortScience, 44(5), 1458-1460.

Flores, F., Martínez-Madrid, M. C., Sánchez-Hidalgo, F. J., \& Romojaro, F. (2001b). Differential rind and pulp ripening of transgenic antisenseACC oxidase melon. Plant Physiology and Biochemistry, 39(1), 37-43.

Flores, F., Romojaro, F., Ben Amor, M., Pech, J. C., \& Latché, A. (2001a). Differential sensitivity to ethylene of the various ripening pathways of ethylene-suppressed cantaloupe melons. Acta Horticulturae, 553, 151-153.

Fu, Q., Zhang, P., Tan, L., Zhu, Z., Ma, D., Fu, Y., ... Sun, C. (2010). Analysis of QTLs for yield-related traits in Yuanjiang common wild rice (Oryza rufipogon Griff.). Journal of Genetics and Genomics, 37(2), 147-157.

Fukino, N., Ohara, T., Monforte, A. J., Sugiyama, M., Sakata, Y., Kunihisa, M., \& Matsumoto, S. (2008). Identification of QTLs for resistance to powdery mildew and SSR markers diagnostic for powdery mildew resistance genes in melon (Cucumis melo L.). Theoretical and Applied Genetics, 118(1), 165-175.

Gabriel, S., Ziaugra, L., Tabbaa, D. (2009). SNP genotyping using the Sequenom MassARRAY iPLEX platform. Current Protocols in Human Genetics, 2(1), 2-12.

Garcia-Mas, J., Benjak, A., Sanseverino, W., Bourgeois, M., Mir, G., González, V. M., ... Alioto, T. (2012). The genome of melon (Cucumis melo L.). Proceedings of the National 
Academy of Sciences, 109(29), 11872-11877.

Ghebretinsae, A. G., Thulin, M., \& Barber, J. C. (2007). Relationships of cucumbers and melons unraveled: Molecular phylogenetics of Cucumis and related genera (Benincaseae, Cucurbitaceae). American Journal of Botany, 94(7), 1256-1266.

Giner, A., Pascual, L., Bourgeois, M., Gyetvai, G., Rios, P., Picò, B., ... Martín-Hernández, A. M. (2017). A mutation in the melon Vacuolar Protein Sorting 41prevents systemic infection of Cucumber mosaic virus. Scientific reports, 7(1), 10471.

Goldman, A. (2002). Melons, for the passionate grower. New York, USA: Artisan.

Gómez, J., Serrano, Y., Pérez, A., Porcel, E., Gómez, R., \& Aguilar, M. I. (2014). Fusarium solani f. sp. cucurbitae, affecting melon in Almería province, Spain. Australasian plant disease notes, 9(1), 136.

Gómez-Guillamon, M., \& Álvarez, J. (2016). Melón. En: J. Ruiz de Galarreta, J. Prohens, \& R. Tierno. Las variedades locales en la mejora genética de plantas (pp. 427-439). Vitoria, Gobierno Vasco: Servicio Central de Publicaciones del Gobierno Vasco.

Gonda, I., Lev, S., Bar, E., Sikron, N., Portnoy, V., Davidovich-Rikanati, R., ... Huang, M. (2013). Catabolism of $1-$ methionine in the formation of sulfur and other volatiles in melon (Cucumis melo L.) fruit. The Plant Journal, 74(3), 458-472.

González, M., Xu, M., Esteras, C., Roig, C., Monforte, A. J., Troadec, C., ... Picò M. B. (2011). Towards a TILLING platform for functional genomics in 'Piel de Sapo' melons. BMC Research Notes, 4(1), 289.

González, V. M., Rodríguez-Moreno, L., Centeno, E., Benjak, A., Garcia-Mas, J., Puigdomènech, P., \& Aranda, M. A. (2010). Genome-wide BAC-end sequencing of Cucumis melo using two BAC libraries. BMC Genomics, 11(1), 618.

Gonzalo, M. J., Díaz, A., Dhillon, N. P. S., Reddy, U. K., Picò, M. B., \& Monforte, A. J. (2019). Re-evaluation of the role of Indian germplasm as center of melon diversification based on genotyping-by-sequencing analysis. BMC Genomics, 20(1), 448.

Gonzalo, M. J., Oliver, M., Garcia-Mas, J., Monfort, A., Dolcet-Sanjuan, R., Katzir, N., ... Monforte, A. J. (2005). Simple-sequence repeat markers used in merging linkage maps of melon (Cucumis melo L.). Theoretical and Applied Genetics, 110(5), 802-811.

Gonzalo, M. R., \& Monforte, A. J. (2017). Genetic mapping of complex traits in cucurbits. In: R. Grumet, N. Katzir, \& J. Garcia-Mas. (Eds.), Genetics and genomics of Cucurbitaceae (Vol. 20, pp. 269-290). Cham, Switzerland: Springer Nature.

Goulao, L. F., \& Oliveira, C. M. (2008). Cell wall modifications during fruit ripening: when a fruit is not the fruit. Trends in Food Science \& Technology, 19(1), 4-25.

Grandillo, S., \& Tanksley, S. D. (2005). Advanced backcross QTL analysis: results and 


\section{INTRODUCCIÓN}

perspectives. In: R. Tuberosa, R. L. Phillips, M. Gale (Eds.), Proceedings of the International Congress "In the Wake of the Double Helix: From the Green Revolution to the Gene Revolution” (pp. 115-132). Bologna, Italy.

Grumet, R., Garcia-Mas, J., \& Katzir, N. (2017). Cucurbit genetics and genomics: A Look to the Future. In: R. Grumet, N. Katzir, \& J. Garcia-Mas (Eds.), Genetics and genomics of Cucurbitaceae (Vol. 20, pp. 414). Cham, Switzerland: Springer Nature.

Grumet, R., \& Colle, M. (2017). Genomic Analysis of Cucurbit Fruit Growth. In: R. Grumet, N. Katzir, \& J. Garcia-Mas (Eds.), Genetics and genomics of Cucurbitaceae (Vol. 20, pp. 321-344). Cham, Switzerland: Springer Nature.

Guis, M., Botondi, R., Ben-Amor, M., Ayub, R., Bouzayen, M., Pech, J. C., \& Latché, A. (1997). Ripening-associated biochemical traits of Cantaloupe Charentais melons expressing an antisense ACC oxidase transgene. Journal of the American Society for Horticultural Science, 122(6), 748-751.

Guiu-Aragonés, C., Monforte, A. J., Saladié, M., Corrêa, R. X., Garcia-Mas, J., \& MartínHernández, A. M. (2014). The complex resistance to cucumber mosaic cucumovirus (CMV) in the melon accession PI161375 is governed by one gene and at least two quantitative trait loci. Molecular breeding, 34(2), 351-362.

Gur, A., Gonda, I., Portnoy, V., Tzuri, G., Chayut, N., Cohen, S., ... Katzir, N. (2017b). Genomic aspects of melon fruit quality. In: R. Grumet, N. Katzir, \& J. Garcia-Mas. (Eds.), Genetics and genomics of Cucurbitaceae (Vol. 20, pp. 377-408). Cham, Switzerland: Springer Nature.

Gur, A., Tzuri, G., Meir, A., Sa'ar, U., Portnoy, V., Katzir, N., .. Tadmor, Y. (2017a). Genomewide linkage disequilibrium mapping to the candidate gene level in melon (Cucumis melo). Scientific reports, 7(1): 9770.

Hamada, H., Petrino, M. G., \& Kakunaga, T. (1982). A novel repeated element with Z-DNAforming potential is widely found evolutionarily diverse eukaryotic genomes. Proceedings of the National Academy of Sciences, 79(21), 6465-6469.

Harel-Beja, R., Tzuri, G., Portnoy, V., Lotan-Pompan, M., Lev, S., Cohen, S., ... Katzir, N. (2010). A genetic map of melon highly enriched with fruit quality QTLs and EST markers, including sugar and carotenoid metabolism genes. Theoretical and Applied Genetics, 121(3), 511-533.

Harvey, J. H. (1975). Gardening books and plant lists of Moorish Spain. Garden History $3(2): 10-21$.

Hayata, Y., Sakamoto, T., Maneerat, C., Li, X., Kozuka, H., \& Sakamoto, K. (2003). Evaluation of aroma compounds contributing to muskmelon flavor in Porapak Q extracts by aroma 
extract dilution analysis. Journal of agricultural and food chemistry, 51(11), 3415-3418.

Hogenboom, N. G. (1973). A model for incongruity in intimate partner relationships. Euphytica, 22(2), 219-233.

Huang, Z., Van Houten, J., Gonzalez, G., Xiao, H., \& van der Knaap, E. (2013). Genome-wide identification, phylogeny and expression analysis of SUN, OFP and YABBY gene family in tomato. Molecular genetics and genomics, 288(3-4), 111-129.

Hughes, M. B. (1948). The inheritance of two characters of Cucumis melo and their interrelationship. Proceedings of the American Society for Horticultural Science, 52, 399402.

Iglesias, A., Picò, B., \& Nuez, F. (2000a). A temporal genetic analysis of disease resistance genes: Resistance to melon vine decline derived from Cucumis melo var. agrestis. Plant Breeding, 119(4), 329-334.

Iglesias, A., Picò, B., \& Nuez, F. (2000b). Pathogenicity of fungi associated with melon vine decline and selection strategies for breeding resistant cultivars. Annals of Applied Biology, 137(2), 141-151.

Iman, M. K., Abo-Bakr, M. A., \& Hanna, H. Y. (1972). Inheritance of some economic characters in crosses between sweet melon and snake cucumber. I. Inheritance of qualitative characters. Assiut Journal of Agricultural Sciences, 3, 363-380.

Jahn, M., Munger, H. M., \& McCreight, J. D. (2002). Breeding cucurbit crops for powdery mildew resistance. In: R. R. Belanger, W. R. Bushnell, A. J. Dik, \& T. L. Carver (Eds.), The powdery mildews: A comprehensive treatise (pp. 239-248.). St. Paul, USA: APS Press.

Janick, J., Paris, H. S., \& Parrish, D. C. (2007). The cucurbits of Mediterranean antiquity: Identification of taxa from ancient images and descriptions. Annals of Botany, 100(7), $1441-1457$.

Jeffrey, C. (1980). A review of the Cucurbitaceae. Botanical journal of the Linnean Society, 81(3), 233-247.

Jeffrey, C. (1990). Systematics of the Cucurbitaceae: An overview. In: Biology and utilization of the Cucurbitaceae, (Eds.), D.M. Bates, R.W. Robinson, \& C. Jeffrey (pp. 77-95). Ithaca, USA: Cornell University Press.

Jordán, M. J., Shaw, P. E., \& Goodner, K. L. (2001). Volatile components in aqueous essence and fresh fruit of Cucumis melo cv. Athena (muskmelon) by GC-MS and GC-O. Journal of agricultural and food chemistry, 49(12), 5929-5933.

Karlova, R., Chapman, N., David, K., Angenent, G. C., Seymour, G. B., \& de Maagd, R. A. (2014). Transcriptional control of fleshy fruit development and ripening. Journal of Experimental Botany, 65(16), 4527-4541. 


\section{INTRODUCCIÓN}

Katsumata, H., \& Yasui, H. (1964). Studies on the combining abilities and classification of the varieties in oriental melons. Bulletin of Horticulture Research Station Kurume Fukuoka Jpn, 500(2):49-65.

Kemp, T. R., Knavel, D. E., \& Stoltz, L. P. (1973). Volatile Cucumis melo components: identification of additional compounds and effects of storage conditions. Phytochemistry, 12(12), 2921-2924.

Kemp, T. R., Stoltz, L. P., \& Knavel, D. E. (1972). Volatile components of muskmelon fruit. Journal of Agricultural and Food Chemistry, 20(2), 196-198.

Kerje, T., \& Grum, M. (2000). The origin of melon, Cucumis melo: a review of the literature. Acta Horticulturae, 510, 37-44.

Kho, Y. O., den Nijs, A. P. M., \& Franken, J. (1980). Interspecific hybridization in Cucumis L. II. The crossability of species, an investigation of in vitro pollen tube growth and seed set. Euphytica, 29(3), 661-672.

Kirkbride, J. H. (1993). Biosystematic monograph of the genus Cucumis (Cucurbitaceae). Boone, USA: Parkway.

Kistler, L., Montenegro, A, Smith, B. D., Gifford, J. A, Green R. E, Newsom L. E, \& Shaprito, B. (2014). Transoceanic drift and the domestication of African bottle gourds in the Americas. Proceedings of the National Academy of Sciences of the United States of America. 111(8), 2937-2941.

Kocyan, A., Zhang, L. B., Schaefer, H., \& Renner, S. S. (2007). A multi-locus chloroplast phylogeny for the Cucurbitaceae and its implications for character evolution and classification. Molecular Phylogenetics and Evolution, 44(2), 553-577.

de Koeyer, D., Douglass, K., Murphy, A., Whitney, S., Nolan, L., Song, Y., \& de Jong, W. (2010). Application of high-resolution DNA melting for genotyping and variant scanning of diploid and autotetraploid potato. Molecular Breeding, 25(1), 67-90.

Kourkoutas, D., Elmore, J. S., \& Mottram, D. S. (2006). Comparison of the volatile compositions and flavour properties of cantaloupe, Galia and honeydew muskmelons. Food Chemistry, 97(1), 95-102.

Křístková, E., Lebeda, A., \& Sedláková, B. (2007). Temporal and spatial dynamics of powdery mildew species on cucurbits in the Czech Republic. Acta Horticulturae, 731, 337-343.

Kř́stková, E., Lebeda, A., \& Sedláková, B. (2009). Species spectra, distribution and host range of cucurbit powdery mildews in the Czech Republic, and in some other European and Middle Eastern countries. Phytoparasitica, 37(4), 337-350.

Kumar, S., Volz, R. K., Alspach, P. A., \& Bus, V. G. (2010). Development of a recurrent apple breeding programme in New Zealand: a synthesis of results, and a proposed revised 
breeding strategy. Euphytica, 173(2), 207-222.

Lázaro, A., Fernández, I. C., Borrero, M. J., Cabello, F., López-Sesé, A. I., Gómez-Guillamón, M. L., \& Picò, B. (2017). Agromorphological genetic diversity of Spanish traditional melons. Genetic resources and crop evolution, 64(7), 1687-1706.

Lebeda, A., \& Sedláková, B. (2006). Identification and survey of cucurbit powdery mildew races in Czech populations. In: G. J. Holmes (Ed.), Proceedings of Cucurbitaceae 2006 (pp. 444-452). Raleigh, USA: Universal Press.

Lebeda, A., \& Sedláková, B. (2010). Screening for resistance to cucurbit powdery mildews (Golovinomyces cichoracearum, Podosphaera xanthii). In: M. M. Spencer, \& A. Lebeda (Eds.), Mass screening techniques for selecting crops resistant to disease (pp. 295-307). Vienna, Austria: International Atomic Energy Agency (IAEA).

Lebeda, A., Křístková, E., Sedláková, B., McCreight, J. D., \& Coffey, M. D. (2016). Cucurbit powdery mildews: methodology for objective determination and denomination of races. European journal of plant pathology, 144(2), 399-410.

Lebeda, A., Widrlechner, M. P., Staub, J., Ezura, H., Zalapa J, \& Kristkova, E. (2007). Cucurbits (Cucurbitaceae; Cucumis spp., Cucurbita spp., Citrullus spp.). In: R. J. Singh (ed.), Genetic resources, chromosome engineering, and crop improvement (Vol. 3, pp. 271-376). Boca Raton, USA: Taylor \& Francis Group.

Leclerc, L. (1883). Traité des Simples par Ibn El-Beïthar. Paris, France: Imprimerie Nationale. Lecoq, H., \& Desbiez, C. (2012). Viruses of cucurbit crops in the Mediterranean region: An ever-changing picture. In: L. Gad, \& L. Hervé (Eds.), Advances in virus research (pp. 67126). London, UK: Academic Press.

Leida, C., Moser, C., Esteras, C., Sulpice, R., Lunn, J. E., de Langen, F., ... Picò, B. (2015). Variability of candidate genes, genetic structure and association with sugar accumulation and climacteric behavior in a broad germplasm collection of melon (Cucumis melo L.). BMC Genetics, 16(1), 28.

Lester, G. E. (2008). Antioxidant, sugar, mineral and phytonutient concentrations across edible fruit tissues of orange-fleshed honeydew melon (Cucumis melo L.). Journal of Agricultural and Food Chemistry, 56(10), 3694-3698.

Lester, G. E., \& Hodges, D. M. (2008). Antioxidants associated with fruit senescence and human health: Novel orange-fleshed non-netted honey dew melon genotype comparisons following different seasonal productions and cold storage durations. Postharvest Biology and Technology, 48(3), 347-354.

Linnaeus, C. (1753 ). Species plantarum, vol. II. Stockholm, Sweden: Laurentii Salvii.

Liu, L., Chen, Y., Su, Z., Zhang, H., \& Zhu, W. (2010). A sequence-amplified characterized 


\section{INTRODUCCIÓN}

region marker for a single, dominant gene in melon PI 134198 that confers resistance to a unique race of Podosphaera xanthii in China. HortScience, 45(9), 1407-1410.

López De Heredia Larrea, U. (2016). Las técnicas de secuenciación masiva en el estudio de la diversidad biológica. Munibe Ciencias Naturales, 64, 7-31.

Luan, F., Delannay, I., \& Staub, J. E. (2008). Chinese melon (Cucumis melo L.) diversity analyses provide strategies for germplasm curation, genetic improvement, and evidentiary support of domestication patterns. Euphytica, 164(2), 445-461.

Malik, A. A., Vashisht, V. K., Singh, K., Sharma, A., Singh, D. K., Singh, H., ... Dhillon, N. P. S. (2014). Diversity among melon (Cucumis melo L.) landraces from the Indo-Gangetic plains of India and their genetic relationship with USA melon cultivars. Genetic Resources and Crop Evolution, 61(6), 1189-1208.

Mammadov, J., Aggarwal, R., Buyyarapu, R., \& Kumpatla, S. (2012). Review article SNP markers and their impact on plant breeding. International Journal of Plant Genomics, 2012, 1-11.

Martyn, R. D., \& Miller, M. E. (1996). Monosporascus root rot and vine decline. An emerging disease of melons worldwide. Plant Disease, 80(7), 716-725.

Mascarell-Creus A, Cañizares, J., Vilarrasa-Blasi, J., Mora-García, S., Blanca, J., GonzalezIbeas, D., ... Caño-Delgado, A. I. (2009). An oligo-based microarray offers novel transcriptomic approaches for the analysis of pathogen resistance and fruit quality traits in melon (Cucumis melo L.) BMC Genomics, 10(1), 467.

McCreight, J. D. (2000). Potential sources of resistance to lettuce infectious yellows virus in melon. HortScience, 35(6), 1118-1120.

McCreight, J. D. (2003). Genes for resistance to powdery mildew races 1 and 2U. S. in melon PI 313970. HortScience, 38(4), 591-594.

McCreight, J. D. (2006). Melon-powdery mildew interactions reveal variation in melon cultigens and Podosphaera xanthii races 1 and 2. Journal of the American Society for Horticultural Science, 131(1), 59-65.

McCreight, J. D. (2017). Cultivation and uses of cucurbits. In: R. Grumet, N. Katzir, \& J. Garcia-Mas (Eds.), Genetics and genomics of Cucurbitaceae (Vol. 20, pp. 1-10). Cham, Switzerland: Springer Nature.

McCreight, J. D., Coffey, M. D., Sedlaková, B., \& Lebeda, A. (2012). Cucurbit powdery mildew of melon incited by Podosphaera xanthii: Global and western U.S. perspectives. In: N. Sari, I. Solmaz, \& V. Arars (Eds.), Proceedings of the Xth Eucarpia meeting on genetics and breeding of Cucurbitaceae (pp. 181-189). Adana, Turkey: Cukurova University. 
McGrath, M., \& Thomas, C. (1996). Powdery mildew. In: T. Zitter, D. Hopkins, \& C. Thomas (Eds.), Compendium of cucurbit diseases (pp. 28-30). St. Paul, USA: APS Press. Monforte, A. J., Díaz, A., Caño-Delgado, A., \& van der Knaap, E. (2014). The genetic basis of fruit morphology in horticultural crops: lessons from tomato and melon. Journal of experimental botany, 65(16), 4625-4637.

Monforte, A. J., Friedman, E., Zamir, D., \& Tanksley, S. D. (2001). Comparison of a set of allelic QTL-NILs for chromosome 4 of tomato: deductions about natural variation and implications for germplasm utilization. Theoretical and Applied Genetics, 102(4), 572590.

Monforte, A. J., Oliver, M., Gonzalo, M. J., Alvarez, J. M., Dolcet-Sanjuan, R., \& Arús, P. (2004). Identification of quantitative trait loci involved in fruit quality traits in melon (Cucumis melo L.). Theoretical and Applied Genetics, 108(4), 750-758.

Moreno, E., Obando, J. M., Dos-Santos, N., Fernández-Trujillo, J. P., Monforte, A. J., \& Garcia-Mas, J. (2008). Candidate genes and QTLs for fruit ripening and softening in melon. Theoretical and Applied Genetics, 116(4), 589-602.

Munger, H. M., Robinson, R.W. (1991). Nomenclature of Cucumis melo L. Cucurbit Genet Cooperative Reports. 14, 43-44.

Naudin, C. (1859). Essais d'une monographie des espèces et des variétés du genre Cucumis. Annales des Sciences Naturelles; Botanique, 11, 5-87.

Nieto, C., Morales, M., Orjeda, G., Clepet, C., Monfort, A., Sturbois, B., ... \& Garcia-Mas, J. (2006). An eIF4E allele confers resistance to an uncapped and non-polyadenylated RNA virus in melon. The Plant Journal, 48(3), 452-462.

Nimmakayala, P., Tomason1, Y. R., Abburi1, V. L., Alvarado, A., Saminathan, T., Vajja1, V. G. ... Reddy, U. K. (2016). Genome-wide differentiation of various melon horticultural groups for use in GWAS for fruit firmness and construction of a high resolution genetic map. Frontiers in Plant Science, 7, 1646.

Nunes, E. W. L. P., Esteras, C., Ricarte, A. O., Martínez-Perez, E., Gómez-Guillamón, M. L., Nunes, G. H. S., \& Picò, M. B. (2017). Brazilian melon landraces resistant to Podosphaera xanthii are unique germplasm resources. Annals of applied biology, 171(2), 214-228.

Nuñez-Palenius, H. G., Huber, D. J., Klee, H. J., \& Cantliffe, D. J. (2007). Fruit ripening characteristics in a transgenic "Galia" male parental muskmelon (Cucumis melo L. var. reticulatus Ser.) line. Postharvest Biology and Technology, 44(2), 95-100.

O’Brien, S. L. (1990). Genetics maps: locus maps of complex genomes. New York, USA: Cold Spring Harbor Laboratory Press.

Obando, J., Fernández-Trujillo, J. P., Martínez, J. A., Alarcón, A. L., Eduardo, I., Arús, P., \& 


\section{INTRODUCCIÓN}

Monforte, A. J. (2008). Identification of melon fruit quality quantitative trait loci using near-isogenic lines. Journal of the American Society for Horticultural Science, 133(1), $139-151$.

Obando-Ulloa, J. M., Moreno, E., García-Mas, J., Nicolai, B., Lammertyn, J., Monforte, A. J., \& Fernández-Trujillo, J. P. (2008). Climacteric or non-climacteric behavior in melon fruit: 1. Aroma volatiles. Postharvest Biology and Technology, 49(1), 27-37.

Obando-Ulloa, J. M., Ruiz, J., Monforte, A. J., \& Fernández-Trujillo, J. P. (2010). Aroma profile of a collection of near-isogenic lines of melon (Cucumis melo L.). Food chemistry, 118(3), 815-822.

Okuda, S., Okuda, M., Sugiyama, M., Sakata, Y., Takeshita, M., \& Iwai, H. (2013). Resistance in melon to Cucurbit chlorotic yellows virus, a whitefly-transmitted crinivirus. European journal of plant pathology, 135(2), 313-321.

Oliver, M., Garcia-Mas, J., Cardús, M., Pueyo, N., López-Sesé, A. I., Arroyo, M., ... de Vicente, M. C. (2001). Construction of a reference linkage map for melon. Genome, 44(5), 836-845.

Oumouloud, A., Arnedo-Andrés, M. S., González-Torres, R., \& Álvarez, J. M. (2010). Inheritance of resistance to Fusarium oxysporum f. sp. melonis races 0 and 2 in melon accession Tortuga. Euphytica, 176(2), 183-189.

Palomares-Ríus, F. J., Garcés-Claver, A., Gómez-Guillamón, M. L. (2016). Detection of two QTLS associated with resistance to Cucurbit Yellow Stunting Disorder Virus in melon line TGR 1551. In: E. U. Kozik, \& H. S. Paris (Eds.), Proceedings of Cucurbitaceae 2016, XIth Eucarpia Meeting on Genetics and Breeding of Cucurbitaceae (pp. 334-337). Warsaw, Poland: Research Institute of Horticulture.

Pang, X., Guo, X., Qin, Z., Yao, Y., Hu, X., \& Wu, J. (2012). Identification of aroma-active compounds in Jiashi muskmelon juice by GC-O-MS and OAV calculation. Journal of agricultural and food chemistry, 60(17), 4179-4185.

Paris, H. S. (1989). Historical records, origins and devolpment of the edible cultivar groups of Curcubita pepo (Curcubitaceae). Economic Botany, 43(4), 423-443.

Paris, H. S, Amar, Z., Lev, E. (2012). Medieval history of the duda'im melon (Cucumis melo, Cucurbitaceae). Economic Botany, 66(3), 276-284.

Paris, M. K., Zalapa, J. E., McCreight, J. D., \& Staub, J. E. (2008). Genetic dissection of fruit quality components in melon (Cucumis melo L.) using a RIL population derived from exoticxelite US Western Shipping germplasm. Molecular Breeding, 22(3), 405-419.

Park, S. O., Hwang, H. Y., \& Crosby, K. M. (2009). A genetic linkage map including loci for male sterility, sugars, and ascorbic acid in melon. Journal of the American Society for 
Horticultural Science, 134(1), 67-76.

Passam, H. C., Karapanos, I. C., \& Alexopoulos, A. A. (2011). The Biological Basis of Fruit Quality. In: M. A. Jenks \& P. J. Bebeli (Eds.), Breeding for Fruit Quality (pp. 5-38). Oxford, UK: Wiley-Blackwell.

Pavan, S., Marcotrigiano, A. R., Ciani, E., Mazzeo, R., Zonno, V., Ruggieri, V., ... Ricciardi, L. (2017). Genotyping-by-sequencing of a melon (Cucumis melo L.) germplasm collection from a secondary center of diversity highlights patterns of genetic variation and genomic features of different gene pools. BMC Genomics, 18(1), 59.

Pech, J. C., Bouzayen, M., \& Latché, A. (2008). Climacteric fruit ripening: ethylene-dependent and independent regulation of ripening pathways in melon fruit. Plant Science, 175(1-2), $114-120$.

Pellat, C. (1961). Le Calendrier de Cordoue publié par R. Dozy. Leiden, Netherlands: E. J. Brill.

Perchepied, L., Bardin, M., Dogimont, C., \& Pitrat, M. (2005). Relationship between loci conferring downy mildew and powdery mildew resistance in melon assessed by Quantitative Trait Loci mapping. Phytopathology, 95(5), 556-565.

Perchepied, L., Dogimont, C., \& Pitrat, M. (2005). Strain-specific and recessive QTLs involved in the control of partial resistance to Fusarium oxysporum f. sp. melonis race 1.2 in a recombinant inbred line population of melon. Theoretical and Applied Genetics, 111(1), $65-74$.

Perchepied, L., \& Pitrat, M. (2004). Polygenic inheritance of partial resistance to Fusarium oxysporum f. sp. melonis race 1.2 in melon. Phytopathology, 94(12), 1331-1336

Pereira L. (2018). Genetic dissection of fruit quality and ripening traits in melon. Barcelona (Doctoral Thesis). Universitat Autònoma de Barcelona. Barcelona, España. Retrieved from https://ddd.uab.cat/record/201529.

Pereira, L., Ruggieri, V., Pérez, S., Alexiou, K. G., Fernández, M., Jahrmann, T., ... GarciaMas, J. (2018). QTL mapping of melon fruit quality traits using a high-density GBS-based genetic map. BMC plant biology, 18(1), 324.

Perez de Castro, A., Esteras, C., Alfaro-Fernández, A., Daròs, J. A., Monforte, A. J., Picò, M. B., \& Gómez-Guillamón, M. L. (2019). Fine mapping of wmv1551, a resistance gene to Watermelon mosaic virus in melon. Article submitted for publication.

Périn, C., Gomez-Jimenez, M., Hagen, L., Dogimont, C., Pech, J. C., Latché, A., ... Lelièvre, J. M. (2002c). Molecular and genetic characterization of a non-climacteric phenotype in melon reveals two loci conferring altered ethylene response in fruit. Plant Physiology, 129(1), 300-309. 


\section{INTRODUCCIÓN}

Périn, C., Hagen, L., De Conto, V., Katzir, N., Danin-Poleg, Y., Portnoy, V., ... Pitrat, M. (2002a). A reference map of Cucumis melo based on two recombinant inbred line populations. Theoretical and Applied Genetics, 104(6-7), 1017-1034.

Périn, C., Hagen, L., Giovinazzo, N., Besombes, D., Dogimont, C., \& Pitrat, M. (2002b). Genetic control of fruit shape acts prior to anthesis in melon (Cucumis melo L.). Molecular Genetics and Genomics, 266(6), 933-941.

Perpiñà, G., Esteras, C., Gibon, Y., Monforte, A. J., \& Picò, B. (2016). A new genomic library of melon introgression lines in a cantaloupe genetic background for dissecting desirable agronomical traits. BMC Plant Biology, 16(1), 164.

Perry, P. L., Wang, Y., \& Lin, J. (2009). Analysis of honeydew melon (Cucumis melo var. inodorus) flavour and GC-MS/MS identification of (E, Z)-2, 6-nonadienyl acetate. Flavour and fragrance journal, 24(6), 341-347.

Pitrat, M. (1991). Linkage groups in Cucumis melo L. Journal of Heredity, 82(5), 406-411.

Pitrat, M. (2003). Melons, concombres et pastèques. In: M. Pitrat \& C. Foury (Eds). Histoires de légumes (291-309). Paris, France: INRA.

Pitrat, M. (2008). Melon (Cucumis melo L.) In: J. Prohens, \& F. Nuez (Eds.), Hand-book of crop breeding vegetables (Vol 1., pp. 283-315). New York, USA: Springer.

Pitrat, M. (2013). Phenotypic diversity in wild and cultivated melons (Cucumis melo). Plant Biotechnology, 30(3), 273-278.

Pitrat, M. (2017). Melon genetic resources: phenotypic diversity and horticultural taxonomy. In: R. Grumet, N. Katzir, \& J. Garcia-Mas (Eds.), Genetics and genomics of Cucurbitaceae (Vol. 20, pp. 25-59). Cham, Switzerland: Springer Nature.

Pitrat, M., \& Lecoq, H. (1984). Inheritance of zucchini yellow mosaic virus resistance in Cucumis melo L. Euphytica, 33(1), 57-61.

Pitrat, M., Hanelt, P., \& Hammer, K. (2000). Some comments on infraspecific classification of cultivars of melon. Acta Horticulturae, 510, 29-36.

Pollack, F. G., \& Uecker, F. A. (1974). Monosporascus cannonballus an unusual ascomycete in Cantaloupe roots. Mycologia, 66, 346-349.

Portnoy, V., Benyamini, Y., Bar, E., Harel-Beja, R., Gepstein, S., Giovannoni, J. J., ... Katzir, N. (2008). The molecular and biochemical basis for varietal variation in sesquiterpene content in melon (Cucumis melo L.) rinds. Plant molecular biology, 66(6), 647-661.

Ramamurthy, R. K., \& Waters, B. M. (2015). Identification of fruit quality and morphology QTLs in melon (Cucumis melo) using a population derived from flexuosus and cantalupensis botanical groups. Euphytica, 204(1), 163-177.

Renner, S. S., Schaefer, H., \& Kocyan, A. (2007). Phylogenetics of Cucumis (Cucurbitaceae): 
Cucumber (C. sativus) belongs in an Asian/Australian clade far from melon (C. melo). BMC Evolutionary Biology, 7(1), 58.

Renner, S., \& Schaefer, H. (2017) Phylogeny and Evolution of the Cucurbitaceae. In: R. Grumet, N. Katzir, \& J. Garcia-Mas (Eds.), Genetics and genomics of Cucurbitaceae (Vol. 20, pp. 253-263). Cham, Switzerland: Springer Nature.

Ribas, F., Cabello, M. J, Castellanos, M. T, Fita, A. M, Roig, C., Nuez, F., \& Picò, M. B. (2011). Recuperación y conservación de cultivares tradicionales de melón castellano-manchego. Agrícola Vergel, 30(347), 206-213.

Ríos, P. (2015). Clonaje posicional y validación de un gen candidato para eth6.3, un QTL implicado en la maduración climatérica del fruto del melón (Tesis Doctoral). Universitat Autònoma de Barcelona. Barcelona, España. Recuperado de https://ddd.uab.cat/record/166043.

Ríos, P., Argyris, J., Vegas, J., Leida, C., Kenigswald, M., Tzuri, G., ... Monforte, A. J. (2017). ETHQV 6.3 is involved in melon climacteric fruit ripening and is encoded by a NAC domain transcription factor. The Plant Journal, 91(4), 671-683.

Robinson, R. W., \& Decker-Walters, D. S. (1997). Cucurbits. New York, USA: CAB International.

Rodrigo, M. J., Zacarías, L., Deleu, W., Garcia-Mas, J., Monforte, A. J., Obando-Ulloa, J. M., \& Fernández-Trujillo, J. P. (2008). Flesh carotenoid profile in climacteric near-isogenic lines of melon obtained from non-climacteric parentals: Implications for fruit design. Acta Horticulturae, 858, 43-49.

Roig, C., Fita, A., Ríos, G., Hammond, J. P., Nuez, F., \& Picò, B. (2012). Root transcriptional responses of two melon genotypes with contrasting resistance to Monosporascus cannonballus (Pollack et Uecker) infection. BMC Genomics, 13(1), 601-612.

Rubio-Cabetas, M. J., Picò, B., Casas, A., \& Badenes, M. L. (2014). Aplicación de la biotecnología en los programas actuales de mejora. In R. Socias, M. J. Rubio-Cabetas, C. Mallor, \& J. M. Álvarez (Eds.), La obtención de variedades : desde la mejora clásica hasta la mejora genética molecular (pp. 97-137). Aragon, España: CITA.

Ruggieri, V., Alexiou, K. G., Morata, J., Argyris, J., Pujol, M., Yano, R., ... Garcia-Mas J. (2018). An improved assembly and annotation of the melon (Cucumis melo L.) reference genome. Scientific Reports, 8(1), 8088.

Sabato, D., Esteras, C., Grillo, O., Peña-Chocarro, L., Leida, C., Ucchesu, M., ... Picò, B. (2019). Molecular and morphological characterisation of the oldest Cucumis melo L. seeds found in the Western Mediterranean Basin. Archaeological and Anthropological Sciences, 11(3), 789-810. 


\section{INTRODUCCIÓN}

Sabbah, M. (1992). Kitab al-Aghdhiya wa al-Adwiya talif Ishaq bin Suliman al-Isra'ili (Book of foods and simple remedies by Ishaq ibn Suliman al-Isra'ili). Beirut: 'Azz al-Dinn.

Sáez, C., Esteras, C., Martínez, C., Ferriol, M., Dhillon, N. P., López, C., \& Picò, B. (2017). Resistance to tomato leaf curl New Delhi virus in melon is controlled by a major QTL located in chromosome 11. Plant cell reports, 36(10), 1571-1584.

Salari, M., Panjehkeh, N., Nasirpoor, Z., \& Abkhoo, J. (2012). Reaction of melon (Cucumis melo L.) cultivars to soil-borne plant pathogenic fungi in Iran. African Journal of Biotechnology, 11(87), 15324-15329.

Sales Júnior, R., Nunes, G. H., Michereff, S. J., Pereira, E. W., \& Guimarães, I. M. (2011). Reaction of families and lines of melon to powdery mildew. Horticultura Brasileira, 29(3), $382-386$.

Schaefer, H., Heibl, C., \& Renner, S. S. (2009). Gourds afloat: A dated phylogeny reveals an Asian origin of the gourd family (Cucurbitaceae) and numerous oversea dispersal events. Proceedings of the Royal Society B: Biological Sciences, 276(1658), 843-851.

Schwab, W., Davidovich-Rikanati, R., \& Lewinsohn, E. (2008). Biosynthesis of plant-derived flavor compounds. The plant journal, 54(4), 712-732.

Sebastian, P., Schaefer, H., Telford, I. R. H., \& Renner, S. S. (2010). Cucumber (Cucumis sativus) and melon (C. melo) have numerous wild relatives in Asia and Australia, and the sister species of melon is from Australia. Proceedings of the National Academy of Sciences, 107(32), 14269-14273.

Sedláková, B., Lebeda, A., Gryczová, K., \& Kř́istková, E. (2014). Virulence structure (pathotypes, races) of cucurbit powdery mildew populations in the Czech Republic in the years 2010-2012. In, Cucurbitaceae 2014, Proceedings (pp. 28-31). Alexandria, Egypt: ASHS Press.

Shalit, M., Katzir, N., Tadmor, Y., Larkov, O., Burger, Y., Shalekhet, F., ... Karchi, Z. (2001). Acetyl-CoA: alcohol acetyltransferase activity and aroma formation in ripening melon fruits. Journal of Agricultural and Food Chemistry, 49(2), 794-799.

Sherman, A., Eshed, R., Harel-Beja, R., Tzuri, G., Portnoy, V., Cohen, S., ... Ophir, R. (2013). Combining bulk segregation analysis and microarrays for mapping of the $\mathrm{pH}$ trait in melon. Theoretical and applied genetics, 126(2), 349-358.

Shishkoff, N. (2000). The name of the cucurbit powdery mildew: Podosphaera (sect. Sphaerotheca) xanthii (Castag.) U. Braun \& N. Shish. comb. nov. Phytopathology, 90(6), 1077-1093.

Singh, A. K., Kumar, S., Singh, H., Rai, V. P., Deo Singh, B., \& Pandey, S. (2015). Genetic diversity in Indian snapmelon (Cucumis melo var. momordica) accessions revealed by 
ISSR markers. Plant OMICS, 8(1), 9-16.

Szabó, Z., Gyulai, G., Humphreys, M., Horváth, L., Bittsánszky, A., Lágler, R., \& Heszky, L. (2005). Genetic variation of melon (C. melo) compared to an extinct landrace from the Middle Ages (Hungary) I. rDNA, SSR and SNP analysis of 47 cultivars. Euphytica, 146(12), 87-94.

Tadmor, Y., Burger, J., Yaakov, I., Feder, A., Libhaber, S. E., Portnoy, V., ... Katzir, N. (2010) Genetics of flavonoid, carotenoid, and chlorophyll pigments in melon fruit rinds. Journal of agricultural and food chemistry, 58(19), 10722-10728.

Tang, K., Fu, D. J., Julien, D., Braun, A., Cantor, C. R., \& Koster, H. (1999). Chip-based genotyping by mass spectrometry. Proceedings of the National Academy of Sciences of the United States of America, 96(18):10016-100020.

Tang, Y., Zhang, C., Cao, S., Wang, X., \& Qi, H. (2015). The effect of CmLOXs on the production of volatile organic compounds in four aroma types of melon (Cucumis melo). PLoS One, 10(11), e0143567.

Teixeira, A. P. M., Barreto, F. A. D. S., \& Camargo, L. E. A. (2008). An AFLP marker linked to the Pm-1 gene that confers resistance to Podosphaera xanthii race 1 in Cucumis melo. Genetics and Molecular Biology, 31(2), 547-550.

Thakur, H., Sharma, S., \& Thakur, M. (2019). Recent trends in muskmelon (Cucumis melo L.) research: an overview. The Journal of Horticultural Science and Biotechnology, 94(4), 533-547.

Tomason, Y., Nimmakayala, P., Levi, A., \& Reddy, U. K. (2013). Map-based molecular diversity, linkage disequilibrium and association mapping of fruit traits in melon. Molecular breeding, 31(4), 829-841.

Torres, A. M., Monforte, A. J., Millan, T., Šatović, Z. (2012). Análisis de QTLs para la mejora genetica vegetal. In: J. J. Ferreira, A. Ordas, \& M. Perez de la Vega (Eds.), La genética de los carácteres cuantitativos en al mejora vegetal del siglo XXI (pp. 177-215). Madrid, España: Sociedad Espanola de Genetica; Sociedad Espanola de Ciencias Horticolas.

Tucker, M. L. (2014) Cell-wall metabolism and softening during ripening. In: P. Nath, M. Bouzayen, A. K. Mattoo, \& J. C. Pech (Eds.), Fruit ripening: physiology, signalling and genomics (pp. 48-62). Boston, USA: CABI.

Tzuri, G., Zhou, X., Chayut, N., Yuan, H., Portnoy, V., Meir, A., ... Fei, Z. (2015). A 'golden'SNP in CmOr governs the fruit flesh color of melon (Cucumis melo). The Plant Journal, 82(2), 267-279.

Vegas, J., Garcia-Mas, J., \& Monforte, A. J. (2013). Interaction between QTLs induces an advance in ethylene biosynthesis during melon fruit ripening. Theoretical and applied 


\section{INTRODUCCIÓN}

genetics, 126(6), 1531-1544.

Verzera, A., Dima, G., Tripodi, G., Ziino, M., Lanza, C. M., \& Mazzaglia, A. (2011). Fast quantitative determination of aroma volatile constituents in melon fruits by headspacesolid-phase microextraction and gas chromatography-mass spectrometry. Food Analytical Methods, 4(2), 141-149.

Vossen, R. H., Aten, E., Roos, A., \& den Dunnen, J. T. (2009). High-Resolution Melting Analysis (HRMA) - More than just sequence variant screening. Human mutation, 30(6), 860-866.

Walters, T. (1989). Historical overview on domesticated plants in China with special emphasis on the Cucurbitaceae. Economic Botany, 43(3), 297-313.

Wang, Y. H., Wu, D. H., Huang, J. H., Tsao, S. J., Hwu, K. K., \& Lo, H. F. (2016). Mapping quantitative trait loci for fruit traits and powdery mildew resistance in melon (Cucumis melo). Botanical studies, 57(1), 19.

Watanabe, K., Saito, T., Hirota, S., Takahashi, B., \& Fujishita, N. (1991). Carotenoid pigments in orange, light orange, green and white flesh colored fruits of melon (Cucumis melo L.). Nippon Shokuhin Kogyo Gakkaishi, 38(2), 153-159.

Winter, P., \& Kahl, G. (1995). Molecular marker technologies for plant improvement. World Journal of Microbiology and Biotechnology, 11(4), 438-448.

Wolff, D. W. (1995). Evaluation of melon germplasm for resistance to monosporascus root rot vine decline. In J. R., Dunlap \& G. E., Lester (Eds), Evaluation and Enhancement of Cucurbit Germplasm (pp. 224-228). Texas, USA: Gateway Printing

Wolff, D. W., \& Miller, M. E. (1998). Tolerance to monosporascus root rot and vine decline in melon (Cucumis melo L.) germplasm. HortScience, 33(2), 287-290

Wu, S., Clevenger, J. P., Sun, L., Visa, S., Kamiya, Y., Jikumaru, Y., ... van der Knaap, E. (2015). The control of tomato fruit elongation orchestrated by sun, ovate and fs 8.1 in a wild relative of tomato. Plant Science, 238, 95-104.

Wu, S. B., Tavassolian, I., Rabiei, G., Hunt, P., Wirthensohn, M., Gibson, J. P., ... Sedgley, M. (2009). Mapping SNP-anchored genes using high-resolution melting analysis in almond. Molecular Genetics and Genomics, 282(3), 273-281

Wu, S., Zhang, B., Keyhaninejad, N., Rodríguez, G. R., Kim, H. J., Chakrabarti, M., ... Pan, Y. (2018). A common genetic mechanism underlies morphological diversity in fruits and other plant organs. Nature communications, 9(1), 4734

Wyllie, S. G., \& Leach, D. N. (1992). Sulfur-containing compounds in the aroma volatiles of melons (Cucumis melo). Journal of agricultural and food chemistry, 40(2), 253-256.

Wyllie, T. D. (1989). Charcoal Rot. In: J. B. Sinclair, \& P. A. Backman (Eds), Compendium of 
Soybean Diseases (Vol. 3, pp. 30-33). St. Paul, USA: American Phytopathological Society Press.

Yamaguchi, M., Hughes, D. L., Yabumoto, K., \& Jennings, W. G. (1977). Quality of cantaloupe muskmelons: variability and attributes. Scientia Horticulturae, 6(1), 59-70.

Yano, R., \& Ezura, H. (2017). Fruit ripening in melon. In: R. Grumet, N. Katzir, \& J. GarciaMas (Eds.), Genetics and genomics of Cucurbitaceae (Vol. 20, pp. 345-375). Cham, Switzerland: Springer Nature.

Yano, R., Nonaka, S. \& Ezura, H. (2018). Melonet-DB, a Grand RNA-Seq Gene Expression Atlas in Melon (Cucumis melo L.). Plant and Cell Physiology, 59(1), e4.

Yuste-Lisbona, F. J., Capel, C., Gómez-Guillamón, M. L., Capel, J., López-Sesé, A. I., \& Lozano, R. (2011). Codominant PCR-based markers and candidate genes for powdery mildew resistance in melon (Cucumis melo L.). Theoretical and applied genetics, 122(4), $747-758$.

Zaitoun, S. Y. A., Jamous, R. M., Shtaya, M. J., Mallah, O. B., Eid, I. S., \& Ali-Shtayeh, M. S. (2018). Characterizing Palestinian snake melon (Cucumis melo var.flexuosus) germplasm diversity and structure using SNP and DArTseq markers. BMC Plant Biology, 18(1), 246.

Zalapa, J. E., Staub, J. E., McCreight, J. D., Chung, S. M., \& Cuevas, H. (2007). Detection of QTL for yield-related traits using recombinant inbred lines derived from exotic and elite US Western Shipping melon germplasm. Theoretical and applied genetics, 114(7), 11851201.

Zhang, L. B., Simmons, M. P., Kocyan, A., \& Renner, S. S. (2006). Phylogeny of the Cucurbitales based on DNA sequences of nine loci from three genomes: Implications for morphological and sexual system evolution. Molecular Phylogenetics and Evolution, 39(2), 305-322. 

2. OBJETIVOS 



\section{OBJETIVOS}

Como se ha comentado en la introducción, el melon es una especie enormemente variable y esta variabilidad puede ser empleada para los dos objetivos de mejora más importantes en la actualidad en la especie, la mejora de la calidad y la mejora de la resistencia a patógenos. En este contexto, el objetivo principal de la presente Tesis Doctoral ha sido el estudio de la variabilidad genética de la especie, fundamentalmente de la accesión 'Queen's pocket melon' (PI 273438), del grupo Dudaim para su utilización en programas de mejora orientados a optimizar las características de calidad del melón y su respuesta a patógenos. Este objetivo general se ha logrado abordando cinco objetivos específicos, que se distribuyen en los dos bloques en que se divide la Tesis:

Bloque 1: APROVECHAMIENTO DE LA VARIABILIDAD INTRAESPECÍFICA DEL MELÓN PARA LA MEJORA DE LA CALIDAD

1) Desarrollar una colección de líneas de introgresión (ILs) en un fondo genético 'Piel de Sapo' (ssp. melo, grupo Ibericus), usando como parental donante 'Queen's pocket melon' (PI 273438, ssp. melo, grupo Dudaim).

2) Caracterizar la colección por parámetros relacionados con la calidad del fruto

3) Mapear regiones genómicas (QTLs) involucradas en la variación de los caracteres de calidad del fruto

Bloque 2: APROVECHAMIENTO DE LA VARIABILIDAD INTRAESPECÍFICA DEL MELÓN PARA LA MEJORA PARA RESISTENCIA A HONGOS DEL SUELO

4) Evaluar la tolerancia derivada del grupo Dudaim al hongo del suelo responsable de la podredumbre carbonosa Macrophomina phaseolina y estudiar la tolerancia de la colección de ILs

5) Identificar nuevas fuentes de resistencia a M. phaseolina y a los hongos del suelo responsables de la muerte súbita del melon Monosporascus eutypoides y M.cannonballus. 



\section{APROVECHAMIENTO DE LA VARIABILIDAD INTRAESPECÍFICA DEL MELÓN PARA LA MEJORA DE LA CALIDAD}



3.1 CAPÍTULO 1 



\subsection{Detección de QTLs durante el proceso de desarrollo de la colección de líneas de introgresión derivadas de 'Piel de Sapo' y Dudaim}

La detección de QTLs en generaciones previas a la obtención de las ILs permite evaluar la evolución de la expresión de los diferentes carácteres asociados a la calidad del fruto y, a su vez, optimizar la selección de individuos para los procesos de autofecundación, para poder obtener líneas homocigotas con la mejor estructura de fondo genético posible. Así pues, durante el desarrollo de las ILs objeto de la presente Tesis Doctoral, se realizó el fenotipado y genotipado en todas las generaciones previas que condujeron al la selección final de las ILs, llevándose a cabo un análisis de QTLs a partir de la generación BC3S1. Este análisis, no se incluyo en la publicación de Euphytica (capitulo 2), donde se describe el análisis realizado en la selección final de ILs. Por ello, estos resultados se describen a continuación en este primer capítulo de esta sección.

\subsection{Introducción}

La amplia variabilidad intraespecífica del melón (Cucumis melo L.), especialmente en relación a caracteres de fruto como el tamaño, la forma, el color de la corteza y la pulpa (Burger et al., 2010; Leida et al., 2015; Pitrat, 2008; Pitrat, 2017), el contenido en azúcares, carotenoides y compuestos volátiles (Esteras et al., 2018; Fernandez-Trujillo, Picò, Garcia-Mas, Alvarez, \& Monforte, 2011; Leida et al., 2015), y caracteres relacionados con los procesos de maduración, que pueden ser climatéricos en distintos grados o no climatéricos (Pereira, 2018; Saladié et al., 2015), constituye el punto de partida en todo proceso de mejora y, aunque existen diversas estrategias para su aprovechamiento, una de las más empleadas es la generación de colecciones de Líneas de Introgresión (ILs). Una colección de ILs desarrolladas a partir del cruce de un genotipo donante, generalmente de tipo silvestre o exótico, y un genotipo de élite (parental recurrente) mediante diversos ciclos de retrocruzamiento y posterior autofecundación, permite no sólo incorporar variación a tipos cultivados, sino también el estudio de las regiones genómicas implicadas en el control de carácteres cuantitativos de interés. En C. melo, diversos estudios se han centrado en la detección y análisis de QTLs (Quantitative Trait Loci) para caracteres relacionados con la calidad del fruto, identificando en algunos casos los principales genes involucrados o genes candidatos (Argyris et al., 2017; Díaz et al., 2011, 2015, 2017; Eduardo, Arús, \& Monforte, 2005; Galpaz et al., 2018; Monforte et al., 2004; Pereira et al., 


\subsection{CAPÍTULO 1}

2018; Perpiñà, Esteras, Gibon, Monforte, \& Picò, 2016). Además, el empleo de poblaciones derivadas de diferente germoplasma permite definir las principales regiones genómicas o metaQTLs responsables de una gran parte de la diversidad morfológica en esta especie (Monforte, Díaz, Caño-Delgado, \& van der Knaap, 2014).

En este capítulo, presentamos los resultados de caracterización morfológica y la disección genética de estos rasgos, llevada a cabo en las primeras generaciones del desarrollo de una colección de ILs cuyo parental recurrente es el cultivar español 'Piñonet', un tipo 'Piel de Sapo' (ssp. melo, grupo Ibericus) (PS), y cuyo parental donante es el tipo asiático PI 273438 'Queen's pocket' (ssp. melo, grupo Dudaim) (DUD). Este análisis nos permitió detectar y mapear diversas regiones genómicas potencialmente involucradas en los caracteres estudiados relacionados con la calidad el fruto como son el tamaño, la forma, el color de la corteza, el contenido en azúcares, o relacionados con el tipo de maduración como la presencia de capa de abscisión o el aroma, y por tanto, nos permitió determinar las líneas más interesantes para el desarrollo final de la colección de ILs.

\subsection{Materiales y métodos}

\subsubsection{Obtención de Líneas de Introgresión}

Los dos genotipos utilizados fueron el cultivar Piñonet 'Piel de Sapo' (ssp. melo, grupo Ibericus) como parental recurrente y 'Queen's pocket melon’ (PI 273438 ssp. melo, grupo Dudaim) como donante exótico. Ambas accesiones se conservan en el banco de germoplasma del Instituto para la Conservación y Mejora de la Agrodiversidad Valenciana (COMAV) de la Universitat Politècnica de València (Valencia, España), aunque la primera fue cedida originalmente por el banco de germoplasma NPGS-USDA (EEUU).

Los ensayos tuvieron lugar durante la primavera-verano de los años 2011 a 2017 en los invernaderos de la Universitat Politècnica de València (Valencia) y la Fundación Cajamar (Paiporta). Se realizó un primer cruce entre los parentales, y la F1 resultante se volvió a cruzar con el parental recurrente PS, obteniendo de esta forma la generación BC2 y posteriormente BC3. Las plantas con un alto porcentaje de fondo PS fueron seleccionadas por su genotipo para ser autofecundadas y obtener así las generaciones BC3S1, BC3S2, BC3S3 y BC3S4. La Figura 1.1 muestra el esquema de cruces realizado.

\subsubsection{Fenotipado}

Las plantas fueron fenotipadas para los siguientes caracteres: peso de la fruta (FW, en gramos), longitud y diámetro de la fruta (FL y FD, en mm), índice de forma de la fruta (FS, relación entre la longitud y el diámetro de la fruta), ancho de la cavidad (CW, relación entre la anchura de la 
cavidad seminal y el diámetro de la fruta), grosor de la pulpa y la corteza (Fth y Rth, en mm), firmeza de la corteza y la pulpa (RF y FF, $\mathrm{kg} / \mathrm{cm}^{2}$, con medidor de presión de frutas, FT 327, con un diámetro de émbolo de $8 \mathrm{~mm}$, Alfonsine, Italia), $\mathrm{pH}$ en una escala de 1 a 14 (1= pH ácido, 14 = pH básico), formación de la capa de abscisión, aroma externo de la fruta y la aparición de reticulado en la corteza (AL, AR y NET, anotadas como 0, ausencia y 1, presencia); concentración de sólidos solubles ( $\mathrm{SSC},{ }^{\circ} \mathrm{Brix}$ ); color de pulpa medido con un colorímetro (CR400, Konica Minolta) y expresado en coordenadas, $\mathrm{L} *$ (FCHl) expresa luminosidad ( $\mathrm{L}=0$ negro y $\mathrm{L}=1$ blanco), $\mathrm{a}^{*}$ (FCa) expresa la dirección del color entre rojo (positivo ) y verde (negativo) y b* (FCb) expresa la dirección del color entre amarillo (positivo) y azul (negativo).

En las generaciones, BC3S1 y BC3S2, se analizó el contenido de azúcar, midiendo el contenido de fructosa (Fruc), glucosa (Gluc) y sacarosa (Suc) en la pulpa ( $\mu \mathrm{mol} / \mathrm{gFW}$ eq.Hexosa), para lo cual se tomaron muestras de pulpa que se congelaron en nitrógeno líquido. Posteriormente, se trituraron hasta homogeneizarlas y se pesaron alícuotas de aproximadamente $20 \mathrm{mg}$ para su envío al instituto francés INRA Bordeaux para su análisis. Los metabolitos se extrajeron por fraccionamiento etanólico siguiendo el protocolo de Hendriks et al. (2003), y Gluc, Fruc y Suc se determinaron enzimáticamente en el sobrenadante etanólico como se describe en Jelitto et al. (1992). Los ensayos se realizaron en microplacas de poliestireno de 96 pocillos utilizando robots de pipeteo Starlet (Hamilton, Villebon-sur-Yvette, Francia), y se leyó la absorbancia a 340 nm en lectores de microplaca MP96 (SAFAS, Mónaco).

\subsubsection{Genotipado}

Ambos parentales fueron previamente genotipados utilizando una plataforma GoldenGate con 600 SNPs mapeados (Esteras et al., 2013; Garcia-Mas et al., 2012), esto permitió seleccionar los 107 marcadores polimórficos útiles en el proceso de genotipado en el desarrollo de las ILs. El ADN fue aislado de cotiledones y hojas, utilizando el método CTAB modificado descrito en Doyle \& Doyle (1990) con modificaciones menores (Esteras et al., 2013). Las poblaciones BC2, BC3, y BC3S3 fueron genotipadas con una plataforma de 107 SNPs previamente validada por Perpiñà et al. (2016) en la Unidad Central de Investigación en Medicina (UCIM) de la Universidad de Valencia, usando la tecnología Agena Bioscience iPLEX ® Gold MassARRAY (Sequenom); mientras que las poblaciones BC3S1, BC3S2 y BC3S4 fueron genotipadas en los laboratorios del COMAV mediante HRM (High Resolution Melting). En la Figura 1.1 se representa con detalle todo el proceso de obtención de la población de ILs incluyendo la selección con marcadores en las distintas generaciones. 


\subsection{CAPÍTULO 1}

\subsubsection{Análisis estadístico de los datos}

En la identificación de QTLs se usó la prueba no paramétrica Kruskal-Wallis implementada en MapQTL v.4.1 (Van Ooijen \& Kyazma, 2009), considerando como asociaciones significativas aquellas a partir de $\mathrm{p}<0.005(* * * *)$. Además, se utilizó el software QGene v.4.4.0 con pruebas paramétricas como la regresión de marcador único (SMR) y el mapeo de intervalo compuesto (CIM). Los QTLs se consideraron significativos cuando la puntuación LOD correspondiente superó el umbral LOD (Logarithm of Odds), referido a la estimación estadística de que dos genes o marcadores se encuentren cerca uno del otro en un cromosoma, por lo tanto es probable que se hereden, este fue calculado mediante 1000 permutaciones y para una tasa de error tipo I $\alpha=0.05$ (Churchill \& Doerge, 1994).

\subsection{Resultados y discusión}

En el proceso de obtención de las ILs, los sucesivos retrocruces y autofecundaciones permitieron aumentar el fondo genético PS (alrededor de 94\%) y fijar las introgresiones, previamente en heterocigosis, disminuyendo de esta manera la interacción con otras regiones genómicas y permitiendo la expresión constante de los diferentes genes localizados dentro de la introgresión diana. El proceso de selección fue crucial para la obtención de líneas homocigotas. Dicho proceso comenzó en BC1, donde la selección se realizó en base a la fórmula: $\quad N=\frac{\log (0,05)}{\log \left(1-0,5^{n}\right)}$ siendo $N$ el número de plantas necesarias para para garantizar la cantidad de progenie ideal que represente la segregación total del parental donante y $n$ el número de individuos de la población de partida. Posteriormente, en las siguientes etapas la selección se realizó en base al genotipado. La Figura 1.2 muestra la evolución de las medias (para dos de los caracteres más interesantes en esta población, peso y forma del fruto) a través de las generaciones por familias, es decir, por grupos a partir de los que se han derivado las 16 ILs finales, objeto del siguiente capítulo de esta Tesis. Se observa, por ejemplo, la disminución del peso con el avance de las generaciones para las familias de las cuales terminarían surgiendo las líneas finales DUD_1-2 y DUD_4-2 (que luego se caracterizan por tener tamaño pequeño), o el alcance de valores similares a los de DUD en cuanto a forma en las familias de las que derivan DUD_4-2 y DUD_5-3 (de forma redondeada) (Figura 1.2).

La disección genética de los diversos caracteres estudiados en las diferentes generaciones y empleando diversas metodologías, muestran algunas regiones genómicas involucradas en la calidad del melón como la forma, la firmeza de la pulpa y la corteza, el color de la pulpa, el contenido de azúcar, el aroma y la formación de la capa de abscisión. Los resultados se muestran en las Tablas 1.1-1.6. Se identificaron diversos QTLs para algunos caracteres, entre ellos cabe 
destacar aquellos consistentes en dos generaciones y al menos identificados por dos de los tres métodos utilizados (SMR, CIM y Kruskal-Wallis).

Por ejemplo, respecto a la formación de la capa de abscisión (AL), tanto en BC3S3 como en BC3S4 se identificaron dos QTLs en los cromosomas 3 y 9 (Tabla 1.3 y 1.4), empleando los tres métodos, SMR, CIM y el test Kruskal-Wallis, que es el método más adecuado para caracteres de este tipo que no presentan una distribución normal. Los QTLs identificados para AL mostraron una considerable aditividad negativa (entre - 0,40 y - 0,44) (Tabla 1.3 y 1.4), sugiriendo el efecto notable de los alelos DUD en la formación de la capa de abscisión, lo que explica el alto porcentaje de variación observada explicada $\left(R^{2}\right.$ entre 0,29 y 0,50$)$ para este carácter (Tabla 1.3 y 1.4). El QTL del cromosoma 3 (AI_18-E05-CMPSNP165) se colocaliza con una introgresión presente en dicho cromosoma en la línea final DUD_3-1 (ver Sección 3.2), línea que presenta de forma estable esta capa de abscisión. La expresión de esta capa de abscisión se ha asociado a la producción de etileno en el proceso de maduración climatérico, por lo que la colocalización de éste con el QTL de producción de etileno ETHQB3.5, previamente publicado por Moreno et al. (2008) y Vegas, Garcia-Mas, \& Monforte (2013) confirma la importancia de esta región. Los alelos Chinensis (PI 161375) para ETHQB3.5 inducen el comportamiento climatérico en el fondo 'Piel de Sapo' no climatérico, como ocurre en nuestra población con los alelos Dudaim.

Otro carácter relacionado con el proceso de maduración mediado por etileno es la presencia de aroma. Para este carácter se identificó un QTL en dos generaciones (BC3S3 y BC3S4) en el cromosoma 6 (CMPSNP292-A38F04) (Tabla 1.3 y 1.4), que se encuentra colocalizado con una introgresión presente en la línea final DUD_6-2 (ver Sección 3.2), cuyos frutos fueron los únicos de toda la población que mostraron presencia de aroma externo en la madurez y un ablandamiento considerable en la firmeza de pulpa y corteza respecto a 'Piel de Sapo'. Como se esperaba, los alelos Dudaim aumentan la presencia del aroma externo.

En relación a la morfología del fruto, se identificaron QTLs en los cromosomas 3, 4, 5 y 12 estables en dos ambientes (BC3S3 y BC4S4). Los QTLs del cromosoma 3 también fueron identificados en generaciones anteriores (BC3S1 y BC3S2), así como el del 4 también en la BC3S1 (Tabla 1.1 y 1.2). Las líneas finales que presentan introgresiones asociadas a estos QTLs de forma identificados, DUD_4-2 y DUD_5-3 (ver sección 3.2), mostraron una clara variación en su forma con relación a 'Piel de Sapo'. En general, sus frutos mostraron una forma más redondeada. La forma del fruto en este estudio depende del ratio entre la longitud y la anchura del mismo (FL/FD). El QTL FL del cromosoma 4 (CMPSNP852) se identificó en tres generaciones (BC3S1, BC3S3 y BC3S4), en las que los alelos Dudaim disminuyen la longitud (aditividad positiva entre 23,1 y 27,1; Tabla 1.1, 1.3 y 1.4), y está presente en la línea DUD_4- 


\subsection{CAPÍTULO 1}

2, línea en la que se aprecia más esta diferencia de forma. Respecto al ancho (FD) se ha encontrado un QTL en la región AI_13-H12 del cromosoma 5, con los alelos Dudaim aumentando el carácter. Para el carácter forma (FS), estas regiones ya mencionadas junto con las del cromosoma 3 (CMPSNP998-CMPSNP712) y 12 (CMPSNP385-AI_35-A08) presentan una aditividad entre 0,16 y 0,22, confirmando el efecto de los alelos Dudaim, que producen formas más redondeadas, y con unos valores de $\mathrm{R}^{2}$ de explicación del carácter en torno al 0,15 - 0,20. En base a nuestros resultados, podemos afirmar que a pesar de que el control genético de la forma del fruto se intuye complejo y poligénico, las regiones de los cromosomas mencionados parecen explicar gran parte de esa variación. Díaz et al. (2017), Harel-Beja et al. (2010), Pereira et al. (2018) y Ramamurthy \& Water (2015) reportaron diversos QTLs repartidos en el genoma del melón que evidencian este control poligénico para la morfología del melón. Por ejemplo, Díaz et al. (2017) reportaron tres QTLs, flqt4.1, faqt4.1 y fdqt4.1, y Ramamurthy \& Water (2015) un QTL, FS2, colocalizados con la introgresión presente en el cromosoma 4 (CMPSNP147-CMPSNP852).

QTLs relacionados con la presencia de reticulado fueron identificados en tres generaciones en los cromosomas 3 (CMPSNP998-CMPSNP712), 4 (CMPSNP852) y 5 (CMPSNP898CMPSNP437) (Tabla 1.1, 1.3 y 1.4). Además, en los cromosomas 2 (CMPSNP128CMPSNP1003) y 8 (F013) se detectaron QTLs en 2 generaciones. En todos los casos la aditividad fue negativa $(-0,44$ a $-1,71)$, por lo que los alelos Dudaim son los responsables del aumento en la densidad del reticulado, aunque este genotipo carece de esta característica. En otros estudios, Harel-Beja et al. (2010), Obando et al. (2008) y Ramamurthy \& Waters (2015), describieron un QTL en el cromosoma 2 colozalizado en la misma región que el identificado por nosotros. Obando et al (2008) también describen un QTL en el cromosoma 8 que colocaliza con el descrito en el presente estudio. El descubrimiento de variabilidad oculta en cierto fondo genético cuando los alelos se transfieren a otro fondo diferente es algo que se ha descrito en muchas poblaciones de ILs, y que podría dar explicación a los resultados obtenidos en nuestro estudio. Los valores del porcentaje de explicación de estos QTLs fueron en general altos $\left(\mathrm{R}^{2}\right.$ 0,17-0,70), siendo la región del cromosoma 5 la que parece tener mayor importancia en el control de carácter (Tabla 1.1, 1.3 y 1.4). Algunas líneas finales presentan regiones cromosómicas que abarcan estos QTLs identificados para reticulado, aunque fenotípicamente no todas mostraron uniformidad y consistencia visual en la expresión del carácter. Sin embargo, en las líneas DUD_5-1 y DUD_5-2, que presentan introgresión DUD en el cromosoma 5, sí se pudo observar casi en la totalidad de sus frutos la formación de reticulado (ver sección 3.2). En esta misma región Paris, Zalapa, McCreight \& Staub (2008) identificaron un QTL relacionado con el reticulado. 
3.1 CAPÍTULO 1

El contenido de azúcares es uno de los caracteres más apreciados por los consumidores y está relacionado directamente con el nivel de sacarosa (Burger et al., 2002). El contenido de azúcar en el melón tiene un control genético complejo (Gur et al., 2017), por lo que hasta la fecha se ha identificado un gran número de QTLs relacionados con este rasgo en diferentes cromosomas (Argyris et al., 2017; Díaz et al., 2015; Pereira et al., 2018), y por otra parte, también se ha descrito una fuerte influencia ambiental en la expresión del mismo. En este trabajo hemos identificado un QTL estable en dos generaciones (BC3S3 y BC3S4) para el contenido de sólidos solubles en el cromosoma 1 (CMPSNP731). Muy cerca de esta región, Eduardo et al. (2007) describieron un QTL para sólidos solubles (36,34 Mpb). Sorprendentemente, los alelos DUD son los que aumentan el dulzor (Tabla 1.3 y 1.4). En la generación BC3S1 y BC3S2 se identificaron QTLs relacionados con el contenido en sacarosa en el cromosoma 5 (CMPSNP387-CMPSNP437) (Tabla 1.5 y 1.6). Mientras se observa una disminución de sacarosa en esta región por efecto de los alelos DUD, el QTL detectado para el contenido de Glucosa en esta misma posición produce un aumento de éste azúcar. La línea DUD_5-1 tiene una introgresión en el cromosoma 5 que incluye esa región del QTL para sacarosa (ver Sección 3.2). Eduardo et al. (2007) previamente identificaron un QTL colocalizado con nuestra introgresión presente en el cromosoma 5. Muy cerca de esta misma introgresión del cromosoma 5 (a 0,03 Mpb), Harel-Beja et al. (2010) reportaron dos QTLs, uno para sólidos solubles y otro para sacarosa.

Con este estudio de las generaciones previas a la obtención de la ILs se ha podido observar variabilidad en caracteres de calidad de fruto, como la maduración climatérica, la morfología y el contenido en azúcares. Estos ensayos preliminares de QTLs refuerzan el interés de esta población y ya destacan algunas regiones genómicas como buenas candidatas a controlar alguno de estos caracteres. El estudio posterior de las ILs obtenidas, analizando todas las introgresiones DUD que portan, confirmará la importancia de cada una de los QTLs postulados en este trabajo. 


\subsection{CAPÍTULO 1}

\subsection{Anexos}

Tabla 1.1. QTLs detectados en la generación BC3S1 (año 2014, UPV).

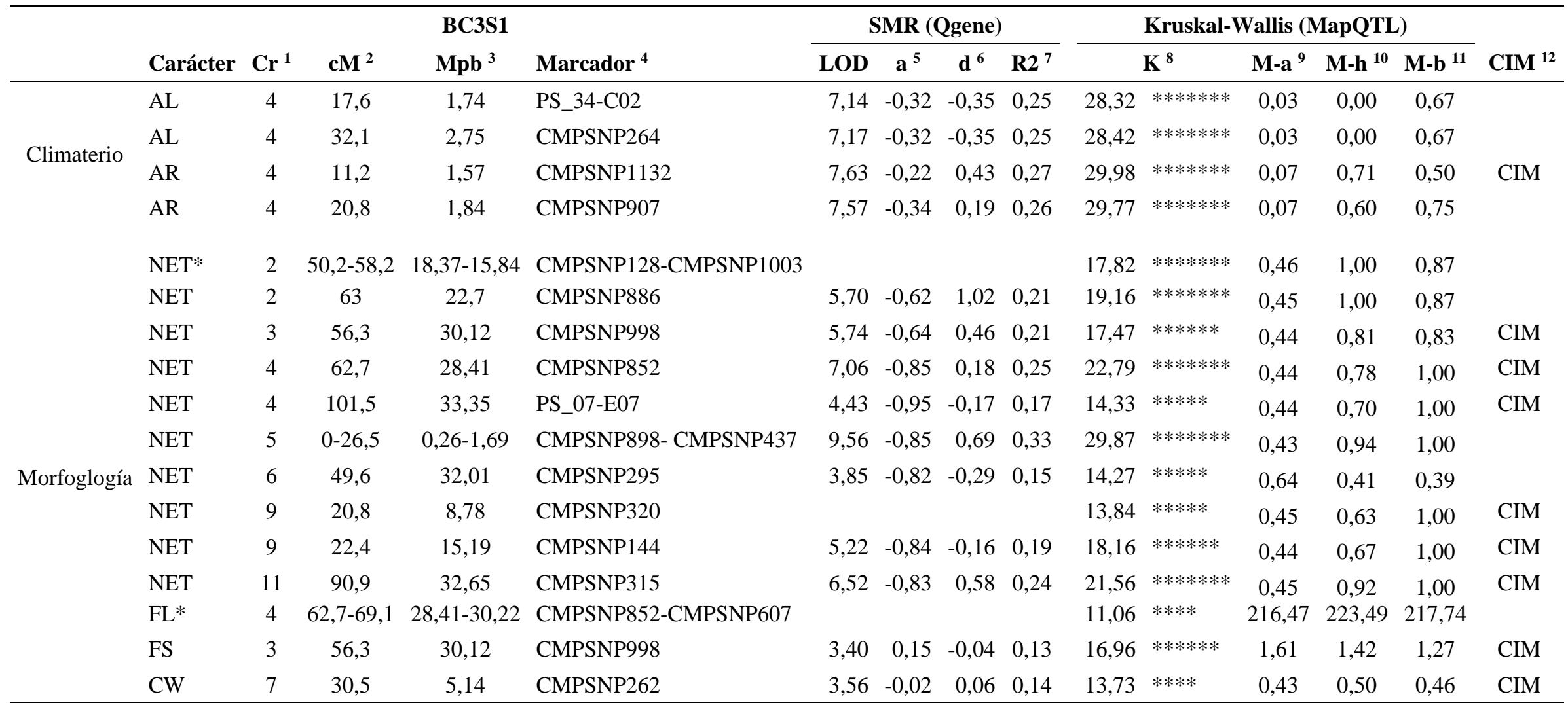

* Identificado solo con un método pero presente también BC3S4 (NET, FL).

${ }^{1}$ Cromosoma.

${ }^{2}$ Posición del pico de QTL en centiMorgan según el mapa de Garcia-Mas et al. (2012).

${ }^{3}$ Posición física en $\mathrm{Mpb}$ en versión 3.6.1 del genoma.

${ }^{4}$ Marcador más cercano al pico del QTL

${ }^{5}$ Efecto aditivo del alelo PS.

${ }^{6}$ Efecto dominante.

${ }^{7}$ Coeficiente de determinación. Porcentaje de variación explicada. 
${ }^{8}$ Valor del parámetro $\mathrm{K}$ del test Krustall-Wallis con su significación de p (****:0.005 *****:0.001 ******:0.0005 *******:0.0001)

${ }^{9}$ Media del rasgo calculado con el total de individuos con el genotipo a (homocigotos para el alelo PS).

${ }^{10}$ Media del rasgo calculado con el total de individuos con el genotipo h (heterocigotos, portanto alelos PS y DUD).

${ }^{11}$ Media del rasgo calculado con el total de individuos con el genotipo b (homocigotos para el alelo DUD).

${ }^{12}$ Detectado también mediante la metodología CIM (Qgene).

Tabla 1.2. QTLs detectados en la generación BC3S2 (año 2015, UPV).

\begin{tabular}{|c|c|c|c|c|c|c|c|c|c|c|c|c|c|c|c|}
\hline & \multirow[b]{2}{*}{ Carácter } & \multirow[b]{2}{*}{$\mathrm{Cr}^{1}$} & \multirow[b]{2}{*}{$\mathbf{c M}^{2}$} & \multicolumn{2}{|l|}{ BC3S2 } & \multicolumn{4}{|c|}{ SMR (Qgene) } & \multicolumn{5}{|c|}{ Kruskal-Wallis (MapQTL) } & \multirow[b]{2}{*}{ CIM $^{12}$} \\
\hline & & & & $\mathbf{M p b}^{3}$ & Marcador $^{4}$ & LOD & $\mathbf{a}^{5}$ & $d^{6}$ & $\mathbf{R} 2^{7}$ & & $\mathbf{K}^{8}$ & M-a ${ }^{9}$ & M-h ${ }^{10}$ & M-b ${ }^{11}$ & \\
\hline Climaterio & $\mathrm{AR}$ & 6 & 1,6 & 0,7 & CMPSNP925 & 5,006 & 0,063 & 1,016 & 0,191 & 20,80 & $* * * * * * *$ & 0,04 & 1,00 & - & \\
\hline \multirow{6}{*}{ Morfología } & NET & 6 & 57,6 & 36,41 & CMPSNP1038 & & & & & 21,13 & $* * * * * * *$ & 0,89 & 0,75 & 0,25 & CIM \\
\hline & NET & 6 & 70,7 & 34,96 & A_38-F04 & 6,78 & 0,28 & 0,18 & 0,25 & 22,05 & $* * * * * * *$ & 0,91 & 0,81 & 0,35 & CIM \\
\hline & NET & 6 & 86,9 & 33,29 & CMPSNP378 & & & & & 18,16 & $* * * * * * *$ & 0,88 & - & 0,13 & CIM \\
\hline & FS & 3 & 3,2 & 3,63 & AI_18-E05 & 4,794 & $-0,095$ & 0,303 & 0,183 & 16,90 & $* * * * * *$ & 1,64 & 2,04 & 1,83 & CIM \\
\hline & $\mathrm{FS}$ & 11 & 66 & 30,28 & CMPSNP30 & 5,259 & $-0,137$ & 0,593 & 0,199 & & & & & & CIM \\
\hline & $\mathrm{RF}$ & 6 & 20,8 & 2,89 & CMPSNP571 & & & & & 16,38 & $* * * * * *$ & 12,95 & 13,00 & 12,90 & CIM \\
\hline
\end{tabular}

$\begin{array}{lllllllllll}\text { Azúcares } & \text { SSC } & 5 & 89,4-94,2 & 28,26-28,87 & \text { AI } 13-H 12-C M P S N P 735 & 4,96 & 5,43 & 7,17 & 0,19\end{array}$

\footnotetext{
${ }^{1}$ Cromosoma.

${ }^{2}$ Posición del pio de QTL en centiMorgan según el mapa de Garcia-Mas et al. (2012).

${ }^{3}$ Posición física en Mpb en versión 3.6.1 del genoma.

${ }^{4}$ Marcador más cercano al pico del QTL

${ }^{5}$ Efecto aditivo del alelo PS.

${ }^{6}$ Efecto dominante.

${ }^{7}$ Coeficiente de determinación. Porcentaje de variación explicada.

${ }^{8}$ Valor del parámetro K del test Krustall-Wallis con su significación de p (****:0.005 *****:0.001 ******:0.0005 *******:0.0001)

${ }^{9}$ Media del rasgo calculado con el total de individuos con el genotipo a (homocigotos para el alelo PS).

${ }^{10}$ Media del rasgo calculado con el total de individuos con el genotipo h (heterocigotos, portanto alelos PS y DUD).

${ }^{11}$ Media del rasgo calculado con el total de individuos con el genotipo b (homocigotos para el alelo DUD).

12 Detectado también mediante la metodología CIM (Qgene).
} 


\subsection{CAPÍTULO 1}

Tabla 1.3. QTLs detectados en la generación BC3S3 (año 2016, paiporta)

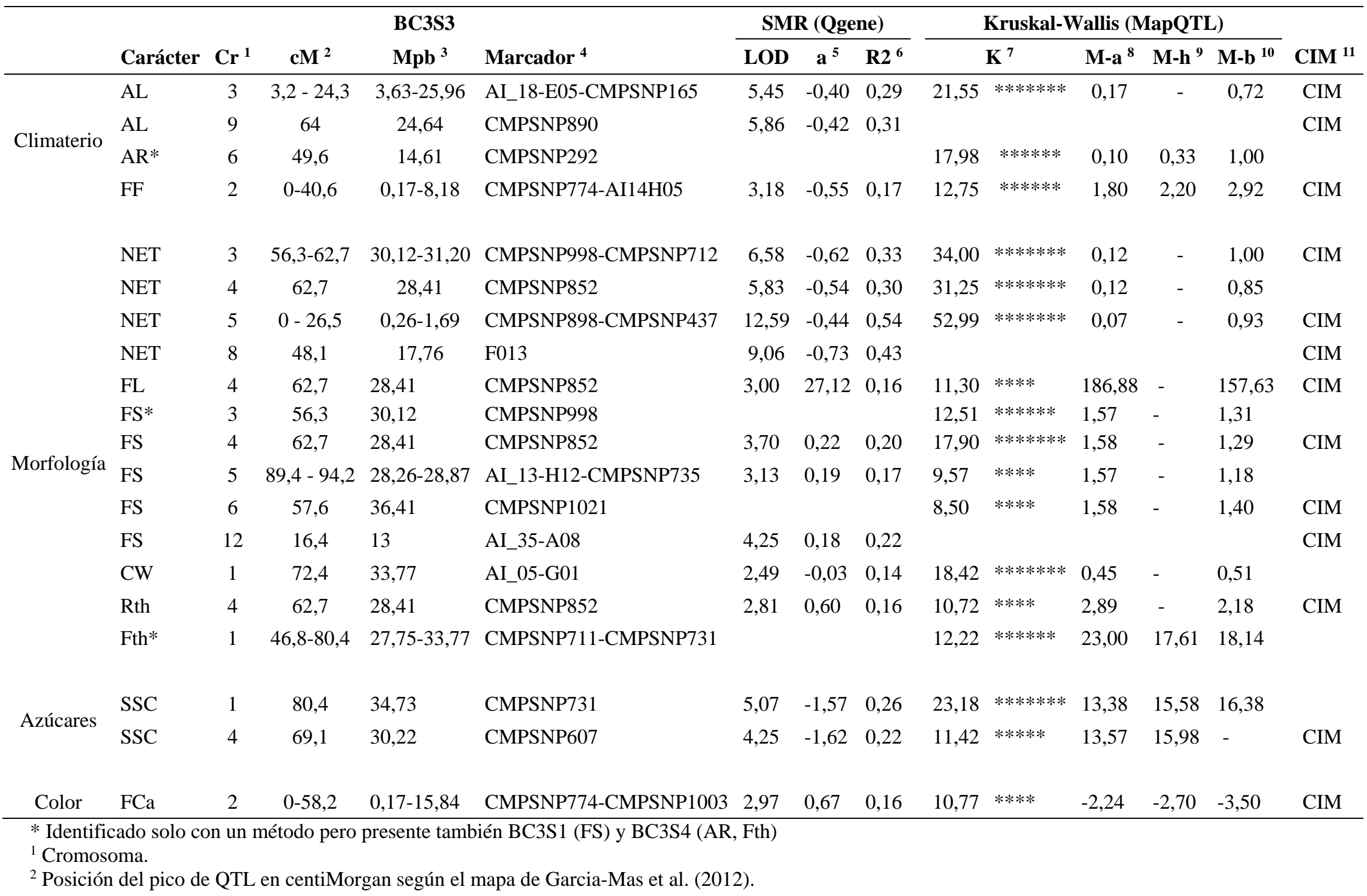


${ }^{3}$ Posición física en Mpb en versión 3.6.1 del genoma.

${ }^{4}$ Marcador más cercano al pico del QTL

${ }^{5}$ Efecto aditivo del alelo PS.

${ }^{6}$ Coeficiente de determinación. Porcentaje de variación explicada.

${ }^{7}$ Valor del parámetro $\mathrm{K}$ del test Krustall-Wallis con su significación de $\mathrm{p}(* * * *: 0.005 * * * * *: 0.001 * * * * * *: 0.0005 * * * * * * *: 0.0001)$

${ }^{8}$ Media del rasgo calculado con el total de individuos con el genotipo a (homocigotos para el alelo PS).

${ }^{9}$ Media del rasgo calculado con el total de individuos con el genotipo h (heterocigotos, portanto alelos PS y DUD).

${ }^{10}$ Media del rasgo calculado con el total de individuos con el genotipo b (homocigotos para el alelo DUD)

${ }^{11}$ Detectado también mediante la metodología CIM (Qgene).

Tabla 1.4. QTLs detectados in la generación BC3S4 (año 2017, paiporta).

\begin{tabular}{|c|c|c|c|c|c|c|c|c|c|c|c|c|c|c|}
\hline & \multirow[b]{2}{*}{ Carácter } & \multirow[b]{2}{*}{$\mathrm{Cr}^{1}$} & \multirow[b]{2}{*}{$\mathbf{c M}^{2}$} & \multicolumn{2}{|l|}{ BC3S4 } & \multicolumn{3}{|c|}{ SMR (Qgene) } & \multicolumn{5}{|c|}{ Kruskal-Wallis (MapQTL) } & \multirow[b]{2}{*}{ CIM $^{11}$} \\
\hline & & & & $\mathbf{M p b}^{3}$ & Marcador $^{4}$ & LOD & $\mathbf{a}^{5}$ & $\mathbf{R 2}^{6}$ & & $\mathbf{K}^{7}$ & M-a ${ }^{8}$ & M-h ${ }^{9}$ & M-b ${ }^{10}$ & \\
\hline \multirow{11}{*}{ Climaterio } & $\mathrm{AL}$ & 1 & $80,4-86,8$ & $34,73-36,65$ & CMPSNP731- CMPSNP204 & 9,03 & $-0,26$ & 0,23 & 16,98 & $* * * * * * *$ & 0,08 & - & 0,04 & \\
\hline & $\mathrm{AL}$ & 3 & $3.2-24.3$ & $3,63-25,96$ & AI_18-E05-CMPSNP165 & 18,14 & $-0,44$ & 0,41 & 78,15 & $* * * * * * * *$ & 0,06 & - & 0,88 & CIM \\
\hline & $\mathrm{AL}$ & 6 & $57,6-70,7$ & $36,41-36,38$ & CMPSNP1038-A_38-F04 & 3,74 & $-0,15$ & 0,11 & 15,59 & $* * * * * * *$ & 0,09 & - & 0,37 & CIM \\
\hline & $\mathrm{AL}$ & 9 & 64 & 24,64 & CMPSNP890 & 23,02 & $-0,41$ & 0,50 & 79,38 & $* * * * * * *$ & 0,06 & 0,25 & 0,88 & CIM \\
\hline & AR & 1 & $80,4-86,8$ & $34,73-36,65$ & CMPSNP731- CMPSNP204 & 23,02 & $-0,41$ & 0,50 & 107,66 & $* * * * * * *$ & 0,00 & - & 0,55 & CIM \\
\hline & AR & 3 & 34,2 & 27,11 & CMPSNP8 & 34,61 & $-0,55$ & 0,65 & & & & & & CIM \\
\hline & $\mathrm{AR}$ & 6 & $49,6-70,7$ & $14,61-34,96$ & CMPSNP292-A38F04 & & & & 33,85 & $* * * * * * *$ & 0,00 & - & 0,20 & CIM \\
\hline & $\mathrm{FF}$ & 1 & 86,8 & 36,65 & CMPSNP204 & 3,81 & 0,40 & 0,11 & 13,70 & $* * * * * *$ & 1,74 & - & 0,78 & \\
\hline & $\mathrm{FF}$ & 2 & $0-4.8$ & $0,17-0,83$ & CMPSNP774-CMPSNP431 & 4,49 & $-0,40$ & 0,13 & 17,56 & $* * * * * * *$ & 1,62 & - & 2,43 & CIM \\
\hline & FF & 2 & 32,6 & 2,72 & CMPSNP502 & 4,49 & $-0,40$ & 0,13 & 17,56 & $* * * * * * *$ & 1,62 & - & 2,43 & \\
\hline & $\mathrm{FF}$ & 6 & 49,6 & 14,61 & CMPSNP292 & & & & 11,27 & $* * * * *$ & 1,76 & - & 1,10 & CIM \\
\hline \multirow{5}{*}{ Morfología } & NET* & 2 & 58,2 & 15,84 & CMPSNP1003 & & & & 27,67 & $* * * * * * *$ & 0,38 & 1,23 & 0,06 & \\
\hline & NET & 3 & $56.3-62.7$ & $30,12-31,20$ & CMPSNP998-CMPSNP712 & 28,57 & $-1,68$ & 0,57 & 44,26 & $* * * * * * *$ & 0,27 & - & 2,49 & CIM \\
\hline & NET & 4 & 62,7 & 28,41 & CMPSNP852 & 6,26 & $-0,72$ & 0,17 & 44,33 & $* * * * * * *$ & 0,27 & 2,49 & 0,28 & CIM \\
\hline & NET & 5 & $0-26,5$ & $0,26-1,69$ & CMPSNP898- CMPSNP437 & 40,56 & $-1,15$ & 0,70 & 77,00 & $* * * * * * *$ & 0,16 & 1,23 & 2,49 & CIM \\
\hline & NET & 8 & 48,1 & 17,76 & F013 & 27,95 & $-1,71$ & 0,57 & 39,67 & $* * * * * * *$ & 0,19 & 2,13 & - & CIM \\
\hline
\end{tabular}


Tabla 1.4. (Continuación)

\begin{tabular}{|c|c|c|c|c|c|c|c|c|c|c|c|c|c|c|}
\hline & \multirow[b]{2}{*}{ Carácter } & \multirow[b]{2}{*}{$\mathrm{Cr}^{1}$} & \multirow[b]{2}{*}{$\mathbf{c M}^{2}$} & \multicolumn{2}{|l|}{ BC3S4 } & \multicolumn{3}{|c|}{ SMR (Qgene) } & \multicolumn{5}{|c|}{ Kruskal-Wallis (MapQTL) } & \multirow[b]{2}{*}{ CIM $^{11}$} \\
\hline & & & & $\mathbf{M p b}^{3}$ & Marcador $^{4}$ & LOD & $\mathbf{a}^{5}$ & $\mathrm{R2}^{6}$ & & $K^{7}$ & $\mathbf{M}^{-a^{8}}$ & M-h ${ }^{9}$ & M-b ${ }^{10}$ & \\
\hline \multirow{16}{*}{ Morfología } & FW & 1 & $59.6-72.4$ & $33,03-33,77$ & CMPSNP410-AI_05-G01 & 2,31 & 264,74 & 0,07 & 15,67 & $* * * * * * *$ & 1542,89 & - & 997,83 & \\
\hline & FW & 1 & 80,4 & 34,73 & CMPSNP731 & & & & 14,74 & $* * * * * *$ & 1562,71 & - & 1128,11 & CIM \\
\hline & FL & 4 & $48,3-54,7$ & $3,94-13,46$ & CMPSNP147-CMPSNP352 & 3,80 & 23,13 & 0,11 & 12,01 & $* * * * *$ & 187,14 & - & 139,83 & \\
\hline & FL & 4 & 62,7 & 28,41 & CMPSNP852 & 6,15 & 24,46 & 0,17 & 24,58 & $* * * * * * *$ & 189,21 & 163,01 & 139,83 & CIM \\
\hline & FD & 5 & 89,4 & 28,26 & AI_13-H12 & 6,76 & $-14,87$ & 0,18 & 19,28 & $* * * * * * *$ & 124,84 & 146,50 & 154,11 & \\
\hline & FS & 1 & 86,8 & 36,65 & CMPSNP204 & 2,08 & 0,10 & 0,06 & 10,65 & $* * * *$ & 1,49 & - & 1,27 & \\
\hline & FS & 3 & $3,2-34,2$ & $3,63-27,11$ & AI_18-E05-CMPSNP8 & 2,52 & $-0,03$ & 0,07 & 12,26 & $* * * * * *$ & 1,46 & - & 1,66 & CIM \\
\hline & FS & $3 *$ & $56,3-62,7$ & $30,12-31,20$ & CMPSNP998-CMPSNP712 & & & & 11,94 & $* * * * *$ & 1,49 & 1,30 & - & \\
\hline & FS & 4 & $48.3-54.7$ & $3,94-13,46$ & CMPSNP147-CMPSNP352 & 3,26 & 0,16 & 0,09 & 13,11 & $* * * * * *$ & 1,48 & - & 1,15 & \\
\hline & FS & 4 & 62,7 & 28,41 & CMPSNP852 & 5,72 & 0,18 & 0,16 & 26,56 & $* * * * * * *$ & 1,50 & 1,30 & 1,15 & CIM \\
\hline & FS & 5 & $89.4-94.2$ & $28,26-28,87$ & AI_13-H12-CMPSNP735 & 5,62 & 0,17 & 0,16 & 18,45 & $* * * * * * *$ & 1,49 & & 1,15 & \\
\hline & FS & 6 & 49,6 & 32,01 & CMPSNP295 & 5,52 & 0,08 & 0,15 & & & & & & CIM \\
\hline & FS & 9 & 64 & 24,64 & CMPSNP890 & 2,67 & $-0,11$ & 0,08 & 20,16 & $* * * * * * *$ & 1,45 & 1,79 & 1,66 & \\
\hline & FS & 12 & $4.8-16.4$ & $0,35-13,00$ & CMPSNP385-AI_35-A08 & 5,47 & 0,22 & 0,15 & 19,79 & $* * * * * *$ & 1,49 & - & 1,15 & CIM \\
\hline & Rth & 4 & $11.2-20.8$ & $1,57-1,84$ & CMPSNP1132-CMPSNP907 & 5,96 & $-0,31$ & 0,16 & 21,88 & $* * * * * * *$ & 2,68 & - & 3,29 & CIM \\
\hline & Fth & 1 & $59,6-72,4$ & $33,03-33,77$ & CMPSNP410-AI_05-G01 & & & & 15,76 & $* * * * * * *$ & 29,43 & - & 22,84 & CIM \\
\hline \multirow{3}{*}{ Azúcares } & $\mathrm{SSC}$ & 1 & 80,4 & 34,73 & CMPSNP731 & & & & 9,43 & $* * * *$ & 12,24 & - & 13,86 & CIM \\
\hline & $\mathrm{SSC}$ & 2 & $0-40.6$ & $0,17-8,18$ & CMPSNP774-AI_14-H05 & 3,81 & 1,31 & 0,11 & 16,59 & $* * * * * * *$ & 12,50 & 13,26 & 11,35 & CIM \\
\hline & $\mathrm{SSC}$ & 6 & 49,6 & 14,61 & CMPSNP292 & & & & 8,56 & $* * * *$ & 12,25 & - & 13,97 & CIM \\
\hline $\mathrm{pH}$ & $\mathrm{pH}$ & 1 & 86,8 & 36,65 & CMPSNP204 & 6,29 & $-0,18$ & 0,17 & 12,48 & $* * * * * *$ & 6,01 & - & 6,38 & \\
\hline \multirow{2}{*}{ Color } & $\mathrm{FCHl}$ & 3 & $3.2-24.3$ & $3,63-25,96$ & AI_18-E05-CMPSNP165 & 2,32 & 2,24 & 0,07 & 13,13 & $* * * * * *$ & 62,68 & - & 57,93 & CIM \\
\hline & $\mathrm{FCb}$ & 6 & $20.8-25.6$ & $2,89-5,69$ & CMPSNP571-CMPSNP1167 & 3,38 & 0,94 & 0,10 & 12,12 & $* * * * * *$ & 10,71 & - & 8,77 & CIM \\
\hline
\end{tabular}


* Identificado solo con un método pero presente también BC3S1 (NET) y BC3S3 (FS)

${ }^{1}$ Cromosoma.

${ }^{2}$ Posición del piso de QTL en centiMorgan según el mapa de Garcia-Mas et al. (2012).

${ }^{3}$ Posición física en Mpb en versión 3.6.1 del genoma.

${ }^{4}$ Marcador más cercano al pico del QTL

${ }^{5}$ Efecto aditivo del alelo PS.

${ }^{6}$ Coeficiente de determinación. Porcentaje de variación explicada.

${ }^{7}$ Valor del parámetro $\mathrm{K}$ del test Krustall-Wallis con su significación de $\mathrm{p}(* * * *: 0.005 * * * * *: 0.001 \quad * * * * * *: 0.0005$ *******:0.0001)

${ }^{8}$ Media del rasgo calculado con el total de individuos con el genotipo a (homocigotos para el alelo PS).

${ }^{9}$ Media del rasgo calculado con el total de individuos con el genotipo h (heterocigotos, portanto alelos PS y DUD).

${ }^{10}$ Media del rasgo calculado con el total de individuos con el genotipo b (homocigotos para el alelo DUD).

${ }^{11}$ Detectado también mediante la metodología CIM (Qgene).

Tabla 1.5. QTLs para glucosa, fructosa y sacarosa detectados en la generación BC3S1 (año 2014)

\begin{tabular}{|c|c|c|c|c|c|c|c|c|c|c|c|c|c|c|}
\hline \multirow[b]{2}{*}{ Azúcar } & \multicolumn{4}{|c|}{ AZÚCARES BC3S1 } & \multicolumn{4}{|c|}{ SMR (Qgene) } & \multicolumn{5}{|c|}{ Kruktal-Wallis (MapQTL) } & \multirow[b]{2}{*}{ CIM $^{12}$} \\
\hline & $\mathrm{Cr}^{1}$ & $\mathbf{c M}^{2}$ & $\mathbf{M p b}^{3}$ & Marcador $^{4}$ & LOD & $\mathbf{a}^{5}$ & $d^{6}$ & $\mathbf{R 2}^{7}$ & & $\mathrm{~K}^{8}$ & M-a ${ }^{9}$ & M-h ${ }^{10}$ & M-b ${ }^{11}$ & \\
\hline Gluc & 3 & 56,3 & 30,12 & CMPSNP998 & 3,55 & $-13,24$ & 19,65 & 0,14 & 14,44 & $* * * * *$ & 89,91 & 122,80 & 117,99 & \\
\hline Gluc & 5 & 26,5 & 1,69 & CMPSNP437 & 3,76 & $-25,48$ & $-2,04$ & 0,15 & 13,70 & $* * * *$ & 90,64 & 114,08 & 141,60 & \\
\hline Suc & 2 & 90,9 & 26,99 & CMPSNP94 & 3,68 & 74,68 & 27,63 & 0,15 & 11,75 & $* * * *$ & 285,21 & 238,17 & 135,86 & \\
\hline Suc & 3 & 56,3 & 30,12 & CMPSNP998 & 3,29 & 34,13 & $-40,12$ & 0,13 & & & & & & CIM \\
\hline Suc & 4 & 62,7 & 28,41 & CMPSNP852 & 6,32 & 75,69 & $-1,75$ & 0,24 & 15,73 & $* * * * * *$ & 286,13 & 208,69 & 134,75 & CIM \\
\hline Suc* & 5 & $18,5-26,5$ & $1,25-1,69$ & CMPSNP387-CMPSNP437 & & & & & 17,92 & $* * * * * *$ & 285,11 & 187,57 & 157,07 & \\
\hline Suc & 5 & 41,2 & 2,37 & CMPSNP726 & 7,10 & 64,13 & $-48,49$ & 0,27 & 20,11 & $* * * * * * *$ & 284,58 & 171,96 & 156,32 & CIM \\
\hline Suc & 9 & $59,2-64$ & $24,19-24,64$ & CMPSNP1133-CMPSNP890 & & & & & 11,85 & $* * * *$ & 282,14 & 210,31 & 282,43 & CIM \\
\hline Suc & 11 & 98,9 & 33,29 & CMPSNP475 & 5,58 & 25,11 & $-110,94$ & 0,22 & 14,49 & $* * * * *$ & 282,17 & 146,11 & 231,94 & CIM \\
\hline
\end{tabular}

* Identificado solo con un método pero presente también BC3S3 (Suc)

${ }^{1}$ Cromosoma.

${ }^{2}$ Posición del pico de QTL en centiMorgan según el mapa de Garcia-Mas et al. (2012).

${ }^{3}$ Posición física en $\mathrm{Mpb}$ en versión 3.6.1 del genoma.

${ }^{4}$ Marcador más cercano al pico del QTL

${ }^{5}$ Efecto aditivo del alelo PS.

${ }^{6}$ Efecto dominante.

${ }^{7}$ Coeficiente de determinación. Porcentaje de variación explicada. 


\subsection{CAPÍTULO 1}

${ }^{8}$ Valor del parámetro K del test Krustall-Wallis con su significación de p (****:0.005 *****:0.001 ******:0.0005 *******:0.0001)

${ }^{9}$ Media del rasgo calculado con el total de individuos con el genotipo a (homocigotos para el alelo PS).

${ }^{10}$ Media del rasgo calculado con el total de individuos con el genotipo h (heterocigotos, portanto alelos PS y DUD).

${ }^{11}$ Media del rasgo calculado con el total de individuos con el genotipo b (homocigotos para el alelo DUD).

${ }^{12}$ Detectado también mediante la metodología CIM (Qgene).

Tabla 1.6. QTLs para glucosa, fructosa y sacarosa detectados en la generación BC3S2 (año 2015).

\begin{tabular}{|c|c|c|c|c|c|c|c|c|c|c|c|c|c|c|}
\hline \multirow[b]{2}{*}{ Azúcar } & \multicolumn{4}{|c|}{ AZÚCARES BC3S2 } & \multicolumn{4}{|c|}{ SMR (Qgene) } & \multicolumn{5}{|c|}{ Kruskal-Wallis (MapQTL) } & \multirow[b]{2}{*}{ CIM $^{12}$} \\
\hline & $\mathrm{Cr}^{1}$ & $\mathrm{cM}^{2}$ & $\mathbf{M p b}^{3}$ & Marcador $^{4}$ & LOD & $\mathbf{a}^{5}$ & $d^{6}$ & $\mathbf{R 2}^{7}$ & $\mathbf{K}$ & $\mathrm{K}^{8}$ & M-a ${ }^{9}$ & M-h ${ }^{10}$ & M-b ${ }^{11}$ & \\
\hline SSC & 2 & 77,9 & 25,25 & CMPSNP658 & & & & & 10,927 & $* * * *$ & 12,3129 & 10,725 & 7,85 & CIM \\
\hline SSC & 5 & 0 & 0,26 & CMPSNP898 & 5,37 & 1,10 & $-4,56$ & 0,21 & 15,40 & $* * * * * *$ & 12,41 & 6,75 & 10,21 & CIM \\
\hline Fruc & 6 & 20,8 & 2,89 & CMPSNP571 & 3,59 & $-14,09$ & 17,17 & 0,14 & 10,62 & $* * * *$ & 90,60 & 121,85 & 118,77 & \\
\hline Fruc & 6 & 85,3 & 33,69 & AI_13-F02 & 3,87 & $-14,12$ & 18,40 & 0,16 & 11,06 & $* * * *$ & 90,54 & 123,06 & 118,77 & CIM \\
\hline Fruc & 10 & 28,8 & 4,75 & CMPSNP671 & 4,01 & $-7,85$ & 30,11 & 0,16 & 11,08 & $* * * *$ & 90,61 & 128,56 & 106,30 & CIM \\
\hline Suc & 5 & 0 & 0,26 & CMPSNP898 & 4,08 & 56,983 & $-46,302$ & 0,162 & 17,079 & $* * * * * *$ & 268,843 & 165,558 & 154,877 & \\
\hline Suc & 5 & $18,5-26,5$ & $1,25-1,69$ & CMPSNP387-CMPSNP437 & & & & & 13,614 & $* * * *$ & 265,828 & 168,12 & 150,297 & CIM \\
\hline
\end{tabular}

${ }^{1}$ Cromosoma.

${ }^{2}$ Posición del pico de QTL en centiMorgan según el mapa de Garcia-Mas et al. (2012).

${ }^{3}$ Posición física en $\mathrm{Mpb}$ en versión 3.6.1 del genoma.

${ }^{4}$ Marcador más cercano al pico del QTL

${ }^{5}$ Efecto aditivo del alelo PS.

${ }^{6}$ Efecto dominante.

${ }^{7}$ Coeficiente de determinación. Porcentaje de variación explicada.

${ }^{8}$ Valor del parámetro $\mathrm{K}$ del test Krustall-Wallis con su significación de p (****:0.005 *****:0.001 ******:0.0005 *******:0.0001)

${ }^{9}$ Media del rasgo calculado con el total de individuos con el genotipo a (homocigotos para el alelo PS).

${ }^{10}$ Media del rasgo calculado con el total de individuos con el genotipo h (heterocigotos, portanto alelos PS y DUD).

${ }^{11}$ Media del rasgo calculado con el total de individuos con el genotipo b (homocigotos para el alelo DUD).

${ }^{12}$ Detectado también mediante la metodología CIM (Qgene). 


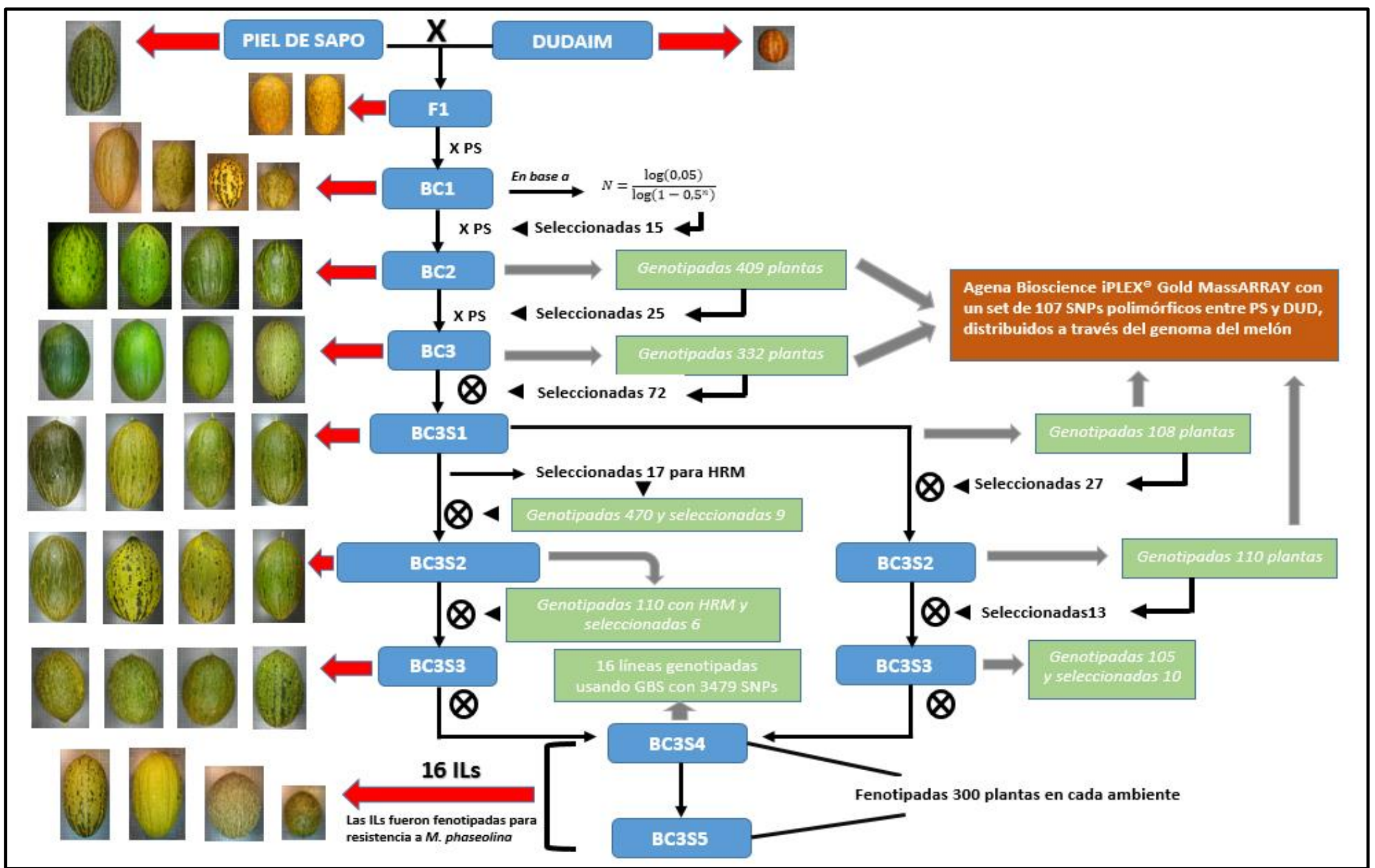

Figura. 1.1. Proceso de elaboración de la colección de ILs. 


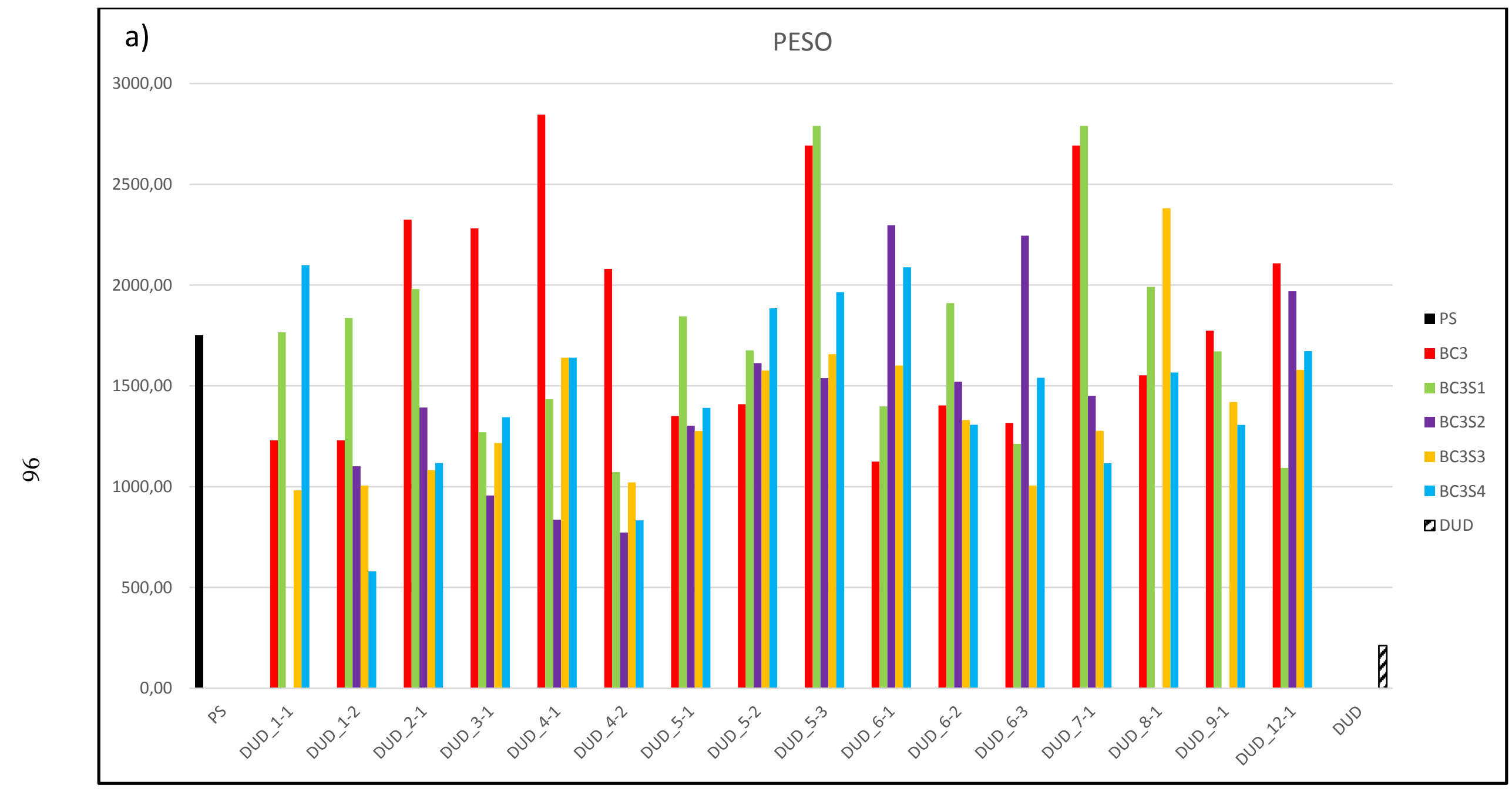




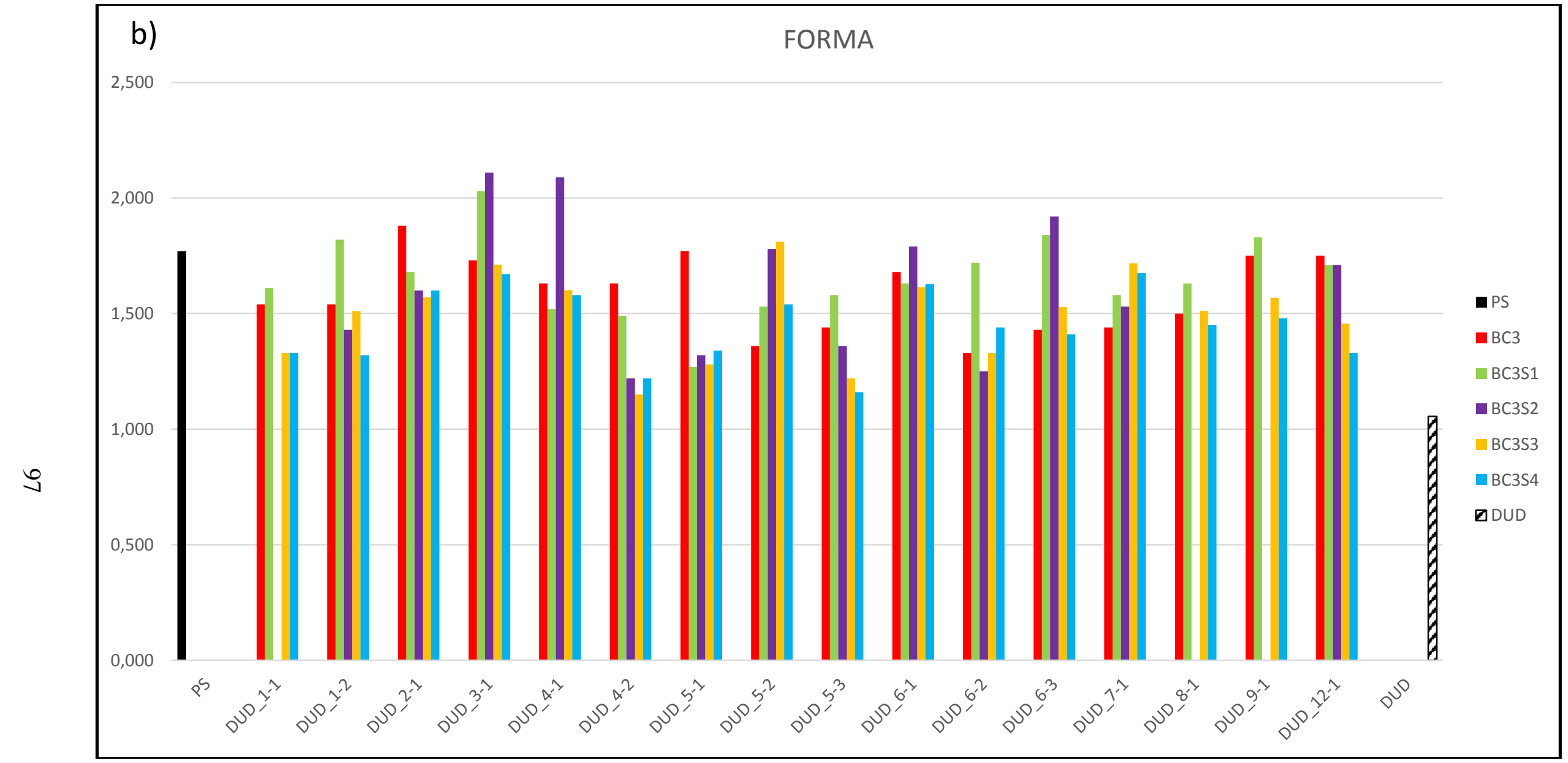

Figura 1.2. Evolución de los caracteres de fruto a) peso y b) forma a lo largo de las diferentes generaciones durante el proceso de obtención del primer grupo de 16 ILs (descritas en la Sección 3.2). 


\subsection{CAPÍTULO 1}

\subsection{Referencias}

Argyris J. M., Díaz, A., Ruggieri, V., Fernández, M., Jahrmann, T., Gibon, Y., ... Garcia-Mas, J. (2017). QTL Analyses in multiple populations employed for the fine mapping and identification of candidate genes at a locus affecting sugar accumulation in melon (Cucumis melo L.). Frontiers in Plant Science, 8, 1679

Burger, Y., Paris, H. S., Cohen, R., Katzir, N., Yishay, R., \& Schaffer, A. A. (2010). Genetic diversity of Cucumis melo. In J. Janick (Ed.), Horticultural reviews (Vol. 36, pp. 165-198). New York, USA: Wiley-Blackwell.

Burger, Y., Sa'ar, U., Katzir, N., Paris, H. S., Yeselson, Y., Levin, I., \& Schaffer, A. A. (2002). A single recessive gene for sucrose accumulation in Cucumis melo fruit. Journal of the American Society for Horticultural Science, 127(6), 938-943.

Churchill, G. A., \& Doerge, R. W. (1994). Empirical threshold values for quantitative trait mapping. Genetics, 138(3), 963-971.

Díaz, A., Fergany, M., Formisano, G., Ziarsolo, P., Blanca, J., Fei, Z., .. Monforte, A. J. (2011). A consensus linkage map for molecular markers and Quantitative Trait Loci associated with economically important traits in melon (Cucumis melo L.). BMC Plant Biology, 11(1), 111.

Díaz, A., Forment, J., Argyris, J. M., Fukino, N., Tzuri, G., Harel-Beja, R., ... Monforte, A. J. (2015). Anchoring the consensus ICuGI genetic map to the melon (Cucumis melo L.) genome. Molecular Breeding, 35(10), 188.

Díaz, A., Martín-Hernández, A. M., Dolcet-Sanjuan, R., Garcés-Claver, A., Álvarez, J. M., Garcia-Mas, J., ... Monforte, A. J. (2017). Quantitative trait loci analysis of melon (Cucumis melo L.) domestication-related traits. Theoretical and Applied Genetics, 130(9), $1837-1856$.

Doyle, J. J., \& Doyle, J. L. (1990). Isolation ofplant DNA from fresh tissue. Focus, 12(13), 3940.

Eduardo, I., Arús, P., \& Monforte, A. J. (2005). Development of a genomic library of near isogenic lines (NILs) in melon (Cucumis melo L.) from the exotic accession PI161375. Theoretical and applied genetics, 112(1), 139-148.

Eduardo, I., Arús, P., Monforte, A. J., Obando, J., Fernández-Trujillo, J. P., Martínez, J. A., ... van der Knaap, E. (2007). Estimating the genetic architecture of fruit quality traits in melon using a genomic library of near isogenic lines. Journal of the American Society for Horticultural Science, 132(1), 80-89.

Esteras, C., Formisano, G., Roig, C., Díaz, A., Blanca, J., Garcia-Mas, J., ... Picò, B. (2013). SNP genotyping in melons: Genetic variation, population structure, and linkage 
disequilibrium. Theoretical and Applied Genetics, 126(5), 1285-1303.

Esteras, C., Rambla, J. L., Sánchez, G., López-Gresa, M. P., González-Mas, M. C., FernandézTrujillo, J. P., ... Picò, M. B. (2018). Fruit flesh volatile and carotenoid profile analysis within the Cucumis melo L. species reveals unexploited variability for future genetic breeding. Journal of the Science of Food and Agriculture, 98(10), 3915-3925.

Fernandez-Trujillo, J. P., Picò, M. B., Garcia-Mas, J., Alvarez, J. M., \& Monforte, A. J. (2001). Breeding for fruit quality in melon. In: M. A. Jenks, \& P. J. Bebeli (Eds.), Breeding for Fruit Quality (261-278). Oxford, UK: Wiley-Blackwell.

Galpaz, N., Gonda, I., Shem-Tov, D., Barad, O., Tzuri, G., Lev, S., ... Harel-Beja, R. (2018). Deciphering genetic factors that determine melon fruit-quality traits using RNA-Seq-based high-resolution QTL and eQTL mapping. The Plant Journal, 94(1), 169-191.

Garcia-Mas, J., Benjak, A., Sanseverino, W., Bourgeois, M., Mir, G., González, V. M., ... Alioto, T. (2012). The genome of melon (Cucumis melo L.). Proceedings of the National Academy of Sciences, 109(29), 11872-11877.

Gur, A., Gonda, I., Portnoy, V., Tzuri, G., Chayut, N., Cohen, S., ... KatziR, N. (2017). Genomic aspects of melon fruit quality. In: R. Grumet, N. Katzir, \& J. Garcia-Mas. (Eds.), Genetics and genomics of Cucurbitaceae (Vol. 20, pp. 377-408). Cham, Switzerland: Springer Nature.

Harel-Beja, R., Tzuri, G., Portnoy, V., Lotan-Pompan, M., Lev, S., Cohen, S., ... Katzir, N. (2010). A genetic map of melon highly enriched with fruit quality QTLs and EST markers, including sugar and carotenoid metabolism genes. Theoretical and Applied Genetics, 121(3), 511-533.

Hendriks, J. H., Kolbe, A., Gibon, Y., Stitt, M., \& Geigenberger, P. (2003). ADP-glucose pyrophosphorylase is activated by posttranslational redox-modification in response to light and to sugars in leaves of Arabidopsis and other plant species. Plant Physiology, 133(2), 838-849.

Jelitto, T., Sonnewald, U., Willmitzer, L., Hajirezeai, M., \& Stitt, M. (1992). Inorganic pyrophosphate content and metabolites in potato and tobacco plants expressing E. coli pyrophosphatase in their cytosol. Planta, 188(2), 238-244.

Leida, C., Moser, C., Esteras, C., Sulpice, R., Lunn, J. E., de Langen, F., ... Picò, B. (2015). Variability of candidate genes, genetic structure and association with sugar accumulation and climacteric behavior in a broad germplasm collection of melon (Cucumis melo L.). BMC Genetics, 16(1), 28.

Monforte, A. J., Díaz, A., Caño-Delgado, A., \& van der Knaap, E. (2014). The genetic basis of fruit morphology in horticultural crops: Lessons from tomato and melon. Journal of 


\subsection{CAPÍTULO 1}

Experimental Botany, 65(16), 4625-4637.

Monforte, A. J., Oliver, M., Gonzalo, M. J., Alvarez, J. M., Dolcet-Sanjuan, R., \& Arús, P. (2004). Identification of quantitative trait loci involved in fruit quality traits in melon (Cucumis melo L.). Theoretical and Applied Genetics, 108(4), 750-758.

Moreno, E., Obando, J. M., Dos-Santos, N., Fernández-Trujillo, J. P., Monforte, A. J., \& Garcia-Mas, J. (2008). Candidate genes and QTLs for fruit ripening and softening in melon. Theoretical and Applied Genetics, 116(4), 589-602.

Obando, J., Fernández-Trujillo, J. P., Martínez, J. A., Alarcón, A. L., Eduardo, I., Arús, P., \& Monforte, A. J. (2008). Identification of melon fruit quality quantitative trait loci using near-isogenic lines. Journal of the American Society for Horticultural Science, 133(1), 139-151.

Paris, M. K., Zalapa, J. E., McCreight, J. D., \& Staub, J. E. (2008). Genetic dissection of fruit quality components in melon (Cucumis melo L.) using a RIL population derived from exoticx elite US Western Shipping germplasm. Molecular Breeding, 22(3), 405-419.

Pereira L. (2018). Genetic dissection of fruit quality and ripening traits in melon. Barcelona (Doctoral Thesis). Universitat Autònoma de Barcelona. Barcelona, España. Recuperado de https://ddd.uab.cat/pub/tesis/2018/hdl_10803_663830/pgl1de1.pdf

Pereira, L., Ruggieri, V., Pérez, S., Alexiou, K. G., Fernández, M., Jahrmann, T., ... GarciaMas, J. (2018). QTL mapping of melon fruit quality traits using a high-density GBS-based genetic map. BMC Plant Biology, 18(1), 324.

Perpiñà, G., Esteras, C., Gibon, Y., Monforte, A. J., \& Picò, B. (2016). A new genomic library of melon introgression lines in a cantaloupe genetic background for dissecting desirable agronomical traits. BMC Plant Biology, 16(1), 154.

Pitrat, M. (2008). Melon (Cucumis melo L.) In: J. Prohens, \& F. Nuez (Eds.), Hand-book of crop breeding vegetables (Vol 1., pp. 283-315). New York, USA: Springer.

Pitrat, M. (2017). Melon genetic resources: phenotypic diversity and horticultural taxonomy. In: R. Grumet, N. Katzir, \& J. Garcia-Mas. (Eds.), Genetics and genomics of Cucurbitaceae (Vol. 20, pp. 253-263). Cham, Switzerland: Springer Nature.

Ramamurthy, R. K., \& Waters, B. M. (2015). Identification of fruit quality and morphology QTLs in melon (Cucumis melo) using a population derived from flexuosus and cantalupensis botanical groups. Euphytica, 204(1), 163-177.

Saladié, M., Cañizares, J., Phillips, M. A., Rodriguez-Concepcion, M., Larrigaudière, C., Gibon, Y., ... Garcia-Mas, J. (2015). Comparative transcriptional profiling analysis of developing melon (Cucumis melo L.) fruit from climacteric and non-climacteric varieties. BMC Genomics, 16(1):440. 
Van Ooijen, J. W., \& Kyazma, B. V. (2009). MapQTL 6. Software for the mapping of quantitative trait loci in experimental populations of diploid species. Wageningen, Netherlands: Kyazma BV

Vegas, J., Garcia-Mas, J., \& Monforte, A. J. (2013). Interaction between QTLs induces an advance in ethylene biosynthesis during melon fruit ripening. Theoretical and Applied Genetics, 126(6), 1531-1544. 

3.2 CAPÍTULO 2 



\section{New melon introgression lines in a 'Piel de Sapo' genetic background with desirable agronomical traits from Dudaim melons}

Castro, G., Perpiñà, G., Monforte, A.J., Picò, B., Esteras, C. (2019). New melon introgression lines in a 'Piel de Sapo' genetic background with desirable agronomical traits from Dudaim melons. Article submitted for publication.

Finalmente, se seleccionaron 16 líneas para la colección final de ILs, que presentaron un alto porcentaje de alelos DUD en homocigosis. Estas líneas se evaluaron para diferentes carácteres de calidad en dos ambientes, con el objetivo de verificar la estabilidad de la expresión de las diferentes regiones del genoma DUD introgresadas. Este trabajo se ha presentado para su publicación a la revista Euphytica, la cual es una revista internacional especializada en aspectos de fitomejoramiento, cuyo contenido técnico-científico tiene como objetivo difundir el trabajo de investigación original asociado con el fitomejoramiento moderno y tradicional.

Este trabajo se ha realizado en el marco de mi participación en los proyectos del grupo de Mejora Genética de Cucurbitáceas Plant KBBE (SAFQIM: PIM2010PKB-00691), SUGARS AND FRUIT QUALITY IN MELON, financiado por el MINECOy el Proyecto AGL2017-85563-C2-1-R CONTROL MULTIDISCIPLINAR DE ENFERMEDADES FUNGICAS Y VIROSIS EN MELON Y SANDIA: UN NUEVO RETO, financiado por el Ministerio de Ciencias, Innovación y Universidades (con financiacion de FEDER). 



\subsection{New melon introgression lines in a 'Piel de Sapo' genetic background with desirable agronomical traits from Dudaim melons}

Castro, G., Perpiñà, G., Monforte, A.J., Picò, B., Esteras, C.

Submitted to Euphytica.

\subsection{Introduction}

Melon (Cucumis melo L.) is a cucurbit species with high agronomic and economic importance worldwide, with almost 32 million tons produced worldwide (FAOSTAT, 2018), and exportation values of more than 1.6 billion U.S dollars (FAOSTAT, 2018), Due to this economic impact, the development of new and more adapted cultivars is required to satisfy consumer preferences and market demands. The first step in a breeding program is to find useful genetic variability. The exploitation of exotic genotypes related to crops is a strategy to increase the variability pool available for breeders.

C. melo presents a high level of genetic variability due to at least two domestication events (Endl et al., 2018; Pitrat, 2013), that have led to a large diversification regarding to seed, vegetative and flowering traits, fruit size and shape, flesh and rind color, ripening behavior, resistances, etc. (Burger et al., 2010; Dantas, Holanda, Esteras, Nunes, \& Picò, 2015; Esteras et al., 2013, 2018; Lázaro et al., 2017; López, Ferriol, \& Picò, 2015; Nunes et al., 2017; Pitrat, 2017; Sabato, Esteras, Grillo, Picò, \& Bacchetta, 2015). This species has been traditionally subdivided into two subspecies, melo and agrestis (Kirkbride, 1993), and recently, Pitrat (2017) has described 19 groups: Agrestis, Kachri, Chito, Tibish, Acidulus, Momordica, Conomon, Makuwa, Chinensis, Flexuosus, Chate, Dudaim, Chandalak, Indicus, Ameri, Cassaba, Ibericus, Inodorus, and Cantalupensis. All this huge diversity can be potentially employed for breeding commercial cultivars, using different strategies, although the high diversity on fruit traits among cultivar types preclude the transfer of genetic variability through different types.

Although high production and disease/pest resistance continue being important breeding objectives, nowadays the development of cultivars with high quality standards is the main goal in melon breeding programs in response to the current consumer's demand. Melon fruit quality is a complex feature that involves morphological traits (fruit shape, size, rind and flesh color) and also organoleptic and nutritional properties such as sweetness, content in vitamins and antioxidants, and aroma (Burger et al., 2006; Gur et al., 2017a). Most of these quality traits 


\subsection{CAPÍTULO 2}

show a quantitative variation, as a consequence of a polygenic genetic control (Quantitative Trait Loci, QTL) (Amanullah et al., 2018; Argyris et al., 2017; Eduardo et al., 2007; Galpaz et al., 2018; Gur et al., 2017a; Pereira et al., 2018; Perpiñà, Esteras, Gibon, Monforte, \& Picò, 2016), and also influenced by environmental factors. Therefore, their breeding is complex and requires the generation of specific populations. Introgression Lines (ILs) are appropriate populations to study QTLs, especially when dealing with exotic variability (Eshed \& Zamir, 1995; Zamir, 2001), allowing a rapid and straightforward association for traits to specific genomic regions and accelerating the development of new commercial cultivars with favourable QTLs (Gur \& Zamir, 2004; Monforte, Friedman, Zamir, \& Tanksley, 2001). With that purpose, the use of exotic or wild genotypes as donors of new alleles, is the most used strategy to exploit the extant diversity through the generation of IL libraries. These are collections of lines, obtained by backcrossing after the first F1 cross, each one containing a chromosome fragment of a selected donor genotype within an elite genetic background. Finally, the whole collection represents the donor's complete genome (Perpiñà et al., 2016; Zamir, 2001).

To date, two IL collections have been reported in melon, both using genotypes with contrasting phenotypes belonging to the two subspecies. The first one used a Spanish cultivar type 'Piel de Sapo' (PS, ssp. melo, group Ibericus) as a recurrent parent and the Korean accession PI 161375 (SC, Songwan Charmi) (ssp. agrestis, group Chinensis) as a donor parent (Eduardo, Arús, \& Monforte, 2005). The second one was developed from the cross of a Charentais 'Vedrantais' type (ssp. melo, group Cantalupensis), as the recurrent parent, and the Japanese accession 'PI 420176' (Ginsen Makuwa) (ssp. agrestis, group Makuwa) (Perpiñà et al., 2016).

Apart from the incorporation of the new variability found in exotic genotypes, these ILs collections also allowed the detection of new QTLs in the species. For instance, Eduardo et al. (2007) reported 75 QTLs involved in main fruit quality traits such as fruit shape, weight, external and flesh color, and soluble solid content using the ILs derived from SC; and recently, Perpiñà et al. (2016) identified 47 QTLs related with the flowering and maturity time, fruit morphology, ripening behavior, rind characteristics, flesh color and sugar content using the ILs derived from Makuwa. In the last few years, using other strategies such as different mapping populations derived from other exotic melons like Flexuosus, Momordica and Agrestis types (Amanullah et al., 2018; Díaz et al., 2017; Galpaz et al., 2018; Ramamurthy \& Waters, 2015), or even germplasm collections through GWA (genome-wide association analysis) (Gur et al., 2017b; Nimmakayala et al., 2016), more than 250 common and new QTLs have been reported for the species regarding fruit quality traits. Moreover, Pereira et al. (2018) recently developed a recombinant inbred line (RIL) population derived from the two most important commercial 
cultivars in Europe, a 'Vedrantais' and a 'Piel de Sapo', detecting 33 QTLs mainly associated to fruit quality.

The large collections of molecular markers currently available in melon as the result of several sequencing projects (Blanca et al., 2011, 2012; Leida et al., 2015; Pavan et al., 2017), as well as saturated genetic maps anchored to the genome sequence like the ones reported by Argyris et al. (2015) and Garcia-Mas et al. (2012), and the consensus maps by Díaz et al. (2011, 2015), are genomic tools which highly improve the efficiency in the development of IL populations through marker assisted selection (MAS), since their use reduces significantly the number of backcross generations to obtain ILs with single donor introgressions (Barrantes et al., 2014; Perpiñà et al., 2016). High Resolution Melting, medium-throughput platforms like Agena Bioscience iPLEX ® Gold MassARRAY, or Genotyping-by-Sequencing (GBS) are available genotyping technologies, which are currently easily affordable, and that can be very useful during ILs development in the different moments of the process.

In this context, we present the development of a new IL collection in melon using a Dudaim melon as new exotic donor with interesting quality traits (Esteras et al., 2018; Leida et al., 2015 Pitrat, 2017) to introduce new variation in the most important non-climacteric melon background in the market ('Piel de Sapo'). Dudaim melons are cultivated from Turkey to Afghanistan. They are characterized by their small reddish-yellow fruits with ochre stripes and smooth surface, round or slightly oval shaped, and with white, mealy flesh. They are early maturing and with dehiscent peduncle. Also, Dudaim fruits have a very unique fragrant, exotic, and musky smell (Aubert \& Pitrat, 2006; Esteras et al., 2018).

\subsection{Material and methods}

\subsubsection{Plant material}

The two genotypes employed in the generation of the IL population were the Spanish cultivar 'Piel de Sapo' (PS) (ssp. melo, group Ibericus) as the recurrent parent, and 'Queen's pocket melon' (DUD) (a selection by selfing from the accession PI 273438, ssp. melo, group Dudaim, of the NPGS GRIN collection) as the exotic donor parent (Figure 2.1). Both accessions were multiplied and conserved at the Genebank of the Institute for the Conservation and Breeding of Agrobiodiversity (COMAV-UPV) in Valencia (Spain) and were previously phenotyped, along with other accessions from the COMAV melon core collection, to confirm their classification in the corresponding horticultural group (Esteras et al., 2018; Leida et al., 2015).

DUD is an exotic Asian variety, mainly used with ornamental purposes. It produces small-size, round, no sutured and white-fleshed fruits, that are highly aromatic and climacteric with low 


\subsection{CAPÍTULO 2}

sugar content. In contrast, PS bears fruits which are big and oval. They are white-fleshed, sweet, without aroma, and non-climacteric.

\subsubsection{Breeding scheme}

The F1 generation derived from the cross between PS and DUD was backcrossed to the recurrent PS parent to generate the $\mathrm{BC} 1$ population. Fourteen $\mathrm{BC} 1$ plants were then backcrossed with the recurrent parent thus producing 14 BC2 families. A total of 409 BC2 plants (28-30 plants per BC2 family) were genotyped at the seedling stage using Agena Bioscience iPLEX® Gold MassARRAY with a set of SNPs evenly distributed throughout the melon genome (see details below). According to these results, a subset of plants was selected, those having the highest proportion of the recurrent (PS) genome while containing DUD introgressions in order to cover the entire donor genome. The selected BC2 plants were grown in the greenhouse and backcrossed to construct the $\mathrm{BC} 3$ population.

The same genotyping platform was employed to select the best BC3 individuals (among a total of 332) according to genotype, using the same criteria that in $\mathrm{BC} 2$ to produce the following generations. Eighty-two BC3 plants, carrying three or fewer DUD introgressions, were selfed, and their offsprings (BC3S1 and BC3S2) were genotyped using the SNPs located in the corresponding target introgressions by High Resolution Melting (HRM) (Vossen, Aten, Roos, \& den Dunnen, 2009) in order to finally select plants with single/double homozygous introgressions. Subsequently, the selected BC3S1 and BC3S2 plants were genotyped using the Agena Bioscience array designed in previous generations. For each progeny the number of plants to screen to obtain a plant with a single introgression was calculated from the binomial distribution of allele segregation (Barrantes et al., 2014). Moreover, in order to remove a few remaining heterozygous markers and provide seeds for future characterization assays, selected plants of the $\mathrm{BC} 3 \mathrm{~S} 2$ generation were subjected to further selfing processes (BC3S3 and BC3S4).

In this work, a first set of 16 ILs (developed in BC3S3 and BC3S4 generations) with single or double homozygous introgressions was agronomically characterized. This is a medium-sized IL population, with one or two lines representing each DUD chromosome.

\subsubsection{Markers and genotyping methods}

Genomic DNA was extracted from young leaves following the method described by Doyle \& Doyle (1990) with minor modifications. The extracted DNA was dissolved in Milli-Q water, and the final concentration was adjusted to $10 \mathrm{ng} / \mu \mathrm{l}$ for the Agena Bioscience array and 30 $\mathrm{ng} / \mu \mathrm{l}$ for the HRM genotyping (Perpiñà et al., 2016). 
Markers included in the Agena Bioscience array performed in this study were selected from the SNP set used by Perpiñà et al. (2016). The selected SNPs were polymorphic between PS and DUD, and evenly distributed in chromosomes, based on the first genetic map anchored to the melon genome by García-Mas et al. (2012) (Table 2.1). This Agena Bioscience array was employed to genotype the full BC2 and BC3 populations, as well as the selected BC3S1, BC3S2 and the final set of ILs selected for phenotyping (BC3S3 and BC3S4). The Agena Bioscience genotyping was carried out at the Epigenetics and Genotyping laboratory at the Central Research Unit of the Faculty of Medicine (UCIM) belonging to the Universitat de València (Spain).

A total of 89 SNPs, out of the 107 employed in the full Agena Bioscience platform, were adapted for HRM analysis. HRM genotyping was used to accelerate the selection and fixation of target introgressions during the construction of the IL population in several specific offsprings. HRM reactions were performed using the LightCycler 480 with the Roche LightCycler 480 High Resolution Melting Master kit.

Five ILs with the most interesting phenotypes, out of the 16 ILs selected were also genotyped by GBS (DUD_3-1; DUD_4-2; DUD_5-1; DU_6-1; DUD_6-2). Genomic DNA extraction was carried out employing DNeasy Plant Mini Kit (Qiagen, Hilden, Germany) and about 400 ng of each one were sent to LGC Genomics GmbH (Berlin, Germany) for the GBS analysis. Libraries were constructed using ApeKI, and 2.5-2.9 million filtered reads per sample were obtained with an average size of $70 \mathrm{bp}$. Quality reads were mapped against the last version of the melon genome (genome assembly v.3.6.1, Melonomics) and SNP calling was performed using freebayes selecting SNPs with at least 3 reads. Polymorphic SNPs between parentals and monomorphic within them were filtered to have a set of useful markers in our lines.

\subsubsection{Agronomic evaluation and traits measured}

The selected plants in every generation were transplanted to the greenhouse for phenotyping and for seed obtention. A total of $22 \mathrm{BC} 2,82 \mathrm{BC} 3,99 \mathrm{BC} 3 \mathrm{~S} 1$ and $126 \mathrm{BC} 3 \mathrm{~S} 2$ plants were grown from 2011 to 2015, during the spring-summer growing season at the greenhouse facilities of the Polytechnic University of Valencia (Valencia, Spain) and the Fundacion Cajamar in Paiporta (Valencia, Spain). Sixteen ILs were selected from the BC3S3 and BC3S4 populations, and evaluated in two trials conducted in two years, 2016 and 2017, in the facilities of the Fundacion Cajamar in Paiporta (Paip16 and Paip17). Each assay included six to eight plants of each IL in a fully randomized design with five to ten plants of each parental line (PS and DUD). Pollination was ensured with insects. Temperature was controlled with cooler and automatic window aperture (with a temperature range of 10 to $25 / 10$ to 20 and of 25 to $37 / 18$ to 35 , 


\subsection{CAPÍTULO 2}

minimum and maximum during the whole growing season for Paip2016/2017, respectively). Plants were grown in substrate bags of $29 \mathrm{~kg}$ (70\% coconut fiber and $30 \%$ coconut chips) with fertirrigation.

Plants were phenotyped for flowering-related traits: the number of male and female flowers 15 and 30 days after the opening of the first flower on each plant was counted (NMaF15, NFeF15, $\mathrm{NMaF} 30$ and NFeF30). Two fruits per plant were set and characterized at full maturity with the following traits: fruit weight (FW in grams, with digital scale), fruit length and diameter (FL, FD in mm, with graduated rule), fruit shape index (FS, as the ratio of fruit length to fruit diameter), cavity width $(\mathrm{CW}$, as the ratio of the width of the seminal cavity to the fruit diameter), flesh and rind thickness (Fth, Rth in $\mathrm{mm}$, with electronic digital caliper, I.C.T, S.L., La Rioja, Spain), rind and flesh firmness (RF, FF, measured as $\mathrm{kg} / \mathrm{cm} 2$ with a fruit pressure tester, FT 327, with a plunger diameter of $8 \mathrm{~mm}$, Alfonsine, Italy), $\mathrm{pH}$ on a scale from 1 to 14 (1= $\mathrm{pH}$ acid, 14= $\mathrm{pH}$ basic), formation of abscission layer, external aroma of the whole fruit and the occurrence of rind netting (AL, AR, NET, scored visually as 0 , absent and 1, present); flesh color measured with a CR-400 colorimeter, Konica Minolta, Inc., Tokyo, Japan (coordinates Hunter Lab. $\mathrm{L}^{*}$ express luminosity ( $\mathrm{L}=0$ black and $\mathrm{L}=1$ white), a* expresses the color direction between red (positive) and green (negative) and $\mathrm{b}^{*}$ expresses the color direction between yellow (positive) and blue (negative) ( $\mathrm{FCHl}, \mathrm{FCa}, \mathrm{FCb}$ ), and also rind color was evaluated visually. Soluble solids concentration (SSC) was measured as ${ }^{\circ}$ Brix from drops of juice with a hand-held "Pocket" refractometer (PAL- $\alpha$, Atago CO., LTD, Tokyo, Japan). Flesh samples were taken from the same regions in the equatorial slice of the fruit and used for firmness, flesh color, ${ }^{\circ}$ Brix and $\mathrm{pH}$ measurements.

\subsubsection{QTL detection in introgression lines}

With the aim of checking the normality of every trait distribution, the Kolmogorov-Smirnov test was carried out using Statgraphics Centurion XVII.II (Table 2.2).

An analysis of variance (ANOVA) was performed with ILs data for trials Paip16 and Paip17 to examine the effects of genotype, environment and genotype x environment interaction. In addition, the mean of every IL in each environment (Paip16 and Paip17) was compared to the control PS mean using the Dunnett's contrast with Type-I error a $\leq 0.05$ (Dunnett, 1955). QTLs for each trait in the DUD introgression were considered to exist in those lines with means significantly different from PS in the two environments. 


\subsection{Results and discussion}

\subsubsection{Development of the several IL generations}

The genome of BC2 plants showed an average of 8.7 introgressions/plant and $81.0 \%$ of the PS background genome (ranging from 68.7 - 88.3\%). The DUD genome was fully represented among the BC2 plants. In the next generation, selected BC3 plants presented an average of 5.9 introgressions/plant and $89.4 \%$ of the PS background genome (range $81.1-97.2 \%$ ). The early selection in a large number of plants facilitated the recovery of the recurrent genetic background, and the reduction of the number of introgressions per plant (to about 3 ) in one backcross generation. Several rounds of selfing (BC3S1, BC3S2, BC3S3, BC3S4) were performed to fix introgressions and to generate enough seeds for further assays. A first collection of 16 ILs (Table 2.3) was obtained. This IL collection has an average of 1.4 introgressions/IL (3.2 introgressions/IL with single-marker introgressions), representing more than $60 \%$ of the DUD genome with $93.9 \%$ of the PS background genome (range $86.9-96.3 \%$ ) (Table 2.3). In Figure 2.2, the evolution in the different generations during IL development regarding the number of introgressions and the recovery of recurrent genetic background is shown.

Five ILs (DUD_3-1; DUD_4-2; DUD_5-1; DU_6-1; DUD_6-2) were further genotyped by GBS. A total of 3,479 SNPs resulted informative for these 5 ILs and the parent genotypes (Table 2.4). The introgressions defined previously with the Agena Bioscience assay (Table 2.3) were confirmed, but also some additional small introgressions were detected (Table 2.4), showing a percentage of PS genome recovery slightly lower than the previously calculated with Agena Bioscience assay $(88.4 \%)$. All this suggests that at the final steps in the process of IL development, a more exhaustive genotyping with thousands of markers is necessary.

\subsubsection{Parent phenotypes}

The two parents showed contrasting phenotypes in a number of traits related to flowering time, fruit morphology, fruit ripening behavior and traits related to organoleptic and nutritive value, such as sugars content and aroma. Table 2.5 depicts the mean values and standard deviations, along with ANOVA results for means comparison of both parents, PS and DUD, for each studied trait in the two trials in which they were phenotyped along with the ILs.

PS fruits were significantly heavier (average fruit weight (FW) $1665.7 \mathrm{~g}$ ) than DUD fruits (213.8 g). PS fruits were more elongated with lower percentages of seminal cavity (FS 1.7 versus 1.0, and CW 0.39 versus 0.53 , respectively for PS and DUD) (Figure 2.1). Additionally, DUD presented an abscission layer at the time of ripening (AL) and the occurrence of external aroma in mature fruits (AR), while these two traits were absent in PS. Accordingly with their 


\subsection{CAPÍTULO 2}

ripening behavior, fruit flesh at time of maturity was firmer in PS $\left(2.00\right.$ versus $0.79 \mathrm{Kg} / \mathrm{cm}^{2}$ in DUD, for flesh firmness (FF)).

While PS is a sweet melon, DUD is a low sugar melon, showing a significant difference of the values of soluble solids content (SSC) in the fruits $\left(13.8^{\circ}\right.$ versus $8.4^{\circ}$ Brix degrees for PS and DUD, respectively) (Table 2.5).

Differences in other traits, such as rind thickness ( $\mathrm{RTh}, 3.4 \mathrm{~mm}$ versus $1.7 \mathrm{~mm}$ in PS and DUD, respectively), rind firmness (RF, 13.0 versus $4.8 \mathrm{Kg} / \mathrm{cm}^{2}$, in PS and DUD, respectively), and rind netting (Net, PS presents low values in netting, while in DUD is absent) were also observed (Table 2.5). Regarding other traits related to flesh quality, both fruits, PS and DUD were white fleshed, with similar values of luminosity $\mathrm{L}^{*}$ and $\mathrm{b}^{*}$ parameter (FCHl 61.9 and $\mathrm{FCb} 10.5$ versus FCHl 62.1 and FCb 7.3, in PS and DUD, respectively), although the greenish-white fleshed PS fruit had significantly lower values of the colorimeter parameter $\mathrm{a}^{*}(\mathrm{FCa}-2.5)$ compared to the white fleshed DUD fruit (FCa-0.6) (Table 2.5).

PS and DUD also showed differences in male and female flowering, being DUD more early flowering (with an average of 0.4 versus 2.8 female flowers (NFeF30), and 0.3 versus 2.5 male flowers (NMaF30), for PS and DUD respectively).

\subsubsection{Introgression line analysis}

The QTLs detected in this set of 16 ILs, representing altogether $62.6 \%$ of the DUD genome, in the two environments using the Dunnett test are summarized in Table 2.6 and Figure 2.3. These QTLs are described with detail in the next section.

\subsubsection{Flowering and ripening behavior}

Although DUD presents a significant early flowering in comparison to PS (Table 2.5), no IL from this set showed significant differences in the number of male and female flowers 15 and 30 days after the opening of the first flower.

As previously said, significant differences between parentals for ripening-associated traits like the presence of abscission layer (AL), occurrence of aroma (AR), and flesh and rind firmness (FF and RF) were detected in the ANOVA analysis (Table 2.5). The presence of the abscission layer had a strong genotype effect (56.9\%) and almost no environmental and no interaction $\mathrm{G}$ x E (0.7 and $1.8 \%$ respectively) (Table 2.7). Also, rind and flesh firmness had an important genotype effect (19.4 - 24.3\% of total variation), with no environmental effect for FF and low effect for RF $(0.8 \%)$ and moderate interaction $\mathrm{Gx}$ E (7.0 - 9.8\% of total variation). On the other hand, a considerable environmental effect was estimated for external aroma (23.4\%), with low genotype and interaction effect (1.8 and 5.6\%, respectively) (Table 2.7). 
The abscission layer was observed in the fruits of the lines DUD_3-1 and DUD_6-2 (Figure 2.4a) with significant differences detected for these ILs in comparison to PS based on ANOVA and Dunnett's test (Table 2.5, Figure 2.3a). DUD_3-1 has a main introgression on chromosome 3 (spanning 25.9 Mbp), only partially shared with DUD_8-1 (Table 2.3 and Table 2.4), and a minor introgression on chromosome $9(0.55 \mathrm{Mbp})$. Additional small introgressions, ranging from 0.01 to $0.14 \mathrm{Mbp}$, were also detected after GBS analysis on chromosomes 4, 5, and 10 (Table 2.4, Table 2.6). QTLs controlling melon abscission layer were reported for first time by Périn et al. (2002), who identified the genes Al-3 and Al-4 in chromosomes 8 and 9, respectively. Moreno et al. (2008) and Vegas, Garcia-Mas, \& Monforte (2013) reported a QTL (ETHQB3.5) associated to ethylene production in fruits, in a region of chromosome 3, spanning from 22 to $30 \mathrm{Mbp}$. The introgression in DUD_3-1 includes partly this region (Table 2.4). ETHQB3.5 alleles of the Conomon accession PI 161375 induce climacteric behavior in the nonclimacteric 'Piel de Sapo' background, with a similar behavior to DUD_3-1, supporting the presence of a QTL for ripening in this introgression. CmACS5 (MELO3C010779, 30,906,213 30,908,525 bp in chromosome 3) was proposed as candidate for ETHQB3.5, although it can be discarded as the responsible of the phenotype observed in DUD_3-1, since this gene is out of the IL DUD_3-1 introgression (located 199 Kbp - 26.1 Mbp) and other IL, DUD_5-1, contains a DUD introgression including CmACS5 (30 - 31.5 Mbp), and does not develop abscission layer (Table 2.4).

DUD_6-2, also displaying abscission layer, carries two main introgressions according to Agena Bioscience assay, on chromosomes 1 (spanning 2.6 Mbp) and 6 (spanning 17.7 and 2.9 Mbp) (Table 2.3 and Table 2.4). Additional small introgressions have been found using GBS on chromosomes 3, 4, 5, 7, and 10 (from 0.01 to $0.65 \mathrm{Mbp}$ in length; Table 2.4). This line, DUD_62, was the only IL that showed consistently significant differences with respect to PS in other ripening related traits since it presents external aroma (AR), and a loss of flesh and rind firmness (FF, RF) (59.5 and 17.4\%, respectively) in both years (Figure 2.3a, Table 2.6). Based on GBS genotyping, the main DUD introgression of chromosome 6 in DUD_6-2 is located from 14.5 to $32.7 \mathrm{Mbp}$ and from 34.8 to $37.7 \mathrm{Mbp}$. In this region is located the previously reported QTL ETHQV6.3 also involved in climacteric ripening of the non-climacteric 'Piel de Sapo' with conomon PI 161375 introgressions (Moreno et al., 2008; Vegas et al., 2013). The gene CmNACNOR (MELO3C016540, 27,663,292 - 27,665,351 bp; Table 2.8), which encodes a NAC transcription factor involved in the regulation of climacteric ripening, has been identified as the responsible of the altered ripening controlled by ETHQV6.3 (Ríos et al., 2017). Although this gene is located within the introgression of DUD_6-2, also the non-climacteric IL DUD_5-1 contains a DUD introgression in this region (27.4 - 27.9 Mbp) showing no effects. However, 


\subsection{CAPÍTULO 2}

CmNAC-NOR cannot be absolutely discarded as a candidate to explain the climacteric phenotype in DUD_6-2, as it places within a region of $551 \mathrm{Kbp}$ between two GBS markers where recombination may have taken place (Table 2.4). The DUD_6.2 introgression in chromosome 6 contains other four genes annotated as NAC domain proteins (MELO3C014922, 20,900,809-20,902,991, MELO3C016444 29,775,058-29,777,132, MELO3C013971, 35,529,924-35,533,985, MELO3C014141, 37,363,939-37,367,039) (Table 2.8) that could also contribute to the climacteric phenotype.

Interestingly, other NAC domain-containing proteins such as MELO3C019845 and MELO3C019954 are located in the genomic region of chromosome 3 from DUD_3-1 (Table 2.8). Also, a recent study using a 'Vedrantais' IL with a chromosome 10 introgression from a makuwa melon (PI 420176) (Perpiñà, Cebolla-Cornejo, Esteras, Monforte, \& Picò, 2017), suggested a NAC/NAM transcription factor (MELO3C012390) as a candidate gene responsible for the delayed ripening process and the absence of abscission layer and external aroma in the climacteric genetic background of 'Vedrantais', highlighting again the close relation between NAC genes and the climacteric behavior.

Our results along with previous studies suggest that the genetic basis of fruit ripening in melon is complex and variety-specific. The presence of NAC factors in most of the main introgressions coming from different exotic genetic backgrounds, suggests that common genetic mechanisms may be involved in ripening regulation through the action of different transcriptions factors of the NAC family located in different genomic regions and that can induce climacteric ripening in non-climacteric background or delay ripening in climacteric-backgrounds, leading to a wide range of climacteric behavior that can be useful for melon breeding.

DUD_3-1 and DUD_6-2 also showed differences in ripening related traits among them. DUD_3-1 forms abscission layer, likely induced by the QTL al.3 defined by this line, but fruits are not aromatic and do not suffer flesh softening, whereas DUD_6-2 forms abscission layer and develops aromatic fruit with an enhanced flesh softening process. Although the genomic region in chromosomes 6 defined by DUD_6-2 is the one more consistently supported by previous studies of QTLs related to climacteric ripening and flesh firmness (Monforte et al. 2004; Paris, Zalapa, McCreight, \& Staub, 2008; Ríos et al. 2017; Vegas et al. 2013), this line has an additional major introgression in chromosome 1. Other studies have reported additional QTLs related to flesh softness in chromosome 1. For instance, Galpaz et al. (2018) detected a QTL for flesh firmness, but this is located $30 \mathrm{Mbp}$ away from our $r f .1$ and ff.1 (Table 2.6). Another QTL involved in ethylene production, ethl.1, was reported in chromosome 1 (Moreno et al., 2008; Périn et al., 2002), being suggested the ethylene receptor CmERS1 (MELO3C015961) as a candidate gene. Although this gene locates outside DUD_6-2 
introgression (at $32 \mathrm{Mbp}$ ), several ethylene-related genes like MELO3C024268 and MELO3C024315, two ethylene-responsive transcription factors, were located in the QTL region of chromosome 1 defined by DUD_6-2 IL. Additionally, other genes involved in volatile metabolism like MELO3C029261 or MELO3C024348 (a malonate-CoA ligase-like protein and a lipoxygenase, enzymes involved in the pathway of phenylpropanoid-derived compound metabolisms) collocated with ar.1 (Table 2.8). Other previous studies have reported QTLs related to the amount of some volatile compounds (chromosomes 4, 8, 11) (Obando-Ulloa, Ruiz, Monforte, \& Fernández-Trujillo, 2010) but no one collocates with introgressions in DUD 6-2. Galpaz et al. (2018) reported more than 140 QTLs, mainly in chromosomes 6, 8 and 11, corresponding to many volatiles detected differentially in their RILs derived from the momordica PI 414723 and the reticulatus Dulce. Only some QTLs in chromosome 6 such as the ones for S-methyl propanethioate or total sesquiterpenes collocate with ar.6. The stronger impact of QTL al.6 compared to al.3 on the ripening process, or the combined impact of al.6 with al.1 in IL DUD 6-2, along with effects from other minor introgressions, could account for these differences.

Segregation of the additional introgressions detected with GBS in these ILs will allow verifying that the QTLs are in the chromosome 3 and 6 introgressions. Aroma is one of the most important quality traits for the consumer, whereas flesh softness is an undesired trait. Both lines might be a prebreeding material useful to develop 'Piel de Sapo' varieties with improved fruit quality and new characteristics.

\subsubsection{Fruit morphology}

The fruit morphology studied in the present report includes fruit weight $(\mathrm{FW})$, length (FL), diameter (FD), shape (FS) and cavity (CW), traits which showed significant differences among PS and DUD (Table 2.5). As expected, these traits showed a strong genotype effect (12.7 $47.4 \%)$ and low interaction $\mathrm{G} \times \mathrm{E}(3.0-9.9 \%)$. CW and FS also displayed a significant environmental effect (Table 2.7). In addition, some of these traits are closely related. For instance, FS was positively correlated with FL $(r=0.65$, mean Paip16 and Paip17), and FW presented a strong correlation with FL and FD ( $r=0.80$ and $r=0.91$, respectively) (Table 2.9). However, FS and FW showed low correlation $(r=0.19)$ (Table 2.9), similar to the results reported by Perpiñà et al. (2016).

DUD_1-1, DUD_1-2, DUD_4-2, DUD_5-1, DUD_5-3, DUD_6-2 showed a significant reduction of FS from $14.4 \%$ to $30.9 \%$ compared with PS in both trials (Figure 2.3b, Table 2.6). In fact, many of these lines also showed a FL reduction from $20.0 \%$ to $38.8 \%$ with respect to 


\subsection{CAPÍTULO 2}

PS parental (with exception of DUD_1-1 and DUD_6-2). These lines define 6 QTLs in $f$ s.1.1, fs.1.2, fs. $4, f s .5, f s .6$ and $f$ s. 12 (Table 2.6).

Regarding fruit shape, Monforte, Díaz, Caño-Delgado, \& van der Knaap (2014) reported several meta-QTLs derived from different studies and populations. In chromosome 1, FSMQ1 was described explaining about $31 \%$ of the phenotypic variation and with ssp. agrestis allele leading to elongated fruits. Our $f s .1 .1$ and $f s .1 .2$ defined by DUD_1-1, DUD_1-2 and DUD_62 collocate in this region, with alleles from DUD decreasing the shape index (rounder fruits; 22.5, 14.4, 24.9\%, respectively; Table 2.6). In fact, the line DUD_1-2 also defined fl.1, displaying a significant decrease in fruit length (22.3\%).

The introgression on chromosome 4 of DUD_4-2 defined $f s .4$ and $f l .4$ (Table 2.6). This IL presented fruits with a significant decrease in fruit shape index (30.9\%) and also in length (38.8\%). No meta-QTL involved in fruit shape was reported by Monforte et al. (2014) in this chromosome. However, QTLs involved in fruit length have been reported by Díaz et al. (2015) in that region of chromosome 4 in their consensus map (FLQC4.3, FLQX4.1), and Ramamurthy \& Water (2015) found that the snake melon allele for QTL FS2 (same region as $f$ s.4) increased the fruit length, while the cantaloupe alleles decreased the trait. Díaz et al. (2017) detected flqt4.1, faqt4.1, and fdqt4.1 in a region partly collocalized with $f s .4$, in a population derived from wild Cucumis trigonus (now reclassified as Cucumis melo ssp agrestis) crossed to 'Piel de Sapo', with the PS alleles increasing length fruit and size, which is coherent with our results for that region.

Wu et al. (2018) presented strong evidences that members of Ovate Family Protein (OFP) gene family are involved in the determination of organ shape in different plant species having a critical role in regulating fruit shape by changing cell division patterns early in the development of organs. Consistently, Díaz et al. (2017) indicated that the QTLs described in chromosome 4 included some candidate genes belonging to the OFP family ( $\mathrm{CmOFP} 4$ corresponding to MELO3C009113, 34,135,042 - 34,136,208 bp; and CmOFP5, corresponding to MELO3C009514, 31,566.369 - 31,567,286 bp), along with other genes like MELO3C013074 $(17,152,898$ - 17,154,990 bp), a calmodulin-binding family protein (involved in orientation during cell division; Huang, van Houten, Gonzalez, Xiao, \& van der Knaap, 2013; Wu, Chang, Wu, Zhan, \& Xie,. 2011; Wu et al.,, 2015). Although the region of $f_{s .4}$ did not include any of these OFP candidates, it included the calmodulin-binding family protein MELO3C013074.

Interestingly, the lines DUD_4-2, DUD_5-1, DUD_5-3 and DUD_6-2, which showed rounder shape in comparison to PS, include OFP genes in their DUD introgressions of chromosomes 1 , 5 and 12, based on the list of OFPs reported by Monforte et al. (2014) (Table 2.8). For example, DUD_4.2 shares with DUD_5-3 an introgression in chromosome 12. In this region maps the 
Transcription repressor OFP6 (MELO3C025581, 12,990,776-12,991,288), that can be a candidate to explain fruit shape variation in these lines (Figure 2.4b). Apart from OFP6, a probable candidate for this QTL is the pentamerous locus $(p)$, which controls the number of carpels (Monforte et al., 2014) and has been mapped in this region on chromosome 12 (16.4 22.4 Mbp; Díaz et al., 2011). As an increase in the number of carpels has been associated to longer diameters and rounder fruits in tomato (Rodriguez et al., 2011), alleles from accessions with 5 carpels (not the usual 3) such as PI 161375 and Dudaim melons may be lead also to rounder shapes. A meta-QTL involved in fruit shape (FSQM12) was reported in chromosome 12 (Monforte et al., 2014). Our fs. 12 collocates with this meta-QTL that explained nearly 30\% of the variation for the trait. For FSQM12, alleles from the conomon PI 161375 lead to rounder fruits, similarly to DUD alleles.

Moreover, based on the DUD introgressions in this line DUD_5-3, putative QTLs in chromosomes 5 and $6(f s .5, f l .5, f s .6, f l .6)$, and not only in chromosome 12 , were defined (Table 2.6). With respect to the introgression on chromosome 6 of DUD_5-3 ( $f s .6)$, it is shared with DUD_1-1, DUD_5-1, and DUD_6-2 with the same effects on FS. Recently, Pereira et al. (2018) detected FSQU6.2, a QTL spanning 31.6 - 36.4 Mbp on chromosome 6 in which 'Vedrantais' alleles, like DUD ones, lead to rounder shapes in contrast to more elongated PS.

Wu et al. (2018), using NILs from the cross between the Indian momordica PI 124112 and 'Piel de Sapo' as recurrent parent, identified a gene of the ovate family (OFP1 transcription repressor, MELO3C025206) on chromosome 8, as the responsible for the decrease of the length, producing round shape if the momordica allele is present. This gene is not represented in our final ILs collection, but the results described above suggest that other OFP-related genes, may also cause differences in fruit shape. Derivation of additional ILs from BC3 and new BC4 is needed to cover this genomic region and confirm if DUD alleles for this gene in a PS background have similar effects on fruit shape.

Regarding fruit size, only DUD_1-2 and DUD_2-1 showed significant differences with respect to PS in both environments (Figure 2.3b), with a reduction in weight of 36.5 and $33.9 \%$, respectively. The former IL not only presents smaller fruits but also rounder ones, as indicated previously $(f l .1, f s .1 .1)$. Previous studies using PS also reported a QTL located in the same region (FWQC1.4, Eduardo et al. 2007) with PS alleles decreasing fruits weight. In addition, fw. 1 collocates with $c w .1$, a QTL involved in the variation of seed cavity width, and fth.l, involved in flesh thickness (Table 2.6). Only this IL DUD_1-2 showed significant effects increasing seed cavity and reducing flesh thickness in both environments (Figure 2.3b, Figure 2.4c, Table 2.6) compared to PS (17.2 and $-24.3 \%$, respectively). 


\subsection{CAPÍTULO 2}

In contrast, DUD_2-1 only presented a difference in weight, as both length and diameter were also significantly lower than PS without an effect on shape (Figure 2.3b, Table 2.5). Thus, fw.2, $f l .2$ and $f d .2$ collocate in a large region on chromosome 2 (from $170 \mathrm{Kbp}$ to $15.8 \mathrm{Mbp}$ ). Previous studies reported QTLs involved in fruit length associated to size and in shape in this region of chromosome 2. For instance, Zalapa, Staub, McCreight, Chung, \& Cuevas (2007) detected a QTL that collocates with our fw.2 (FWQI2.1, Díaz et al. 2015), and Harel-Beja et al. (2010), using RILs derived from the momordica PI 414723 and the reticulatus Dulce, reported flqn2.1 (0.7 - $23 \mathrm{Mbp}$, with Dulce reducing the length by 31.5\%) and $f \operatorname{sh} 2.1$ (0.8 - $20.0 \mathrm{Mbp}$ ). In our PS background, DUD alleles lead to a reduction in length (19.8\%, Table 2.6) like Dulce alleles in flqn2.1. Subsequently, a QTL for weight including the same region was detected using ILs derived from makuwa and 'Vedrantais', although in this case makuwa alleles increased fruit weight, the opposite of Dudaim. Recently, Díaz et al. (2017), using the F2 from PS and the wild Trigonus, detected flqt2.1 in an overlapping region to our $f w .2(1.4-2.1 \mathrm{Mbp}$, region of andromonoecious a gene (CmACS7; MELO3C015444: 1,709,035 - 1,711,473 bp), with PS alleles decreasing fruit length, similar to our DUD reported effect. Monforte et al. (2014) reported a meta-QTL for weight in that region (FWMQ2) co-segregating with a gene. Previously, Monforte, Eduardo, Abad, \& Arús (2005) suggested that sex expression affects fruit size and shape since the presence of stamens prevent the normal longitudinal growth leading to a reduced elongation of the ovary. Since DUD and PS melons are andromonoecious and carry the non-functional allele for $C m A C S 7$ ( $a$ ), this pleiotropic effect does not explain the observed phenotype caused by this DUD introgression in chromosome 2. Therefore, we suggest that maybe other gene is involved in this trait in our population, or simply that fruit length and andromonoecious phenotype only co-segregates without a cause-effect relation as previously thought.

Also, in a GWA study carried out in a germplasm collection, Gur et al. (2017b) found association between several SNPs along chromosome 2 and shape, but not unambiguously related to fruit size.

The small size of melons may be a desired attribute in current markets. Thus both DUD_1-2 and DUD_2-1 can be promising pre-breeding lines, and especially DUD_2-1, since flesh thickness is not affected.

\subsubsection{Rind thickness and netting}

The rind characteristics, such as the thickness and netting are important in the processes of resistance to storage and transport (shelf life). These two traits, Rth and Net, displayed a negative correlation of $r=-0.17$ (Table 2.9). Moderate heritability has been reported for them 
(Perpiñà et al. 2016). We found important G effects (17.7 - 44.9\%), non-significant E effects, and moderate $\mathrm{G} x$ E interaction (Table 2.7).

Based on ANOVA, parentals showed significant differences for Rth in Paip16 and Paip17, while for Net the differences were only significant in one environment (Table 2.5). Four ILs presented significant differences with PS in both trials for Rth (DUD_4-2, DUD_5-1, DUD_63 and DUD_7-1) and two for Net (DUD_5-1 and DUD_5-2) (Figure 2.3c). For rind thickness these lines presented an average of 2.2, 2.3, 2.5 and $2.6 \mathrm{~mm}$ respectively versus 3.4 in PS (Table 2.5). Putative genomic regions responsible to the decrease in these lines were identified ( $r$ th.3, rth.4, rth.6 and rth.7) (Table 2.6), although DUD_4-2 and DUD_5-1 carries some other introgressions based on GBS analysis (from 0.02 to $11.2 \mathrm{Mbp}$ long) that will be necessary to study. A 20 Mbp- introgression on chromosome 12 in DUD_4-2 was discarded by its partial overlapping with other IL with no effect, and by its heterozygosity. DUD_6-3 has a single introgression in chromosome 6 which defines a QTL (rth.6) due to the partial overlapping with other ILs (Table 2.3). Perpiñà et al. (2016) reported in the same chromosome a QTL with a similar effect, although it was not in same location than our rth.6.

One region in chromosome 5 seemed to control netting density (Table 2.6). Although DUD is a non-netted type (likely due to a genetic background effect), DUD alleles in this region spanning $2 \mathrm{Mbp}$ lead to more intense netting in DUD_5-1 and DUD_5-2 fruits (Figure 2.4d), with an increase of 451.3 and $379.5 \%$ with respect to PS, respectively. Perpiñà et al. (2016) identified QTLs associated with this trait on chromosomes 5, 6 and 7, with no correspondence with the reported herein. Also, Paris et al. (2008) using a cross with the cantaloupe Top Mark, reported PNQJ5.1 in chromosome 5, which is located $1 \mathrm{Mbp}$ away from our net.5.

\subsubsection{Rind and flesh color and sugars content}

Despite the differences in rind color between parentals only one IL, DUD_6-1, presented a yellowish rind (Figure 2.4e). It is well known that the rind color in melon changes during the ripening process due to the loss of the green pigment chlorophyll and the synthesis of other pigments such as carotenoids and flavonoids. Monforte et al. (2004) detected in chromosome 10 a QTL involved in this trait, which is not associated to the climacteric behavior. Subsequently, Feder et al. (2015) identified a Kelch domain-containing F-box protein coding gene (CmKFB, MELO3C011980: 3,475,283 - 3,476,416 bp) in that region as the causal factor of the yellow rind phenotype. This gene negatively regulates the accumulation of naringenin chalcone, a yellow flavonoid, and affects to downstream flavonoid pathway. Based on the GBS genotyping, DUD_6-1 has two main introgressions in chromosome 10 (4.2 - 6.2 Mbp, and 19 $-26.5 \mathrm{Mbp}$ ) and small ones in 1, 2, 4, 5, 6, 7, 8 and 11 (spanning small regions from 0.02 to 


\subsection{CAPÍTULO 2}

$1.68 \mathrm{Mbp}$ ) (Table 2.4). However, $C m K F B$ is outside the DUD introgressions in chromosome 10, therefore other genes must be controlling this trait in this Dudaim derived population. For example, in the chromosome 10 introgression of DUD_6-1 is located MELO3C018335 $(19,402,491-19,403,056)$ that catalyzes the $35^{\prime}$-hydroxylation of naringenin and other flavonoids and could be a good candidate for this genotype.

PS and DUD have similar white flesh, with similar values of FCHl and FCb, and differences in FCa (greenish flesh in PS fruit) (Table 2.5). ILs did not show high variability for these traits (Figure 2.3d). For these color parameters a considerable genotype effect (10.9, 23.8 and 26.1\%, for $\mathrm{FCHl}, \mathrm{FCb}$ and $\mathrm{FCa}$, respectively) and interaction $\mathrm{G}$ x E (6.6, 14.8 and 15.6\%, respectively) were found, while low or no environmental effect was estimated (1.5\% for FCa) (Table 2.7). Only some lines showed significant effects based on Dunnett's test for FCa and FCb, but only in one environment, none showing a consistent effect in both assays (Figure 2.3d).

Regarding nutritional content, sweetness is one of the most appreciated traits. Sugar content in melon has a complex genetic control (Gur et al., 2017b), so a large number of QTLs related to this trait have been identified in different chromosomes to date (Argyris et al. 2017; Díaz et al. 2015; Pereira et al. 2018). Parentals showed differences in SSC (13.8 ${ }^{\circ}$ Brix for sweet PS versus $8.18^{\circ}$ Brix for non-sweet DUD). Although a significant environmental effect (3.1\%) and G x E $(6.9 \%)$ was estimated, also a moderate genotype effect existed for this trait (16.9\%) (Table 2.7). Only DUD_2-1, had a consistent effect in both environments (average $10.9^{\circ}$ Brix versus $13.8^{\circ}$ Brix in PS) with a significant decrease in ${ }^{\circ}$ Brix (19.2 - 23.1\%) (Table 2.6, Figure 2.3e). This IL defined QTL ssc.2, and as expected, DUD alleles led to a reduction in the soluble solid content (Table 2.6). Harel-Beja et al. (2010) reported some QTLs in that region of chromosome 2 (sscqn2.1, sscqc2.2), with Dulce allele increasing SSC. Although only in one location, Argyris et al. (2017), using NILs derived from SC, also detected QTLs in this chromosome for SSC and sucrose in the region $0-1.4 \mathrm{Mbp}$ overlapping ssc.2. SC alleles led to a decrease of the sugar content relative to PS (more than 25.2\%). Although RIL population by Pereira et al. (2018) was also developed from PS, no QTL for SSC was detected in common with our population. Although only in one environment, other three ILs presented significantly lower SSC with respect to PS (Figure 2.3e) that should be noted due to the importance of G x E interaction in this trait (DUD_5-1, DUD_5-3, and DUD_6-1). In Paip16, DUD_5-3 and DUD_6-1 showed a decrease of $18.0 \%$ and $18.3 \%$, and in Paip17, DUD_5-1 decreased 19.2\% with respect to PS. Argyris et al. (2017) detected stable QTLs in chromosome 5 (region 1.69 - $1.75 \mathrm{Mbp}$ ), for sucrose, fructose, glucose and SSC in several environments reporting MELO3C014519 (putative BEL1-like homeodomain protein; 1,745,222 - 1,749,158 bp) as a candidate gene. This region corresponds to CMPSNP437 $(26.5 \mathrm{cM})$ and is included in the introgression carried by 
DUD_5-1 (Table 2.3), although also in DUD_5-2 which showed no effect. Despite the introgression in DUD_5-3 $(28.23-28.87 \mathrm{Mbp})$ is outside that region, it collocated with sucqsc5.4_CAM by Argyris et al. (2017) (28.3 -29 Mbp, -40\% relative to PS) and also implied sugar decrease. Previously, sscqa5.2 had been detected in the same genomic region (Díaz et al. 2015; Monforte et al, 2004). DUD_6-1 and DUD_5-1 may define other regions also leading to sweetness loss in chromosome 6 (2.9 - 5.7 Mbp and 32.3 - 36.4 Mbp, respectively). In fact, other QTLs have been reported collocated with these regions in chromosome 6 decreasing fructose and SSC, and with both effects for glucose (Argyris et al., 2017; Díaz et al., 2015). Despite the fact that many other studies have mapped sugar-related traits also in other chromosomes, some QTLs seem to be conserved across distinct germplasm suggesting that common genetic mechanisms regulate sugar content (Argyris et al., 2017), especially in populations involving non-sweet Oriental alleles (from DUD, SC, Trigonus).

Differences between parentals for flesh acidity $(\mathrm{pH})$ only were detected in one environment (Paip17) and only DUD_6-2 was slightly more acid than PS demonstrating there is low genetic variability for this trait in this population (Figure 2.3e). 


\subsection{Supporting information}

Table 2.1. SNPs employed in the construction of the IL population. This set was selected from those previously mapped and employed to anchor the first version of the melon genome (Garcia-Mas et al., 2012). Also, positions in the new genetic map by Argyris et al. (2015) are indicated, as well as the physical position for genome assembly in the version v.3.5.1 and the most recent v.3.6.1, available at Melonomics. Information about the SNP and flanking sequence is included for all the markers used in the Sequenom assay, and the primers for those that were adapted to the HRM genotyping procedure are also provided. Markers that could not be accurately called in the Sequenom assay are marked as failed markers (f).

\begin{tabular}{|c|c|c|c|c|c|c|c|}
\hline SNP source & Marker & Chromosome & $\begin{array}{c}\text { cM } \\
\text { Garcia-Mas } \\
\text { et al. (2012) }\end{array}$ & $\begin{array}{c}\text { cM } \\
\underset{(2015)}{\text { Argyris et al. }}\end{array}$ & $\begin{array}{c}\text { Pseudomolecule } \\
\text { coordinates } \\
\text { v.3.5.1 }\end{array}$ & $\begin{array}{c}\text { Pseudomolecule } \\
\text { coordinates } \\
\text { v.3.6.1 }\end{array}$ & $\begin{array}{c}\text { Failed } \\
\text { markers }^{3}\end{array}$ \\
\hline in silico Blanca et al., 2011 & CMPSNP83 & 1 & 18.1 & 24.5 & $7,292,924$ & $7,678,616$ & \\
\hline Deleu et al., 2009 & P01.16 & 1 & 35.7 & 25.2 & $9,621,279$ & $10,073,085$ & \\
\hline Deleu et al., 2009 & AI_17-E07 & 1 & 45.2 & - & $19,121,639$ & $20,367,567$ & \\
\hline in silico Blanca et al., 2011 & CMPSNP711 & 1 & 46.8 & 41.4 & $26,445,177$ & $27,749,108$ & \\
\hline in silico Blanca et al., 2011 & CMPSNP410 & 1 & 59.6 & 53.4 & $31,732,436$ & $33,034,724$ & \\
\hline Deleu et al., 2009 & AI_05-G01 & 1 & 72.4 & 60 & $32,470,358$ & $33,772,708$ & \\
\hline in silico Blanca et al., 2011 & CMPSNP731 & 1 & 80.4 & 71.6 & $33,423,744$ & $34,725,764$ & \\
\hline in silico Blanca et al., 2011 & CMPSNP204 & 1 & 86.8 & 91.5 & $34,997,884$ & $36,651,937$ & \\
\hline in silico Blanca et al., 2011 & CMPSNP774 & 2 & 0 & 0 & 170,884 & 170,757 & \\
\hline Argyris et al., 2015 & CMPSNP431 & 2 & 4.8 & 5.884 & 827,502 & 827,515 & \\
\hline in silico Blanca et al., 2011 & CMPSNP502 & 2 & 32.6 & 36.9 & $2,718,909$ & $2,718,723$ & \\
\hline in silico Blanca et al., 2011 & CMPSNP1057 & 2 & 37.4 & 40.3 & $3,609,858$ & $3,609,955$ & \\
\hline Deleu et al., 2009 & AI_14-H05 & 2 & 40.6 & - & $7,375,537$ & $8,177,102$ & \\
\hline in silico Blanca et al., 2011 & CMPSNP128 & 2 & 50.2 & 57.7 & $17,549,016$ & $18,371,829$ & \\
\hline in silico Blanca et al., 2011 & CMPSNP1003 & 2 & 58.2 & 51.5 & $15,033,699$ & $15,836,032$ & \\
\hline in silico Blanca et al., 2011 & CMPSNP886 & 2 & 63 & 61.3 & $21,840,921$ & $22,704,163$ & \\
\hline in silico Blanca et al., 2011 & CMPSNP658 & 2 & 77.9 & 82.7 & $24,385,547$ & $25,249,284$ & \\
\hline in silico Blanca et al., 2011 & CMPSNP94 & 2 & 90.9 & 100.8 & $26,118,656$ & $26,989,616$ & \\
\hline
\end{tabular}


Table 2.1. (Continued)

\begin{tabular}{|c|c|c|c|c|c|c|c|}
\hline SNP source & Marker & Chromosome & $\begin{array}{c}\text { cM } \\
\text { Garcia-Mas } \\
\text { et al. (2012) }\end{array}$ & $\begin{array}{c}\mathrm{cM} \\
\underset{(2015)}{\text { Argyris et al. }}\end{array}$ & $\begin{array}{c}\text { Pseudomolecule } \\
\text { coordinates } \\
\text { v.3.5.1 }^{1}\end{array}$ & $\begin{array}{c}\text { Pseudomolecule } \\
\text { coordinates } \\
\text { v.3.6.1 }\end{array}$ & $\begin{array}{c}\text { Failed } \\
\text { markers }\end{array}$ \\
\hline Deleu et al., 2009 & AI_18-E05 & 3 & 3.2 & - & $3,631,494$ & $3,631,174$ & \\
\hline in silico Blanca et al., 2011 & CMPSNP275 & 3 & 4.8 & - & $21,474,136$ & $22,700,105$ & \\
\hline in silico Blanca et al., 2011 & CMPSNP540 & 3 & 8 & - & $22,280,838$ & $23,506,476$ & \\
\hline in silico Blanca et al., 2011 & CMPSNP165 & 3 & 24.3 & - & $23,683,172$ & $25,960,809$ & \\
\hline in silico Blanca et al., 2011 & CMPSNP8 & 3 & 34.2 & 49.5 & $24,829,145$ & $27,107,000$ & \\
\hline in silico Blanca et al., 2011 & CMPSNP769 & 3 & 42.8 & - & $25,676,382$ & $27,954,286$ & \\
\hline in silico Blanca et al., 2011 & CMPSNP164 & 3 & 46.2 & - & $26,334,505$ & $28,613,121$ & \\
\hline in silico Blanca et al., 2011 & CMPSNP998 & 3 & 56.3 & - & $27,841,857$ & $30,121,173$ & \\
\hline in silico Blanca et al., 2011 & CMPSNP712 & 3 & 62.7 & - & $28,923,355$ & $31,202,854$ & \\
\hline in silico Blanca et al., 2011 & CMPSNP480 & 4 & 0 & 0 & 362,781 & 363,061 & \\
\hline Leida et al., 2015 & CMPSNP1132 & 4 & 11.2 & - & $1,567,022$ & $1,567,059$ & \\
\hline Deleu et al., 2009 & PS_34-C02 & 4 & 17.6 & - & $1,743,227$ & $1,743,247$ & \\
\hline Leida et al., 2015 & CMPSNP907 & 4 & 20.8 & - & $1,843,071$ & $1,843,016$ & \\
\hline in silico Blanca et al., 2011 & CMPSNP264 & 4 & 32.1 & - & $2,753,638$ & $2,754,054$ & \\
\hline in silico Blanca et al., 2011 & CMPSNP147 & 4 & 48.3 & - & $3,943,575$ & $3,943,829$ & \\
\hline Deleu et al., 2009 & AI_03-F03 & 4 & 53.1 & 6.3 & $13,459,028$ & $13,463,555$ & \\
\hline in silico Blanca et al., 2011 & CMPSNP352 & 4 & 54.7 & - & $15,114,501$ & $15,119,135$ & \\
\hline in silico Blanca et al., 2011 & CMPSNP852 & 4 & 62.7 & - & $27,215,175$ & $28,408,179$ & \\
\hline in silico Blanca et al., 2011 & CMPSNP607 & 4 & 69.1 & 46.4 & $29,028,077$ & $30,221,393$ & \\
\hline in silico Blanca et al., 2011 & CMPSNP677 & 4 & 77.1 & - & $29,823,968$ & $31,017,147$ & \\
\hline in silico Blanca et al., 2011 & CMPSNP24 & 4 & 86.8 & - & $31,066,110$ & $32,259,279$ & \\
\hline in silico Blanca et al., 2011 & CMPSNP808IR38B & 4 & 96.6 & 69.7 & $31,788,239$ & $32,982,373$ & \\
\hline Deleu et al., 2009 & PS_07-E07 & 4 & 101.5 & - & $32,158,449$ & $33,352,512$ & \\
\hline Esteras et al., 2013 & SC51-3375 & 4 & 114.6 & 76.8 & $32,707,809$ & $33,902,565$ & \\
\hline
\end{tabular}


Table 2.1. (Continued)

SNP source Marker

cM

cM

Pseudomolecule Pseudomolecule

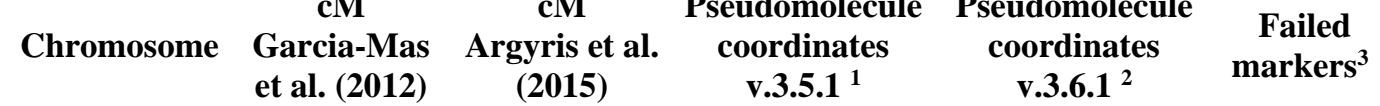

et al. (2012) (2015)

v.3.5.1 ${ }^{1}$

v.3.6.1 ${ }^{2}$

in silico Blanca et al., 2011 CMPSNP898

in silico Blanca et al., 2011 CMPSNP387

in silico Blanca et al., 2011 CMPSNP437

in silico Blanca et al., 2011 CMPSNP726

Deleu et al., 2009

SSH9G15

Deleu et al., 2009

AI_13-H12

in silico Blanca et al., 2011 CMPSNP735

in silico Blanca et al., 2011 CMPSNP925

in silico Blanca et al., 2011 CMPSNP218

in silico Blanca et al., 2011 CMPSNP571

$$
\text { Leida et al., } 2015
$$

CMPSNP1167

in silico Blanca et al., 2011 CMPSNP3

in silico Blanca et al., 2011 CMPSNP292

in silico Blanca et al., 2011 CMPSNP295

in silico Blanca et al., 2011 CMPSNP1038

in silico Blanca et al., 2011 CMPSNP1021

$$
\text { Deleu et al., } 2009 \text { A_38-F04 }
$$

Deleu et al., 2009 AI_13-F02

in silico Blanca et al., 2011 CMPSNP378

Deleu et al., 2009 AI_05-F11

in silico Blanca et al., 2011 CMPSNP249

in silico Blanca et al., 2011 CMPSNP262

in silico Blanca et al., 2011 CMPSNP287

in silico Blanca et al., 2011 CMPSNP56

$\begin{array}{lc}5 & 0 \\ 5 & 18.5 \\ 5 & 26.5 \\ 5 & 41.2 \\ 5 & 52.5 \\ 5 & 89.4 \\ 5 & 94.2 \\ 6 & 1.6 \\ 6 & 8 \\ 6 & 20.8 \\ 6 & 25.6 \\ 6 & 43.2 \\ 6 & 49.6 \\ 6 & 49.6 \\ 6 & 57.6 \\ 6 & 57.6 \\ 6 & 70.7 \\ 6 & 85.3 \\ 6 & 86.9 \\ 7 & 4.9 \\ 7 & 11.3 \\ 7 & 30.5 \\ 7 & 35.3 \\ 7 & 43.3\end{array}$

$\begin{array}{ccc}0 & 259,923 & 259,320 \\ 14.1 & 1,253,798 & 1,252,870 \\ 22.1 & 1,694,154 & 1,693,033 \\ 34.3 & 2,372,338 & 2,371,705 \\ 45.8 & 5,896,066 & 5,908,586 \\ - & 27,276,309 & 28,262,505 \\ - & 27,884,511 & 28,870,979 \\ 0 & 700,136 & 699,936 \\ 6.8 & 1,370,898 & 1,370,773 \\ - & 2,893,202 & 2,892,625 \\ - & 5,691,777 & 5,691,048 \\ - & 5,926,468 & 5,925,611 \\ 59.9 & 13,527,747 & 14,605,002 \\ 69.2 & 30,045,130 & 32,007,462 \\ - & 32,291,903 & 36,382,388 \\ 73.6 & 32,261,025 & 36,413,297 \\ 83 & 33,709,578 & 34,965,067 \\ - & 34,982,242 & 33,691,708 \\ 108 & 35,382,572 & 33,291,607 \\ 8.2 & 913,994 & 913,762 \\ - & 1,345,312 & 1,345,216 \\ 37.6 & 5,136,630 & 5,136,564 \\ - & 21,259,438 & 22,793,546 \\ 61.5 & 22,969,141 & 25,153,931\end{array}$


Table 2.1. (Continued)

\begin{tabular}{|c|c|c|c|c|c|c|c|}
\hline SNP source & Marker & Chromosome & $\begin{array}{c}\text { cM } \\
\text { Garcia-Mas } \\
\text { et al. (2012) }\end{array}$ & $\begin{array}{c}\mathbf{c M} \\
\text { Argyris et al. } \\
\quad(2015)\end{array}$ & $\begin{array}{l}\text { Pseudomolecule } \\
\text { coordinates } \\
\text { v.3.5.1 }^{1}\end{array}$ & $\begin{array}{l}\text { Pseudomolecule } \\
\text { coordinates } \\
\text { v.3.6.1 }\end{array}$ & $\begin{array}{c}\text { Failed } \\
\text { markers }\end{array}$ \\
\hline in silico Blanca et al., 2011 & CMPSNP465 & 7 & 59.4 & 89.9 & $25,199,771$ & $27,384,271$ & \\
\hline in silico Blanca et al., 2011 & CMPSNP415 & 7 & 72.2 & - & $26,540,472$ & $28,724,771$ & \\
\hline in silico Blanca et al., 2011 & CMPSNP12 & 8 & 0 & - & 616,486 & 618,918 & \\
\hline in silico Blanca et al., 2011 & CMPSNP766 & 8 & 4.8 & - & $1,711,723$ & $1,709,984$ & \\
\hline in silico Blanca et al., 2011 & CMPSNP718 & 8 & 11.2 & - & $2,720,921$ & $2,719,619$ & \\
\hline in silico Blanca et al., 2011 & CMPSNP97 & 8 & 19.2 & 27.6 & $4,063,802$ & $4,062,976$ & \\
\hline in silico Blanca et al., 2011 & CMPSNP44 & 8 & 22.4 & - & $4,426,648$ & $4,425,649$ & \\
\hline Deleu et al., 2009 & AI_21-D08 & 8 & 28.8 & - & $5,350,603$ & $5,349,454$ & $\mathrm{f}$ \\
\hline in silico Blanca et al., 2011 & CMPSNP181 & 8 & 35.2 & - & $6,343,604$ & $6,342,468$ & \\
\hline in silico Blanca et al., 2011 & CMPSNP281 & 8 & 46.5 & 57.2 & $8,680,001$ & $9,828,824$ & \\
\hline Deleu et al ., 2009 & F013 & 8 & 48.1 & 59.4 & $15,100,508$ & $17,760,405$ & \\
\hline Deleu et al., 2009 & PSI_25-H03 & 8 & 59.4 & 77.4 & $29,533,077$ & $31,418,369$ & \\
\hline in silico Blanca et al., 2011 & CMPSNP1066 & 8 & 79.2 & 103.2 & $31,862,302$ & $34,113,953$ & \\
\hline in silico Blanca et al., 2011 & CMPSNP553 & 9 & 0 & - & 121,325 & 121,254 & \\
\hline in silico Blanca et al., 2011 & CMPSNP173 & 9 & 3.2 & 4.1 & 593,280 & 593,433 & \\
\hline Deleu et al., 2009 & P5.64 & 9 & 8 & - & $1,404,683$ & $1,404,394$ & \\
\hline in silico Blanca et al., 2011 & CMPSNP1077 & 9 & 19.2 & 35.8 & $5,055,926$ & $5,059,384$ & \\
\hline in silico Blanca et al., 2011 & CMPSNP320 & 9 & 20.8 & 39 & $8,741,784$ & $8,776,233$ & \\
\hline in silico Blanca et al., 2011 & CMPSNP144 & 9 & 22.4 & 42.3 & $14,870,978$ & $15,193,475$ & \\
\hline in silico Blanca et al., 2011 & CMPSNP1035 & 9 & 33.6 & - & $19,967,877$ & $21,103,363$ & \\
\hline in silico Blanca et al., 2011 & CMPSNP159 & 9 & 36.8 & 60.7 & $20,540,958$ & $21,676,053$ & \\
\hline in silico Blanca et al., 2011 & CMPSNP1133 & 9 & 59.2 & 88.9 & $23,050,120$ & $24,185,886$ & \\
\hline in silico Blanca et al., 2011 & CMPSNP890 & 9 & 64 & 95.1 & $23,504,523$ & $24,640,073$ & \\
\hline Esteras et al., 2013 & PSI36-839 & 10 & 0 & - & 439,912 & 440,777 & \\
\hline
\end{tabular}


Table 2.1. (Continued)

\begin{tabular}{|c|c|c|c|c|c|c|c|}
\hline SNP source & Marker & Chromosome & $\begin{array}{l}\text { cM } \\
\text { Garcia-Mas } \\
\text { et al. (2012) }\end{array}$ & $\begin{array}{c}\mathrm{cM} \\
\underset{(2015)}{\text { Argyris et al. }}\end{array}$ & $\begin{array}{c}\text { Pseudomolecule } \\
\text { coordinates } \\
\text { v.3.5.1 }{ }^{1}\end{array}$ & $\begin{array}{c}\text { Pseudomolecule } \\
\text { coordinates } \\
\text { v.3.6.1 }\end{array}$ & $\begin{array}{c}\text { Failed } \\
\text { markers }\end{array}$ \\
\hline Esteras et al., 2013 & PSI36-10864 & 10 & 0 & - & 449,914 & 450,775 & \\
\hline in silico Blanca et al., 2011 & CMPSNP528 & 10 & 8 & - & $1,722,391$ & $1,722,779$ & \\
\hline in silico Blanca et al., 2011 & CMPSNP65 & 10 & 14.4 & - & $2,226,565$ & $2,226,894$ & \\
\hline in silico Blanca et al., 2011 & CMPSNP671 & 10 & 28.8 & 44.8 & $4,747,876$ & $4,747,687$ & \\
\hline in silico Blanca et al., 2011 & CMPSNP426 & 11 & 0 & - & $1,759,815$ & $1,760,634$ & \\
\hline Deleu et al., 2009 & HS_35-E11 & 11 & 16.4 & NULL & $19,597,841$ & $20,433,841$ & \\
\hline in silico Blanca et al., 2011 & CMPSNP389 & 11 & 47.7 & 86.2 & $28,601,430$ & $31,483,418$ & \\
\hline in silico Blanca et al., 2011 & CMPSNP30 & 11 & 66 & - & $27,401,711$ & $30,283,269$ & \\
\hline in silico Blanca et al., 2011 & CMPSNP315 & 11 & 90.9 & 91.9 & $29,638,590$ & - & \\
\hline in silico Blanca et al., 2011 & CMPSNP475 & 11 & 98.9 & - & $30,277,496$ & $33,292,541$ & \\
\hline in silico Blanca et al., 2011 & CMPSNP385 & 12 & 4.8 & 0 & 347,765 & 347,738 & \\
\hline in silico Blanca et al., 2011 & CMPSNP310 & 12 & 9.8 & 20 & $5,144,172$ & $5,144,670$ & \\
\hline Deleu et al., 2009 & AI_35-A08 & 12 & 16.4 & 26 & $13,943,513$ & $13,002,224$ & \\
\hline in silico Blanca et al., 2011 & CMPSNP5 & 12 & 58.1 & 70 & $24,491,712$ & $25,654,096$ & \\
\hline Deleu et al., 2009 & FR14F22 & 12 & 67.7 & 81 & $25,309,588$ & $26,472,362$ & \\
\hline Deleu et al., 2009 & $\mathrm{P} 02.03$ & 12 & 69.3 & - & $25,933,698$ & $27,096,629$ & \\
\hline
\end{tabular}

${ }^{1}$ The physical position in the previous version of the melon genome v3.5.1 is indicated.

${ }^{2}$ The physical position in the new version of the melon genome v3.6.1 available at Melonomics is indicated.

${ }^{3}$ Markers not accurately called in the Sequenom assay (f). 
Table 2.2. Evaluation of the normality of every trait distribution for Paip 16 and Paip 17 populations with the Shapiro-Wilk and Kolmogorov-Smirnov tests.

\begin{tabular}{|c|c|c|c|c|c|c|c|c|}
\hline \multicolumn{3}{|c|}{ PAIP16 } & \multicolumn{3}{|c|}{ Shapiro-Wilk } & \multicolumn{3}{|c|}{ Kolmogorov-Smirnov } \\
\hline Trait & Mean & SD & Statistic & P-value & & Statistic & P-value & \\
\hline NMaF15 & 0.56 & 0.58 & 0.71 & 0.00 & Non-Normal & 0.31 & 0.00 & Non-Normal \\
\hline NFeF15 & 0.57 & 0.63 & 0.71 & 0.00 & Non-Normal & 0.34 & 0.00 & Non-Normal \\
\hline NMaF30 & 0.60 & 0.68 & 0.74 & 0.00 & Non-Normal & 0.31 & 0.00 & Non-Normal \\
\hline NFeF30 & 0.45 & 0.56 & 0.70 & 0.00 & Non-Normal & 0.35 & 0.00 & Non-Normal \\
\hline $\mathbf{A L}$ & 0.25 & 0.43 & 0.52 & 0.00 & Non-Normal & 0.47 & 0.00 & Non-Normal \\
\hline $\mathbf{A R}$ & 0.12 & 0.33 & 0.38 & 0.00 & Non-Normal & 0.52 & 0.00 & Non-Normal \\
\hline $\mathbf{R F}$ & 12.82 & 0.98 & 0.98 & 0.00 & Non-Normal & 0.53 & 0.00 & Normal \\
\hline FF & 1.84 & 0.85 & 0.96 & 0.00 & Non-Normal & 0.07 & 0.31 & Normal \\
\hline FW & 1289.37 & 476.55 & 0.95 & 0.00 & Non-Normal & 0.08 & 0.29 & Normal \\
\hline FS & 1.56 & 0.21 & 0.98 & 0.38 & Normal & 0.05 & 0.87 & Normal \\
\hline FL & 184.32 & 30.42 & 0.97 & 0.04 & Non-Normal & 0.05 & 0.79 & Normal \\
\hline FD & 118.92 & 15.83 & 0.97 & 0.11 & Normal & 0.05 & 0.68 & Normal \\
\hline CW & 0.45 & 0.06 & 0.98 & 0.52 & Normal & 0.05 & 0.78 & Normal \\
\hline Fth & 22.49 & 5.60 & 0.97 & 0.04 & Non-Normal & 0.08 & 0.26 & Normal \\
\hline Rth & 2.77 & 0.78 & 0.97 & 0.08 & Normal & 0.06 & 0.61 & Normal \\
\hline NET & 0.22 & 0.41 & 0.49 & 0.00 & Non-Normal & 0.48 & 0.00 & Non-Normal \\
\hline FCHI & 59.45 & 6.79 & 0.98 & 0.39 & Normal & 0.06 & 0.64 & Normal \\
\hline FCa & -2.34 & 1.07 & 0.90 & 0.00 & Non-Normal & 0.15 & 0.00 & Non-Normal \\
\hline $\mathbf{F C b}$ & 10.02 & 2.04 & 0.94 & 0.00 & Non-Normal & 0.08 & 0.28 & Normal \\
\hline SSC & 13.63 & 2.38 & 0.96 & 0.00 & Non-Normal & 0.08 & 0.24 & Normal \\
\hline pH & 5.97 & 0.52 & 0.80 & 0.00 & Non-Normal & 0.33 & 0.00 & Non-Normal \\
\hline
\end{tabular}


Table 2.2. (Continued)

\begin{tabular}{|c|c|c|c|c|c|c|c|c|}
\hline \multicolumn{3}{|c|}{ PAIP17 } & \multicolumn{3}{|c|}{ Shapiro-Wilk } & \multicolumn{3}{|c|}{ Kolmogorov-Smirnov } \\
\hline Trait & Mean & SD & Statistic & P-value & & Statistic & P-value & \\
\hline NMaF15 & 0.30 & 0.62 & 0.54 & 0.00 & Non-Normal & 0.46 & 0.00 & Non-Normal \\
\hline NFeF15 & 0.25 & 0.61 & 0.47 & 0.00 & Non-Normal & 0.48 & 0.00 & Non-Normal \\
\hline NMaF30 & 0.08 & 0.30 & 0.31 & 0.00 & Non-Normal & 0.53 & 0.00 & Non-Normal \\
\hline NFeF30 & 0.04 & 0.19 & 0.20 & 0.00 & Non-Normal & 0.54 & 0.00 & Non-Normal \\
\hline $\mathbf{A L}$ & 0.14 & 0.34 & 0.40 & 0.00 & Non-Normal & 0.52 & 0.00 & Non-Normal \\
\hline $\mathbf{A R}$ & 0.04 & 0.19 & 0.19 & 0.00 & Non-Normal & 0.54 & 0.00 & Non-Normal \\
\hline $\mathbf{R F}$ & 12.90 & 0.62 & 0.18 & 0.00 & Non-Normal & 0.53 & 0.00 & Non-Normal \\
\hline FF & 1.74 & 0.74 & 0.96 & 0.00 & Non-Normal & 0.07 & 0.13 & Normal \\
\hline FW & 1432.53 & 548.49 & 0.92 & 0.00 & Non-Normal & 0.10 & 0.01 & Non-Normal \\
\hline FS & 1.47 & 0.22 & 0.98 & 0.12 & Normal & 0.05 & 0.52 & Normal \\
\hline FL & 182.26 & 30.04 & 0.98 & 0.42 & Normal & 0.05 & 0.46 & Normal \\
\hline FD & 124.89 & 16.66 & 0.98 & 0.17 & Normal & 0.05 & 0.41 & Normal \\
\hline CW & 0.39 & 0.06 & 0.98 & 0.40 & Normal & 0.05 & 0.40 & Normal \\
\hline Fth & 28.32 & 6.11 & 0.97 & 0.00 & Non-Normal & 0.05 & 0.40 & Normal \\
\hline Rth & 2.72 & 0.57 & 0.98 & 0.08 & Normal & 0.04 & 0.82 & Normal \\
\hline NET & 0.46 & 0.89 & 0.55 & 0.00 & Non-Normal & 0.43 & 0.00 & Non-Normal \\
\hline FCHI & 62.35 & 5.48 & 0.98 & 0.48 & Normal & 0.05 & 0.56 & Normal \\
\hline $\mathbf{F C a}$ & -2.14 & 0.59 & 0.94 & 0.00 & Non-Normal & 0.10 & 0.01 & Non-Normal \\
\hline FCb & 10.56 & 1.78 & 0.98 & 0.28 & Normal & 0.05 & 0.36 & Normal \\
\hline SSC & 12.23 & 2.57 & 0.97 & 0.00 & Non-Normal & 0.05 & 0.55 & Normal \\
\hline pH & 6.03 & 0.24 & 0.44 & 0.00 & Non-Normal & 0.47 & 0.00 & Normal \\
\hline
\end{tabular}


Table 2.3. Genotype of the 16 ILs selected. Location in chromosomes including genetic position according to maps by Garcia-Mas et al. (2012) and Argyris et al. (2015), and physical position in melon genome assembly v.3.6.1., for the genetic background markers is indicated. Violet boxes indicate DUD homozygous introgressions, green boxes indicate the PS genetic background, yellow boxes indicate DUD heterozygosis and red boxes correspond to no calls.

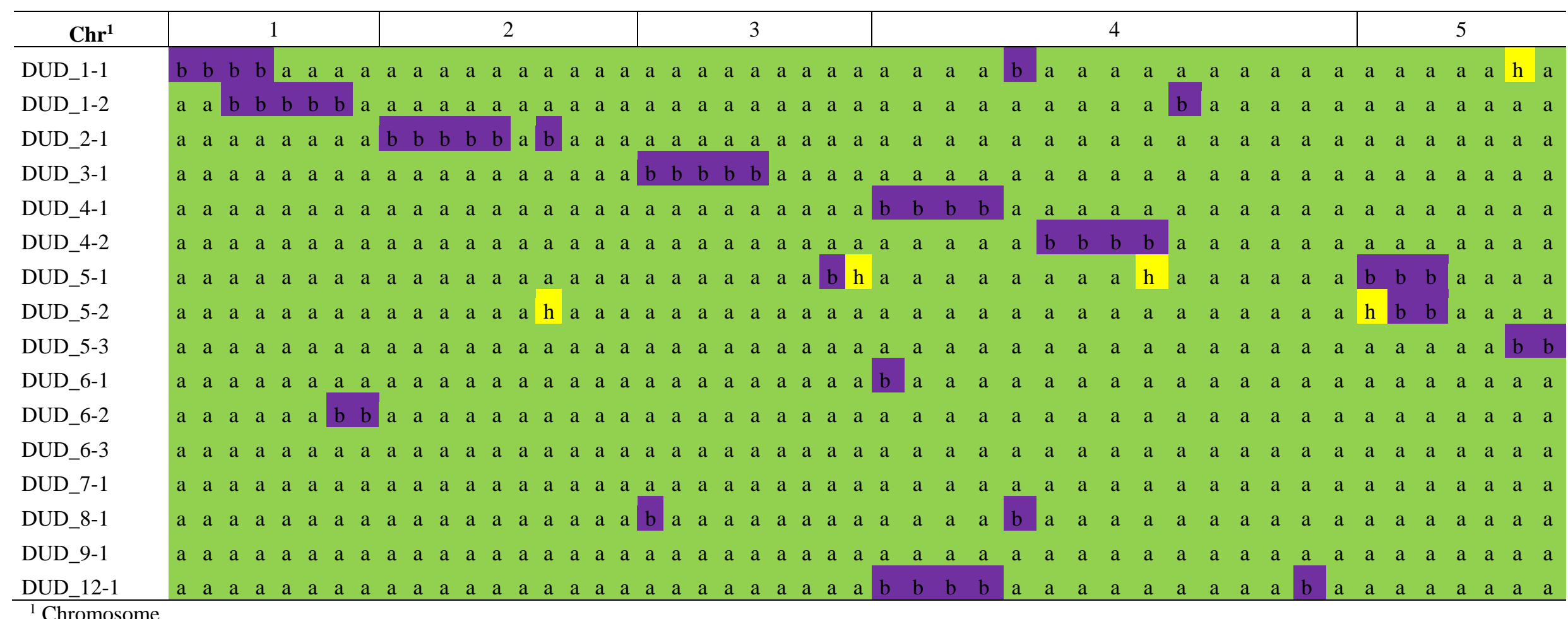

Chromosome 


\subsection{CAPÍTULO 2}

Table 2.3. (Continued)

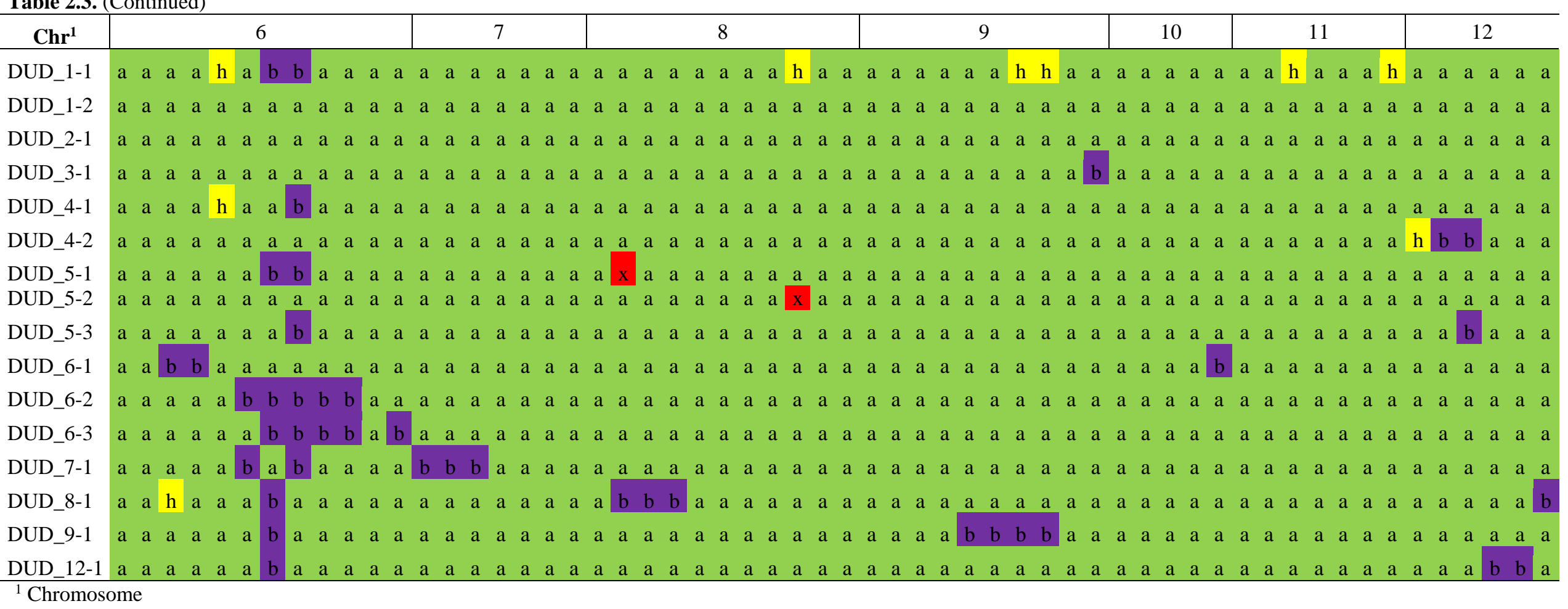


Table 2.4. Summary of introgressions found in the 5 selected Ils genotyped using GBS technology (only introgressions longer than 5Kbp) (Melon genome version 3.6.1).

\begin{tabular}{|c|c|c|c|c|c|}
\hline Chromosome & introgression beginning (bp) & introgression end (bp) & comments & bp & Introgression length in Mbp \\
\hline \multicolumn{6}{|c|}{ DUD_3-1 } \\
\hline 3 & 199,089 & $26,131,600$ & \multirow[t]{4}{*}{ previously described without GBS } & $25,932,511$ & 25.93 \\
\hline 4 & 818,265 & 824,121 & & 5,856 & 0.01 \\
\hline 4 & $33,938,856$ & $33,958,153$ & & 19,297 & 0.02 \\
\hline 5 & $3,464,043$ & $3,567,314$ & & 103,271 & 0.10 \\
\hline 9 & $24,640,073$ & $25,193,720$ & \multirow[t]{2}{*}{ previously described without GBS } & 553,647 & 0.55 \\
\hline 10 & $26,404,891$ & $26,545,573$ & & 140,682 & 0.14 \\
\hline \multicolumn{6}{|l|}{ DUD_4-2 } \\
\hline 1 & $17,907,410$ & $18,139,390$ & & 231,980 & 0.23 \\
\hline 1 & $29,386,854$ & $29,476,577$ & & 89,723 & 0.09 \\
\hline 4 & 818,265 & 824,121 & & 5,856 & 0.01 \\
\hline 4 & $2,371,829$ & $26,172,343$ & \multirow{6}{*}{$\begin{array}{l}\text { previously described without GBS } \\
\text { previously described without GBS }\end{array}$} & $23,800,514$ & 23.80 \\
\hline 4 & $26,406,871$ & $29,633,631$ & & $3,226,760$ & 3.23 \\
\hline 5 & $3,464,043$ & $3,566,438$ & & 102,395 & 0.10 \\
\hline 7 & $25,630,902$ & $25,663,347$ & & 32,445 & 0.03 \\
\hline 10 & $4,018,447$ & $4,044,092$ & & 25,645 & 0.03 \\
\hline 10 & $5,521,968$ & $6,176,206$ & & 654,238 & 0.65 \\
\hline 12 & $1,010,436$ & $21,367,892$ & \multirow[t]{2}{*}{ previously described without GBS } & $20,357,456$ & 20.36 \\
\hline \multicolumn{5}{|c|}{ 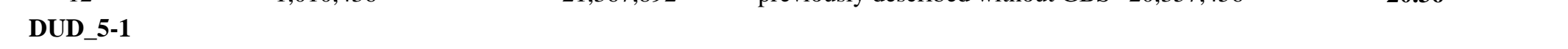 } & \\
\hline 1 & 27,328 & 226,258 & & 198,930 & 0.20 \\
\hline 1 & $4,546,697$ & $4,565,977$ & & 19,280 & 0.02 \\
\hline 1 & $17,907,410$ & $18,139,390$ & & 231,980 & 0.23 \\
\hline 1 & $29,386,854$ & $29,476,577$ & & 89,723 & 0.09 \\
\hline 1 & $35,380,850$ & $35,602,200$ & \multirow{3}{*}{ previously described without GBS } & 221,350 & 0.22 \\
\hline 3 & $30,080,208$ & $31,512,310$ & & $1,432,102$ & 1.43 \\
\hline 4 & $17,305,704$ & $26,172,343$ & & $8,866,639$ & 8.87 \\
\hline
\end{tabular}




\subsection{CAPÍTULO 2}

Table 2.4. (Continued)

\begin{tabular}{|c|c|c|c|c|c|}
\hline Chromosome & introgression beginning (bp) & introgression end (bp) & comments & bp & Introgression length in Mbp \\
\hline 4 & $26,406,871$ & $29,214,914$ & previously described without GBS & $2,808,043$ & 2.81 \\
\hline 4 & $33,938,856$ & $33,958,153$ & & 19,297 & 0.02 \\
\hline 5 & 36,677 & $2,043,123$ & previously described without GBS & $2,006,446$ & 2.01 \\
\hline 5 & $3,464,043$ & $3,567,314$ & & 103,271 & 0.10 \\
\hline 6 & $19,611,493$ & $20,013,068$ & & 401,575 & 0.40 \\
\hline 6 & $22,661,517$ & $24,675,352$ & & $2,013,835$ & 2.01 \\
\hline 6 & $27,421,608$ & $27,972,777$ & & 551,169 & 0.55 \\
\hline 6 & $30,016,520$ & $30,259,064$ & & 242,544 & 0.24 \\
\hline 6 & $31,927,456$ & $32,185,025$ & previously described without GBS & 257,569 & 0.26 \\
\hline 6 & $37,578,213$ & $37,784,403$ & & 206,190 & 0.21 \\
\hline 7 & $12,217,924$ & $12,862,518$ & & 644,594 & 0.64 \\
\hline 7 & $19,112,963$ & $19,293,090$ & & 180,127 & 0.18 \\
\hline 10 & $5,521,968$ & $16,746,176$ & & $11,224,208$ & 11.22 \\
\hline 10 & $17,503,581$ & $19,013,529$ & & $1,509,948$ & 1.51 \\
\hline 10 & $22,478,144$ & $26,545,573$ & & $4,067,429$ & 4.07 \\
\hline 11 & $12,237,119$ & $13,417,160$ & & $1,180,041$ & 1.18 \\
\hline 12 & $26,820,759$ & $26,876,807$ & & 56,048 & 0.06 \\
\hline \multicolumn{6}{|l|}{ DUD_6-2 } \\
\hline 1 & 27,328 & 226,258 & & 198,930 & 0.20 \\
\hline 1 & $4,546,697$ & $4,565,977$ & & 19,280 & 0.02 \\
\hline 1 & $17,907,410$ & $18,139,390$ & & 231,980 & 0.23 \\
\hline 1 & $29,386,854$ & $29,476,577$ & & 89,723 & 0.09 \\
\hline 1 & $34,399,378$ & $37,029,410$ & previously described without GBS & $2,630,032$ & 2.63 \\
\hline 3 & $31,261,825$ & $31,386,415$ & & 124,590 & 0.12 \\
\hline 4 & $33,938,856$ & $33,958,153$ & & 19,297 & 0.02 \\
\hline 5 & $3,464,043$ & $3,567,314$ & & 103,271 & 0.10 \\
\hline 6 & $14,522,865$ & $32,185,025$ & previously described without GBS & $17,662,160$ & 17.66 \\
\hline
\end{tabular}


Table 2.4. (Continued)

\begin{tabular}{|c|c|c|c|c|c|}
\hline Chromosome & introgression beginning (bp) & introgression end (bp) & comments & bp & Introgression length in Mbp \\
\hline 6 & $34,844,607$ & $37,784,403$ & previously described without GBS & $2,939,796$ & 2.94 \\
\hline 7 & 340,053 & 346,557 & & 6,504 & 0.01 \\
\hline 7 & $19,092,582$ & $19,293,090$ & & 200,508 & 0.20 \\
\hline 10 & $5,521,968$ & $6,176,206$ & & 654,238 & 0.65 \\
\hline \multicolumn{6}{|l|}{ DUD_6-1 } \\
\hline 1 & 27,328 & 865,409 & & 838,081 & 0.84 \\
\hline 1 & $4,546,697$ & $4,565,977$ & & 19,280 & 0.02 \\
\hline 1 & $17,907,410$ & $18,139,390$ & & 231,980 & 0.23 \\
\hline 1 & $29,386,854$ & $29,476,577$ & & 89,723 & 0.09 \\
\hline 2 & $9,795,356$ & $10,538,394$ & & 743,038 & 0.74 \\
\hline 4 & 229,138 & $1,366,420$ & previously described without GBS & $1,137,282$ & 1.14 \\
\hline 4 & $21,630,101$ & $21,641,157$ & & 11,056 & 0.01 \\
\hline 4 & $24,005,571$ & $24,038,904$ & & 33,333 & $\mathbf{0 . 0 3}$ \\
\hline 4 & $33,187,832$ & $33,199,040$ & & 11,208 & 0.01 \\
\hline 4 & $33,938,856$ & $33,958,153$ & & 19,297 & 0.02 \\
\hline 5 & $4,744,788$ & $4,882,314$ & & 137,526 & 0.14 \\
\hline 6 & $2,070,582$ & $3,754,884$ & previously described without GBS & $1,684,302$ & 1.68 \\
\hline 7 & 340,053 & 346,557 & & 6,504 & 0.01 \\
\hline 7 & $3,428,219$ & $3,566,129$ & & 137,910 & 0.14 \\
\hline 7 & $24,001,555$ & $24,044,504$ & & 42,949 & 0.04 \\
\hline 7 & $25,630,902$ & $25,663,347$ & & 32,445 & 0.03 \\
\hline 8 & $3,116,992$ & $3,628,238$ & & 511,246 & 0.51 \\
\hline 8 & $31,843,726$ & $33,225,822$ & & $1,382,096$ & 1.38 \\
\hline 10 & $4,180,521$ & $6,176,206$ & previously described without GBS & $1,995,685$ & 2.00 \\
\hline 10 & $19,013,407$ & $26,545,573$ & & $7,532,166$ & 7.53 \\
\hline 11 & $12,237,119$ & $13,417,160$ & & $1,180,041$ & 1.18 \\
\hline
\end{tabular}




\subsection{CAPÍTULO 2}

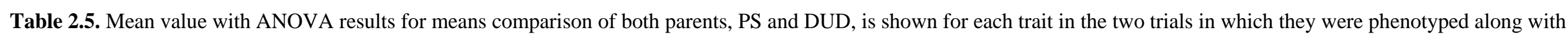
the ILs. The asterisk $(*)$ indicate significant difference with respect to the parent PS.

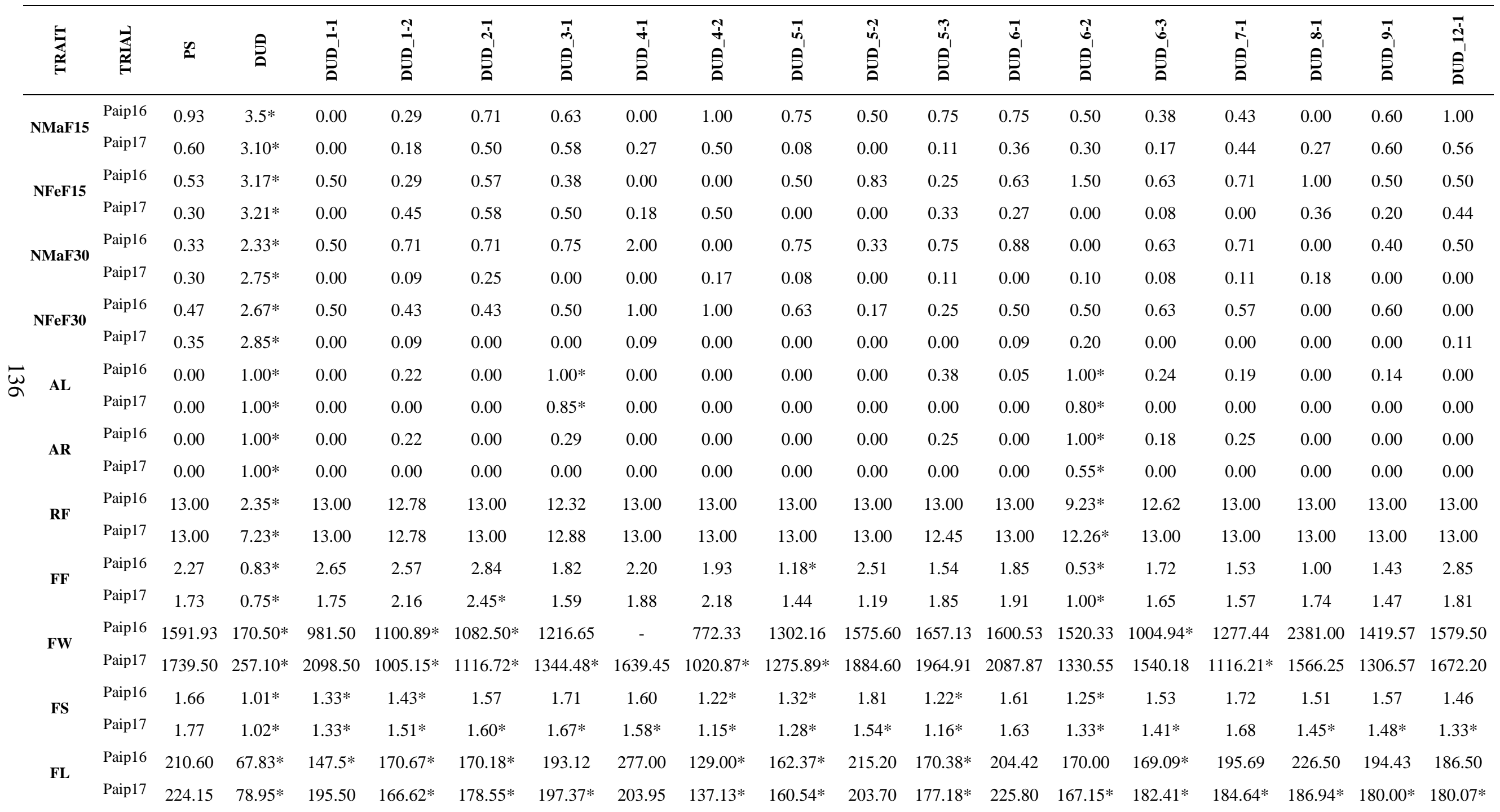


3.2 CAPÍTULO 2

Table 2.5. (Continued)

\begin{tabular}{|c|c|c|c|c|c|c|c|c|c|c|c|c|c|c|c|c|c|c|c|}
\hline$\Xi$ & 或 & $\mathscr{2}$ & కิ & $\begin{array}{l}\vec{I} \\
\vec{a} \\
\vec{a}\end{array}$ & $\frac{\mathfrak{I}}{\mathfrak{I}^{\prime}}$ & 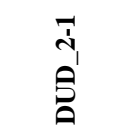 & $\begin{array}{l}\vec{m} \\
\hat{n}^{\prime}\end{array}$ & $\begin{array}{l}\vec{z}_{1} \\
\mathfrak{g}^{\prime} \\
\stackrel{0}{0}\end{array}$ & $\begin{array}{l}\mathfrak{I}^{\prime} \\
\mathfrak{z}^{\prime} \\
\tilde{\Omega}\end{array}$ & 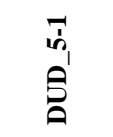 & 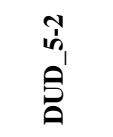 & $\begin{array}{l}\hat{b}_{1} \\
\hat{n}^{\prime} \\
\hat{0}\end{array}$ & $\begin{array}{l}\vec{b} \\
\vec{b}^{\prime} \\
\hat{\sigma}^{\prime}\end{array}$ & $\begin{array}{l}\tilde{\jmath} \\
\tilde{b}^{\prime} \\
\widehat{\Xi}\end{array}$ & $\begin{array}{l}\mathfrak{b}_{0} \\
\mathfrak{b}_{1} \\
\hat{0}\end{array}$ & $\begin{array}{l}\vec{T}^{\prime} \\
\hat{\sigma}^{\prime}\end{array}$ & $\begin{array}{l}\tilde{o}_{1} \\
\hat{\sigma}^{\prime}\end{array}$ & $\begin{array}{l}\hat{a}^{\prime} \\
\hat{a}\end{array}$ & 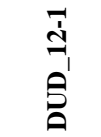 \\
\hline \multirow{2}{*}{ FD } & Paip16 & 128.13 & $67.16^{*}$ & 111.50 & 119.33 & $109.67 *$ & $112.71 *$ & 173.00 & 106.33 & 123.47 & 119.40 & 139.88 & 126.89 & 135.67 & $110.88^{*}$ & 114.56 & 149.50 & 123.57 & 127.50 \\
\hline & Paip17 & 126.90 & $77.30 *$ & 146.50 & $111.08 *$ & $112.21 *$ & 118.44 & 129.55 & 119.06 & 125.79 & 133.26 & $152.82 *$ & 139.27 & 126.00 & 129.27 & $111.43^{*}$ & 128.81 & 121.29 & 135.93 \\
\hline \multirow{2}{*}{$\mathrm{CW}$} & Paip16 & 0.41 & $0.54^{*}$ & 0.41 & $0.50 *$ & 0.46 & 0.44 & 0.35 & 0.43 & 0.42 & 0.44 & 0.48 & 0.44 & 0.46 & $0.49 *$ & 0.44 & 0.42 & 0.45 & 0.46 \\
\hline & Paip17 & 0.37 & $0.52 *$ & 0.33 & $0.42 *$ & $0.44 *$ & 0.36 & 0.38 & $0.45^{*}$ & 0.38 & 0.36 & $0.46^{*}$ & 0.39 & $0.43^{*}$ & 0.38 & 0.37 & 0.36 & 0.40 & 0.34 \\
\hline \multirow{2}{*}{ Fth } & Paip16 & 25.63 & $9.41^{*}$ & 21.39 & $18.79 *$ & 20.80 & 21.19 & 38.70 & 21.65 & 25.79 & 24.39 & 25.19 & 23.17 & 29.81 & 20.57 & 20.48 & 29.69 & 25.55 & 27.19 \\
\hline & Paip17 & 29.53 & $11.64 *$ & 37.98 & $23.05^{*}$ & $23.47 *$ & 28.36 & 29.01 & 26.01 & 29.50 & 32.39 & 31.81 & 30.97 & 24.91 & 30.13 & 27.19 & 30.82 & 26.86 & 34.42 \\
\hline \multirow{2}{*}{ Rth } & Paip16 & 3.56 & $1.51^{*}$ & 2.45 & 3.23 & 3.12 & 3.18 & 4.80 & $1.78^{*}$ & $2.22 *$ & 3.04 & 3.01 & $2.63^{*}$ & 2.52 & $2.40^{*}$ & $2.58^{*}$ & 4.04 & 2.69 & 3.21 \\
\hline & Paip17 & 3.17 & $1.90^{*}$ & 2.99 & $2.44 *$ & 2.82 & $2.51^{*}$ & 3.12 & $2.58^{*}$ & $2.36^{*}$ & $2.48^{*}$ & 3.10 & 2.90 & $2.59 *$ & $2.67 *$ & $2.44^{*}$ & 2.95 & 3.16 & 3.47 \\
\hline \multirow{2}{*}{ NET } & Paip16 & 0.13 & 0.00 & 0.00 & 0.00 & 0.00 & 0.18 & 0.00 & $0.67^{*}$ & $1.00 *$ & $0.90^{*}$ & 0.00 & 0.00 & 0.00 & 0.06 & 0.06 & 0.00 & 0.00 & $1.00 *$ \\
\hline & Paip17 & 0.30 & $0.00^{*}$ & 0.00 & 0.00 & 0.07 & 0.26 & 0.40 & 0.25 & $1.00^{*}$ & $0.80 *$ & 0.00 & 0.07 & 0.00 & 0.36 & 0.00 & 0.19 & 0.00 & 0.33 \\
\hline \multirow{2}{*}{ FCHI } & Paip16 & 61.62 & 53.44 & 58.68 & 58.95 & 60.43 & 55.49 & 75.84 & 59.61 & 60.61 & 61.16 & 60.38 & 60.98 & 56.74 & 58.59 & 59.52 & 78.74 & 58.65 & 55.76 \\
\hline & Paip17 & 62.19 & $70.76^{*}$ & 59.33 & 61.90 & 64.36 & 57.86 & 62.09 & 62.30 & 60.26 & 64.54 & 67.28 & 61.89 & 61.97 & 63.08 & 65.97 & 61.18 & 64.82 & 61.94 \\
\hline \multirow{2}{*}{ FCa } & Paip16 & -3.01 & $-0.22^{*}$ & -1.27 & -2.62 & -3.85 & -2.05 & -1.81 & -2.04 & -2.30 & -2.68 & -2.64 & $-1.86^{*}$ & -2.08 & $-1.63^{*}$ & -2.77 & -6.16 & -2.38 & -1.53 \\
\hline & Paip17 & -2.03 & $-0.97 *$ & -2.73 & -1.72 & $-2.68 *$ & -2.10 & -1.90 & -2.01 & -2.26 & -2.02 & $-2.83^{*}$ & -1.76 & -2.19 & -2.22 & -2.25 & -1.92 & -2.23 & -2.07 \\
\hline \multirow{2}{*}{ FCb } & Paip16 & 11.41 & $5.03 *$ & 7.85 & 10.87 & 11.88 & 9.78 & 8.95 & 11.16 & $9.12 *$ & 9.63 & 10.48 & $8.56^{*}$ & 9.76 & 9.97 & 10.91 & 21.64 & 9.14 & 9.67 \\
\hline & Paip17 & 9.54 & 9.55 & $13.16^{*}$ & 9.30 & $11.54^{*}$ & 10.46 & 9.75 & $11.28 *$ & $11.02 *$ & 9.96 & $12.17^{*}$ & 9.10 & 10.31 & $11.16^{*}$ & $12.07^{*}$ & 10.42 & 9.51 & 10.41 \\
\hline \multirow{2}{*}{ SSC } & Paip16 & 14.63 & $8.58^{*}$ & 14.05 & 16.64 & $11.83^{*}$ & 14.43 & 15.70 & 11.87 & 12.94 & 12.90 & $11.99^{*}$ & $11.96^{*}$ & 15.60 & 14.31 & 12.74 & 15.80 & 13.59 & 14.05 \\
\hline & Paip17 & 12.97 & $8.18^{*}$ & 15.05 & 13.12 & $9.97 *$ & 13.81 & 12.66 & 11.50 & $10.48^{*}$ & 13.25 & 11.23 & 13.45 & 13.87 & 12.25 & 12.94 & 11.12 & 11.80 & 12.24 \\
\hline \multirow[t]{2}{*}{ pH } & Paip16 & 5.97 & 5.83 & 5.50 & 6.06 & 5.71 & 6.15 & 6.00 & 6.67 & 5.87 & 5.80 & 5.69 & 5.84 & 6.33 & 6.12 & 6.25 & 6.50 & 5.86 & 5.50 \\
\hline & Paip17 & 5.95 & $6.23^{*}$ & 6.00 & 6.02 & 5.98 & 6.06 & 6.00 & 6.00 & 6.07 & 6.15 & 5.86 & 5.93 & $6.25 *$ & 6.01 & 5.96 & 6.00 & 6.00 & 6.00 \\
\hline
\end{tabular}




\subsection{CAPÍTULO 2}

Table 2.6. QTLs identified by the Dunnett's Test in two environments in the IL collection. Abbreviated trait name, QTL name, chromosome, QTL position (cM) and flanking markers, DUD effect relative to the PS parental abçnd expressed in percentage (\%) with positive/negative effects, IL carrying the introgression, introgression position (cM) and flanking markers in the IL, and information about other introgressions in these ILs.

\begin{tabular}{|c|c|c|c|c|c|c|c|c|c|c|c|c|}
\hline \multirow{2}{*}{ Trait } & \multirow{2}{*}{ QTL } & \multirow{2}{*}{ Chromosome } & \multirow{2}{*}{$\begin{array}{l}\text { QTL position cM/ Flanking- } \\
\text { markers }\end{array}$} & \multicolumn{2}{|c|}{$\begin{array}{c}\text { DUD effect } \\
\text { relative to PS }\end{array}$} & \multicolumn{3}{|c|}{$\begin{array}{c}\begin{array}{c}\text { DUD effect relative to PS } \\
(\%)\end{array} \\
\end{array}$} & \multirow{2}{*}{ IL } & \multirow{2}{*}{$\begin{array}{l}\text { Introgression position } \\
\text { cM/Flanking markers }{ }^{1}\end{array}$} & \multirow{2}{*}{$\begin{array}{l}\text { Others introgression (position chr/ cM/ } \\
\text { Flanking markers) }\end{array}$} & \multirow{2}{*}{$\begin{array}{c}\text { Chromosomes with } \\
\text { other introgressions } \\
\text { detected by GBS }^{2}\end{array}$} \\
\hline & & & & Paip16 & Paip17 & Paip16 & Paip17 & Mean & & & & \\
\hline \multirow[t]{4}{*}{ AL } & al.1 & 1 & 86.8 / CMPSNP204 & 1.00 & 0.80 & 100.00 & 80.00 & 90.00 & DUD_6_2* & $\begin{array}{l}\text { 80.4-86.8 / CMPSNP731 - } \\
\text { CMPSNP204 }\end{array}$ & \multirow[t]{2}{*}{ 6/ 49.6-70.7 / CMPSNP292 - A_38-F04 } & $3,4,5,6,7,10$ \\
\hline & al. 3 & 3 & 3.2-34.2 / AI_18-E05 - CMPSNP8 & 1.00 & 0.85 & 100.00 & 85.00 & 92.50 & DUD_3_1* & 3.2-34.2 / AI_18-E05 - CMPSNP8 & & $4,5,9,10$ \\
\hline & al. 6 & 6 & $\begin{array}{c}\text { 49.6-49.6 / CMPSNP292 - } \\
\text { CMPSNP295 }\end{array}$ & 1.00 & 0.80 & 100.00 & 80.00 & 90.00 & DUD_6_2* & 49.6-70.7 / CMPSNP292 - A_38-F04 & $\begin{array}{c}\text { 1 / 80.4-86.8 / CMPSNP731 - } \\
\text { CMPSNP204 }\end{array}$ & $1,3,4,5,7,10$ \\
\hline & ar.l & 1 & 86.8 / CMPSNP204 & \multirow{2}{*}{1.00} & \multirow{2}{*}{0.55} & \multirow{2}{*}{100.00} & \multirow{2}{*}{55.00} & \multirow{2}{*}{77.50} & \multirow{2}{*}{ DUD_6_2* } & $\begin{array}{l}\text { 80.4-86.8 / CMPSNP731 - } \\
\text { CMPSNP204 }\end{array}$ & \multirow{8}{*}{$\begin{array}{c}\text { 6 / 49.6-70.7 / CMPSNP292 - A_38-F04 } \\
\text { 1 / 80.4-86.8 / CMPSNP731 - } \\
\text { CMPSNP204 } \\
\text { 6/ 49.6-57.6 / CMPSNP295 - } \\
\text { CMPSNP1021 and 3 / 56.3-62.7/ } \\
\text { CMPSNP998 - CMPSNP712 }\end{array}$} & $3,4,5,6,7,10$ \\
\hline $\mathbf{A R}$ & ar.6 & 6 & $\begin{array}{l}\text { 49.6-49.6 / CMPSNP292 - } \\
\text { CMPSNP295 }\end{array}$ & & & & & & & 49.6-70.7 / CMPSNP292 - A_38-F04 & & $1,3,4,5,7,10$ \\
\hline NET & net. 5 & 5 & 0-26.5 / CMPSNP898 - CMPSNP437 & 0.87 & 0.70 & 669.23 & 233.33 & 451.28 & DUD_5_1* & $\begin{array}{c}\text { 0-26.5 / CMPSNP898 - } \\
\text { CMPSNP437 }\end{array}$ & & $1,3,4,6,7,10,11,12$ \\
\hline \multirow{6}{*}{ FW } & & & & 0.77 & 0.50 & 592.31 & 166.67 & 379.49 & DUD_5_2 & $\begin{array}{l}\text { 18.5-26.5 / CMPSNP387 - } \\
\text { CMPSNP437 }\end{array}$ & & \\
\hline & $f w .1$ & 1 & $\begin{array}{c}\text { 59.6-72.4 / CMPSNP410 - AI_05- } \\
\text { G01 }\end{array}$ & -579.57 & -734.35 & -30.85 & -42.22 & -36.54 & DUD_1_2 & $\begin{array}{l}\text { 45.2-80.4 / AI_17-E07 - } \\
\text { CMPSNP731 }\end{array}$ & & \\
\hline & fw. 2 & 2 & 0-40.6 / CMPSNP774 - AI_14_H05 & -509.43 & -622.78 & -32.00 & -35.80 & -33.90 & DUD_2_1 & 0-40.6 / CMPSNP774 - AI_14_H05 & & \\
\hline & $f l .1$ & 1 & $\begin{array}{l}\text { 59.6-72.4 / CMPSNP410- AI_05- } \\
\text { G01 }\end{array}$ & -35.96 & -57.53 & -18.96 & -25.67 & -22.32 & DUD_1_2 & $\begin{array}{c}\text { 45.2-80.4/ AI_17-E07 - } \\
\text { CMPSNP731 }\end{array}$ & & \\
\hline & $f l .2$ & 2 & 0-40.6 / CMPSNP774 - AI_14_H05 & -40.42 & -45.60 & -19.19 & -20.34 & -19.77 & DUD_2_1 & 0-40.6 / CMPSNP774 - AI_14_H05 & & \\
\hline & $f l .3$ & 3 & $\begin{array}{l}\text { 56.3-62.7 / CMPSNP998 - } \\
\text { CMPSNP712 }\end{array}$ & -48.23 & -63.61 & -22.90 & -28.38 & -25.64 & DUD_5_1* & $\begin{array}{l}\text { 56.3-62.7 / CMPSNP998 - } \\
\text { CMPSNP712 }\end{array}$ & $\begin{array}{c}\text { 5 / 0-26.5 / CMPSNP898 - CMPSNP437 } \\
\text { and } \\
\text { 6/ 49.6-57.6 / CMPSNP295 - } \\
\text { CMPSNP1021 }\end{array}$ & $1,4,5,6,7,10,11,12$ \\
\hline \multirow[t]{4}{*}{ FL } & $f l .4$ & 4 & $\begin{array}{l}\text { 48.3-62.7 / CMPSNP147 - } \\
\text { CMPSNP852 }\end{array}$ & -81.60 & -87.03 & -38.75 & -38.82 & -38.79 & DUD_4_2* & $\begin{array}{l}\text { 48.3-62.7 / CMPSNP147 - } \\
\text { CMPSNP852 }\end{array}$ & \multirow[t]{2}{*}{ 12 / 4.8-16.4 / CMPSNP385 - AI_35-A08 } & \multirow[t]{2}{*}{$1,5,7,10,12$} \\
\hline & $f l .5$ & 5 & 94.2 / CMPSNP735 & -40.23 & -46.97 & -19.10 & -20.95 & -20.03 & DUD_5_3 & $\begin{array}{l}\text { 89.4-94.2 / AI_13-H12 - } \\
\text { CMPSNP735 }\end{array}$ & & \\
\hline & fl. 6 & 6 & $\begin{array}{l}\text { 49.6-57.6 / CMPSNP295 - } \\
\text { CMPSNP1021 }\end{array}$ & -48.23 & -63.61 & -22.90 & -28.38 & -25.64 & DUD_5_1* & $\begin{array}{l}\text { 49.6-57.6 / CMPSNP295 - } \\
\text { CMPSNP1021 }\end{array}$ & $\begin{array}{l}3 / 56.3-62.7 / \text { CMPSNP998 - } \\
\text { CMPSNP712 and 5/0-26.5 / } \\
\text { CMPSNP898 - CMPSNP437 }\end{array}$ & $1,3,4,5,7,10,11,12$ \\
\hline & & & & -41.54 & -41.74 & -19.71 & -18.62 & -19.17 & DUD_6_3 & 49.6-70.7 / CMPSNP295 - A_38-F04 & & \\
\hline \multirow[t]{2}{*}{ FD } & $f d .2$ & 2 & 0-40.6 / CMPSNP774 - AI_14_H05 & -18.47 & -14.69 & -14.41 & -11.58 & -13.00 & DUD_2_1 & 0-40.6 / CMPSNP774 - AI_14_H05 & \multirow{3}{*}{$\begin{array}{c}\text { 6/ 49.6-57.6 / CMPSNP295 - } \\
\text { CMPSNP1021 }\end{array}$} & \\
\hline & fs. 1.1 & 1 & $\begin{array}{l}\text { 45.2-46.8 / AI_17-E07 - } \\
\text { CMPSNP711 }\end{array}$ & -0.33 & -0.44 & -19.97 & -24.98 & -22.48 & DUD_1_1 & $\begin{array}{l}\text { 18.1-46.8 / CMPSNP83 - } \\
\text { CMPSNP711 }\end{array}$ & & \\
\hline FS & 10 & 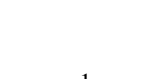 & 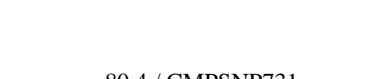 & -0.23 & -0.27 & -13.96 & -14.83 & -14.40 & DUD_1_2 & $\begin{array}{l}\text { 45.2-80.4 / AI_17-E07 - } \\
\text { CMPSNP731 }\end{array}$ & & \\
\hline
\end{tabular}


3.2 CAPÍTULO 2

Table 2.6. (Continued)

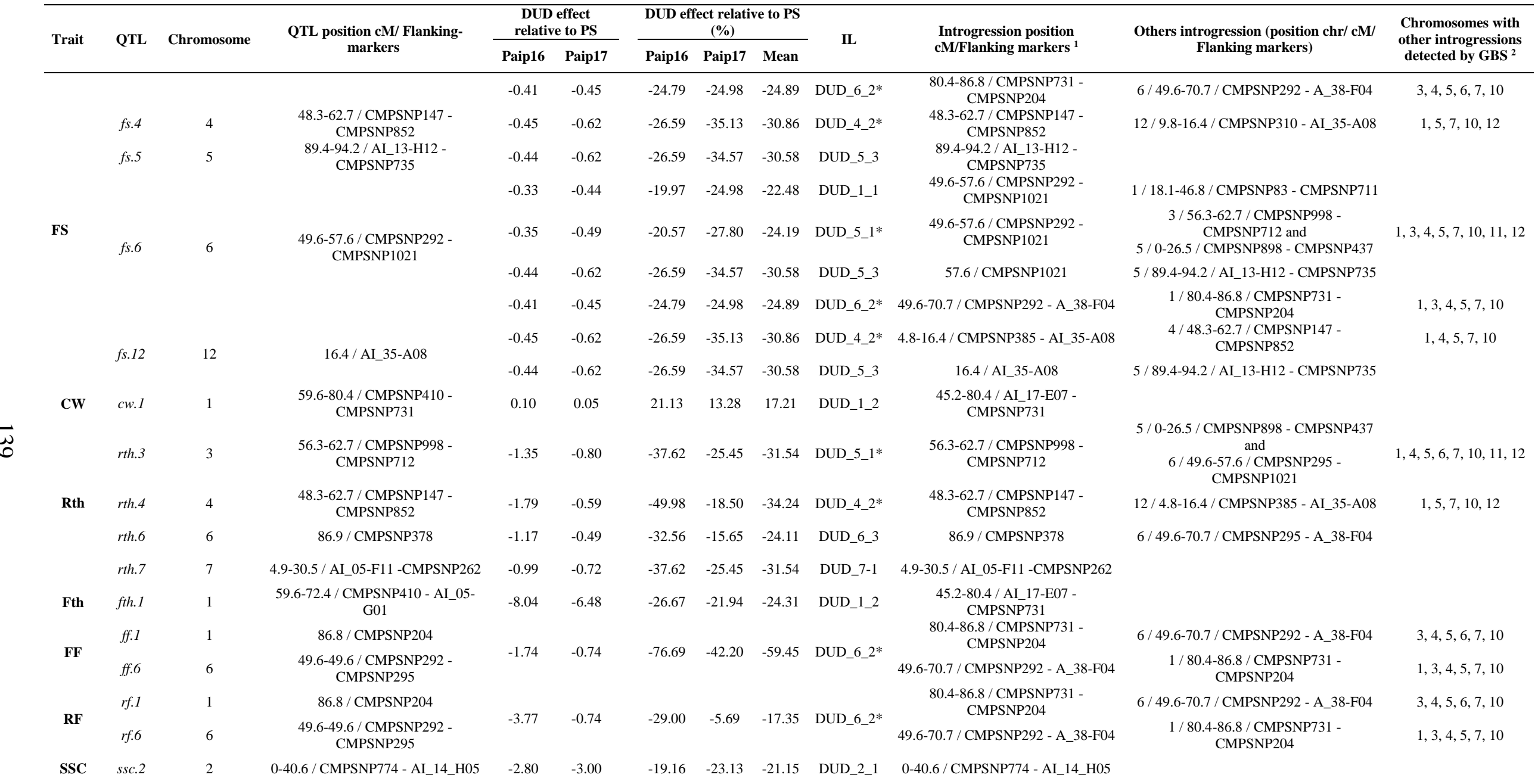


Table 2.7. Percentage of variance explained for every trait for genotype, environment and the interaction. $* \mathrm{p}<0.05 ; * * \mathrm{p}<0.001$; NS: non-significant differences.

\begin{tabular}{lccc}
\hline & \multicolumn{3}{c}{$\%$ VARIATION } \\
\cline { 2 - 4 } & GENOTYPE & ENVIRONMENT & INTERACTION (G x E) \\
\hline NMaF15 & NS & NS & NS \\
NFeF15 & NS & $3.26^{* *}$ & NS \\
NMaF30 & NS & $14,30^{* *}$ & NS \\
NFeF30 & NS & $15,92^{* *}$ & NS \\
AL & $56.88^{* *}$ & $0.74^{*}$ & $1.79^{*}$ \\
AR & $1.78^{* *}$ & $23.40^{* *}$ & $5.63^{*}$ \\
RF & $19.38^{* *}$ & $0.78^{*}$ & $9.82^{* *}$ \\
FF & $24.33^{* *}$ & $\mathrm{NS}$ & $6.97 * *$ \\
FW & $27.30^{* *}$ & $\mathrm{NS}$ & $9.90^{* *}$ \\
FS & $47.43^{* *}$ & $0.49^{*}$ & $2.98^{*}$ \\
FL & $35.48^{*}$ & $\mathrm{NS}$ & $5.00^{* *}$ \\
FD & $27.86^{* *}$ & $\mathrm{NS}$ & $8.37 * *$ \\
CW & $12.75^{* *}$ & $7.64^{* *}$ & $5.01^{*}$ \\
Fth & $13.44^{* *}$ & $5.31^{* *}$ & $6.19^{* *}$ \\
Rth & $17.72^{* *}$ & $\mathrm{NS}$ & $10.49^{* *}$ \\
NET & $44.89^{* *}$ & $\mathrm{NS}$ & $7.57^{* *}$ \\
FCHI & $10.92^{* *}$ & $\mathrm{NS}$ & $6.63^{* *}$ \\
Fca & $26.11^{* *}$ & $1.49^{*}$ & $15.56^{* *}$ \\
FCb & $23.80^{* *}$ & $\mathrm{NS}$ & $14.80^{* *}$ \\
SSC & $16.94^{* *}$ & $3.09^{* *}$ & $6.91^{* *}$ \\
pH & $10.96^{* *}$ & $\mathrm{NS}$ & $8.83^{* *}$ \\
\hline
\end{tabular}


Table 2.8. Genes located in the introgressions detected in the set of 16 Ils related to the traits analyzed.

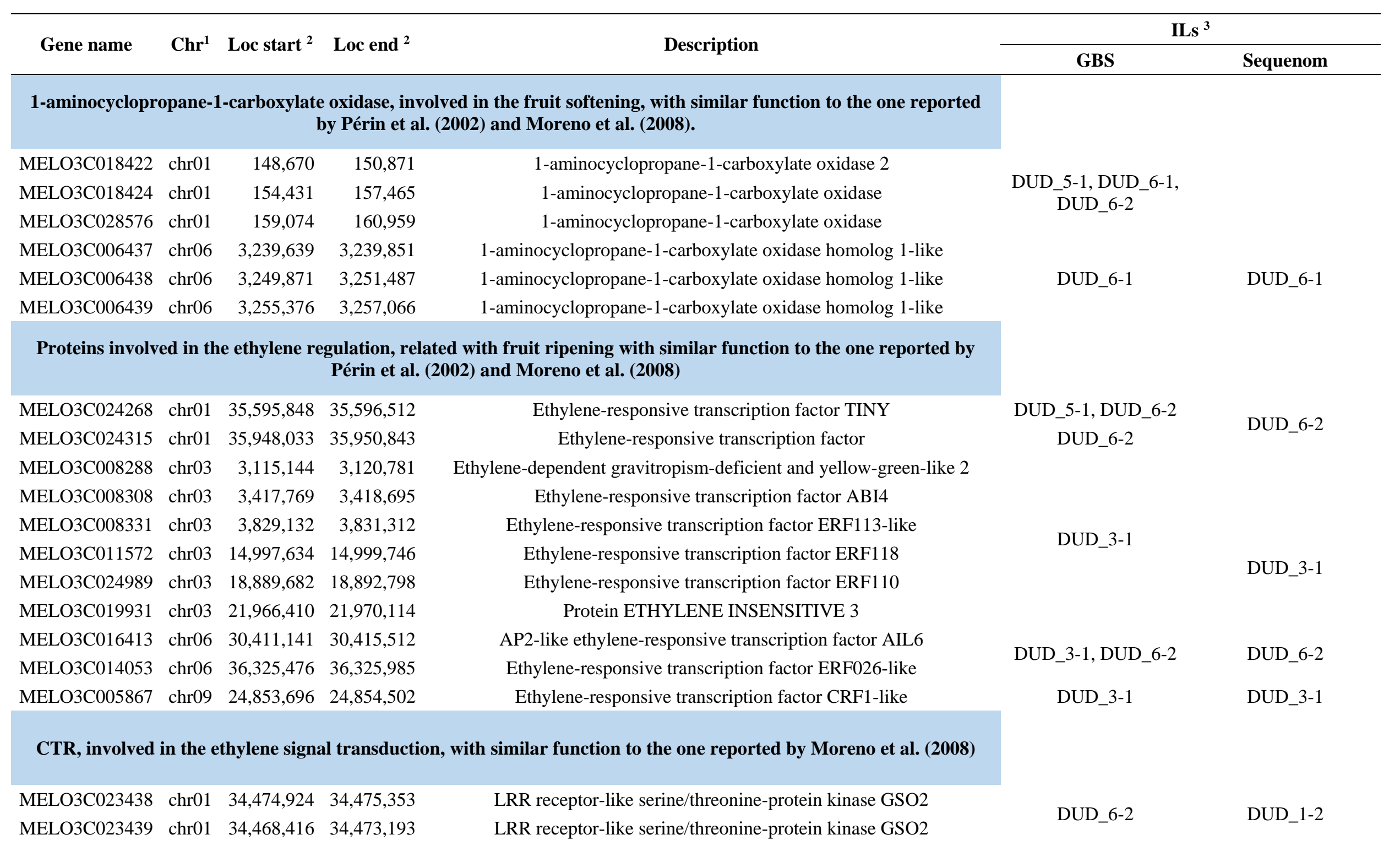




\subsection{CAPÍTULO 2}

Table 2.8. (Continued)

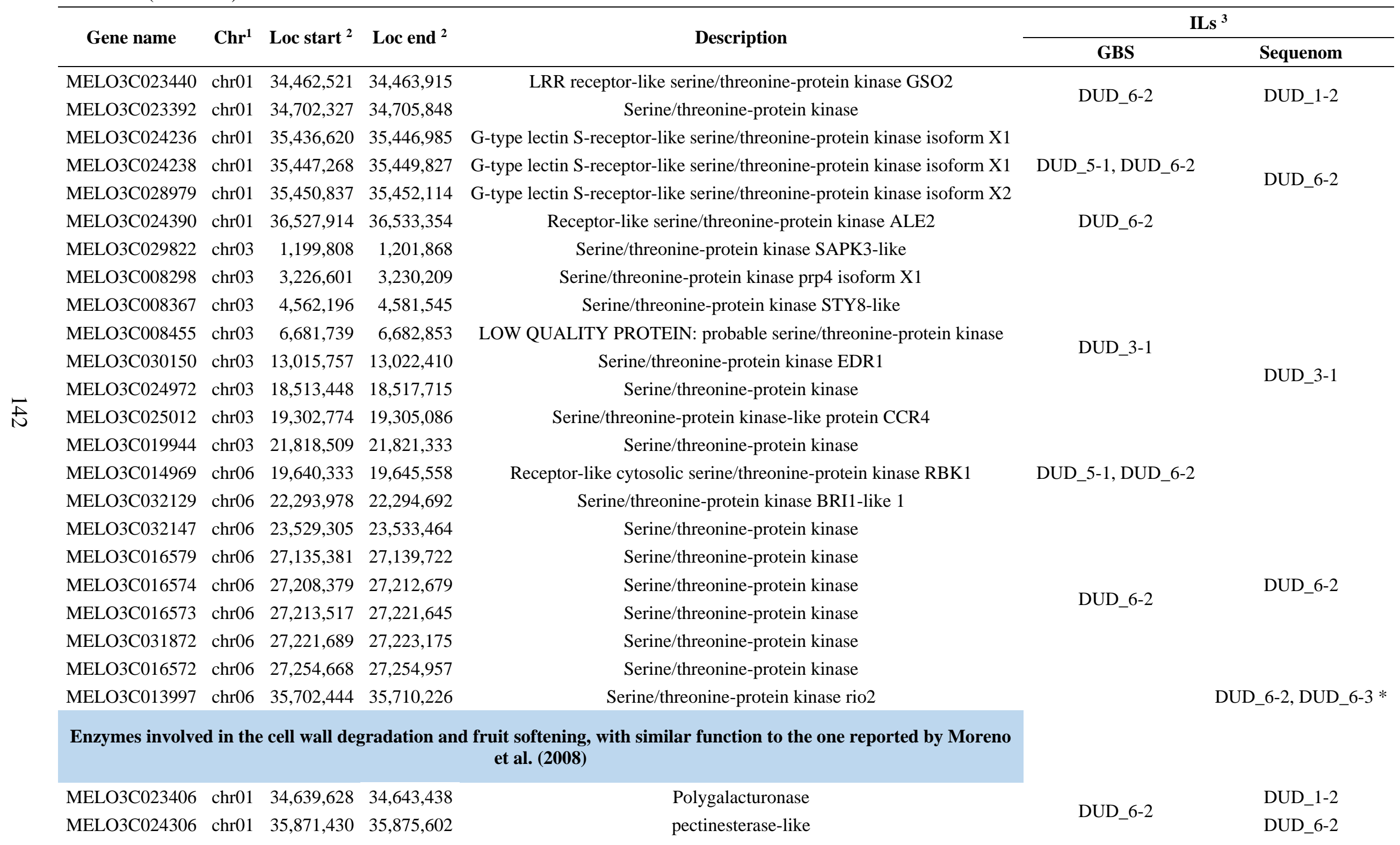


Table 2.8. (Continued)

\begin{tabular}{|c|c|c|c|c|c|c|}
\hline \multirow{2}{*}{ Gene name } & \multirow{2}{*}{ Chr $^{1}$} & \multirow{2}{*}{ Loc start ${ }^{2}$} & \multirow{2}{*}{ Loc end $^{2}$} & \multirow{2}{*}{ Description } & \multicolumn{2}{|c|}{ ILs $^{3}$} \\
\hline & & & & & GBS & Sequenom \\
\hline MELO3C011706 & chr03 & $10,593,135$ & $10,597,393$ & Xyloglucan endotransglucosylase/hydrolase & \multirow{19}{*}{ DUD_3-1 } & \multirow{27}{*}{ DUD_6-2, DUD_6-3 * } \\
\hline MELO3C020005 & $\operatorname{chr03}$ & $20,813,189$ & $20,814,802$ & Expansin & & \\
\hline MELO3C020005 & chr03 & $20,813,189$ & $20,814,802$ & Expansin & & \\
\hline MELO3C030075 & chr03 & $22,769,054$ & $22,769,532$ & Pectinesterase inhibitor-like & & \\
\hline MELO3C030062 & chr03 & $22,815,585$ & $22,816,103$ & Pectinesterase inhibitor-like & & \\
\hline MELO3C030066 & chr03 & $22,815,822$ & $22,816,082$ & Pectinesterase inhibitor-like & & \\
\hline MELO3C019867 & chr03 & $22,832,650$ & $22,833,223$ & Pectinesterase inhibitor-like & & \\
\hline MELO3C030067 & $\operatorname{chr} 03$ & $22,836,680$ & $22,837,198$ & Pectinesterase inhibitor-like & & \\
\hline MELO3C019866 & chr03 & $22,856,798$ & $22,857,316$ & Pectinesterase inhibitor-like & & \\
\hline MELO3C021269 & chr03 & $22,885,618$ & $22,886,130$ & Pectinesterase inhibitor-like & & \\
\hline MELO3C030077 & $\operatorname{chr} 03$ & $22,873,030$ & $22,873,604$ & Pectinesterase inhibitor-like & & \\
\hline MELO3C019864 & chr03 & $22,905,141$ & $22,905,659$ & Pectinesterase inhibitor-like & & \\
\hline MELO3C030063 & chr03 & $22,910,070$ & $22,910,434$ & Pectinesterase inhibitor-like & & \\
\hline MELO3C001749 & chr03 & $22,910,070$ & $22,910,588$ & Pectinesterase inhibitor-like & & \\
\hline MELO3C030071 & $\operatorname{chr03}$ & $22,931,181$ & $22,931,741$ & Pectinesterase inhibitor-like & & \\
\hline MELO3C030064 & chr03 & $22,940,702$ & $22,941,243$ & Pectinesterase inhibitor-like & & \\
\hline MELO3C030065 & chr03 & $22,981,570$ & $22,982,142$ & Pectinesterase inhibitor-like & & \\
\hline MELO3C019840 & chr03 & $23,201,991$ & $23,206,180$ & Pectate lyase & & \\
\hline MELO3C019774 & chr03 & $23,792,708$ & $23,794,277$ & Pectate lyase-like & & \\
\hline MELO3C010706 & chr03 & $31,366,122$ & $31,368,237$ & Pectate lyase & \multirow[t]{3}{*}{ DUD_5-1, DUD_6-2 } & \\
\hline MELO3C016609 & chr06 & $26,291,685$ & $26,294,294$ & Pectinesterase & & \\
\hline MELO3C016517 & chr06 & $28,193,159$ & $28,197,043$ & Expansin-A12 & & \\
\hline MELO3C016494 & chr06 & $28,763,801$ & $28,765,960$ & Polygalacturonase & \multirow{5}{*}{ DUD_6-2 } & \\
\hline MELO3C013968 & chr06 & $35,482,149$ & $35,483,752$ & Xyloglucan galactosyltransferase KATAMARI1 homolog & & \\
\hline MELO3C014013 & chr06 & $35,846,449$ & $35,847,828$ & Expansin-A18 & & \\
\hline MELO3C014147 & chr06 & $37,400,293$ & $37,402,154$ & Exopolygalacturonase-like & & \\
\hline MELO3C014148 & chr06 & $37,413,668$ & $37,415,736$ & Exopolygalacturonase-like & & \\
\hline
\end{tabular}




\subsection{CAPÍTULO 2}

Table 2.8. (Continued)

\begin{tabular}{|c|c|c|c|c|}
\hline Gene name & Chr $^{1}$ & Loc start ${ }^{2}$ & Loc end ${ }^{2}$ & Description \\
\hline MELO3C014013 & chr06 & $37,696,722$ & $37,697,885$ & Expansin-A9 \\
\hline MELO3C005839 & chr09 & $24,675,584$ & $24,677,935$ & Glycoside hydrolase family 28 protein/polygalacturonase family protein \\
\hline MELO3C005885 & chr09 & $24,982,484$ & $24,987,733$ & Pectinesterase \\
\hline \multicolumn{5}{|c|}{ NAC, involved in melon climacteric fruit ripening. Reported or similar to the candidates suggested by Ríos et al. (2017) } \\
\hline MELO3C029850 & $\operatorname{chr} 03$ & $5,090,827$ & $5,091,945$ & NAC domain-containing protein 105-like \\
\hline MELO3C019954 & $\operatorname{chr} 03$ & $21,651,203$ & $21,654,526$ & NAC domain-containing protein 17-like \\
\hline MELO3C019845 & chr03 & $23,167,105$ & $23,170,413$ & NAC domain-containing protein 78-like isoform X2 \\
\hline MELO3C014922 & chr06 & $20,900,809$ & $20,902,991$ & NAC domain-containing protein 83 isoform X2 \\
\hline MELO3C016540 & chr06 & $27,663,292$ & $27,665,351$ & NAC domain protein, \\
\hline MELO3C016536 & chr06 & $27,797,578$ & $27,799,282$ & NAC domain-containing protein 55 \\
\hline MELO3C016444 & chr06 & $29,775,058$ & $29,777,132$ & NAC domain-containing protein 55 \\
\hline MELO3C013971 & chr06 & $35,529,924$ & $35,533,985$ & NAC domain-containing protein 26-like \\
\hline MELO3C014141 & chr06 & $37,363,939$ & $37,367,039$ & NAC domain-containing protein 91-like \\
\hline
\end{tabular}

\begin{tabular}{cc}
\multicolumn{2}{c}{ ILs $^{3}$} \\
\hline GBS & Sequenom \\
\hline DUD_6-2 & \\
DUD_3-1 & \\
\end{tabular}

Proteins involved in the aroma with the enzymatic activities described by Gonda et al. (2016)

$\begin{array}{llll}\text { MELO3C029261 } & \text { chr01 } & 35,541,998 & 35,546,219 \\ \text { MELO3C024348 } & \text { chr01 } & 34,593,405 & 34,594,702 \\ \text { MELO3C024307 } & \text { chr01 } & 35,880,601 & 35,887,362 \\ \text { MELO3C014749 } & \text { chr06 } & 18,693,180 & 18,693,947 \\ \text { MELO3C032095 } & \text { chr06 } & 19,847,100 & 19,850,019 \\ \text { MELO3C032097 } & \text { chr06 } & 19,921,772 & 19,926,442 \\ \text { MELO3C014897 } & \text { chr06 } & 22,163,714 & 22,164,637 \\ \text { MELO3C016495 } & \text { chr06 } & 25,919,977 & 25,920,428 \\ \text { MELO3C016565 } & \text { chr06 } & 27,311,694 & 27,319,572 \\ \text { MELO3C016586 } & \text { chr06 } & 27,760,939 & 27,761,234\end{array}$

Malonate--CoA ligase-like protein Lipoxygenase

Alanine aminotransferase 2

Acetyl-coenzyme A synthetase

Lipoxygenase

Carotenoid cleavage dioxygenas

DUD_3-1

DUD_3-1

DUD_6-2

DUD_5-1, DUD_6-2

DUD_6-2

Short-chain dehydrogenase/reductase family protein

Prolycopene isomerase, chloroplastic isoform X1

Malonate--CoA ligase isoform X1

Sesquiterpene synthase Tps1

DUD 5-1, DUD_6-2 
Table 2.8. (Continued)

\begin{tabular}{|c|c|c|c|c|}
\hline Gene name & Chr $^{1}$ & Loc start ${ }^{2}$ & Loc end ${ }^{2}$ & Description \\
\hline MELO3C016587 & chr06 & $27,762,555$ & $27,762,924$ & Sesquiterpene synthase Tps1 \\
\hline MELO3C016588 & $\operatorname{chr} 06$ & $27,831,934$ & $27,832,445$ & (+)-gamma-cadinene synthase \\
\hline MELO3C016593 & chr06 & $28,004,356$ & $28,004,738$ & Sesquiterpene synthase Tps1 \\
\hline MELO3C016594 & chr06 & $28,005,987$ & $28,006,333$ & Sesquiterpene synthase Tps1 \\
\hline MELO3C016595 & chr06 & $28,032,477$ & $28,032,849$ & Alpha-farnesene synthase \\
\hline MELO3C025423 & chr06 & $30,156,193$ & $30,156,344$ & Unknown protein \\
\hline MELO3C013774 & chr06 & $35,326,922$ & $35,327,801$ & Cystathionine gamma-synthase \\
\hline MELO3C013771 & chr06 & $35,361,105$ & $35,361,409$ & Beta-carotene isomerase D27, chloroplastic \\
\hline MELO3C013735 & chr06 & $35,607,712$ & $35,609,137$ & CoA ligase \\
\hline MELO3C023494 & chr01 & 34056569 & 34058273 & 4-coumarate:CoA ligase \\
\hline \multicolumn{5}{|c|}{$\begin{array}{l}\text { OFP, involved in the elongation and cell division with domains and function similar to the ones reported by Huang et } \\
\text { al. (2013), Liu et al. (2002), Wang et al. (2011) and Wu et al. (2015) }\end{array}$} \\
\hline MELO3C024232 & chr01 & $35,416,793$ & $35,418,020$ & Transcription repressor OFP14 \\
\hline MELO3C019910 & chr03 & $22,334,455$ & $22,335,138$ & Transcription repressor OFP13 \\
\hline MELO3C004557 & $\operatorname{chr} 05$ & $28,533,628$ & $28,534,341$ & Transcription repressor OFP8-like \\
\hline MELO3C025581 & $\operatorname{chr} 12$ & $12,990,776$ & $12,991,288$ & Transcription repressor OFP6 \\
\hline
\end{tabular}

MELO3C032288 chr06 37,280,436 37,282,584

Cytochrome P450 78A5

Calmodulin, regulates the orientation of cell division based on works by Huang et al. (2013), Tanksley (2004), Wu et al. $(2011,2015)$, and Xiao et al. (2008)

\begin{abstract}
MELO3C030256 chr03 21,952,977 21,953,619
MELO3C003889 chr04 6,281,019 6,281,581

MELO3C013074 chr04 17,154,990 17,148,948

MELO3C009820 chr04 28,962,889 27,767,920

MELO3C009818 chr04 28,972,906 28,973,693
\end{abstract}

Calcium/calmodulin dependent protein kinase

$$
\text { Calmodulin }
$$

Calmodulin-binding family protein

Calmodulin-binding domain, plant

Calmodulin-like family protein
DUD_5-1, DUD_6-2 DUD_6-2
DUD_3-1 DUD_3-1
DUD_5-3

DUD_4-2

DUD_6-2

DUD_4-2

ILs $^{3}$

DUD_5-1, DUD_6-2

DUD_6-2

DUD_6-2

DUD_6-2, DUD_6-3 *

$\begin{array}{ll}\text { DUD_3-1 } & \text { DUD_3-1 } \\ \text { DUD_4-2 } & \text { DUD_4-2 }\end{array}$

DUD_4-2,DUD_5-1 


\subsection{CAPÍTULO 2}

Table 2.8. (Continued)

\begin{tabular}{|c|c|c|c|c|c|c|}
\hline \multirow{2}{*}{ Gene name } & \multirow{2}{*}{ Chr $^{1}$} & \multirow{2}{*}{ Loc start ${ }^{2}$} & \multirow{2}{*}{ Loc end $^{2}$} & \multirow{2}{*}{ Description } & \multicolumn{2}{|c|}{ ILs $^{3}$} \\
\hline & & & & & GBS & Sequenom \\
\hline MELO3C014698 & chr05 & 328,299 & 331,219 & Calmodulin & DUD_5-1 & DUD_5-1, DUD_5-2 \\
\hline MELO3C013982 & chr06 & $35,606,270$ & $35,607,466$ & Calmodulin, putative & DUD_6-2 & DUD_6-2, DUD_6-3* \\
\hline \multicolumn{7}{|c|}{ Proteins involved in color based on Ferder et al. (2015) } \\
\hline MELO3C018335 & $\operatorname{chr} 10$ & $19,402,491$ & $19,403,056$ & flavonoid 3',5'-hydroxylase 1-like & DUD_6-1 & \\
\hline \multicolumn{7}{|c|}{ Proteins involved in SSC based on Argyris et al. (2017) } \\
\hline MELO3C014519 & chr05 & $1,745,222$ & $1,749,158$ & BEL1-like homeodomain protein 1 & DUD_5-1 & DUD_5-1, DUD_5-2 \\
\hline \multicolumn{7}{|c|}{ Proteins related to sex (boualem et al. 2008) and suggested to be associated to ovary and fruit shape (Monforte et al. } \\
\hline MELO3C015444 & chr02 & $1,709,035$ & $1,711,473$ & $a$ gene, $C m A C S 7$ - 1-aminocyclopropane-1-carboxylate synthase & & DUD_2-1 \\
\hline
\end{tabular}

(*) Lines DUD_6-2 and DUD_6-3 present introgresions in chromosome 6 in locatios with some discrepancies between genetic and physical positions, and in some cases the location of a gene cab not be ensured

${ }^{1}$ Chromosome position based on melon genome assembly v.3.6.1

2 Physical position based on melon genome assembly v.3.6.1

의 $\quad 3$ Ils with introgressions in the regions where the candidate genes locate. Introgressions detected by GBS or Sequenom assays. 
Table 2.9. Correlation coefficient $(\mathrm{p}<0.05)$ for the traits analized in Paip16 and Paip17.

\begin{tabular}{|c|c|c|c|c|c|c|c|c|c|c|c|c|c|c|c|c|c|}
\hline \multicolumn{18}{|c|}{ PAIP16 } \\
\hline TRAIT & $\mathrm{AL}$ & AR & NET & FW & FL & FD & FS & $\mathrm{CW}$ & Rth & Fth & FF & $\mathrm{RF}$ & SSC & $\mathrm{pH}$ & $\mathrm{FCHl}$ & $\mathrm{FCa}$ & $\mathrm{FCb}$ \\
\hline $\mathrm{AR}$ & 0.5752 & & & & & & & & & & & & & & & & \\
\hline NET & & -0.1713 & & & & & & & & & & & & & & & \\
\hline FL & & & & 0.8346 & & & & & & & & & & & & & \\
\hline FD & & & & 0.9171 & 0.638 & & & & & & & & & & & & \\
\hline FS & 0.1748 & & -0.2275 & 0.1869 & 0.6641 & & & & & & & & & & & & \\
\hline $\mathrm{CW}$ & & & -0.2121 & -0.3102 & -0.226 & -0.2218 & & & & & & & & & & & \\
\hline Rth & & & & 0.1968 & 0.3139 & & 0.246 & & & & & & & & & & \\
\hline Fth & & & 0.295 & 0.6869 & 0.4217 & 0.722 & & -0.4121 & & & & & & & & & \\
\hline $\mathrm{FF}$ & -0.1838 & -0.2936 & & & & & 0.1726 & & 0.3199 & & & & & & & & \\
\hline $\mathrm{RF}$ & -0.3946 & -0.5755 & & & & & & & & & 0.2712 & & & & & & \\
\hline SSC & 0.3453 & & & & & & & & & & & & & & & & \\
\hline $\mathrm{pH}$ & 0.3186 & 0.287 & & & & & & & & & & & & & & & \\
\hline FCHl & -0.3201 & -0.2752 & & 0.2761 & 0.2224 & 0.2579 & & & & & & 0.3034 & & -0.4515 & & & \\
\hline $\mathrm{FCa}$ & & & & & & & & & -0.2981 & & -0.307 & & & 0.2552 & -0.3092 & & \\
\hline $\mathrm{FCb}$ & & & & & & & & & & & 0.3116 & & & & 0.3577 & -0.6845 & \\
\hline
\end{tabular}




\subsection{CAPÍTULO 2}

Table 2.9. (Continued)

\begin{tabular}{|c|c|c|c|c|c|c|c|c|c|c|c|c|c|c|c|}
\hline \multicolumn{16}{|c|}{ PAIP17 } \\
\hline TRAIT & $\mathrm{AL}$ & AR & NET & FW & FL & FD & FS & $\mathrm{CW}$ & Rth & Fth & $\mathrm{FF}$ & RF & $\mathrm{SSC}$ & $\mathrm{pH}$ & $\mathrm{FCHl} \mathrm{FCa} \mathrm{FCb}$ \\
\hline AR & 0.4135 & & & & & & & & & & & & & & \\
\hline NET & -0.1364 & & & & & & & & & & & & & & \\
\hline FL & & & & 0.7678 & & & & & & & & & & & \\
\hline FD & & & & 0.8985 & 0.5076 & & & & & & & & & & \\
\hline FS & & & -0.1519 & & 0.6307 & -0.3368 & & & & & & & & & \\
\hline $\mathrm{CW}$ & & & -0.1711 & -0.3974 & -0.3732 & -0.2706 & -0.1548 & & & & & & & & \\
\hline Rth & -0.1889 & & -0.1652 & 0.3417 & 0.2621 & 0.344 & & -0.139 & & & & & & & \\
\hline Fth & & & & 0.7495 & 0.4693 & 0.7511 & -0.1604 & -0.641 & 0.26 & & & & & & \\
\hline FF & -0.2156 & -0.2877 & -0.2051 & & & -0.1504 & & & & & & & & & \\
\hline $\mathrm{RF}$ & -0.2276 & -0.3871 & & & & & 0.1282 & -0.1753 & & & & & & & \\
\hline $\mathrm{SSC}$ & 0.2457 & 0.181 & & 0.1435 & 0.2609 & & 0.2456 & & -0.1527 & & -0.1903 & & & & \\
\hline $\mathrm{pH}$ & 0.2171 & 0.2062 & & -0.1269 & & & & & & & & -0.1806 & & & \\
\hline $\mathrm{FCHl}$ & -0.2276 & & -0.2143 & & & & & & & & 0.1846 & & -0.2893 & -0.1377 & \\
\hline $\mathrm{FCa}$ & & & & 0.1773 & 0.1856 & & & -0.1495 & & & & & 0.3284 & & \\
\hline $\mathrm{FCb}$ & & & & -0.2102 & -0.2049 & -0.1524 & & & & & & & -0.2128 & & \\
\hline
\end{tabular}




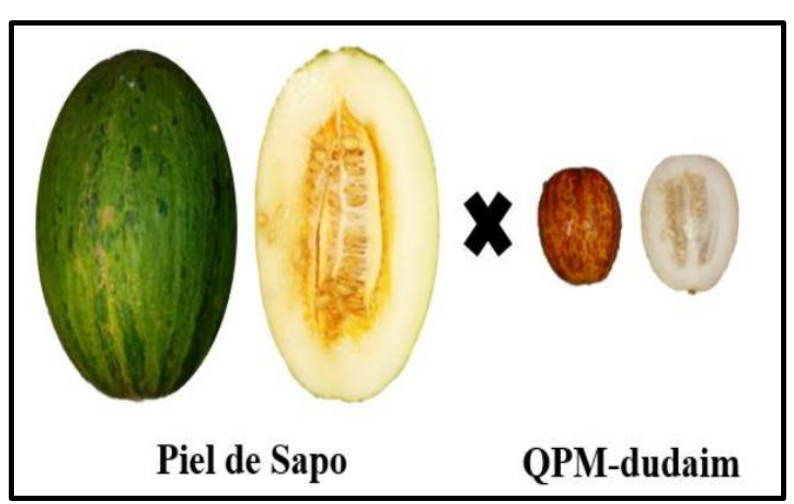

Figure 2.1. Fruits of the parentals used to develop the ILs population ‘Piel de Sapo’ x Dudaim.
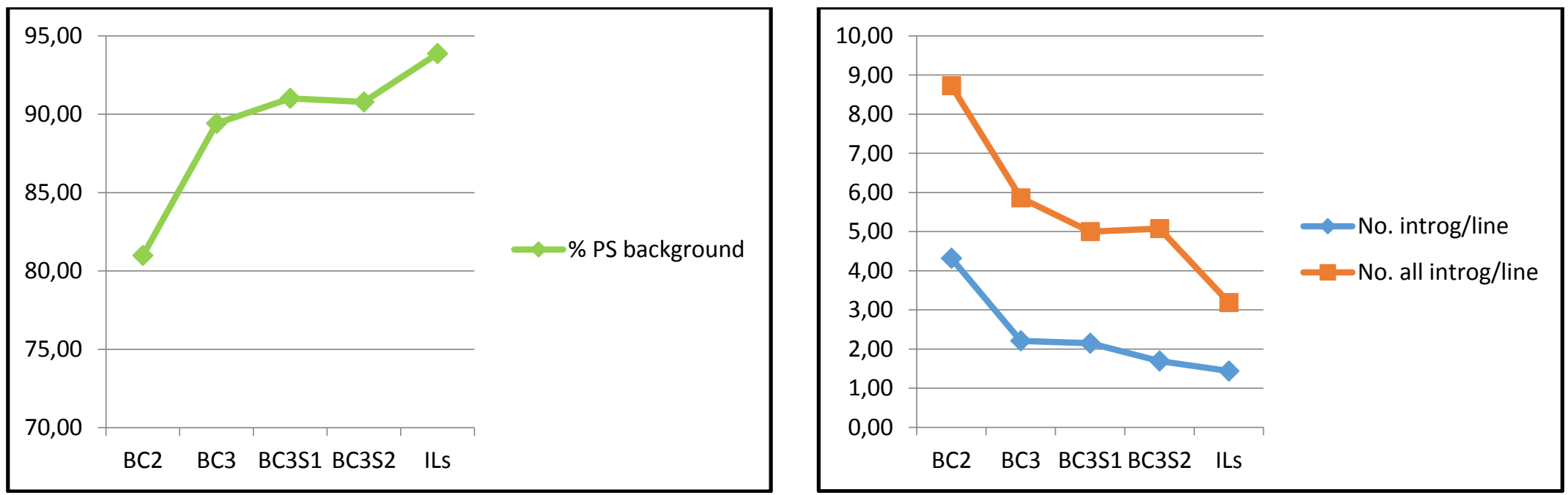

Figure 2.2. Evolution in the recovery of the recurrent genetic background (in percentage) and in the number of introgressions per plant, taking into account all introgressions including single-introgressions or not, during the process of IL construction. 
a)
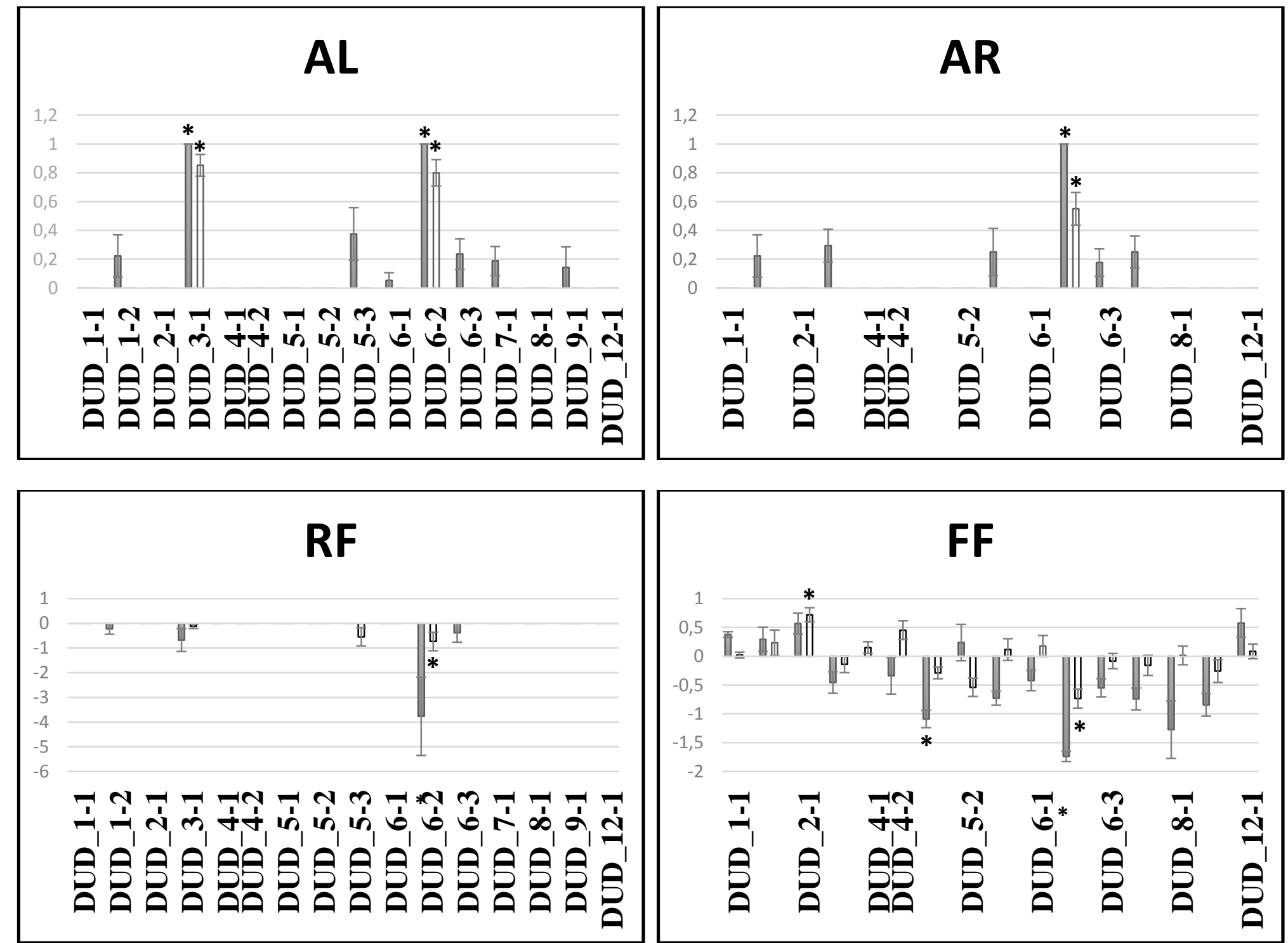
b)
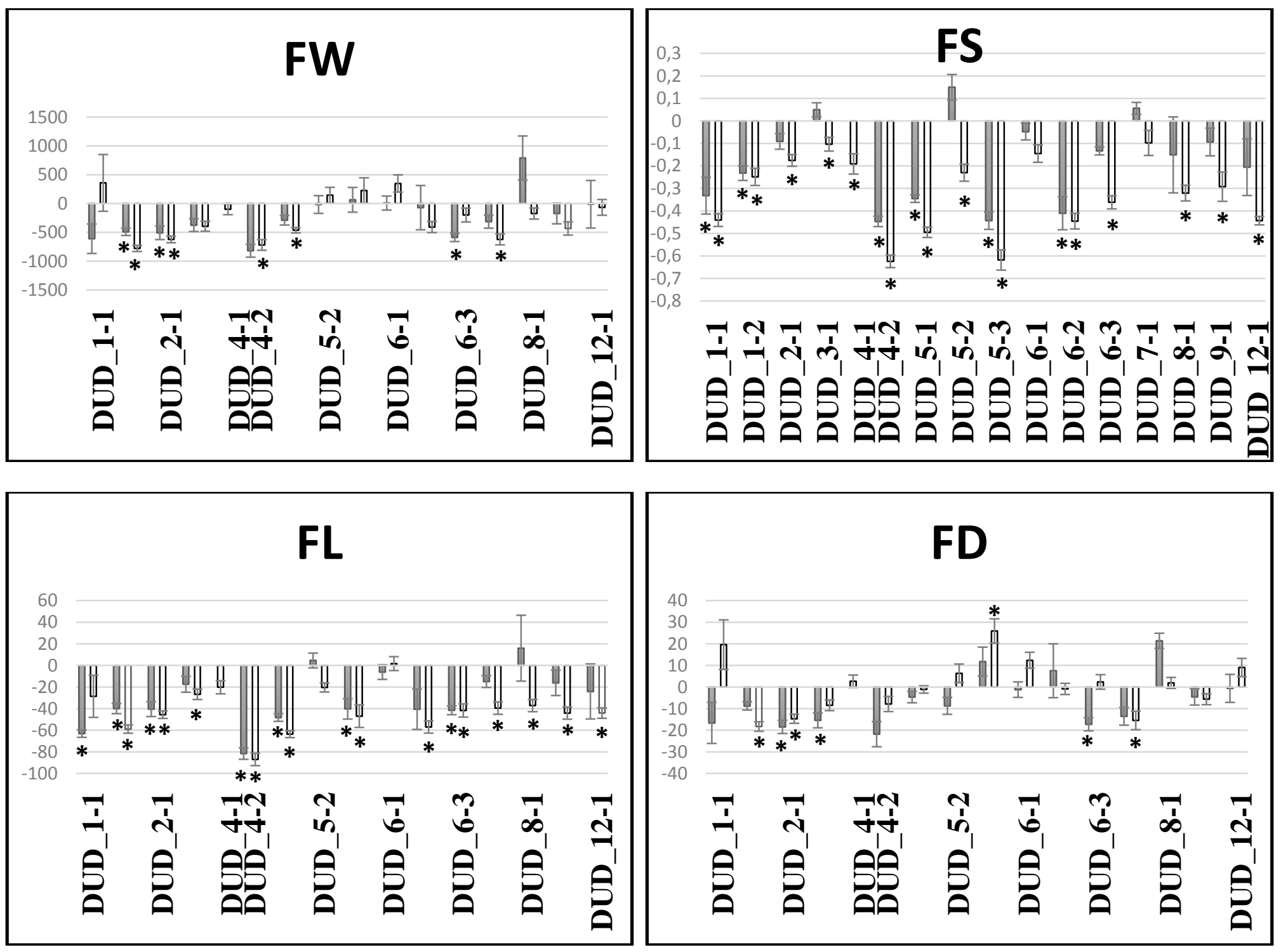


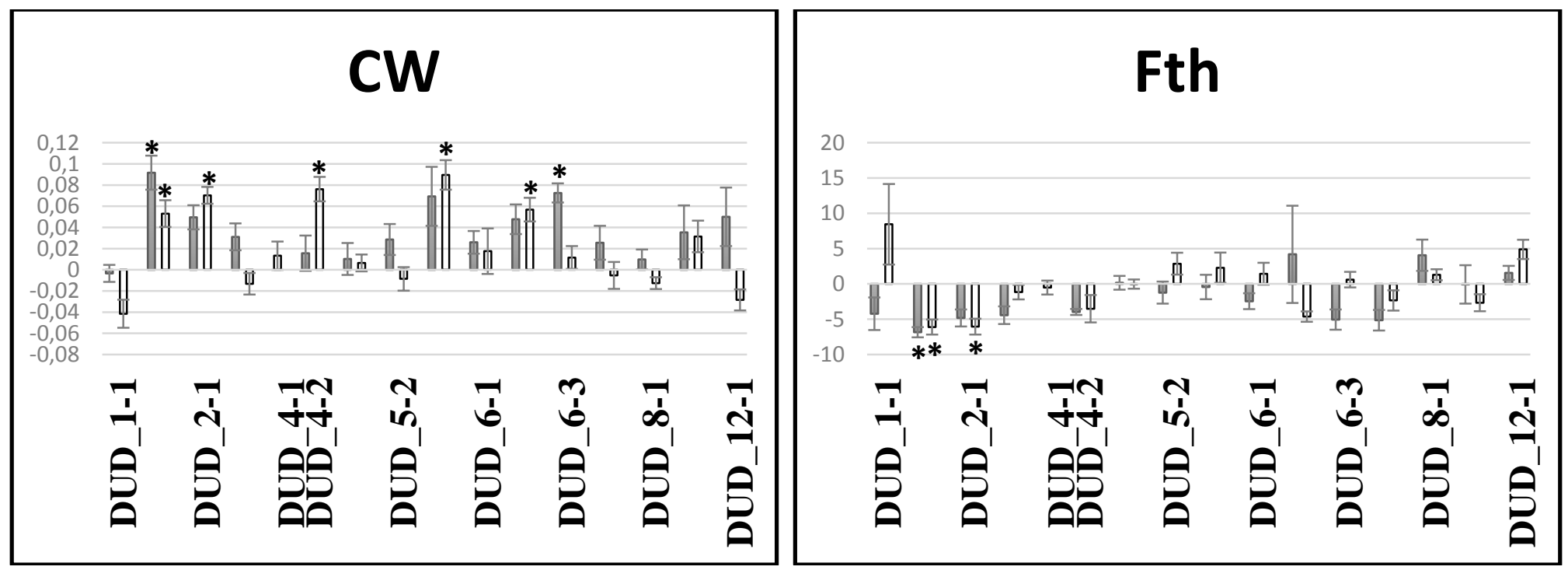

岀 c)
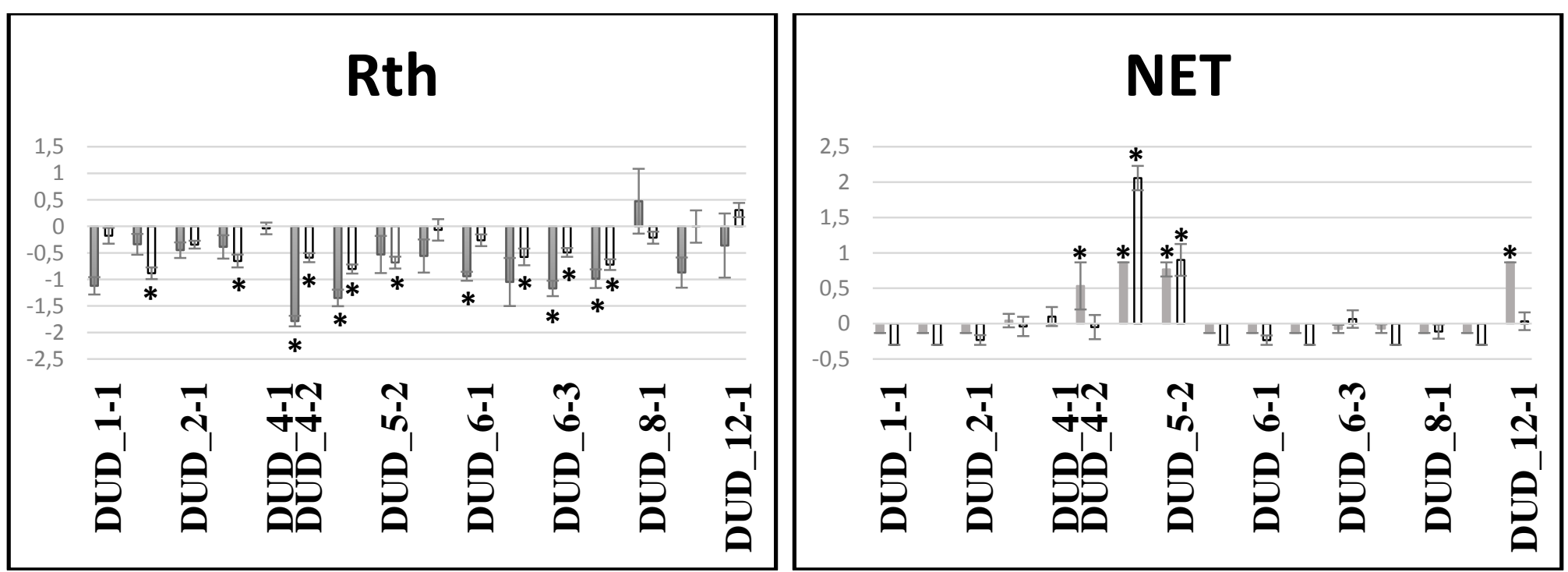
d)
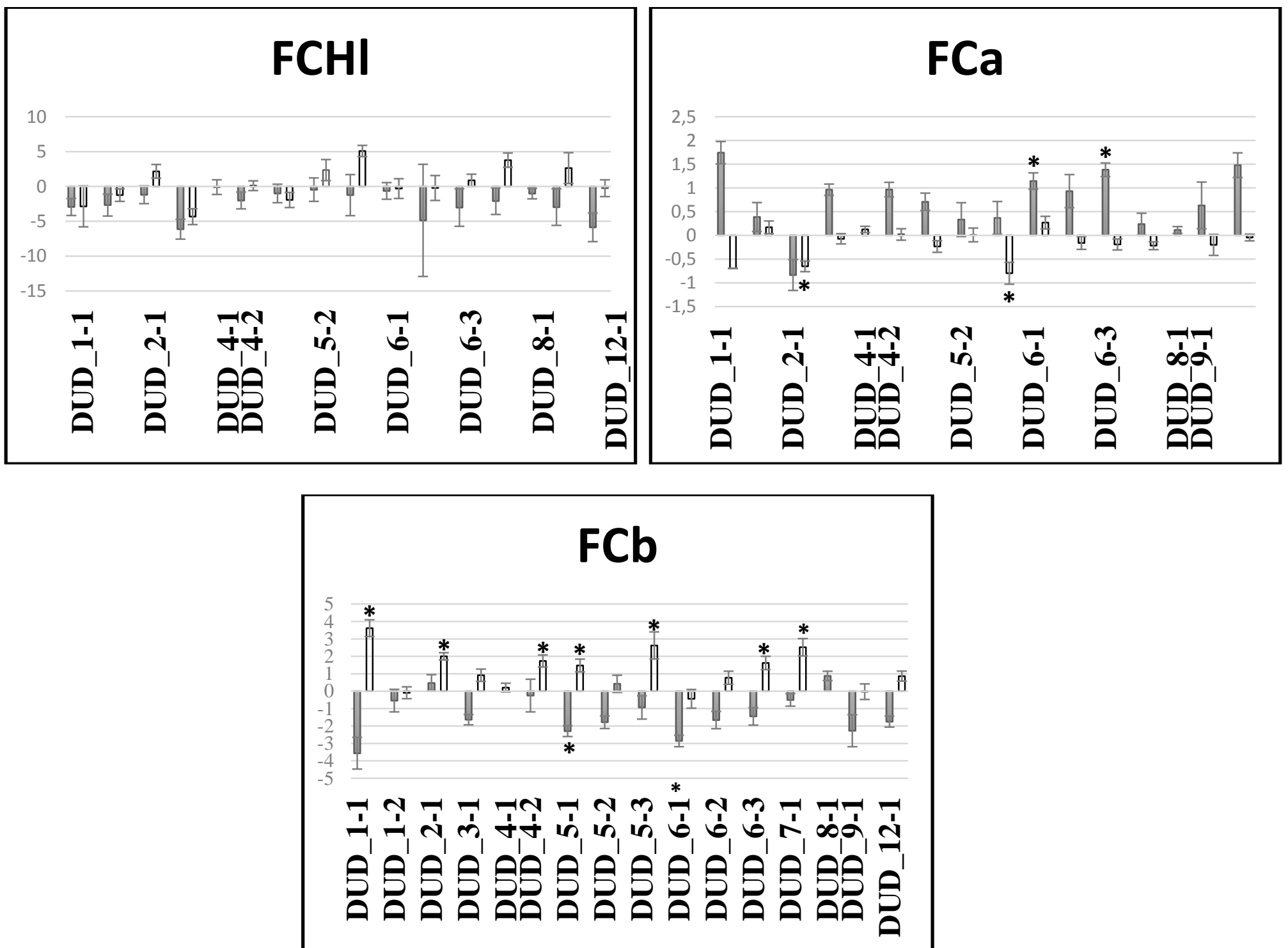
e)
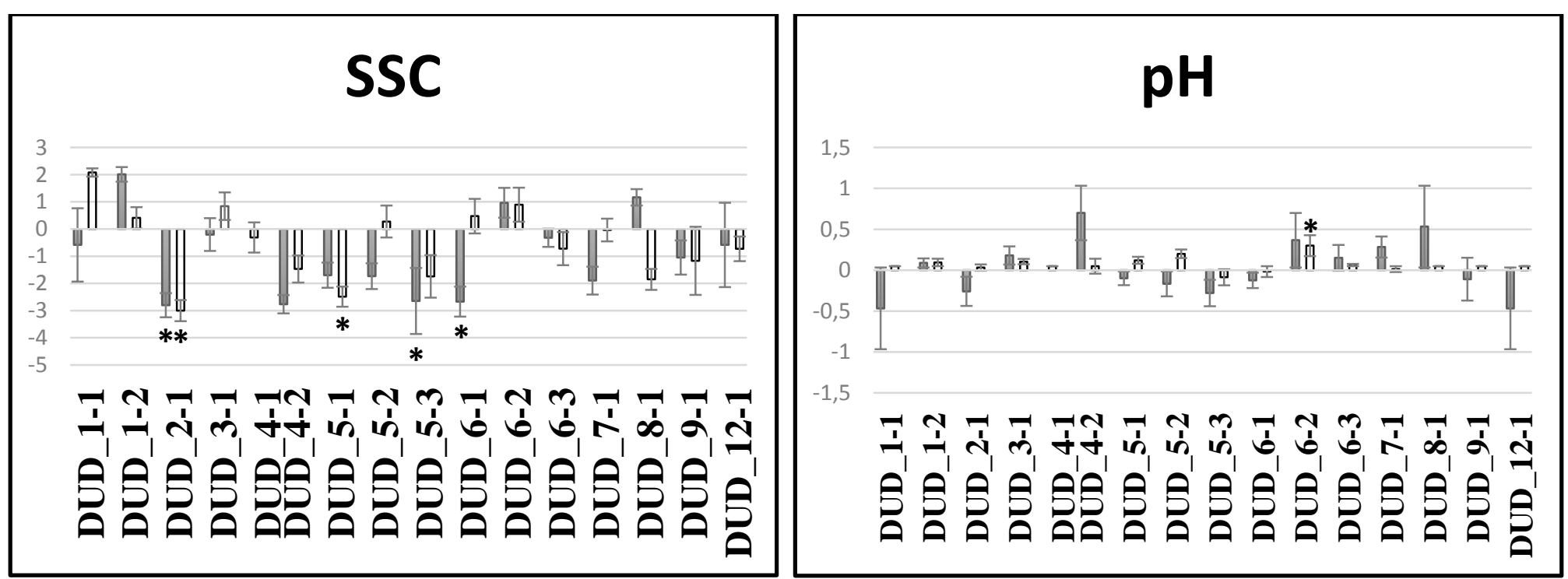

Figure 2.3. Comparison of the means of the set of ILs with the mean of the recurrent parent (PS) using the Dunnett's test. The means and standard errors are shown for each trial (gray bars for Paip16, white bars for Paip17). Bars with an asterisk show significantly different ( $\mathrm{p}<0.05) \mathrm{IL}$ and PS means. a) Traits evaluated are: AL = presence or absence of abscission layer, $\mathrm{AR}=$ presence or absence of external aroma, $\mathrm{RF}=$ rind firmness in $\mathrm{kg} / \mathrm{cm}^{2}, \mathrm{FF}=$ flesh firmness in $\left.\mathrm{kg} / \mathrm{cm}^{2} . \mathrm{b}\right)$ Traits evaluated are: $\mathrm{FW}=$ fruit weight in grams, FS = fruit shape as the ratio between fruit length and fruit diameter, $\mathrm{FL}=$ fruit length in $\mathrm{mm}, \mathrm{FD}=$ fruit diameter in $\mathrm{mm}, \mathrm{CW}=$ cavity width (as the ratio between the width of the seminal cavity and the fruit diameter) and Fth $=$ flesh thickness in $\mathrm{mm}$. c) Traits evaluated are: Rth $=$ rind thickness in $\mathrm{mm}$ and Net $=$ presence or absence of rind netting. d) Traits evaluated are: Hunter coordinates, $\mathrm{FCHl}=$ flesh color luminosity, $\mathrm{FCa}=$ flesh color $\mathrm{a}^{*}$ parameter and $\mathrm{FCb}=$ flesh color $\mathrm{b}^{*}$ parameter. e) Traits evaluated are: $\mathrm{SSC}=$ soluble solids content in Brix degree, $\mathrm{pH}=$ degree of acidity. 


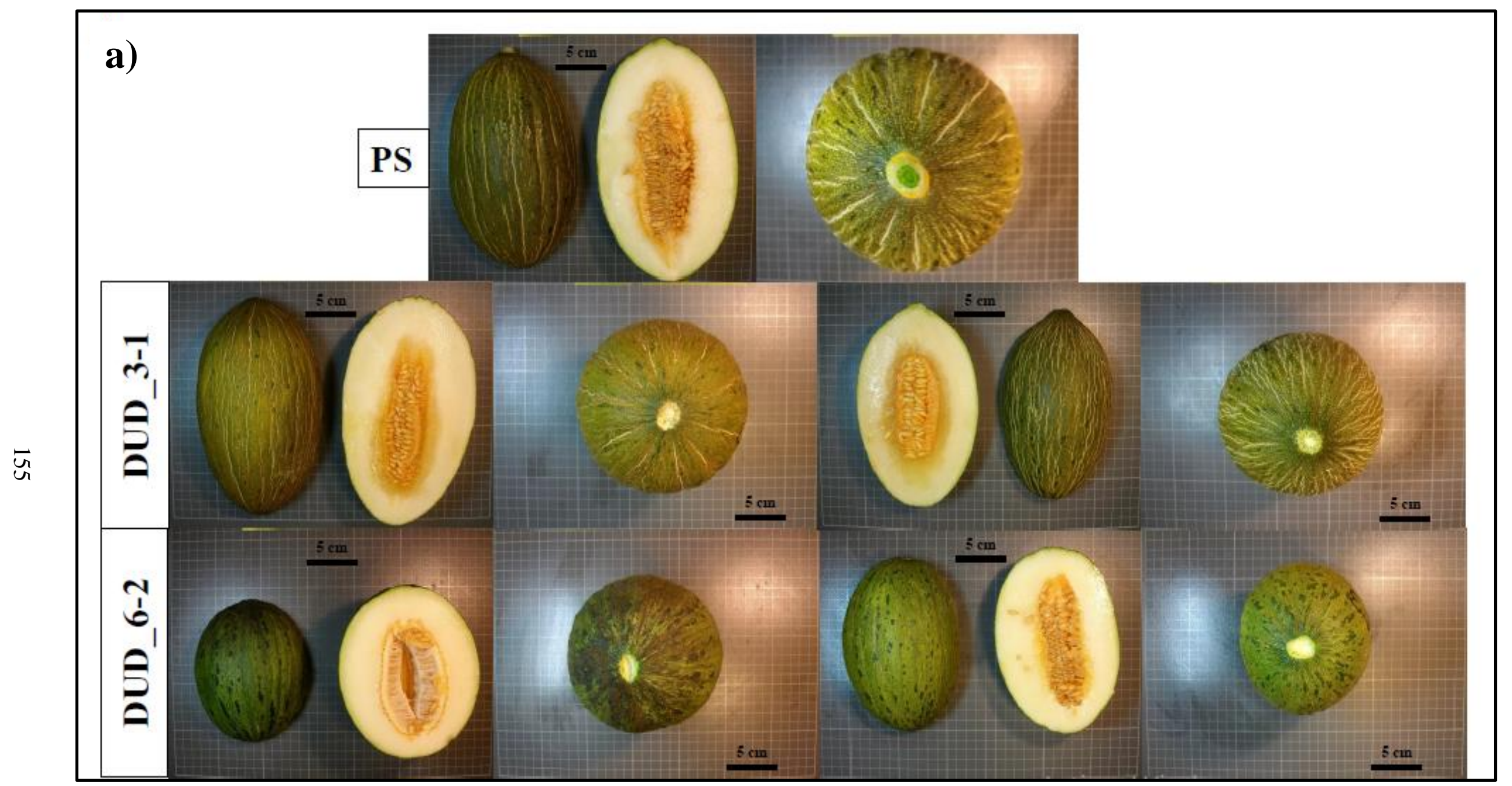




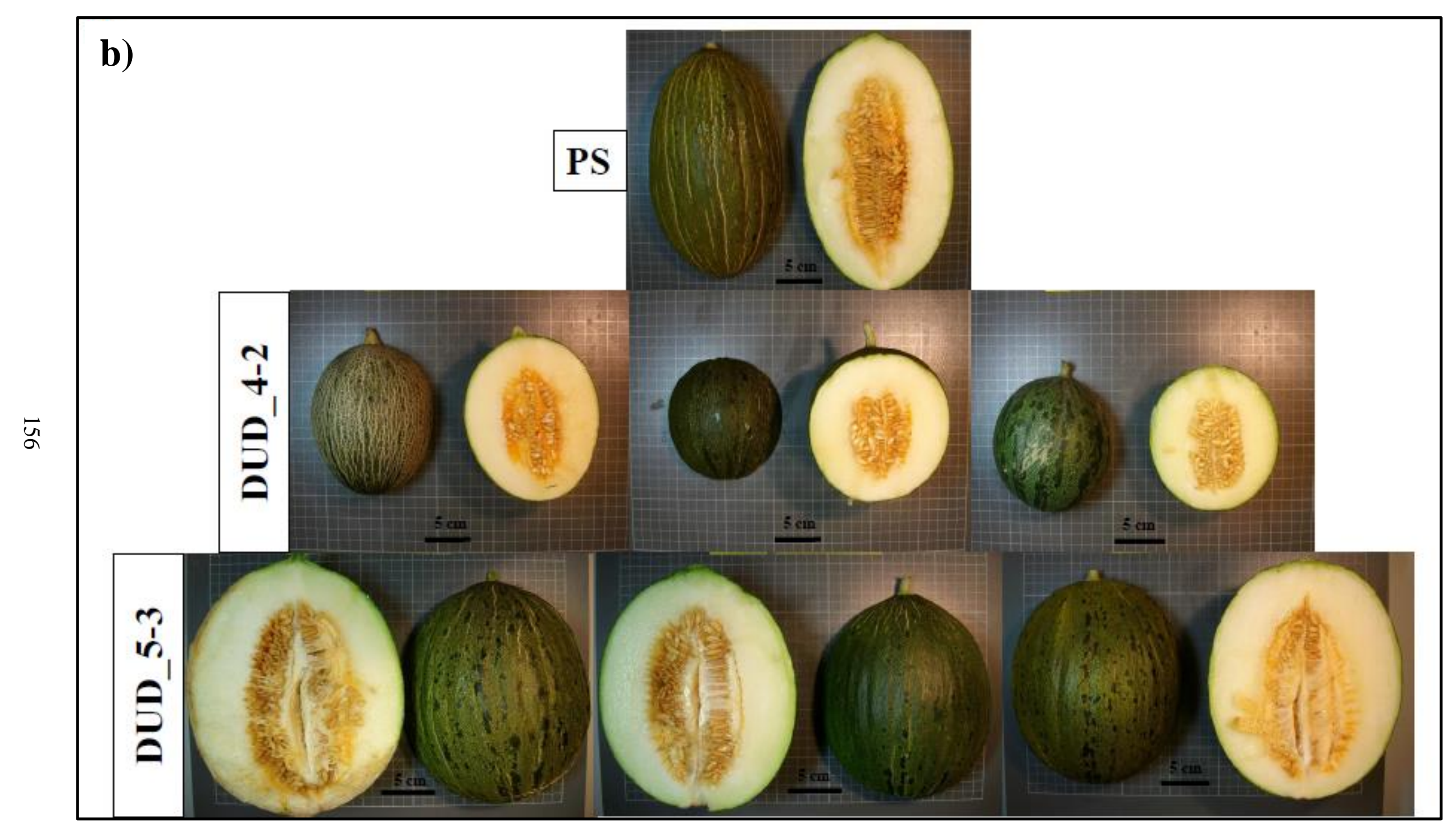




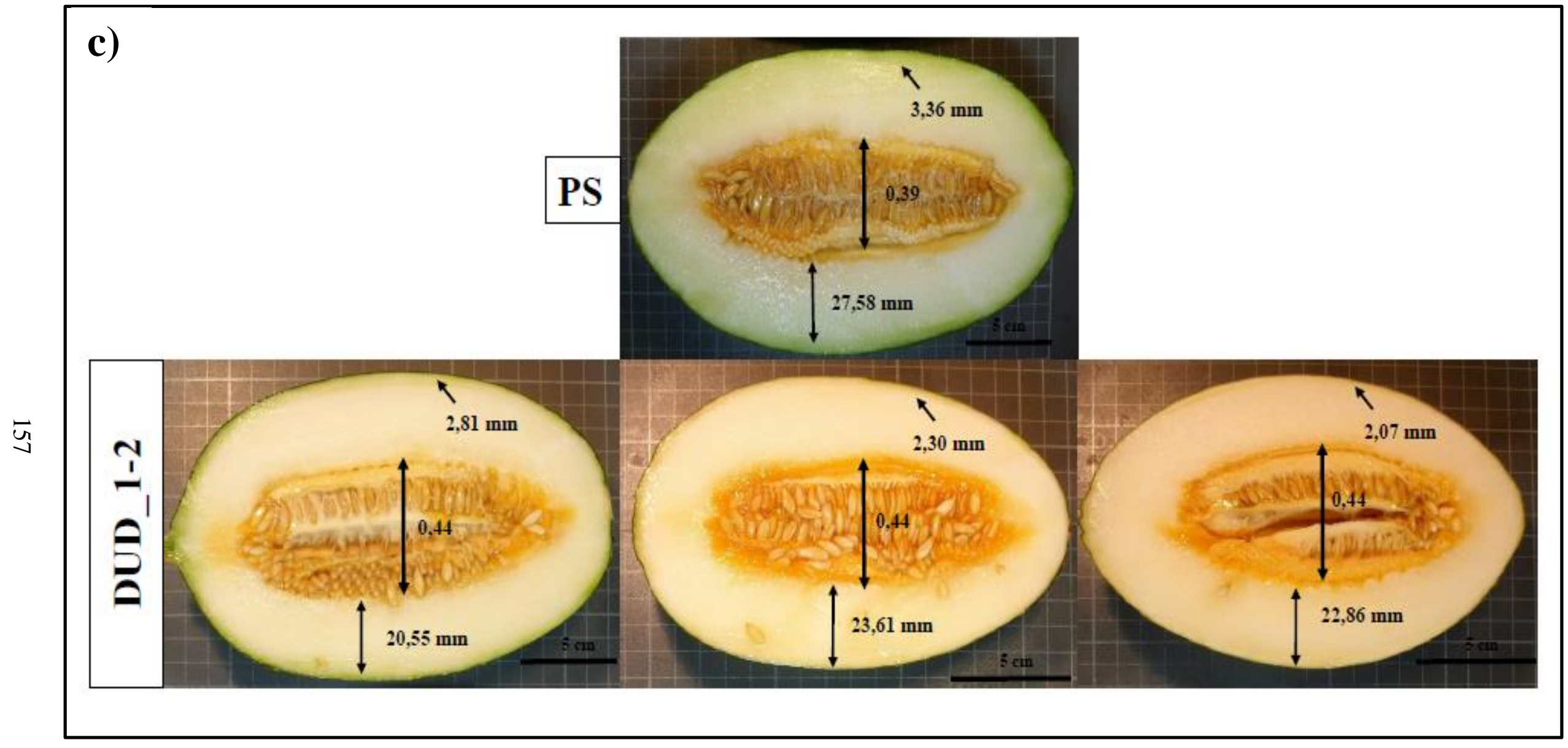


3.2 CAPÍTULO 2

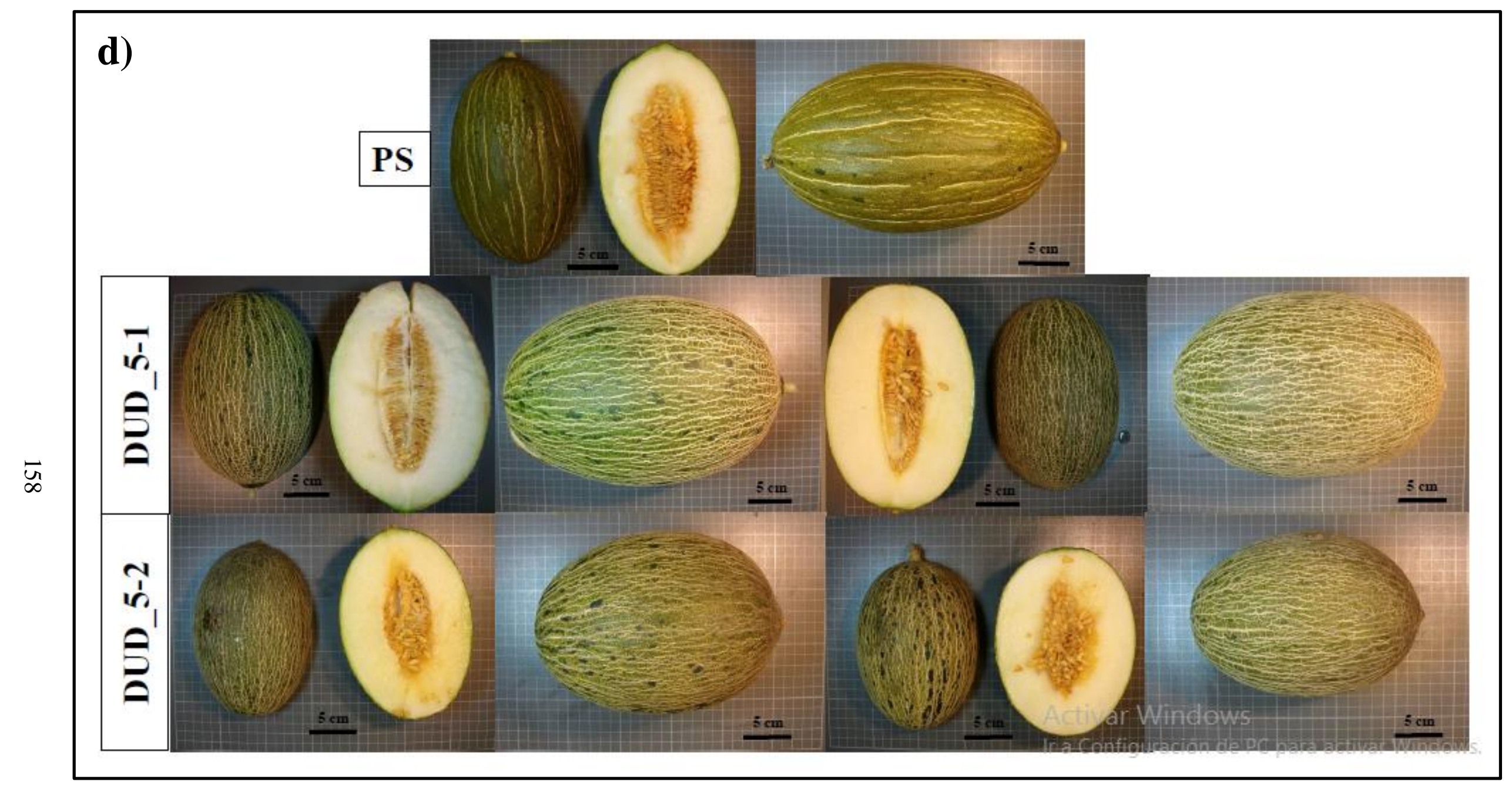




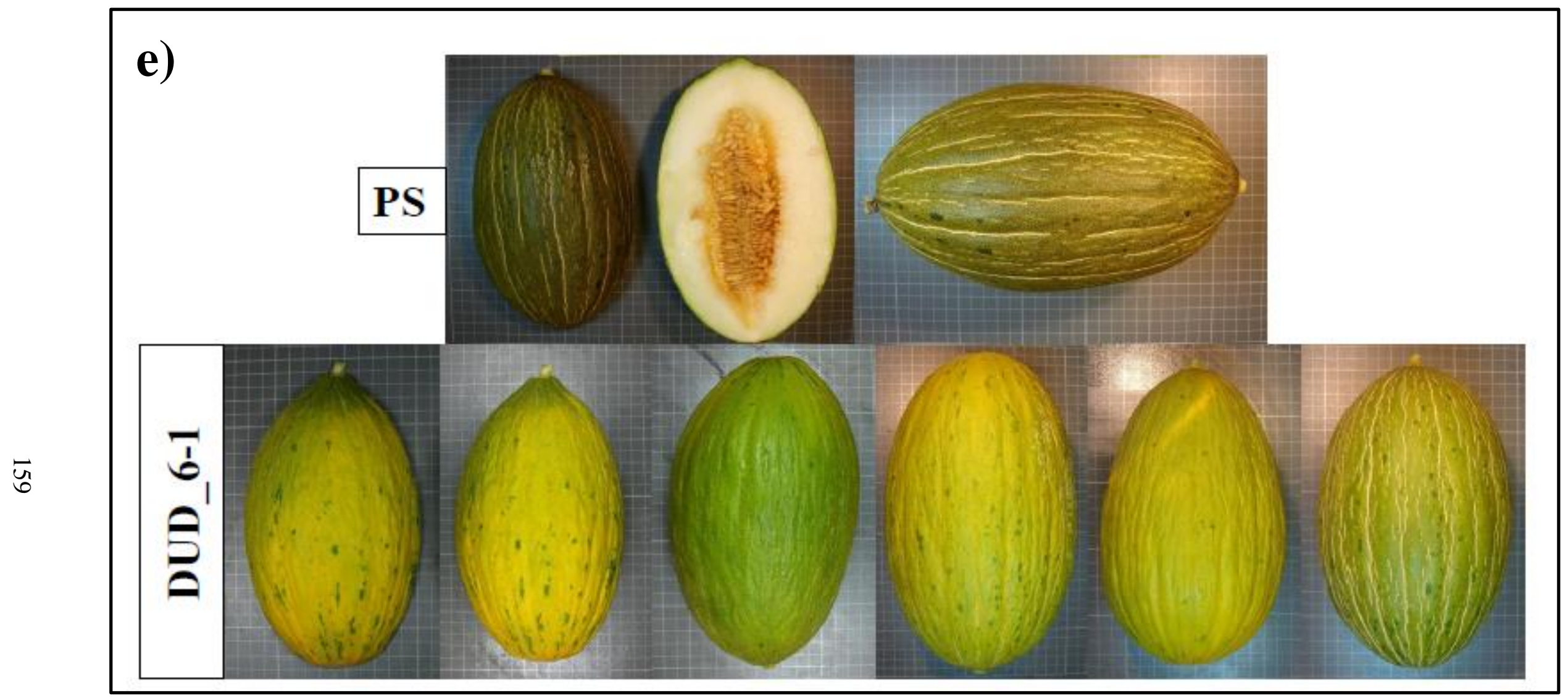

Figure 2.4. Pictures showing characteristic phenotypes of some ILs in comparison to PS. a) Mature fruits of parental PS without abscission layer and of line DUD_3-1 and DUD 6-2 with abscission layer. b) Variation of fruit morphology in DUD 4-2 and DUD 5-3 likely caused by the DUD introgressions in chromosomes 4, 6 or 12 in the genetic background of PS affecting the FS and FL. c) Effect of the DUD introgressions in the line DUD_1-2 produces increase the CW (18.1\%) and reduction the Rth (15.7\%) and Fth (24.1\%) in comparison with the parental PS. d) Mature fruits of parental PS (netted) and of lines DUD_5-1 and DUD_5-2 with more intense netting. e) Mature fruits of parental PS and DUD_6-1 showing the effect of yellowish rind. 


\subsection{CAPÍTULO 2}

\subsection{References}

Amanullah, S., Liu, S., Gao, P., Zhu, Z., Zhu, Q., Fan, C., \& Luan, F. (2018). QTL mapping for melon (Cucumis melo L.) fruit traits by assembling and utilization of novel SNPs based CAPS markers. Scientia Horticulturae, 236, 18-29.

Argyris, J. M., Díaz, A., Ruggieri, V., Fernández, M., Jahrmann, T., Gibon, Y., ... Garcia-Mas, J. (2017). QTL Analyses in multiple populations employed for the fine mapping and identification of candidate genes at a locus affecting sugar accumulation in melon (Cucumis melo L.). Frontiers in Plant Science, 8, 1679.

Argyris, J. M., Ruiz-Herrera, A., Madriz-Masis, P., Sanseverino, W., Morata, J., Pujol, M., ... Garcia-Mas, J. (2015). Use of targeted SNP selection for an improved anchoring of the melon (Cucumis melo L.) scaffold genome assembly. BMC Genomics, 16(1), 4.

Aubert, C., \& Pitrat, M. (2006). Volatile compounds in the skin and pulp of Queen Anne's pocket melon. Journal of Agricultural and Food Chemistry, 54(21), 8177-8182.

Barrantes, W., Fernández-del-Carmen, A., López-Casado, G., González-Sánchez, M. Á., Fernández-Muñoz, R., Granell, A., \& Monforte, A. J. (2014). Highly efficient genomicsassisted development of a library of introgression lines of Solanum pimpinellifolium. Molecular Breeding, 34(4), 1817-1831.

Blanca, J. M., Cañizares, J., Ziarsolo, P., Esteras, C., Mir, G., Nuez, F., ... Picò, M. B. (2011). Melon transcriptome characterization: Simple sequence repeats and single nucleotide polymorphisms discovery for high throughput genotyping across the species. The Plant Genome, 4(2), 118-131.

Blanca, J., Esteras, C., Ziarsolo, P., Pérez, D., Collado, C., de Pablos, R. R., ... Picò, B. (2012). Transcriptome sequencing for SNP discovery across Cucumis melo. BMC Genomics, 13(1), 280.

Burger, Y., Paris, H. S., Cohen, R., Katzir, N., Yishay, R., \& Schaffer, A. A. (2010). Genetic diversity of Cucumis melo. In J. Janick (Ed.), Horticultural reviews (Vol. 36, pp. 165-198). New York, USA: Wiley-Blackwell.

Burger, Y., Sa'ar, U., Paris, H. S., Lewinsohn, E., Katzir, N., Tadmor, Y., \& Schaffer, A. A. (2006). Genetic variability for valuable fruit quality traits in Cucumis melo. Israel Journal of Plant Sciences, 54(3), 233-242.

Dantas, A. C. A, Holanda, I. S. A., Esteras, C., Nunes, G. H. S, \& Picò, M. B. (2015). Diversity of melon accessions from northeastern Brazil and their relationships with germplasms of diverse origins. Journal of the American Society for Horticultural Science, 140(5), 504517.

Díaz, A., Fergany, M., Formisano, G., Ziarsolo, P., Blanca, J., Fei, Z., ... Oliver, M. (2011). A 
consensus linkage map for molecular markers and quantitative trait loci associated with economically important traits in melon (Cucumis melo L.). BMC Plant Biology, 11(1), 111. Díaz, A., Forment, J., Argyris, J. M., Fukino, N., Tzuri, G., Harel-Beja, R., ... Monforte, A. J. (2015). Anchoring the consensus ICuGI genetic map to the melon (Cucumis melo L.) genome. Molecular Breeding, 35(10), 188.

Díaz, A., Martín-Hernández, A. M., Dolcet-Sanjuan, R., Garcés-Claver, A., Álvarez, J. M., Garcia-Mas, J., ... Monforte, A. J. (2017). Quantitative trait loci analysis of melon (Cucumis melo L.) domestication-related traits. Theoretical and applied genetics, 130(9), 1837-1856.

Doyle, J. J., \& Doyle, J. L. (1990). Isolation of plant DNA from fresh tissue. Focus, 12(13), 39-40.

Dunnett, C. W. (1955). A multiple comparison procedure for comparing several treatments with a control. Journal of the American Statistical Association, 50(272), 1096-1121.

Eduardo, I., Arús, P., \& Monforte, A. J. (2005). Development of a genomic library of near isogenic lines (NILs) in melon (Cucumis melo L.) from the exotic accession PI161375. Theoretical and Applied Genetics, 112(1), 139-148.

Eduardo, I., Arús, P., Monforte, A. J., Obando, J., Fernández-Trujillo, J. P., Martínez, J. A., ... van der Knaap, E. (2007). Estimating the genetic architecture of fruit quality traits in melon using a genomic library of near isogenic lines. Journal of the American Society for Horticultural Science, 132(1), 80-89.

Endl, J., Achigan-Dako, E. G., Pandey, A. K., Monforte, A. J., Picò, B., \& Schaefer, H. (2018). Repeated domestication of melon (Cucumis melo) in Africa and Asia and a new close relative from India. American Journal of Botany, 105(10), 1662-1671.

Eshed, Y., \& Zamir, D. (1995). An introgression line population of Lycopersicon pennellii in the cultivated tomato enables the identification and fine mapping of yield-associated QTL. Genetics, 141(3), 1147-1162.

Esteras, C., Formisano, G., Roig, C., Díaz, A., Blanca, J., Garcia-Mas, J., ... Picò, B. (2013). SNP genotyping in melons: genetic variation, population structure, and linkage disequilibrium. Theoretical and Applied Genetics, 126(5), 1285-1303.

Esteras, C., Rambla, J. L., Sánchez, G., López-Gresa, M. P., González-Mas, M. C., FernándezTrujillo, J. P., ... Picò, M. B. (2018). Fruit flesh volatile and carotenoid profile analysis within the Cucumis melo L. species reveals unexploited variability for future genetic breeding. Journal of the Science of Food and Agriculture, 98(10), 3915-3925.

FAOSTAT. (2018). Food and Agriculture Organization Corporate Statistical Database. Retrieve from http://faostat3.fao.org/home/S [Access on 22 October 2018] 


\subsection{CAPÍTULO 2}

Feder, A., Burger, J., Gao, S., Lewinsohn, E., Katzir, N., Schaffer, A. A., ... Fei, Z. (2015). A Kelch domain-containing F-Box coding gene negatively regulates flavonoid accumulation in muskmelon. Plant physiology, 169(3), 1714-1726.

Galpaz, N., Gonda, I., Shem-Tov, D., Barad, O., Tzuri, G., Lev, S., ... Harel-Beja, R. (2018). Deciphering genetic factors that determine melon fruit-quality traits using RNA-Seq-based high-resolution QTL and eQTL mapping. The Plant Journal, 94(1), 169-191.

Garcia-Mas, J., Benjak, A., Sanseverino, W., Bourgeois, M., Mir, G., González, V. M., ... \& Alioto, T. (2012). The genome of melon (Cucumis melo L.). Proceedings of the National Academy of Sciences, 109(29), 11872-11877.

Gur, A., Gonda, I., Portnoy, V., Tzuri, G., Chayut, N., Cohen, S., .. Katzir, N. (2017). Genomic aspects of melon fruit quality. In: R. Grumet, N. Katzir, \& J. Garcia-Mas. (Eds.), Genetics and genomics of Cucurbitaceae (Vol. 20, pp. 377-400). Cham, Switzerland: Springer Nature

Gur, A., Tzuri, G., Meir, A., Sa'ar, U., Portnoy, V., Katzir, N., ... Tadmor, Y. (2017). Genomewide linkage-disequilibrium mapping to the candidate gene level in melon (Cucumis melo). Scientific reports, 7(1), 9770.

Gur, A., \& Zamir, D. (2004). Unused natural variation can lift yield barriers in plant breeding. PLoS biology, 2(10), e245.

Harel-Beja, R., Tzuri, G., Portnoy, V., Lotan-Pompan, M., Lev, S., Cohen, S., ... Avisar, E. (2010). A genetic map of melon highly enriched with fruit quality QTLs and EST markers, including sugar and carotenoid metabolism genes. Theoretical and applied genetics, 121(3), 511-533.

Huang, Z., Van Houten, J., Gonzalez, G., Xiao, H., \& van der Knaap, E. (2013). Genome-wide identification, phylogeny and expression analysis of SUN, OFP and YABBY gene family in tomato. Molecular genetics and genomics, 288(3-4), 111-129.

Kirkbride, J. H. (1993). Biosystematic monograph of the genus Cucumis (Cucurbitaceae). Boone, USA: Parkway.

Lázaro, A., Fernández, I. C., Borrero, M. J., Cabello, F., López-Sesé, A. I., Gómez-Guillamón, M. L., \& Picò, B. (2017). Agromorphological genetic diversity of Spanish traditional melons. Genetic resources and crop evolution, 64(7), 1687-1706.

Leida, C., Moser, C., Esteras, C., Sulpice, R., Lunn, J. E., de Langen, F., ...Picò, B. (2015). Variability of candidate genes, genetic structure and association with sugar accumulation and climacteric behavior in a broad germplasm collection of melon (Cucumis melo L.). BMC genetics, 16(1), 28.

López, C., Ferriol, M., \& Picò, M. B. (2015). Mechanical transmission of Tomato leaf curl New 
Delhi virus to cucurbit germplasm: selection of tolerance sources in Cucumis melo. Euphytica, 204(3), 679-691.

Monforte, A. J., Díaz, A., Caño-Delgado, A., \& van der Knaap, E. (2014). The genetic basis of fruit morphology in horticultural crops: lessons from tomato and melon. Journal of experimental botany, 65(16), 4625-4637.

Monforte, A. J., Eduardo, I., Abad, S., \& Arús, P. (2005). Inheritance mode of fruit traits in melon: Heterosis for fruit shape and its correlation with genetic distance. Euphytica, 144(1-2), 31-38.

Monforte, A. J., Friedman, E., Zamir, D., \& Tanksley, S. D. (2001). Comparison of a set of allelic QTL-NILs for chromosome 4 of tomato: deductions about natural variation and implications for germplasm utilization. Theoretical and Applied Genetics, 102(4), 572590.

Monforte, A. J., Oliver, M., Gonzalo, M. J., Alvarez, J. M., Dolcet-Sanjuan, R., \& Arus, P. (2004). Identification of quantitative trait loci involved in fruit quality traits in melon (Cucumis melo L.). Theoretical and Applied Genetics, 108(4), 750-758.

Moreno, E., Obando, J. M., Dos-Santos, N., Fernández-Trujillo, J. P., Monforte, A. J., \& Garcia-Mas, J. (2008). Candidate genes and QTLs for fruit ripening and softening in melon. Theoretical and Applied Genetics, 116(4), 589-602.

Nimmakayala, P., Tomason, Y. R., Abburi, V. L., Alvarado, A., Saminathan, T., Vajja, V. G., ... McCreight, J. D. (2016). Genome-wide differentiation of various melon horticultural groups for use in GWAS for fruit firmness and construction of a high resolution genetic map. Frontiers in plant science, 7, 1437.

Nunes, E. W. L. P., Esteras, C., Ricarte, A. O., Martínez-Perez, E., Gómez-Guillamón, M. L., Nunes, G. H. S., \& Picò, M. B. (2017). Brazilian melon landraces resistant to Podosphaera xanthii are unique germplasm resources. Annals of applied biology, 171(2), 214-228.

Obando-Ulloa, J. M., Ruiz, J., Monforte, A. J., \& Fernández-Trujillo, J. P. (2010). Aroma profile of a collection of near-isogenic lines of melon (Cucumis melo L.). Food chemistry, 118(3), 815-822.

Paris, M. K., Zalapa, J. E., McCreight, J. D., \& Staub, J. E. (2008). Genetic dissection of fruit quality components in melon (Cucumis melo L.) using a RIL population derived from exoticx elite US Western Shipping germplasm. Molecular Breeding, 22(3), 405-419.

Pavan, S., Marcotrigiano, A. R., Ciani, E., Mazzeo, R., Zonno, V., Ruggieri, V., ... Ricciardi, L. (2017). Genotyping-by-sequencing of a melon (Cucumis melo L.) germplasm collection from a secondary center of diversity highlights patterns of genetic variation and genomic features of different gene pools. BMC genomics, 18(1), 59. 


\subsection{CAPÍTULO 2}

Pereira, L., Ruggieri, V., Pérez, S., Alexiou, K. G., Fernández, M., Jahrmann, T., ... GarciaMas, J. (2018). QTL mapping of melon fruit quality traits using a high-density GBS-based genetic map. BMC plant biology, 18(1), 324.

Périn, C., Gomez-Jimenez, M., Hagen, L., Dogimont, C., Pech, J. C., Latché, A., ... Lelièvre, J. M. (2002). Molecular and genetic characterization of a non-climacteric phenotype in melon reveals two loci conferring altered ethylene response in fruit. Plant Physiology, 129(1), 300-309.

Perpiñà, G., Cebolla-Cornejo, J., Esteras, C., Monforte, A. J., \& Picò, B. (2017). 'MAK-10': A long shelf-life charentais breeding line developed by introgression of a genomic region from Makuwa Melon. HortScience, 52(11), 1633-1638.

Perpiñà, G., Esteras, C., Gibon, Y., Monforte, A. J., \& Picò, B. (2016). A new genomic library of melon introgression lines in a cantaloupe genetic background for dissecting desirable agronomical traits. BMC plant biology, 16(1), 154.

Pitrat, M. (2013). Phenotypic diversity in wild and cultivated melons (Cucumis melo). Plant Biotechnology, 13-0813.

Pitrat, M. (2017). Melon genetic resources: phenotypic diversity and horticultural taxonomy. In: R. Grumet, N. Katzir, \& J. Garcia-Mas. (Eds.), Genetics and genomics of Cucurbitaceae (Vol. 20, pp. 25-59). Cham, Switzerland: Springer Nature.

Ramamurthy, R. K., \& Waters, B. M. (2015). Identification of fruit quality and morphology QTLs in melon (Cucumis melo) using a population derived from flexuosus and cantalupensis botanical groups. Euphytica, 204(1), 163-177.

Ríos, P., Argyris, J., Vegas, J., Leida, C., Kenigswald, M., Tzuri, G., ... Monforte, A. J. (2017). ETHQV 6.3 is involved in melon climacteric fruit ripening and is encoded by a NAC domain transcription factor. The Plant Journal, 91(4), 671-683.

Rodríguez, G. R., Muños, S., Anderson, C., Sim, S. C., Michel, A., Causse, M., ... van der Knaap, E. (2011). Distribution of SUN, OVATE, LC, and FAS in the tomato germplasm and the relationship to fruit shape diversity. Plant physiology, 156(1), 275-285.

Sabato, D., Esteras, C., Grillo, O., Picò, B., \& Bacchetta, G. (2015). Seeds morphocolourimetric analysis as complementary method to molecular characterization of melon diversity. Scientia Horticulturae, 192, 441-452.

Vegas, J., Garcia-Mas, J., \& Monforte, A. J. (2013). Interaction between QTLs induces an advance in ethylene biosynthesis during melon fruit ripening. Theoretical and applied genetics, 126(6), 1531-1544.

Vossen, R. H., Aten, E., Roos, A., \& den Dunnen, J. T. (2009). High-Resolution Melting Analysis (HRMA) - More than just sequence variant screening. Human mutation, 30(6), 
$860-866$.

Wu, J., Chang, Z., Wu, Q., Zhan, H., \& Xie, S. (2011). Molecular diversity of Chinese Cucurbita moschata germplasm collections detected by AFLP markers. Scientia Horticulturae, 128(1), 7-13.

Wu, S., Clevenger, J. P., Sun, L., Visa, S., Kamiya, Y., Jikumaru, Y., ... van der Knaap, E. (2015). The control of tomato fruit elongation orchestrated by sun, ovate and fs8. 1 in a wild relative of tomato. Plant Science, 238, 95-104.

Wu, S., Zhang, B., Keyhaninejad, N., Rodríguez, G. R., Kim, H. J., Chakrabarti, M., ... Pan, Y. (2018). A common genetic mechanism underlies morphological diversity in fruits and other plant organs. Nature communications, 9(1), 4734.

Zalapa, J. E., Staub, J. E., McCreight, J. D., Chung, S. M., \& Cuevas, H. (2007). Detection of QTL for yield-related traits using recombinant inbred lines derived from exotic and elite US Western Shipping melon germplasm. Theoretical and applied genetics, 114(7), 11851201.

Zamir, D. (2001). Improving plant breeding with exotic genetic libraries. Nature reviews genetics, 2(12), 983. 

3.3 Capítulo 3 



\section{Aumentando la diversificación de las variedades de melón 'Piel de Sapo', aprovechando la variación de variedades asiáticas tipo Dudaim.}

Castro, G., Perpiñà, G., Monforte, A. J., Esteras, C., Picò, B. (2018). Aumentando la diversificación de las variedades de melón "Piel de Sapo", mediante el aprovechamiento de la variación de variedades asiáticas tipo Dudaim. Agrícola Vergel, 409, 101-105.

De la colección de ILs obtenida, algunas líneas presentaron características agronómicas de gran interés. Por tal motivo, se realizó un análisis más detallado de las líneas con mayor relevancia agrónomica, lo que permitirá diversificar el mercado del melón de tipo 'Piel de sapo'. Este trabajo se ha publicado en la revista de divulgación Agrícola Vergel, una revista profesional especializada en fucticultura, horticultura y floricultura, cuyos contenidos técnico-científicos tienen como objetivo divulgar los trabajos de investigación y aplicación práctica realizados en distintas disciplinas relacionadas con la agricultura.

El trabajo realizado es el resultado de mi participación en los proyectos AGL2014-53398-C2-2-R, APROXIMACIONES BIOTECNOLÓGICAS Y CULTURALES PARA LA MEJORA DE LAS RESISTENCIAS Y EL CONTROL DE ENFERMEDADES EN MELÓN Y SANDÍA, PLANT KBBE project (SAFQIM: PIM2010PKB-00691), SUGARS AND FRUIT QUALITY IN MELON, financiado por el MINECO (cofinanciado con fondos FEDER), y el proyecto del programa PROMETEO para grupos de excelencia /2017/078, SELECCION DE VARIEDADES TRADICIONALES Y DESARROLLO DE NUEVAS VARIEDADES DE CUCURBITACEAS ADAPTADAS A LA PRODUCCION ECOLOGICA, financiado por la Consellería d'Educació, Investigació, Cultura i Esport de la Generalitat Valenciana. 



\subsection{Aumentando la diversificación de las variedades de melón 'Piel de Sapo', aprovechando la variación de variedades asiáticas tipo Dudaim}

Castro, G., Perpiñà, G., Monforte, A. J., Esteras, C., Picò, B. Aumentando la diversificación de las variedades de melón "Piel de Sapo", mediante el aprovechamiento de la variación de variedades asiáticas tipo Dudaim. Agrícola Vergel, 409, 101-105.

\subsection{Introducción}

El melón, Cucumis melo L., es uno de los cultivos con mayor importancia económica en nuestro país. Ocupa el séptimo lugar en cuanto a producción entre las frutas y hortalizas, tras algunas solanáceas (como el tomate o el pimiento) y otras cucurbitáceas (como la sandía o el pepino) (MAPAMA, 2016). España es el primer productor y exportador europeo, con 661.897 toneladas producidas en 2016 (FAOSTAT, 2017), lo que supone casi el 40\% de la producción europea. En España, las comunidades autónomas con mayor producción son Castilla La Mancha, con 224.821 toneladas, y las Regiones de Murcia y Andalucía, con 189.013 y 169.276 toneladas, respectivamente. Los tipos de melón cuyo cultivo está más extendido en España pertenecen principalmente al grupo Ibericus, propuesto recientemente por Pitrat (2017). Este grupo incluye diversos tipos de melones que se han clasificado durante mucho tiempo en el grupo Inodorus, debido a la ausencia de aroma del fruto cerrado consecuencia de su maduración no climatérica, a diferencia de los melones de tipo Cantalupensis, climatéricos y aromáticos, que constituyen el otro grupo importante a nivel comercial. El grupo Ibericus incluye los melones tradicionalmente cultivados en España, y en la actualidad difundidos a las principales zonas productoras del área Mediterránea, y Norte y Sudamérica. Desarrollan plantas vigorosas, de floración tardía y andromonoica, con frutos de tamaño medio-grande, de forma elíptica o redondeada y de corteza gruesa, a veces arrugada y algo reticulada, de pulpa blanco-cremosa o blanco-verdosa, ligeramente aromática con alto contenido en azúcar, con una larga vida postcosecha, debido a su carácter no climatérico. Se diferencian varios subgrupos de cultivares que se caracterizan por el color de la corteza. El subgrupo más importante es sin duda el 'Piel de Sapo', con su característica corteza verde, con manchas oscuras, aunque también se comercializan los tipos Amarillos, y se cultivan de forma más local cultivares de tipo Blanco, Tendral o Rochet. 


\subsection{CAPÍTULO 3}

Dada su importancia económica, las empresas productoras de semillas están muy interesadas en el desarrollo de nuevos cultivares de melón 'Piel de Sapo', que respondan a la demanda del agricultor, presentando una producción elevada, estable y homogénea, pero también del consumidor, con un nivel elevado de calidad y con características atractivas. Como en la mayoría de cultivos adaptados a una agricultura intensiva, altamente productiva, durante el proceso de domesticación y de selección de cultivares modernos de melón se ha perdido una enorme diversidad genética. No se ha explotado lo suficiente la gran variabilidad intraespecífica existente en esta especie, infravalorando muchos tipos tradicionales adaptados a condiciones locales (Lázaro et al., 2017; Pitrat, 2017) y variedades pertenecientes a otros tipos no comunes en Europa que sí que son cultivados en países asiáticos. La mejora se ha orientado básicamente a incrementar o mantener la producción, introduciendo resistencias a enfermedades. Sin embargo, las necesidades de la sociedad han ido evolucionando, así como la percepción de la calidad de los frutos, por lo que en la actualidad los consumidores están demandando productos de mayor calidad organoléptica, pero además más saludables.

La calidad tiene una connotación compleja, que en melón no sólo incluye la forma y tamaño del fruto, la coloración de la pulpa y corteza, el reticulado, etc., sino también el aroma y el contenido en azúcares, ácidos, vitaminas y compuestos antioxidantes, como carotenos. La mayoría de estos rasgos son de carácter cuantitativo y poligénico (Quantitative Trait Loci, QTL), lo que dificulta en gran medida la identificación y selección de alelos favorables (Gonzalo \& Monforte, 2017). Los recientes avances en los métodos de secuenciación (Next Generation sequencing, NGS) han posibilitado la identificación de polimorfismos entre diferentes tipos varietales de melón en el marco de diversos proyectos de secuenciación de transcriptomas y genomas (Casacuberta, Puigdomènech, \& García-Mas, 2017). A estas herramientas de análisis genómico para la especie se unen la disponibilidad de mapas genéticos anclados al genoma (Díaz et al., 2015), que posibilitan una mejora más eficiente.

La disponibilidad de recursos genéticos aún no explotados tiene un papel crucial para avanzar en la mejora de la calidad. Una forma de desarrollar nuevos cultivares, es la generación de líneas de introgresión (Introgression lines, ILs), a partir del cruzamiento entre variedades élite y tipos exóticos de melón, seguido de retrocruzamientos continuados hacia la variedad de élite. Las ILs son portadoras de ciertas introgresiones genómicas del parental exótico, en el fondo genético de la variedad de élite (Perpiñà, Esteras, Gibon, Monforte, \& Picò, 2016). En melón, existen dos colecciones de ILs descritas hasta la fecha, ambas obtenidas de cruces entre tipos con características contrastantes pertenecientes a las dos subespecies en que se divide la especie (ssp. melo y ssp. agrestis) (Kirkbride, 1993). La primera se obtuvo a partir del cruce de un cultivar español tipo 'Piel de Sapo' (ssp. melo, grupo Ibericus) como parental recurrente y la 
entrada coreana PI 161375 (Songwan Charmi) (ssp. agrestis, grupo Chinensis) como parental donante (Eduardo, Arús, \& Monforte, 2005). La segunda se ha desarrollado recientemente en el grupo de Mejora de Cucurbitáceas del COMAV a partir del cruce de un tipo Charentais 'Vedrantais' (ssp. melo, grupo Cantalupensis) x Ginsen makuwa (ssp.agrestis, grupo Makuwa) (Perpiñà et al., 2016), para lo que se han empleado algunas de las herramientas genómicas previamente mencionadas. Actualmente, este grupo está desarrollando una nueva población de ILs con fondo genético de 'Piel de Sapo' (PS), utilizando como parental donante el melón iraní Queen's pocket melon (ssp. melo grupo Dudaim) (DUD) (Figura 3.1). El grupo Dudaim incluye melones fundamentalmente distribuidos desde Turquía hasta Afganistán. No se utilizan para consumo, sino como ornamentales por su intenso aroma. El aroma de algunas variedades de este grupo se ha analizado recientemente y supone uno de los más complejos y completos de la especie (Esteras et al., 2018). Desarrollan plantas andromonoicas, con frutos climatéricos de pequeño tamaño, forma redondeada, corteza muy fina y lisa de color naranja y manchas marrones, y pulpa blanca con bajo nivel de azúcares.

En este trabajo se presentan 4 líneas de introgresión, con introgresiones genómicas de Dudaim en fondo genético 'Piel de Sapo' (DUD_3-1; DUD_4-2; DUD_6-1 y DUD_6-2) que han sido seleccionadas por presentar características de interés, diferenciales respecto al parental 'Piel de Sapo', como son el desarrollo de la capa de abscisión, la ocurrencia de aroma, el cambio del color de la corteza y de la forma y tamaño del fruto. Estas líneas de premejora resultan de interés como punto de partida para diversificar la oferta de variedades de melón 'Piel de Sapo'.

\subsection{Materiales y métodos}

\subsubsection{Material vegetal}

El material de estudio del presente trabajo son 4 ILs (BC3S4) derivadas del cruce entre el cultivar español PS y DUD (Figura 3.1). Estos parentales fueron seleccionados a partir de la colección de melón del COMAV-UPV, previamente caracterizada (Esteras et al., 2018). El parental PS fue seleccionado como recurrente por representar un tipo de élite en el comercio español, y DUD por presentar características diferenciales de interés. Como se ha comentado anteriormente, ambos parentales presentan características contrastantes en relación al tamaño, forma, textura y color del fruto, contenido en azúcares y aroma de la pulpa, tipo de maduración y duración post cosecha.

\subsubsection{Manejo de Cultivo}

Las generaciones finales de esta colección de ILs se obtuvieron en las instalaciones de la Fundación Cajamar en Paiporta, Valencia (2015-2017). Las condiciones utilizadas para los 


\subsection{CAPÍTULO 3}

ensayos fueron las siguientes: ciclo de cultivo de marzo a julio en invernadero de vidrio con control automático de temperatura (con un rango de 18 a $25^{\circ} \mathrm{C}$ (mínimo) a $35-37^{\circ} \mathrm{C}$ (máximo) durante todo el ciclo de cultivo). Las plantas se cultivaron en bolsas de sustrato de $29 \mathrm{~kg}$ (70\% de fibra de coco y $30 \%$ de chips de coco). En todos los casos, se proporcionaron nutrientes a través del sistema de riego, y la poda se realizó manualmente cuando fue necesario para regular el crecimiento vegetativo y la floración. Para realizar los cruces de forma controlada se realizó hibridación artificial embolsando las flores emasculadas en pre-antesis. Una vez obtenidos frutos suficientes de cada una de las líneas mediante polinización controlada se utilizaron abejorros para poder obtener dos frutos por planta.

\subsubsection{Obtención y selección de líneas}

La F1 del cruce entre PS y DUD se retrocruzó con el parental recurrente PS para obtener la población BC1 y, posteriormente BC2 y BC3. En diversas generaciones se realizó una selección genotípica con el objetivo de reducir el número de introgresiones por línea (y aumentar el porcentaje de fondo genético PS), para lo que se utilizaron las técnicas de genotipado HRM (High Resolution Melting) y Sequenom iPLEX® Gold MassARRAY, siguiendo el protocolo descrito en Perpiñà et al. (2016). Las plantas BC3 seleccionadas fueron sometidas a autofecundaciones sucesivas con la finalidad de eliminar algunas introgresiones en heterocigosis, obteniendo las generaciones $\mathrm{BC} 3 \mathrm{~S} 1, \mathrm{BC} 3 \mathrm{~S} 2, \mathrm{BC} 3 \mathrm{~S} 3$ y $\mathrm{BC} 3 \mathrm{~S} 4$. Esta última generación BC3S4 presenta un porcentaje de fondo genético PS $(91,58 \%)$, y de ella se seleccionaron las 4 líneas objetivo de este trabajo (DUD_3-1; DUD_4-2; DUD_6-1 Y DUD_62), que presentan entre 1 y 2 introgresiones DUD fijadas por línea. Producto de las introgresiones DUD fijadas en el fondo genético PS, estas líneas presentan rasgos de interés, como es la generación de capa de abscisión en los frutos maduros (DUD_3-1; DUD_6-2), el desarrollo de frutos aromáticos (DUD_6-2), redondeados (DUD_4-2) y amarillos en la madurez (DUD_6-1).

\subsubsection{Caracterización de frutos}

Cada ensayo incluyó diez plantas de cada una de estas líneas seleccionadas, que se cultivaron con un diseño completamente aleatorizado junto con diez plantas de cada línea parental (PS y DUD). Los siguientes rasgos se evaluaron para cada fruto: peso del fruto (PF en gramos, con balanza digital), longitud y diámetro del fruto (LF, DF en mm, con regla graduada), índice de la forma del fruto (FF, relación entre la longitud del fruto y el diámetro), firmeza de la pulpa (FP, medida como kg/cm2 con un penetrómetro de presión, FT 327, con un diámetro de émbolo de $8 \mathrm{~mm}$, Alfonsine, Italia), la formación de una capa de abscisión en la zona de unión del fruto 
al pedúnculo y el aroma externo del fruto (CA, AR, evaluados visual y olfativamente como 0 , ausente, y 1, presente), color de la pulpa (CP) (medido con un colorímetro CR-400, Konica Minolta, Inc., Tokio, Japón (coordenadas Hunter Lab: L * luminosidad ( $\mathrm{L}=0$ negro y L $=1$ blanco); a * dirección del color entre rojo (positivo) y verde (negativo); b * dirección del color entre amarillo (positivo) y azul (negativo)). Para el color de la corteza (CC) se utilizó el mismo método descrito anteriormente para la pulpa y solo se tomó medición de la línea que presentaba el cambio de color. La concentración de sólidos solubles (CSS) se midió en la región ecuatorial del fruto (medido como ${ }^{\circ}$ Brix a partir de gotas de zumo con un refractómetro de mano "Pocket" (PAL- $\alpha$ ), Atago CO., LTD, Tokio, Japón).

\subsubsection{Análisis estadístico}

Para el tratamiento estadístico se usó el programa informático IBM SPSS Statistics 25.0. En el análisis de datos se usó el test de Dunnett, con el que la media de cada IL se comparó con el parental recurrente PS utilizado como control.

\subsection{Resultados y discusión}

En la caracterización de la población BC3S4 se identificaron ILs con efectos significativos con respecto al parental PS para algunos rasgos específicos de interés, como la ocurrencia de capa de abscisión y de aroma, la forma redondeada del fruto y el color amarillo de la corteza, siendo similares en el resto de carácteres al parental 'Piel de Sapo' (Tablas 3.1, 3.2 y 3.3). Estas diferencias son debidas a las introgresiones fijadas de DUD en el fondo genético PS. Así en las líneas DUD_3-1 y DUD_6-2, con introgresiones DUD en los cromosomas III y VI, respectivamente, se evidenció la ocurrencia de capa de abscisión durante el proceso de maduración (Figura 3.2 A). Este resultado es coherente con estudios anteriores en los que se identificaron genes implicados en la maduración del fruto en esas regiones, pero provenientes del cultivar coreano "Songwan Charmi” (Vegas, Garcia-Mas, \& Monforte, 2013). El desarrollo de la capa de abscisión en DUD_3-1 no fue acompañado de una menor firmeza de la pulpa, lo que suele ocurrir en los frutos de maduración climatérica. De hecho, esta línea sólo difirió de PS en sus frutos de menor tamaño. Los frutos de DUD_6-2 presentaron una reducción similar del peso, aunque mayor de la longitud, resultando en frutos de forma más ovalada (Figura 3.2 D). También fueron aromáticos y con menor firmeza de la pulpa. La línea DUD_4-2, con introgresiones en los cromosomas IV y XII, fue la que presentó una mayor reducción del peso del fruto, y sobre todo de la longitud del mismo (cercana al 40\%) respecto a PS, adquiriendo el fruto una forma redondeada con apariencia de mini melones 'Piel de Sapo' (Figura 3.2 B). La 


\subsection{CAPÍTULO 3}

línea DUD_6-1, con introgresión en el cromosoma VI, presentó un color de la corteza amarillo en la madurez (Figura 3.2 C). 


\subsection{Anexos}

Tabla 3.1. Comparación de medias de las líneas DUD_3-1, DUD_4-2, DUD_6-1 y DUD_62 para los carácteres relacionados con el tamaño y la forma del fruto.

\begin{tabular}{|c|c|c|c|c|c|c|c|c|c|c|c|}
\hline \multirow{2}{*}{ LÍNEA } & \multicolumn{3}{|c|}{ PF (g) } & \multicolumn{3}{|c|}{$\mathbf{L F}(\mathbf{m m})$} & \multicolumn{2}{|c|}{$\mathbf{A F}(\mathbf{m m})$} & \multicolumn{3}{|c|}{ FF } \\
\hline & Media & $\mathrm{EEM}^{1}$ & Sig. & Media & EEM & Sig. & Media & EEM Sig. & Media & EEM & Sig \\
\hline PS & 1739,50 & 95,12 & & 224,15 & 5,37 & & 126,9 & 2,69 & 1,77 & 0,04 & \\
\hline DUD & 257,10 & 13,88 & & 78,95 & 2,07 & & 77,3 & 1,28 & 1,02 & 0,02 & \\
\hline DUD_3-1 & 1344,48 & 79,75 & $*$ & 197,37 & 4,47 & $*$ & 118,44 & 2,29 & 1,67 & 0,03 & \\
\hline DUD_4-2 & 1020,88 & 93,97 & $*$ & 137,13 & 5,78 & $*$ & 119,06 & 3,52 & 1,15 & 0,03 & $*$ \\
\hline DUD_6-1 & 2121,25 & 143,16 & & 227,75 & 6,3 & & 139,5 & 3,46 & 1,64 & 0,04 & \\
\hline DUD_6-2 & 1262,58 & 71,28 & $*$ & 162,42 & 3,35 & $*$ & 125,11 & 2,55 & 1,30 & 0,03 & * \\
\hline
\end{tabular}

Tabla 3.2. Comparación de medias de las líneas DUD_3-1, DUD_4-2, DUD_6-1 y DUD_6-2 para los carácteres relacionados con la maduración del fruto.

\begin{tabular}{|c|c|c|c|c|c|c|c|c|c|}
\hline \multirow{2}{*}{ LÍNEA } & \multicolumn{3}{|c|}{$\mathrm{FP}(\mathrm{Kg} / \mathrm{cm})$} & \multicolumn{3}{|c|}{$\mathbf{A R}$} & \multicolumn{3}{|c|}{ CA } \\
\hline & Media & EEM $^{1}$ & Sig. & Media & EEM & Sig. & Media & EEM & Sig. \\
\hline PS & 1,73 & 0,13 & & 0 & 0 & & 0 & 0 & \\
\hline DUD & 0,76 & 0,08 & & 1 & 0 & & 1 & 0 & \\
\hline DUD_3-1 & 1,59 & 0,13 & & 0 & 0 & & 0,85 & 0,07 & $*$ \\
\hline DUD_4-2 & 2,07 & 0,13 & & 0 & 0 & & 0 & 0 & \\
\hline DUD_6-1 & 1,97 & 0,18 & & 0 & 0 & & 0 & 0 & \\
\hline DUD_6-2 & 0,74 & 0,17 & $*$ & 0,58 & 0,12 & $*$ & 0,84 & 0,09 & $*$ \\
\hline
\end{tabular}

$(*)$ Diferencias significativas basadas en el test de Dunnett $(\mathrm{p} \leq 0,05)$ entre las líneas y PS

${ }^{1}$ Error estándar de la media 


\subsection{CAPÍTULO 3}

Tabla 3.3. Comparación de medias de las líneas DUD_3-1, DUD_4-2, DUD_6-1 y DUD_6-2 para los carácteres relacionados con el color de la pulpa y corteza y el contenido de sólidos solubles.

\begin{tabular}{|c|c|c|c|c|c|c|c|c|c|c|c|c|c|c|c|c|c|c|c|c|c|}
\hline \multirow{2}{*}{ LÍNEA } & \multicolumn{3}{|c|}{ HI (Pulpa) } & \multicolumn{3}{|c|}{ a (Pulpa) } & \multicolumn{3}{|c|}{ b (Pulpa) } & \multicolumn{3}{|c|}{ CSS ( ${ }^{\circ}$ Brix) } & \multicolumn{3}{|c|}{ HI (Corteza) } & \multicolumn{3}{|c|}{ a (Corteza) } & \multicolumn{3}{|c|}{ b (Corteza) } \\
\hline & Media & $\mathrm{EEM}^{1}$ & Sig. & Media & EEM & Sig. & Media & EEM & Sig. & Media & EEM & Sig. & Media & EEM & Sig. & Media & EEM & Sig. & Media & EEM & Sig. \\
\hline PS & 62,19 & 1,39 & & $-2,03$ & 0,1 & & 9,54 & 0,39 & & 12,97 & 0,49 & & 29,98 & 0,79 & & $-1,41$ & 0,3 & & 11,64 & 0,71 & \\
\hline DUD & 70,76 & 0,93 & & $-0,97$ & 0,11 & & 9,55 & 0,36 & & 8,18 & 0,16 & & & & & & & & & & \\
\hline DUD_3-1 & 57,86 & 1,07 & & $-2,06$ & 0,11 & & 10,25 & 0,38 & & 13,81 & 0,47 & & & & & & & & & & \\
\hline DUD_4-2 & 62,47 & 0,69 & & $-2,01$ & 0,12 & & 11,49 & 0,4 & $*$ & 11,5 & 0,51 & & & & & & & & & & \\
\hline DUD_6-1 & 62,56 & 1,48 & & $-1,77$ & 0,13 & & 9,1 & 0,5 & & 13,23 & 0,63 & & 47,23 & 3,09 & $*$ & $-2,97$ & 0,83 & $*$ & 24,62 & 3,13 & $*$ \\
\hline DUD_6-2 & 61,38 & 1,84 & & $-2,17$ & 0,14 & & 10,23 & 0,41 & & 14,07 & 0,62 & & & & & & & & & & \\
\hline
\end{tabular}

(*) Diferencias significativas basadas en el test de Dunnett $(\mathrm{p}<0,05)$ entre las líneas y PS.

Error estándar de la media 


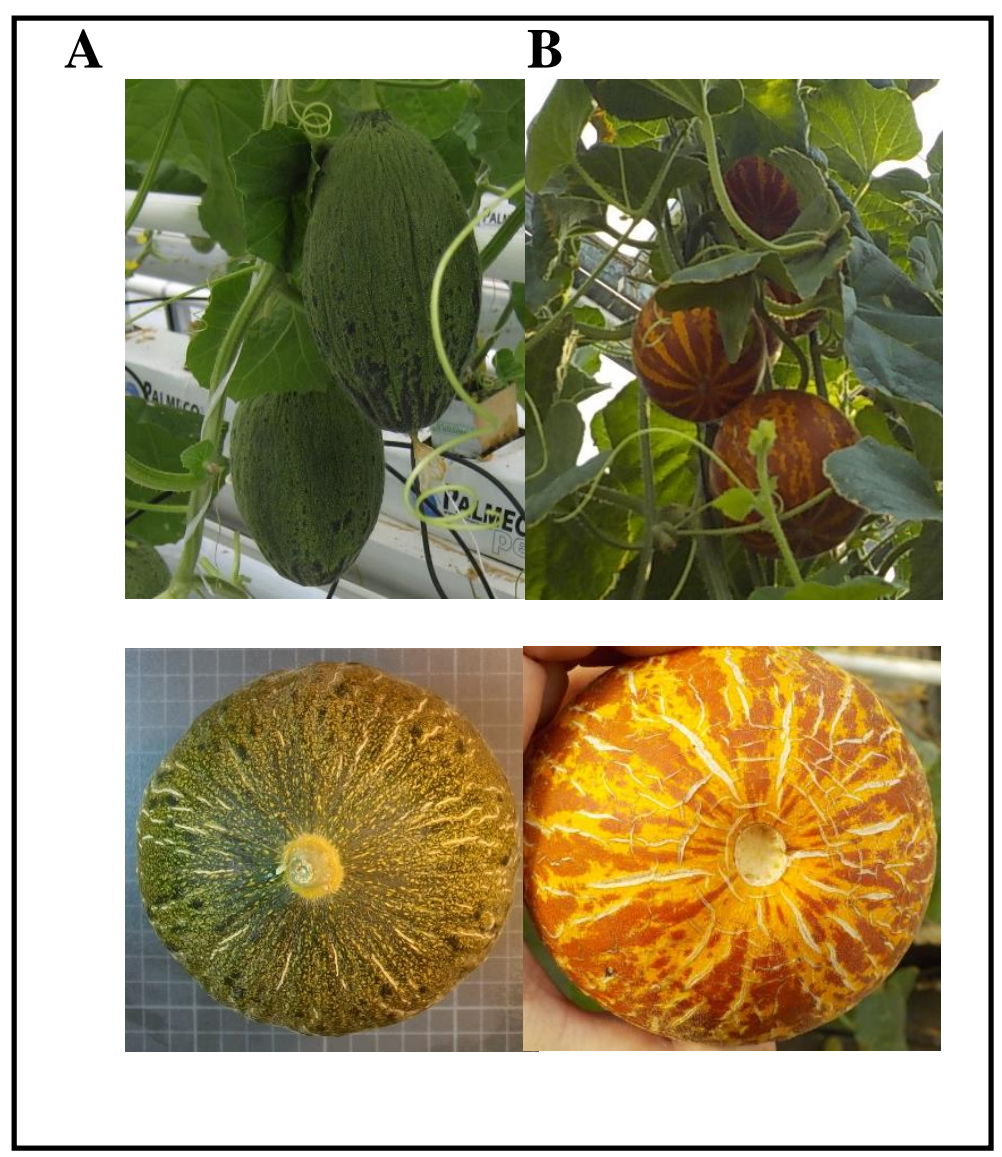

Figura 3.1. Parentales utilizados para la creación de la población de líneas de introgresión desarrollada en el fondo genético 'Piel de Sapo' (A), utilizando como donante un melón asiático perteneciente al grupo Dudaim (B). Arriba se muestran los frutos en planta y abajo un detalle de los mismos, donde se observa la formación de la capa de abscisión de Dudaim ausente en el melón no climatérico 'Piel de Sapo'. 


\subsection{CAPÍTULO 3}

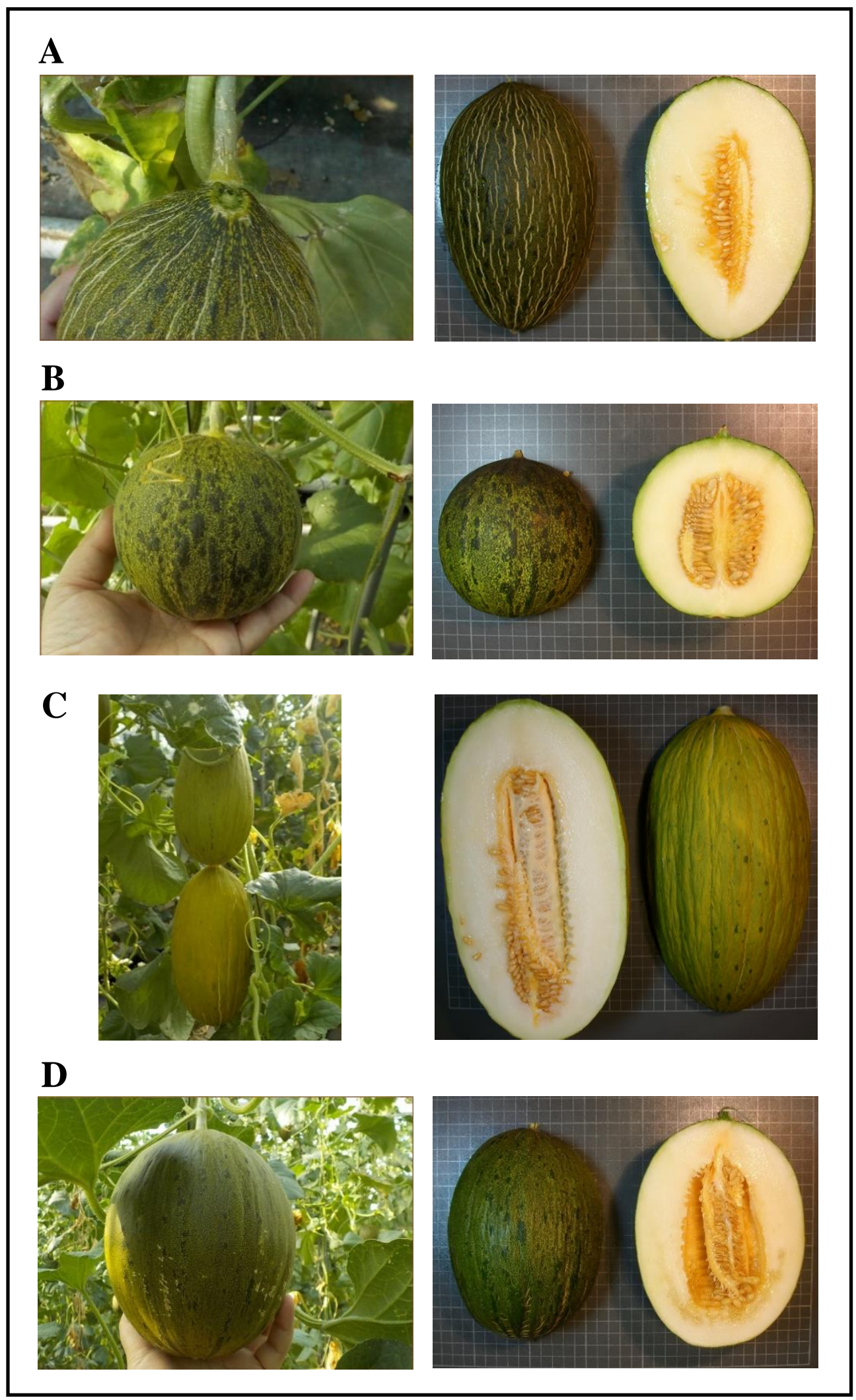

Figura 3.2. A. Frutos DUD_3-1 con capa de abscisión. B. Frutos DUD_4-2 forma redondeada. C. Frutos DUD_6-1 con corteza amarilla. D. Frutos DUD_6-2 con capa de abscisión, aroma externo, forma ovalada y maduración temprana. 


\subsection{Referencias}

Casacuberta, J., Puigdomènech, P., \& García-Mas, J. (2017). The melon genome. In: R. Grumet, N. Katzir, \& J. Garcia-Mas. (Eds.), Genetics and genomics of Cucurbitaceae (Vol. 20, pp. 173-181). Cham, Switzerland: Springer Nature.

Díaz, A., Forment, J., Argyris, J. M., Fukino, N., Tzuri, G., Harel-Beja, R., .. Monforte, A. J. (2015). Anchoring the consensus ICuGI genetic map to the melon (Cucumis melo L.) genome. Molecular Breeding, 35(10), 188.

Eduardo, I., Arús, P., \& Monforte, A. J. (2005). Development of a genomic library of near isogenic lines (NILs) in melon (Cucumis melo L.) from the exotic accession PI161375. Theoretical and applied genetics, 112(1), 139-148.

Esteras, C., Rambla, J. L., Sánchez, G., López-Gresa, M. P., González-Mas, M. C., FernandézTrujillo, J. P., ... Picò, M. B. (2018). Fruit flesh volatile and carotenoid profile analysis within the Cucumis melo L. species reveals unexploited variability for future genetic breeding. Journal of the Science of Food and Agriculture, 98(10), 3915-3925.

FAOSTAT. (2017). Food and Agriculture Organization Corporate Statistical Database. Retrieve from http://faostat3.fao.org/home/S [Acceso on 07 Enero 2017]

Gonzalo, M. J., \& Monforte, A. J. (2017). Genetic mapping of complex traits in cucurbits. In: R. Grumet, N. Katzir, \& J. Garcia-Mas. (Eds.), Genetics and genomics of Cucurbitaceae (Vol. 20, pp. 269-290). Cham, Switzerland: Springer Nature.

Kirkbride, J. H. (1993). Biosystematic monograph of the genus Cucumis (Cucurbitaceae). Boone, USA: Parkway.

Lázaro, A., Fernández, I. C., Borrero, M. J., Cabello, F., López-Sesé, A. I., Gómez-Guillamón, M. L., \& Picò, B. (2017). Agromorphological genetic diversity of Spanish traditional melons. Genetic resources and crop evolution, 64(7), 1687-1706.

MAPAMA (Ministerio de Agricultura, Pesca, Alimentación y Medio Ambiente). Anuario de Estadística. (2016). Recuperado de http://www.mapama.gob.es/es/. Acceso 08 Enero 2017. Perpiñà, G., Esteras, C., Gibon, Y., Monforte, A. J., \& Picò, B. (2016). A new genomic library of melon introgression lines in a cantaloupe genetic background for dissecting desirable agronomical traits. BMC Plant Biology, 16(1), 154.

Pitrat, M. (2017). Melon genetic resources: phenotypic diversity and horticultural taxonomy. In: R. Grumet, N. Katzir, \& J. Garcia-Mas. (Eds.), Genetics and genomics of Cucurbitaceae (Vol. 20, pp. 25-59). Cham, Switzerland: Springer Nature.

Vegas, J., Garcia-Mas, J., \& Monforte, A. J. (2013). Interaction between QTLs induces an advance in ethylene biosynthesis during melon fruit ripening. Theoretical and Applied Genetics, 126(6), 1531-1544. 

3.4 Capítulo 4 



\section{A 'Mini PS': A new small rounded 'Piel de Sapo' breeding line derived from Dudaim melon.}

Castro, G., Perpiñà, G., Picò, B., Esteras, C. (2019). A'Mini PS': a new small rounded 'Piel de Sapo' breeding line derived from Dudaim melon. Article submitted for publication.

De entre las ILs con mejores características para el desarrollo de nuevas variedades se seleccionó la ILDUD_4-2, cuyo fenotipo se analizó en ambientes adicionales confirmandose sus características de interés para el desarrollo de nuevas variedades de tipo 'Piel de Sapo' Los resultados se han enviado a publicar a una revista SCI del sector, Horticultural Science, la cual es una revista internacional especializada en aspectos de genética y mejoramiento vegetal

Este trabajo es el resultado de mi participación en los proyectos Plant KBBE (SAFQIM: PIM2010PKB-00691), SUGARS AND FRUIT QUALITY IN MELON, AGL2014-53398-C2-2-R, APROXIMACIONES BIOTECNOLÓGICAS Y CULTURALES PARA LA MEJORA DE LAS RESISTENCIAS Y EL CONTROL DE ENFERMEDADES EN MELÓN Y SANDÍA, y AGL2017-85563-C2-1-R, CONTROL MULTIDISCIPLINAR DE ENFERMEDADES FUNGICAS Y VIROSIS EN MELON Y SANDIA: UN NUEVO RETO, financiados por el Ministerio de Economía, Industria y Competitividad y por el Ministerio de Ciencias, Innovación y Universidades (cofinanciados con fondos FEDER). 



\subsection{A 'Mini PS': A new small rounded 'Piel de Sapo' breeding line derived from Dudaim melon}

Castro, G., Perpiñà, G., Picò, B.; Esteras, C.

Submitted to Horticultural Science

\subsection{Introduction}

Melon, Cucumis melo L., is one of the most important crops worldwide. This species exhibits high phenotypic diversity regarding morphological, physiological and biochemical aspects including fruit size and shape, rind and flesh color, and organoleptic properties (Burger et al., 2010; Esteras et al., 2018; Pitrat, 2017;).

Apart from the extant diversity, the rapid development of molecular tools is allowing important advances in melon breeding programs. Most of them aim to design strategies to modify the expression of specific traits, usually controlled by several genes and to some point influenced by environmental conditions (Quantitative Trait Loci, QTL), that improve fruit quality in response to new consumer demands (Fernández-Trujillo, Picò, Garcia-Mas, Alvarez, \& Monforte, 2011; Gur et al., 2017). One of the strategies for the production of new varieties is the development of introgression lines (ILs). ILs are usually generated by backcrossing and marker assisted selection, introgressing pieces of an exotic genome on an elite genetic background (Pereira et al., 2018; Perpiñà, Esteras, Gibon, Monforte, \& Picò, 2016; Zamir, 2001). Ideally, each IL carries one or few selected introgressions with exotic alleles that lead to favourable phenotypes in some specific traits, but that do not alter other features of the elite genotype (Eduardo et al., 2007; Perpiñà et al., 2016; Perpiñà, Cebolla-Cornejo, Esteras, Monforte, Picò, 2017).

Based on the last intraspecific classification by Pitrat (2017), 'Piel de Sapo' (PS) melons, the most important class in the Spanish market and very popular in all the Mediterranean area, are considered a sub-group of the horticultural Ibericus group of melons. PS fruits are large, elongated, without ribs and vein tracts, and no or slightly netted. They are characterized by having thick rind, which is green with yellow speckles and dark-green spots, thick white juicy flesh with high sugar content and low aroma, and late non-climacteric ripening behavior associated to long shelf life (Pitrat, 2017).

In this work, we present a breeding line derived from the introgression line DUD_4-2 (Castro, Perpiñà, Monforte, Picò, Esteras, 2019), selected from a ILs collection generated using the Spanish cv. Piñonet, a PS melon (ssp. melo, group Ibericus), as the recurrent parent, and the 


\subsection{CAPÍTULO 4}

Asian accession PI 273438, known as Queen's pocket melon (DUD) (ssp. melo, group Dudaim), as donor parent. This exotic group of melons is mainly characterized by its round and small, white-fleshed climacteric fruits, with a characteristic thin rind, yellow to orange with ochre stripes, and its strong external aroma. For their differential and exotic features, Dudaim melons are interesting genetic resources to diversify melon cultivars. The DUD introgressions in this PS breeding line caused a significant decrease in the fruit size and changed its shape and some rind features in comparison to PS, so it has been denominated 'Mini PS'.

\subsection{Materials and Methods}

'Mini PS' was selected after several selfing cycles from the IL DUD_4-2, a BC3S3 generation obtained from the cross PS x DUD after three backcrosses and three selfing generations, using marker assisted selection. The parental IL DUD_4-2 was genotyped using genotyping by sequencing (GBS) (Castro et al., 2019) and so, it is known to have a $84.6 \%$ of PS genetic background with two major homozygous DUD introgressions in chromosomes 4 (23.80 Mb) and $12(20.36 \mathrm{Mb})$, and several minor introgressions on chromosomes 1, 4, 5, 7 and 10 (from 6 Kbp to 3.2 Mbp long) (Table 4.1).

Three characterization assays were carried out at the Cajamar Foundation under greenhouse conditions during 3 years (2016, 2017 and 2018). EighteenTwelve plants were characterized for each 'Mini PS', as well as for parentals PS and DUD. Greenhouse conditions of each phenotyping assays were as follows: growing season from March to July in a glass greenhouse with automatic temperature control with cooler and automatic window aperture (with a temperature range of 25 to $35^{\circ} \mathrm{C}$, minimum and maximum during the whole growing season for the three environments). Plants were grown in substrate bags of $29 \mathrm{~kg}$ (70 \% coconut fiber and $30 \%$ coconut chips), and nutrients were provided through the irrigation system. Pruning was done manually when necessary to regulate vegetative growth and flowering. Two fruits per plant were set and characterized at full maturity based on the methodology described by Perpiñà et al. (2016) on the following traits: fruit weight (FW, in grams), fruit shape index (FS, as the ratio of fruit length to fruit diameter), cavity width $(\mathrm{CW}$, as the ratio of the width of the seminal cavity to the fruit diameter), flesh and rind thickness (Fth, Rth in millimetres), rind and flesh firmness (RF, FF, measured with penetrometer as $\mathrm{kg} / \mathrm{cm}^{2}$ ), flesh color (FCHl, FCa, FCb; HL, a and $\mathrm{b}$ coordinates measured with colorimeter), soluble solids content (SSC, measured as Brix degrees). Also a sensory evaluation was carried out for the fruit external aroma (AR), the formation of an abscission layer (AL) and the netting occurrence on rind (NET) using a scale 0-1 (0, absent and 1, present). 
We used the ANOVA analysis to identify significant differences between 'Mini PS' fruits and those of the recurrent parent PS ( $p$-value>0.05). In the case of qualitative traits scaled $0-1$ with no variances the t-test was employed.

\subsection{Results and discussion}

Differences on vine development and flowering time between 'Mini PS' plants and 'Piñonet' 'Piel de Sapo' were not noticed in greenhouse assays. Phenotypic data for 'Mini PS' fruit traits assessed in comparison to PS are shown in Table 4.2. Despite the clear differences between the parents, DUD and PS, 'Mini PS' fruits did not differ from PS in most flesh features and ripening behaviour. In fact, 'Mini PS' flesh color (FCH1, FCa and FCb) and rind and flesh firmness (RF, FF) did not differ significantly from the recurrent parent PS in any of the environments. Regarding to the ripening behaviour and associated traits, 'Mini PS' did not develop an abscission layer (AL) and show no external aroma (AR), features typical of the PS nonclimacteric behaviour.

The main new and interesting characteristics in this cultivar were related to fruit size and shape, which were significantly different from PS in the three assays (Figure 4.1, Table 4.2). 'Mini PS' presented a significant reduction in FW $(-51.48 \%,-41.3 \%$ and $-52.2 \%$, in 2016, 2017 and 2018, respectively). The fruit shape parameter also was significantly lower, and fruits were consequently rounder than PS $(-26.59 \%,-35.1 \%$ and $-27.4 \%$, in 2016, 2017 and 2018, respectively). Additionally, seed cavity width $(\mathrm{CW})$, also related to shape, was somewhat higher than PS in all environments (13.16\%, 21.4\% and 29.7\%, in 2016, 2017 and 2018, respectively), and associated to a slight reduction of flesh thickness $(-26.96 \%,-20.2 \%$ and $35.1 \%$, in 2016, 2017 and 2018, respectively). 'Mini PS' fruits displayed a rind slightly thinner than that of PS melons $(-49.98 \%,-18.5 \%$ and $-35.5 \%$ in Rth in 2016, 2017 and 2018, respectively), but much thicker than that of DUD melons (Table 4.2). Although these 'Mini PS' melons were as sweet as PS in 2016 and 2017, they showed a significant slight decrease in SSC of $16.2 \%$ in 2018 (Table 4.2).

Fruit quality has a complex biological basis, involving many aspects not only related to internal or external appearance, but also to other traits such as aroma, flavour, presence and amount of nutrients, texture, etc. Nowadays, improving for quality traits is one of the main objectives in breeding programs, and market preferences must guide breeding efforts (Fernández- Trujillo et al., 2011). For instance, PS is a melon cultivar widely consumed in the Mediterranean area, but its large size can be a negative aspect for its commercialization since individual consumption is a current tendency, and families tend to be smaller than before. Therefore, the decrease in weight reported in the 'Mini PS' breeding line (FW in the range from $750 \mathrm{~g}$ to $1 \mathrm{~kg}$ ) might be 


\subsection{CAPÍTULO 4}

of great interest in some markets. Fruit weight reduction is associated to a slightly thinner rind (only $30.76 \%$ reduction, on average, in comparison to PS), but as the rind is still much wider than that of the DUD parental it does not seem an inconvenient for marketing and storing. This breeding line also presents a rounder shape, which might be singular for consumers that are used to associate round shape to honeydew or cantaloupe melons, but not to PS types. Interestingly, 'Mini PS' shows typical PS features regarding other important traits such as flesh color and firmness, rind netting and ripening behaviour. Also flesh sweetness remains similar, as only in one assay was detected a significant decrease (Table 4.2). Moreover, despite DUD melons are quite low sweet (SSC ranging from 5 to 8 Brix degrees), 'Mini PS' reaches 10-12 Brix degrees, which is in the range of commercial sweet melons. This trait should be further studied to check that this result in 2018 is not consistent, since the environment influence on sweetness is well known.

From a breeding point, this line is providing information about the genomic regions from DUD that control fruit weight, shape and rind and flesh thickness. QTL analysis performed on the whole ILs population in (Castro et al., 2019) allowed the detection of QTLs for FS and Rth in chromosome 4 ( $f s .4$, rth.4), as well as for FS in chromosome 12 (fs. 12). Previous studies using other populations supported the fruit shape-related QTLs on chromosome 4 (merged map by Díaz et al., 2015, 2017; Ramamurthy \& Waters, 2015), and on chromosome 12 (meta-QTL reported by Monforte, Díaz, Caño-Delgado, \& van der Knaap, 2014).

In conclusion, this breeding line provides fruits with a smaller size than 'Piel de Sapo', suitable for individual consumption based on current market preferences, and rounder, which can generate new interest on consumers, but retaining the specific organoleptic properties of PS. These new characteristics make the 'Mini PS' an ideal candidate for future breeding programs aimed to obtain new commercial cultivars. 


\subsection{Supporting information}

Table 4.1. Dudaim introgressions longer than 5Kbp carried by the line DUD_4-2 based on previous genotyping assays by GBS.

\begin{tabular}{cccc}
\hline Chromosome & Introgression beginning & Introgression end & Introgression length in Mbp $^{2}$ \\
\hline 1 & $17,907,410$ & $18,139,390$ & 0.232 \\
1 & $29,386,854$ & $29,476,577$ & 0.090 \\
4 & 818,265 & 824,121 & 0.006 \\
4 & $2,371,829$ & $26,172,343$ & 23.801 \\
4 & $26,406,871$ & $29,633,631$ & 3.227 \\
4 & $33,740,656$ & $33,802,086$ & 0.061 \\
5 & $3,464,043$ & $3,566,438$ & 0.102 \\
7 & $25,630,902$ & $25,663,347$ & 0.032 \\
10 & $4,018,447$ & $4,044,092$ & 0.026 \\
10 & $5,521,968$ & $6,176,206$ & 0.654 \\
12 & $1,010,436$ & $21,367,892$ & 20.357
\end{tabular}

${ }^{1}$ Melon genome assembly v. 3.6.1

${ }^{2}$ Mega basis pairs

Table 4.2. Mean value and standard deviation, along with statistical results for means comparison between both parents, 'Piel de Sapo' (PS) and Dudaim (DUD), for each trait assessed in the three trials in which 'Mini PS' was phenotyped: the formation of an abscission layer (AL), sensory evaluation was carried out for the fruit external aroma (AR), rind and flesh firmness (RF, FF, measured with penetrometer as $\left.\mathrm{kg} / \mathrm{cm}^{2}\right)$, fruit weight ( $\mathrm{FW}$, in grams), fruit shape index (FS, as the ratio of fruit length to fruit diameter), cavity width (CW, as the ratio of the width of the seminal cavity to the fruit diameter), flesh and rind thickness (Fth, Rth in millimetres), the netting occurrence on rind (NET) using a scale 0-1 (0, absent and 1, present), flesh color (FCHl, FCa, FCb; HL, a and b coordinates measured with colorimeter), and soluble solids content (SSC, measured as Brix degrees). Asterisk $(*)$ indicates a significant difference ( $p$-value>0.05) with respect to PS based on the ANOVA test. Positive symbol $(+)$ indicates significant difference ( $p$-value $>0.05$ ) with respect to PS based on the t-student analysis for populations with no variances.

\begin{tabular}{|c|c|c|c|c|c|c|c|c|}
\hline \multirow{2}{*}{ Trait $^{1}$} & \multirow{2}{*}{ Trial } & \multicolumn{2}{|c|}{ PS } & \multicolumn{2}{|c|}{ DUD } & \multicolumn{3}{|c|}{ 'Mini PS' } \\
\hline & & Mean & $\mathbf{S D}^{2}$ & Mean & SD & Mean & SD & Phenotype effect (\%) \\
\hline \multirow{3}{*}{$\mathbf{A L}$} & 2016 & 0.00 & 0.00 & $1.00^{+}$ & 0.00 & 0.00 & 0.00 & - \\
\hline & 2017 & 0.00 & 0.00 & $1.00^{+}$ & 0.00 & 0.00 & 0.00 & - \\
\hline & 2018 & 0.00 & 0.00 & $1.00^{+}$ & 0.00 & 0.00 & 0.00 & - \\
\hline \multirow{3}{*}{$\mathbf{A R}$} & 2016 & 0.00 & 0.00 & $1.00^{+}$ & 0.00 & 0.00 & 0.00 & - \\
\hline & 2017 & 0.00 & 0.00 & $1.00^{+}$ & 0.00 & 0.00 & 0.00 & - \\
\hline & 2018 & 0.00 & 0.00 & $1.00^{+}$ & 0.00 & 0.00 & 0.00 & - \\
\hline \multirow{3}{*}{$\mathbf{R F}$} & 2016 & 13.00 & 0.00 & $2.35^{*}$ & 1.94 & 13.00 & 0.00 & - \\
\hline & 2017 & 13.00 & 0.00 & $7.23 *$ & 3.21 & 13.00 & 0.00 & - \\
\hline & 2018 & 13.00 & 0.00 & 4.78 & 1.90 & 13.00 & 0.00 & - \\
\hline \multirow{3}{*}{ FF } & 2016 & 2.27 & 1.19 & $0.83 *$ & 0.52 & 1.93 & 0.55 & - \\
\hline & 2017 & 1.73 & 0.57 & $0.75^{*}$ & 0.34 & 2.18 & 0.65 & - \\
\hline & 2018 & 4.28 & 1.05 & $1.46^{*}$ & 0.50 & 3.90 & 0.75 & - \\
\hline
\end{tabular}




\subsection{CAPÍTULO 4}

Table 4.2 (Continued)

\begin{tabular}{|c|c|c|c|c|c|c|c|c|}
\hline \multirow{2}{*}{ Trait $^{1}$} & \multirow{2}{*}{ Trial } & \multicolumn{2}{|c|}{ PS } & \multicolumn{2}{|c|}{ DUD } & \multicolumn{3}{|c|}{ 'Mini PS' } \\
\hline & & Mean & $\mathbf{S D}^{2}$ & Mean & SD & Mean & SD & Phenotype effect (\%) \\
\hline \multirow{3}{*}{ FW } & 2016 & 1591.93 & 614.54 & $170.50 *$ & 56.56 & $772.33 *$ & 193.17 & -51.48 \\
\hline & 2017 & 1739.50 & 425.39 & $257.10^{*}$ & 62.07 & $1020.87 *$ & 375.88 & -41.31 \\
\hline & 2018 & 1741.00 & 147.56 & $186.80 *$ & 40.90 & $832.71 *$ & 277.23 & -52.17 \\
\hline \multirow{3}{*}{ FS } & 2016 & 1.66 & 0.18 & $1.01 *$ & 0.06 & $1.22 *$ & 0.04 & -26.59 \\
\hline & 2017 & 1.77 & 0.18 & $1.02 *$ & 0.08 & $1.15^{*}$ & 0.11 & -35.13 \\
\hline & 2018 & 1.68 & 0.13 & $1.08 *$ & 0.12 & $1.22 *$ & 0.09 & -27.45 \\
\hline \multirow{3}{*}{ CW } & 2016 & 0.38 & 0.03 & $0.54 *$ & 0.05 & $0.43 *$ & 0.03 & 13.16 \\
\hline & 2017 & 0.37 & 0.02 & $0.52 *$ & 0.05 & $0.45^{*}$ & 0.05 & 21.37 \\
\hline & 2018 & 0.37 & 0.10 & $0.57 *$ & 0.05 & $0.48 *$ & 0.05 & 29.68 \\
\hline \multirow{3}{*}{ Fth } & 2016 & 29.64 & 3.96 & $9.41 *$ & 1.03 & $21.65^{*}$ & 0.73 & -26.96 \\
\hline & 2017 & 29.53 & 4.08 & $11.64 *$ & 2.46 & $23.57 *$ & 4.03 & -20.18 \\
\hline & 2018 & 33.28 & 5.62 & $10.60 *$ & 0.98 & $21.58 *$ & 4.56 & -35.15 \\
\hline \multirow{3}{*}{ Rth } & 2016 & 3.56 & 1.02 & $1.51^{*}$ & 0.20 & $1.78 *$ & 0.17 & -50.00 \\
\hline & 2017 & 3.17 & 0.46 & $1.90 *$ & 0.21 & $2.58 *$ & 0.34 & -18.50 \\
\hline & 2018 & 4.08 & 0.25 & $1.42 *$ & 0.39 & $3.11 *$ & 0.66 & -23.77 \\
\hline \multirow{3}{*}{ NET } & 2016 & 0.13 & 0.35 & 0.00 & 0.00 & 0.33 & 0.58 & - \\
\hline & 2017 & 0.30 & 0.47 & $0.00^{+}$ & 0.00 & 0.25 & 0.68 & - \\
\hline & 2018 & 0.75 & 0.50 & $0.00^{+}$ & 0.00 & 0.57 & 0.50 & - \\
\hline \multirow{3}{*}{ FCHI } & 2016 & 61.62 & 5.61 & 53.44 & 17.90 & 59.61 & 2.09 & - \\
\hline & 2017 & 62.19 & 6.20 & $70.76^{*}$ & 4.15 & 62.30 & 2.79 & - \\
\hline & 2018 & 51.83 & 4.38 & $67.42 *$ & 2.07 & 55.64 & 5.88 & - \\
\hline \multirow{3}{*}{ FCa } & 2016 & -3.01 & 1.38 & $-0.22 *$ & 0.68 & -2.04 & 0.27 & - \\
\hline & 2017 & -2.03 & 0.45 & $-0.97 *$ & 0.50 & -2.01 & 0.48 & - \\
\hline & 2018 & -2.28 & 0.66 & $-0.91 *$ & 0.25 & -2.60 & 1.07 & - \\
\hline \multirow{3}{*}{ FCb } & 2016 & 11.41 & 1.98 & $5.03 *$ & 5.16 & 11.16 & 1.63 & - \\
\hline & 2017 & 9.54 & 1.76 & 9.55 & 1.60 & 11.28 & 1.38 & - \\
\hline & 2018 & 10.99 & 1.24 & 9.96 & 1.19 & 10.13 & 1.67 & - \\
\hline \multirow{3}{*}{ SSC } & 2016 & 12.67 & 1.46 & $8.58 *$ & 1.26 & 11.87 & 0.59 & -6.31 \\
\hline & 2017 & 11.91 & 1.15 & $8.18^{*}$ & 0.73 & 12.23 & 1.44 & -11.33 \\
\hline & 2018 & 12.00 & 0.56 & $5.08 *$ & 0.38 & $10.06^{*}$ & 0.65 & -26.15 \\
\hline
\end{tabular}

${ }^{1}$ Traits: Traits phenotyped for each plant.

${ }^{2}$ SD: Standard deviation 


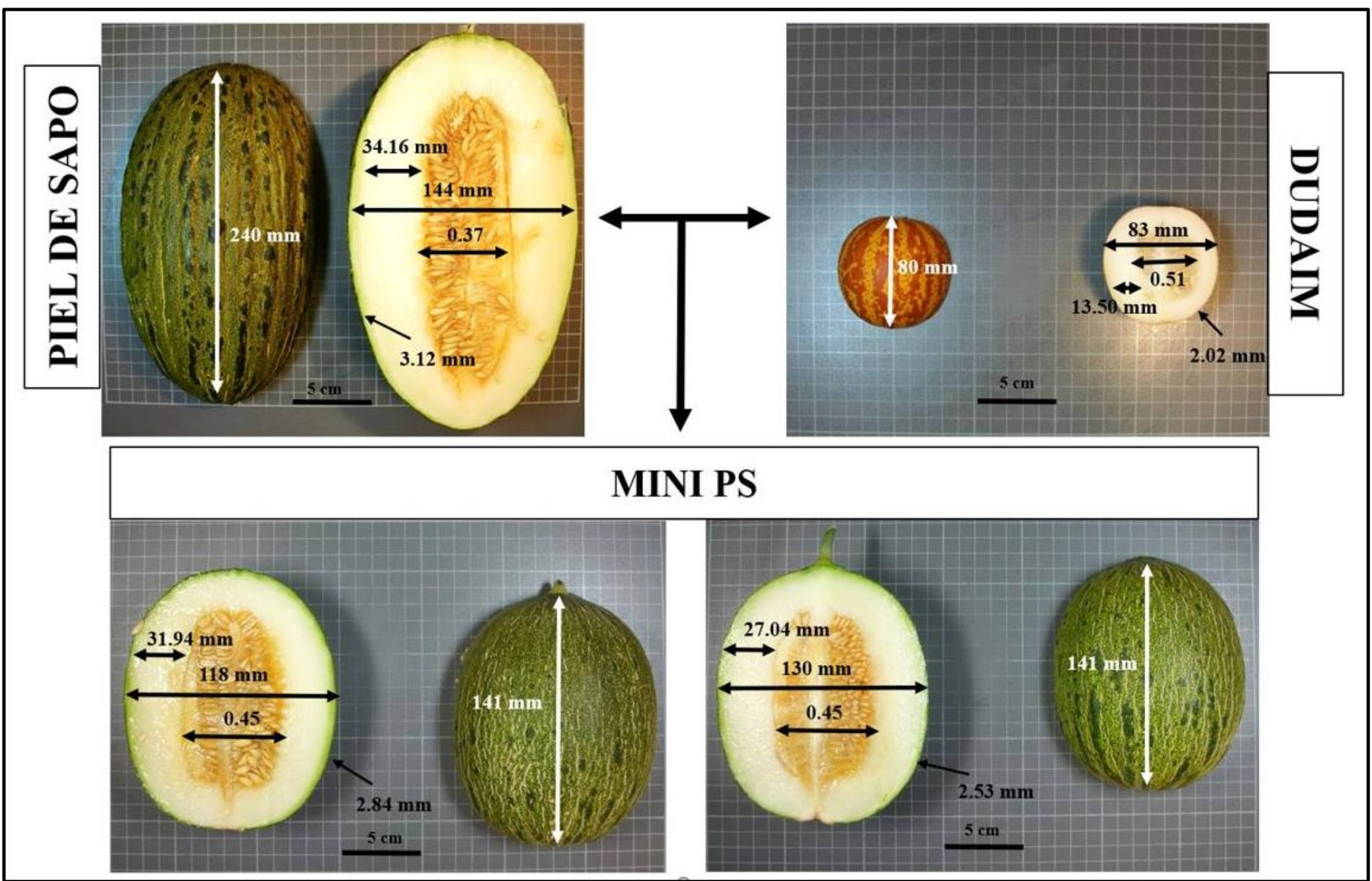

Figura 4.1. Variation of fruit morphology in 'Mini PS' caused by the DUD introgressions in the genetic background of PS affecting the FW, FS, CW, Rth and Fth. 


\subsection{CAPÍTULO 4}

\subsection{References}

Burger, Y., Paris, H. S., Cohen, R., Katzir, N., Yishay, R., \& Schaffer, A. A. (2010). Genetic diversity of Cucumis Melo. In J. Janick (Ed.), Horticultural reviews (Vol. 36, pp. 165198). New York, USA: Wiley-Blackwell.

Castro, G., Perpiñà, G., Monforte, A. J., Picò, M. B., \& Esteras, C. (2019). New melon introgression lines in a 'Piel de Sapo' genetic background with desirable agronomical traits from Dudaim melons. Article submitted for publication.

Díaz, A., Forment, J., Argyris, J. M., Fukino, N., Tzuri, G., Harel-Beja, R., ... Monforte, A. J. (2015). Anchoring the consensus ICuGI genetic map to the melon (Cucumis melo L.) genome. Molecular Breeding, 35(10), 188.

Díaz, A., Martín-Hernández, A. M., Dolcet-Sanjuan, R., Garcés-Claver, A., Álvarez, J. M., Garcia-Mas, J., ... Monforte, A. J. (2017). Quantitative trait loci analysis of melon (Cucumis melo L.) domestication-related traits. Theoretical and Applied Genetics, 130(9), $1837-1856$.

Eduardo, I., Arús, P., Monforte, A. J., Obando, J., Fernández-Trujillo, J. P., Martínez, J. A., ... van der Knaap, E. (2007). Estimating the genetic architecture of fruit quality traits in melon using a genomic library of near isogenic lines. Journal of the American Society for Horticultural Science, 132(1), 80-89.

Esteras, C., Rambla, J. L., Sánchez, G., López-Gresa, M. P., González-Mas, M. C., FernandézTrujillo, J. P., ... Picò, M. B. (2018). Fruit flesh volatile and carotenoid profile analysis within the Cucumis melo L. species reveals unexploited variability for future genetic breeding. Journal of the Science of Food and Agriculture, 98(10), 3915-3925.

Fernandez-Trujillo, J. P., Picò, M. B., Garcia-Mas, J., Alvarez, J. M., \& Monforte, A. J. (2001). Breeding for fruit quality in melon. In: M. A. Jenks, \& P. J. Bebeli (Eds.), Breeding for Fruit Quality (261-278). Oxford, UK: Wiley-Blackwell.

Gur, A., Gonda, I., Portnoy, V., Tzuri, G., Chayut, N., Cohen, S., ... Katzir, N. (2017). Genomic aspects of melon fruit quality. In: R. Grumet, N. Katzir, \& J. Garcia-Mas. (Eds.), Genetics and genomics of Cucurbitaceae (Vol. 20, pp. 377-400). Cham, Switzerland: Springer Nature.

Monforte, A. J., Díaz, A., Caño-Delgado, A., \& van der Knaap, E. (2014). The genetic basis of fruit morphology in horticultural crops: Lessons from tomato and melon. Journal of Experimental Botany, 65(16), 4625-4637.

Pereira, L., Ruggieri, V., Pérez, S., Alexiou, K. G., Fernández, M., Jahrmann, T., ... GarciaMas, J. (2018). QTL mapping of melon fruit quality traits using a high-density GBS-based genetic map. BMC Plant Biology, 18(1), 324. 
Perpiñà, G., Cebolla-Cornejo, J., Esteras, C., Monforte, A. J., Picò, M. B. (2017). “MAK-10”: A long shelf-life charentais breeding line developed by introgression of a genomic region from Makuwa melon. HortScience, 52(11),1633-1638.

Perpiñà, G., Esteras, C., Gibon, Y., Monforte, A. J., \& Picò, B. (2016). A new genomic library of melon introgression lines in a cantaloupe genetic background for dissecting desirable agronomical traits. BMC Plant Biology, 16(1), 154.

Pitrat, M. (2017). Melon genetic resources: phenotypic diversity and horticultural taxonomy. In: R. Grumet, N. Katzir, \& J. Garcia-Mas. (Eds.), Genetics and genomics of Cucurbitaceae (Vol. 20, pp. 253-263). Cham, Switzerland: Springer Nature.

Ramamurthy, R. K., \& Waters, B. M. (2015). Identification of fruit quality and morphology QTLs in melon (Cucumis melo) using a population derived from flexuosus and cantalupensis botanical groups. Euphytica, 204(1), 163-177.

Zamir D, 2001. Improving plant breeding with exotic genetic libraries. Nature Reviews Genetics, 2(1), 983-989. 

4. APROVECHAMIENTO DE LA VARIABILIDAD

INTRAESPECÍFICA DEL MELÓN

PARA LA RESISTENCIA A

HONGOS DEL SUELO 



$$
\text { 4.1 CAPÍTULO } 1
$$





\subsection{Evaluación de la colección de líneas de introgresión de 'Piel de Sapo' derivada de Dudaim por su respuesta al hongo Macrophomina pasheolina.}

El germoplasma silvestre y exótico asociado al melón constituye una fuente importante de resistencia a patógenos útil para la mejora de este cultivo. Un estudio previo (Ambrósio et al. 2015) identificó que el grupo Dudaim presentaba entradas con resistencia al hongo del suelo Macrophomina phaseolina. Una de esas entradas era el parental DUD empleado en el desarrollo de la colección de ILs descrita en la presente tesis doctoral. Por ello, se decidió realizar un cribado de la colección de ILs, para evaluar el nivel de tolerancia que presentaba cada línea, estudiar la genética de la resistencia y establecer su utilidad en programas de mejora. Los trabajos realizados se descriebn a continuación.

Este trabajo se realizó en el marco de mi participación en el proyectos AGL2014-53398-C2-2R, APROXIMACIONES BIOTECNOLÓGICAS Y CULTURALES PARA LA MEJORA DE LAS RESISTENCIAS Y EL CONTROL DE ENFERMEDADES EN MELÓN Y SANDÍA, financiado por el Ministerio de Economía, Industria y Competitividad (cofinanciado con fondos FEDER) y se agradece el apor Técnico de Eva Maria Martínez Pérez, por el apoyo técnico prestado.

\subsection{Introducción}

Macrophomina phaseolina (Tassi) Goidanich es un hongo oportunista del suelo y uno de los más potencialmente dañinos del mundo. Es el causante de la enfermedad conocida como 'podredumbre carbonosa' en un amplio rango de huéspedes que incluye más de 500 especies silvestres y cultivadas (Radwan, Rouhana, Hartman, \& Korban, 2014; Salari, Panjehkeh, Nasirpoor, \& Abkhoo, 2012). La 'podredumbre carbonosa' se caracteriza por una coloración oscura en el tejido del huésped infectado (Pratt, McLaughlin, Pederson, \& Rowe, 1998). Esta coloración se debe a la obstrucción por parte del hongo del tejido vascular de las raíces y tallos inferiores, produciendo su posterior pudrición (Wyllie, 1989).

M. phaseolina es el causante de pérdidas económicas significativas en muchos cultivos de cucurbitáceas (Cohen, Elkabetz, \& Edelstein, 2016). Los ataques más importantes se asocian a la ocurrencia de condiciones de estrés por sequía y altas temperaturas (Andrade, Michereff, Biondi, Nascimento, \& Sales, 2005; Cohen et al. 2016; Etebarian, 2006; Mahdizadeh, Safaie, \& Aghajani, 2011; Manici, Caputo, \& Cerato, 1995). A pesar de que el hongo ha sido descrito 


\subsection{CAPÍTULO 1}

en prácticamente todo el mundo, tiene mayor incidencia en zonas tropicales y subtropicales con climas semi-áridos (Purkayastha, Kaur, Dilbaghi, \& Chaudhury, 2006). Sin embargo, con el contexto de cambio climático en el que nos encontramos actualmente, se esperan incrementos globales de temperatura y situaciones de sequía, por lo que se prevé un incremento en la severidad de los ataques de este patógeno.

Como ha ocurrido con otros hongos del suelo, los métodos químicos de control, como la fumigación de los suelos, no han mostrado la efectividad esperada, más aún desde la prohibición de algunos productos de amplio espectro muy eficientes para los que no se han encontrado alternativas (Bruton \& Wann, 1996). Además, la diversidad genética del hongo (Almeida et al., 2003) y la formación de esclerocios, que pueden sobrevivir durante más de 10 meses, dificultan su control (Khan, 2007).

Entre las cucurbitáceas más afectadas se encuentran el melón y la sandía, pero es el primero el que muestra síntomas más severos (Cohen et al., 2016). Aunque en España, M. phaseolina ha sido aislada de las raíces de plantas de melón colapsadas (García-Jiménez et al., 1993), no se ha destacado en las últimas décadas como un patógeno importante del melón. Sin embargo, en muestreos realizados los dos últimos años en campos de las distintas zonas productoras de nuestro país, este patógeno ha sido uno de los detectados con más frecuencia, lo que apoya una extensión rápida de esta enfermedad (B. Picò comunicación personal). La identificación de resistencia genética a este patógeno sería un método adecuado de control del mismo, pero hasta el momento han sido muy escasos los cribados de germoplasma en melón para la identificación de resistencias a M. phaseolina. Recientemente, Ambrosió et al. (2015), en el marco de un proyecto de colaboración de los grupos de Mejora Genética de cucurbitáceas del COMAV y de la UFERSA (Brasil), realizaron un cribado de germoplasma variable de melón, identificando algunas entradas con cierto nivel de tolerancia. Una de las entradas identificadas fue precisamente la entrada de Cucumis melo ssp. melo grupo Dudaim PI 273438, el parental exótico empleado en el desarrollo de la colección de líneas de introgresión descritas anteriormente en el marco de esta Tesis Doctoral (Castro, Perpiñà, Monforte, Picò, Esteras, 2019). Esta colección podría resultar un material adecuado para la determinación de las regiones genómicas que controlan la resistencia a $M$. phaseolina derivada de esta entrada. En este contexto, hemos realizado un ensayo de evaluación de la respuesta frente a M. phaseolina, usando la población de ILs descrita y empleando una estrategia de inoculación artificial. 


\subsection{Materiales y métodos}

\subsubsection{Material Vegetal}

Se usaron 17 lotes de semillas, conformadas por la generación F1, derivada del cruzamiento $C$. melo ssp. melo grupo Ibericus cultivar Piñonet ('Piel de Sapo', PS) y la accesión PI 273438, C. melo ssp. melo, grupo Dudaim cultivar 'Queen's pocket melon' (DUD), 14 líneas de introgresión derivadas de este cruzamiento (Castro et al., 2019), y los parentales PS y DUD como controles. Los dos parentales se multiplicaron y conservaron en el banco de germoplasma del COMAV-UPV.

\subsubsection{Inóculo de Macrophomina phaseolina}

Se utilizó un aislado de $M$. phaseolina agresivo, obtenido de plantas de melón afectadas en un campo de Valencia (España). El inóculo se obtuvo siguiendo el procedimiento usado por Ambrósio et al. (2015). Se emplearon palillos de dientes de $12 \mathrm{~mm}$ de largo, que se colocaron en una placa de Petri y se autoclavaron a $121^{\circ} \mathrm{C}$ dos veces durante 30 minutos, con un intervalo de 24 h entre cada operación de autoclavado. Se añadió $20 \mathrm{ml}$ de PDA fundido (patata-dextrosaagar) + sulfato de estreptomicina a cada placa de Petri que contenía un palillo. Una vez solidificadas, las placas de PDA se inocularon con tres tapones miceliales (6 $\mathrm{mm}$ de diámetro) del aislado de $M$. phaseolina y luego se incubaron a $28 \pm 2{ }^{\circ} \mathrm{C}$ en la oscuridad durante 7 días. Para las plantas control se utilizaron palillos de dientes esterilizados (sin hongo).

\subsubsection{Inoculación de plantas}

El experimento se realizó en 2017 durante la primavera-verano en los invernaderos de la Universitat Politècnica de València (Valencia, España). La temperatura promedio, máxima y mínima se midió de forma automática en los invernaderos, indicándose el perfil térmico en la Figura 1.1. Las temperaturas durante el ensayo en los meses de mayo, junio, julio, agosto y septiembre fueron en promedio de $29.6{ }^{\circ} \mathrm{C}, 22.5^{\circ} \mathrm{C}$ y $25.6^{\circ} \mathrm{C}$ (temperaturas máximas, mínimas y medias, respectivamente). Se inocularon con M. phaseolina 12 plantas por cada IL y 6 plantas de la generación $F_{1}$, PS y DUD.

Las plántulas se inocularon 12 días después del trasplante, insertando una punta de palillo cubierta de micelios y microesclerocios del aislado español indicado en el cuello de las plántulas, con un ángulo de $45^{\circ} \mathrm{C}$. Para los controles se siguió el mismo procedimiento usando palillos estériles sin inóculo de M. phaseolina. 


\subsection{CAPÍTULO 1}

\subsubsection{Evaluación de síntomas}

A los 15 y 30 días después de cada inoculación (DDI), se evaluaron los síntomas de la enfermedad, utilizando una versión modificada de la escala descrita por Ravf \& Ahmad (1998), donde, $0=\sin$ síntomas, $1=$ menos del $3 \%$ de los tejidos del hipocotilo afectados, $2=3$ a 10\% de los tejidos del hipocotilo afectados, $3=11$ a $25 \%$ de los tejidos del hipocótilo afectados, $4=26$ al 50\% de los tejidos del hipocótilo afectados, y 5= más de un 50\% de los tejidos del hipocótilo afectados. La gravedad promedio de la enfermedad se calculó para cada genotipo y se usó para clasificar los cultivares en cinco clases de reacción: $0=$ inmune (I); $0.1-1.0=$ altamente resistente $(\mathrm{AR}) ; 1,1$ a $2,0=$ moderadamente resistente $(\mathrm{MR}) ; 2,1-4,0=$ susceptible (SU) y 4,1-5,0= altamente susceptible (AS) (Salari et al. 2012). De igual manera, a los 30 días se midió la longitud de la lesión (en mm, con un calibrador digital electrónico).

\subsubsection{Análisis estadístico}

Los datos del ensayo se analizaron mediante el programa Statgraphics Centurion XVII.II., utilizando un análisis de varianza (ANOVA).

\subsection{Resultados y discusión}

La inoculación de genotipos que contienen introgresiones de variedades resistentes en un fondo genético susceptible constituye una buena estrategia para determinar de forma rápida regiones genómicas involucradas en la resistencia a patógenos. A pesar que los métodos de inoculación artificial en plántulas no son concluyentes en la confirmación de resistencia a M. phaseolina en condiciones de infestación natural en campo, y deben combinarse con inoculaciones naturales (Ambrósio et al. 2015), permiten seleccionar genotipos con buenas proyecciones de resistencia. Diversos estudios han reportado un buen nivel de concordancia entre la respuesta de inoculaciones artificiales y en condiciones naturales (Grezes-Besset, Lucante, Kelechian, Dargent, \& Muller, 1996; Twizeyimana, Hill, Pawlowski, Paul, \& Hartman, 2012). En este estudio, hemos evaluado 14 líneas de introgresión con fondo genético PS e introgresiones genotipadas de DUD (Castro et al., 2019), junto a los dos parentales PS y DUD y su correspondiente F1 (Tabla 1.1). Al comparar la respuesta de los dos parentales PS y DUD, se observa que las lesiones de DUD son significativamente inferiores que las de PS $(0,00 \pm 0,00$ frente a $1,50 \pm 1,22$ ), pero sólo a 15 DDI. Los síntomas de DUD a 30 DDI, aunque fueron moderados $(1,83 \pm 1,17)$, no fueron significativamente inferiores a los encontrados en PS $(2,17 \pm 0,75)$, aunque según la escala empleada DUD fue moderadamente resistente y PS susceptible. La F1 mostró un comportamiento más parecido al parental PS que a DUD, siendo también susceptible a los 30 DDI $(2,60 \pm 0,55)$. Estos resultados son similares a los descritos en 
Ambrósio et al. (2015). Sin embargo, en este trabajo previo el parental DUD (denominado Dud-QPMAfg) se describe como altamente resistente, con síntomas inferiores a 1 , significativamente inferiores a los encontrados en el control PS, superiores a 2,5. La respuesta de la F1 también fue similar con síntomas superiores a 2, siendo clasificada como susceptible, aunque en este caso sus síntomas fueron inferiores a los del parental PS.

Aunque los síntomas de PS no fueron especialmente graves, la mayoría de las ILs evaluadas mostró síntomas graves de la enfermedad a los $15(0,67 \pm 0,98$ a 3,50 1,05$)$ y 30 DDI $(2,67 \pm 1,21$

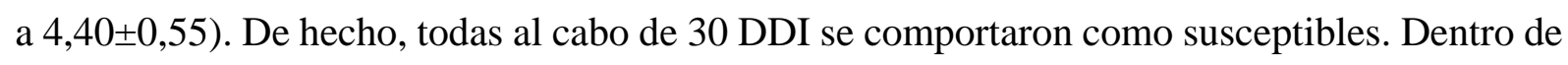
este comportamiento susceptible podemos destacar 5 líneas que tuvieron un índice inferior a 3 (DUD_1-2, DUD_2-1, DUD_4-2, DUD_5-1 y DUD_8-1). Entre éstas, se puede destacar el comportamiento de la DUD_2-1, DUD_4-2, DUD_5-1 y DUD_8-1, que teniendo índices inferiores a 3 presentaron menos extensión de la lesión en comparación con el resto de líneas. La Figura 1.2 muestra una fotografía de los síntomas modelo en cada una de las líneas evaluadas y en sus parentales y en la F1.

Como se ha comentado en la introducción, $M$ phaseolina es un hongo cuyo efecto es altamente dependiente de las condiciones de temperatura. De hecho, Fang, Phillips, Li, Sivasithamparam, \& Barbetti (2011) ya observaron un aumento de la agresividad de un inóculo de $M$ phaseolina (WUF-STMP3) con el método de inoculación artificial del palillo al pasar de $27^{\circ} \mathrm{C}$ a $32^{\circ} \mathrm{C}$; reportaron un aumento de $500 \%$ de daño en la parte aérea de la planta y de alrededor de $200 \%$ a nivel de raíz. En el estudio realizado por Ambrósio et al. (2015) la temperatura media del ensayo fue de $28^{\circ} \mathrm{C}$, aunque no se disponen datos de las medias, mínimas y máximas, mientras que en nuestro ensayos las temperaturas (en los meses de ensayo junio, julio y agostos) fueron $26^{\circ} \mathrm{C}$ de promedio (con máximas $30^{\circ} \mathrm{C}$ minimas de $23^{\circ} \mathrm{C}$ ). Las diferencias en la temperatura podrían explicar la divergencia de comportamiento entre los parentales en ambos ensayos. Aunque las diferencias entre ambos parentales en nuestro ensayo solo fueron significativas a los 15 DDI, se observa un mejor comportamiento frente al hongo en DUD que en PS, aunque el nivel de moderada resistencia no podemos determinar que sea de utilidad en campo y serían necesarios ensayos en condiciones de infestación natural. Ambrósio et al. (2015) describen además de la resistencia en DUD, altos niveles de resistencia en otras accesiones de melón pertenecientes a distintos tipos horticulturales (Cantalupensis, Conomon, Acidulus, Agrestis silvestres). Entre éstas destacan la entrada Coreana Pat 81, ahora clasificada dentro del grupo chinensis (Pitrat, 2017) (denominada Con-Pat81Ko), la entrada de Zimbawe del grupo acidulus TGR1551 (Ac-TGR1551Zimb) y las dos entradas silvestres africanas (Ag-15591Ghana y AgC38Nig). Será necesario comprobar la resistencia de estas otras fuentes en condiciones 


\subsection{CAPÍTULO 1}

variables de temperatura y confirmarla en condiciones de infestación natural en campo, para determinar si su resistencia es mayor que la descrita en DUD.

En cuanto a la genética de la resistencia, el comportamiento de la F1 sugiere una herencia recesiva. Respecto al índice de síntomas, todas las ILs se clasificaron como moderadamente susceptibles, aunque las 4 destacadas anteriormente presentan una menor extensión de la lesión, lo que podría contribuir a una cierta tolerancia. Estas líneas no comparten ninguna región genómica, según los genotipados disponibles hasta el momento (Tabla 1.2), por lo que de momento no podemos asociar ninguna región genómica al nivel de tolerancia encontrado en las mismas.

En cualquier caso, el comportamiento de las ILs fue peor que el del parental tolerante y no consideramos que las ILs evaluadas sean un material prometedor para la mejora de variedades con resistencia a M. phaseolina. Aunque sería de interés confirmar la correlación entre estos resultados con inoculación artificial y los resultados de infección natural en campo, ya que se ha demostrado que las plántulas ofrecen menos resistencia al ataque de patógenos que las plantas más desarrolladas (Bedendo, 2011).

Como las ILs evaluadas no representan todo el genoma de DUD, no podemos descartar la posibilidad de localizar regiones genéticas involucradas directamente en la resistencia a $M$. phaseolina, en nuevas ILs que se desarrollen con introgresiones de los fragmentos faltantes. La identificación de regiones genómicas involucradas en la resistencia a M. phaseolina resultaría un recurso valioso para el manejo de la 'podredumbre carbonosa' en melones, ya que a diferencia de los métodos químicos, presenta seguridad a nivel ambiental, facilidad de incorporar la resistencia independientemente del tipo de suelo y, además, puede usarse de manera complementaria a otros métodos de control (Ambrósio et al. 2015). 


\subsection{Anexos}

Tabla 1.1. Valores de medias y desviaciones estándar de la respues a $M$. phaseolina en las distintas ILs evaluadas junto con los parentales y la F1, junto con resultados de ANOVA para la comparación de medias para cada rasgo evaluado. Las letras indican diferencias significativas entre los genotipos empleados en el estudio.

\begin{tabular}{|c|c|c|c|c|c|c|c|}
\hline \multirow[b]{2}{*}{ Genotipos } & \multirow{2}{*}{\multicolumn{2}{|c|}{$\frac{15 \text { DDI }}{\text { Media SD }}$}} & \multirow{2}{*}{\multicolumn{2}{|c|}{$\frac{\text { 30 DDI }}{\text { Media SD }}$}} & \multicolumn{3}{|c|}{ Longitud Lesión $(\mathrm{mm})$} \\
\hline & & & & & Media & SD & \\
\hline DUD & 0,00 & $0,00 \quad \mathrm{a}$ & 1,83 & $1,17 \quad \mathrm{a}$ & & 3,68 & $\mathrm{a}$ \\
\hline DUD_1-2 & 0,67 & $0,98 \quad a b$ & 2,92 & $1,16 \mathrm{bcd}$ & 01 & 9,52 & $a b c$ \\
\hline DUD_2-1 & 1,00 & $1,33 \mathrm{abc}$ & 2,90 & 1,45 abcd & 06 & 11,80 & $\mathrm{ab}$ \\
\hline DUD_3-1 & 2,75 & 1,58 efg & 3,38 & $1,19 \mathrm{cdef}$ & 22,33 & 18,43 & $a b c$ \\
\hline DUD_4-1 & 1,00 & 1,15 abcd & 3,25 & 0,96 bcdef & 13,75 & 8,97 & $a b c$ \\
\hline DUD_4-2 & 1,67 & 1,37 bcde & 2,83 & $0,41 \mathrm{abcd}$ & & 2,10 & $\mathrm{ab}$ \\
\hline DUD_ & 2,00 & 1,22 bcdefg & 2,40 & $0,89 \mathrm{abc}$ & & & $a b c$ \\
\hline DUD_5-2 & 2,17 & 0,41 cdefg & 3,50 & 1,22 cdef & 24,95 & 21,67 & $a b c$ \\
\hline DUD_5-3 & 2,08 & 1,08 def & 3,17 & 1,34 bcde & 16,73 & 9,55 & $a b c$ \\
\hline DUD_6-1 & 1,33 & 1,44 bcd & 3,42 & 1,08 cdef & 1,78 & 52,58 & $\mathrm{c}$ \\
\hline DUD_6-2 & 3,40 & $1,14 \quad \mathrm{fg}$ & 4,40 & $0,55 \mathrm{f}$ & & 14,51 & $a b c$ \\
\hline DUD_6-3 & 1,83 & 1,47 cde & 4,25 & $0,87 \mathrm{f}$ & & 19,04 & $\mathrm{bc}$ \\
\hline DUD_7-1 & 2,78 & 1,48 efg & 4,00 & 1,12 ef & 21,97 & 11,14 & $a b c$ \\
\hline DUD_8-1 & 1,00 & $1,67 \mathrm{abcd}$ & 2,67 & $1,21 \mathrm{abcd}$ & 12,28 & 12,70 & $a b c$ \\
\hline DUD_9-1 & 3,50 & $1,05 \quad \mathrm{~g}$ & 3,83 & 1,17 def & 28,30 & 14,51 & $a b c$ \\
\hline F1 & 1,60 & 1,52 bcde & 2,60 & $0,55 \mathrm{abcd}$ & 7,08 & 1,52 & $\mathrm{a}$ \\
\hline PS & 1,50 & 1,22 bcde & 2,17 & $0,75 \mathrm{ab}$ & 7,22 & 2,73 & $\mathrm{a}$ \\
\hline
\end{tabular}




\subsection{CAPÍTULO 1}

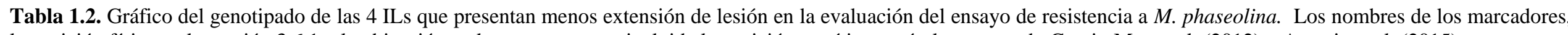

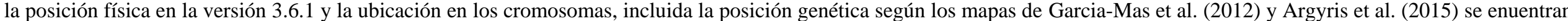

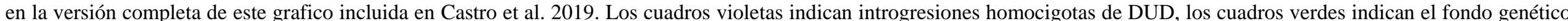
de PS, los cuadros amarillos indican heterocigosis de DUD y los cuadros rojos marcadores no genotipados.

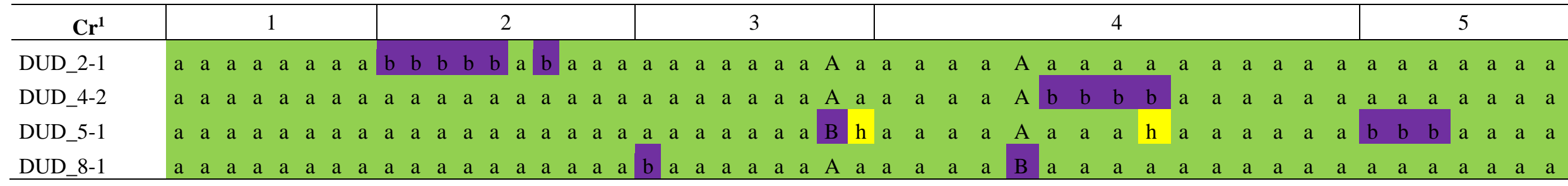

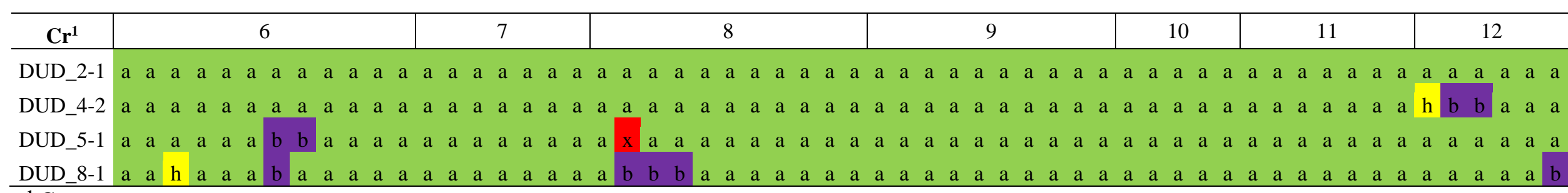

${ }^{1}$ Cromosoma 


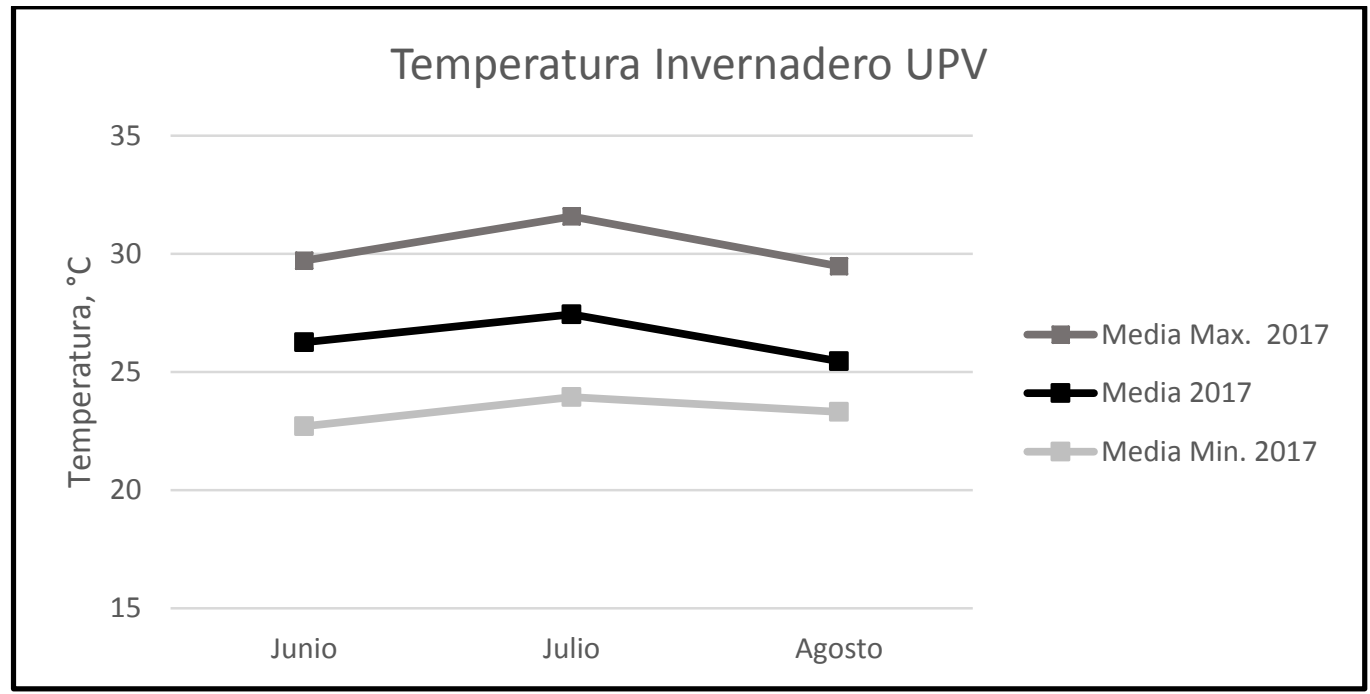

Figura 1.1. Promedio mensual de temperatura máxima, mínima y media en los invernaderos de la Universitat Politècnica de València durante los meses de junio a agosto.

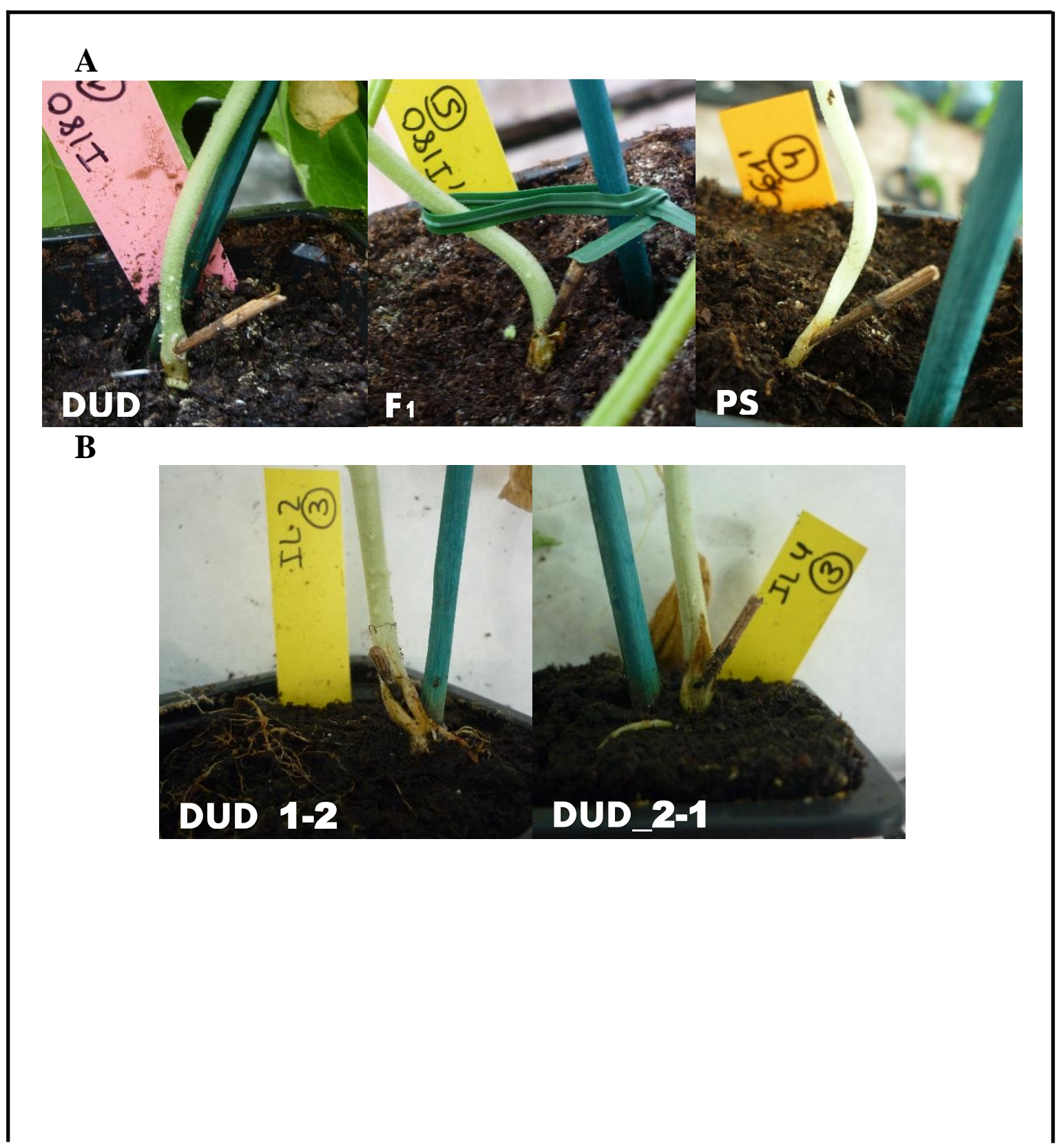




\subsection{CAPÍTULO 1}
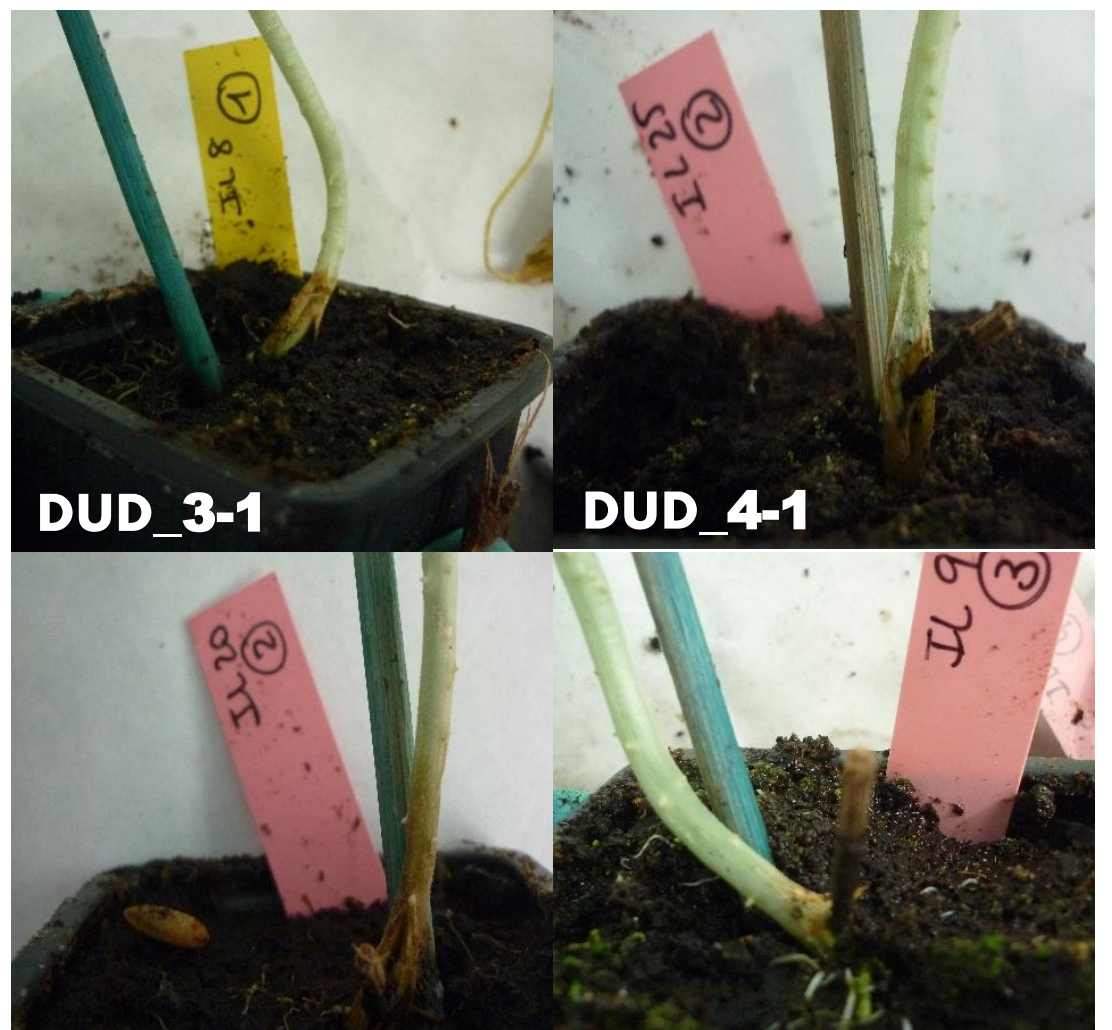

\section{DUD $4=2$}

DUD 5-1
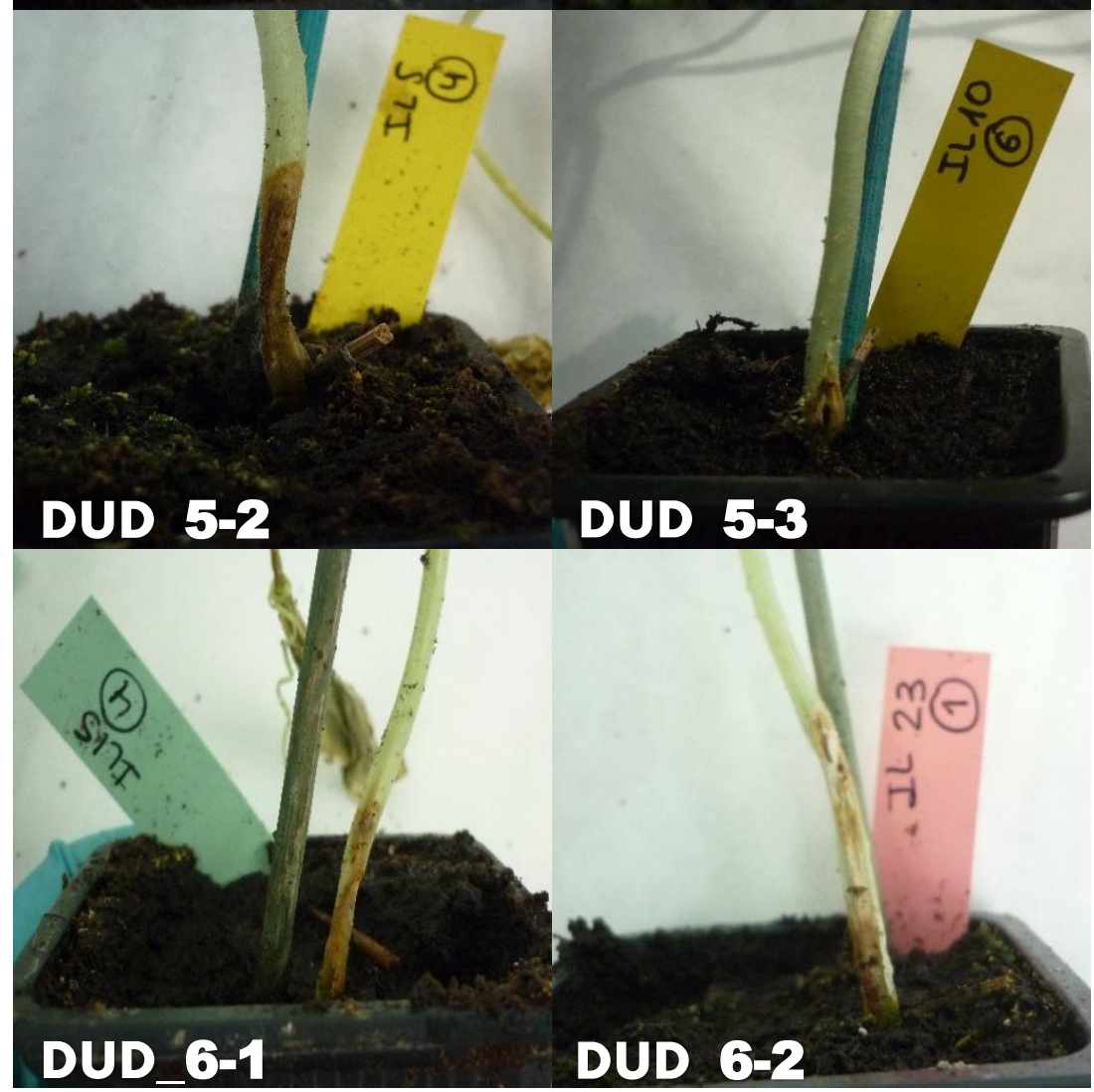


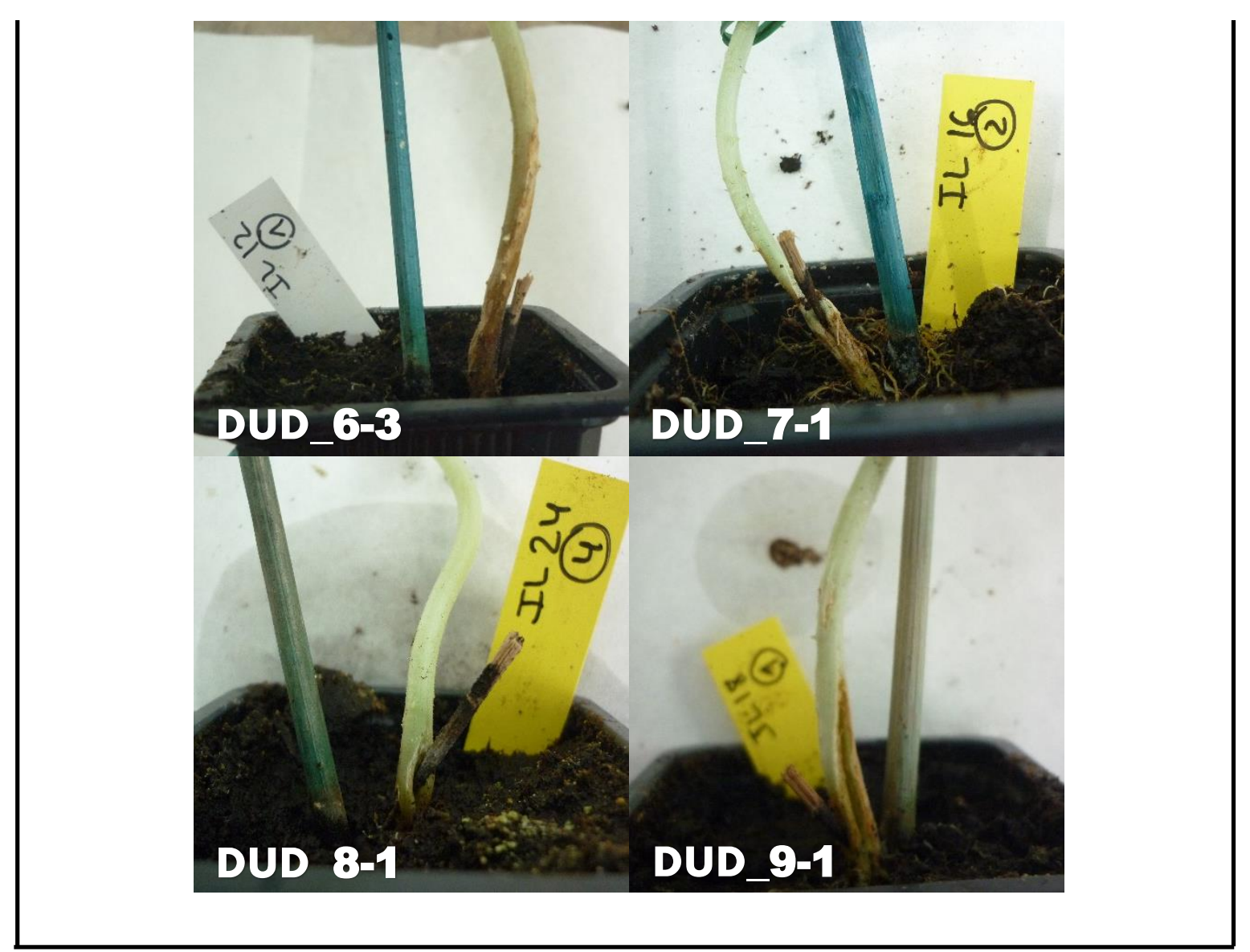

Figura 1.2. Representación de los síntomas de las poblaciones inoculadas con M. phaseolina a los 30 dias después de la inocualación. (A) Dudaim, F1 Y 'Piel de Sapo'. (B) Líneas de introgresión. 


\subsection{CAPÍTULO 1}

\subsection{Referencias}

Almeida, Á. M., Abdelnoor, R. V., Arias, C. A. A., Carvalho, V. P., Jacoud Filho, D. S., Marin, S. R., ... Carvalho, C. G. (2003). Genotypic diversity among Brazilian isolates of Macrophomina phaseolina revealed by RAPD. Fitopatologia Brasileira, 28(3), 279-285.

Ambrósio, M. M., Dantas, A. C., Martínez-Perez, E., Medeiros, A. C., Nunes, G. H., \& Picò, M. B. (2015). Screening a variable germplasm collection of Cucumis melo L. for seedling resistance to Macrophomina phaseolina. Euphytica, 206(2), 287-300.

Andrade, D. E. G. T., Michereff, S. J., Biondi, C. M., Nascimento, C. W., \& Sales Jr, R. (2005). Frequiência de fungos associados ao colapso do meloeiro e relação com características físicas, químicas e microbiológicas dos solos. Summa Phytopathologica, 31(04), 326-331. Bedendo, I. P. (2011). Podridões de raiz e de colo. In: L. Amorin, J. A. M. Rezende, A. F. Bergamin (Eds), Manual de Fitopatologia: Princípios e Conceitos (pp. 443-448). São Paulo, Brasil: Agronômica Ceres.

Bruton, B. D., \& Wann, E. V. (1996). Charcoal rot. In: T. A. Zitter, D. L. Hopkins, \& C. E. Thomas (Eds.), Compendium of Cucurbit Diseases (pp.49-50). St. Paul, USA: American Phytopathological Society Press.

Castro, G., Perpiñà, G., Monforte, A. J., Picò, M. B., Esteras, C. (2019). New melon introgression lines in a 'Piel de Sapo' genetic background with desirable agronomical traits from Dudaim melons. Article submitted for publication.

Cohen, R., Elkabetz, M., \& Edelstein, M. (2016). Variation in the responses of melon and watermelon to Macrophomina phaseolina. Crop Protection, 85, 46-51.

Etebarian, H. R. (2018). Evaluation of Trichoderma isolates for biological control of charcoal stem rot in melon caused by Macrophomina phaseolina. Journal of Agricultural Science and Technology, 8, 243-250.

Fang, X., Phillips, D., Li, H., Sivasithamparam, K., \& Barbetti, M. J. (2011). Comparisons of virulence of pathogens associated with crown and root diseases of strawberry in Western Australia with special reference to the effect of temperature. Scientia Horticulturae, 131(22), 39-48.

García-Jiménez, J., Martínez-Ferrer, G., Armengol, J., Velázquez, M. T., Orts, M., Juárez, M., ... Alfaro, A. (1993). Agentes asociados al" colapso del melón" en distintas zonas españolas. Boletín de Sanidad Vegetal. Plagas, 19(3), 401-423.

Grezes-Besset, B., Lucante, N., Kelechian, V., Dargent, R., \& Muller, H. (1996). Evaluation of castor bean resistance to sclerotial wilt disease caused by Macrophomina phaseolina. Plant disease, 80(8), 842-846. 
Khan, S. N. (2007). Macrophomina phaseolina as causal agent for charcoal rot of sunflower. Mycopath, 5(2), 111-118.

Mahdizadeh, V., Safaie, N., \& Aghajani, M. A. (2011). New hosts of Macrophomina phaseolina in Iran. Journal of Plant Pathology, 93, S4.63-S4.89.

Manici, L. M., Caputo, F., \& Cerato, C. (1995). Temperature responses of isolates of Macrophomina phaseolina from different climatic regions of sunflower production in Italy. Plant disease, 79, 834-838.

Pratt, R. G., McLaughlin, M. R., Pederson, G. A., \& Rowe, D. E. (1998). Pathogenicity of Macrophomina phaseolina to mature plant tissues of alfalfa and white clover. Plant disease, 82(9), 1033-1038.

Purkayastha, S., Kaur, B., Dilbaghi, N., \& Chaudhury, A. (2006). Characterization of Macrophomina phaseolina, the charcoal rot pathogen of cluster bean, using conventional techniques and PCR-based molecular markers. Plant pathology, 55(1), 106-116.

Radwan, O., Rouhana, L. V., Hartman, G. L., \& Korban, S. S. (2014). Genetic mechanisms of host-pathogen interactions for charcoal rot in soybean. Plant Molecular Biology Reporter, $32(3), 617-629$.

Ravf, B. A., \& Ahmad, I. (August 1998). Studies on correlation of seed infection to field incidence of Alternaria alternate and Macrophomina phaseolina in Sunflower. In 13th Iranian Plant Protection Congress. Karaj, Iran. pp. 113.

Salari, M., Panjehkeh, N., Nasirpoor, Z., \& Abkhoo, J. (2012). Reaction of melon (Cucumis melo L.) cultivars to soil-borne plant pathogenic fungi in Iran. African Journal of Biotechnology, 11(87), 15324-15329.

Twizeyimana, M., Hill, C. B., Pawlowski, M., Paul, C., \& Hartman, G. L. (2012). A cut-stem inoculation technique to evaluate soybean for resistance to Macrophomina phaseolina. Plant Disease, 96(8), 1210-1215.

Wyllie, T. D. (1989). Charcoal Rot. In: J. B. Sinclair, \& P. A. Backman (Eds), Compendium of Soybean Diseases (Vol. 3, pp. 30-33). St. Paul, USA: American Phytopathological Society Press. 



\subsection{CAPÍTULO 2}





\section{Effect of temperature on charcoal rot on stem of melons.}

Linhares, C. M. S., Ambrósio, M. M. Q, Castro, G., Esteras, C., Nunes, G. H. S and Picò, B. En preparación para ser enviado a Plant Disease

Puesto que en el trabajo anterior verificamos que el parental DUD no era tan resistente a $M$. phaseolina como inicialmente pensabamos y que su comportamiento diferencial en el nuevo trabajo podria deberse al efecto de la temperatura, decidimos, en colaboración con el grupo de melón de la UFERSA, estudiar el efecto de la temperatura en la evolución de la enfermedad causada por este patógeno y en la respuesta de germoplasma con distintos niveles de resistencia. Por motivos técnicos (conseguir temperaturas elevadas en condiciones de óptimo desarrollo de las plantas de melón y evaluaciones en campo con temperaturas elevadas constantes), los estudios se llevaron a cabo en Brasil, consistiendo mi participación en la selección del material, los diseños de los ensayos, la interpretación de resultados y redacción del paper, junto con el resto de coautores.

Este trabajo esta siendo preparado para su envio a la revista SCI Plant Disease, una revista internaciona especializada en informes rápidos de investigaciones sobre enfermedades de pantas nuevas, emergentes o establecidas, cuyo contenido técnico-científico se centra en aspectos prácticos del diagnóstico, el desarrollo y la gestión de enfermedades en cultivos agrícolas y hortícolas.

Este trabajo es el resultado de mi participación en los proyectos AGL2014-53398C2-2-R, APROXIMACIONES BIOTECNOLÓGICAS Y CULTURALES PARA LA MEJORA DE LAS RESISTENCIAS Y EL CONTROL DE ENFERMEDADES EN MELÓN Y SANDÍA, y AGL2017-85563-C2-1-R, CONTROL MULTIDISCIPLINAR DE ENFERMEDADES FUNGICAS Y VIROSIS EN MELON Y SANDIA: UN NUEVO RETO, financiados por el Ministerio de Economía, Industria y Competitividad y por el Ministerio de Ciencias, Innovación y Universidades (cofinanciados con fondos FEDER) y en el proyecto PROMETEO/2017/078 financiado por la Conselleria d'Educació, 
Investigació, Cultura i Esports de la Generalitat Valenciana para grupos de Excelencia. Así mismo, se ha realizado en el marco de una colaboración muy estrecha con el grupo de melon de la UFERSA, en el marco del apoyo de Coordenação de Aperfeiçoamento de Pessoal de Nível Superior CAPES (Brazil) 


\subsection{Effect of temperature on charcoal rot on stem of melons.}

Linhares, C. M. S., Ambrósio, M. M. Q, Castro, G., Esteras, C., Nunes, G. H. S and Picò, B.

Prepared to be Submitted to Plant Disease.

\subsection{Introducction}

Brazil is the main producer and exporter of melons in South America. In 2017, it produced 540,229 tons in a cultivated area of 23,390 ha (FAO, 2019). The Brazilian production is concentrated in the semiarid region (> $95 \%$ ), especially in the states of Ceará and Rio Grande do Norte, which have excellent environmental conditions for crop development such as high temperatures $\left(>28^{\circ} \mathrm{C}\right)$, low rainfall rate (approx. $600 \mathrm{~mm}$ per year), and high luminosity. (Nunes, Aragao, Nunes, \& Ricarte, 2016).

Melon is usually cultivated all year long and, without crop rotation, or rotating with another cucurbit, such as watermelon (Citrullus lanatus L.). This intensive use of producing fields increases problems with soil borne pathogens. The Ascomycete Macrophomina phaseolina (Tassi) Goidanich is one of the most important soil borne fungus in cucurbits worldwide (Cohen, Elkabetz, \& Edelstein, 2016). It has been detected infecting melons in Spain, Honduras, Israel, Chile, Iran, Oman, Australia and Brazil (Al-Mawaali, Al-Sadi, Al-Said, \& Deadman, 2013; Ambrósio et al. 2015; Apablaza, 1993; Bruton \& Miller 1997; Edraki \& Banihashemi 2011; García-Jiménez, Armengol, Sales, Jordá, \& Bruton, 2000; Reuveni, Krikun, Nachmias, \& Shlevin, 1982; Walker, 1994). In Brazil it is usually isolated from damaged plants, both cultivated melons (Andrade, Michereff, Biondi, Nascimento, \& Sales, 2005; Dantas et al. 2013; Marinho et al. 2002) and weeds (Sales Júnior et al. 2012). It causes a disease known as charcoal rot (Salari, Panjehkeh, Nasirpoor, \& Abkhoo, 2012). Symptoms of charcoal rot start as depressed dark lesions in the stem. Affected plants show sometimes chlorosis, vine wilt and stem and root rot (Bianchini, Maringoni, \& Carneiro, 2005). Severely infected plants die early due to the effect of toxins produced by the fungus and to the interruption of the xylem flow (Islam et al. 2012).

One of the most efficient methods to control soil borne pathogens is the use of resistant cultivars. However, there are not commercial varieties resistant to M. phaseolina, and few scientific studies report efforts to identify sources of resistance. Salari et al. (2012) evaluated the reaction of seven Iranian cultivars and identified two melon sources with partial resistance. More recently, Ambrosio et al. (2015), studying a collection of melons representing the diversity of the species, found different levels of resistance in five accessions belonging to 


\subsection{CAPÍTULO 2}

different infraspecific taxa (Pitrat, 2017) and from different origins two African accessions of wild agrestis type, from Gana and Nigeria, one Korean accession of the Asian Conomon group, one dudaim accession from Afghanistan, and the cantaloupe cultivar Noy Israel. In this study, they used the toothpick method to inoculate the pathogen, the experiment was conducted at an average air temperature of $28{ }^{\circ} \mathrm{C}$ and average humidity $65 \%$, and the response studied after 30 days post inoculation.

The response of all these genotypes was evaluated later in a similar assay, using the same inoculation method in Mossoró (State Rio Grande do Norte, Brazil), with temperatures higher than $35^{\circ} \mathrm{C}$ and excellent epidemiological conditions for the development of M. phaseolina. In this assay, most of the plants of all accessions died in the first two weeks after transplanting, except from those of one of the wild African accession. It is well known that environmental factors influence the interaction between pathogen and host, affecting pathogenicity and defense responses of hosts. Temperature stands out as the one with major effect on resistance of plants to different pathogens, such as fungi, viruses, bacteria and nematodes (Castro et al. 2019; Garrett, Dendy, Frank, Rouse, \& Travers, 2006; Wosula, Tatineni, Wegulo, \& Hein, 2017). A classic example that illustrates temperature interference in resistance-breaking occur with Meloidogyne incognitta in Solanum lycopersicum L. (tomato). Resistant cultivars possess the $M i-1$ gene. However, when soil temperature rises over $32^{\circ} \mathrm{C}$, the resistance is broken (Williamson, 1998). Also, studies report an effect of soil temperature on disease development in melon plants infected by another soil borne melon pathogen associated to melon vine decline (Pivonia, Cohen, Kigel, \& Katan, 2002). There is no information about the effect of temperature on the reaction of muskmelon accessions to M. phaseolina. The purpose of the present study was to evaluate the effect of temperature on the reaction of melon accessions with different resistance levels to this pathogens.

\subsection{Material and Methods}

\subsubsection{Germplasm}

Six accessions were evaluated: two wild African accessions belonging to Cucumis melo subspecies Agrestis, PI 185111 (Ag-15591Ghana) and CUM 287 (Ag-C38Nig), two Asian melons belonging to the Dudaim, PI 273438 (Dud-QMPAfg), and Chinensis, Pat 81 (ConPat81Ko), groups of $C$. melo subspecies agrestis, and two commercial melons belonging to the two main groups of $C$. melo subspecies melo, a 'Piel de Sapo' type of the Ibericus group (InPsPiñSp), and the cultivar Noy Israel of the Cantalupensis group (Can-NYIsr). All these accessions were reported to have different levels of resistance to M. phaseolina by Ambrosio 
et al (2015), except from the 'Piel de sapo' cultivar that was used as susceptible control. PI and CUM accessions were kindly provided by the USDA- NPGS and IPK genebanks respectively. The other accessions were provided by the COMAV-UPV Genebank.

\subsubsection{Inoculum preparation}

The Me-248 pathogenic isolate, isolated from roots and stems of symptomatic muskmelons, was used because of its aggressiveness (Medeiros, Melo, Ambrósio, Nunes, \& Costa, 2015). Tests were made to prove fungi pathogenicity. The isolate was inoculated in potato dextrose agar (PDA) + antibiotic (tetracycline $0.05 \mathrm{~g} / \mathrm{L})$. Four discs ( $5 \mathrm{~mm}$-diameter) of PDA medium with fungal structures were inoculated into Petri dishes containing toothpicks in PDA medium. Plates were stored in BOD incubators at $28 \pm 2{ }^{\circ} \mathrm{C}$ for seven days.

\subsubsection{Assay conditions}

Selected seeds were disinfested in $\mathrm{NaClO}(1.5 \%)$ and placed in Petri dish with filter paper and damped cotton. Plates were wrapped in aluminum foil and stored in incubator for 24 hours at $37{ }^{\circ} \mathrm{C}$. Pots of $0.4 \mathrm{~kg}$ of capacity were filled with commercial substrate (Tropstrato ${ }^{\circledR} \mathrm{HT}$ Hortaliças). Substrate was sterilized in autoclave at $121^{\circ} \mathrm{C}$.

Four trials were conducted simultaneously at the Laboratório de Sementes da UFERSA in Mossoró (State Rio Grande do Norte, Brazil), in four BOD (Biochemical Oxygen Demand) incubators for ten days at constant temperatures of $25,28,31$, and $34{ }^{\circ} \mathrm{C}$, and relative humidity of $60 \%$, with light-period of 12 hours. Temperatures were chosen according to Ambrosio et al. (2015), which reported the average temperature in Mossoró (Brazil) and Valencia (Spain), throughout the study. The four trials were conducted in a randomized block design with seven replicates. Experimental unit was formed by two pots of $0.4 \mathrm{~kg}$ of capacity with one plant each.

\subsubsection{Plant inoculation and disease assessment.}

Twenty days after transplanting the inoculation was conducted, via direct insertion of infested toothpick at the base of the stem (Ambrosio et al. 2015) and stored in BOD. Ten days after inoculation, accessions were evaluated for disease severity using a score scale ( 0 to 5$)$, where 0: asymptomatic, 1: less than $3 \%$ of infected tissue, 2: 3 to $10 \%$ of infected tissue, $3: 11$ to 25 $\%$ of infected tissue, 4: 26 to $50 \%$ of infected tissue, and 5: more than $50 \%$ of infested tissue (Ambrosio et al. 2015). The average disease severity was calculated for each accession and classified in five classes of reaction 0 : immune (I); 0.1 to 1.0 : highly resistant (AR); 1.1 to 2.0: moderately resistant (MR); 2.1 to 4.0: susceptible (SU); and 4.1 to 5.0: highly susceptible (AS) (Salari et al. 2012). 


\subsection{CAPÍTULO 2}

\subsubsection{Statistical analysis}

As the variable response considered is not quantitative and the residuals do not present normal distribution, we chose different statistical tests according to Non-parametric methods in factorial (Brunner \& Puri, 2002). The first is the so-called Wald-type statistic (WTS), which has, asymptotically, a chi-square distribution (with a - 1 degrees of freedom $[\mathrm{df}=\mathrm{a}-1]$ ) under the null hypothesis. The second statistic is known as the so-called ANOVA type statistic (ATS), which has, based on asymptotic theory, an approximate $\mathrm{F}$ distribution (with dfN [numerator] and dfD [denominator] degrees of freedom) under the null hypothesis (Shah \& Madden, 2004). The SAS program was used to carry out the analyzes from the procedures PROC RANK and PROC MIXED (Brunner \& Puri, 2001). The mean ranks of the main effects of accessions and temperature were compared and the correlation coefficients of Spearman and Gamma were calculated according to Siegel \& Castellan Jr. (1988).

\subsection{Results and discussion}

A significant effect of the accession in the response to M. phaseolina was observed ( $\mathrm{p}<0.0001)$ (Table 2.1). This was an expected result as the accessions were selected for their differential response to this pathogen in a previous study (Ambrósio et al. 2015). The effect of temperature was also significant $(p<0,0001)$, indicating the influence of temperature on the reaction of the accessions to the fungus $(\mathrm{p}<0.0001)$. However, there was no significant effect for the interaction accession $x$ temperature $(\mathrm{p}>0.05)$ (Table 2.1). Absence of interaction evidence a similar behavior of genotypes (accessions) with the temperature increase (Yan, Kang, Ma, Woods, \& Cornelius, 2007). This fact indicates that the levels of the two factors considered in the present study (accession and temperature) can be compared independently.

Regarding the accession effect, the wild agrestis accession from Ghana (Ag-15591Ghana) was the most resistant (average disease score $=0.40$ ) and the cultivar 'Piel the Sapo' (In-PsPiñSp) the most susceptible (average disease score $=4.39$ ), in all tested temperatures (Table 2.2), displaying the other accessions an intermediate response in all assays (average disease scores between 1 and 2).

Concerning the temperatures, there was an evident tendency to increase the severity of the disease as temperature rises, average scores from 1,02 to 2,80 at 25 and $34{ }^{\circ} \mathrm{C}$ respectively (Figure 2.1 and 2.2). The Spearman's coefficient estimate between temperature and mean severity was positive ( $r s=0,57 ; p<0,01)$, and also the estimation of Gamma coefficient between temperature and resistance classes was positive $(\gamma=0,82 ; \mathrm{p}<0,01)$, indicating that temperature increased the susceptibility to the disease of all accessions. 
The 'Piel de Sapo' cultivar was used as susceptible control and according to the observed response it was classified as susceptible in the assay performed at $25^{\circ} \mathrm{C}$ and as highly susceptible in all the assays performed at higher temperatures (Table 2.2 and Figure 2.1). This result indicate that all the inoculation assays successfully resulted in a severe M. phaseolina infection and that temperature increases the severity of the infection in susceptible genotypes (AbduBaki, Haroon, \& Chitwood, 1996).

Under these infection conditions that caused severe damage to the susceptible control, the African Agrestis accession, Ag-15591Ghana, behaved as resistant in all the assays (Figure 2.1 and 2.2). The increase in temperature also increased the disease severity in this resistant genotype (Table 2.2), but according to the scores this accession was highly resistant the assays conducted at 25,28 and $31^{\circ} \mathrm{C}$, and still moderately resistant at the assay performed with the highest temperature (Figure 2.1).

The other four accessions displayed a similar intermediate response, all being on average moderately resistant to the infection. However, the increase of the temperature affected less to the Far Eastern Pat 81 accession, Con-Pat81Ko. In fact this was highly resistant, even at the third assay performed at $31{ }^{\circ} \mathrm{C}$, being only susceptible at $34{ }^{\circ} \mathrm{C}$, whereas the other three genotypes were only highly resistant at $25^{\circ} \mathrm{C}$ (Ag-C38Nig and Dud-QMPAfg) or till 28 (CanNYIsr), being only moderately resistant at intermediate temperatures and susceptible at $34^{\circ} \mathrm{C}$ (Figure 2.1 and 2.2).

Results agree only in part with those reported in Ambrosio et al. (2015). In fact in this previous study, conducted an a average temperature of $28^{\circ} \mathrm{C}$ and relative humidity of $65 \%$, 'Piel de Sapo' behaved as a susceptible cultivar and the other genotypes displayed all a highly resistant response. In fact Ambrosio et al. (2015) results are comparable with those obtained in the two assays of this study performed at 25 and $28{ }^{\circ} \mathrm{C}$, although the disease severity was a bit higher in the present study, and Ag-C38Nig and Dud-QMPAfg were classified as moderately resistant at $28^{\circ} \mathrm{C}$ (Table 2.2). However the present study indicate that this moderately resistant accession is not a good option under high temperature conditions as they are susceptible at the assays with highest temperature. The use of a wide range of temperatures allowed us to detect differences among these genotypes with intermediate resistance. For example, the chinensis genotype, ConPat81Ko that behaved as the three previous accessions under moderate temperature was highly resistant till $31^{\circ} \mathrm{C}$. These four accessions were also checked under greenhouse conditions in Mossoró (> $34^{\circ}$ ) where most of the plants died four days after inoculation. In BOD incubators at $34^{\circ} \mathrm{C}$ these accessions were susceptible, but plat death was not observed. The higher severity in the greenhouse can be due to differences in humidity, greater in BOD incubators than in the greenhouse, and to differences in the thermal amplitude higher in greenhouses, that make plants 


\subsection{CAPÍTULO 2}

more prone to pathogen attacks. These is in agreement with the proposed idea that $M$. phaseolina is more adapted and aggressive in hot and dry climates, with high temperatures and reduced humidity (Cohen et al. 2016).

Additionally, the wild African Agrestis, Ag-15591Ghana, remained resistant even at high temperatures (Figure 2.1 and 2.2). Therefore, our results indicate that the use of different assay temperatures may result in a better characterization of the resistance levels allowing the selection the sources most appropriated for the different climatic conditions. For example, some of the sources with intermediate levels of resistance could be useful in countries with moderate growing conditions, such as Spain or other European countries, but for more stressful countries as Brazil, Israel, African of Asian regions would need the use of resistant sources with stable resistance at higher temperatures.

The influence of temperature is an important aspect studied in other pathosystems. A number of published studies involve the $M$. incognita nematode, an important pathogen of tomato crops. Recent studies reported resistance-breaking resulted from the $\mathrm{Mi}$ - 1 gene in temperatures $\geq 28$ ${ }^{\circ} \mathrm{C}$ (Dropkin, 1969; Medina \& Stevens, 1980) and $\geq 32{ }^{\circ} \mathrm{C}$ (Williamson, 1998). However, other authors say that the resistance-breaking does not occur in $34^{\circ} \mathrm{C}$ for all cultivars (Abdul-Baki et al. 1996; Verdejo-Lucas, Blanco, Cortada, \& Sorribas, 2013).

Although the pathogenicity levels of $M$. phaseolina vary depending on the host, generally has been observed a relationship of increased pathogenicity when the temperature increases, peaking at $32^{\circ} \mathrm{C}$ (Akhtar, Sarwar \& Arshad, 2009; Fang, Phillips, Li, Sivasithamparam, \& Barbetti, 2011; Manici, Caputo \& Cerato 1995). The temperature is an important factor in the incidence of pathogenicity, however in other soil fungi, such as Monosporascus cannonballus, the increase in the severity of the disease in the melon when the temperature increases can also be due to other factors such as the adverse effect on the resistance of the host (Pivonia et al. 2002), since it has been demonstrated in other species as cucumber, that the growth of the root and the metabolism of plants grown at high temperatures are significantly affected ( Du \& Tachibana, 1994). This indicates that other factors derived from the increase in temperature in addition to increase of pathogenicity may also contribute to an earlier and faster expression of the disease and the collapse of the plant.

The Ag-15592Ghana accession was one of the first melon accessions reported with high level of resistance to Macrophomina phaseolina (Ambrosio et al., 2015). The present study confirms the high level of resistance in this accession stable even at high temperature conditions and confirm its potential use as source of resistance in genetic breeding programs with $M$. phaseolina. To use this source in breeding programs the genetics of this resistance should be 
4.2 CAPÍTULO 2

studied. The effect of the temperature on disease severity should be taken in to account during the genetic studies. Also differences in the genetic background should be considered to recover the quality of commercial melon and select against the wild traits of the Agrestis background during the development of new resistant varieties 


\subsection{CAPÍTULO 2}

\subsection{Supporting information}

Table 2.1. Chi-square and $F$ values and associated probability obtained in nonparametric ANOVA-Type Statistics (ATS) for the response (score) of six melon accessions inoculated with Macrophomina phaseolina in four temperature.

\begin{tabular}{|c|c|c|c|c|c|c|}
\hline \multirow{2}{*}{ Effect } & \multirow{2}{*}{ df1 } & \multirow{2}{*}{ df 2} & \multicolumn{2}{|c|}{ Wald-type statistic } & \multicolumn{2}{|c|}{ ANOVA-type statistic } \\
\hline & & & Value $\left(\chi^{2}\right)$ & Prob & Value $(\mathrm{F})$ & Prob \\
\hline Temperature $(\mathrm{T})$ & 3 & 312 & 66,56 & $<0,0001$ & 22,19 & $<0,0001$ \\
\hline Genotype (G) & 5 & 312 & 158,74 & $<0,001$ & 31,75 & $<0,001$ \\
\hline $\mathrm{G} \times \mathrm{T}$ & 15 & 312 & 21,72 & 0,1152 & 1,45 & 0,1235 \\
\hline
\end{tabular}

Table 2.2. Average disease score of the six melon accessions inoculated with Macrophomina phaseolina grown at in four temperature regimes.

\begin{tabular}{|c|c|c|c|c|c|}
\hline \multirow[t]{2}{*}{ Accession } & \multicolumn{4}{|c|}{ Temperature } & \multirow[t]{2}{*}{ Average } \\
\hline & $25^{\circ} \mathrm{C}$ & $28^{\circ} \mathrm{C}$ & $31^{\circ} \mathrm{C}$ & $34^{\circ} \mathrm{C}$ & \\
\hline Ag-15591Ghana & 0,07 & 0,14 & 0,21 & 1,14 & $0,40 \mathrm{c}$ \\
\hline Con-Pat81Ko & 0,07 & 0,57 & 0,64 & 3,43 & $1,18 \mathrm{~b}$ \\
\hline Ag-C38Nig & 0,79 & 1,07 & 1,43 & 2,50 & $1,45 \mathrm{~b}$ \\
\hline In-PsPiñSp & 4,00 & 4,36 & 4,46 & 4,73 & $4,39 \mathrm{a}$ \\
\hline Can-NYIsr & 0,36 & 0,71 & 2,07 & 2,14 & $1,32 \mathrm{~b}$ \\
\hline Dud-QMPAfg & 0,86 & 1,07 & 2,00 & 2,86 & $1,70 \mathrm{~b}$ \\
\hline Average & $1,02 \mathrm{c}$ & $1,32 \mathrm{bc}$ & $1,80 \mathrm{~b}$ & $2,80 \mathrm{a}$ & \\
\hline
\end{tabular}

Mean ranks followed by the same letter do not differ by test mean Rank (p>0.05) (Siegel \& Castellani jr., 1988). 


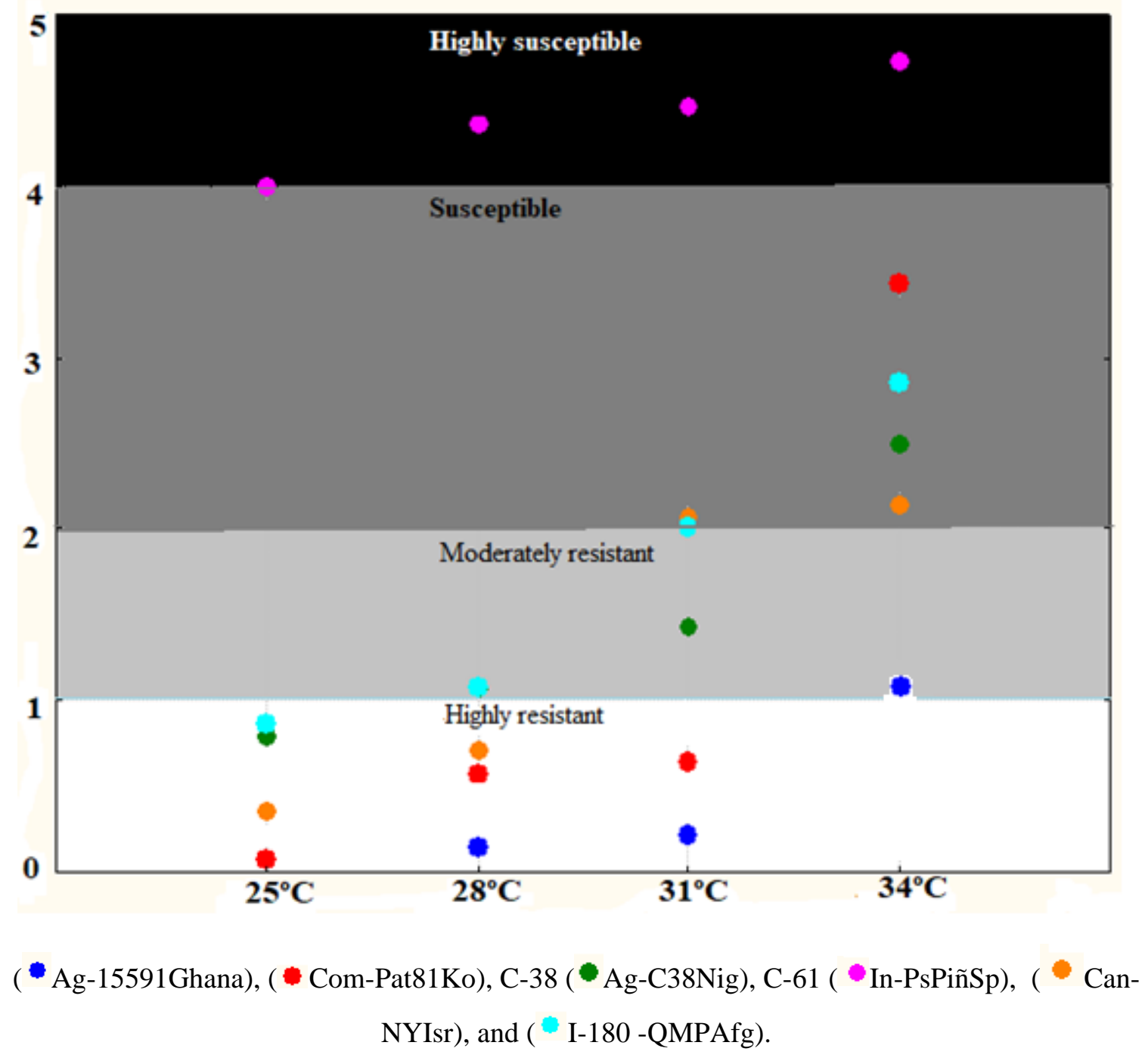

Figure 2.1. Severity of gray rot as a function of temperature. 0: immune (I); 0.1-1.0: Highly resistant (AR); 1.1-2.0: Moderately resistant (MR); 2.1-4.0: susceptible (SU) and 4.1-5.0: highly susceptible (AS). 


\subsection{CAPÍTULO 2}
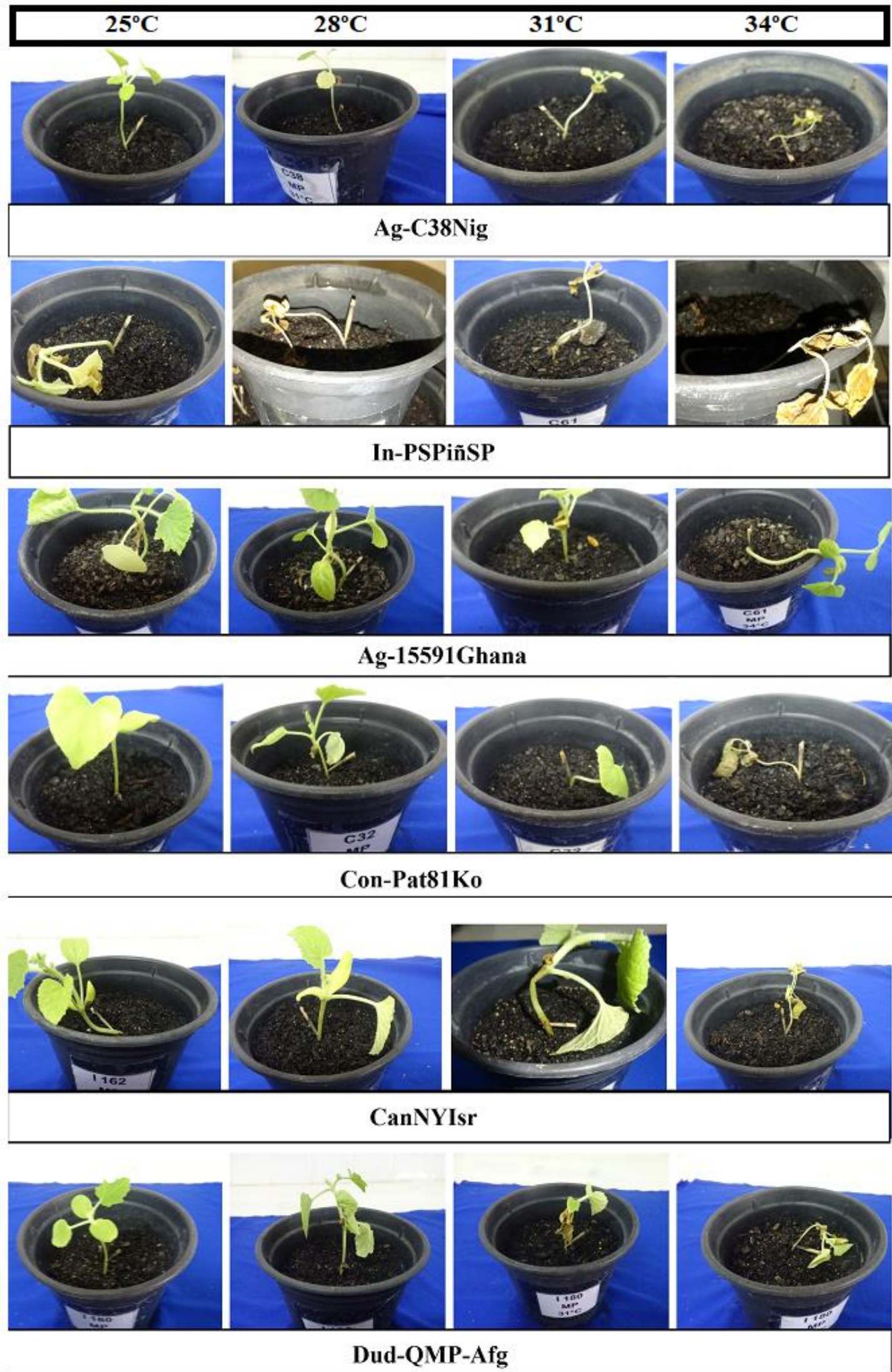

Figure 2.2. Reaction of plants of six accessions of melon to Macrophomina phaseolina in four temperatures. 


\subsection{References}

Abdul-Baki, A. A., Haroon, S. A., \& Chitwood, D. J. (1996). Temperature effects on resistance to Meloidogyne spp. in excised tomato roots. HortScience, 31(1), 147-149.

Akhtar, K. P., Sarwar, G., \& Arshad, H. M. I. (2011). Temperature response, pathogenicity, seed infection and mutant evaluation against Macrophomina phaseolina causing charcoal rot disease of sesame. Archives of phytopathology and plant protection, 44(4), 320-330.

Al-Mawaali, Q. S., Al-Sadi, A. M., Al-Said, F. A., \& Deadman, M. L. (2013). Etiology, development and reaction of muskmelon to vine decline under arid conditions of Oman. Phytopathologia Mediterranea, 457-465.

Ambrósio, M. M., Dantas, A. C., Martínez-Perez, E., Medeiros, A. C., Nunes, G. H., \& Picó, M. B. (2015). Screening a variable germplasm collection of Cucumis melo L. for seedling resistance to Macrophomina phaseolina. Euphytica, 206(2), 287-300.

Andrade, D. E. G. T., Michereff, S. J., Biondi, C. M., Nascimento, C. W., \& Sales Jr, R. (2005). Freqüência de fungos associados ao colapso do meloeiro e relação com características físicas, químicas e microbiológicas dos solos. Summa Phytopathologica, 31(04), 326-331. Apablaza, H. (1993). Charcoal rot of melon and watermelon (Macrophomina phaseolina (Tassi) Goidanich) in the metropolitan region of Chile. Ciencia e Investigación Agraria, 20(3), 101-105.

Bianchini, A., Maringoni, A. C., \& Carneiro, S. M. T. P. G. (2005). Doenças do feijoeiro. In: H. Kimati, L. Amorim, A. Bergamin Filho, L. E. A. Camargo, J. A. M. Rezende (Eds.), Manual de fitopatologia: Doenças das plantas cultivadas (pp. 333-349). São Paulo, Brasil: Ceres.

Brunner, E., \& Puri, M. L. (2001). Nonparametric methods in factorial designs. Statistical papers, 42(1), 1-52.

Brunner, E., \& Puri, M. L. (2002). A class of rank-score tests in factorial designs. Journal of statistical planning and inference, 103(1-2), 331-360.

Bruton, B. D., \& Miller, M. E. (1997). Occurrence of vine decline diseases of melons in Honduras. Plant Disease, 81(6), 696-696.

Carvalho, L. M., Benda, N. D., Vaughan, M. M., Cabrera, A. R., Hung, K., Cox, T., ... Teal, P. E. (2015). Mi-1-mediated nematode resistance in tomatoes is broken by short-term heat stress but recovers over time. Journal of nematology, 47(2), 133.

Castro, G.; Perpiñá, G.; Esteras, C.; Armengol, J., Picó, B.; Pérez-de-Castro, A. (2019). Resistance in melon to Monosporascus cannonballus and M. eutypoides; fungal pathogens associated with Monosporascus root rot and vine decline. Article submitted for publication. 


\subsection{CAPÍTULO 2}

Cohen, R., Elkabetz, M., \& Edelstein, M. (2016). Variation in the responses of melon and watermelon to Macrophomina phaseolina. Crop Protection, 85, 46-51.

Dantas, A. M. M., Ambrósio, M. M. Q., Nascimento, S. R. C., Senhor, R. F., Cézar, M. A., Lima, J. S. S. (2013) Incorporation of plant materials in the control of root pathogens in mushmelon.Revista Agro@ambiente on-line 7(3):338-344.

Dropkin, V. (1969). The necrotic reaction of tomatoes and other hosts resistant to Meloidogyne: reversal by temperature. Phytopathology, 59, 1632-1637.

Du, Y. C., \& Tachibana, S. (1994). Effect of supraoptimal root temperature on the growth, root respiration and sugar content of cucumber plants. Scientia Horticulturae, 58(4), 289-301.

Edraki, V., \& Banihashemi, Z. (2011). Phenotypic diversity among isolates of Macrophomina phaseolina and its relation to pathogenicity. Iranian Journal of Plant Pathology, 46(4).

Fang, X., Phillips, D., Li, H., Sivasithamparam, K., \& Barbetti, M. J. (2011). Comparisons of virulence of pathogens associated with crown and root diseases of strawberry in Western Australia with special reference to the effect of temperature. Scientia Horticulturae, 131, $39-48$.

FAOSTAT. (2019). Food and Agriculture Organization Corporate Statistical Database. Retrieve from http://faostat3.fao.org/home/S [Access on 08 July 2019]

García-Jiménez, J., Armengol, J., Sales, R., Jordá, C., \& Bruton, B. D. (2000). Fungal pathogens associated with melon collapse in Spain. EPPO Bulletin, 30(2), 169-173.

Garrett, K. A., Dendy, S. P., Frank, E. E., Rouse, M. N., \& Travers, S. E. (2006). Climate change effects on plant disease: genomes to ecosystems. Annu. Rev. Phytopathol., 44, 489509 .

Islam, M. S., Haque, M. S., Islam, M. M., Emdad, E. M., Halim, A., Hossen, Q. M. M., ... Alam, M. M. (2012). Tools to kill: genome of one of the most destructive plant pathogenic fungi Macrophomina phaseolina. Bmc Genomics, 13(1), 493.

Manici, L. M., Caputo, F., \& Cerato, C. (1995). Temperature responses of isolates of Macrophomina phaseolina from different climatic regions of sunflower production in Italy. Plant disease, 79(8), 834-838.

Marinho, R. E. M., Sales Jr, R., Maracajá, P. B., Silva, G. F., Costa, F. M., \& Silva, E. C. (2002). Identificação da micoflora associada a raízes de meloeiro nos estados do Rio Grande do Norte e Ceará. Revista Caatinga, 15(01), 25-28.

Medina-Filho, H. P., and M.A. Stevens, M. A. (1980). Tomato breeding for nematode resistance: Survey of resistant varieties for horticultural characteristics and genotype of acid phosphates. Acta Horticulturae, 100, 383-393. 
Medeiros, A. C., Melo, D. R. M. D., Ambrósio, M. M. D. Q., Nunes, G. H. D. S., \& Costa, J. M. D. (2015). Methods of inoculation of Rhizoctonia solani and Macrophomina phaseolina in melon (Cucumis melo). Summa Phytopathologica, 41(4), 281-286.

Nunes, G. D. S., Aragao, F. A. S., Nunes, E. W. L. P., \& Ricarte, A. D. O. (2016). Melhoramento de melão. Embrapa Agroindústria Tropical-Capítulo em livro técnico (INFOTECA-E).

Pitrat, M. (2017). Melon genetic resources: phenotypic diversity and horticultural taxonomy. In: R. Grumet, N. Katzir, \& J. Garcia-Mas (Eds.), Genetics and genomics of Cucurbitaceae (Vol. 20, pp. 25-59). Cham, Switzerland: Springer Nature.

Pivonia, S., Cohen, R., Kigel, J., \& Katan, J. (2002). Effect of soil temperature on disease development in melon plants infected by Monosporascus cannonballus. Plant Pathology, 51(4), 472-479.

Reuveni, R., Krikun, J., Nachmias, A., \& Shlevin, E. (1982). The role ofMacrophomina phaseolina in a collapse of melon plants in Israel. Phytoparasitica, 10(1), 51-56.

Salari, M., Panjehkeh, N., Nasirpoor, Z., \& Abkhoo, J. (2012). Reaction of melon (Cucumis melo L.) cultivars to soil-borne plant pathogenic fungi in Iran. African Journal of Biotechnology, 11(87), 15324-15329.

Sales Junior, S., de Oliveira, O. F., de Medeiros, É. V., Guimarães, I. M., Correia, K. C., \& Michereff, S. J. (2012). Ervas daninhas como hospedeiras alternativas de patógenos causadores do colapso do meloeiro. Revista Ciência Agronômica, 43(1), 195-198.

Shan, D.A., \& Madden, L.V. (2004). Nonparametric Analysis of Ordinal Data in Designed Factorial Experiments. Phytopathology, 9(1), 33-43.

Siegel, S., \& Castellani Jr., N.J. (1988). Nonparametric statistics for the behavioral sciences. New York, USA: McGraw-Hill.

Verdejo-Lucas, S., Blanco, M., Cortada, L., \& Sorribas, F. J. (2013). Resistance of tomato rootstocks to Meloidogyne arenaria and Meloidogyne javanica under intermittent elevated soil temperatures above 28 C. Crop Protection, 46, 57-62.

Walker, G. E. (1994). First report of Macrophomina phaseolina associated with vine decline in muskmelon in South Australia. Plant Disease, 78(6).

Williamson, V. M. (1998). Root-knot nematode resistance genes in tomato and their potential for future use. Annual review of phytopathology, 36(1), 277-293.

Wosula, E. N., Tatineni, S., Wegulo, S. N., \& Hein, G. L. (2017). Effect of temperature on wheat streak mosaic disease development in winter wheat. Plant disease, 101(2), 324-330. Yan, W., Kang, M. S., Ma, B., Woods, S., \& Cornelius, P. L. (2007). GGE biplot vs. AMMI analysis of genotype-by-environment data. Crop science, 47(2), 643-653. 



\subsection{CAPÍTULO 3}





\section{Resistance in melon to Monosporascus cannonballus and M. eutypoides; fungal pathogens associated with Monosporascus root rot and vine decline}

Castro, G., Perpiñà, G., Esteras, C., Armengol, J., Picò, B., Pérez-de-Castro, A. (2019). Resistance in melon to Monosporascus cannonballus and M. eutypoides; fungal pathogens associated with Monosporascus root rot and vine decline. Article submitted for publication.

Tras la realización del cribado de la colección de ILs para resistencia a $M$. phaseolina y el studio del efecto de la temperatura sobre el desarrollo de la infección y la respuesta a la misma de las distintas entradas, aprovechamos la experiencia adquirida para hacer un cribado de varias accesiones de melón en busca de nuevas fuentes de resistencia a Monosporascus spp, género que incluye varias especies responsables de la muerte súbita del melon, estudiando tambien el efecto de la temeratura en la respuesta de las distintas fuentes a este patógeno.

Este trabajo se ha enviado para su publicación a la revista Annals of Applied Biology, una revista internacional especialziada en aspectos de agricultura y ciencias de plantas, cuyo contenido técnico-científico tiene como objetivo difundir trabajos científicos originales relacionados con la producción, la protección y ecosistema de cultivos en múltiples áreas, como fisiología de plantas, micología, genética, mejora vegetal, etc.

Este trabajo se ha realizado en el marco de mi participación en los proyectos AGL2014-53398-C2-2-R, APROXIMACIONES BIOTECNOLÓGICAS Y CULTURALES PARA LA MEJORA DE LAS RESISTENCIAS Y EL CONTROL DE ENFERMEDADES EN MELÓN Y SANDÍA financiado por el Ministerio de Economía y Competitividad, el proyecto AGL2017-85563-C2-1-R, CONTROL MULTIDISCIPLINAR DE ENFERMEDADES FUNGICAS Y VIROSIS EN MELON Y SANDIA: UN NUEVO RETO, financaido por el 
Ministerio de Ciencias, Innovación y Universidades y el PROMETEO/2017/078 financiado por la Conselleria d'Educació, Investigació, Cultura i Esports de la Generalitat Valenciana, en el marco del programa de financiación de grupos de excelencia (cofinanciados con fondos FEDER). Se ha realizado en colaboración con el griupo de patología del Instituto Agroforestal Mediterráneo de la UPV corrdinado por el Dr J.Armengol. 


\subsection{Resistance in melon to Monosporascus cannonballus and M. eutypoides; fungal pathogens associated with Monosporascus root rot and vine decline}

Castro, G.; Perpiñà, G.; Esteras, C.; Armengol, J., Picò, B.; Pérez-de-Castro, A. Submitted to Annals of Applied Biology

\subsection{Introduction}

Melon vine decline is a syndrome characterized by the wilting of the vines followed by plant collapse late in the season (Martyn \& Miller, 1996). Different causal agents have been reported for many melon vine declines (Bruton, Russo, García-Jiménez, \& Miller, 1998). However, among them, Monosporascus root rot and vine decline (MRRVD) caused by Monosporascus spp. is well characterized (Cohen, Pivonia, Crosby, \& Martyn, 2012). This soil-borne disease mainly affects melon (Cucumis melo L.) and watermelon (Citrullus lanatus (Thunb.) Matsum. \& Nakai) crops in hot arid and semiarid cucurbit-growing areas worldwide (Al-Mawaali, AlSadi, Al-Said, \& Deadman, 2013; Chew-Madinaveitia, Gaytán-Mascorro, \& Herrera-Pérez, 2012; Cohen et al., 2012; Iglesias, Picò, \& Nuez, 2000a; Hamza, Belkadhi, Triki \& Zouba, 2007; Martyn, Batten, Park, \& Miller, 1996; Markakis et al., 2018; Sales et al., 2012; Yan, Zang, Huang, \& Wang, 2016). The disease causes important economic loses in certain areas, such as the southwestern region of the United States, and the main cucurbits producing areas of Central and South America (Brazil, Guatemala, Honduras and Mexico), the Mediterranean basin (Israel, Tunisia, Greece, Spain and Italy), and Middle to Far East (Iran, Pakistan, India, Saudi Arabia, Oman, Japan, China and Taiwan) (Cohen et al., 2012; Martyn et al., 1996; Negreiros, Júnior, Rodrigues, León, \& Armengol, 2019).

Symptoms of MRRVD often appear at time of fruit maturity. The vines show an initial yellowing and decay of leaves. These symptoms are followed by progressive defoliation and partial or complete canopy collapse. As a consequence, fruit sunburn occurs and production is lost at harvest. Root lesions develop as rots or necrosis at the joints between secondary and tertiary roots or at the rot tips. Loss of feeder roots also occurs (Cluck et al., 2009; Martyn \& Miller, 1996; Picò, Roig, Fita, \& Nuez, 2008). Perithecia of Monosporascus spp. develop on affected roots, which release ascospores at the end of the cropping season (Martyn \& Miller, 1996), being the primary survival structure and the primary inoculum. Root infections may 


\subsection{CAPÍTULO 3}

occur from the germination of ascospores or active mycelium in infested soils (Cohen et al., 2000; Stanghellini, Alcantara, \& Ferrin, 2010).

The ascomycete genus Monosporascus has been traditionally reported to include five species: Monosporascus adenantherae (S. D. \& C. Ramesh) A. Pande (Patil \& Ramesh, 1987), M. cannonballus Pollack \& Uecker (Pollack \& Uecker, 1974), M. eutypoides (Petrak) von Arx (Ben Salem et al., 2013; Petrak \& Ahmad, 1954), M. ibericus Collado, Ant. González, Stchigel, Guarro \& Peláez (Collado et al., 2002) and M. monosporus (Malloch \& Cain) D. Hawksw. \& Ciccar (Malloch \& Cain, 1971). Recently, five new Monosporascus species have been described, isolated from native weed species in Northeastern Brazil (Negreiros et al., 2019). These species are: M. brasiliensis, M. caatinguensis, M. mossoroensis, M. nordestinus and $M$. semiaridus (the authority of all of them is A. Negreiros, M. León, J. Armengol \& R. Sales Júnior). But, up to date only the species M. cannonballus and M. eutypoides have been reported as causal agents of MRRVD disease in cucurbits (Cohen et al., 2002; Ben Salem et al., 2013; Martyn \& Miller, 1996; Negreiros et al., 2019). Both species were suggested to be conspecific, until recent results demonstrated that they are distinct, being M. cannonballus the most wellknown species of the genus and the most wide-spread (Ben Salem et al., 2013). M. eutypoides has been reported associated to MRRVD in different cucurbit growing areas such Israel (Reuveni, Krikun, \& Shani, 1983) or Tunisia (Ben Salem et al., 2013).

Monosporascus spp. are adapted to hot semiarid climates, where they are pathogenic, while persist saprophytically in cooler areas (Aegerter, Gordon, \& Davisc, 2000). Several researches have investigated the relationship of air and soil temperatures with disease development. Canopy collapse has been associated with high ambient temperatures late in the growing season (Bruton, Júnior, Rodrigues, León, \& Armengol, 1999; Wolff, 1996; Wolff, Leskovar, Black, \& Miller, 1997). Besides that, a high correlation has been found between soil temperatures above $20^{\circ} \mathrm{C}$ during the first 30 days after planting and collapse at the end of the season (Pivonia, Cohen, Kigel, \& Katan, 2002). Root colonization by the pathogen is higher with higher temperatures, given that ascospore germination and hyphal penetration are enhanced by increasing temperatures (Pivonia et al., 2002).

The influence of environmental factors in the expression of symptoms associated with MRRVD hinders the identification of resistance to this disease and hampers the comparison of resistance sources evaluated in different conditions. Resistance to collapse caused by M. cannonballus in United States was reported in some melon cultivars, such as 'Doublon' (C. melo L. ssp. melo cantalupensis group) and 'Deltex' (C. melo ssp. melo ananas group) (Crosby, 2000a; Crosby, Wolff, \& Miller, 2000; Wolff, 1995; Wolff \& Miller, 1998). Further field assays described variable responses in 'Deltex' (Cohen et al., 2000; Fita, Picò, Dias, \& Nuez, 2008; Sinclair, 
2003), while resistance in 'Doublon' was later confirmed in different conditions (Fita et al., 2008). Only moderate resistance has been identified within the ssp. melo in screenings under different conditions (Esteva \& Nuez, 1994; Sales Júnior, Picò, Dias, \& Nuez, 2019). The spp. agrestis of $C$. melo has been more useful in providing pathogen resistance for melon breeding (Pitrat, 2017). Although, screenings against M. cannonballus are scarce, a few papers report resistance to $M$. cannonballus derived from melon ssp. agrestis accessions, being their resistance superior than that of the best ssp. melo resistant lines (Dias, Picò, Espinos \& Nuez, 2004; Iglesias, Picò \& Nuez, 1999; Crosby 2001). For example, the Korean ssp. agrestis accession 'Pat 81' (C. melo L. ssp. agrestis chinensis group) has been reported as highly resistant to M. cannonballus under field and artificial inoculation (Iglesias, Picò, \& Nuez, 2000 a,b). Resistance in 'Pat 81' is expressed as a low level of collapse in field assays. Root lesions are less widespread and less severe than those observed in the susceptible genotypes. A second factor, a better root structure in 'Pat 81 ', is also critical to overcome the disease. The development of a long and branched root system allows a deeper rooting ability and increases the soil volume explored (Dias et al., 2004; Iglesias et al., 2000b). This second mechanism has not been described in resistance sources belonging to the ssp. melo. The resistance derived from this source has been introgressed into the genetic background of the 'Piel de Sapo' market class, by crossing it to the Piñonet 'Piel de Sapo' cultivar (Cucumis melo spp. agrestis group Ibericus) (Fita, Esteras, Picò \& Nuez, 2009a; Fita, Picò, Dias \& Nuez, 2009b). 'Pat 81' has also proven useful as rootstock for melon, given that it retains its favourable root architecture, while having reduced effect on fruit quality (Fita, Picò, Roig \& Nuez, 2007a). The molecular basis of the resistance in 'Pat 81 ' has also been investigated by comparing root transcriptional responses in both, the susceptible 'Piel de Sapo' cultivar Piñonet and the resistant 'Pat 81'. Differences between both genotypes suggest that the jasmonic acid-mediate response might be associated to the resistance in 'Pat 81 ' (Roig et al., 2012).

To date, resistance to M. eutypoides in melon cultivars (ssp. melo) has not been investigated and it should be confirmed in previously reported sources of resistance to M. cannonballus. Also, the variability in the response against MRRVD of the subspecies agrestis of Cucumis melo has been underexploited to date and the identification of new resistance sources to this disease would increase the range of variation available in breeding programs for its use either as donors of resistance genes or as rootstocks. The objective of the work here presented was the evaluation of the response of different genotypes selected to represent intraspecific variation of C. melo spp. agrestis to both species, M. cannonballus and M. eutypoides, in a multiyear assay under different infection conditions. 


\subsection{CAPÍTULO 3}

\subsection{Material and Methods}

\subsubsection{Isolates of Monosporascus cannonballus and eutypoides}

The isolates of Monosporascus cannonballus and M. eutypoides used in the assays were MC0504 (collected from melon in Spain) and MT47 (collected from watermelon in Tunisia), respectively, obtained from the Culture Collection of the Instituto Agroforestal Mediterráneo (Valencia, Spain). Both isolates were hyphal-tipped and stored at $-80^{\circ} \mathrm{C}$ in cryovials. To obtain fresh cultures, agar plugs from each isolate were transferred to potato dextrose agar (PDA) plates and incubated at $25^{\circ} \mathrm{C}$ for 10 days in the dark.

\subsubsection{Plant material}

The Korean accession 'Pat 81' (Chin-Pat81Ko, C. melo spp. agrestis, chinensis group) previously reported as highly resistant to $M$. cannonballus, as well as its F1 hybrid to Piñonet 'Piel de Sapo' (F1 Pat81xPs), previously used as resistant rootstock for melon (Fita et al. 2007a), were included as resistant controls. The Piñonet 'Piel de Sapo' cultivar (Ib-PsPiñSp, $C$. melo spp. melo, group Ibericus) was used as the susceptible control. A Brazilian ssp. melo landrace (La-PE4Bra), that showed previously tolerance in Brazilian infested fields (Dantas, Araujo, Esteras, Nunes \& Picò, 2015) was also included as reference. Other accessions belonging to different groups of the ssp. agrestis were assayed: two wild agrestis types (C. melo ssp. agrestis wild type group), one African, from Ghana (Ag-15591Gha, a selection by selfing of the USDA accession PI 185111), and the second from India (Ag-TriInd, Ames 24297), representing the two molecular groups of wild African and Asian agrestis (Gonzalo et al., 2019: Leida et al., 2015), and an African acidulus (C. melo ssp. agrestis acidulus group) from Zimbabwe (Ac-TGR139Zimb, a selection by selfing of the USDA accession PI 482394). Apart from the melon accessions, an accession belonging to the close African Cucumis species $C$. metuliferus (Met-BGV11135Afr), previously used as nematode resistant rootstock for melons, was also evaluated (Exposito et al., 2018).

These eight genotypes were tested in all the artificial inoculation assays and in the natural field assay, where two 'Piel de Sapo' commercial hybrids were also included: Don Quixote (Sakata) and Iberico (Syngenta), both resistant to Fusarium oxysporum f. sp. melonis, races 0,1 and races $0,1,2$, respectively.

\subsubsection{Artificial inoculation assays}

The artificial inoculation tests were carried out in a greenhouse at the UPV for three consecutive years (summer 2015, summer 2016 and summer 2017) and with both fungal species, $M$. 
cannonballus and M. eutypoides. Through the paper these assays are referred to as the year followed by the initials of the fungal species (i.e., 2015MC, 2015ME, 2016MC, etc.).

Monosporascus spp. inoculum (isolates MC0504 and MT47) was prepared as described by Ben Salem, Armengol, Berbegal, \& Boughalleb-M'Hamdi (2015). Wheat seeds were hydrated for 24 hours in water and then the water was removed. About half kilo of wet seeds were distributed to each $1 \mathrm{~L}$ glass bottle, which were autoclaved on three successive days at $120^{\circ} \mathrm{C}$ for 1 hour and 1 atmosphere pressure. Each bottle was inoculated by introducing 4 disks of the 1 weekold Monosporascus spp. PDA cultures. Bottles were incubated at $25^{\circ} \mathrm{C}$ for 4 weeks until colonization ended. Bottles were shaken manually when a third part of wheat was colonized to avoid clustering of inoculum.

The wheat seeds inoculum was mixed with the substrate (peat). Firstly, all the bottles inoculated with each isolate (MC0504 and MT47) were poured into a $10 \mathrm{~L}$ bowl and mixed manually to homogenize the inoculum. Secondly, all the inoculum and the peat were mixed in the suitable proportions (200 $\mathrm{g}$ of fungal inoculum/ Kg of peat). Once prepared, the mixture of the peat and the wheat seed inoculum was distributed in $0.52 \mathrm{~L}$ pots at which the germinated seedlings were transplanted ten days after germinating in Petri dishes. The experimental protocol was a completely randomized design with 8 plants per genotype and per assay (2015MC, 2015ME, 2016MC, 2016ME, 2017MC, 2017ME). A treatment consisting in 4 plants per genotype growing in peat substrate was included as a non-inoculated control.

Plants were grown in a greenhouse at the UPV facilities. Temperature was measured in the greenhouse at 10 minutes intervals to register ambient conditions. The inoculated substrate was sterilized in autoclave after plants evaluation, at $120^{\circ} \mathrm{C}$ for $90 \mathrm{~min}$ and 1 atmosphere pressure.

\subsubsection{Disease evaluation}

Fifteen and thirty days after transplanting (dat) the vigor of the developing plants was scored using a vigor index (VI) ( 0 to 4 VI scale), where $0=$ dead plant; $1=$ vigor less than $25 \%$ of the control plant; $2=$ vigor less than $50 \%$ of the control plant; $3=$ vigor less than $75 \%$ of the plant control; and $4=$ more than $75 \%$ of the plant control.

At the end of the experiment, the roots were carefully washed to remove the substrate, and evaluated for hypocotyl and root damage using different indices: hypocotyl disease index (HDI), visually scored from 0 to 4 , where $0=$ healthy with no lesions or discoloration, $1=$ =slight discoloration, $2=$ moderate discoloration and/or with lesions, $3=$ moderate maceration, and 4=severe maceration (Biernacki \& Bruton 2000; Dias et al., 2004), and root disease index (RDI), visually scored from 0 to 4 , where $0=$ No symptoms; $1=$ lesions covering less than $10 \%$ of the root system/hypocotyl, 2 = rot of secondary roots or lesions covering approximately $25 \%$ 


\subsection{CAPÍTULO 3}

of the root system/hypocotyl, 3 = lesions covering more than $50 \%$ of the root system and dead secondary roots; and $4=$ more than $50 \%$ of the root are rotted (Ben Salem, Armengol, Berbegal, \& Boughalleb-M'Hamdi, 2015). According to previous studies, those plants with average severity indices $<2.5$ are considered resistant whereas those $>2.5$ are considered susceptible (Dias et al., 2004).

In addition, vine fresh weight (VFW, g), vine dry weight (VDW, g), vine length (VL, cm), root fresh weight (RFW, g) and root dry weight (RDW, g) were also measured for each plant. The vine and root dry weights were measured after drying plants at $70^{\circ} \mathrm{C}$ for 2 days.

\subsubsection{Digital analysis of root systems}

After scoring, vines were cut and roots extended over a transparent sheet, scanned at high resolution and digitally analyzed using the specific software WinRhizo Pro 2.3 (Regent Instruments Inc., Quebec, Canada). The following parameters were measured using WinRhizo Pro 2.3: total root length (TRL, $\mathrm{cm}$ ), total projected root area (TPRA, $\mathrm{cm}^{2}$ ), average root diameter (ARD, mm), number of tips, forks and crossings.

\subsubsection{Natural field inoculation assay}

The natural field inoculation test was carried out in Valencia (summer 2016). The selected field was naturally infested with $M$. cannonballus and had a history of MRRVD incidence on melon crops in previous years. The 11 genotypes assayed were placed in 3 blocks, a total of 9 plants per genotype, 3 per block. During the cultivation, VI was evaluated at 15 and 30 days after transplanting (dat), using the scale previously described. At the end of the assay roots were carefully washed to remove the soil, and evaluated for hypocotyl and root damage as described for artificial inoculation analysis.

\subsubsection{Re-isolation of M. cannonballus and M. eutypoides from infected plants}

Both species were re-isolated from one plant of each genotype and assay after artificial inoculation, and M. cannonballus was re-isolated from field assays. For this purpose, roots were washed and small root pieces were transferred to Petri dishes containing PDA amended with $0.5 \mathrm{~g} / \mathrm{L}$ of streptomycin sulfate, which were incubated during 1 week at $25^{\circ} \mathrm{C}$ in darkness. All colonies were transferred to PDA plates and incubated at $25^{\circ} \mathrm{C}$ in darkness for growth and sporulation. 


\subsubsection{Data analyses}

ANOVA analyses were performed using Statgraphics Centurion XVI. Student's Least Significant Difference Multiple Range test was used to separate main effect means when the pvalue was significant $(\mathrm{p}<0.05)$.

\subsection{Results and discussion}

\subsubsection{Artificial inoculation}

\subsubsection{Mortality and plant development}

Artificial inoculation assays were carried out in the same greenhouse for three consecutive years, in approximately a 40 days period from mid-June to the beginning of August. Clear differences were found among years, regarding temperature during the assay period (Figure 3.1). Average, average maximum and average minimum temperature were much higher in 2015 between June and August. Thermal regime was similar in 2016 and 2017, except for June, in the initial stages of plant development, when temperatures were higher in 2017.

Mortality at 30 dat caused by both Monosporascus species was higher in 2015 for most of the accessions tested (Figure 3.2). All the plants of the susceptible control, Ib-PsPiñSp, died as a consequence of the inoculation with M. cannonballus in this year (2015MC), with percentages of mortality between 50 and $83 \%$ in the rest of the genotypes assayed. This year percentages of mortality associated with inoculation with M. eutypoides (2015ME) were lower. All plants of Ib-PsPiñSp and Chin-Pat81Ko survived in 2015ME, with mortality for the rest of the genotypes between 16 and 50\%. In 2016 and 2017 mortality affected a lower number of genotypes with lower percentages. In fact, mortality in Ib-PsPiñSp was 0 and $40 \%$, respectively in 2016MC and $2017 \mathrm{MC}$, and 0 and $20 \%$ in 2016ME and 2017ME, while none of the plants of the resistant control, Chin-Pat81Ko, died in these assays. Wild African and Asian accessions, showed a behaviour similar to Chin-Pat81Ko after MC inoculation, whereas the remaining genotypes were intermediated between Chin-Pat81Ko and the susceptible control, Ib-PsPiñSp.

Evolution of plant vigour between 15 dat and 30 dat differed when comparing the year and the fungal species used for inoculation (Figure 3.3). In 2015, when temperatures and plant mortality were higher, vigour index for most of the accessions and with both species, either was similar or decreased between 15 dat and 30 dat. The tendency for most of the accessions in 2016, with milder temperatures and lower mortality percentages, was an increase in vigour index with time for both, M. cannonballus and M. eutypoides. In the 2017 assay, in which the temperatures in the initial stages of plant development were intermediate between 2015 and 2016, the response depended on the fungal species: in plants inoculated with $M$. cannonballus vigour index was 


\subsection{CAPÍTULO 3}

similar between 15 dat and 30 dat for most of the accessions, while for plants inoculated with M. eutypoides there was an increase in vigour at 30 dat.

Plants of most genotypes inoculated with $M$. eutypoides showed higher vigour index than those inoculated with M. cannonballus, with few exceptions (Figure 3.3). The most severe assay conditions were in $2015 \mathrm{MC}$, i.e. high temperature with the most aggressive species, $M$. cannonballus. In these conditions, the susceptible control, Ib-PsPiñSp, exhibited lower vigour index than the rest of the accessions, while the highest vigour was shown by F1Pat81xPs. The vigour index in wild accessions was intermediate between Ib-PsPiñSp and F1Pat81xPs at 30 dat in these conditions. The response was similar in 2017MC, although with higher vigour for all the genotypes. Chin-Pat81Ko developed the most vigorous plants along with their F1 Pat 81xPs. Differences between the genotypes were less accused with milder conditions, i.e., the moderate temperatures of 2016 and/or inoculation with M. eutypoides. With these conditions, plant vigour did not seem to discriminate between susceptible and resistant accessions.

The plant vigour index was positively correlated to vine fresh and dry weight and to vine length at 30 dat (Table 3.1). Correlations were higher in the three M. cannonballus assays $\left(r^{2}=0.49\right.$ to $0.61,0.29$ to 0.37 and 0.51 to 0.63 with $\mathrm{p}<0.01$, respectively for 2015,2016 and 2017) than in M. eutypoides assay (ns for 2015 and 2017 and $\mathrm{r}^{2}=0.38$ to $0.46 \mathrm{p}<0.01$ for 2016), where less differences in vigour among genotypes were observed. Fungal infection resulted in a significant decrease in vine weight and length, observed when comparing inoculated plants with respect to the non-inoculated controls (Table 3.2). These losses were, in average, higher at each year in plants inoculated with M. cannonballus with respect to plants inoculated with M. eutypoides this same year. Moreover, differences were observed among years, being more pronounced in 2015, accordingly to the warmer temperatures. The susceptible control, Ib-PsPiñSp, showed the highest losses, particularly in the case of inoculations with M. cannonballus.

\subsubsection{Root damage}

Differences in plant development were associated to differences in root damage. In figure 3.4 photograph of a root system per genotype, treatment and assay is included, showing root development and fungal damage on roots.

Higher root damage indices (RDI) were observed in roots from assays of 2015 (2015MC and 2015ME), when compared with assays in 2016 and 2017, for most of the accessions assayed (Figure 3.5A). As previously stated, MC2015 represented the most unfavourable conditions. In the susceptible control, Ib-PsPiñSp, it was not possible to score RDI that year, given that mortality was $100 \%$. Average RDI in the resistant control, Pat81, in 2015MC was higher than 3. In fact, the only accession with significantly lower RDI (<2.5) in MC2015 was C. metuliferus. 
Root damage caused by M. eutypoides in 2015ME, was significantly lower for most of the accessions, with respect to 2015MC, which indicated the lower aggressiveness of $M$. eutypoides, even in unfavourable conditions The genotypes with the more damaged roots (RDI>2.5) were the susceptible control, Ib-PsPiñSp, and the Indian agrestis wild type AgrTriInd. The resistant control, Chin-Pat81Ko, and the wild African agrestis Agr-15991Gha, showed the best response (RDI<1.5).

In 2016 and 2017 the assays took place in milder conditions. In 2016MC and 2017MC, RDI was significantly higher in the susceptible control, Ib-PsPiñSp, when compared with the rest of the accessions assayed (Figure 3.5A). In 2016MC the response in the rest of the accessions, all with low RDI index, was similar (RDI from 0.4 to 1.5 ). In 2017MC, the remaining accessions were still resistant, but significant differences were identified between some of them (Figure 3.5A). Chin-Pat81Ko showed the lowest RDI (0.25), followed by F1 Pat81xPs and Agr15991Gha (both with RDI<1). The results in 2016 and 2017 confirmed the lower aggressiveness of M. eutypoides. Despite the lower root damage in Ib-PsPiñSp, RDI in this susceptible control was higher than that of most of the remaining genotypes in both assays (RDI 2 versus 0 to 1.89 and RDI 1.3 versus 0.3 to 1 in Ib-PsPiñSp and the remaining genotypes in ME2016 and ME 2017 respectively).

Similar results were found for Hypocotyl damage index (HDI) (Figure 3.5B). Correlation between HDI and RDI was significant for all the assays, but was higher in the inoculations with M. cannonballus (values ranging from 0.84-0.97 in MC versus 0.48-0.85 in ME, in all cases $\mathrm{p}<0,0002$ ) (Table 3.1). The highest correlation values corresponded to the assay with the more severe conditions in inoculations with M. cannonballus (2015MC) (those plants with severely affected roots showed also severe lesions in hypocotyls), and the lowest in 2015ME. In fact, the high-pressure conditions in 2015 were enough for $M$. eutypoides to cause root damage higher than that of 2016 and 2017, but not enough to cause important hypocotyls lesions. Lesions in hypocotyls caused by the two pathogens were similar under low-pressure conditions in 2016 and 2017 assays (Figure 3.5B).

Significant negative correlations were found between RDI, and in some cases HDI, and Root fresh weight (Table 3.1), higher in the most severe assays of $2015\left(r^{2}=-0.62\right.$ and $-0.47 p<0.001$ for MC and ME respectively), but also significant in $2016\left(\mathrm{r}^{2}=-0.33\right.$ and -0.45$)$. In 2017, they were not significant, but RDI negatively correlated to plant vigour $\left(\mathrm{r}^{2}=0.78\right.$ and 0.5 for $\mathrm{MC}$ and ME respectively). Therefore, under severe infection, root damage results in severely root losses, and under less severe conditions, the observation of root lesions is associated to a decrease in plant development, even when root losses are not yet apparent. Table 3.2 shows Root fresh and dry weight decrease in inoculated plants with respect to the non-inoculated plants. Reduction 


\subsection{CAPÍTULO 3}

was higher in assays inoculated with $M$. cannonballus and with higher temperatures, and higher reductions on average in the susceptible control Ib-PsPiñ Sp.

Root image analysis allowed a more detailed characterization of root systems. All the parameters measuring root size (TRL, TPRA, TRSA, and TRV) were highly correlated ( $\mathrm{r} 2>0.9059, \mathrm{p}<0.00001)$, as well as all related to the level of root branching (tips, crossings and forks) $(0.7293, \mathrm{p}<0.00001)$. Interestingly there was a high positive correlation between Root weight and all WhinRhizo's parameters related to root size and branching, suggesting that root lesions lead to root pruning, affecting root structure. This effect was observed with both pathogens.

\subsubsection{Field response}

The same accessions artificially inoculated in the three assays, were tested in field conditions in 2016. Two F1 hybrids of the 'Piel de Sapo' market class were also included. For most of the accessions, plant vigour increased between 15 and 30 dat (Figure 3.6). Only in the most susceptible ones, Ib-PsPiñSp and Quixote, there was a slight decrease in vigour with time. The highest vigour indices corresponded to F1 Pat81xPs, whereas the lowest values corresponded to the commercial 'Piel de Sapo' hybrids Quixote and Iberico. Plant vigour was consistent with root damage, being the susceptible control Ib-PsPiñSp and Iberico scored with the highest RDI, thus showing the susceptibility of this F1 hybrid. Among the wild accessions, the Indian agrestis wild type Agr-TriInd was the only one with significantly higher RDI than the resistant control, Chin-Pat81Ko. The African wild agrestis and acidulus accessions, Ag-15591Gha and AcTGR139Zimb, as well as the African wild relative C. metuliferus behaved similarly to the resistant control. Also the F1 Pat $81 x$ Ps hybrid had a very good resistant response under field conditions.

\subsubsection{Discussion}

Monosporascus root rot and vine decline can be caused by M. cannonballus and M. eutypoides, but most of the previous studies dealing with this disease focused only on M. cannonballus, which has a wider geographical distribution (Ben Salem et al., 2013; Reuveni et al., 1983). In fact, this is the first research evaluating the response of different genotypes of $C$. melo spp. agrestis to inoculation with $M$. eutypoides. MRRVD symptoms, root lesions and the occurrence of vine collapse, are highly dependent on several factors, such as temperature, method of inoculation or cultural practices, among others (Fita et al., 2007a; Martyn, 2007). These factors difficult the selection of the best resistant sources in breeding programs. 
In the work here presented, evaluations with artificial inoculation were carried out in three different years, representing different environmental conditions, and testing the aggressiveness of both species, $M$ cannonballus and $M$. eutypoides, on a selection of genotypes with different levels of resistance.

In all the conditions assayed, aggressiveness shown by $M$. eutypoides was lower than that exhibited by M. cannonballus. Despite the low aggressiveness, this pathogen was able to cause moderate root lesions. These mild root damage was similar in MRRVD susceptible and resistant genotypes under moderate temperature conditions (even the susceptible control Ib-PsPiñSp behaved as tolerant), and only under high temperature stressful conditions, root lesions were more severe in susceptible genotypes. Even, under these stressful conditions, the moderate root damage had a low impact on plant development and did not result in plant death. In a previous study, Ben Salem et al. (2013), in a pathogenicity test with different isolates of M. cannonballus and M. eutypoides did not found significant differences between the pathogenic isolates of both species. The different conditions used in these assays could explain these discrepancies. In fact, in our assay differences between both species were not so important in the 2016 assay, with the low temperatures.

Apart from the species effect, the results obtained support the strong influence of temperature conditions on this disease. Previous studies have reported that high ambient temperatures late in the growing season (Bruton et al., 1999; Wolff, 1996; Wolff et al., 1997), as well as temperatures above $20^{\circ} \mathrm{C}$ during the first 30 days after planting (Pivonia et al., 2002), are associated with a more severe canopy collapse caused by M. cannonballus. Our results also confirmed the effect of high temperatures (for both fungal species) on root and vine symptoms. The effect of the more aggressive species (M. cannonballus) on roots varied with temperature, with highly severe to moderate and milder symptoms in assays conducted at high (2015), moderate (2017) or lower (2016) temperatures, respectively. M. cannonballus root lesions affected plant development at both high and moderate temperature assay conditions, whereas M. eutypoides only interfered with plant growth at high temperatures.

Our assays also confirmed the utility of the root damage indices, especially RDI that correlated better to plant and root development, as well as several parameters measured with WhinRhizo Pro in disease assessment. High and significant correlations were identified between parameters related to root development and between parameters related to root structure. Similar results were reported previously (Fita et al., 2007a). Thus, it would be possible to reduce the number of parameters considered in the analysis. Moreover, correlation between both, RDI and HDI, with root development and root structure parameters measured with WhinRhizo Pro were significant for both fungal species with the thermal regimes in 2015 and 2016. These results 


\subsection{CAPÍTULO 3}

imply that with certain environmental conditions in artificial inoculation assays, it would be possible to use objective parameters in disease evaluation, instead of the score systems. As previously stated, visual score systems are time consuming, require skilled expertise and are subjective measurements that depend on the observer (Fita, Picò \& Nuez, 2007b). The use of image system evaluation can complement the score evaluation with more objective measurements, highly correlated with disease indexes.

Screening assays aimed at the identification of tolerance or resistance to collapse caused by $M$. cannonballus have been carried out in different conditions (Crosby, 2000a; Esteva \& Nuez, 1994; Crosby et al., 2000; Wolff, 1995; Wolff \& Miller, 1998; Sales Júnior et al., 2019). However, very few resistance sources have been identified so far. A recent screening of commercial melon cultivars under natural M. cannonballus-infested soils in Brazil has attributed the difficulty in identifying resistant sources to the aggressiveness of the pathogen (Sales Júnior et al., 2019). The influence of the environmental factors in the expression of symptoms has also been reported as hindering the identification of resistance sources (Cohen et al., 2000; Fita, Picò, Monforte \& Nuez, 2008). In the artificial inoculation assays presented here, RDI was high for all the accession in 2015MC, while with milder conditions, most of them were considered resistant. Extremely high disease pressure in artificial inoculation assays has been described as restricting performance of genotypes that grow well in the field (Crosby, 2000b). On the contrary, good performance under greenhouse conditions does not always imply good response in field (Crosby, 2000b). The resistance of all the accessions found resistant in our inoculation assays was confirmed in field conditions, with the only exception of Ag-TriInd, which was not resistant under field conditions. However, consistently, this Indian wild agrestis was the only agrestis type that showed RDI $>3$ (considered susceptible) in the high pressure assay of 2015 with M. cannonballus.

Resistance under field and artificial inoculation conditions has been confirmed in the 'Pat 81 ' source and in their derived F1 with 'Piel de Sapo' (Iglesias et al., 2000a; Dias et al., 2004; Roig et al., 2012), but also in new germplasm, originated from Africa. Among the most interesting sources are Ag-15591Gha that represented the group of wild African agrestis, molecularly different from that of Indian wild types (Endl et al., 2018; Gonzalo et al., 2019), and the African acidulus accession Ac-TGR139Zimb. These accessions showed a similar behavior to Pat 81 in all artificial inoculation assays, although with higher RDI in MC inoculations, but showed a very good performance under field conditions. The spp. agrestis has been reported as an interesting source for pathogen resistance in melon breeding (Pitrat, 2017). Both wild accessions and acidulus accessions have been proven useful, such as the multiresistant TGR1551, resistant to powdery mildew caused by Podosphaera xanthii (Yuste-Lisbona, López- 
Sesé, Gómez-Guillamón, 2009), to the yellowing caused by Cucurbit yellow stunting disorder virus (López-Sesé \& Gómez-Guillamón, 2000) and to the potyvirus Watermelon mosaic virus (Díaz-Pendón et al. 2003). These accessions can be easily used in breeding programs as they belong to the $C$. melo species and there are no compatibility problems with commercial melons. Also interesting is the behaviour of the close relative Cucumis metuliferus. The accession MetBGV11135Afr behaved as resistant in both, artificial inoculation and field assays presented here, even with RDI lower than Pat 81 under high-pressure conditions, although with high HDI in fields. C. metuliferus cannot be crossed to C.melo so its interest mainly relies in its advantages as a rootstock for melon, without effects on plant growing and melon fruit quality. Moreover, this accession shows resistance to Fusarium wilt (Gisbert et al., 2014) as well as to different root-knot nematode isolates (Expósito et al., 2018). Confirmation of resistance to MRRVD increases the interest for the potential use of this accession as melon rootstock.

The Brazilian Landrace La-PE4Bra has previously been reported as promising source of resistance to different pathogens (Dantas et al., 2005) and showed tolerance to MRRVD in Brazilian infested soils (Dr. de Sousa, personal communication). Our field results also confirm god behavior in Spanish fields, but under artificial inoculation, root damage was more severe than in the agrestis sources.

The accessions selected here can be useful for breeding new melon cultivars and rootstocks resistant to the two main pathogens involved in MRRVD, M. cannonballus and M. eutypoides. 


\subsection{CAPÍTULO 3}

\subsection{Supporting information}

Table 3.1. Correlations (and significance values, below; $p<0.05$ highlighted in grey) between vigour, root and vine weight and length parameters, disease indeces and parameters measured with WinRhizo, for the six artificial inoculation assays (each assay in the correspondign sheet).

\begin{tabular}{|c|c|c|c|c|c|c|c|c|c|c|c|c|c|c|c|}
\hline 2015MC & $\begin{array}{l}\text { Vigour } \\
15 \text { dat } \\
\end{array}$ & $\begin{array}{l}\text { Vigour } \\
30 \text { dat }\end{array}$ & VFW & VDW & VL & HDI & RDI & RFW & RDW & TRL & TPRA & ARD & Tips & Forks & Crossings \\
\hline Vigour & & 0.9569 & & & & & & & & & & & & & \\
\hline 15 dat & & $<0.0001$ & 0.0082 & 0.0004 & 0.0014 & $<0.0001$ & $<0.0001$ & 0.214 & 0.0726 & 0.0182 & & & & & 0.0195 \\
\hline Vigour & 0.9569 & & 0.4888 & 0.605 & 0.5663 & -0.6833 & -0.7692 & 0.297 & 0.3727 & 0.4468 & 0.4105 & -0.3618 & 0.4165 & 0.425 & 0.4287 \\
\hline 30 dat & $<0.0001$ & & 0.0039 & 0.0002 & 0.0006 & $<0.0001$ & $<0.0001$ & 0.0988 & 0.0327 & 0.0091 & 0.0177 & 0.0385 & 0.0159 & 0.0137 & 0.0128 \\
\hline \multirow[t]{2}{*}{ VFW } & 0.4527 & 0.4888 & & 0.8321 & 0.6739 & -0.7452 & -0.7357 & 0.7288 & 0.7053 & 0.4938 & 0.55 & -0.0779 & 0.3829 & & 0.4092 \\
\hline & 0.0082 & 0.0039 & & $<0.0001$ & $<0.0001$ & $<0.0001$ & $<0.0001$ & $<0.0001$ & $<0.0001$ & 0.0035 & 0.0009 & 0.6667 & 0.0279 & 0.0075 & 0.018 \\
\hline \multirow[t]{2}{*}{ VDW } & 0.5793 & 0.605 & 0.8321 & & 0.7023 & -0.7697 & -0.7626 & 0.4763 & 0.762 & 0.4005 & 0.4591 & -0.1744 & 0.2856 & 0.373 & 0.3194 \\
\hline & & 0.0002 & & & & & & & & & & & & & 0.07 \\
\hline \multirow[t]{2}{*}{ VL } & 5338 & 0.5663 & & 0.7023 & & & & & & & & & & & \\
\hline & 0.0014 & 0.0006 & $<0.0001$ & $<0.0001$ & & $<0.0001$ & $<0.0001$ & 0.0001 & $<0.0001$ & 0.0001 & 0.0001 & 0.0644 & 0.0002 & 0.0001 & 0.0001 \\
\hline \multirow[t]{2}{*}{ HDI } & & -0.6833 & & & -0.8159 & & & & & & & & & & \\
\hline & $<0.0001$ & $<0.0001$ & $<0.0001$ & $<0.0001$ & $<0.0001$ & & & & & & & 0.0598 & & & 0.0009 \\
\hline \multirow[t]{2}{*}{ RDI } & -0.7291 & -0.7692 & -0.7357 & -0.7626 & -0.8011 & 0.9697 & & -0.6259 & 06221 & -0.6132 & -0.6207 & 0.3494 & -0.5423 & -0.5771 & -0.5517 \\
\hline & $<0.0001$ & $<0.0001$ & $<0.0001$ & $<0.0001$ & $<0.0001$ & $<0.0001$ & & & 0.0001 & & & 0.0462 & 0.0011 & 0.0004 & 0.0009 \\
\hline \multirow[t]{2}{*}{ RFW } & 0.2258 & 0.297 & 0.7288 & 0.4763 & & -0.6626 & & & & & & & & & 0.5801 \\
\hline & 0.214 & 0.0988 & $<0.0001$ & 0.0059 & & $<0.0001$ & 0.0001 & & & & & & & & \\
\hline \multirow[t]{2}{*}{ RDW } & 0.3166 & 0.3727 & 0.7053 & 0.762 & 0.6856 & -0.6221 & -0.6221 & 0.5029 & & 0.4006 & 0.4706 & -0.1164 & 0.3118 & 0.3677 & 0.3071 \\
\hline & 0.0726 & 0.0327 & $<0.0001$ & $<0.0001$ & $<0.0001$ & 0.0001 & 0.0001 & 0.0034 & & 0.0209 & 0.0057 & 0.5189 & 0.0773 & 0.0353 & 0.0822 \\
\hline \multirow[t]{2}{*}{ TRL } & 0.4088 & 0.4468 & & 0.4005 & & -0.6162 & & & 0.4006 & & & -0.3047 & 0.9717 & 0.99 & 0.9786 \\
\hline & 0.0182 & 0.0091 & 0.0035 & 0.0209 & 0.0001 & 0.0001 & 0.0001 & 0.0003 & 0.0209 & & $<0.0001$ & 0.0847 & $<0.0001$ & $<0.0001$ & $<0.0001$ \\
\hline \multirow[t]{2}{*}{ TPRA } & 0.3609 & 0.4105 & 0.55 & 0.4591 & 0.6201 & -0.6277 & -0.6207 & 0.6171 & 0.4706 & 0.9839 & & -0.2329 & 0.9263 & 0.965 & 0.9334 \\
\hline & 0.0391 & 0.0177 & 0.0009 & 0.0072 & 0.0001 & 0.0001 & 0.0001 & 0.0002 & 0.0057 & $<0.0001$ & & 0.1921 & $<0.0001$ & $<0.0001$ & $<0.0001$ \\
\hline ARD & -0.4518 & -0.3618 & -0.0779 & -0.1744 & -0.3257 & 0.3311 & 0.3494 & -0.084 & -0.1164 & -0.3047 & -0.2329 & & -0.3292 & -0.2861 & -0.3123 \\
\hline
\end{tabular}


Table 3.1. (Continued)

\begin{tabular}{|c|c|c|c|c|c|c|c|c|c|c|c|c|c|c|c|}
\hline 2015MC & $\begin{array}{l}\text { Vigour } \\
15 \text { dat }\end{array}$ & $\begin{array}{l}\text { Vigour } \\
30 \text { dat }\end{array}$ & VFW & VDW & VL & HDI & RDI & RFW & RDW & TRL & TPRA & ARD & Tips & Forks & Crossings \\
\hline \multirow{3}{*}{ Tips } & 0.0083 & 0.0385 & 0.6667 & 0.3316 & 0.0644 & 0.0598 & 0.0462 & 0.6477 & 0.5189 & 0.0847 & 0.1921 & & 0.0614 & 0.1066 & 0.0769 \\
\hline & 0.3866 & 0.4165 & 0.3829 & 0.2856 & 0.6065 & -0.5411 & -0.5423 & 0.6193 & 0.3118 & 0.9717 & 0.9263 & -0.3292 & & 0.987 & 0.9916 \\
\hline & 0.0263 & 0.0159 & 0.0279 & 0.1072 & 0.0002 & 0.0011 & 0.0011 & 0.0002 & 0.0773 & $<0.0001$ & $<0.0001$ & 0.0614 & & $<0.0001$ & $<0.0001$ \\
\hline \multirow[t]{2}{*}{ Forks } & 0.391 & 0.425 & 0.4573 & 0.373 & 0.6264 & -0.5784 & -0.5771 & 0.6188 & 0.3677 & 0.99 & 0.965 & -0.2861 & 0.987 & & 0.9916 \\
\hline & 0.0245 & 0.0137 & 0.0075 & 0.0325 & 0.0001 & 0.0004 & 0.0004 & 0.0002 & 0.0353 & $<0.0001$ & $<0.0001$ & 0.1066 & $<0.0001$ & & $<0.0001$ \\
\hline Crossings & 0.0195 & 0.0128 & 0.018 & 0.07 & 0.0001 & 0.0009 & 0.0009 & 0.0005 & 0.0822 & $<0.0001$ & $<0.0001$ & 0.0769 & $<0.0001$ & $<0.0001$ & \\
\hline
\end{tabular}

\begin{tabular}{lcccccccccccccccc}
\hline 2016MC & $\begin{array}{l}\text { Vigour } \\
\text { 15 dat }\end{array}$ & Vigour & VFW & VDW & VL & HDI & RDI & RFW & RDW & TRL & TPRA & ARD & Tips & Forks & Crossings \\
\hline Vigour & & 0.4303 & 0.3116 & 0.3934 & 0.3352 & -0.0151 & -0.198 & 0.2786 & 0.2299 & 0.3516 & 0.3496 & 0.0566 & 0.2611 & 0.3007 & 0.3001 \\
15 dat & & 0.0001 & 0.0077 & 0.0006 & 0.004 & 0.8981 & 0.0908 & 0.0162 & 0.0487 & 0.0023 & 0.0024 & 0.6342 & 0.0257 & 0.0097 & 0.0099 \\
Vigour & 0.4303 & & 0.2854 & 0.348 & 0.3695 & -0.2086 & -0.3271 & 0.3056 & 0.113 & 0.2874 & 0.2881 & 0.1228 & 0.2434 & 0.2566 & 0.2522 \\
30 dat & 0.0001 & & 0.0151 & 0.0027 & 0.0014 & 0.0745 & 0.0045 & 0.0081 & 0.3379 & 0.0137 & 0.0134 & 0.3007 & 0.038 & 0.0285 & 0.0314 \\
VFW & 0.3116 & 0.2854 & & 0.6079 & 0.4098 & -0.2793 & -0.3343 & 0.568 & 0.2497 & 0.4267 & 0.472 & 0.2737 & 0.3279 & 0.339 & 0.2941 \\
& 0.0077 & 0.0151 & & $<0.0001$ & 0.0004 & 0.0175 & 0.0041 & $<0.0001$ & 0.0344 & 0.0002 & $<0.0001$ & 0.0209 & 0.0052 & 0.0038 & 0.0128 \\
\hline \multirow{2}{*}{ VDW } & 0.3934 & 0.348 & 0.6079 & & 0.3551 & -0.1269 & -0.2271 & 0.5114 & 0.2344 & 0.4218 & 0.4526 & 0.2844 & 0.3913 & 0.4062 & 0.3819 \\
& 0.0006 & 0.0027 & $<0.0001$ & & 0.0022 & 0.2882 & 0.055 & $<0.0001$ & 0.0475 & 0.0002 & 0.0001 & 0.0162 & 0.0007 & 0.0004 & 0.001 \\
VL & 0.3352 & 0.3695 & 0.4098 & 0.3551 & & -0.2597 & -0.3183 & 0.2046 & 0.0908 & 0.3736 & 0.3851 & 0.1653 & 0.2911 & 0.2911 & 0.2643 \\
& 0.004 & 0.0014 & 0.0004 & 0.0022 & & 0.0276 & 0.0064 & 0.0848 & 0.4481 & 0.0013 & 0.0009 & 0.1684 & 0.0138 & 0.0138 & 0.0259 \\
HDI & -0.0151 & -0.2086 & -0.2793 & -0.1269 & -0.2597 & & 0.8375 & -0.2588 & -0.1464 & -0.3162 & -0.3395 & -0.0876 & -0.2377 & -0.2316 & -0.1881 \\
& 0.8981 & 0.0745 & 0.0175 & 0.2882 & 0.0276 & & $<0.0001$ & 0.026 & 0.2131 & 0.0064 & 0.0033 & 0.4611 & 0.0429 & 0.0486 & 0.111 \\
RDI & -0.198 & -0.3271 & -0.3343 & -0.2271 & -0.3183 & 0.8375 & & -0.3274 & -0.1897 & -0.4057 & -0.4073 & 0.0167 & -0.345 & -0.2981 & -0.267 \\
& 0.0908 & 0.0045 & 0.0041 & 0.055 & 0.0064 & $<0.0001$ & & 0.0044 & 0.1054 & 0.0004 & 0.0003 & 0.8884 & 0.0028 & 0.0104 & 0.0224 \\
\multirow{2}{*}{ RFW } & 0.2786 & 0.3056 & 0.568 & 0.5114 & 0.2046 & -0.2588 & -0.3274 & & 0.1865 & 0.7351 & 0.797 & 0.336 & 0.7153 & 0.7644 & 0.7003 \\
& 0.0162 & 0.0081 & $<0.0001$ & $<0.0001$ & 0.0848 & 0.026 & 0.0044 & & 0.1117 & $<0.0001$ & $<0.0001$ & 0.0037 & $<0.0001$ & $<0.0001$ & $<0.0001$ \\
\hline
\end{tabular}




\subsection{CAPÍTULO 3}

Table 3.1. (Continued)

\begin{tabular}{|c|c|c|c|c|c|c|c|c|c|c|c|c|c|c|c|}
\hline 2016MC & $\begin{array}{l}\text { Vigour } \\
15 \text { dat } \\
\end{array}$ & $\begin{array}{l}\text { Vigour } \\
30 \text { dat }\end{array}$ & VFW & VDW & VL & HDI & RDI & RFW & RDW & TRL & TPRA & ARD & Tips & Forks & Crossings \\
\hline \multirow[t]{2}{*}{ RDW } & 0.2299 & 0.113 & 0.2497 & 0.2344 & 0.0908 & -0.1464 & -0.1897 & 0.1865 & & 0.2822 & 0.2742 & 0.0293 & 0.272 & 0.2647 & 0.2935 \\
\hline & 0.0487 & 0.3379 & 0.0344 & 0.0475 & 0.4481 & 0.2131 & 0.1054 & 0.1117 & & 0.0156 & 0.0189 & 0.8058 & 0.0199 & 0.0236 & 0.0117 \\
\hline \multirow[t]{2}{*}{ TRL } & 0.3516 & 0.2874 & 0.4267 & 0.4218 & 0.3736 & -0.3162 & -0.4057 & 0.7351 & 0.2822 & & 0.9784 & 0.015 & 0.9682 & 0.9617 & 0.9392 \\
\hline & 0.0023 & 0.0137 & 0.0002 & 0.0002 & 0.0013 & 0.0064 & 0.0004 & $<0.0001$ & 0.0156 & & $<0.0001$ & 0.8998 & $<0.0001$ & $<0.0001$ & $<0.0001$ \\
\hline \multirow[t]{2}{*}{ TPRA } & 0.3496 & 0.2881 & 0.472 & 0.4526 & 0.3851 & -0.3395 & -0.4073 & 0.797 & 0.2742 & 0.9784 & & 0.1943 & 0.9254 & 0.9623 & 0.9133 \\
\hline & 0.0024 & 0.0134 & $<0.0001$ & 0.0001 & 0.0009 & 0.0033 & 0.0003 & $<0.0001$ & 0.0189 & $<0.0001$ & & 0.0995 & $<0.0001$ & $<0.0001$ & $<0.0001$ \\
\hline \multirow[t]{2}{*}{ ARD } & 0.0566 & 0.1228 & 0.2737 & 0.2844 & 0.1653 & -0.0876 & 0.0167 & 0.336 & 0.0293 & 0.015 & 0.1943 & & -0.0618 & 0.1126 & 0.0001 \\
\hline & 0.6342 & 0.3007 & 0.0209 & 0.0162 & 0.1684 & 0.4611 & 0.8884 & 0.0037 & 0.8058 & 0.8998 & 0.0995 & & 0.6032 & 0.3429 & 0.9993 \\
\hline \multirow[t]{2}{*}{ Tips } & 0.2611 & 0.2434 & 0.3279 & 0.3913 & 0.2911 & -0.2377 & -0.345 & 0.7153 & 0.272 & 0.9682 & 0.9254 & -0.0618 & & 0.9501 & 0.9451 \\
\hline & 0.0257 & 0.038 & 0.0052 & 0.0007 & 0.0138 & 0.0429 & 0.0028 & $<0.0001$ & 0.0199 & $<0.0001$ & $<0.0001$ & 0.6032 & & $<0.0001$ & $<0.0001$ \\
\hline \multirow[t]{2}{*}{ Forks } & 0.3007 & 0.2566 & 0.339 & 0.4062 & 0.2911 & -0.2316 & -0.2981 & 0.7644 & 0.2647 & 0.9617 & 0.9623 & 0.1126 & 0.9501 & & 0.9805 \\
\hline & 0.0097 & 0.0285 & 0.0038 & 0.0004 & 0.0138 & 0.0486 & 0.0104 & $<0.0001$ & 0.0236 & $<0.0001$ & $<0.0001$ & 0.3429 & $<0.0001$ & & $<0.0001$ \\
\hline \multirow[t]{2}{*}{ Crossings } & 0.3001 & 0.2522 & 0.2941 & 0.3819 & 0.2643 & -0.1881 & -0.267 & 0.7003 & 0.2935 & 0.9392 & 0.9133 & 0.0001 & 0.9451 & 0.9805 & \\
\hline & 0.0099 & 0.0314 & 0.0128 & 0.001 & 0.0259 & 0.111 & 0.0224 & $<0.0001$ & 0.0117 & $<0.0001$ & $<0.0001$ & 0.9993 & $<0.0001$ & $<0.0001$ & \\
\hline
\end{tabular}

\begin{tabular}{|c|c|c|c|c|c|c|c|c|c|c|c|c|c|c|c|}
\hline $2017 \mathrm{MC}$ & $\begin{array}{l}\text { Vigour } \\
15 \text { dat } \\
\end{array}$ & $\begin{array}{l}\text { Vigour } \\
30 \text { dat } \\
\end{array}$ & VFW & VDW & VL & HDI & RDI & RFW & RDW & TRL & TPRA & ARD & Tips & Forks & Crossings \\
\hline Vigour & & 0.7896 & & & 0.4035 & & & & & & & & & 0,2814 & \\
\hline 15 dat & & $<0.0001$ & 0.0001 & $<0.0001$ & 0.0066 & 0.0002 & $<0.0001$ & & 0.1137 & & 0.1225 & 0.0906 & 0.0002 & 0,0676 & 0,0225 \\
\hline Vigour & 0.7896 & & 0.6329 & 0.5145 & 0.5241 & -0.6459 & -0.7783 & 0.3754 & 0.1906 & & & -0.2106 & 0.431 & & 0,2936 \\
\hline 30 dat & $<0.0001$ & & $<0.0001$ & 0.0004 & 0.0003 & $<0.0001$ & $<0.0001$ & & & & & & & & 0,056 \\
\hline \multirow[t]{2}{*}{ VFW } & 0.5679 & 0.6329 & & 0.643 & 0.3986 & -0.3176 & -0.5058 & 0.7326 & 0.3177 & 0.6378 & 0.4242 & -0.1192 & 0.6234 & 0,4365 & 0,5304 \\
\hline & 0.0001 & $<0.0001$ & & $<0.0001$ & 0.0074 & 0.0356 & 0.0005 & $<0.0001$ & 0.0356 & $<0.0001$ & 0.0046 & 0.4463 & $<0.0001$ & 0,0034 & 0,0003 \\
\hline \multirow[t]{2}{*}{ VDW } & 0.5843 & 0.5145 & 0.643 & & 0.573 & -0.4178 & -0.5027 & 0.4773 & 0.1088 & 0.2374 & -0.0616 & -0.5087 & 0.7828 & $-0,0025$ & 0,1479 \\
\hline & $<0.0001$ & 0.0004 & $<0.0001$ & & $<0.0001$ & 0.0048 & 0.0005 & 0.0011 & 0.482 & 0.1254 & 0.6948 & 0.0005 & $<0.0001$ & 0,9874 & 0,344 \\
\hline VL & 0.4035 & 0.5241 & 0.3986 & 0.573 & & -0.3997 & -0.477 & 0.1162 & 0.0595 & 0.0103 & -0.2199 & -0.5495 & 0.5668 & $-0,1816$ & $-0,0668$ \\
\hline
\end{tabular}


Table 3.1. (Continued)

\begin{tabular}{|c|c|c|c|c|c|c|c|c|c|c|c|c|c|c|c|}
\hline 2017MC & $\begin{array}{l}\text { Vigour } \\
15 \text { dat }\end{array}$ & $\begin{array}{l}\text { Vigour } \\
30 \text { dat }\end{array}$ & FW & VDW & VL & HDI & RDI & RFW & RDW & TRL & TPRA & ARD & Tips & Forks & Crossings \\
\hline & 0.0066 & 0.0003 & & & & & & & & & & & & & \\
\hline \multirow[t]{2}{*}{ HDI } & -0.5322 & -0.6459 & -0.3176 & -0.4178 & -0.3997 & & 0.8526 & -0.0746 & -0.1389 & -0.0428 & 0.1442 & 0.3467 & -0.3801 & 0.1287 & -0.0896 \\
\hline & 0.0002 & $<0.0001$ & & 0.0048 & 0.0072 & & $<0.0001$ & 0.6305 & 0.3686 & 0.7853 & 0.3561 & 0.0228 & & 0.4108 & 0.5676 \\
\hline \multirow[t]{2}{*}{ RDI } & -0.6212 & -0.7783 & -0.5058 & -0.5027 & -0.477 & 0.8526 & & -0.2573 & -0.1906 & -0.2069 & 0.0153 & 0.3849 & -0.4819 & -0.0084 & \\
\hline & $<0.0001$ & $<0.0001$ & 0.0005 & 0.0005 & & $<0.0001$ & & & 0.2153 & & 0.9226 & & & & \\
\hline \multirow[t]{2}{*}{ RFW } & 0.5069 & 0.3754 & 0.7326 & 0.4773 & 0.1162 & -0.0746 & -0.2573 & & 0.2131 & 0.7914 & 0.6464 & 0.0251 & & 0.6929 & 0.6183 \\
\hline & 0.0004 & 0.012 & $<0.0001$ & 0.0011 & 0.4526 & 0.6305 & 0.0918 & & 0.1649 & $<0.0001$ & $<0.0001$ & 0.8732 & $<0.0001$ & $<0.0001$ & $<0.0001$ \\
\hline \multirow[t]{2}{*}{ RDW } & 0.2418 & 0.1906 & & & & -0.1389 & -0.1906 & & & & & & & & \\
\hline & 0.1137 & 0.2152 & & 0.482 & & 0.3686 & 0.2153 & 0.1649 & & & 0.9848 & 0.1194 & 0.128 & 0.9713 & 0.6598 \\
\hline \multirow[t]{2}{*}{ TRL } & 0.4125 & 0.3416 & 0.6378 & 0.2374 & 0.0103 & -0.0428 & -0.2069 & 0.7914 & 0.0793 & & 0.914 & 0.3943 & 0.347 & 0.9075 & 0.8734 \\
\hline & 0.006 & .025 & $<0.0001$ & & & & & $<0.0001$ & 0.6134 & & & & & & $<0.0001$ \\
\hline \multirow[t]{2}{*}{ TPRA } & 0.2391 & 0.1754 & 0.4242 & -0.0616 & & & & & & & & & & & \\
\hline & 0.1225 & 0.2606 & 0.0046 & 0.6948 & 0.1564 & 0.3561 & 0.9226 & $<0.0001$ & 0.9848 & $<0.0001$ & & $<0.0001$ & 0.8857 & $<0.0001$ & $<0.0001$ \\
\hline \multirow[t]{2}{*}{ ARD } & -0.2612 & -0.2106 & -0.1192 & -0.5087 & -0.5495 & 0.3467 & 0.3849 & 0.0251 & -0.2411 & 0.3943 & 0.6772 & & -0.6014 & 0.5571 & 0.3773 \\
\hline & 0.0906 & 0.1752 & 0.4463 & 0.0005 & 0.0001 & 0.0228 & 0.0108 & 0.8732 & 0.1194 & 0.0089 & $<0.0001$ & & $<0.0001$ & 0.0001 & 0.0126 \\
\hline \multirow[t]{2}{*}{ Tips } & 0.5375 & 0.431 & 0.6234 & & & & & & 0.2357 & & & & & & \\
\hline & 0.0002 & 0.0039 & $<0.0001$ & $<0.0001$ & 0.0001 & 0.0119 & 0.0011 & $<0.0001$ & 0.128 & 0.0226 & 0.8857 & $<0.0001$ & & 0.5211 & 0.1158 \\
\hline \multirow[t]{2}{*}{ Forks } & 0.2814 & 0.1804 & 0.4365 & -0.0025 & -0.1816 & 0.1287 & -0.0084 & 0.6929 & -0.0057 & 0.9075 & 0.9509 & 0.5571 & 0.1006 & & 0.8698 \\
\hline & 0.0676 & 0.2469 & 0.0034 & 0.9874 & 0.2438 & 0.4108 & 0.9573 & $<0.0001$ & 0.9713 & $<0.0001$ & $<0.0001$ & 0.0001 & 0.5211 & & $<0.0001$ \\
\hline \multirow[t]{2}{*}{ Crossings } & 0.3473 & 0.2936 & 0.5304 & 0.1479 & -0.0668 & -0.0896 & -0.2218 & 0.6183 & -0.0691 & 0.8734 & 0.7954 & 0.3773 & 0.2434 & 0.8698 & \\
\hline & 0.0225 & 0.056 & 0.0003 & 0.344 & 0.6705 & 0.5676 & 0.1528 & $<0.0001$ & 0.6598 & $<0.0001$ & $<0.0001$ & 0.0126 & 0.1158 & $<0.0001$ & \\
\hline
\end{tabular}




\subsection{CAPÍTULO 3}

Table 3.1. (Continued)

\begin{tabular}{|c|c|c|c|c|c|c|c|c|c|c|c|c|c|c|c|}
\hline 2015ME & $\begin{array}{l}\text { Vigour } \\
15 \text { dat }\end{array}$ & $\begin{array}{l}\text { Vigour } \\
30 \text { dat }\end{array}$ & VFW & VDW & VL & HDI & RDI & RFW & RDW & TRL & TPRA & ARD & Tips & Forks & Crossings \\
\hline Vigour & & 0.6988 & & -0.0806 & 0.0486 & -0.0021 & & 0.0749 & -0.0611 & & -0.0301 & -0.3709 & 0.1412 & 0.0485 & 0.1124 \\
\hline 15 dat & & $<0.0001$ & 0.0356 & 0.5901 & 0.7269 & 0.988 & 0.0324 & 0.5941 & 0.6831 & 0.6648 & 0.8272 & 0.0053 & 0.3038 & 0.7249 & 0.4137 \\
\hline Vigour & 0.6988 & & -0.2073 & -0.1057 & -0.046 & -0.1773 & -0.3813 & 0.1586 & -0.1263 & 0.172 & 0.1206 & -0.3372 & 0.21 & 0.1888 & 0.2242 \\
\hline 30 dat & $<0.0001$ & & 0.1288 & 0.4794 & 0.7414 & 0.1954 & 0.0041 & 0.2567 & 0.3976 & 0.2094 & 0.3803 & 0.0118 & 0.1238 & 0.1675 & 0.0999 \\
\hline \multirow[t]{2}{*}{ VFW } & -0.284 & -0.2073 & & 0.7477 & 0.1542 & -0.0642 & -0.2324 & 0.4572 & 0.3687 & 0.2994 & 0.3806 & 0.3013 & 0.2175 & 0.309 & 0.244 \\
\hline & 0.0356 & 0.1288 & & $<0.0001$ & 0.2657 & 0.6415 & 0.0877 & 0.0006 & 0.0108 & 0.0264 & 0.0041 & 0.0254 & 0.1107 & 0.0217 & 0.0726 \\
\hline \multirow[t]{2}{*}{ VDW } & -0.0806 & -0.1057 & 0.7477 & & 0.2954 & -0.1403 & -0.1299 & 0.4001 & 0.5678 & 0.2717 & 0.3747 & 0.2133 & 0.1445 & 0.2875 & 0.2082 \\
\hline & 0.5901 & 0.4794 & $<0.0001$ & & 0.0462 & 0.3468 & 0.3842 & 0.0065 & $<0.0001$ & 0.0647 & 0.0095 & 0.1501 & 0.3324 & 0.0501 & 0.1602 \\
\hline \multirow[t]{2}{*}{ VL } & 0.0486 & -0.046 & 0.1542 & 0.2954 & & 0.0558 & 0.0074 & 0.1247 & 0.2667 & 0.2008 & 0.1925 & -0.1436 & 0.199 & 0.1849 & 0.1939 \\
\hline & 0.7269 & 0.7414 & 0.2657 & 0.0462 & & 0.6887 & 0.9577 & 0.3786 & 0.0732 & 0.1454 & 0.1632 & 0.3003 & 0.1492 & 0.1807 & 0.1601 \\
\hline \multirow[t]{2}{*}{ HDI } & -0.0021 & -0.1773 & -0.0642 & -0.1403 & 0.0558 & & 0.4829 & -0.3466 & -0.2744 & -0.3909 & -0.3813 & 0.4539 & -0.3718 & -0.3732 & -0.3704 \\
\hline & 0.988 & 0.1954 & 0.6415 & 0.3468 & 0.6887 & & & 0.011 & 0.062 & 0.0032 & 0.0041 & 0.0005 & 0.0052 & 0.005 & 0.0054 \\
\hline \multirow[t]{2}{*}{ RDI } & -0.289 & -0.3813 & -0.2324 & -0.1299 & 0.0074 & 0.4829 & & -0.4649 & 0.0319 & -0.4541 & -0.4306 & 0.2689 & -0.4868 & -0.4619 & -0.4722 \\
\hline & 0.0324 & 0.0041 & 0.0877 & 0.3842 & 0.9577 & 0.0002 & & 0.0005 & 0.8317 & 0.0005 & 0.001 & 0.0471 & 0.0002 & 0.0004 & 0.0003 \\
\hline \multirow[t]{2}{*}{ RFW } & 0.0749 & 0.1586 & 0.4572 & 0.4001 & 0.1247 & -0.3466 & -0.4649 & & 0.3795 & 0.7133 & 0.722 & -0.1445 & 0.7275 & 0.7458 & 0.7178 \\
\hline & 0.5941 & 0.2567 & 0.0006 & 0.0065 & 0.3786 & 0.011 & 0.0005 & & 0.0101 & $<0.0001$ & $<0.0001$ & 0.3018 & $<0.0001$ & $<0.0001$ & $<0.0001$ \\
\hline \multirow[t]{2}{*}{ RDW } & -0.0611 & -0.1263 & 0.3687 & 0.5678 & 0.2667 & -0.2744 & 0.0319 & 0.3795 & & 0.3078 & 0.3598 & -0.1392 & 0.1772 & 0.255 & 0.2036 \\
\hline & 0.6831 & 0.3976 & 0.0108 & $<0.0001$ & 0.0732 & 0.062 & 0.8317 & 0.0101 & & & 0.013 & 0.3506 & 0.2335 & 0.0837 & 0.1699 \\
\hline \multirow[t]{2}{*}{ TRL } & 0.0598 & 0.172 & 0.2994 & 0.2717 & 0.2008 & -0.3909 & -0.4541 & 0.7133 & & & 0.9836 & -0.3755 & 0.9561 & 0.987 & 0.9763 \\
\hline & 0.6648 & 0.2094 & 0.0264 & 0.0647 & 0.1454 & 0.0032 & 0.0005 & $<0.0001$ & 0.0353 & & $<0.0001$ & 0.0047 & $<0.0001$ & $<0.0001$ & $<0.0001$ \\
\hline \multirow[t]{2}{*}{ TPRA } & -0.0301 & 0.1206 & 0.3806 & 0.3747 & 0.1925 & -0.3813 & -0.4306 & 0.722 & 0.3598 & 0.9836 & & -0.2796 & 0.9021 & 0.9711 & 0.9351 \\
\hline & 0.8272 & 0.3803 & 0.0041 & 0.0095 & 0.1632 & 0.0041 & 0.001 & $<0.0001$ & 0.013 & $<0.0001$ & & 0.0387 & $<0.0001$ & $<0.0001$ & $<0.0001$ \\
\hline \multirow[t]{2}{*}{ ARD } & -0.3709 & -0.3372 & 0.3013 & 0.2133 & -0.1436 & 0.4539 & 0.2689 & -0.1445 & -0.1392 & -0.3755 & -0.2796 & & -0.4158 & -0.3436 & -0.3972 \\
\hline & 0.0053 & 0.0118 & 0.0254 & 0.1501 & 0.3003 & 0.0005 & 0.0471 & 0.3018 & 0.3506 & 0.0047 & 0.0387 & & 0.0016 & 0.0102 & 0.0027 \\
\hline \multirow[t]{2}{*}{ Tips } & 0.1412 & 0.21 & 0.2175 & 0.1445 & 0.199 & -0.3718 & -0.4868 & 0.7275 & 0.1772 & 0.9561 & 0.9021 & -0.4158 & & 0.965 & 0.9848 \\
\hline & 0.3038 & 0.1238 & 0.1107 & 0.3324 & 0.1492 & 0.0052 & 0.0002 & $<0.0001$ & 0.2335 & $<0.0001$ & $<0.0001$ & 0.0016 & & $<0.0001$ & $<0.0001$ \\
\hline
\end{tabular}


Table 3.1. (Continued)

\begin{tabular}{|c|c|c|c|c|c|c|c|c|c|c|c|c|c|c|c|}
\hline 2015ME & $\begin{array}{l}\text { Vigour } \\
15 \text { dat }\end{array}$ & $\begin{array}{l}\text { Vigour } \\
30 \text { dat }\end{array}$ & VFW & VDW & VL & HDI & RDI & RFW & RDW & TRL & TPRA & ARD & Tips & Forks & Crossings \\
\hline \multirow[t]{2}{*}{ Forks } & 0.0485 & 0.1888 & 0.309 & 0.2875 & 0.1849 & -0.3732 & -0.4619 & & 0.255 & & & & & & \\
\hline & 7249 & 0.1675 & 0.0217 & & 0.1807 & 0.005 & 0.0004 & $<0.0001$ & 0.0837 & $<0.0001$ & $<0.0001$ & 0.0102 & $<0.0001$ & & $<0.0001$ \\
\hline \multirow[t]{2}{*}{ Crossings } & 0.1124 & 0.2242 & 0.244 & 0.2082 & 0.1939 & -0.3704 & -0.4722 & 0.7178 & 0.2036 & 0.9763 & 0.9351 & -0.3972 & 0.9848 & 0.9883 & \\
\hline & 4137 & 0.0999 & 726 & & 0.1601 & & & & 0.1699 & & & & & & \\
\hline 2016ME & & & VFW & VDW & VL & & & & RDW & & & & Tips & Forks & Crossings \\
\hline Vigour & & 0.4664 & 0.5007 & 0.6281 & 0.351 & & & & & & & & & & \\
\hline 15 dat & & 0.0001 & $<0.0001$ & $<0.0001$ & 0.0041 & 0.0 & & & 0.0309 & & & & & & \\
\hline Vigour & 0.4664 & & 0.3824 & 0.3901 & 0.46 & -0.3 & -0.3989 & & & & & & & & \\
\hline 30 dat & 0.0001 & & 0.0017 & 0.0013 & 0.0001 & 0.0067 & & & 0.2932 & & & & & & \\
\hline \multirow[t]{2}{*}{ VFW } & 0.5007 & 0.3824 & & 0.8291 & 0.4786 & -0.2891 & -0.3701 & 0.6676 & 0.2347 & 0.5 & & 0.455 & 468 & & 0.45 \\
\hline & $<0.0001$ & 0.0017 & & $<0.00$ & 0.0001 & 0.0 & & $<0$. & 0.0599 & $<0.0$ & & & & & \\
\hline \multirow[t]{2}{*}{ VDW } & 0.6281 & 0.3901 & 0.8291 & & 0.5406 & -0.454 & -0.4709 & 0.682 & 0.3277 & 0.6 & & 0.3195 & & & 0.6036 \\
\hline & $<0.0001$ & 0.0013 & $<0.0001$ & & $<0.0001$ & & & $<0.0001$ & 0.0077 & & & & & & \\
\hline \multirow[t]{2}{*}{ VL } & 0.351 & 0.4617 & 0.4786 & 0.5406 & & -0.3393 & -0.3185 & 0.4073 & 0.086 & 0.51 & 0.48 & 0.1872 & 0.4682 & & 0.461 \\
\hline & 0.0041 & 0.0001 & 0.0001 & $<0.0001$ & & & & & 0.4957 & & & 0.1418 & & & \\
\hline \multirow[t]{2}{*}{ HDI } & -0.4712 & -0.333 & -0.2891 & -0.454 & -0.3393 & & 0.8479 & -0.4085 & -0.1703 & -0.4814 & -0.4539 & -0.2113 & -0.4322 & -0.4006 & -0.4261 \\
\hline & 0.0001 & 0.0067 & & 0.0001 & 0.0057 & & & & 0.1751 & & & 0.0965 & & & 0.0005 \\
\hline \multirow[t]{2}{*}{ RDI } & -0.5487 & -0.3989 & -0.3701 & -0.4709 & -0.3185 & 0.8479 & & -0.453 & -0.1718 & -0.5285 & -0.4981 & -0.2308 & -0.4534 & -0.4305 & -0.4517 \\
\hline & $<0.0001$ & 0.001 & 0.0024 & 0.0001 & 0.0097 & $<0.0001$ & & 0.0002 & 0.1712 & $<0.0001$ & $<0.0001$ & 0.0688 & 0.0002 & 0.0004 & 0.0002 \\
\hline \multirow[t]{2}{*}{ RFW } & 0.417 & 0.3418 & 0.6676 & 0.682 & 0.4073 & -0.4085 & -0.453 & & 0.2062 & 0.8371 & 0.8714 & 0.4847 & 0.8132 & 0.855 & 0.8116 \\
\hline & 0.0005 & 0.0053 & $<0.0001$ & $<0.0001$ & 0.0008 & & & & 0.0994 & & $<0.0001$ & 0.0001 & $<0.0001$ & $<0.0001$ & $<0.0001$ \\
\hline \multirow[t]{2}{*}{ RDW } & 0.2681 & 0.1324 & 0.2347 & 0.3277 & 0.086 & -0.1703 & -0.1718 & 0.2062 & & & 0.269 & 0.0548 & 0.3165 & 0.2698 & 0.3153 \\
\hline & 0.0309 & 0.2932 & 0.0599 & 0.0077 & & & & 0.0994 & & 0.0195 & & 0.6698 & & 0.0325 & 0.0118 \\
\hline \multirow[t]{2}{*}{ TRL } & 0.5463 & 0.3462 & 0.5415 & 0.6619 & 0.5105 & -0.4814 & -0.5285 & 0.8371 & 0.2937 & & 0.9864 & 0.282 & 0.9775 & 0.9657 & 0.9461 \\
\hline & $<0.0001$ & 0.0054 & $<0.0001$ & $<0.0001$ & $<0.0001$ & 0.0001 & $<0.0001$ & $<0.0001$ & 0.0195 & & $<0.0001$ & 0.0251 & $<0.0001$ & $<0.0001$ & $<0.0001$ \\
\hline
\end{tabular}




\subsection{CAPÍTULO 3}

Table 3.1. (Continued)

\begin{tabular}{|c|c|c|c|c|c|c|c|c|c|c|c|c|c|c|c|}
\hline 2016ME & $\begin{array}{l}\text { Vigour } \\
15 \text { dat }\end{array}$ & $\begin{array}{l}\text { Vigour } \\
30 \text { dat }\end{array}$ & VFW & VDW & VL & HDI & RDI & RFW & RDW & TRL & TPRA & ARD & Tips & Forks & Crossings \\
\hline \multirow[t]{2}{*}{ TPRA } & 0.522 & 0.3211 & 0.5766 & 0.6613 & 0.4887 & -0.4539 & -0.4981 & 0.8714 & 0.269 & 0.9864 & & 0.3935 & 0.9562 & 0.9648 & 0.9262 \\
\hline & $<0.0001$ & 0.0103 & $<0.0001$ & $<0.0001$ & $<0.0001$ & 0.0002 & $<0.0001$ & $<0.0001$ & 0.033 & $<0.0001$ & & 0.0014 & $<0.0001$ & $<0.0001$ & $<0.0001$ \\
\hline \multirow[t]{2}{*}{ ARD } & 0.1746 & 0.2814 & 0.455 & 0.3195 & 0.1872 & -0.2113 & -0.2308 & 0.4847 & 0.0548 & 0.282 & & & 0.2425 & & 0.2447 \\
\hline & 0.1711 & 0.0255 & 0.0002 & 0.0107 & 0.1418 & 0.0965 & 0.0688 & 0.0001 & 0.6698 & 0.0251 & 0.0014 & & & 0.0086 & 0.0532 \\
\hline \multirow[t]{2}{*}{ Tips } & 0.4677 & 0.3466 & 0.4468 & 0.5837 & 0.4682 & -0.4322 & -0.4534 & 0.8132 & 0.3165 & 0.9775 & 0.9562 & 0.2425 & & 0.9757 & 0.9658 \\
\hline & 0.0001 & 0.0054 & 0.0002 & $<0.0001$ & 0.0001 & 0.0004 & 0.0002 & $<0.0001$ & 0.0115 & $<0.0001$ & $<0.0001$ & 0.0555 & & $<0.0001$ & $<0.0001$ \\
\hline \multirow[t]{2}{*}{ Forks } & 0.4349 & 0.3169 & 0.5035 & 0.6111 & 0.4613 & -0.4006 & -0.4305 & 0.855 & 0.2698 & 0.9657 & 0.9648 & 0.3283 & 0.9757 & & 0.9839 \\
\hline & 0.0004 & 0.0114 & $<0.0001$ & $<0.0001$ & 0.0001 & 0.0011 & 0.0004 & $<0.0001$ & 0.0325 & $<0.0001$ & $<0.0001$ & 0.0086 & $<0.0001$ & & $<0.0001$ \\
\hline \multirow[t]{2}{*}{ Crossings } & 0.4246 & 0.3234 & 0.4533 & 0.6036 & 0.461 & -0.4261 & -0.4517 & 0.8116 & 0.3153 & 0.9461 & 0.9262 & 0.2447 & 0.9658 & 0.9839 & \\
\hline & 0.0005 & 0.0097 & 0.0002 & $<0.0001$ & 0.0001 & 0.0005 & 0.0002 & $<0.0001$ & 0.0118 & $<0.0001$ & $<0.0001$ & 0.0532 & $<0.0001$ & $<0.0001$ & \\
\hline
\end{tabular}

\begin{tabular}{|c|c|c|c|c|c|c|c|c|c|c|c|c|c|c|c|}
\hline 2017ME & $\begin{array}{l}\text { Vigour } \\
15 \text { dat }\end{array}$ & $\begin{array}{l}\text { Vigour } \\
30 \text { dat }\end{array}$ & VFW & VDW & VL & HDI & RDI & RFW & RDW & TRL & TPRA & ARD & Tips & Forks & Crossings \\
\hline Vigour & & 0.5186 & 0.4901 & 0.4265 & 0.7246 & -0.387 & -0.5009 & 0.4568 & 0.3071 & 0.5548 & & -0.0818 & 0.5486 & 0.4436 & 0.4084 \\
\hline 15 dat & & 0.0004 & 0.001 & 0.0049 & $<0.0001$ & 0.0124 & 0.0009 & 0.0024 & 0.0479 & 0.0002 & 0.0012 & 0.611 & 0.0002 & 0.0037 & 0.008 \\
\hline Vigour & 0.5186 & & 0.0809 & 0.1775 & 0.2307 & -0.2668 & -0.0693 & 0.1941 & 0.1943 & 0.4421 & 0.3271 & -0.2903 & 0.4733 & 0.3268 & 0.3214 \\
\hline 30 dat & 0.0004 & & 0.6105 & 0.2607 & 0.1416 & 0.0918 & 0.667 & 0.2182 & 0.2175 & 0.0038 & 0.0368 & 0.0656 & 0.0018 & 0.037 & 0.0405 \\
\hline \multirow[t]{2}{*}{ VFW } & 0.4901 & 0.0809 & & 0.5429 & 0.3335 & 0.0724 & -0.0935 & 0.5775 & 0.1747 & 0.5748 & 0.6409 & 0.5415 & 0.4979 & 0.5937 & 0.4704 \\
\hline & 0.001 & 0.6105 & & & & 0.653 & 0.5608 & 0.0001 & 0.2685 & 0.0001 & $<0.0001$ & 0.0003 & & $<0.0001$ & 0.0019 \\
\hline \multirow[t]{2}{*}{ VDW } & 0.4265 & 0.1775 & 0.5429 & & & -0.3348 & -0.3386 & & 0.1193 & 0.6213 & & 0.3165 & & 0.5813 & 0.4409 \\
\hline & 0.0049 & 0.2607 & 0.0002 & & 0.0151 & 0.0324 & 0.0304 & $<0.0001$ & 0.4517 & $<0.0001$ & $<0.0001$ & 0.0438 & $<0.0001$ & 0.0001 & 0.0039 \\
\hline \multirow[t]{2}{*}{ VL } & 0.7246 & 0.2307 & 0.3335 & 0.3725 & & -0.3569 & -0.4573 & 0.3204 & 0.1084 & 0.3742 & 0.2921 & -0.1462 & 0.4285 & 0.2485 & 0.2452 \\
\hline & $<0.0001$ & 0.1416 & 0.0309 & 0.0151 & & 0.022 & 0.0027 & 0.0386 & 0.4945 & 0.0159 & 0.0639 & 0.3617 & 0.0052 & 0.1173 & 0.1223 \\
\hline \multirow[t]{2}{*}{ HDI } & -0.387 & -0.2668 & 0.0724 & -0.3348 & -0.3569 & & 0.5736 & -0.2423 & -0.2042 & -0.1941 & -0.1254 & 0.1251 & -0.2165 & -0.1151 & -0.1634 \\
\hline & 0.0124 & 0.0918 & 0.653 & 0.0324 & 0.022 & & 0.0001 & 0.1269 & 0.2004 & 0.23 & 0.4407 & 0.442 & 0.1797 & 0.4794 & 0.3137 \\
\hline \multirow[t]{2}{*}{ RDI } & -0.5009 & -0.0693 & -0.0935 & -0.3386 & -0.4573 & 0.5736 & & -0.1913 & -0.2106 & -0.1231 & -0.0621 & 0.1605 & -0.1748 & -0.0539 & 0.0711 \\
\hline & 0.0009 & 0.667 & 0.5608 & 0.0304 & 0.0027 & 0.0001 & & 0.2309 & 0.1862 & 0.4493 & 0.7034 & 0.3224 & 0.2807 & 0.7411 & 0.6627 \\
\hline
\end{tabular}


Table 3.1. (Continued)

\begin{tabular}{|c|c|c|c|c|c|c|c|c|c|c|c|c|c|c|c|}
\hline 2017ME & $\begin{array}{l}\text { Vigour } \\
15 \text { dat }\end{array}$ & $\begin{array}{l}\text { Vigour } \\
30 \text { dat }\end{array}$ & VFW & VDW & VL & HDI & RDI & RFW & RDW & TRL & TPRA & ARD & Tips & Forks & Crossings \\
\hline \multirow[t]{2}{*}{ RFW } & 0.4568 & 0.1941 & 0.5775 & 0.7603 & 0.3204 & -0.2423 & -0.1913 & & 0.2358 & 0.7458 & 0.7703 & 0.4243 & 0.7698 & 0.6898 & 0.6255 \\
\hline & 0.0024 & 0.2182 & 0.0001 & $<0.0001$ & 0.0386 & 0.1269 & 0.2309 & & 0.1328 & $<0.0001$ & $<0.0001$ & 0.0057 & $<0.0001$ & $<0.0001$ & $<0.0001$ \\
\hline \multirow[t]{2}{*}{ RDW } & 0.3071 & 0.1943 & 0.1747 & 0.1193 & 0.1084 & -0.2042 & -0.2106 & 0.2358 & & 0.1376 & 0.0886 & -0.1107 & 0.1832 & 0.0339 & 0.0122 \\
\hline & 0.0479 & 0.2175 & 0.2685 & 0.4517 & 0.4945 & 0.2004 & 0.1862 & 0.1328 & & 0.3911 & 0.5816 & 0.4908 & 0.2516 & 0.8334 & 0.9399 \\
\hline \multirow[t]{2}{*}{ TRL } & 0.5548 & 0.4421 & 0.5748 & 0.6213 & 0.3742 & -0.1941 & -0.1231 & 0.7458 & 0.1376 & & 0.9698 & 0.3034 & 0.9455 & 0.9554 & 0.8789 \\
\hline & 0.0002 & 0.0038 & 0.0001 & $<0.0001$ & 0.0159 & 0.23 & 0.4493 & $<0.0001$ & 0.3911 & & $<0.0001$ & 0.0538 & $<0.0001$ & $<0.0001$ & $<0.0001$ \\
\hline \multirow[t]{2}{*}{ TPRA } & 0.4893 & 0.3271 & 0.6409 & 0.6298 & 0.2921 & -0.1254 & -0.0621 & 0.7703 & 0.0886 & 0.9698 & & 0.5113 & 0.868 & 0.9819 & 0.9031 \\
\hline & 0.0012 & 0.0368 & $<0.0001$ & $<0.0001$ & 0.0639 & 0.4407 & 0.7034 & $<0.0001$ & 0.5816 & $<0.0001$ & & 0.0006 & $<0.0001$ & $<0.0001$ & $<0.0001$ \\
\hline \multirow[t]{2}{*}{ ARD } & -0.0818 & -0.2903 & 0.5415 & 0.3165 & -0.1462 & 0.1251 & 0.1605 & 0.4243 & -0.1107 & 0.3034 & 0.5113 & & 0.14 & 0.4818 & 0.4147 \\
\hline & 0.611 & 0.0656 & 0.0003 & 0.0438 & 0.3617 & 0.442 & 0.3224 & 0.0057 & 0.4908 & 0.0538 & 0.0006 & & 0.3827 & 0.0014 & 0.007 \\
\hline \multirow[t]{2}{*}{ Tips } & 0.5486 & 0.4733 & 0.4979 & 0.6568 & 0.4285 & -0.2165 & -0.1748 & 0.7698 & 0.1832 & 0.9455 & 0.868 & 0.14 & & 0.8464 & 0.7524 \\
\hline & 0.0002 & 0.0018 & 0.0009 & $<0.0001$ & 0.0052 & 0.1797 & 0.2807 & $<0.0001$ & 0.2516 & $<0.0001$ & $<0.0001$ & 0.3827 & & $<0.0001$ & $<0.0001$ \\
\hline \multirow[t]{2}{*}{ Forks } & 0.4436 & 0.3268 & 0.5937 & 0.5813 & 0.2485 & -0.1151 & -0.0539 & 0.6898 & 0.0339 & 0.9554 & 0.9819 & 0.4818 & 0.8464 & & 0.9123 \\
\hline & 0.0037 & 0.037 & $<0.0001$ & 0.0001 & 0.1173 & 0.4794 & 0.7411 & $<0.0001$ & 0.8334 & $<0.0001$ & $<0.0001$ & 0.0014 & $<0.0001$ & & $<0.0001$ \\
\hline \multirow[t]{2}{*}{ Crossings } & 0.4084 & 0.3214 & 0.4704 & 0.4409 & 0.2452 & -0.1634 & 0.0711 & 0.6255 & 0.0122 & 0.8789 & 0.9031 & 0.4147 & 0.7524 & 0.9123 & \\
\hline & 0.008 & 0.0405 & 0.0019 & 0.0039 & 0.1223 & 0.3137 & 0.6627 & $<0.0001$ & 0.9399 & $<0.0001$ & $<0.0001$ & 0.007 & $<0.0001$ & $<0.0001$ & \\
\hline $\mathrm{MC}$ & \multicolumn{15}{|c|}{ Monosporascus cannonballus } \\
\hline $\mathrm{ME}$ & \multicolumn{15}{|c|}{ Monosporascus eutypoides } \\
\hline dat & \multicolumn{15}{|c|}{ days after transplanting } \\
\hline VFW & \multicolumn{15}{|c|}{ vine fresh weight $(\mathrm{g})$} \\
\hline VDW & \multicolumn{15}{|c|}{ vine dry weight $(\mathrm{g})$} \\
\hline VL & \multicolumn{15}{|c|}{ vine length $(\mathrm{cm})$} \\
\hline HDI & \multicolumn{15}{|c|}{ hypocotyl disease index $(0-4)$} \\
\hline RDI & \multicolumn{15}{|c|}{ root disease index $(0-4)$} \\
\hline RFW & \multicolumn{15}{|c|}{ root fresh weight $(\mathrm{RFW}, \mathrm{g})$} \\
\hline RDW & \multicolumn{15}{|c|}{ root dry weight $(\mathrm{RDW}, \mathrm{g})$} \\
\hline TRL & \multicolumn{15}{|c|}{ total root length (TRL, cm) } \\
\hline TPRA & \multicolumn{15}{|c|}{ total projected root area (TPRA, $\mathrm{cm} 2$ ), } \\
\hline ARD & \multirow{2}{*}{\multicolumn{15}{|c|}{$\begin{array}{l}\text { average root diameter (ARD, mm), } \\
\text { number of tips }\end{array}$}} \\
\hline Tips & & & & & & & & & & & & & & & \\
\hline
\end{tabular}




\subsection{CAPÍTULO 3}

$\begin{array}{ll}\text { Forks } & \text { number of forks } \\ \text { Crossings } & \text { number of crossings }\end{array}$

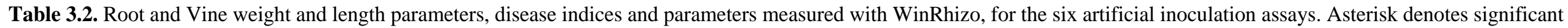

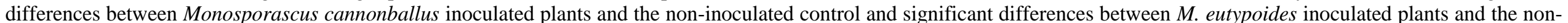
inoculated control, for each genotype and year $(\mathrm{p}<0.05$, Student's t test $)$.

\begin{tabular}{|c|c|c|c|c|c|c|c|c|c|}
\hline & \multicolumn{3}{|c|}{2015} & \multicolumn{3}{|c|}{2016} & \multicolumn{3}{|c|}{2017} \\
\hline & Control & M. cannonballus & M. eutypoides & Control & M. cannonballus & M. eutypoides & Control & M. cannonballus & M. eutypoides \\
\hline & Mean & Mean & Mean & Mean & Mean & Mean & Mean & Mean & Mean \\
\hline & \multicolumn{9}{|c|}{ Vine Fresh Weight $(\mathrm{g})$} \\
\hline Chin-Pat81Ko & 11.77 & $0.96^{*}$ & 11.99 & 18.87 & 19.07 & 10.52 & 14.08 & 10.80 & 16.20 \\
\hline Ag-15591Gha & 7.27 & $1.44 *$ & 10.79 & 17.87 & $6.22 *$ & $2.04 *$ & 12.54 & 10.72 & 15.45 \\
\hline Ag-TriInd & 11.60 & $0.64 *$ & $5.22 *$ & 11.25 & $6.75^{*}$ & 8.04 & 9.49 & 9.93 & 4.90 \\
\hline Met-BGV11135Afr & 17.82 & $9.04 *$ & 12.86 & 12.81 & $3.83 *$ & 6.38 & 18.25 & 9.22 & $7.43^{*}$ \\
\hline Ac-TGR139Zimb & 10.63 & $2.51^{*}$ & 10.65 & 12.88 & 18.04 & 11.78 & 20.12 & 19.32 & 13.39 \\
\hline La-PE4Bra & 19.46 & $3.53 *$ & 20.80 & 26.11 & $17.78 *$ & 10.04 & - & - & - \\
\hline F1 Pat81xPs & 13.82 & $0.76^{*}$ & $4.82 *$ & 25.39 & $7.69 *$ & 12.54 & 24.18 & $13.70 *$ & 18.91 \\
\hline \multirow[t]{2}{*}{ Ib-PsPiñSp } & 15.30 & - & 12.51 & 31.62 & $6.25^{*}$ & $15.86^{*}$ & 19.10 & $3.99 *$ & $28.15^{*}$ \\
\hline & \multicolumn{9}{|c|}{ Vine Dry Weight (g) } \\
\hline Chin-Pat81Ko & 1.70 & $0.16^{*}$ & 1.46 & 4.64 & 3.90 & 1.91 & 1.89 & $0.99 *$ & 1.33 \\
\hline Ag-15591Gha & 1.61 & $0.31 *$ & 1.95 & 3.43 & $0.96^{*}$ & $0.66^{*}$ & 1.82 & 0.80 & 1.41 \\
\hline Ag-TriInd & 1.46 & $0.09 *$ & 1.26 & 2.25 & 2.06 & 1.58 & 1.10 & 0.97 & 1.00 \\
\hline Met-BGV11135Afr & 3.45 & $0.7 *$ & 2.42 & 2.68 & 2.58 & 1.55 & 2.07 & $0.74 *$ & $0.63 *$ \\
\hline Ac-TGR139Zimb & 1.56 & 0.37 & 1.55 & 2.02 & 2.97 & 2.00 & 2.68 & $1.04 *$ & 1.62 \\
\hline La-PE4Bra & 1.41 & 0.34 & 2.47 & 4.00 & $1.54 *$ & $1.72 *$ & - & - & - \\
\hline F1 Pat81xPs & 1.98 & $0.21 *$ & 1.45 & 4.34 & 3.00 & $1.89 *$ & 2.73 & $0.62 *$ & 1.79 \\
\hline \multirow[t]{2}{*}{ Ib-PsPiñSp } & 2.27 & - & 1.78 & 3.48 & 2.45 & 1.97 & 1.17 & $0.34 *$ & 1.18 \\
\hline & \multicolumn{9}{|c|}{ Vine Lenght $(\mathrm{cm})$} \\
\hline Chin-Pat81Ko & 105.00 & $10.47 *$ & 106.83 & 146.45 & 135.68 & 123.75 & 85.50 & 78.75 & 66.40 \\
\hline
\end{tabular}


Table 3.2. (Continued)

\begin{tabular}{|c|c|c|c|c|c|c|c|c|c|}
\hline & \multicolumn{3}{|c|}{2015} & \multicolumn{3}{|c|}{2016} & \multicolumn{3}{|c|}{2017} \\
\hline & Control & M. cannonballus & M. eutypoides & Control & M. cannonballus & M. eutypoides & Control & M. cannonballus & M. eutypoides \\
\hline & Mean & Mean & Mean & Mean & Mean & Mean & Mean & Mean & Mean \\
\hline & \multicolumn{9}{|c|}{ Vine Lenght (cm) } \\
\hline Ag-TriInd & 163.50 & $19.33^{*}$ & 117.40 & 208.65 & $113.28 *$ & 140.69 & 101.00 & 62.40 & $37.50 *$ \\
\hline Met-BGV11135Afr & 153.50 & $98.00 *$ & 126.80 & 154.80 & 108.25 & 122.10 & 129.00 & $43.39 *$ & $65.50 *$ \\
\hline Ac-TGR139Zimb & 60.50 & 19.75 & 81.20 & 98.00 & 108.67 & 105.50 & 71.50 & 56.60 & $47.60 *$ \\
\hline La-PE4Bra & 77.25 & $14.00^{*}$ & 97.00 & 99.35 & 85.75 & 108.15 & - & - & - \\
\hline F1 Pat81xPs & 104.00 & $21.00 *$ & 83.75 & 134.35 & 125.38 & 99.88 & 127.50 & $52.80 *$ & $53.88^{*}$ \\
\hline \multirow[t]{2}{*}{ Ib-PsPiñSp } & 100.00 & - & 123.75 & 170.28 & $106.52 *$ & 111.37 & 78.00 & 45.50 & 75.75 \\
\hline & \multicolumn{9}{|c|}{ Root Fresh Weight (g) } \\
\hline Chin-Pat81Ko & 1.53 & $0.25 *$ & $0.30^{*}$ & 1.60 & 1.42 & 1.11 & 1.08 & $0.61 *$ & 0.88 \\
\hline Ag-15591Gha & 1.12 & $0.32 *$ & 1.23 & 1.13 & 0.69 & $0.36^{*}$ & 0.83 & 0.43 & 0.95 \\
\hline Ag-TriInd & 1.25 & $0.17 *$ & $0.31 *$ & 0.80 & 1.17 & 0.95 & 0.75 & 0.61 & $0.26^{*}$ \\
\hline Met-BGV11135Afr & 1.04 & 1.11 & 0.79 & 2.53 & $0.70^{*}$ & $0.70 *$ & 2.07 & $0.79 *$ & $0.55^{*}$ \\
\hline Ac-TGR139Zimb & 1.35 & 0.87 & 0.99 & 1.52 & 1.97 & 1.52 & 2.08 & 2.14 & 1.37 \\
\hline La-PE4Bra & 0.98 & 0.44 & 0.66 & 2.00 & 1.17 & 1.25 & - & - & - \\
\hline F1 Pat81xPs & 1.08 & $0.22 *$ & $0.26^{*}$ & 1.57 & 1.24 & 1.02 & 1.74 & $0.91 *$ & 1.35 \\
\hline \multirow[t]{2}{*}{ Ib-PsPiñSp } & 1.28 & - & $0.43^{*}$ & 1.22 & 0.65 & 1.02 & 1.08 & $0.22 *$ & 0.98 \\
\hline & \multicolumn{9}{|c|}{ Root Dry Weight (g) } \\
\hline Chin-Pat81Ko & 0.04 & 0.02 & 0.04 & 0.16 & 0.08 & 0.11 & 0.19 & 0.09 & 0.07 \\
\hline Ag-15591Gha & 0.06 & $0.02 *$ & 0.09 & 0.19 & $0.05 *$ & $0.03 *$ & 0.07 & 0.08 & $0.04 *$ \\
\hline Ag-TriInd & 0.05 & $0.02 *$ & 0.05 & 0.18 & $0.10^{*}$ & $0.08 *$ & 0.07 & 0.10 & $0.04 *$ \\
\hline Met-BGV11135Afr & 0.07 & 0.05 & 0.06 & 0.23 & $0.04 *$ & $0.06^{*}$ & 0.26 & $0.10^{*}$ & $0.04 *$ \\
\hline Ac-TGR139Zimb & 0.04 & 0.04 & 0.08 & 0.07 & 0.23 & 0.17 & 0.17 & 0.17 & 0.12 \\
\hline La-PE4Bra & 0.04 & 0.02 & 0.06 & 0.17 & 0.09 & 0.06 & - & - & - \\
\hline F1 Pat81xPs & 0.04 & 0.03 & 0.05 & 0.18 & $0.06^{*}$ & $0.10^{*}$ & 0.09 & 0.06 & 0.13 \\
\hline Ib-PsPiñSp & 0.05 & - & 0.03 & 0.14 & $0.04 *$ & 0.10 & 0.14 & 0.05 & $0.06^{*}$ \\
\hline
\end{tabular}




\subsection{CAPÍTULO 3}

Table 3.2. (Continued)

\begin{tabular}{|c|c|c|c|c|c|c|c|c|c|}
\hline & \multicolumn{3}{|c|}{2015} & \multicolumn{3}{|c|}{2016} & \multicolumn{3}{|c|}{2017} \\
\hline & Control & M. cannonballus & M. eutypoides & Control & M. cannonballus & M. eutypoides & Control & M. cannonballus & M. eutypoides \\
\hline & Mean & Mean & Mean & Mean & Mean & Mean & Mean & Mean & Mean \\
\hline & \multicolumn{9}{|c|}{ Total root length $(\mathrm{cm})$} \\
\hline Chin-Pat81Ko & 580.21 & 63.83 & 99.90 & 535.41 & 353.90 & 312.24 & 63.36 & $151.42 *$ & 62.49 \\
\hline Ag-15591Gha & 536.99 & $92.33^{*}$ & 503.80 & 420.18 & 227.67 & $103.23 *$ & 129.50 & 117.80 & - \\
\hline Ag-TriInd & 587.56 & 48.97 & $135.71 *$ & 356.53 & 315.27 & 290.03 & 62.29 & 134.37 & 26.44 \\
\hline Met-BGV11135Afr & 606.39 & $211.47^{*}$ & 345.11 & 783.94 & $215.65^{*}$ & $223.34^{*}$ & 160.06 & 131.18 & 71.84 \\
\hline Ac-TGR139Zimb & 434.31 & 330.27 & 477.85 & 236.25 & 303.59 & 323.37 & 159.87 & 287.50 & 72.85 \\
\hline La-PE4Bra & 196.36 & 182.30 & 352.02 & 378.12 & 222.75 & 256.18 & - & - & - \\
\hline F1 Pat81xPs & 298.54 & 156.25 & 75.75 & 565.87 & 281.22 & $196.53 *$ & 218.70 & $131.99 *$ & 156.40 \\
\hline \multirow[t]{2}{*}{ Ib-PsPiñSp } & 550.01 & - & 120.70 & 388.02 & 230.22 & 233.11 & 110.65 & $17.37 *$ & 97.03 \\
\hline & \multicolumn{9}{|c|}{ Projected Area $(\mathrm{cm} 2)$} \\
\hline Chin-Pat81Ko & 16.37 & 2.34 & 3.96 & 22.89 & 14.57 & 13.10 & 2.74 & $12.85^{*}$ & 3.30 \\
\hline Ag-15591Gha & 17.71 & $3.38 *$ & 17.40 & 19.55 & $8.96^{*}$ & $3.95^{*}$ & 4.76 & 7.73 & - \\
\hline Ag-TriInd & 18.29 & 1.88 & $4.74 *$ & 13.95 & 12.48 & 12.54 & 2.24 & 10.79 & 1.11 \\
\hline Met-BGV11135Afr & 21.63 & 8.71 & 13.67 & 37.09 & $9.08^{*}$ & $9.83^{*}$ & 6.42 & 9.93 & 2.95 \\
\hline Ac-TGR139Zimb & 17.00 & 13.50 & 18.23 & 5.77 & 11.11 & $12.66^{*}$ & 7.58 & 25.98 & 3.57 \\
\hline La-PE4Bra & 7.65 & 7.85 & 14.71 & 17.97 & 9.89 & 11.85 & - & - & - \\
\hline F1 Pat81xPs & 10.00 & 4.65 & 2.68 & 24.60 & 13.30 & $9.73 *$ & 9.65 & 10.40 & 7.88 \\
\hline \multirow[t]{2}{*}{ Ib-PsPiñSp } & 18.95 & - & 5.30 & 17.18 & 9.20 & 10.99 & 3.99 & 1.27 & 4.92 \\
\hline & \multicolumn{9}{|c|}{ Average Diameter (mm) } \\
\hline Chin-Pat81Ko & 0.27 & 0.37 & $0.41 *$ & 0.43 & 0.41 & 0.36 & 0.42 & $0.85 *$ & 0.48 \\
\hline Ag-15591Gha & 0.33 & 0.45 & 0.35 & 0.45 & 0.40 & 0.37 & 0.36 & $0.64 *$ & - \\
\hline Ag-TriInd & 0.33 & 0.42 & 0.35 & 0.39 & 0.39 & 0.42 & 0.35 & $0.78^{*}$ & 0.41 \\
\hline Met-BGV11135Afr & 0.36 & $0.41^{*}$ & $0.40^{*}$ & 0.48 & $0.42 *$ & 0.45 & 0.38 & $0.76^{*}$ & 0.41 \\
\hline Ac-TGR139Zimb & 0.39 & 0.40 & 0.38 & 0.24 & 0.36 & $0.39 *$ & 0.46 & $0.88^{*}$ & 0.48 \\
\hline La-PE4Bra & 0.39 & 0.39 & 0.43 & 0.48 & 0.44 & 0.44 & - & - & - \\
\hline
\end{tabular}


Table 3.2. (Continued)

\begin{tabular}{|c|c|c|c|c|c|c|c|c|}
\hline \multicolumn{3}{|c|}{2015} & \multicolumn{3}{|c|}{2016} & \multicolumn{3}{|c|}{2017} \\
\hline Control & M. cannonballus & M. eutypoides & Control & M. cannonballus & M. eutypoides & Control & M. cannonballus & M. eutypoides \\
\hline Mean & Mean & Mean & Mean & Mean & Mean & Mean & Mean & Mean \\
\hline \multicolumn{9}{|c|}{ Average Diameter (mm) } \\
\hline 0.33 & 0.30 & 0.36 & 0.44 & 0.49 & $0.49 *$ & 0.44 & $0.78 *$ & $0.51 *$ \\
\hline
\end{tabular}

\begin{tabular}{|c|c|c|c|c|c|c|c|c|c|}
\hline F1 Pat81xPs & 0.33 & 0.30 & 0.36 & 0.44 & 0.49 & $0.49 *$ & 0.44 & $0.78 *$ & $0.51 *$ \\
\hline \multirow[t]{2}{*}{ Ib-PsPiñSp } & 0.36 & - & 0.46 & 0.44 & 0.43 & 0.47 & 0.36 & $0.72 *$ & 0.49 \\
\hline & \multicolumn{9}{|c|}{ Tips } \\
\hline Chin-Pat81Ko & 2559.00 & 248.67 & 306.00 & 1397.00 & 1127.00 & 893.50 & 664.50 & $291.50 *$ & 603.50 \\
\hline Ag-15591Gha & 2132.50 & $314.00 *$ & 1588.80 & 917.00 & 594.22 & $236.38 *$ & 1318.00 & $217.20 *$ & - \\
\hline Ag-TriInd & 2301.50 & 200.00 & 316.20 & 817.00 & 936.00 & 744.00 & 728.50 & $242.20 *$ & $250.00^{*}$ \\
\hline Met-BGV11135Afr & 2142.00 & 758.00 & $908.80 *$ & 2071.33 & $601.57 *$ & $663.40^{*}$ & 1518.50 & 350.33 & $601.20 *$ \\
\hline Ac-TGR139Zimb & 1442.50 & 1064.50 & 1228.20 & 649.00 & 1026.50 & $949.50 *$ & 1363.00 & $529.80 *$ & 824.00 \\
\hline La-PE4Bra & 545.00 & 507.00 & 964.00 & 843.00 & 580.50 & 643.00 & - & - & - \\
\hline F1 Pat81xPs & 961.50 & 712.50 & 219.50 & 1495.50 & 771.63 & $514.75^{*}$ & 1952.00 & $303.60 *$ & 1186.00 \\
\hline \multirow[t]{2}{*}{ Ib-PsPiñSp } & 1500.00 & - & $295.33 *$ & 793.00 & 657.22 & 617.89 & 1094.00 & $85.67 *$ & $740.75^{*}$ \\
\hline & \multicolumn{9}{|c|}{ Forks } \\
\hline Chin-Pat81Ko & 6555.50 & 746.67 & 860.17 & 5497.00 & 3413.00 & 3749.00 & $\mathbf{7 8 . 5 0}$ & $391.50 *$ & 100.75 \\
\hline Ag-15591Gha & 6152.50 & $873.33 *$ & 5089.60 & 3833.00 & $1935.33 *$ & $770.375^{*}$ & 173.50 & 203.40 & - \\
\hline Ag-TriInd & 5994.00 & 536.67 & 767.00 & 2910.50 & 3204.10 & 3117.50 & 68.00 & 273.60 & 29.25 \\
\hline Met-BGV11135Afr & 6827.50 & $2162.00^{*}$ & 3383.20 & 8566.33 & $2414.14^{*}$ & $2624.80^{*}$ & 207.50 & 324.33 & 92.80 \\
\hline Ac-TGR139Zimb & 4579.50 & 3159.50 & 4841.00 & 1728.00 & 2648.00 & $3249.50 *$ & 267.00 & 854.40 & 112.00 \\
\hline La-PE4Bra & 1522.00 & 1689.50 & 3551.00 & 3882.00 & 2023.50 & 2210.50 & - & - & - \\
\hline F1 Pat81xPs & 3011.00 & 1441.00 & 557.25 & 5642.50 & 3523.63 & $2234.50 *$ & 410.00 & 324.00 & $330.00^{*}$ \\
\hline \multirow[t]{2}{*}{ Ib-PsPiñSp } & 4889.50 & - & 1032.00 & 3244.25 & 2583.78 & 2697.22 & 117.00 & $32.33 *$ & 170.50 \\
\hline & \multicolumn{9}{|c|}{ Crossings } \\
\hline Chin-Pat81Ko & 1314.50 & 96.00 & 105.33 & 767.00 & 473.20 & 568.50 & 5.00 & 21.50 & 8.25 \\
\hline Ag-15591Gha & 1028.00 & $120.33 *$ & 841.00 & $\mathbf{5 1 5 . 5 0}$ & $249.33^{*}$ & $115.13^{*}$ & 12.00 & 19.80 & - \\
\hline Ag-TriInd & 1140.50 & 76.67 & 116.20 & 413.00 & 456.50 & 420.50 & 10.50 & 17.20 & 3.50 \\
\hline
\end{tabular}




\subsection{CAPÍTULO 3}

Table 3.2. (Continued)

\begin{tabular}{|c|c|c|c|c|c|c|c|c|c|}
\hline & \multicolumn{3}{|c|}{2015} & \multicolumn{3}{|c|}{2016} & \multicolumn{3}{|c|}{2017} \\
\hline & Control & M. cannonballus & M. eutypoides & Control & M. cannonballus & M. eutypoides & Control & M. cannonballus & M. eutypoides \\
\hline & Mean & Mean & Mean & Mean & Mean & Mean & Mean & Mean & Mean \\
\hline & \multicolumn{9}{|c|}{ Crossings } \\
\hline Met-BGV11135Afr & 1126.00 & $280.00 *$ & 488.00 & 1062.00 & $324.43^{*}$ & $358.40^{*}$ & 22.00 & 19.33 & 11.40 \\
\hline Ac-TGR139Zimb & 660.00 & 432.00 & 717.40 & 338.00 & 352.00 & 482.50 & 18.00 & 37.40 & 10.00 \\
\hline La-PE4Bra & 217.00 & 227.50 & 482.00 & 479.00 & 261.50 & 303.50 & - & - & - \\
\hline F1 Pat81xPs & 513.00 & 233.00 & 71.75 & 806.50 & 481.88 & $253.25 *$ & 32.50 & 23.40 & 30.50 \\
\hline Ib-PsPiñSp & 876.50 & - & 109.83 & 414.25 & 372.67 & 319.11 & 8.00 & $1.00 *$ & 14.25 \\
\hline
\end{tabular}




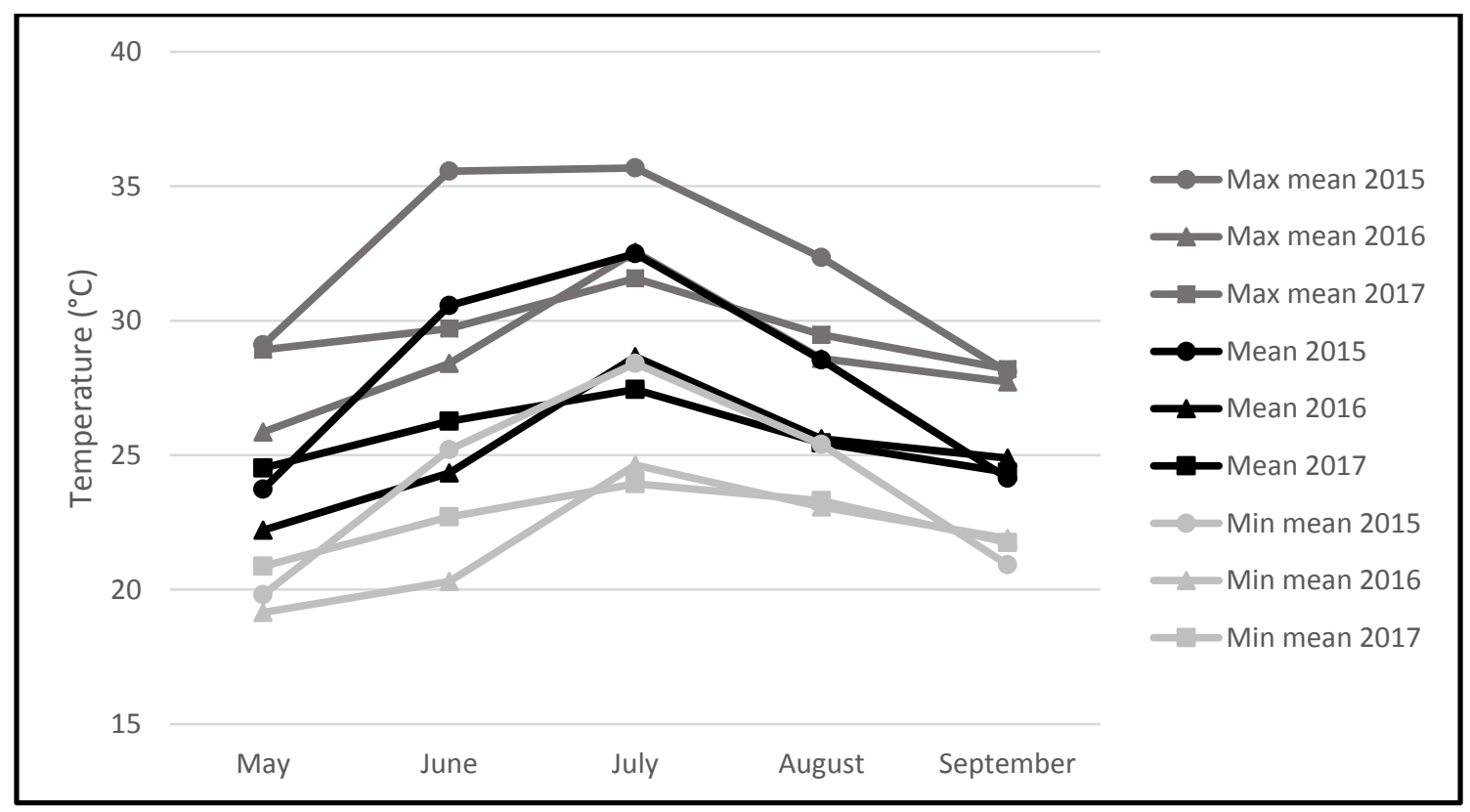

Figure 3.1. Greenhouse temperatures in the artificial inoculation assays: Mean temperature, mean of the daily maximum temperatures and mean of the daily minimum temperatures. 


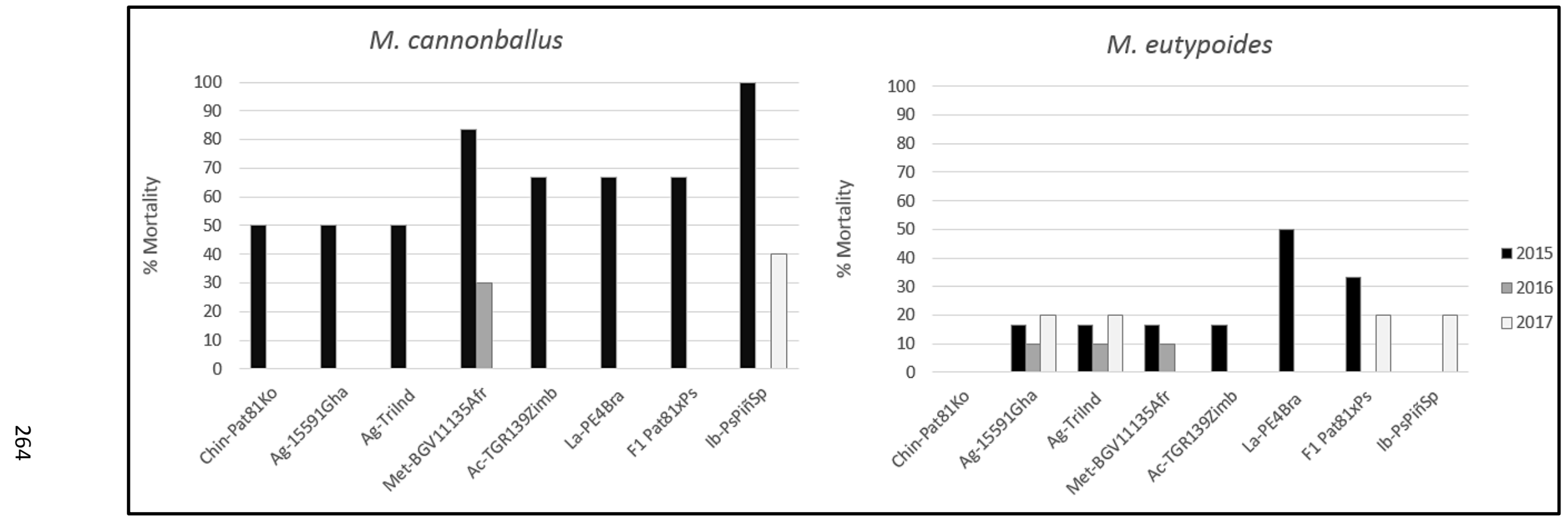

Figure 3.2. Percentage of dead plants in the three artificial inoculation assays at 30 days after transplanting. 


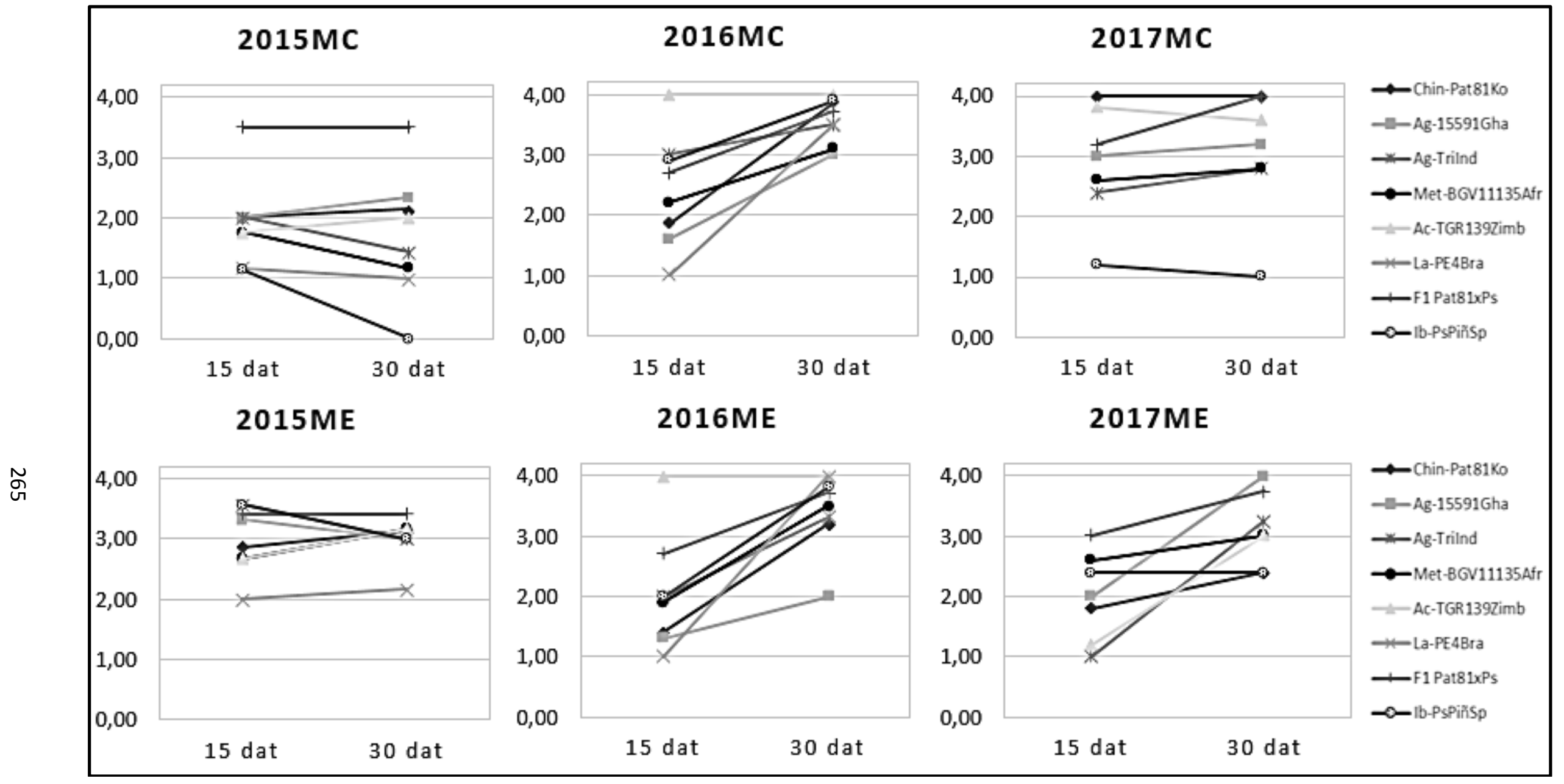

Figure 3.3. Evolution of plant vigour (0-4, see text for description) in the three artificial inoculation assays at 15 and 30 days after transplanting (dat). 


\subsection{CAPÍTULO 3}

Figure 3.4. a) WinRhizo images of roots corresponding to each of the genotypes, for each of the assays. Each slide includes a representative of the non-inoculated control, a plant inoculated with Monosporascus cannonballus and a plant inoculated with M. eutypoides. b) Pictures of roots from the field assay.

a)

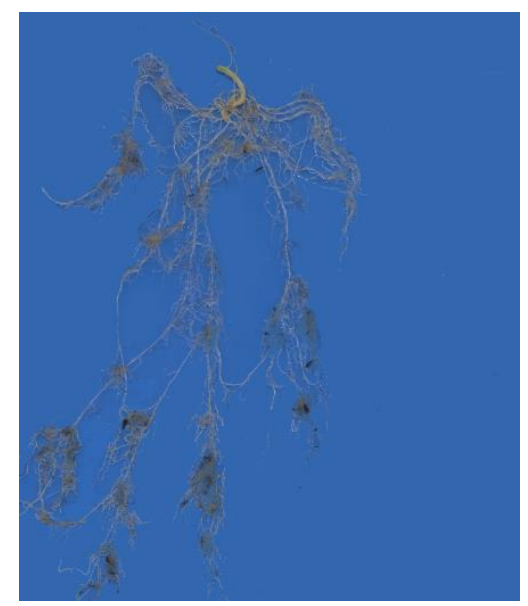

Chin-Pat81Ko

Control

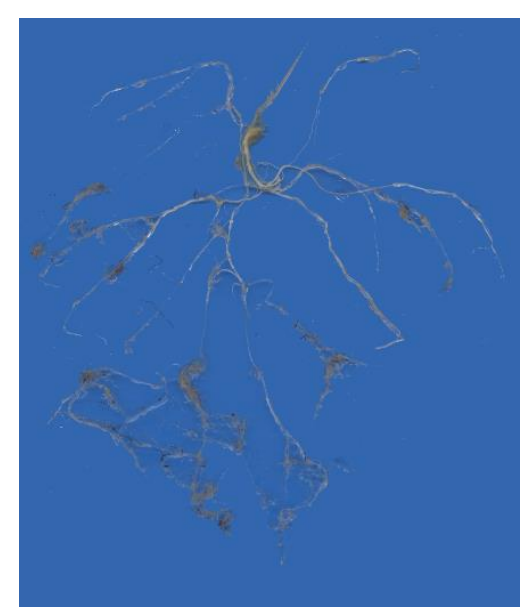

Ag-15591Gha

Control

\section{5}

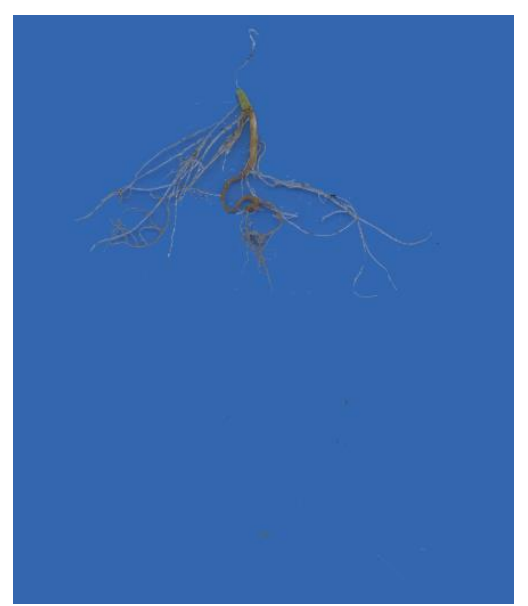

Chin-Pat81Ko

M. cannonballus

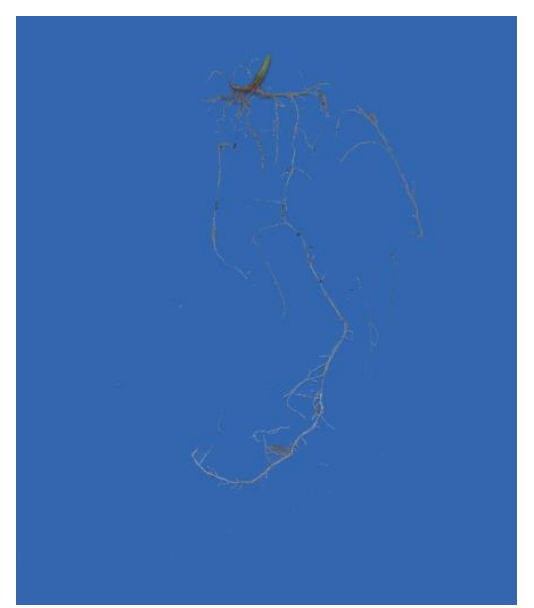

Ag-15591Gha

M. cannonballus

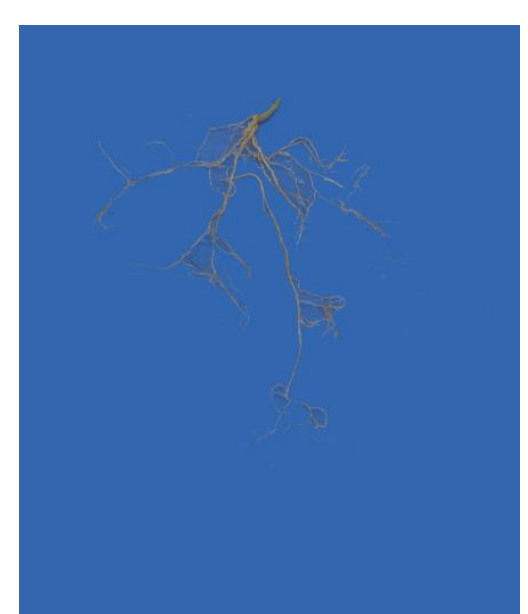

Chin-Pat81Ko

M. eutypoides

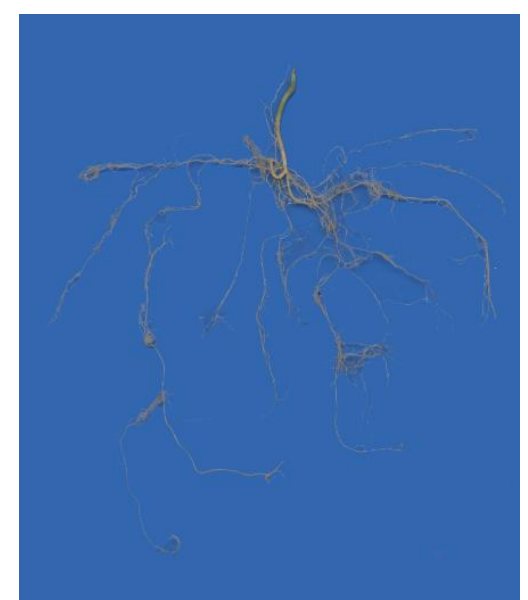

Ag-15591Gha

M. eutypoides 


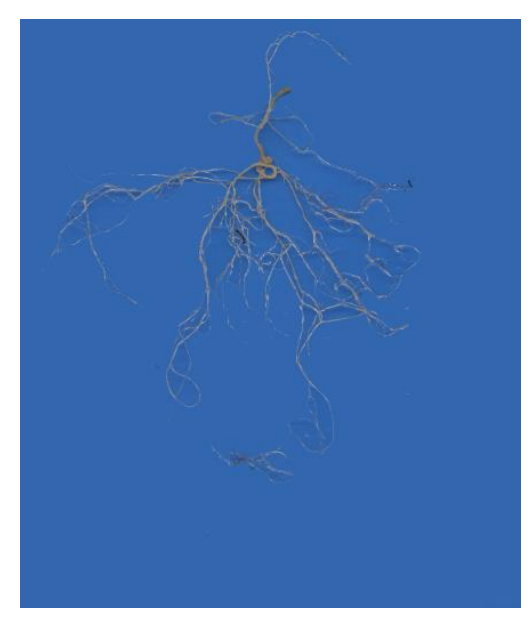

Ag-TriInd

Control

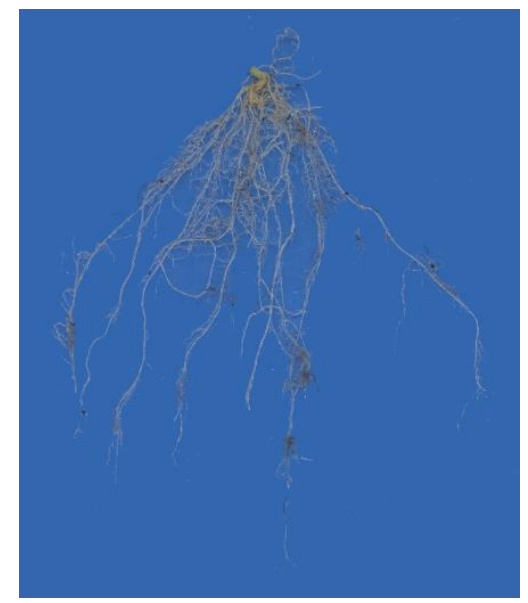

Met-BGV11135Afr

Control

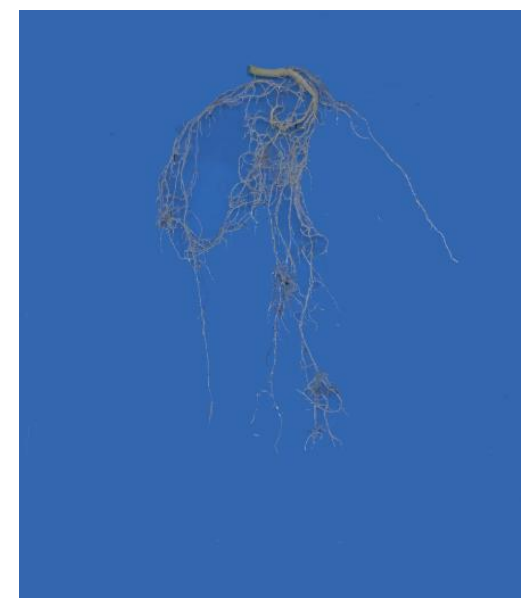

Ac-TGR139Zimb

Control

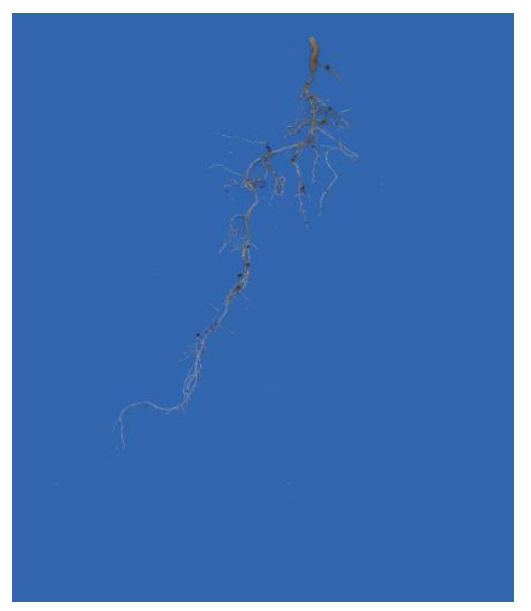

Ag-Trilnd

M. cannonballus

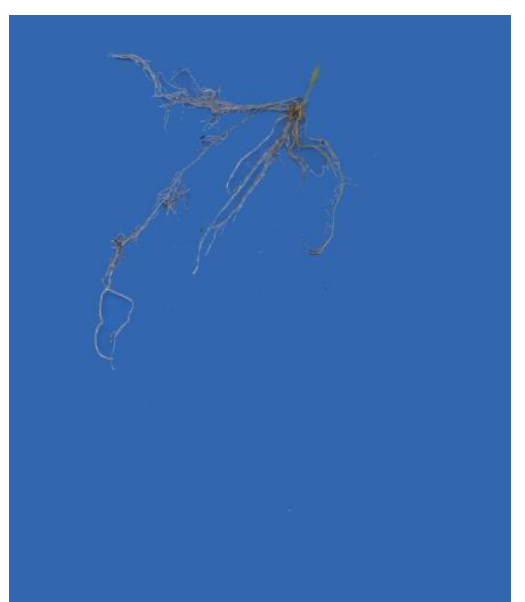

Met-BGV11135Afr

M. cannonballus

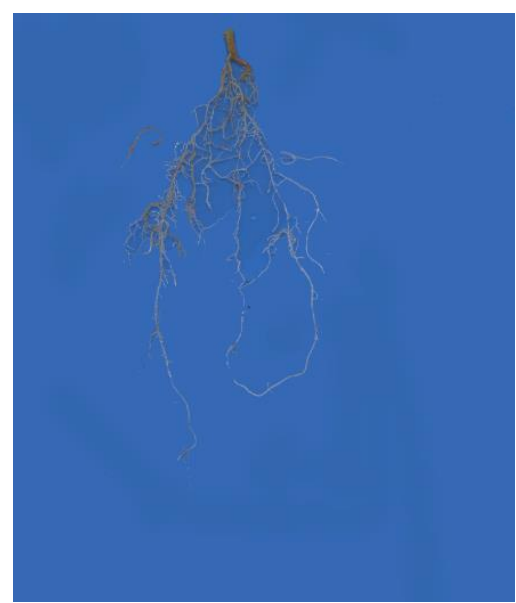

Ac-TGR139Zimb

M. cannonballus

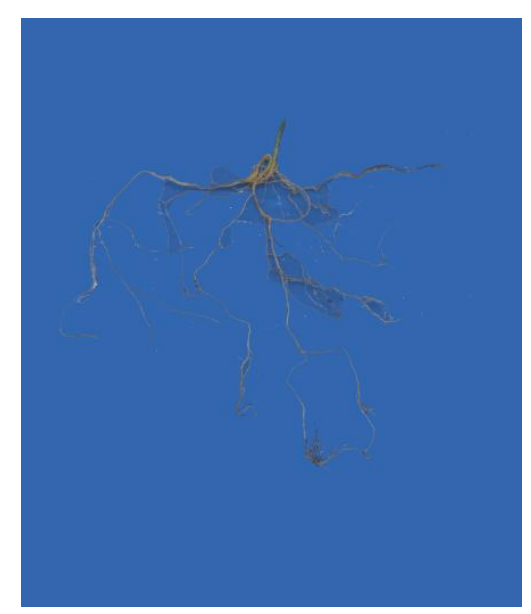

Ag-TriInd

M. eutypoides

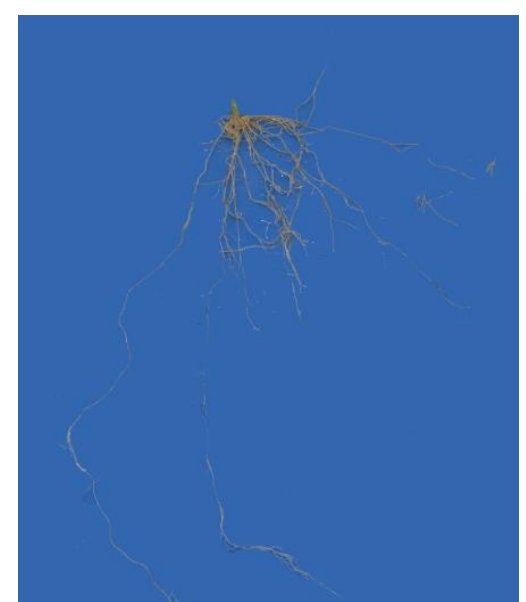

Met-BGV11135Afr

M. eutypoides

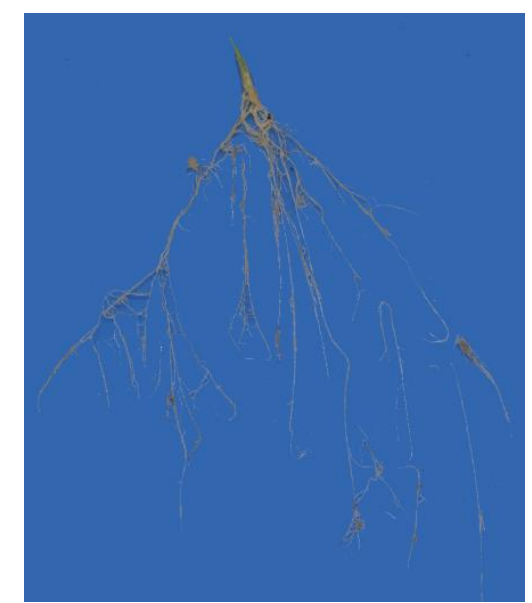

Ac-TGR139Zimb

M. eutypoides 

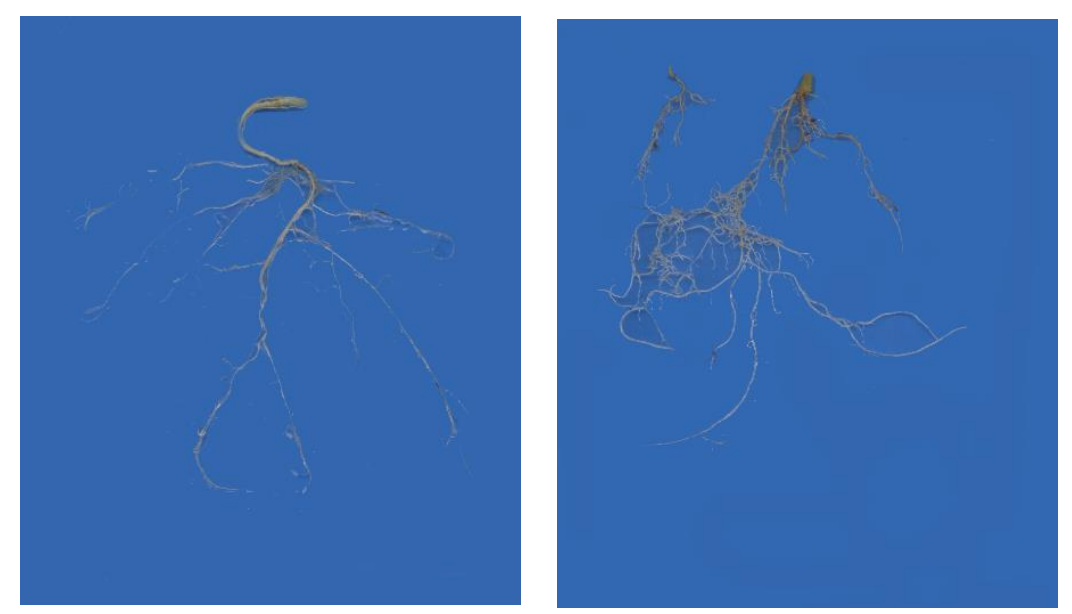

La-PE4Bra

M. cannonballus

Control

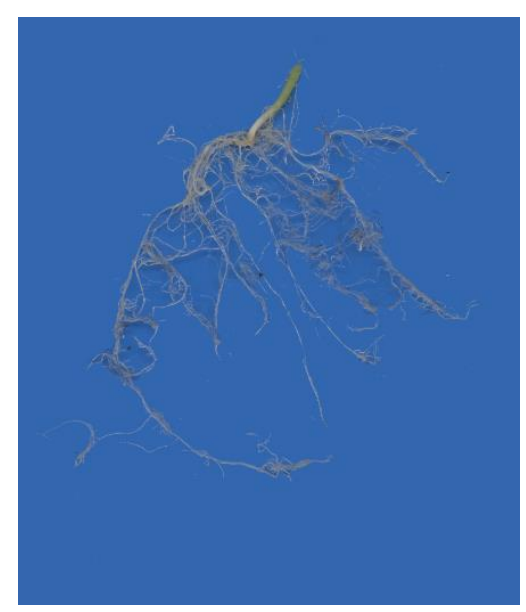

F1 Pat81xPs

Control

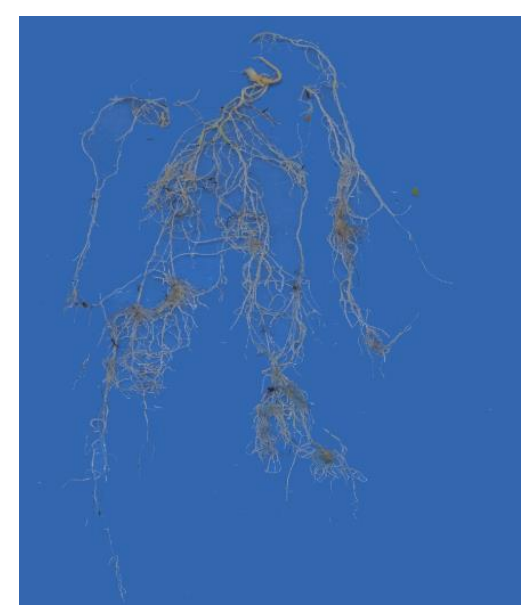

Ib-PsPiñSp

Control
F1 Pat81xPs

M. cannonballus

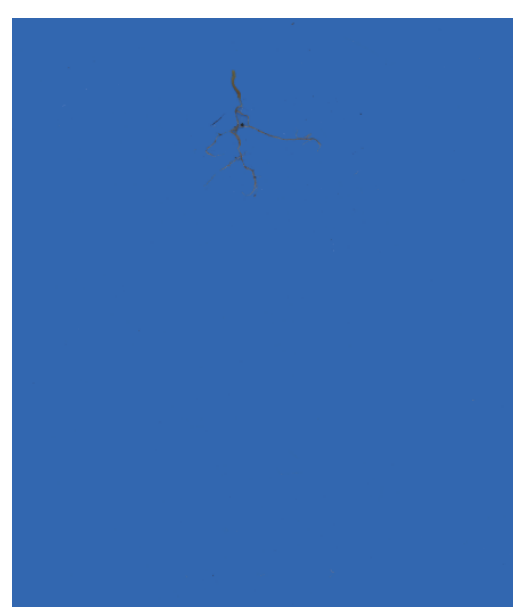

Ib-PsPiñSp

M. cannonballus

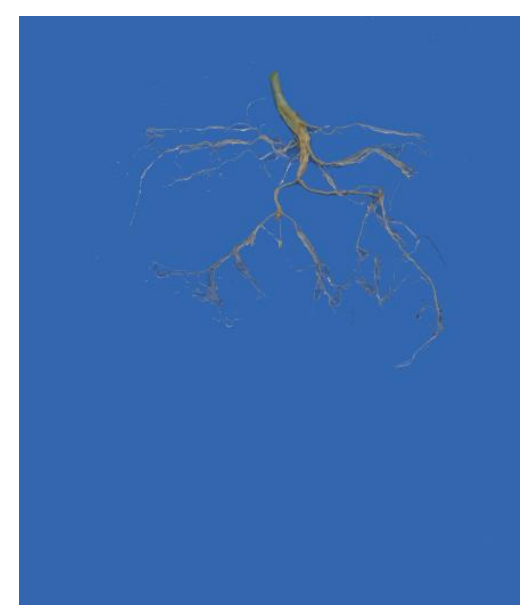

La-PE4Bra

M. eutypoides

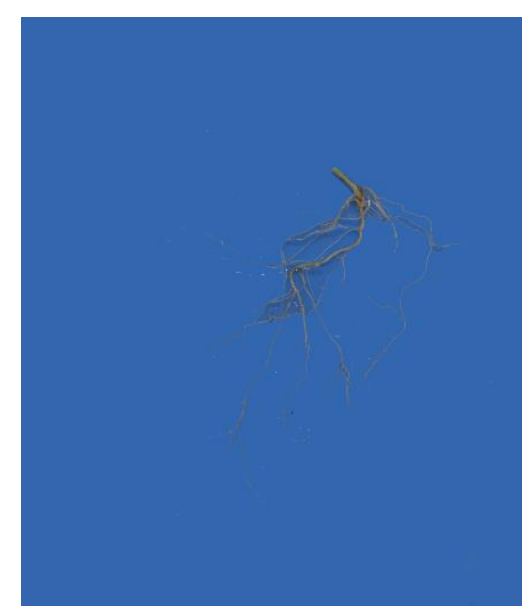

F1 Pat81xPs

M. eutypoides

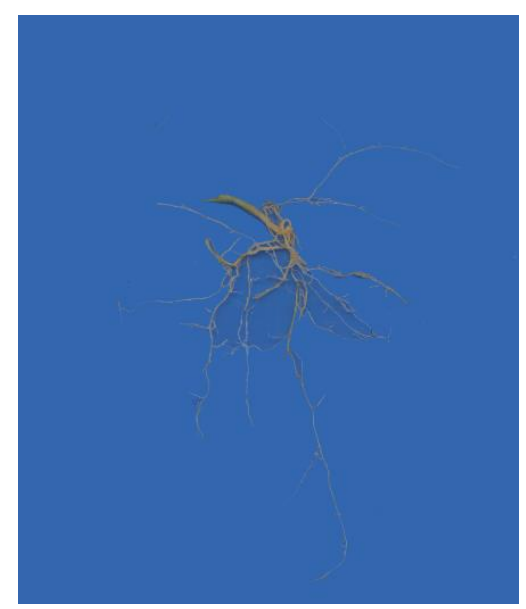

Ib-PsPiñSp

M. eutypoides 
2016

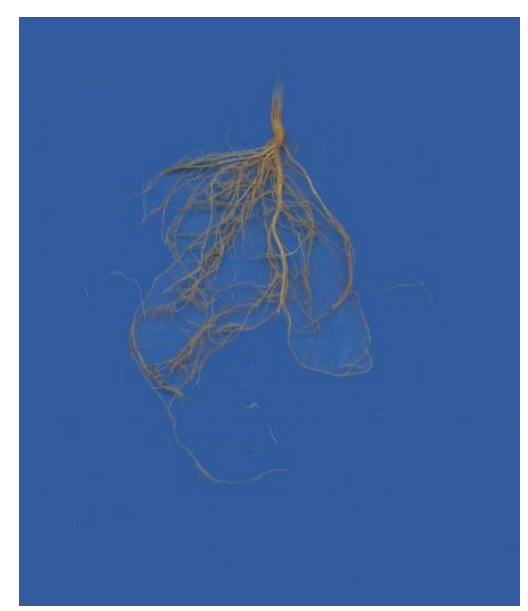

Chin-Pat81Ko

Control

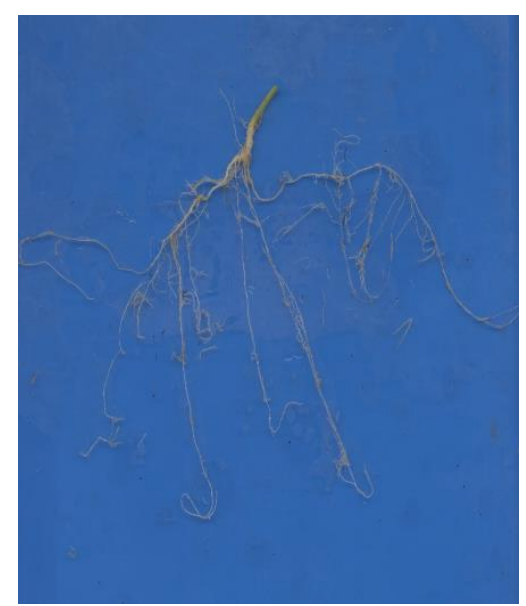

Ag-15591Gha

Control

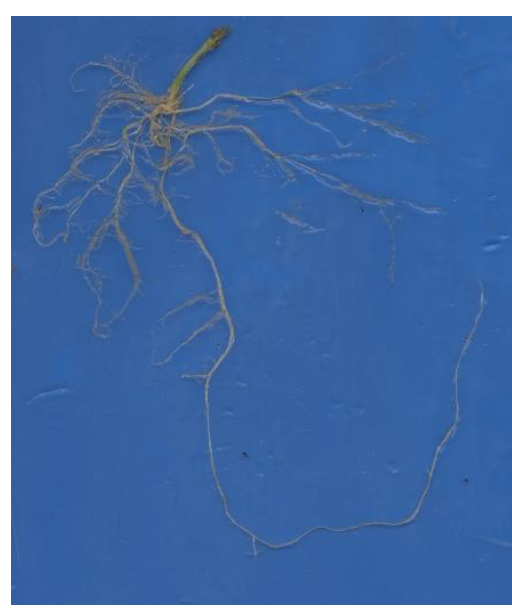

Chin-Pat81Ko

M. cannonballus

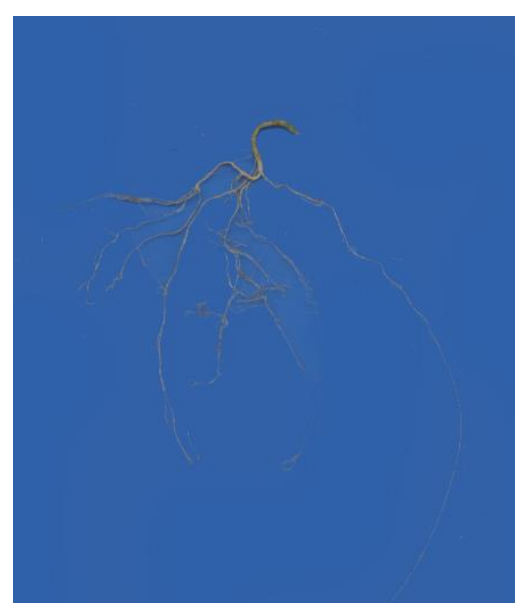

Ag-15591Gha

M. cannonballus

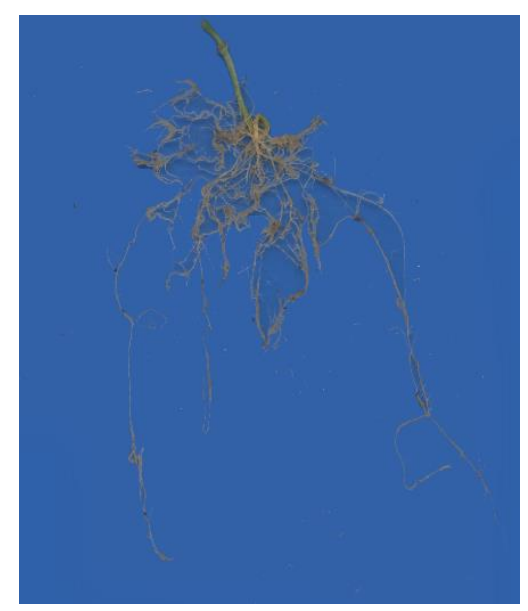

Chin-Pat81Ko

M. eutypoides

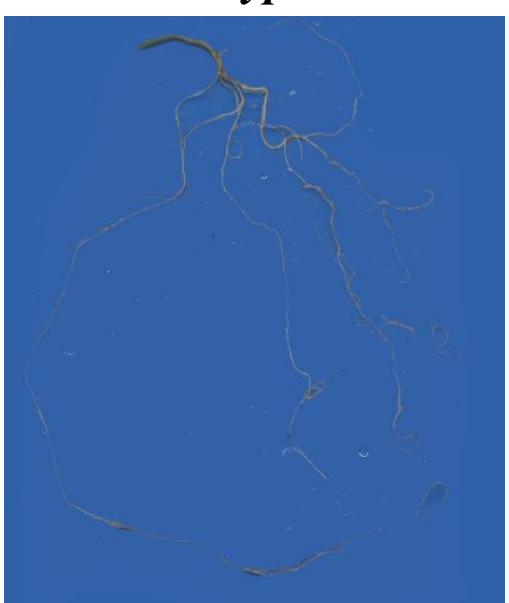

Ag-15591Gha

M. eutypoides 

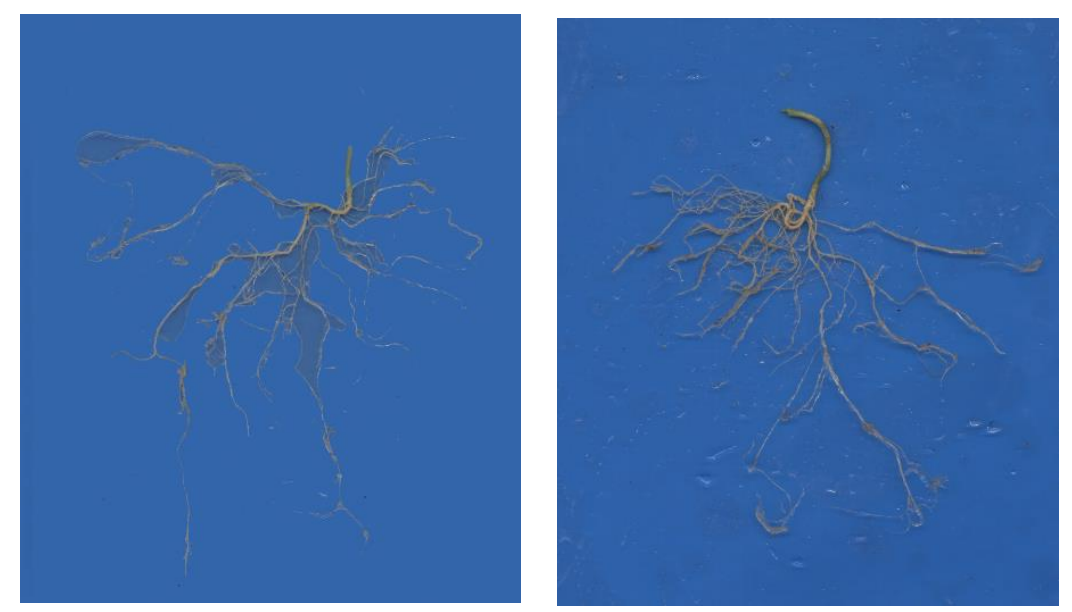

Ag-TriInd Ag-TriInd

Control

M. cannonballus

Ag-TriInd

M. eutypoides

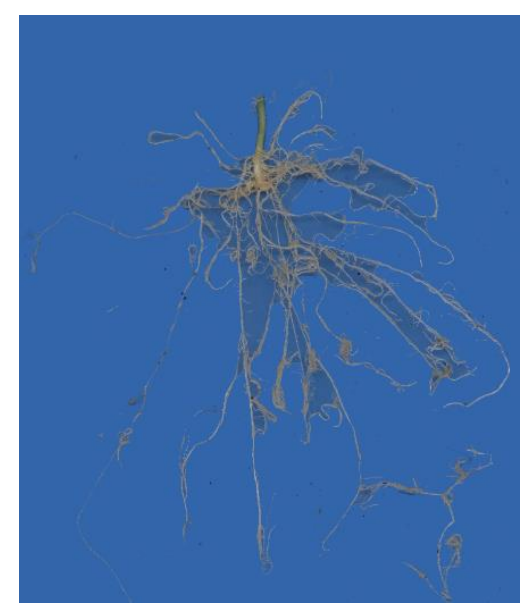

Met-BGV11135Afr

Control

Met-BGV11135Afr

M. cannonballus

Met-BGV11135Afr

M. eutypoides

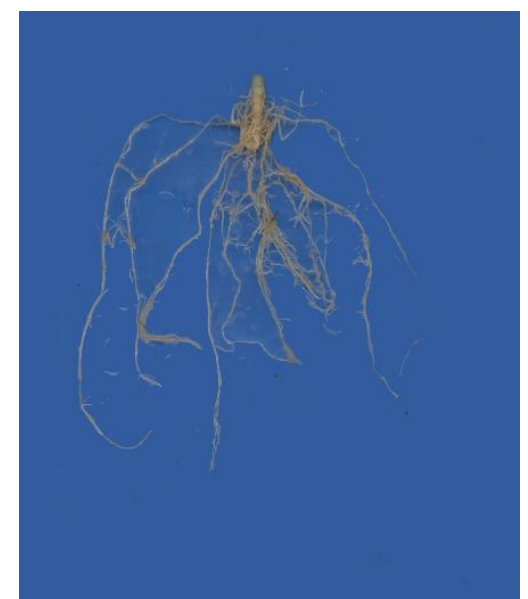

Ac-TGR139Zimb

Control

Ac-TGR139Zimb

M. cannonballus

Ac-TGR139Zimb

M. eutypoides

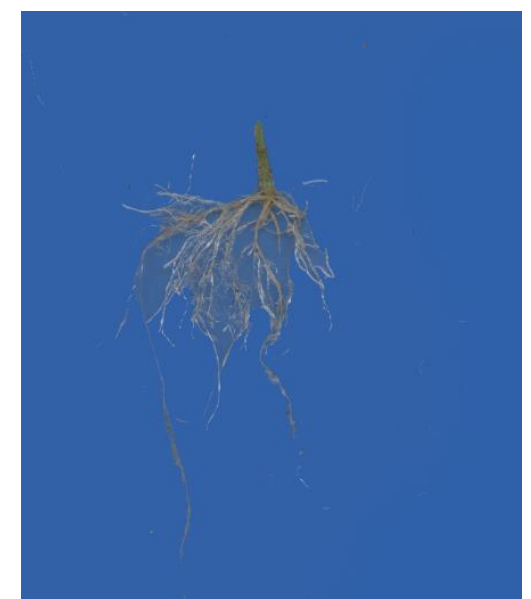




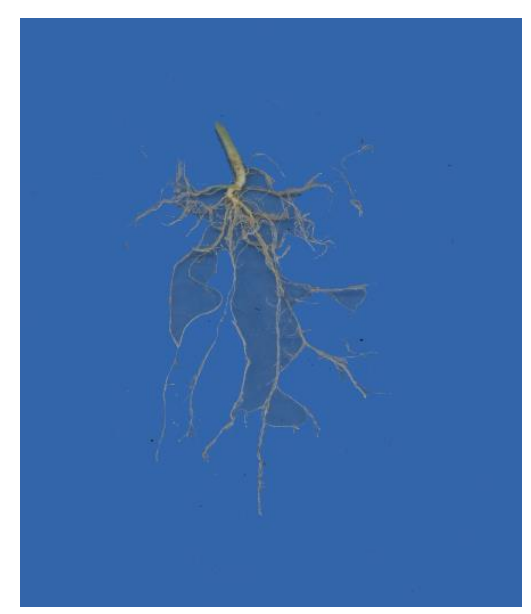

La-PE4Bra

Control

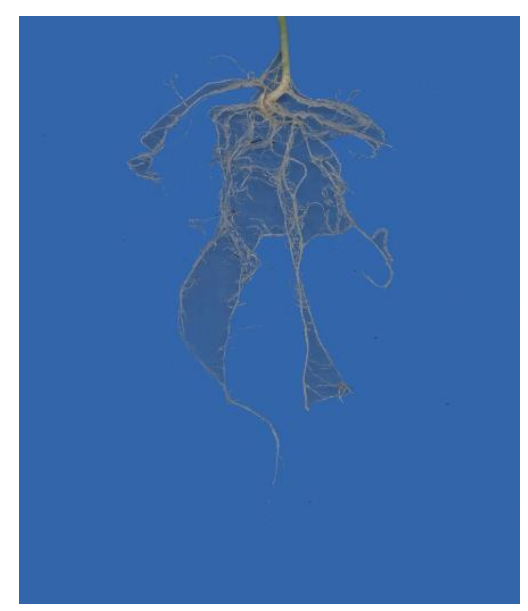

F1 Pat81xPs

Control

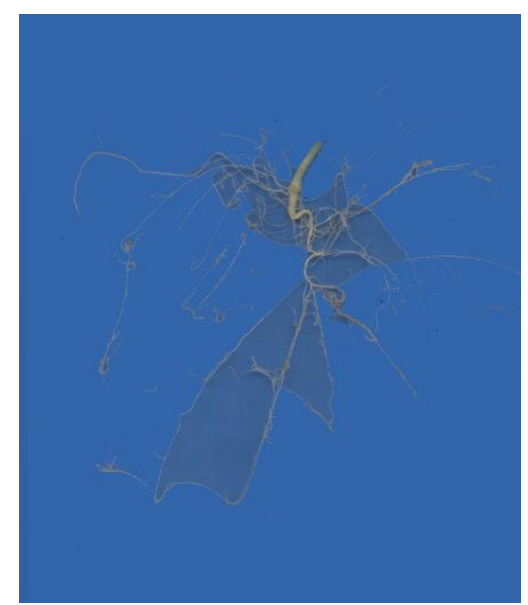

Ib-PsPiñSp

Control

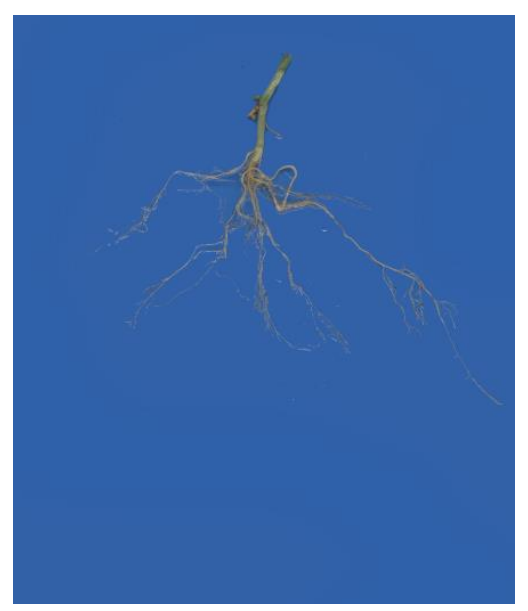

La-PE4Bra

M. cannonballus

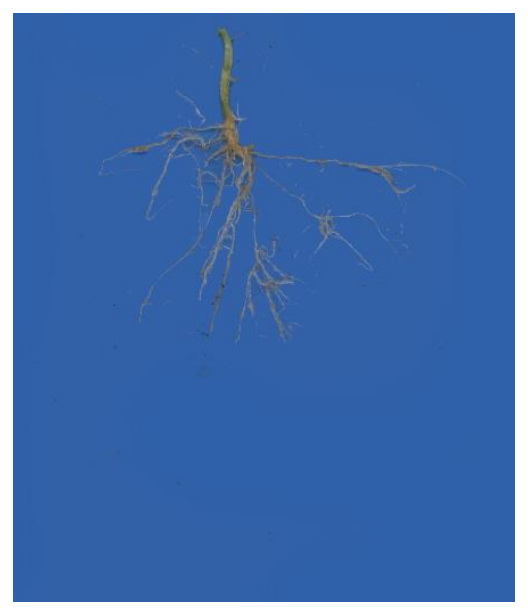

F1 Pat81xPs

M. cannonballus

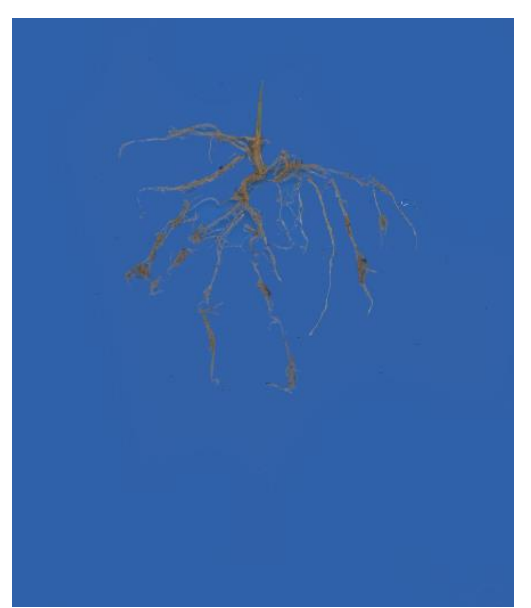

Ib-PsPiñSp

M. cannonballus

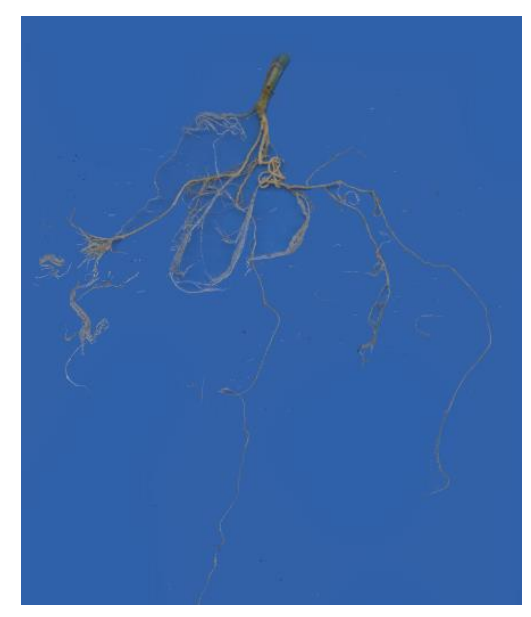

La-PE4Bra

M. eutypoides

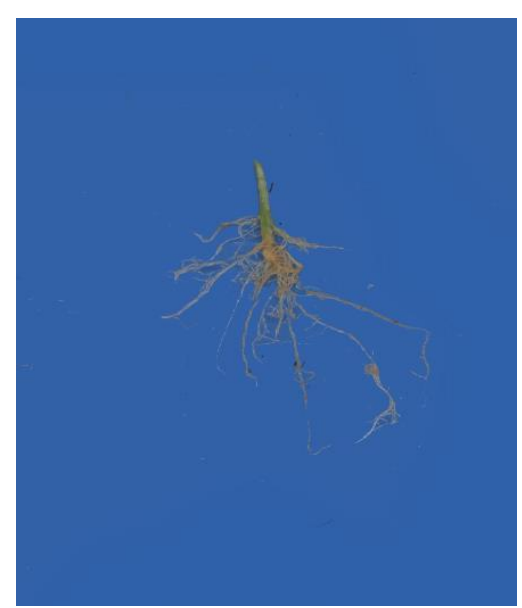

F1 Pat81xPs

M. eutypoides

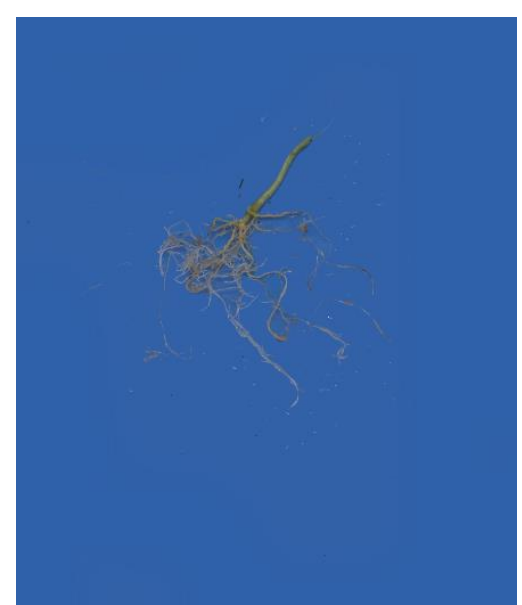

Ib-PsPiñSp

M. eutypoides 


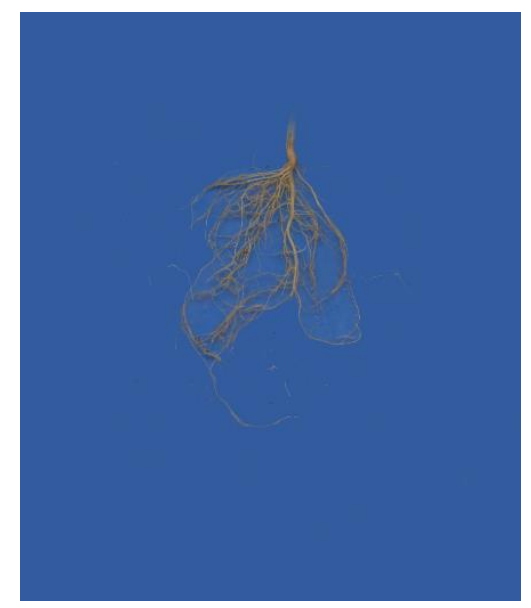

Chin-Pat81Ko

Control

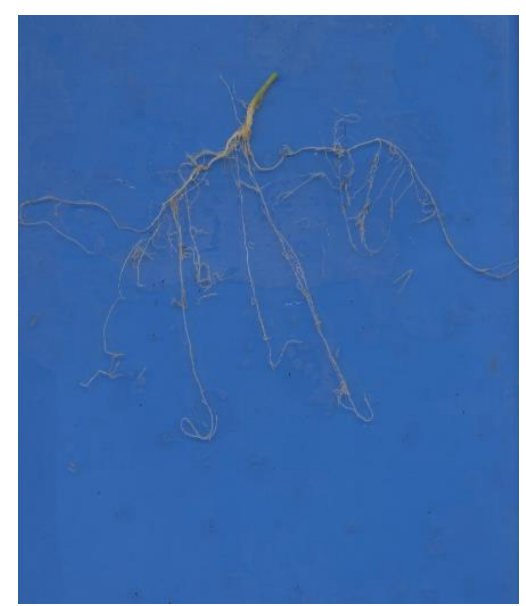

Ag-15591Gha

Control
2017

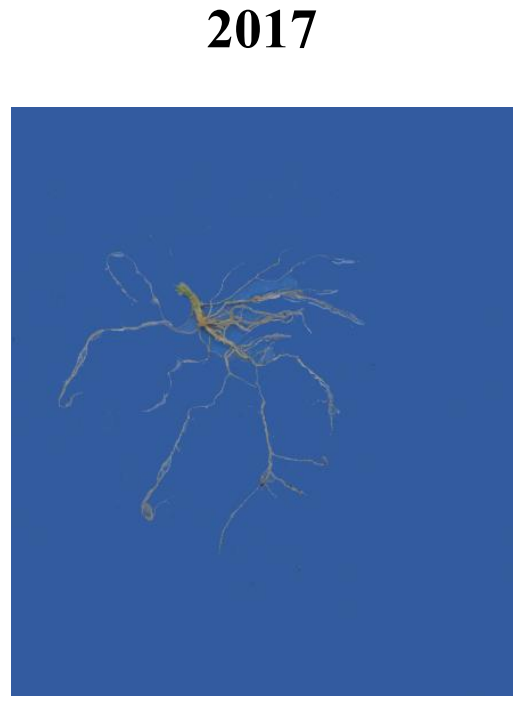

Chin-Pat81Ko

M. cannonballus

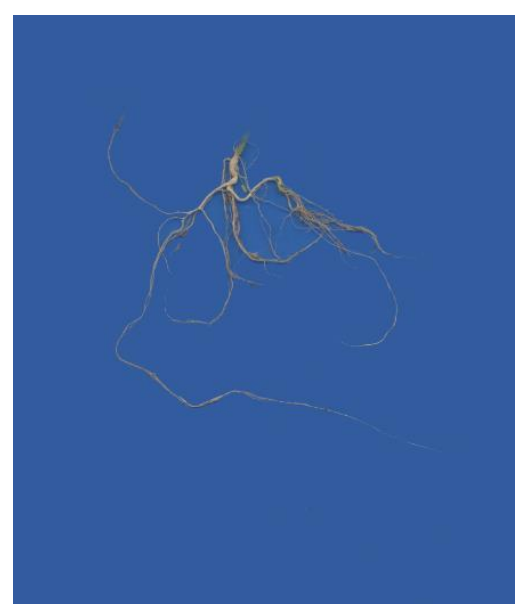

Ag-15591Gha

M. cannonballus

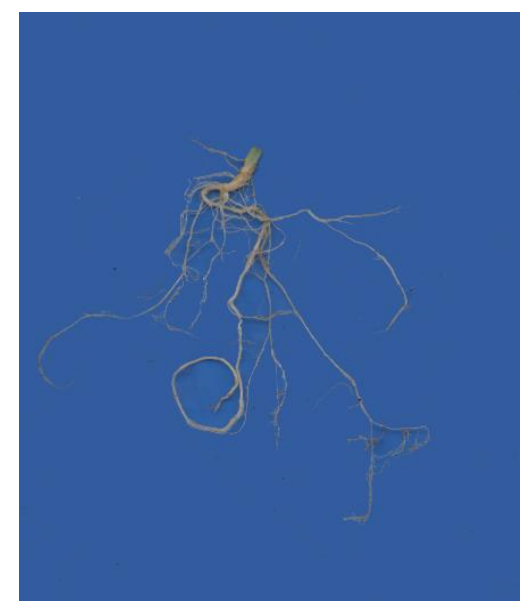

Chin-Pat81Ko

M. eutypoides 


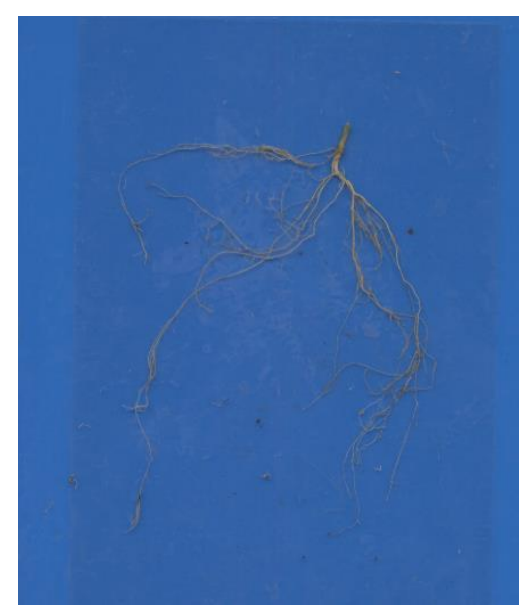

Ag-TriInd

Control

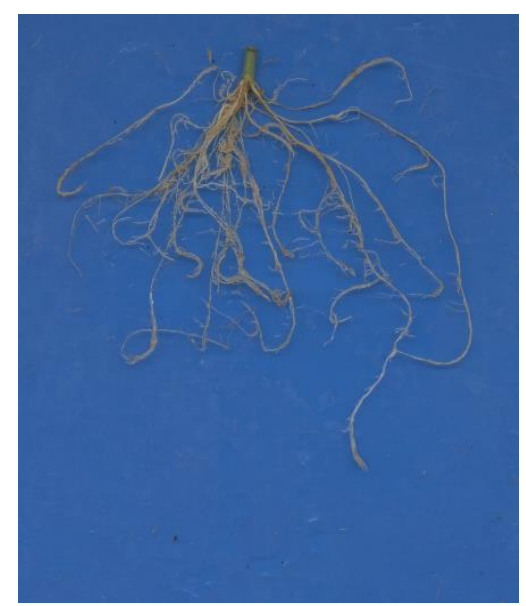

Met-BGV11135Afr

Control

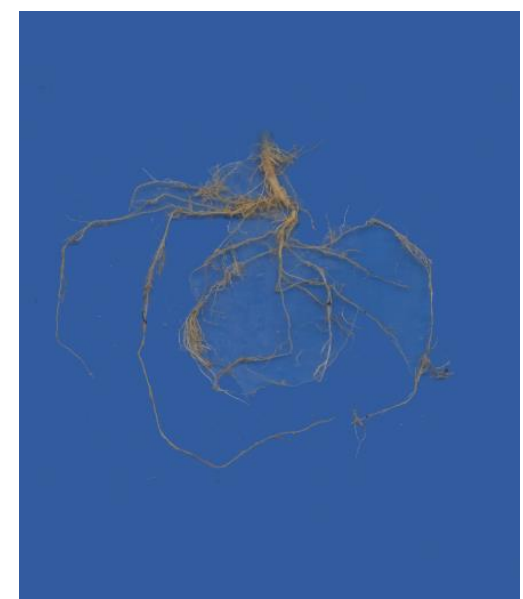

Ac-TGR139Zimb

Control

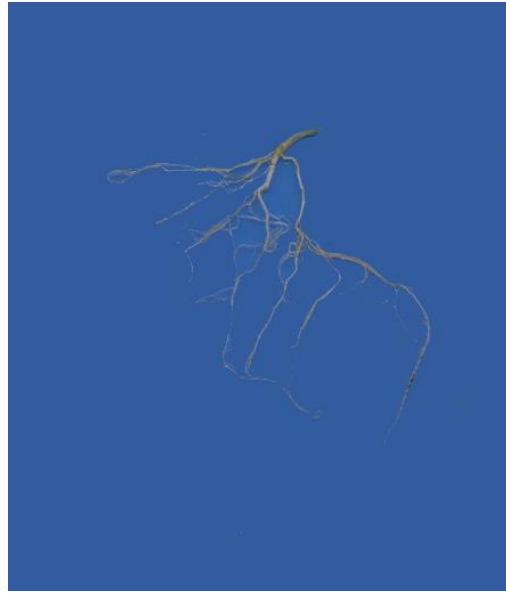

Ag-Trilnd

M. cannonballus

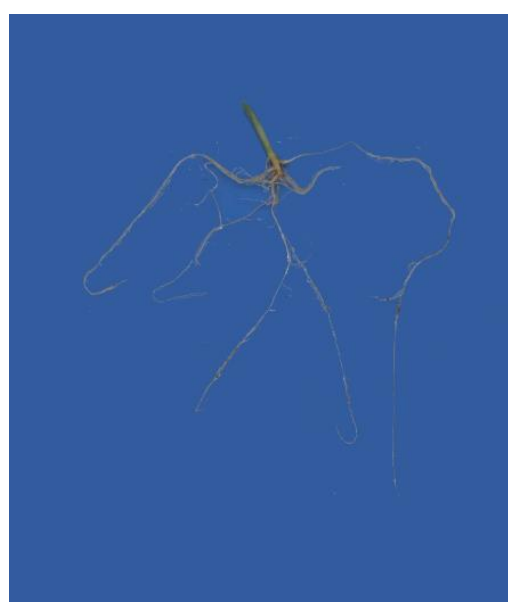

Met-BGV11135Afr

M. cannonballus

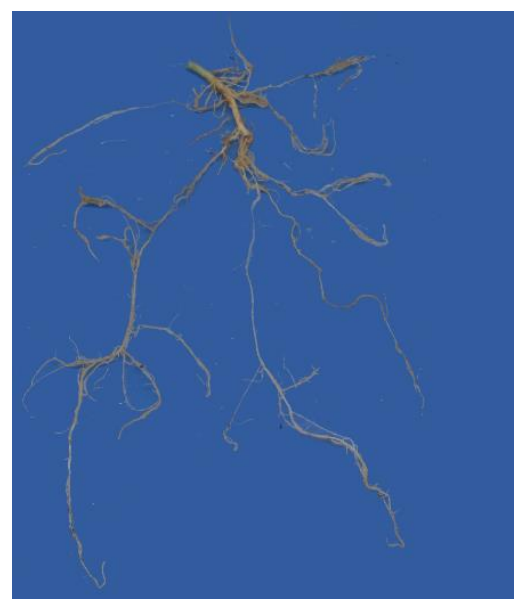

Ac-TGR139Zimb

M. cannonballus

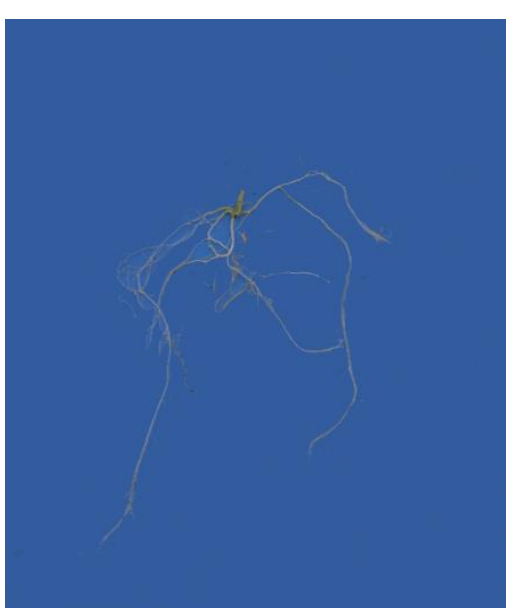

Ag-TriInd

M. eutypoides

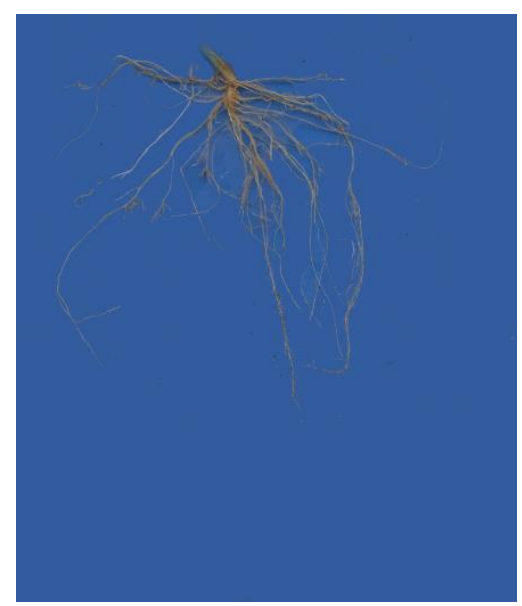

Met-BGV11135Afr

M. eutypoides

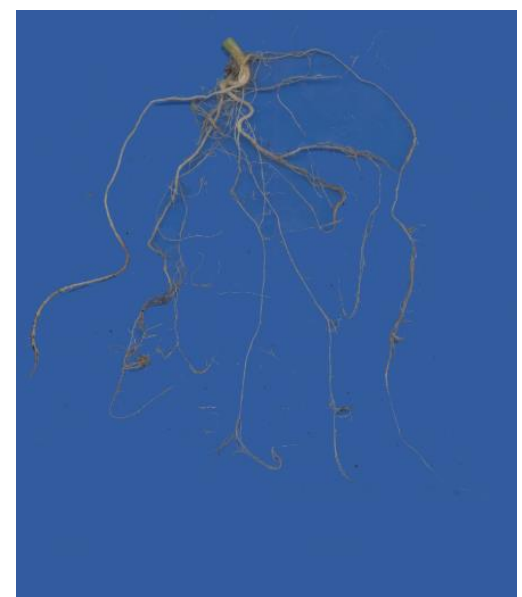

Ac-TGR139Zimb

M. eutypoides 


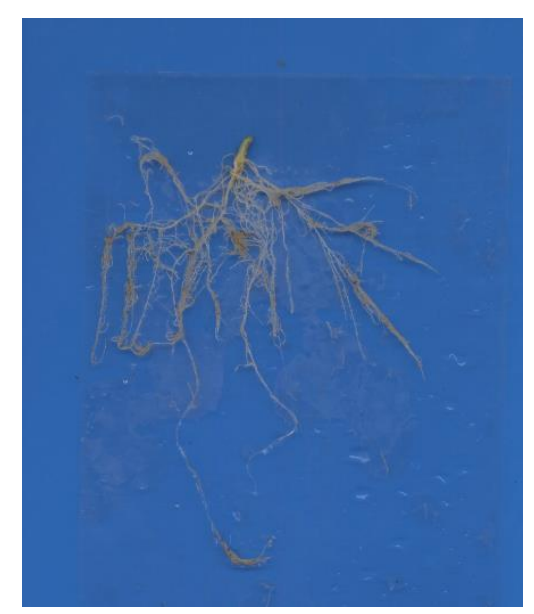

F1 Pat81xPs

Control

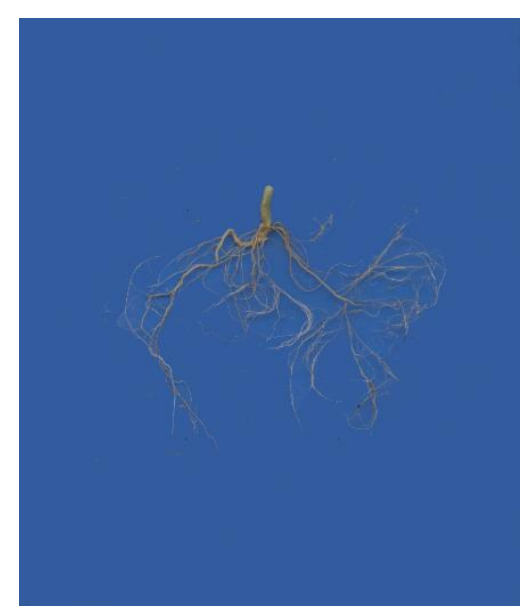

Ib-PsPiñSp

Control

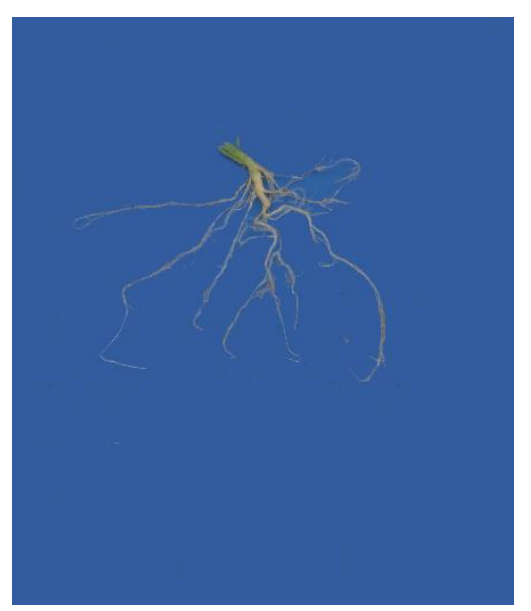

F1 Pat81xPs

M. cannonballus

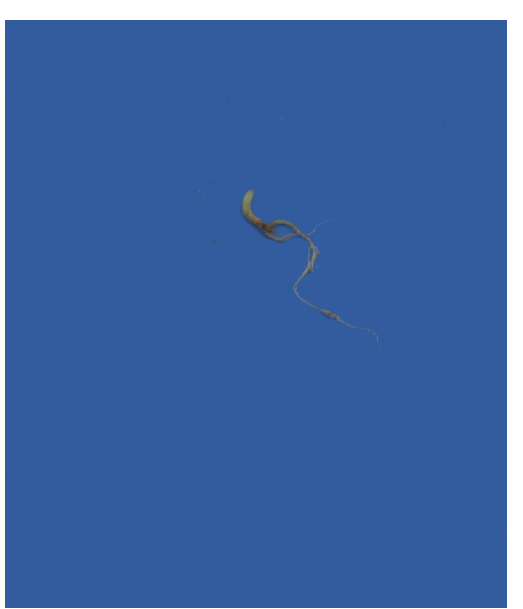

Ib-PsPiñSp

M. cannonballus

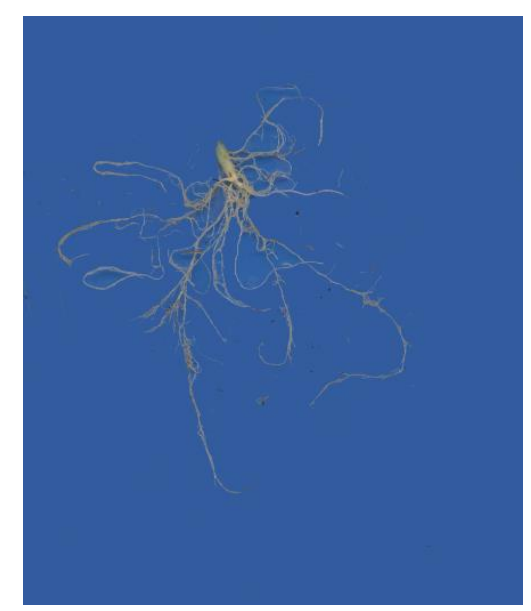

F1 Pat81xPs

M. eutypoides

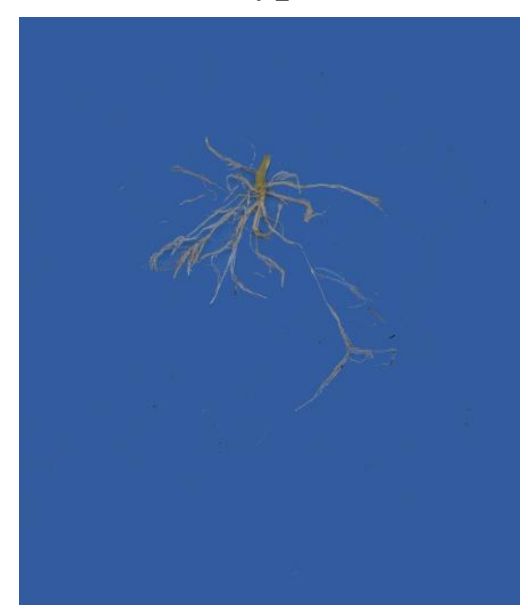

Ib-PsPiñSp

M. eutypoides 
4.3 CAPÍTULO 3

b)

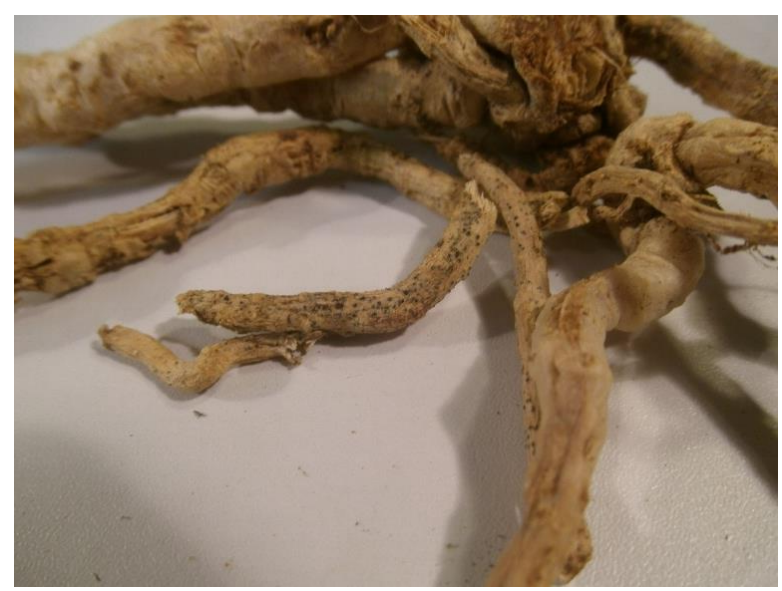

Ib-PsPiñSp

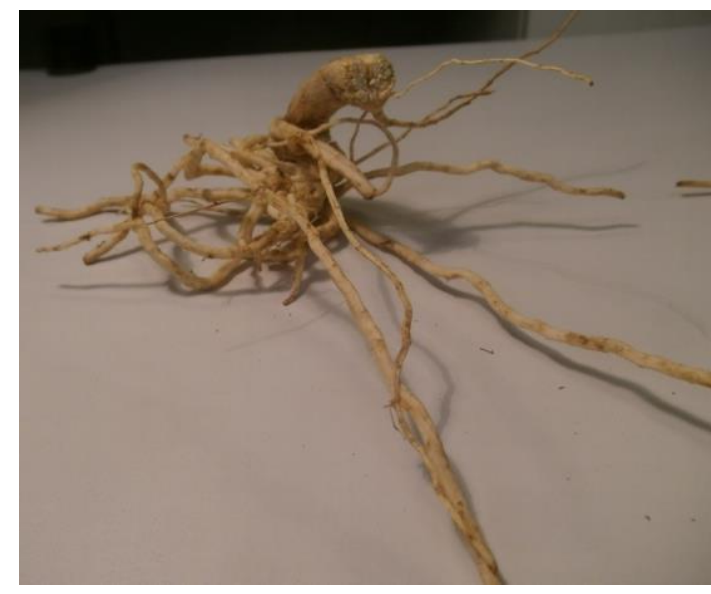

F1 Pat81xPs

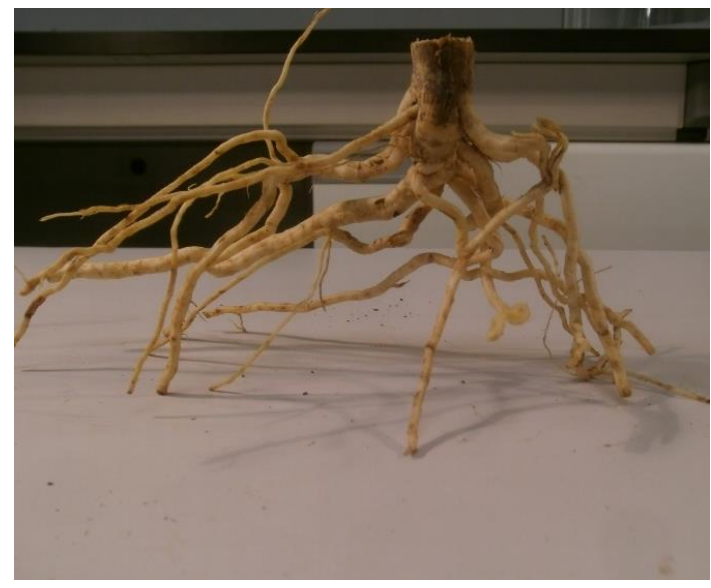

Met-BGV11135Afr 
4.3 CAPÍTULO 3

(a) Root Disease Index

4,50
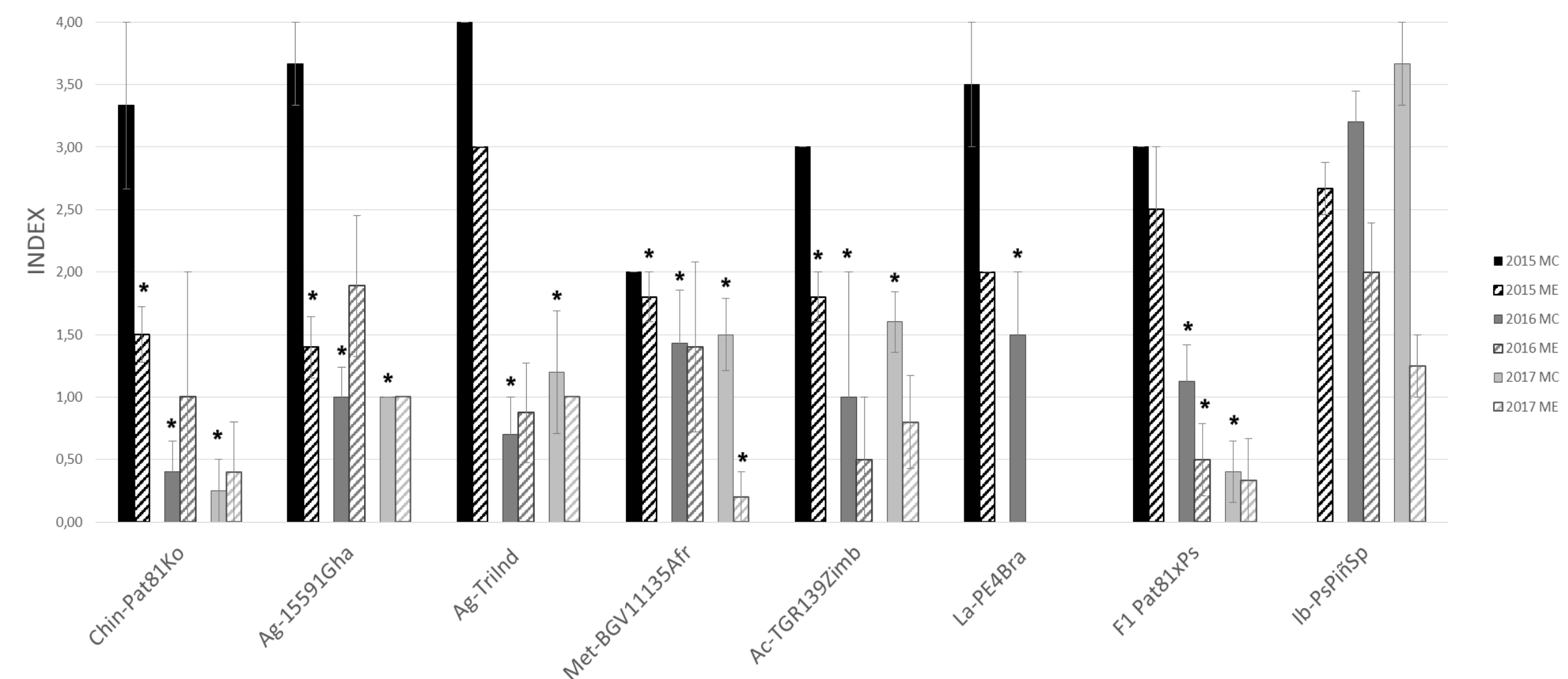

GENOTYPE 


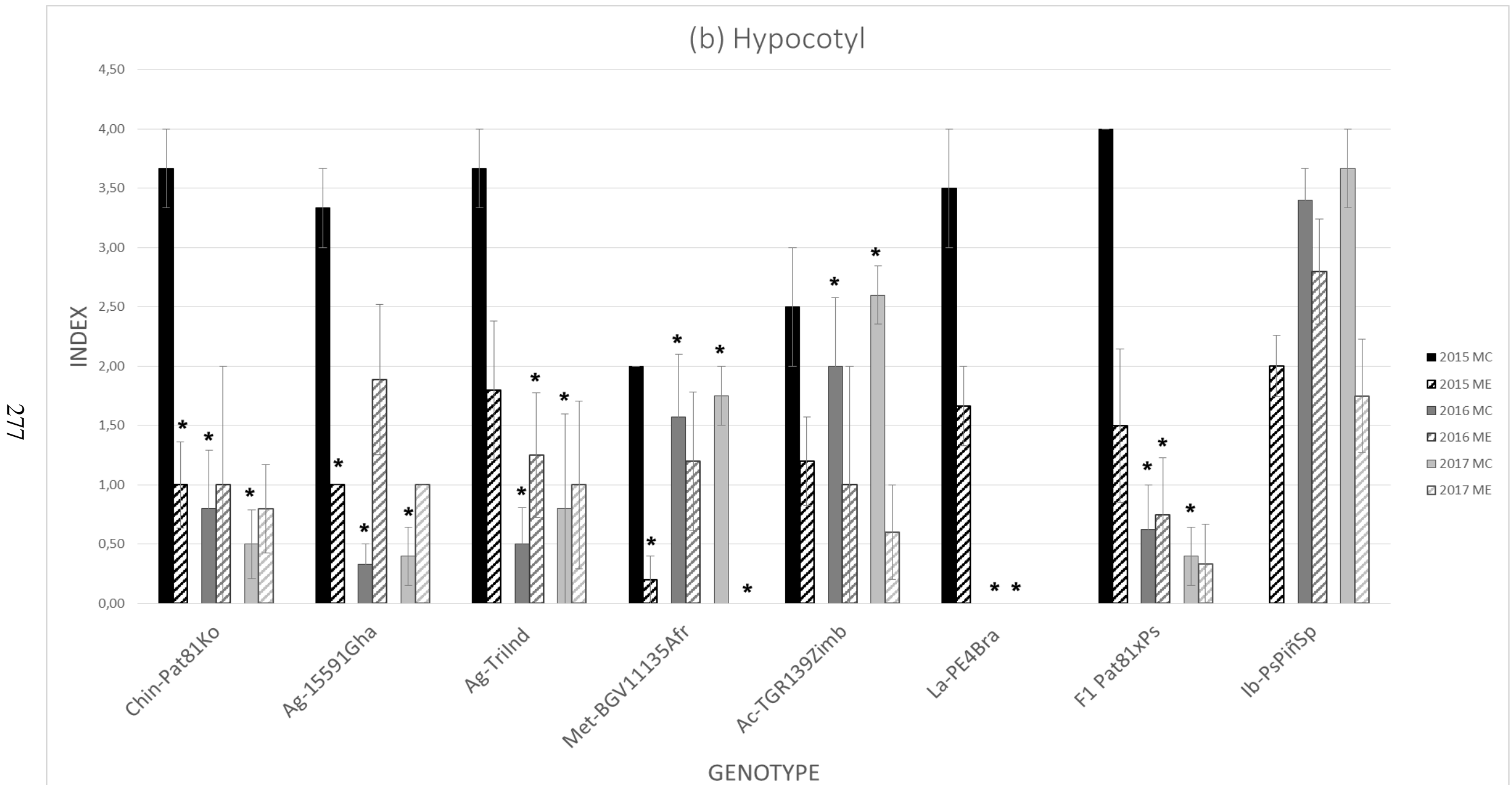

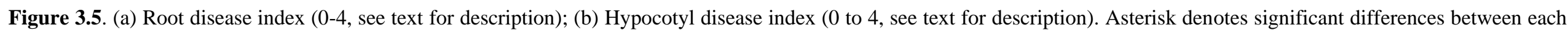
genotype compared to the susceptible control Ib-PsPiñSp, for inoculation with each fungal species and year ( $<<0.05$, Student's t test). Error bars represent standard error. 

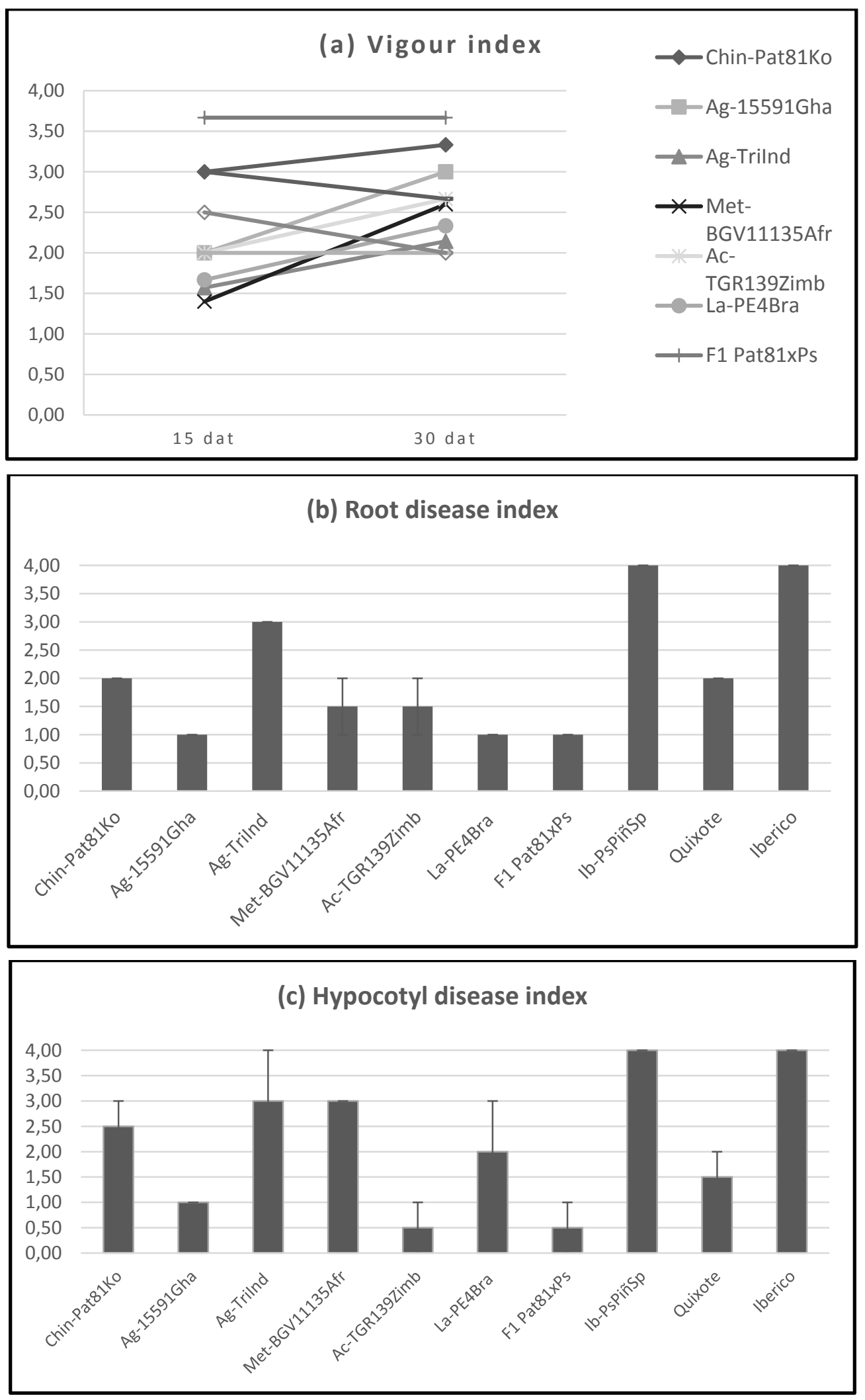

Figure 3.6. Field assay: (a) Evolution of plant vigour at 15 and 30 days after transplanting (dat). (b) Root disease index (c) Hypocotyl disease index; the three indices were evaluated from 0 to 4 (see text for description). 


\subsection{References}

Aegerter, B. J., Gordon, T. R., \& Davis, R. M. (2000). Occurrence and pathogenicity of fungi associated with melon root rot and vine decline in California. Plant Disease, 84(3), 224230.

Al-Mawaali, Q. S., Al-Sadi, A. M., Al-Said, F. A., \& Deadman, M. L. (2013). Etiology, development and reaction of muskmelon to vine decline under arid conditions of Oman. Phytopathologia Mediterranea, 52, 457-465.

Ben Salem, I., Correia, K. C., Boughalleb, N., Michereff, S. J., León, M., Abad-Campos, ... Armengol, J. (2013). Monosporascus eutypoides, a cause of root rot and vine decline in Tunisia , and evidence that $M$. cannonballus and M. eutypoides are distinct species. Plant Disease, 97, 737-743.

Ben-Salem, I., Armengol, J., Berbegal, M., \& Boughalleb-M'Hamdi, N. (2015). Development of a screening test for resistance of cucurbits and Cucurbita Hybrid Rootstocks to Monosporascus. Tunisian Journal of Plant Protection, 10, 23-34.

Bruton, B. D., García-Jiménez, J., \& Armengol., J. (1999). Analysis of the relationship between temperature and vine declines caused by Acremonium curcurbitacearum and Monosporascus cannonballus on muskmelon. Subtropical Plant Science, 51, 23-8.

Bruton B. D., Russo V. M., García-Jiménez J., \& Miller M. E. (1998). Carbohydrate partitioning, cultural practices, and vine decline diseases of cucurbits. In J. McCreight (Ed) Cucurbitaceae (pp. 189-200). Virginia, USA: American Society for Horticultural Science Press.

Chew-Madinaveita, Y. I., Gaytán-Mascorro, A., \& Herrera-Pérez, T. (2012). First report of Monosporascus cannonballus on melón in Mexico. Plant Diasease, 96 (7), 1068

Cluck, T. W., Biles, C. L., Duggan, M., Jackson, T., Carson, K., Armengol, J., ... Bruton, B. D. (2009). Association of dsRNA to down-regulation of perithecial synthesis in Monosporascus cannonballus. The Open Mycology Journal, 3(1), 9-19.

Cohen, R., Horev, C., Burger, Y., Shriber, S., Hershenhorn, J., Katan, J., \& Edelstein, M. (2002). Horticultural and pathological aspects of fusarium wilt management using grafted melons. HortScience, 37(7), 1069-1073.

Cohen, R., Pivonia, S., Burger, Y., Edelstein, M., Gamliel, A., \& Katan, J. (2000). Toward integrated management of monosporascus wilt of melons in Israel. Plant Disease, 84(5), 496-505.

Cohen, R., Pivonia, S., Crosby, K. M., \& Martyn, R. D. (2012). Advances in the biology and management of monosporascus vine decline and wilt of melons and other cucurbits. In J. 


\subsection{CAPÍTULO 3}

Janick (Ed), Horticultural Reviews (pp. 77-120). New Jersey, USA: Wiley-Blackwell

Collado, J., Gonzalez, A., Platas, G., Stchigel, A. M., Guarro, J., \& Pelaez, F. (2002). Monosporascus ibericus sp. nov., an endophytic ascomycete from plants on saline soils, with observations on the position of the genus based on sequence analysis of the 18S rDNA. Mycological Research, 106(1), 118-127.

Crosby, K. (2000a). Narrow-sense heritability estimates for root traits and Monosporascus cannonballus tolerance in melón (Cucumis melo) by parent-offspring regression. In Acta Horticulturae (pp. 149-154).

Crosby, K. M. (2000b). Impact of Monosporascus cannonballus on root growth of diverse melon varieties and their F1 progeny in the field. Subtropical Plant Science, 52, 8-11.

Crosby, K., Wolff, D., \& Miller, M. (2000). Comparisons of root morphology in susceptible and tolerant melon cultivars before and after infection by Monosporascus cannonballus. HortScience, 35(4), 681-683.

Crosby, K.M. (2001). Screening Cucumis melo L. agrestis germplasm for resistance to Monosporascus cannonballus. Subtropical Plant Science, 53, 24-26.

Dantas, A. C. A., Araujo, I. S., Esteras, C., Nunes, G. H. S., \& Picò, M. B. (2015). Diversity of melon accessions from northeastern Brazil and their relationships with germplasms of diverse origins. Journal of the American Society for Horticultural Science, 10, 505-517.

Dias, R. D. C. S., Picò, B., Espinos, A., \& Nuez, F. (2004). Resistance to melon vine decline derived from Cucumis melo ssp. agrestis: Genetic analysis of root structure and root response. Plant Breeding, 123(1), 66-72.

Díaz-Pendón, J. A, Mallor, C., Soria C., Camero R., Garzo, E., Fereres, ... Moriones, E. (2003). Potential Sources of resistance for melon to non-persistently aphid-borne viruses. Plant Disease, 87, 960-964

Endl, J., Achigan-Dako, E. G., Pandey, A. K., Monforte, A. J., Picò, B., \& Schaeffer, H (2018). Repeated domestication of melon (Cucumis melo) in Africa and Asia and a new close relative from India. American Journal of Botany, 105, 1662-1671.

Esteva, J., \& Nuez, F. (1994). Field resistence to melon dieback in Cucumis melo L. Cucurbit Genetics Cooperative, 17, 76-77.

Expósito, A., Munera, M., Giné, A., López-Gómez, M., Cáceres, A., ... Sorribas, F. J. (2018). Cucumis metuliferus is resistant to root- knot nematode Mi1.2 gene (a) virulent isolates and a promising melon rootstock. Plant Pathology, 67, 1161-1167.

Fita, A., Esteras, C., Picò, B., \& Nuez, F. (2009a). Cucumis melo L. new breeding lines tolerant to melon vine decline. HortScience, 44(7), 2022-2024.

Fita, A., Picò, B., Dias, R. C. S., \& Nuez, F. (2008). Effects of root architecture on response to 
melon vine decline. Journal of Horticultural Science and Biotechnology, 83(5), 616-623.

Fita, A., Picò, B., Dias, R. C. S., \& Nuez, F. (2009b). 'Piel de Sapo' breeding lines tolerant to melon vine decline. HortScience, 44(5), 1458-1460.

Fita, A., Picò, B., Monforte, A. J., \& Nuez, F. (2008). Genetics of root system architecture using near-isogenic lines of melon. Journal of the American Society for Horticultural Science, 133(3), 448-458.

Fita, A., Picò, B., Roig, C., \& Nuez, F. (2007a). Performance of Cucumis melo ssp. agrestis as a rootstock for melon. Journal of Horticultural Science and Biotechnology, 82(2), 184190.

Fita, A., Picò, B. \& Nuez, F. (2007b). Melon roots under stress: Melon Vine Decline. Plant Stress, 1, 93-104.

Gisbert C., Sorribas F. J., Martínez E.M., Gammoudi N., Bernat G., \& Picò M. B. (October 2014). Grafting melons onto potential Cucumis spp. rootstocks. In COST ACTION FA1204, 2nd Annual Conference - Innovation in vegetable grafting for sustainability. Proceedings (pp. 57). Carcavelos, Portugal.

Gonzalo M. J., Díaz, A., Dhillon, N., Reddy, U., Picò, M. B., \& Monforte, A. J. (2019). Reevaluation of the role of Indian germplasm as center of melon diversification based on Genotyping-by-Sequencing analysis. BMC Genomics in press.

Hamza H., Belkadhi M. S., Triki M. A., \& Zouba A. (2007). Morphological and biological studies of Monosporascus cannonballus, the cause of root rot and vine decline of melon in Southern Tunisia. Tunisian Journal of Plant Protection, 2, 71-77.

Iglesias, A., Picò, B. \& Nuez, F. (1999). Resistance to melon dieback in Cucumis melo ssp. agrestis 'Pat 81'. Phytopathology, 89, 35.

Iglesias, A., Picò, B., \& Nuez, F. (2000a). A temporal genetic analysis of disease resistance genes: Resistance to melon vine decline derived from Cucumis melo var. agrestis. Plant Breeding, 119(4), 329-334.

Iglesias, A., Picò, B., \& Nuez, F. (2000b). Pathogenicity of fungi associated with melon vine decline and selection strategies for breeding resistant cultivars. Annals of Applied Biology, 137(2), 141-151.

Leida, C., Moser, C., Esteras, C., Sulpice, R., Lunn, J. E., de Langen, F., ... Picò, B. (2015) Variability of candidate genes, genetic structure and association with sugar accumulation and climacteric behavior in a broad germplasm collection of melon (Cucumis melo L.). BMC Genetics, 16, 1-17.

López-Sesé, A. I., \& Gómez-Guillamon, M. L. (2000). Resistance to Cucurbit Yellowing 


\subsection{CAPÍTULO 3}

Stunting Disorder Virus (CYSDV) in Cucumis melo L. HortScience, 35, 110-113.

Malloch, D., \& Cain, R. F. (1971). New cleistothecial Sordariaceae and a new family, Coniochaetaceae. Canadian Journal of Botany, 49(6), 869-880.

Markakis, E. A., Trantas, E. A., Lagogianni, C. S., Mpalantinaki, E., Pagoulatou, M., Ververidis, F \& Goumas, D. E. (2018). First report of root rot and vine decline of melon caused by Monosporascus cannonballus in Greece. Plant Disease, 102(5), 1036.

Martyn, R. D. (2007). Late-season vine declines of melons: pathological, cultural or both? Acta Horticulturae, 731, 345-356.

Martyn, R. D., \& Miller, M. E. (1996). Monosporascus root rot and vine decline. An emerging disease of melons worldwide. Plant Disease, 80(7), 716-725.

Martyn, R. D., Batten, J. S., Park, Y. J., \& Miller, M. E. (1996). First report of monosporascus root rot/vine decline of watermelon in Mexico. Plant Disease, 80.

Negreiros, A. M. P., Júnior, R. S., Rodrigues, A. P. M. S., León, M., \& Armengol, J. (2019). Prevalent weeds collected from cucurbit fields in Northeastern Brazil reveal new species diversity in the genus Monosporascus. Annals of Applied Biology, 174, 349-363.

Patil, S. D., \& Ramesh, C. (1987). Notes on some fungi of Pleosporaceae (Loculoascomycetes) from Maharashtra (India). Transactions of the Mycological Society of Japan, 28, 229-236.

Petrak, F., \& Ahmad, S. (1954). Beiträge zur Pilzflora Pakistans. Sydowia, 8, 162-185.

Picò, B., Roig, C., Fita, A., \& Nuez, F. (2008) Quantitative detection of Monosporascus cannonballus in infected melon roots, using real-time PCR. European Journal of Plant Pathology, 12, 147-156.

Pitrat M. (2017). Melon genetic resources: phenotypic diversity and horticultural taxonomy. In R. Grumet, N. Katzir, J. Garcia-Mas (Eds), Genetics and genomics of the Cucurbitaceae (pp. 25-60). New York, USA: Springer.

Pivonia, S., Cohen, R., Kigel, J., \& Katan, J. (2002). Effect of soil temperature on disease development in melon plants infected by Monosporascus cannonballus. Plant Pathology, 51(4), 472-479.

Pollack, F. G., \& Uecker, F. A. (1974). Monosporascus cannonballus an unusual ascomycete in Cantaloupe roots. Mycologia, 66, 346-349.

Reuveni, R., Krikun, J., \& Shani, U. (1983). The role of Monosporascus eutypoides in a collapse of melon plants in an arid area of Israel. Phytopathology, 72, 1223-1226.

Roig, C., Fita, A., Ríos, G., Hammond, J. P., Nuez, F., \& Picò, B. (2012). Root transcriptional responses of two melon genotypes with contrasting resistance to Monosporascus cannonballus (Pollack et Uecker) infection. BMC Genomics, 13(1), 601-612.

Sales Júnior, R., Oliveira, O. F., Medeiros, E. V., Guimarães, I. M., Correia, K. C., \& Michereff, 
S. J. (2012). Ervas daninhas como hospedeiras alternativas de patógenos causadores do colapso do meloeiro. Revista Ciência Agronômica, 43, 195-198.

Sales Júnior, R., Senhor R. F., Michereff S. J., Negreiros A. M. (2019). Reaction of melon genotypes to the root's rot caused by Monosporascus. Caatinga, 32, 288-294

Sinclair, J. W. (2003). Screening for resistance to cucurbit yellow stunting disorder virus, gummy stem blight, and monosporascus root rot and detection of rapd markers associated with qtl for soluble solids, sugars, and vitamin $\mathrm{C}$ in melon (Cucumis melo L.) (Doctoral thesis). Texas A\&M University, Texas, USA.

Stanghellini, M. E., Alcantara, T. P., \& Ferrin, D. M. (2010). Germination of Monosporascus cannonballus ascospores in the rhizosphere: a hostspecific response. Canadian Journal of Plant Pathology 32, 402-405.

Wolff, D. W. (1995). Evaluation of melon germplasm for resistance to monosporascus root rot vine decline. In J. R., Dunlap \& G. E., Lester (Eds), Evaluation and Enhancement of Cucurbit Germplasm (pp. 224-228). Texas, USA: Gateway Printing.

Wolff, D. W. (1996). Genotype, fruit load, and temperature affect monosporascus root rot/vine decline symptom expression in melon (Cucumis melo L.). In M. L. Gomez-Guillamon, C. Soria, J. Cuartero, J. A. Tores, R Fernandez Munoz (Eds). Cucurbits Toward 2000: Proceedings of the 6th Eucarpia Meeting on Curcurbit Genetics and Breeding (pp. 280284). Malaga, Spain.

Wolff, D. W, Leskovar, D. I, Black, M. C, \& Miller, M. E. (1997). Differential fruit load in melon (Cucumis melo L.) affects shoot and root growth, and vine decline symptoms. HortScience, 32(3), 526.

Wolff, D. W., \& Miller, M. E. (1998). Tolerance to monosporascus root rot and vine decline in melon (Cucumis melo L.) germplasm. HortScience, 33(2), 287-290.

Yan, L. Y., Zang, Q. Y., Huang, Y. P., \& Wang, Y. H. (2016). First report of root rot and vine decline of melon caused by Monosporascus cannonballus in Eastern Mainland China. Plant Disease, 100, 651

Yuste-Lisbona F. J., López-Sesé, A. I., \& Gómez-Guillamón, M. L. (2009). Inheritance of resistance to races 1, 2 and 5 of powdery mildew in the melon TGR- 1551 Plant Breeding, 129(1), 72-75. 



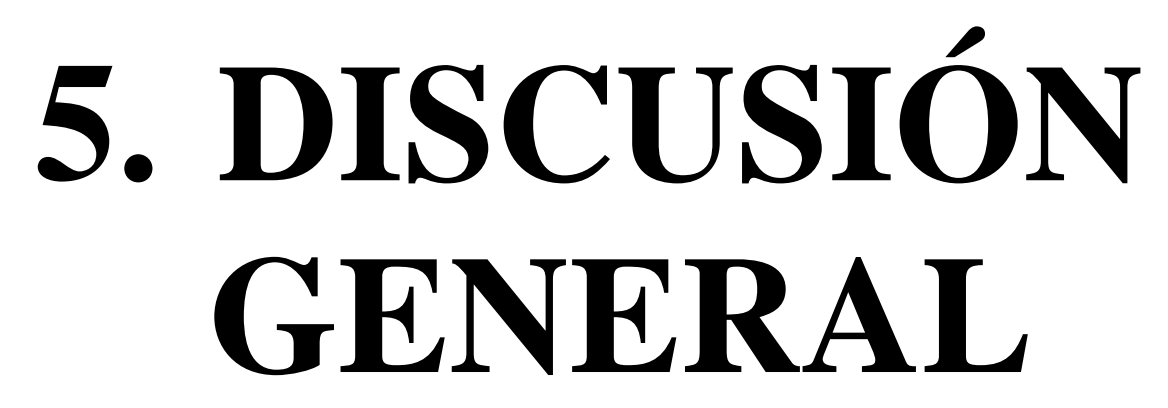





\section{DISCUSIÓN GENERAL}

Esta Tesis Doctoral tiene como objetivo principal proporcionar nueva información, a la comunidad científica y a los mejoradores de melón, sobre la utilidad del grupo Dudaim, y otros recursos genéticos, de interés para la mejora del melón. Este trabajo, se fundamenta, en parte, en el hecho de que, a pesar de la gran variabilidad genética existente en la especie, se evidencia una importante uniformidad genética en las variedades comerciales, consecuencia de la agricultura intensiva establecida en décadas pasadas y de la búsqueda de estabilidad en la producción. El objetivo principal de los programas de mejora durante mucho tiempo ha estado enfocado hacia el aumento de la producción, dejando en muchos casos los aspectos relacionados con la calidad en un segundo plano. Ya hace décadas, autores de relevancia como Pitrat (1991) y Guis, Roustan, Dogimont, Pitrat, \& Pech (1998) dieron cuenta del enorme potencial en mejora que posee nuestra especie objetivo Cucumis melo por su elevada variabilidad genética. Con el desarrollo de los primeros marcadores moleculares y mapas genéticos, como el elaborado por Périn et al. (2002), se posibilitó la detección de QTLs, para posteriormente desarrollar métodos eficientes para introducirlos en cultivares modernos. La disponibilidad de herramientas moleculares y genómicas en esta especie no ha dejado de crecer en los últimos años, impulsando de manera muy notable la consecución de objetivos en los programas de mejora. Las tendencias de un mercado, en constante cambio, impulsan a promover el consumo de frutos con una alta calidad, tanto sensorial como nutricional. Para suplir las nuevas exigencias del mercado ha sido necesario replantear las estrategias de mejora y recurrir a variedades exóticas o silvestres, que permitan introducir nuevas características que mejoren la calidad, así como también hacer frente a las enfermedades o plagas que afectan al cultivo. Por otra parte, en los programas de obtención de nuevas variedades no se pueden desestimar ciertos condicionantes que garantizarán su aceptación comercial (Welch \& Graham 2004). Por ejemplo, la productividad del cultivo debe mantenerse o aumentarse para garantizar la aceptación del agricultor, los niveles de enriquecimiento de nutrientes deben tener un impacto significativo en la salud humana y tener la aceptación sensorial del consumidor y, por último, los rasgos incorporados deben ser estables en entornos diversos. Estas circunstancias han planteado un desafío en la planificación y elaboración de estrategias que permitan explotar el potencial de las especies exóticas y silvestres como fuente de diversidad en programas de mejora.

Entre las diversas estrategias existentes para explotar la variabilidad genética presente en tipos exóticos, como los melones de tipo Dudaim, se decidió optar por el desarrollo de una colección de líneas de introgresión (ILs). Previamente a esta Tesis sólo se había publicado la existencia de dos colecciones de ILs en melón (Eduardo, Arús, \& Monforte, 2005; Perpiñà, Esteras, Gibon, 


\section{DISCUSIÓN GENERAL}

Monforte, \& Picò, 2016), y durante el desarrollo de ésta se han publicado dos más (Pereira, 2018). Estas poblaciones de ILs tienen el fondo genético de dos de los genotipos de mayor importancia en España y Europa, el tipo Ibericus 'Piel de Sapo' y el cantalupo 'Vedrantais'. En general, el número de este tipo de colecciones es reducido, en gran medida por el esfuerzo, recursos y tiempo que conlleva su desarrollo.

\section{Desarrollo y evaluación de las ILs.}

Se utilizó como parental recurrente el cultivar español 'Piñonet', un tipo 'Piel de Sapo' (PS) (grupo Ibericus) y como parental donante 'Queen's pocket melon' (DUD) (grupo Dudaim). Ambos parentales difieren significativamente para muchos caracteres. Mientras PS es una variedad comercial muy extendida en la zona Mediterránea, con frutos de tamaño mediano, forma ovalada, corteza gruesa de color verde, pulpa blanca, crujiente, con alto contenido de azúcar, de maduración tardía y no climatérico, los frutos DUD son pequeños, de forma esférica, corteza fina, de color amarillo con manchas naranja/ocre, con bajo contenido de azúcar, climatéricos, y desprenden un aroma muy intenso y singular, por lo que son usados comúnmente por su fragancia de forma ornamental, fundamentalmente en zonas de Oriente Medio. Gracias a las grandes diferencias fenotípicas exhibidas por ambos parentales y a través del desarrollo de las líneas de introgresión, se puede tener una mejor comprensión del control genético asociado a los diferentes caracteres fenotípicos evaluados, para su aprovechamiento en la mejora de la calidad.

Es así, como en los capítulos 1 y 2 (secciones 3.1 y 3.2) de la primera parte de esta Tesis, sobre el aprovechamiento de la variabilidad intraespecífica del melón para la mejora de la calidad, se describe la evolución del desarrollo de una colección de ILs y su posterior evaluación. La generación de la colección se llevó a cabo mediante una estrategia que permitió la optimización del tiempo empleado en su desarrollo. El uso de retrocruzamientos y autofecundaciones en las diferentes generaciones, así como la utilización de diversas plataformas de genotipado, permitieron optimizar el proceso de selección de plantas con mayor proporción del fondo genético recurrente y con las introgresiones diana. La selección de marcadores empleados en el genotipado se realizó en base al trabajo de Blanca et al. (2012), en el que se resecuenciaron 67 genotipos de melón distribuidos en 8 "pools", con el fin de identificar polimorfismos entre diferentes tipos horticulturales de melón. De las más de 300,000 variantes detectadas, una pequeña parte se empleó para obtener un mapa genético que se ancló al genoma desarrollado por García-Mas et al. (2012), basado en la población doble haploide 'Songwhan Charmi' x 'Piel de Sapo'. Actualmente, existen mapas de mayor densidad en C. melo, como el desarrollado por Branham, Levi, Katawczik, Fei, \& Wechter (2018), a partir de una población de RILs obtenida 
del cruce entre las accesiones 'MR-1' y 'AY', que cuenta con 5663 SNPs. La utilización de los mapas de alta densidad disponibles en la actualidad constituye un recurso valioso para la identificación de QTLs con gran precisión. Sin embargo, el mapa usado en este trabajo, a pesar de no presentar una alta cobertura de SNPs, no representa un problema en el estudio, ya que existe una alta correlación (98.5\%) entre el mapa genético utilizado y el elaborado recientemente por Branham et al. (2018). Además, el genotipado con tal cantidad de marcadores se hace inviable en cada generación, por lo que los genotipados de tal envergadura, empleando plataformas de alto rendimiento o estrategias como GBS, suelen realizarse únicamente en los últimos pasos de la obtención de las líneas, como se ha hecho en la presente Tesis doctoral.

En base a los marcadores seleccionados del mapa de Garcia-Mas et al. (2012), previamente ya validados y empleados por Perpiñà et al. (2016), se realizó un genotipado con la tecnología de medio rendimiento Agena Bioscience iPLEX® Gold MassARRAY en los individuos de las diferentes generaciones, a partir del cual se realizó la selección de las plantas con el genotipo idóneo, teniendo en cuenta el número de introgresiones y el porcentaje de fondo genético PS. Esto permitió obtener un aumento considerable del fondo genético PS en las primeras generaciones, pasando de $81 \%$ en BC2 a alrededor del $90 \%$ en BC3. Posteriormente, con la selección asistida por HRM (High Resolution Melting) se pudo aumentar el porcentaje de fondo en generaciones sucesivas, alcanzando alrededor del 94\% en BC3S4. Por lo tanto, se puede afirmar que la selección asistida por genotipado en las primeras generaciones repercutió de forma directa en las generaciones futuras (BC3S1 y BC3S2), a partir de las cuales se seleccionaron las primeras líneas definitivas que conformarían la población final de ILs. Una vez obtenida esta colección de ILs, en el segundo capítulo, se detalla la evaluación del fenotipo mostrado por cada línea y la identificación de los QTLs responsables de las diversas variaciones fenotípicas en las líneas finales mediante el test estadístico de Dunnett. Es preciso anotar que durante el estudio no se evidenciaron problemas de compatibilidad entre los genomas parentales, lo que permitió el desarrollo óptimo de los cruces. Es así, como se obtuvo una colección final de 16 ILs con un promedio de 93,9\% de fondo genético y 1,4 introgresiones/IL, no muy diferente a lo publicado en trabajos previos como las ILs de Perpiñà et al. (2016), con un 95,4\% de fondo 'Vedrantais' y 1,3 introgresiones/IL, o las dos colecciones recíprocas de ILs de Pereira (2018) con un 95\% de fondo 'Vedrantais' y un promedio de 1,2 introgresiones/IL, en una, y con un 90,9\% de fondo genético 'Piel de Sapo' y 1,6 introgresiones/IL en la otra. Las 16 ILs presentadas en esta Tesis representan el 62.6\% del genoma del parental donante (Dudaim), por lo que se sigue trabajando en obtener más ILs que completen la colección a partir de generaciones anteriores. El tamaño promedio de las introgresiones en la colección final de ILs fue de 8,42 Mpb y el porcentaje de introgresiones no-diana presentes en la colección fue de 


\section{DISCUSIÓN GENERAL}

alrededor del $2 \%$. Alrededor de un tercio de las ILs presentaron doble introgresión. Tanto la presencia de dobles introgresiones, como de introgresiones no-diana pueden deberse a fenómenos de doble recombinación. En nuestra población la incidencia de introgresiones nodiana fue reducida, debido en gran medida al genotipado de las primeras generaciones (BC2 y BC3), que permitió seleccionar las plantas no sólo con introgresiones grandes de parental donante, sino también tener en cuenta aquellas que poseían menos introgresiones no-diana.

En conclusión, la estrategia adoptada permitió obtener ILs a partir de la sexta generación, reduciendo considerablemente el tiempo de obtención sin el empleo de selección asistida por marcadores en fases tempranas. Cabe destacar también que el uso de distintos métodos de genotipado en el proceso de selección ha permitido la racionalización de los recursos y la optimización del proceso, consiguiéndose una buena isogenicidad en el fondo genético. Además, a la luz de nuestros resultados de GBS, se propone una caracterización molecular de alta densidad mediante GBS al final del proceso de obtención para todas las líneas, debido a las introgresiones pequeñas que de otra manera quedan "ocultas".

Por otra parte, el hecho de haber fenotipado cada generación para todos los caracteres, y no sólo en las últimas fases, nos ha aportado mayor información acerca de aquéllos que resultan más interesantes en esta población y las familias o líneas de mayor interés como líneas premejora. Esto ha permitido hacer un seguimiento de la evolución generación a generación de los caracteres evaluados. El realizar los análisis preliminares de QTLs a partir de BC3S1 mediante el uso de tres métodos estadísticos distintos (SMR, CIM y Kruskal-Wallis), ha contribuido a identificar las regiones genómicas involucradas en los diferentes caracteres observados en cada generación, optimizando de esta forma aún más el proceso de selección de las líneas. Entre estas regiones identificadas, podemos destacar aquellas que fueron consistentes en varias generaciones y que después se han confirmado con los resultados del test de Dunnett comparando cada una de las 16 ILs con el genotipo de referencia PS en dos ambientes. Además, la disponibilidad de marcadores anclados al genoma y de información transcriptómica para $C$. melo (MELONOMICS project), ha facilitado la identificación de genes candidatos para algunos de los QTLs detectados.

En total, empleando las 16 ILs, se identificaron 74 QTLs, de los cuales 32 fueron estables en dos ambientes. Algunos de estos QTLs no han sido descritos anteriormente, mientras que otros suponen una confirmación, en otra población diferente, de QTLs descritos previamente. En general, los efectos relacionados con los QTLs fueron coherentes con el fenotipo mostrado por el parental donante. Por ejemplo, empleando el test de Dunnett y relacionados con el climaterio se detectaron los QTLs al.1, al.3 y al.6, para capa de abscisión, y ar.1 y ar.6, para presencia de aroma, definidos por las líneas DUD_3-1 y DUD_6-2, que poseen introgresiones en dichos 
cromosomas y que fenotípicamente expresan características asociadas al proceso de maduración típicas de Dudaim, como la formación de la capa de abscisión en ambos casos, y la emisión de aroma y el ablandamiento de la pulpa en el caso de la línea DUD_6-2. A su vez, estos QTLs fueron detectados con efectos similares en el análisis realizado con métodos como SMR, CIM o Krustal-Wallis, lo que supone una confirmación de la importancia de estas regiones, y además, podrían corresponderse con QTLs detectados previamente como ETHQB3.5 o ETHQV6.3 (Moreno et al. 2008; Ríos et al. 2017; Vegas, Garcia-Mas, \& Monforte, 2013). Por otra parte, algunas regiones identificadas en la sección 3.1 y no descritas previamente, como la región del cromosoma 9 relacionada con el desarrollo de la capa de abscisión, habría que estudiarlas con más detalle en el futuro, pues DUD_3-1 tiene una pequeña introgresión, confirmada por GBS en esa zona y con los datos disponibles no se puede descartar su contribución al fenotipo observado en esta IL.

Cabe destacar también que para algunos de los QTLs detectados en esta Tesis se han identificado genes candidatos que podrían explicar lo efectos encontrados, pero que habría que estudiar con mayor profundidad en el futuro. Por ejemplo, respecto al aroma, que está relacionado directamente con los procesos de maduración dependientes de etileno, en la región del QTL ar.1 se localizan dos genes relacionados con etileno (MELO3C024268 y MELO3C024315) y otros dos genes (MELO3C029261 y MELO3C024348) asociados al metabolismo de volátiles. Recientemente, Galpaz et al. (2018), reportaron un QTL en el cromosoma 1, involucrado en la producción de un tioester, que se solapa con una introgresión presente en la línea aromática DUD_6-2. En esta región hemos encontrado más genes relacionados en la formación de ésteres, compuestos que contribuyen de forma importante al aroma del melón (MELO3C024364, MELO3C025383 y MELO3C026941, entre otros). Por tanto, estos genes son buenos candidatos para explicar la presencia de aroma en esta línea.

Otro aspecto de gran relevancia estudiado en esta población es la morfología de fruto. En esta Tesis, se han identificado diversos QTLs relacionados con el peso y la forma. Algunos de estos QTLs, localizados en los cromosomas 3 (fl.3), 4 (fl.4, fs.4), 5 (fl.5, fs.5) y 12 (fs. 12) han sido también confirmados por otras metodologías en la sección 3.1, con los alelos DUD que dan lugar a formas más redondeadas respecto PS. Por ejemplo, el correspondiente al cromosoma 3, presente en DUD_5-1, ha sido confirmado en todas las generaciones analizadas. Estudios previos sobre el papel de los genes de la familia Ovate (OFP) en la regulación de la forma del fruto (Wu et al. 2018) junto con el listado de OFPs en C. melo publicado por Monforte, Díaz, A., Caño-Delgado, A., \& van der Knaap (2014), han facilitado también la identificación de genes candidatos para estos QTLs, como el OFP6 (MELO3C025581), localizado en la región de la introgresión del cromosoma 12 presente en las líneas DUD_4-2 y DUD_5-3. 


\section{DISCUSIÓN GENERAL}

El fenotipado posterior más detallado de líneas derivadas de algunas de estas ILs también ha supuesto un avance y una confirmación de algunos de los QTLs presentados. Es el caso de la línea de pre-mejora llamada 'Mini PS', derivada de la DUD_4-2, que tras ser evaluada en varios ambientes, ha mostrado un tamaño significativamente menor que PS (sección 3.4), además del efecto de forma mas redondeada previamente identificado en DUD_4.2. Por consiguiente, además de los QTLs $f w .1$ y $f w .2$, en esta Tesis se propone considerar $f w .4$ y $f w .12$ como QTLs potenciales para el control del tamaño del fruto, aspecto muy importante para los mejoradores, dada la actual tendencia de consumo.

La co-localización de algunas de estas regiones identificadas en este trabajo con meta-QTLs (detectados en diferentes poblaciones) de forma y peso como FSQM12 y FWMQ2 (Monforte et al. 2014) apoya la validez de estos QTLs. Sin embargo, nuestros resultados también sugieren el papel de otros genes diferentes involucrados en estos caracteres en nuestra población. Por ejemplo, el hasta ahora considerado efecto pleiotrópico del gen $a$ en relación a la forma y tamaño del fruto no explica el fenotipo observado debido a los alelos DUD para $f l .2$ y $f d .2$, pues ambas líneas son andromonoicas.

Otro carácter de interés en esta colección de ILs en relación al aspecto del fruto es el reticulado. Se apreció una herencia transgresiva para net.5 (QTL también detectado en generaciones previas), puesto que los alelos Dudaim provocan un reticulado que no se observa en ninguno de los parentales.

\section{Genotipos de interés comercial y científico}

En nuestro trabajo hemos identificado cuatro ILs que presentan fenotipos claros de potencial interés en programas de mejora (DUD_3-1, DUD_4-2, DUD_6-1, DUD_6-2), siendo también herramientas de utilidad para el estudio del control genético de características de calidad (sección 3.3). Estas líneas presentan características como capa de abscición, reticulado y aroma, corteza de color amarillo, y cambios en la forma del fruto en relación al parental recurrente. Aspectos sensoriales como el aroma, son muy importantes en el momento de elección del fruto por parte del consumidor. La línea DUD_6-2 desprende un aroma dulce muy intenso que se puede describir como una mezcla de piña, con un toque de jazmín, un aroma que no se ha descrito en variedades comerciales de melón de tipo 'Piel de Sapo'. La línea DUD_3-1 es climatérica al igual que DUD_6-2, pero no aromática, presentando ambas diferencias en el grado de maduración. La comparación de ambas líneas puede aportar información acerca del control genético del proceso de maduración (Ríos et al. 2017 y Vegas et al. 2013). La línea DUD_6-1, mostró un cambio de color externo a amarillo sin ser climatérica. Existen pocas excepciones donde el cambio de color externo sea independiente de etileno, una de ellas es el 
Amarillo Canario, tipo casaba (no climatérico), en el que se ha asociado el cambio de color a la síntesis de flavonoides (Burger et al., 2010). Esta línea permitirá profundizar en el estudio genético de este carácter y además proporciona un material de premejora para diversificar el mercado de los melones 'Piel de Sapo'. El tamaño del fruto es otro carácter importante a nivel comercial, en el caso de 'Piel de Sapo'. Debido a su tamaño habitual es normal su comercialización por mitades, por lo que la posibilidad de obtener una variedad de tamaño más reducido que conserve las propiedades intrínsecas de calidad resulta de gran impacto comercial. La línea DUD_4-2 ofrece esta posibilidad, y por tanto, es una de las que mayor interés comercial presenta. Por ello, se ha analizado adicionalmente en la sección 3.4. Se evaluó una línea derivada de esta IL para verificar la estabilidad fenotípica de los alelos DUD presentes en la principal introgresión que porta, a la cual se le atribuye el efecto de la disminución de la longitud y por consiguiente del tamaño. El peso de los frutos de esta línea en 2018 disminuyó alrededor del 50\%. En base a estos últimos fenotipados se puede hablar de los frutos DUD_4-2 como Mini 'Piel de Sapo'. Esta línea 'Mini PS' fruto de los trabajos de esta Tesis puede tener mucho interés, pues es mucho más pequeña que otros Mini melones que se están intentando lanzar ahora al mercado como la reciente HMC 464851 de HM Clause.

\section{Resistencia a enfermedades}

Otro de los objetivos de la presente Tesis fue el aprovechamiento de la variabilidad intraespecífica del melón para la resistencia a hongos del suelo. En esta línea, el capítulo 1 de dicho bloque (sección 4.1) se centra en la realización de un fenotipado en búsqueda de resistencia a Macrophomina phaseolina, hongo responsable de una de las principales enfermedades de suelo en cucurbitáceas, en la colección de ILs obtenida previamente. Este estudio se planteó debido a la resistencia moderada frente a este patógeno que se observó en el parental Dudaim en un cribado previo de germoplasma de melón (Ambrosio et al. 2015). A pesar de que ninguna IL fue resistente al patógeno, el interés del trabajo radica en que cuatro de las líneas (DUD_2-1, DUD_4-2, DUD_5-1 y DUD_8-1) presentaron una extensión de la lesión considerablemente inferior al promedio observado en el resto de ILs, cuyo comportamiento fue similar al del cultivar susceptible PS. Las resistencias a hongos pueden estar asociadas a un gen principal (como Fom-1 para las razas 0 y 2 de Fusarium oxysporum f.sp. melonis, Risser, Banihashemi, \& Davis, 1976), pero existen también resistencias bajo control poligénico (Thakur, Sharma, \& Thakur, 2019). La acción conjunta de diferentes regiones genómicas ya ha sido planteada en otros estudios, como por ejemplo, los de la resistencia de diversos genotipos a la raza 1.2 de F. oxysporum (Chikh-Rouhou, GonzálezTorres, Alvarez, \& Oumouloud, 2010; Perchepied, Dogimont C, \& Pitrat, 2005). En las 


\section{DISCUSIÓN GENERAL}

introgresiones de las cuatro ILs mencionadas se han identificado genes relacionados con glicerol-3-fosfato (G3P), compuesto necesario para la inducción del mecanismo SAR de resistencia sistémica adquirida (Daley, Branham, Levi, Hassell, \& Wechter, 2017). Sin embargo, la asociación de estos genes con el menor índice de lesión aún es prematuro. Aunque la resistencia de estas líneas debe ser probada en condiciones de infección natural en campo, los resultados obtenidos en la sección 4.1 sugieren que la colección de ILs no resulta prometedora para programas orientados a la mejora de la resistencia frente a M. phaseolina. Teniendo en cuenta que el porcentaje del genoma de Dudaim representado en las ILs analizadas no es del $100 \%$, no se puede descartar la posibilidad de que existan otras regiones de Dudaim que proporcionen una resistencia más eficaz frente a $M$. phaseolina, pero no estén representadas en la colección actual.

Debido a estos resultados y con el objetivo de estudiar qué otros factores podrían estar afectando a la respuesta frente al patógenó del parental DUD, se decidió realizar una evaluación de la incidencia de la temperatura en la resistencia a M. phaseolina en un conjunto de accesiones con distinto nivel de resistencia, incluyendo el parental DUD. Este trabajo constituye el capítulo 2 de este segundo bloque (sección 4.2) y pone de manifiesto la importancia de probar las fuentes de resistencia en distintas condiciones de estrés térmico para poder seleccionar una resistencia eficaz y estable frente a este patógeno. En el ensayo se emplearon seis accesiones: dos silvestres de origen africano (PI 185111 y CUM 287), dos asiáticas (el parental DUD del grupo Dudaim y Pat 81 del grupo Chinensis) y dos comerciales, 'Piel de Sapo' del grupo Ibericus (el parental PS de las ILs) y el cultivar de Israel Noy Israel del grupo Cantalupensis. Se evidenció una tendencia al aumento de la gravedad de la enfermedad a medida que la temperatura de ensayo aumentaba. Este efecto fue aparente en todos los genotipos, tanto en los más susceptibles como en aquellos con niveles variables de resistencia.

La única entrada que demostró ser resistente en todos los ensayos, incluso en condiciones de temperatura elevada, en cámara y en condiciones de campo, fue la accesión silvestre africana PI 185111. El resto de entradas ensayadas exhibieron un comportamiento intermedio similar, es decir fueron moderadamente resistentes a la infección en ensayos a temperaturas bajas o moderadas, pero con el aumento de la temperatura su resistencia fue disminuyendo progresivamente. Esto explica en parte los resultados obtenidos con la población de ILs, pues se hace evidente que la resistencia de Dudaim es muy dependiente de factores ambientales como la temperatura. Aunque el efecto de la temperatura sobre el desarrollo de M. phaseolina se había descrito anteriormente (Akhtar, Sarwar, \& Arshad, 2011; Manici, Caputo, \& Cerato, 1995), no existen estudios previos que caractericen el nivel de resistencia en melón en base a este parámetro. Estos trabajos previos evaluaron la tasa de crecimiento de más de 60 aislados del 
hongo in vitro en un rango de temperaturas muy amplio y vieron que la temperatura óptima se encuentra entre 30 y $35^{\circ} \mathrm{C}$. La escasez de agua también se ha descrito como un factor importante en la severidad de síntomas de M. phaseolina, estando este factor bastante relacionado con la temperatura en muchas regiones. En este sentido, Akhtaret al (2011) ya reportaron diferencias importantes en el nivel de daños en un conjunto de genotipos de sésamo en dos años con diferente climatología. Estos aislados procedentes de sésamo y girasol evaluados por Manici et al. (1995) y Akhtar et al. (2011) resultaron patogénicos también para otras especies, incluidas C. melo y C. sativus, por lo que además, a la vista de nuestros resultados, parece que este comportamiento respecto a las condiciones ambientales es general. Este trabajo aquí presentado, por tanto, refuerza el cambio de enfoque en cuanto a la búsqueda de resistencias para este tipo de patógenos de suelo, al demostrarse necesaria la evaluación de germoplasma en diversas condiciones y no sólo en un ambiente. Esto permite una mejor selección de las fuentes de resistencia más apropiadas para un rango mayor de condiciones climáticas. Por ejemplo, accesiones como el parental DUD PI 273438, que exhibe una moderada resistencia a $28^{\circ} \mathrm{C}$, puede ser útil en regiones con temperaturas moderadas como Europa, mientras para regiones más cálidas, y por tanto condiciones más estresantes, como Brasil, Israel o ciertas regiones de África, se necesitaría el uso de germoplasma con resistencia estable a temperaturas altas.

Por otra parte, con este planteamiento y con la experiencia adquirida en el trabajo con hongos patógenos de suelo, se decidió abordar un cribado en búsqueda de resistencia a Monosporascus spp., principal causante de la enfermedad llamada muerte súbita o colapso del melón. Este trabajo, supone el último capítulo de esta Tesis (sección 4.3), y en él se caracterizaron un grupo de entradas en condiciones de inoculación artificial y de campo, incluyendo el parental PS de la colección de ILs, entradas de la ssp. agrestis africanas y de la India, y una entrada de la especie C. metuliferus proxima al melón. Los resultados obtenidos apoyan la tesis de que la temperatura constituye un factor de importancia en la patogenicidad del hongo también en el género Monosporascus, por lo que este efecto parece no ser un caso aislado, como ya se sugería en trabajos anteriores como el de Pivonia, Cohen, R., Kigel, J., \& Katan (2002). Ya en trabajos antiguos se hablaba de la influencia de la temperatura en la agresividad de patógenos de suelo en términos de factores no sólo del patógeno, sino también del hospedante y de la actividad antagonista de los microorganismos del suelo (Katan, 1989).

De las dos especies implicadas en el estudio, M. cannonballus, la especie con mayor prevalencia en el colapso de melón en España, siempre presentó mayor agresividad que M. eutypoides bajo inoculación artificial. La accession Pat 81 se había descrito previamente como resistente a Acremonium cucurbitacearum y a M. cannonballus en distintas condiciones de ensayo 


\section{DISCUSIÓN GENERAL}

(Iglesias, Picò, \& Nuez, 2000). En este estudio, se confirma su resistencia incluso en condiciones de alta temperatura e infección severa. Esta entrada, además, presentó cierta tolerancia a Macrophomina phaseeolina, en el estudio de la sección 4.2, por lo que resulta un recurso de interés en la mejora de la resistencia frente a hongos del suelo en melón. También se describe por primera vez resistencia a $M$. cannonballus en la entrada PI 185111, también resistente a $M$. phaseolina, sugiriendo la ocurrencia de un mecanismo común en la resistencia a ambos hongos del suelo, en el cual la arquitectura de la raíz puede estar involucrada, proporcionando una ventaja desde el punto de vista morfológico (Fita, Picò, Dias, \& Nuez, 2008).

A pesar que se han realizado diversos estudios de resistencia a Monosporascus spp. en una gran variedad de germoplasma y en diferentes condiciones, no se han encontrado muchas fuentes de resistencia (Crosby, 2001; Dias, Senhor, Michereff, Negreiros, 2004; Esteva \& Nuez, 1994; Salari, Panjehkeh, Nasirpoor, \& Abkhoo 2012; Sales Júnior, Senhor, Michereff, Negreiros, 2019). Por ello, las fuentes identificadas son de gran interés, ya que además no presentan problemas de compatibilidad sexual con los cultivares comerciales al pertenecer a la misma especie. Estos trabajos suponen un paso más en la búsqueda de resistencias estables a patógenos de suelo. Una alternativa al desarrollo de variedades resistentes es el empleo de estas fuentes como portainjertos de variedades comerciales de melón para evitar estas enfermedades de suelo (Cáceres, Perpiñà, Ferriol, Picò, \& Gisbert, 2017), estrategia que permite explotar especies resistentes no compatibles sexualmente con el melón, como C. metuliferus. La problemática asociada a este sistema en cuanto a costes e influencia en la calidad del fruto, hacen que los esfuerzos en la búsqueda de genes de resistencia para su introgresión en los tipos cultivados siga siendo esencial. 


\section{Referencias}

Akhtar, K. P., Sarwar, G., \& Arshad, H. M. I. (2011). Temperature response, pathogenicity, seed infection and mutant evaluation against Macrophomina phaseolina causing charcoal rot disease of sesame. Archives of phytopathology and plant protection, 44(4), 320-330.

Ambrósio, M. M., Dantas, A. C., Martínez-Perez, E., Medeiros, A. C., Nunes, G. H., \& Picò, M. B. (2015). Screening a variable germplasm collection of Cucumis melo L. for seedling resistance to Macrophomina phaseolina. Euphytica, 206(2), 287-300.

Blanca, J., Esteras, C., Ziarsolo, P., Pérez, D., Collado, C., de Pablos, R. R., ... Picò, B. (2012). Transcriptome sequencing for SNP discovery across Cucumis melo. BMC Genomics, 13(1), 280.

Branham, S. E., Levi, A., Katawczik, M., Fei, Z., \& Wechter, W. P. (2018). Construction of a genome-anchored, high-density genetic map for melon (Cucumis melo L.) and identification of Fusarium oxysporum f. sp. melonis race 1 resistance QTL. Theoretical and Applied Genetics, 131(4), 829-837.

Burger, Y., Paris, H. S., Cohen, R., Katzir, N., Yishay, R., \& Schaffer, A. A. (2010). Genetic diversity of Cucumis melo. In J. Janick (Ed.), Horticultural reviews (Vol. 36, pp. 165-198). New York, USA: Wiley-Blackwell.

Cáceres, A., Perpiñà, G., Ferriol, M., Picò, B., \& Gisbert, C. (2017). New Cucumis rootstocks for melon:'UPV-FA'and 'UPV-FMy'. HortScience, 52(5), 792-797.

Chikh-Rouhou, H., González-Torres, R., Alvarez, J. M., \& Oumouloud, A. (2010). Screening and morphological characterization of melons for resistance to Fusarium oxysporum $\mathrm{f}$. sp. melonis race 1.2. HortScience, 45(7), 1021-1025.

Crosby, K.M. (2001). Screening Cucumis melo L. agrestis germplasm for resistance to Monosporascus cannonballus. Subtropical Plant Science, 53, 24-26.

Daley, J., Branham, S., Levi, A., Hassell, R., \& Wechter, P. (2017). Mapping Resistance to Alternaria cucumerina in Cucumis melo. Phytopathology, 107(4), 427-432.

Dias, R. D. C. S., Picò, B., Espinos, A., \& Nuez, F. (2004). Resistance to melon vine decline derived from Cucumis melo ssp. agrestis: Genetic analysis of root structure and root response. Plant Breeding, 123(1), 66-72.

Eduardo, I., Arús, P., \& Monforte, A. J. (2005). Development of a genomic library of near isogenic lines (NILs) in melon (Cucumis melo L.) from the exotic accession PI161375. Theoretical and Applied Genetics, 112(1), 139-148.

Esteva, J., \& Nuez, F. (1994). Field resistence to melon dieback in Cucumis melo L. Cucurbit Genetics Cooperative, 17, 76-77.

Fita, A., Picò, B., Dias, R. C. S., \& Nuez, F. (2008). Effects of root architecture on response to 


\section{DISCUSIÓN GENERAL}

melon vine decline. Journal of Horticultural Science and Biotechnology, 83(5), 616-623.

Galpaz, N., Gonda, I., Shem-Tov, D., Barad, O., Tzuri, G., Lev, S., ... Harel-Beja, R. (2018). Deciphering genetic factors that determine melon fruit-quality traits using RNA-Seq-based high-resolution QTL and eQTL mapping. The Plant Journal, 94(1), 169-191.

Garcia-Mas, J., Benjak, A., Sanseverino, W., Bourgeois, M., Mir, G., González, V. M., ... Alioto, T. (2012). The genome of melon (Cucumis melo L.). Proceedings of the National Academy of Sciences, 109(29), 11872-11877.

Guis, M., Roustan, J. P., Dogimont, C., Pitrat, M., \& Pech, J. C. (1998). Melon biotechnology. Biotechnology and Genetic Engineering Reviews, 15(1), 289-312.

Iglesias, A., Picò, B., \& Nuez, F. (2000). A temporal genetic analysis of disease resistance genes: resistance to melon vine decline derived from Cucumis melo var. agrestis. Plant Breeding, 119(4), 329-334.

Katan, J. (1989). Soil temperature interaction with the biotic components of vascular wilt diseases. In: C. Beckman, \& E. Tjamos (Eds.), The Interaction of Genetic and Environmental Factors in the Development of Vascular Wilt Diseases of Plants (pp. 353 366). Berlin, Germany: Springer.

Manici, L. M., Caputo, F., \& Cerato, C. (1995). Temperature responses of isolates of Macrophomina phaseolina from different climatic regions of sunflower production in Italy. Plant disease, 79(8), 834-838.

Monforte, A. J., Díaz, A., Caño-Delgado, A., \& van der Knaap, E. (2014). The genetic basis of fruit morphology in horticultural crops: Lessons from tomato and melon. Journal of Experimental Botany, 65(16), 4625-4637.

Moreno, E., Obando, J. M., Dos-Santos, N., Fernández-Trujillo, J. P., Monforte, A. J., \& Garcia-Mas, J. (2008). Candidate genes and QTLs for fruit ripening and softening in melon. Theoretical and Applied Genetics, 116(4), 589-602.

Perchepied, L., Dogimont, C., \& Pitrat, M. (2005). Strain-specific and recessive QTLs involved in the control of partial resistance to Fusarium oxysporum f. sp. melonis race 1.2 in a recombinant inbred line population of melon. Theoretical and applied genetics, 111(1), $65-74$

Pereira L. (2018). Genetic dissection of fruit quality and ripening traits in melon. Barcelona (Dcotoral Thesis). Universitat Autònoma de Barcelona. Barcelona, España. Retrieved from https://ddd.uab.cat/record/201529

Périn, C., Hagen, L., De Conto, V., Katzir, N., Danin-Poleg, Y., Portnoy, V., ... Pitrat, M. (2002). A reference map of Cucumis melo based on two recombinant inbred line populations. Theoretical and Applied Genetics, 104(6-7), 1017-1034. 
Perpiñà, G., Esteras, C., Gibon, Y., Monforte, A. J., \& Picò, B. (2016). A new genomic library of melon introgression lines in a cantaloupe genetic background for dissecting desirable agronomical traits. BMC Plant Biology, 16(1), 164.

Pitrat, M. (1991). Linkage groups in Cucumis melo L. Journal of Heredity, 82(5), 406-411.

Pivonia, S., Cohen, R., Kigel, J., \& Katan, J. (2002). Effect of soil temperature on disease development in melon plants infected by Monosporascus cannonballus. Plant Pathology, 51(4), 472-479.

Ríos, P., Argyris, J., Vegas, J., Leida, C., Kenigswald, M., Tzuri, G., ... Monforte, A. J. (2017). ETHQV 6.3 is involved in melon climacteric fruit ripening and is encoded by a NAC domain transcription factor. The Plant Journal, 91(4), 671-683.

Risser, G., Banihashemi, Z., \& Davis, D. W. (1976). A proposed nomenclature of Fusarium oxysporum f. sp. melonis races and resistance genes in Cucumis melo [Muskmelon, fungal diseases]. Phytopathology, 66(9), 1105-1106.

Salari, M., Panjehkeh, N., Nasirpoor, Z., \& Abkhoo, J. (2012). Reaction of melon (Cucumis melo L.) cultivars to soil-borne plant pathogenic fungi in Iran. African Journal of Biotechnology, 11(87), 15324-15329.

Sales Júnior, R., Senhor R. F., Michereff S. J., Negreiros A. M. (2019). Reaction of melon genotypes to the root's rot caused by Monosporascus. Caatinga, 32, 288-294

Thakur, H., Sharma, S., \& Thakur, M. (2019). Recent trends in muskmelon (C ucumis melo L.) research: an overview. The Journal of Horticultural Science and Biotechnology, 94(4), 533-547.

Vegas, J., Garcia-Mas, J., \& Monforte, A. J. (2013). Interaction between QTLs induces an advance in ethylene biosynthesis during melon fruit ripening. Theoretical and applied genetics, 126(6), 1531-1544.

Welch, R. M., \& Graham, R. D. (2004). Breeding for micronutrients in staple food crops from a human nutrition perspective. Journal of experimental botany, 55(396), 353-364.

Wu, S., Zhang, B., Keyhaninejad, N., Rodríguez, G. R., Kim, H. J., Chakrabarti, M., ... Pan, Y. (2018). A common genetic mechanism underlies morphological diversity in fruits and other plant organs. Nature communications, 9(1), 4734. 

6.CONCLUSIONES 



\section{CONCLUSIONES}

Aprovechamiento de la variabilidad intraespecífica del melón para la mejora de la calidad

1) Se ha obtenido la primera colección de 16 líneas de introgresión de melón a partir de la entrada Queen's pocket melon (ssp. melo, grupo Dudaim, PI 273438) en el fondo genético del cultivar Piñonet tipo 'Piel de Sapo' (ssp. melo, grupo Ibericus). La colección presenta una media de 1,4 introgresiones/IL, con una recuperación del fondo genético 'Piel de Sapo' del 93,87\% (rango 86,9-96,3 \%), y representa el 62,6\% del genoma donante Dudaim. Esta colección supone la primera utilización de una entrada del grupo Dudaim para su explotación con fines de mejora del melón 'Piel de Sapo'.

2) La estrategia empleada, basada en la utilización de diversas técnicas de genotipado, como la plataforma Agena Biosciences o la técnica HRM, para la selección de las mejores plantas en cada generación de retrocruce y/o autofecundación, ha permitido la optimización de este proceso selectivo, reduciendo sustancialmente el número de generaciones necesarias y, por consiguiente, el tiempo necesario para la generación de la colección de ILs.

3) La realización en la fase final de obtención de las ILs de un genotipado de alta densidad mediante GBS se ha demostrado necesario para la caracterización en profundidad de las líneas. El resultado para las cinco líneas analizadas por GBS (DUD_3-1; DUD_4-2; DUD_5-1; DU_6-1; DUD_6-2), ha confirmado las introgresiones ya detectadas con otras técnicas de genotipado y ha desvelado la existencia de pequeñas introgresiones que habría que eliminar en el futuro.

4) La realización de un fenotipado en cada generación durante el proceso de obtención de ILs ha permitido el seguimiento de la evolución de los caracteres de interés en la población y la detección de un total de 74 QTLs preliminares en la colección final de ILs mediante el test de Dunnett, de los que 32 fueron estables en dos ambientes (Paip16 y Paip17). De éstos, 22 QTLs están relacionados con aspectos morfológicos (forma del fruto, reticulado, ancho de cavidad, espesor de la pulpa y de la corteza), 9 con el proceso de maduración (presencia de aroma, capa de abscisión, firmeza de la pulpa y de la corteza) y uno con el contenido en sólidos solubles. El empleo de marcadores anclados al genoma en su versión 3.6.1 ha facilitado, por otra parte, la identificación de genes candidatos en algunas de estas regiones genómicas.

5) Se han obtenido ILs que por sus características relacionadas con aspectos de calidad como maduración climatérica, y menor tamaño y forma redondeada del fruto resultan especialmente interesantes. A nivel de maduración, cabe destacar las líneas DUD_3-1 y DUD_6-2. Ambas presentaron capa de abscisión, pero sólo la segunda mostró además 


\section{CONCLUSIONES}

aroma externo y ablandamiento de la pulpa. En cuanto a la morfología del fruto, destaca la línea DUD_2-1 por su reducción de peso respecto al parental 'Piel de Sapo' y las líneas DUD_4-2,DUD_5-1 y DUD_5-3 por presentar frutos más redondeados. El estudio de una línea de premejora derivada de DUD_4-2 ha puesto de manifiesto además el efecto de tamaño en esta línea, que podría ser usada en programas de mejora para disminuir el tamaño del fruto sin afectar otros rasgos, consiguiendo de esta manera melones de tamaño unipersonal (Mini melones), algo que está siendo demandado por el mercado.

Aprovechamiento de la variabilidad intraespecífica del melón para la resistencia a hongos del suelo

6) El cribado de la colección de líneas de introgresión para resistencia a Macrophomina phaseolina ha mostrado que la resistencia moderada previamente observada en el parental Dudaim no se ha traducido en la obtención de líneas derivadas resistentes a este patógeno de suelo. A pesar de esto, no se puede descartar que otras regiones de Dudaim no representadas en esta colección sean responsables de la resistencia moderada observada en el parental.

7) Se ha demostrado que el aumento de la temperatura resulta en una mayor severidad de la infección de M. phaseolina y Monosporascus spp., afectando a la respuesta de entradas con distintos niveles de resistencia. Cabe destacar que, independientemente de factores que inciden en la agresividad de los patógenos, se ha podido establecer de forma inequívoca que la severidad de las infecciones causadas por Monosporascus cannonballus es mayor a la de Monosporascus eutypoides.

8) Tres accesiones de la subespecie agrestis de melón, procedentes de Africa y de la India (PI 185111, Ames 24297, PI 482394), mostraron un buen nivel de resistencia a Monosporascus spp., tanto en condiciones de inoculación artificial como en campo, confirmándose además la resistencia de la entrada del tipo Chinensis (Pat 81), previamente descrita como altamente resistente a $M$. cannonballus, a M. eutypoides. Además, PI 185111 también exhibió resistencia a M. phaseolina, incluso en condiciones de temperatura elevada, factor que fue determinante en la pérdida de resistencia en otras accesiones del tipo Dudaim. La resistencia de PI 185111 y la tolerancia de Pat81 a estos dos patógenos de suelo sugiere la existencia de un mecanismo común, por ejemplo basado en el mayor vigor o mejor estructura de su sistema radicular. Los resultados también parecen indicar que podría existir algún otro factor genético responsable del elevado nivel de resistencia de PI 185111. En conclusión, las accesiones PI 185111 y Pat 81 constituyen buenos candidatos para futuros programas de mejora para la 
resistencia a hongos en melon, puesto que se trata de variabilidad intraespecífica y no presentan problemas de incompatibilidad con el melón cultivado. 